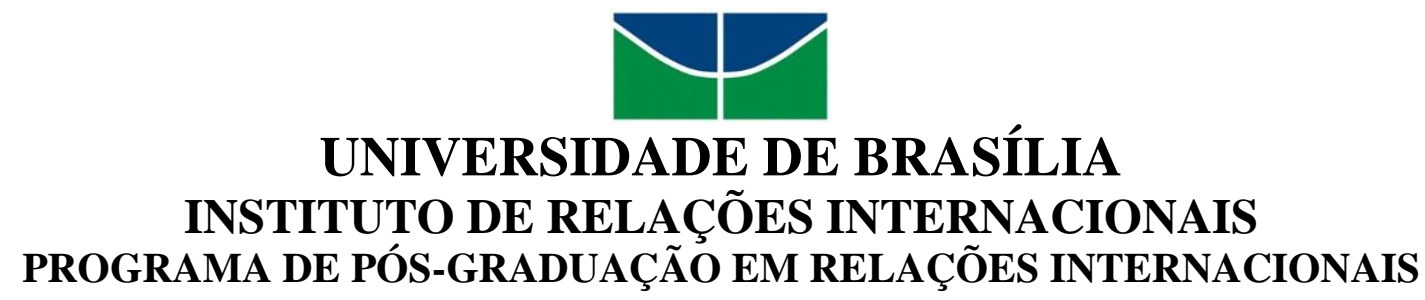

VIVIAN PATRICIA PERON VIEIRA

OS EFEITOS DA COMUNICAÇÃO DIGITAL NA DINÂMICA DO ATIVISMO TRANSNACIONAL CONTEMPORÂNEO: UM ESTUDO SOBRE AL-QAEDA, WIKILEAKS E PRIMAVERA ÁRABE 
OS EFEITOS DA COMUNICAÇÃO DIGITAL NA DINÂMICA DO ATIVISMO TRANSNACIONAL CONTEMPORÂNEO: UM ESTUDO SOBRE AL-QAEDA, WIKILEAKS E PRIMAVERA ÁRABE

Tese apresentada ao Programa de Pós-graduação em Relações Internacionais, Instituto de Relações Internacionais, Universidade de Brasília, como requisito parcial para obtenção do grau de Doutorado em Relações Internacionais.

Orientador: Prof. Dr. Estevão Chaves de Rezende Martins 


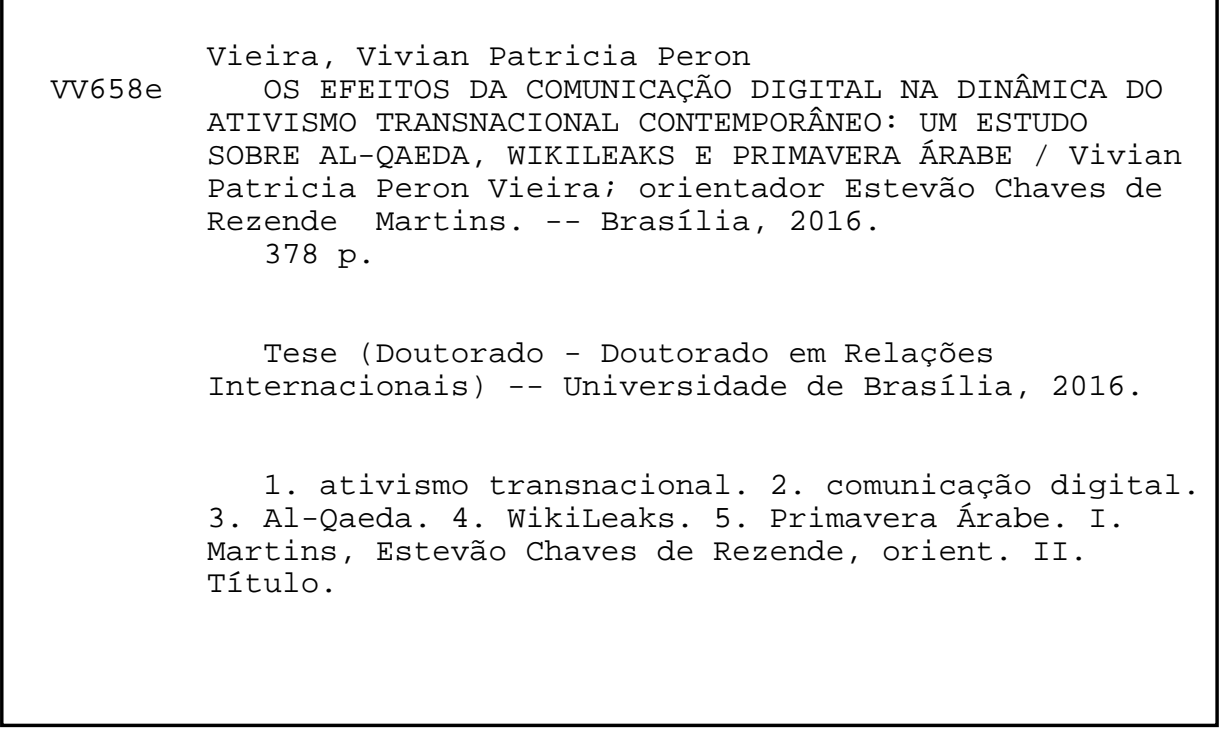




\section{OS EFEITOS DA COMUNICAÇÃO DIGITAL NA DINÂMICA DO ATIVISMO TRANSNACIONAL CONTEMPORÂNEO: UM ESTUDO SOBRE AL-QAEDA, WIKILEAKS E PRIMAVERA ÁRABE}

Tese apresentada ao Programa de Pós-graduação em Relações Internacionais, Instituto de Relações Internacionais, Universidade de Brasília, como requisito parcial para obtenção do grau de Doutorado em Relações Internacionais.

Data da aprovação: 11 de março de 2016

BANCA EXAMINADORA:

Prof. Dr. Estevão Chaves de Rezende Martins (Orientador)

Universidade de Brasília (UnB)

Prof. Dra. Elizabete Sanches Rocha (Examinadora) Universidade Estadual Paulista Júlio de Mesquita Filho (Unesp)

Prof. Dra. Marisa von Bülow (Examinadora)

Universidade de Brasília (UnB)

Prof. Dra. Giovanna Maria Frisso (Examinadora)

Universidade Federal Fluminense (UFF)

Prof. Dr. Arthur Cezar de Araujo Ituassu Filho (Examinador)

Pontifícia Universidade Católica do Rio de Janeiro (PUC-Rio) 
A Sivaldo e Carmel, com amor e gratidão. 


\section{AGRADECIMENTOS}

Escrever uma tese é um exercício que envolve além da razão, muita paixão, resistência e um ambiente frutífero. Por isso, acredito que a realização de um doutorado vai para além dos esforços acadêmicos individuais. E apesar de ser um exercício em sua maior parte do tempo solitário, envolve uma série de pessoas, instituições e contribuições de diversas naturezas que, sem elas, certamente este projeto não sairia do papel. Por isso, considero tão importante estes agradecimentos que se seguem.

Primeiramente, agradeço ao meu orientador, Prof. Estevão Martins, uma pessoa que, pela sua experiência, capacidade e conhecimentos já seria suficiente para pontuar a importância que teve nesta trajetória, ademais, seus ensinamentos e dedicação à vida acadêmica são um exemplo de inspiração que carregarei comigo para a vida.

Agradeço ao grande corpo humano da Universidade de Brasília (UnB): professores, colegas, funcionários e alunos das aulas de estágio-docente que ministrei. Todos eles me mostraram como o aprendizado é horizontal e contínuo.

Agradeço à minha segunda casa acadêmica: Massachusetts Institute of Technology (MIT). Nesta instituição tive oportunidade de dialogar sobre minha pesquisa com uma heterogeneidade de pesquisadores que marcaram profundamente minha forma de entender a multidisciplinaridade e a pluralidade do fazer científico. Sou imensamente grata a Profa. Nazli Choucri, pela supervisão, apoio e frutífero diálogo durante o ano que me recebeu como pesquisadora visitante em seu grupo de pesquisa sobre Cyberpolitics and International Relations. Sem dúvida, este ano foi fundamental para o amadurecimento de minha pesquisa e se delineou como um valioso intercâmbio acadêmico e profissional.

Eu não poderia deixar de agradecer a dois grupos acadêmicos que me acolheram no Brasil: Centro de Estudos Avançados em Democracia Digital/UFBA e GPolitics/UFAL - com os quais pude contar com uma importante interlocução acadêmica a partir de outras áreas de estudo.

Agradeço àqueles que contribuíram para minha formação mais ampla e compartilharam profícuo diálogo em determinados momentos dessa caminhada: Bete Sanches, Thalia Rubio, Guilherme Canela e Saint-Clair.

Importante agradecer a Instituição de fomento CAPES pelos recursos de minha bolsa de doutorado e pela bolsa de estágio doutoral no exterior. 
Agradeço com alegria aos amigos que estiveram presentes em diferentes momentos desse processo. Grande parte da ajuda e força que obtive veio de pessoas fora do ambiente acadêmico, quando espairecer era necessário, e a vida pedia um pouco mais de calma e cor. Em especial, Clare Jerome, Alice Braga, Ciro Ferreira, Letícia Cortellazzi, Paula Facci, Leandro Scavacini, Luana Gouveia, Fabrício Carrijo, Lucilene Calza, Isabela Ferraioli, Gabriela Sandroni, Yasmine Hoffman, Ana Paula Carrijo, Daniela Becker, Karin Popov e Guilhermetes.

Agradeço com muito carinho a minha família, que incondicionalmente me apoiou e cujo amor é minha estrutura mais forte: minha mãe Madeleine Peron, meu pai Aécio Vieira, e minha irmã Vanessa Taciane.

Agradeço em especial ao meu marido Sivaldo Pereira, o maior companheiro dessa jornada, que além de me incentivar em cada uma das etapas desse processo, tive a oportunidade de contar com um interlocutor de qualidades raras.

Agradeço a nossa filha Carmel, que sendo gestada na etapa final deste extenso e intenso trabalho, acompanhou-me tranquila, compreendendo todos os momentos de cansaço, noites em claro e dias sem sol, trazendo-me em troca muita energia, equilíbrio e luz.

Por fim o mais importante: agradeço imensamente a Deus por guiar a minha vida, sempre. 


\section{RESUMO}

O início deste século foi marcado por um conjunto significativo de transformações nas relações internacionais. $\mathrm{O}$ fortalecimento de movimentos antiglobalização, a maior propagação do terrorismo, o empoderamento de organizações civis e a ocorrência de grandes protestos coordenados em rede são algumas das vinculações deste período. Todos esses eventos possuem algumas características em comum: Envolvem ações ativistas; sustentam algum impacto transnacional; utilizam em alguma medida a comunicação digital para suas ações. Com este cenário de fundo, esta pesquisa de doutorado tem como indagação central o seguinte questionamento: Quais os efeitos da comunicação digital na dinâmica do ativismo transnacional contemporâneo? Para responder tal inquirição, o trabalho buscou integrar diferentes áreas de conhecimento como Relações Internacionais, Comunicação Social e Tecnologia. No tocante à metodologia utilizada, foram adotados a pesquisa qualitativa e o método de estudo de caso como ferramentas basilares. Para operacionalizar e criar linhasmestras de análise, desenvolveu-se indicadores qualitativos. Estes foram aplicados em três casos de ativismo transnacional contemporâneo considerados representativos e emblemáticos: (a) Al-Qaeda, WikiLeaks e Primavera Árabe. Os resultados identificaram a ocorrência de cinco categorias de efeitos da comunicação digital sobre o ativismo transnacional e seus respectivos indicadores: Estímulo à configuração da causa (articulação, difusão e massificação); Multiplicação do engajamento de indivíduos (coordenação, adesão e colaboração); Flexibilização da estrutura (virtualização, descentralização e transnacionalização); Instrumentalização do planejamento (elaboração, datificação e instrução); e Diversificação da ação (cibereventos e ciberataque). A pesquisa aponta que os efeitos da comunicação digital no ativismo são hoje fenômenos reais, com implicações nos diversos processos que compõem o ativismo em geral e o ativismo transnacional em específico. Os dados e fatos descritos comprovam o lastro das categorias de efeitos e também demonstram a sua complexidade e entrelaçamento, enquadrando o ativismo transnacional como um fenômeno cada vez mais relevante no cenário internacional.

Palavras-chave:

ativismo transnacional, comunicação digital, Al-Qaeda, WikiLeaks, Primavera Árabe 


\begin{abstract}
The beginning of this century was marked by a significant number of changes in international relations. The strengthening of anti-globalization movements, the further spread of terrorism, the empowerment of civil society organizations and coordinated protests are some changes that characterize this period. All these events have some elements in common: activists actions; transboundary impacts; digital communication usage. This doctoral research centers around the following question: What are the effects of digital communication on the dynamics of contemporary transnational activism? To answer this inquiry, the study integrated different areas of knowledge, including International Relations, Social Communication and Technology. Regarding the methodology, qualitative research and the case study method were adopted as basic tools. To operate and create guidelines for analysis, qualitative indicators were developed. These were applied in three cases of contemporary transnational activism considered emblematic of this new century: (a) Al-Qaeda, WikiLeaks and Arab Spring. The results showed the occurrence of five digital communication categories of effects on transnational activism and their respective indicators: Encouraging the setting of the cause (articulation, diffusion and mass mediafication); Multiplying the individual's engagement (coordination, support and collaboration); Flexible structure (virtualization, decentralization and transnationalization); Instrumentalization of the planning (elaboration, datification and instruction); and Action diversification (cyber event and cyber attack). The research shows the digital communication effects on activism today are a real phenomena, with implications in all the activism's stages in general - and transnational activism in particular. Data and facts described in this research show the validity of the categories of effects and also demonstrate their complexity and merging, framing the transnational activism as an increasingly important phenomenon in the current international arena.
\end{abstract}

Keywords:

transnational activism, digital communication, Al-Qaeda, WikiLeaks, Arab Spring 


\section{LISTA DE ILUSTRAÇÕES}

Figura 1 - Registro da primeira mensagem transmitida pela Internet em 1969 ..........28

Figura 2 - Diagrama do movimento relacional das camadas do ciberespaço.................35

Figura 3 - Tecnologia e assuntos internacionais: Um modelo integrativo ....................46

Figura 4 - Impactos sociais da comunicação digital e seus efeitos na

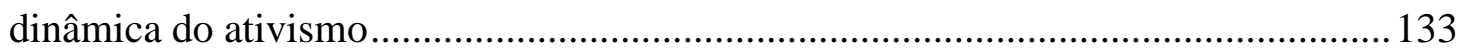

Figura 5 - Reprodução da home do website Alneda ................................................. 185

Figura 6 - Banner de Internet com propaganda da Al-Qaeda intitulada

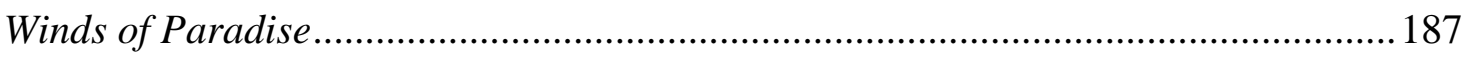

Figura 7 - Imagem de trecho do vídeo Badr Ar-Riyadh ......................................... 190

Figura 8 - Tela do site da Al Jazeera com vídeo de Osama bin Laden ...................... 193

Gráfico 1 - Tendências de busca do termo WikiLeaks no Google .............................240

Gráfico 2 - Menções ao WikiLeaks no Twitter ............................................................241

Gráfico 3 - Fluxo de doações para o WikiLeaks 2010-2011 .....................................257

Figura 9 - Tela de submissões de arquivos no website do WikiLeaks .......................272

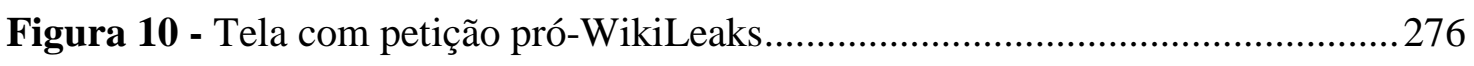

Figura 11 - Tela com chamado de mobilização para Operação PayBack .................278

Figura 12 - Versão em inglês da página no Facebook We are all Khaled Said .........290

Figura 13 - Egípcios e o uso de telefones celulares nos levantes em 2011 ................293

Figura 14 - Imagem televisiva com cobertura ao vivo da Al Jazeera ........................299

Figura 15 - Tela com imagem de vídeo da vlogueira Asmaa Mahfouz .....................304

Figura 16 - Logotipo do hotsite TuniLeaks publicado em novembro de 2010 ...........318

Figura 17 - Reprodução da versão traduzida do Activists' Action Plan .......................325

Figura 18 - Tela do website da Universidade Harvard hackeado ................................327 


\section{LISTA DE QUADROS E TABELAS}

Quadro 1 - Sistema integrado ciber-RI - situando questões e ênfases........................48

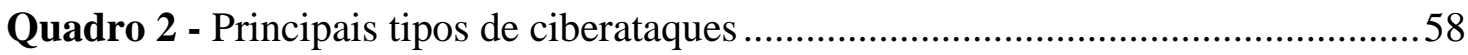

Quadro 3 - Dimensões físicas e virtuais do cyberpower ............................................. 77

Quadro 4 - Categorias de efeitos e seus respectivos indicadores qualitativos ............175

Tabela 1 - Dias de maior impacto no Twitter - por menções ao WikiLeaks ...............242

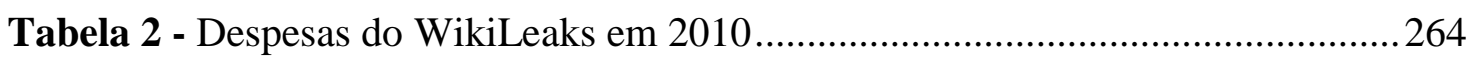




\section{SUMÁRIO}

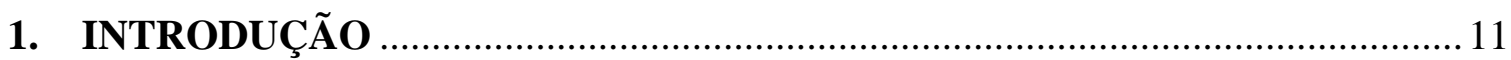

1.1 OBJETIVOS DA PESQUISA ………………………………………………...... 13

1.2 PERCURSO, ESTUDOS DE CASO E PARÂMETROS METODOLÓGICOS .........13

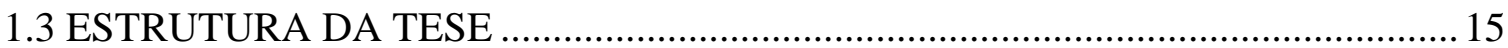

2. SOCIEDADE, TECNOLOGIA E COMUNICAÇAO DIGITAL ……………........ 17

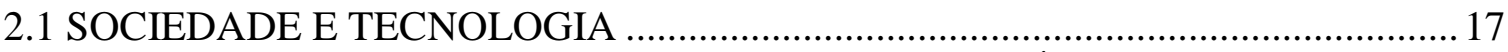

2.2 COMUNICAÇÃO DIGITAL: ORIGENS E CARACTERÍSTICAS ..........................26

2.3 COMUNICAÇÃO DIGITAL E SEUS IMPACTOS NAS PRÁTICAS SOCIAIS .....38

3. COMUNICAÇÃO DIGITAL E RELAÇÕES INTERNACIONAIS .42

3.1 TEORIAS DAS RELAÇÕES INTERNACIONAIS E COMUNICAÇÃO

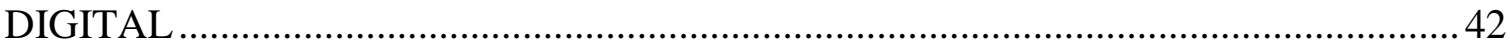

3.2 CIBERSEGURANÇA: ATAQUE, DEFESA E ATORES INTERNACIONAIS .......54

3.3 CIBERGOVERNANÇA: REGULAÇÃO E GERENCIAMENTO...............................65

3.4 ATORES NÃO-ESTATAIS, ARENA INTERNACIONAL E CYBERPOWER …..... 70

4. ATIVISMO TRANSNACIONAL E COMUNICAÇÃO DIGITAL ……………....87

4.1 DELIMITANDO O ATIVISMO E SUAS DIMENSÕES FUNDAMENTAIS ............87

4.2 ATIVISMO TRANSNACIONAL, ESTADO E PODER ………………………….....99

4.3 ATIVISMO: TEORIAS E DINÂMICA........................................................... 109

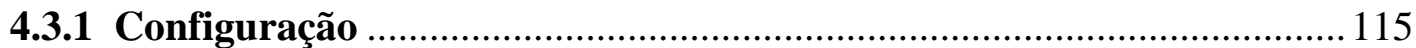

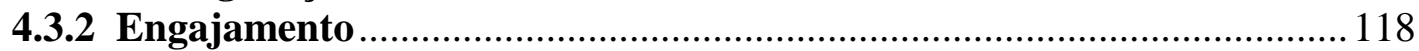

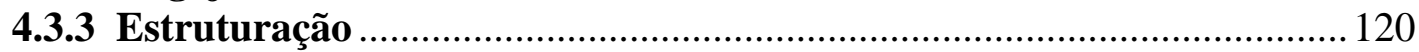

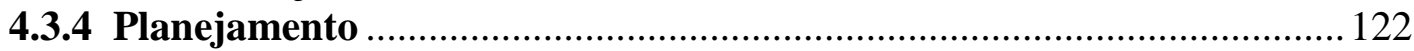

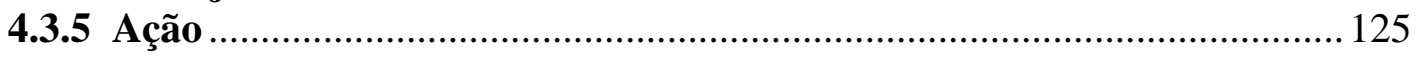

4.4 EFEITOS DA COMUNICAÇÃO DIGITAL NO ATIVISMO

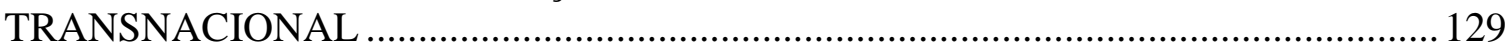

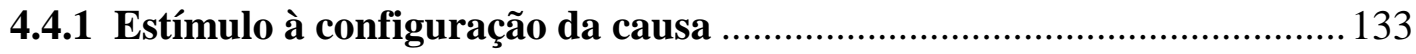

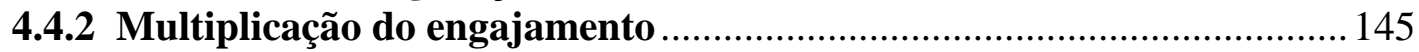

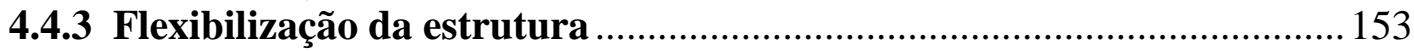

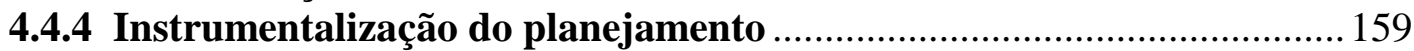

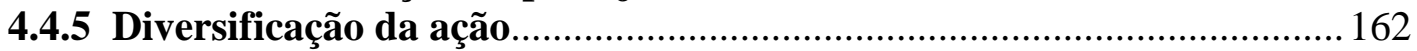

5. INDICADORES E TRÊS ESTUDOS DE CASO: AL-QAEDA, WIKILEAKS E

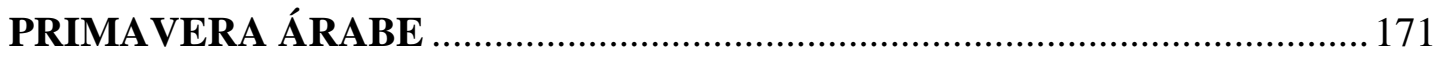

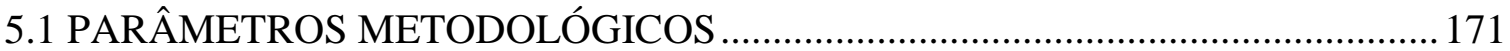

5.2 AL-QAEDA: ESTRATÉGIA ONLINE E TERRORISMO ……………………...... 179

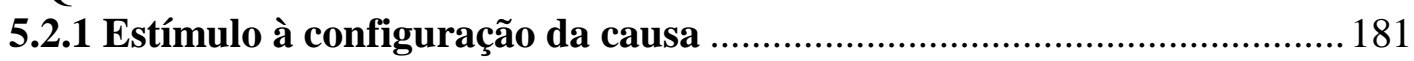

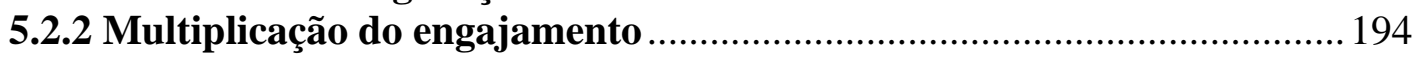

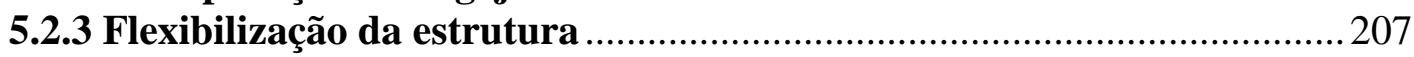

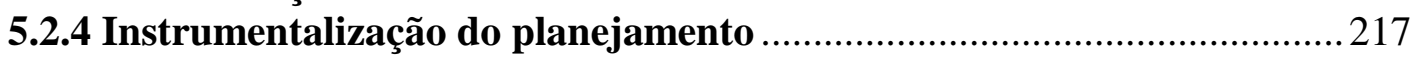

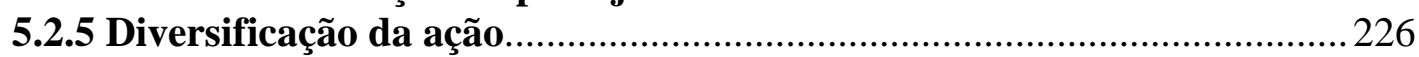

5.3 WIKILEAKS: VAZAMENTOS DIGITAIS E REDES COLABORATIVAS .........230

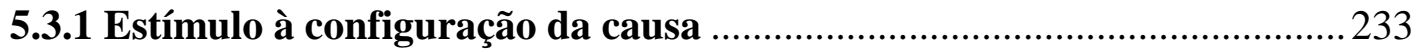




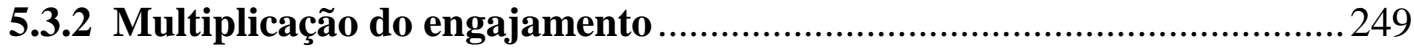

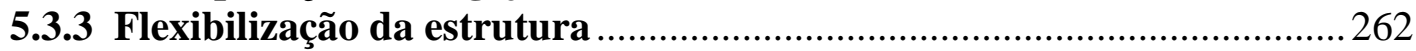

5.3.4 Instrumentalização do planejamento ...............................................269

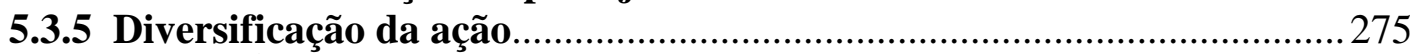

5.4 PRIMAVERA ÁRABE: MOBILIZAÇÃO ONLINE E LEVANTES DE RUA......228

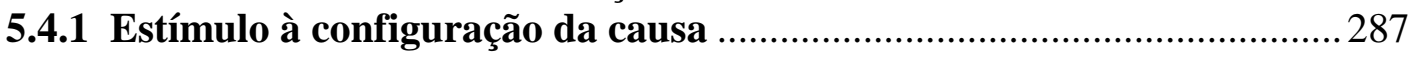

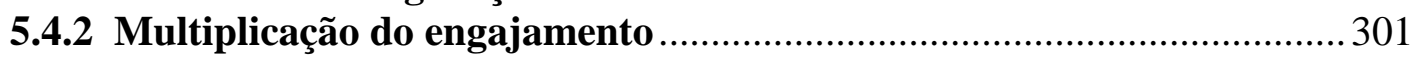

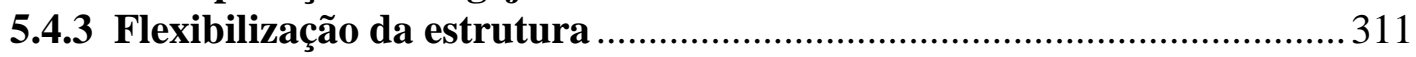

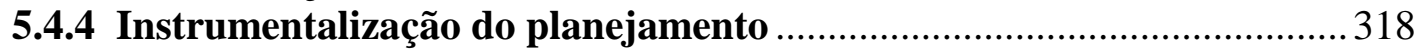

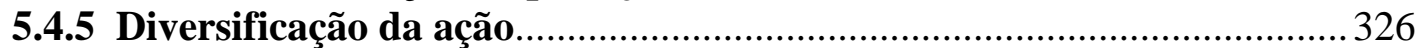

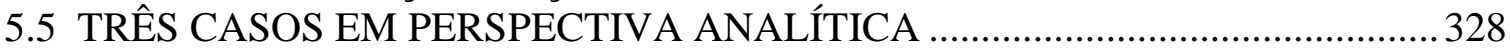

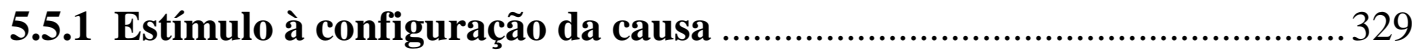

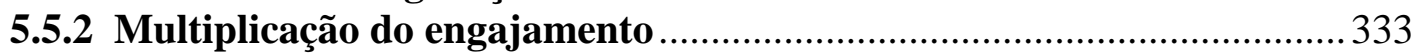

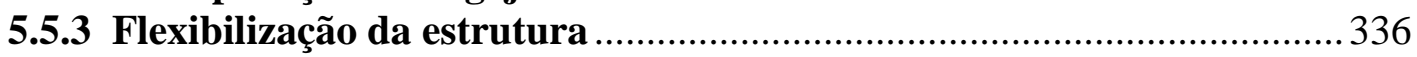

5.5.4 Instrumentalização do planejamento ............................................... 339

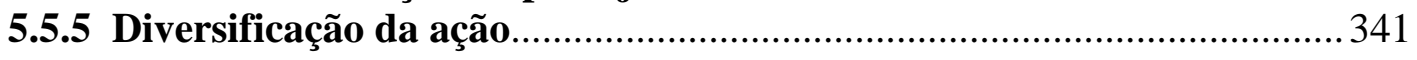

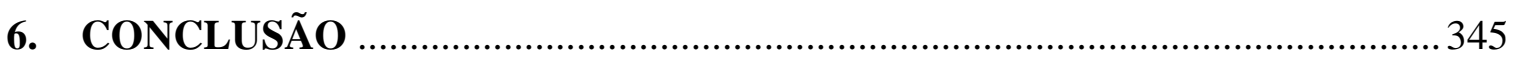

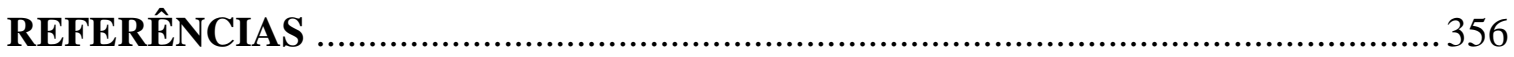




\section{INTRODUÇÃO}

O final do século XX e o início do novo século marcam um conjunto de transformações políticas, econômicas e culturais significativas para as relações internacionais. Dentre elas, o sistema bipolar deixou de existir com o fim da Guerra Fria; a Internet se consolidou como uma plataforma global de comunicação incrementando de forma ágil o fluxo de informação e interação social; os movimentos antiglobalização passaram a se articular em rede ganhando em importância e impacto, fenômeno evidenciado nos protestos contra as rodadas econômicas multilaterais. Nesta conjuntura, o ativismo transnacional tem se tornado um fenômeno cada vez mais proeminente.

Se, por um lado, os Estados continuaram atuando como peças chaves no cenário internacional - principalmente aqueles que detêm lugar estratégico quanto aos recursos econômicos, tecnológicos e militares -, por outro lado, é notório que o papel dos atores nãoestatais ganhou em escala e em importância e tem intensificado a troca e os embates com os demais atores, inclusive desafiando Estados, configurando assim um ambiente internacional bem mais complexo do que aquele vivenciado nas décadas que marcaram o século XX.

No bojo deste cenário também estão os meios de comunicação, que historicamente se constituíram como elementos importantes de mediação da realidade. Principalmente a partir do último século, isso se tornou um traço inevitável da vida moderna, difundindo informações sobre acontecimentos para além das fronteiras nacionais. A formação da opinião pública, as pressões internas e externas sobre ações governamentais, a difusão de informação necessária às intervenções políticas são alguns dos elementos que perpassam e envolvem a ação dos meios de comunicação e também afetam as relações internacionais.

Diante da importância desta intersecção, o entrelaçamento disciplinar entre a área de Relações Internacionais e Comunicação Social foi ganhando relevância e alcançando um certo volume de estudos nas últimas décadas, principalmente em países como Estados Unidos, França, Itália e Inglaterra. Diferentemente dessa realidade, no Brasil o assunto ainda é pouco explorado, embora já existam pesquisas ${ }^{1}$ que buscam analisar esta interface, mas não na quantidade desejável e compatível com a relevância crescente do tema.

\footnotetext{
${ }^{1}$ Conforme contabiliza Camargo (2009) até 2009 existiam apenas 13 trabalhos de dissertações de mestrado e teses de doutorado junto aos principais programas de pós-graduação em Relações Internacionais especificamente os programas da PUCRJ, UNB e Instituto Rio Branco (IRB) - abordando tal intersecção. Atualizando estes dados (a partir de prospecção própria realizada em fevereiro de 2014) e considerando o período a partir de 2010 até 2013 foram consultadas as publicações de teses e dissertações dos seguintes programas de pós-graduação em Relações Internacionais no país: Santiago Dantas, USP, PUC RJ, UnB, UERJ, UFSC, UEPB, PUC MINAS, Instituto Rio Branco. Nesta nova prospecção foram encontrados mais 14 trabalhos
} 
Se os media já eram importantes peças da arena internacional, a comunicação digital reforça e amplia esse papel pois significa uma inovação no modo de produção das narrativas sobre eventos e realidades políticas e no modo de circulação e interações para além das fronteiras. A comunicação digital - isto é, o fenômeno social no qual a Internet e outras tecnologias digitais estão inseridas - tem dado novos insumos para o ativismo transnacional e esta intersecção precisa ser melhor explorada.

A criação desse novo espaço simbólico de realização das relações políticas, econômicas e sociais, também denominado de ciberespaço, não é apenas um novo locus de se fazer as antigas coisas, mas remodela o conteúdo e possibilita novas formas de ação, de modo que a Internet tem se tornado uma parte crítica da emergente infraestrutura de comunicação global.

A comunicação digital tem sido considerada um fundamental traço do mundo atual. Entretanto, é recente o seu reconhecimento para o campo das Relações Internacionais. Isto se deve à chamada tradição dos estudos deste campo, cujas questões centrais tangenciavam segurança nacional e assuntos militares, englobando o sistema de decisões e interesses dos Estados, como guerras, conflitos e efetivas participações políticas. Os demais assuntos, incluindo questões econômicas, tecnológicas e a comunicação social, estavam relegados a um segundo plano.

Dentre as características emergentes do ambiente digital e sua interface com a política, tem-se a instantaneidade, transcendência de barreiras físicas e jurídicas, configuração de um locus de maior participação e de maior accountability. Este novo ramo agrega os mecanismos de maior atividade política junto a este novo domínio de interações que cria potenciais fontes de poder, fornece expansão na influência e capacita novos serviços, recursos e potencializa a produção de conhecimento. Trata-se de uma nova arena emergente de embates que mobiliza outros tipos de recursos.

Do ponto de vista terminológico, quando se menciona a expressão "comunicação digital" significa falar simultaneamente em um conjunto de quatro elementos fundamentais: (1) a Internet, que diz respeito à rede de computadores conectados e capazes de se comunicar; (2) a World Wide Web, que não é a Internet em si mas uma parte desta, ou seja, trata da dimensão lógica mais visível, especificamente o conjunto de páginas com interface gráfica

correlatos produzidos nos últimos quatro anos. Camargo (2009) também lembra que análises acerca da presença dos media no cenário internacional já encontram espaço enquanto subáreas, como a chamada Comunicação Internacional. Entretanto, Camargo (2009) enfatiza que "sob um prisma teórico, observa-se que a literatura existente sobre mídia e Relações Internacionais é bastante limitada e se desenvolve a partir de duas teorias que se chocam: CNN Effect e Manufacturing Consense" (p. 46). 
que funciona neste maquinário digital; (3) os dispositivos móveis e outros gadgets baseados em bits (como câmeras digitais, scanners, filmadoras etc.); (4) a interação entre os diversos atores através dessa estrutura. Logo, quando se fala em "comunicação digital" não estamos falando apenas de Internet em si, mas de processos de comunicação social mais amplo, viabilizados pelas ferramentas digitais. Do ponto-de-vista histórico, a comunicação digital deve ser compreendida como um fenômeno que tem alterado de modo substantivo os processos de produção e circulação de informação e interação social.

É considerando este conjunto de elementos que a presente pesquisa se situa. De modo mais específico, a principal questão que guia este estudo é compreender os efeitos da comunicação digital no ativismo transnacional. No plano mais amplo, isso nos serve como subsídio para entender o lugar desse fenômeno hoje no campo das Relações Internacionais, constituindo assim uma contribuição pertinente para o debate.

\subsection{OBJETIVOS DA PESQUISA}

O objetivo geral da pesquisa é caracterizar e compreender quais os efeitos da comunicação digital na dinâmica do ativismo transnacional contemporâneo. Como desdobramento deste horizonte mais geral, os objetivos específicos podem ser sintetizados em quatro linhas de análise:

a) Contribuir para o aprofundamento dos estudos sobre Relações Internacionais e Comunicação Social, especificamente no tocante ao papel das novas tecnologias de informação e comunicação nesta intersecção disciplinar;

b) Compreender de que forma o ativismo transnacional contemporâneo tem se apropriado da comunicação digital e que impactos isso tem gerado em sua própria forma de atuação;

c) Contribuir com o desenvolvimento de indicadores aplicáveis ao estudo sobre o fenômeno da comunicação digital e sua relação com o ativismo transnacional;

d) Identificar elementos da apropriação da comunicação digital pelo ativismo transnacional que interferem nas relações internacionais.

\subsection{PERCURSO, ESTUdOS DE CASO E PARÂMETROS METODOLÓGICOS}

Para testar, comprovar e ilustrar os objetivos pretendidos, optou-se por uma análise baseada em método qualitativo de fenômenos representativos do problema proposto. 
Especificamente, considerou-se apropriado o método do estudo de caso na medida em que este ilustra e aprofunda o fenômeno a partir do cruzamento de diferentes fontes de informação: pesquisas quantitativas e qualitativas; análises teóricas; estudos sobre os eventos; relatos sobre os fatos.

Assim, três estudos de caso foram selecionados por se tratarem de exemplos emblemáticos deste cenário: (a) Al-Qaeda; (b) WikiLeaks; e (c) Primavera Árabe. O primeiro caso se refere a uma rede terrorista, a qual se atribui a autoria dos atentados de 11 de Setembro. A Al-Qaeda consiste em uma organização islâmica fundamentalista, que opera através da estruturação de células descentralizadas. O segundo caso, WikiLeaks, diz respeito a uma organização transnacional, composta por uma rede de ativistas atuantes em diversos países, cuja bandeira é difundir informações sigilosas de governos em prol do que denominam de "transparência total". O terceiro caso, a Primavera Árabe, trata-se de um fenômeno político ocorrido no Oriente Médio e Norte da África, caracterizado por uma onda de protestos, repercutindo na derrubada de governos em países, como a Tunísia e Egito, e abalando outros.

A escolha desses três objetos não se dá por acaso. Primeiramente, cada um a seu modo, tratam-se de três importantes fenômenos transnacionais que marcaram as Relações Internacionais neste início de século e que tendem a ter desdobramentos relevantes. Segundo, os três casos possuem em comum o fato de repercutirem em rota de colisão com entes estatais, trazendo exemplos do ativismo transnacional contemporâneo. Terceiro, embora sejam bastante distintos em seus princípios e métodos de ação (um grupo terrorista islâmico, uma organização civil de viés liberal-anarquista e um movimento social de caráter revolucionário-democrático), esta diferenciação é rica e complementar do ponto de vista analítico, pois abarca os diferentes fins para os quais redes utilizaram das tecnologias de comunicação neste período recente da História. Os três casos são considerados representativos e cada uma de suas análises foram dispostas nesta tese respeitando a sequência de surgimento temporal.

Para produzir um estudo condizente com os objetivos propostos e abarcar a complexidade dos casos, a análise qualitativa foi estruturada a partir de um conjunto de 14 indicadores resultantes das cinco categorias de efeitos identificadas da comunicação digital no ativismo transnacional. Respectivamente: (1) Estímulo à configuração da causa (articulação, difusão e massificação); (2) Multiplicação do engajamento (coordenação, adesão e colaboração); (3) Flexibilização da estrutura (virtualização, descentralização e transnacionalização); (4) Instrumentalização do planejamento (elaboração, datificação e instrução); e (5) Diversificação da ação (cibereventos e ciberataque). 
A função do conjunto de indicadores foi operacionalizar a coleta de dados para testar a ocorrência das categorias analíticas, servindo como fio condutor capaz de viabilizar o concatenamento e o significado de fatos e informações, comprovando assim as teorizações defendidas nesta tese.

Importante frisar que o desenvolvimento da pesquisa foi um árduo processo, pois requereu transitar em três campos de estudo que, tradicionalmente, nem sempre estabeleceram diálogos contínuos ou perenes entre eles de forma concomitante: (a) Relações Internacionais; (b) Comunicação Social e (c) Tecnologia. Para produzir essas pontes de modo qualificado, buscou-se formação e interlocução no interior dessas áreas, através da cobertura do estado da arte naquilo que dizia respeito ao tema da pesquisa em cada um desses âmbitos: através da participação e apresentação de trabalhos em congressos e encontros científicos ${ }^{2}$; inserção em grupos de pesquisa $^{3}$ e, por fim, através da vivência em estágio doutoral nos EUA. Este último foi realizado no Massachusetts Institute of Technology (MIT), durante o período de 12 meses (outubro de 2014 a setembro de 2015), sob supervisão da prof. Dra. Nazli Choucri, especificamente no Political Science Department, o que possibilitou uma intensa e fértil interlocução com a referida pesquisadora e outros estudiosos vinculados a este conceituado centro de pesquisa estadunidense sobre ciberpolítica e relações internacionais. Uma vez que o MIT possui diversos convênios e projetos ${ }^{4}$ com a Harvard University, essa vivência também se estendeu a esta universidade.

O conjunto desses espaços de interlocução possibilitou identificar e amadurecer as categorias de efeitos e estabelecer indicadores operacionalizáveis, testando-os e colocando-os à prova no decorrer do percurso científico.

\subsection{ESTRUTURA DA TESE}

Para concretizar o estudo proposto, esta pesquisa de doutorado tem, além desta Introdução, uma sequência de mais quatro capítulos e a conclusão. O capítulo seguinte (capítulo 2) intitulado Sociedade, Tecnologia e Comunicação Digital, tem como foco trazer

\footnotetext{
${ }^{2}$ II Seminário de Pesquisadores do Centro de Estudos Avançados em Democracia Digital (Salvador, Brasil); V Congresso da Associação Brasileira de Pesquisadores em Comunicação e Política - Compolítica (Curitiba, Brasil); Seminário sobre Cibersecurity (Cambridge, EUA) e International Association for Media and Communication Research (IAMCR) (Montreal, Canadá).

${ }^{3}$ Pesquisadora visitante no projeto sobre Cybersecurity and International Relations, coordenado pela prof. Dra. Nazli Choucri (MIT) e pesquisadora convidada do Grupo de Pesquisa em Política e Tecnologias da Informação e Comunicação (GPOLITICs), coordenado pelo prof. Dr. Sivaldo Pereira da Silva (UFAL/UnB).

${ }^{4}$ Por exemplo: "MIT and Harvard Explorations in Cyber International Relations (ECIR)".
} 
discussões basilares necessárias para suportar as análises que se desenvolverão, clareando alguns pressupostos. A relação entre sociedade e tecnologia, especificamente temas que envolvem questões como o quanto a tecnologia influencia ou é influenciada pelo social, será uma primeira discussão do capítulo. Em seguida, delineia-se o que se compreende por comunicação digital, fenômeno que está no cerne da análise proposta nesta pesquisa, apontando suas origens, características e peculiaridades. O capítulo encerra-se identificando o lugar da comunicação digital e seus impactos nas práticas sociais.

Com a discussão de base efetivada, o capítulo 3, denominado Comunicação digital $e$ Relações Internacionais, analisa de forma mais concentrada o fenômeno comunicacional online para o campo das RI. Neste momento, analisa-se como algumas abordagens teóricas das Relações Internacionais têm interseccionado com a comunicação digital. Em seguida, são identificadas e caracterizadas as principais ênfases de pesquisa atualmente desenvolvidas sobre este fenômeno no campo das Relações Internacionais, situando avanços e vácuos no estudo sobre o tema proposto. A relação entre atores não-estatais, cyberpower e o cenário internacional encerra este momento da discussão, construindo assim as pontes necessárias para adentrar no tema do ativismo na sequência.

O capítulo 4, intitulado Ativismo transnacional e a comunicação digital, afunila a análise delimitando primeiramente a concepção de ativismo e suas dimensões fundamentais. Em seguida, estabelece-se seu lugar nas relações de poder com os Estados contemporâneos e então configura-se as principais teorias sobre ativismo a fim de compreendermos a dinâmica deste fenômeno para ao final situá-lo em sua forma transnacional. A partir das análises e argumentos levantados, são identificados os principais efeitos da comunicação digital nos processos do ativismo transnacional, através de cinco categorias analíticas.

Por fim, para testar, enquadrar e vislumbrar de modo mais concreto as categorias analíticas elencadas, o capítulo 5 dedicou-se a estudar os três casos (Al-Qaeda, WikiLeaks e Primavera Árabe). Para tanto, neste último capítulo são delineados os parâmetros metodológicos adotados, baseados principalmente na configuração de indicadores qualitativos aplicados e a análise propriamente dita em cada um dos casos estipulados. O cruzamento dos indicadores a partir dos três casos é trazido na última seção, apresentando entendimentos mais amplos sobre os elementos elencados. 


\section{SOCIEDADE, TECNOLOGIA E COMUNICAÇÃO DIGITAL}

Este capítulo tem como objetivo delinear conceitos de fundo que servem como ponto de partida para alicerçarmos o desenvolvimento subsequente desta pesquisa de doutoramento. Para isso, primeiramente discutem-se conceitos basilares sobre o binômio sociedade e tecnologia, especificamente aqueles que abordam como a tecnologia influencia ou é influenciada pelo domínio social. O pressuposto é que o fenômeno do ativismo transnacional - foco desta pesquisa - está inevitavelmente vinculado às práticas sociais, uma vez que essas últimas consequentemente influenciam as ações políticas coletivas.

Em seguida, com este debate de fundo desenhado, a seção posterior busca conceituar e caracterizar o que se compreende por "comunicação digital", fenômeno que está no cerne da análise proposta nesta pesquisa. Por se tratar de um tema complexo que envolve questões técnicas geralmente não trabalhadas por áreas como Relações Internacionais, o entendimento sobre o modo de funcionamento do que vem sendo chamado de ciberespaço é de fundamental importância para uma verdadeira compreensão da dinâmica de apropriação social e política das ferramentas digitais de comunicação. Nesta seção, o intuito não é fazer uma discussão tecnicista e sim uma análise dos aspectos técnicos e conceituais que tocam diretamente no campo das Ciências Humanas.

Por fim, com essas duas bases conceituais pressupostas, este capítulo se encerra ao sintetizar e elencar como a comunicação digital repercute nas práticas sociais contemporâneas. Isto é útil para pactuarmos algumas premissas. Estas também servem como insumos teóricos eventualmente mencionados nos capítulos posteriores, propiciando assim um aporte inicial necessário para o devido entendimento mais completo do fenômeno em análise.

\subsection{SOCIEDADE E TECNOLOGIA}

Nas reflexões sobre tecnologias da comunicação, tal como a Internet, é relevante analisar como a apropriação social interage com a tecnologia, isto é, como as pessoas usam, aperfeiçoam, exploram, adaptam, e, provavelmente, moldam a tecnologia ou são moldados por esta. Aprofundando sobre esta interação são levantadas algumas questões acerca dos limites de influência entre os objetos técnicos e práticas sociais, a exemplo de como Carr (2009, p. 5) elenca: "How does technology impact upon social structures? How and why do 
social groups seek to shape technology?" Diferentes respostas direcionam a diferentes perspectivas. Assim, abordagens aproximando sociedade e tecnologia são apresentadas aqui para uma melhor compreensão da importância e papel do ciberespaço nos assuntos globais e auxiliam a vincular apropriadamente a comunicação digital ao ativismo transnacional, linha de horizonte desta pesquisa.

A discussão sobre os impactos da tecnologia nos diversos campos da vida social como cultura, política, economia etc. - pode parecer especialmente contemporânea. Porém, trata-se na verdade de um debate de longa data. É possível encontrar suas raízes ainda na Antiguidade, em torno do conceito grego de techné (o "fazer prático"), chegando à Modernidade através de campos de estudo como Filosofia e Sociologia da Técnica. Essa discussão é intensificada principalmente a partir do século XX através de diversos autores considerados já clássicos nesta área como Heidegger (2001), Habermas (1987), Stiegler, (1994), Leroi-Gourhan (1964) e Heilbroner (1969). A título de recorte, interessa-nos manter o foco na discussão mais vinculada aos objetivos deste capítulo, isto é, sobre como a tecnologia molda as práticas sociais e vice-versa. Dentro desse escopo, levou-se a análise mais especificamente para a relação entre técnica e relações internacionais, bem como sobre técnica e comunicação.

Ao analisarmos a relação entre técnica e sociedade duas visões distintas preponderaram historicamente, resultando em um debate polarizado entre o que se convenciou chamar de (a) Determinismo tecnológico, de um lado, e (b) Construtivismo social, do outro. Determinismo tecnológico é o termo utilizado para caracterizar uma visão de mundo onde os artefatos técnicos são vistos como condicionantes da condição humana, atribuindolhes um certo grau de autonomia e poder inerentes. Smith e Marx (1994) explicam que a crença na tecnologia como a chave que governa as forças em uma sociedade tem suas origens nos primeiros estágios da Revolução Industrial:

Inspired by their contacts with the great inventions of the age, writers and
artists often purposely endowed steamboats, railway locomotives,
machinery, and other inanimate objectes with life-like qualities in order to
cultivate emotions of wonderment, awe, magic, and, at times, even dread in
their audiences. The discovery of what cultural historians would later call the
"technological sublime" added yet another dimension to the growing popular
belief in technology's power to shape the course of human history (SMITH;
MARX, 1994, p. 8).

Esta ênfase no poder sublime da tecnologia sobreviveu ao tempo e alcançou o século XXI. Tal perspectiva não permaneceu apenas como uma visão positivista: a concepção do 
artefato técnico como um objeto exógeno capaz de alterar os rumos da humanidade também ganhou ares distópicos, e as grandes invenções tecnológicas do século $\mathrm{XX}$, como a bomba nuclear, são um bom exemplo disso. Seja de forma positiva ou negativa, nesta visão as inovações tecnológicas seriam responsáveis por injetar uma maior influência na evolução social do que qualquer outro fator (SMITH; MARX, 1994).

O termo "determinismo tecnológico" não deve ser compreendido como uma corrente na qual autores se filiam. Trata-se, na verdade, de uma terminologia cunhada no século XX para caracterizar posicionamentos (e autores) que tentam explicar os fenômenos sociais através dos artefatos técnicos, dando a estes um papel e poder central, com uma certa independência e um certo caráter quase transcendental. Nesta crítica, concentrar-se no objeto técnico seria um reducionismo. Além disso, grande parte dos autores enquadrados como "deterministas tecnológicos" não qualificariam a si próprios com esta nomenclatura. Isto porque tal denominação surgiu em grande parte imbuída de críticas.

No campo da comunicação um exemplo de autor cuja obra é comumente qualificada como determinismo tecnológico é Marshall McLuhan (1996). Dentre outros temas sobre indústria cultural, ele trabalhou a ideia de que os meios de comunicação seriam extensões do homem e se interessou especificamente pelos efeitos culturais desta concepção. Para críticos como Raymond Williams (WILLIAMS, 1974), a abordagem de McLuhan (1996) seria incorreta pois trataria a cultura a as práticas sociais como um fenômeno meramente reduzido a uma relação de causa-efeito onde a tecnologia aparecia como o elemento determinante per si. Isso seria uma simplificação, pois ignoraria os fatores que estão para além do artefato técnico (cultura, política, economia etc.), o que colocaria o objeto técnico em uma posição determinística e como artefato exógeno e independente.

Fritsch (2011) argumenta que a prática tecnológica, ou sistema tecnológico, envolve três aspectos que se triangulam para um amplo entendimento da tecnologia: são os aspectos culturais, organizacionais e técnicos. Deste modo, a definição mais restrita, bastante criticada do determinismo, ignoraria os aspectos "softs" culturais e organizacionais, focando apenas na técnica. Segundo o autor, os aspectos culturais envolvem metas; normas e códigos éticos; crença no progresso; consciência e criatividade. Os aspectos organizacionais, por sua vez, abrangem atividades econômicas e industriais; atividades profissionais; consumidores e usuários; e uniões de trabalhadores (FRITSCH, 2011).

Se por um lado a ênfase na centralidade da tecnologia é bastante comum e difundida, outras análises deslocarão este foco colocando nas interações sociais um maior peso. É o caso do construtivismo social. Nesta perspectiva, a tecnologia é vista como socialmente construída 
e inteiramente dependente das interações de indivíduos e grupos, bem como de suas reinterpretações (CARR, 2009; FRITSCH, 2012; RADU, 2014; HUGHES, 1994). Carr (2009) utiliza este conceito para explicar que as tecnologias são apenas compreendidas "in the context of social and political forces at work which influence choices and preferences" (CARR, 2009, p 8). Igualmente, Fritsch (2011) enfatiza que a tecnologia não pode ser concebida como um valor-neutro, uma vez que ela encoraja certos interesses sociais e parcialmente favorece alguns grupos sociais em detrimento de outros.

Carr (2009) rejeita o entendimento da tecnologia como um instrumento neutro para resolver problemas ou como uma força que ameaça a autonomia humana. Nessa mesma esteira, Fritsch (2011) adiciona que a tecnologia ao invés de resolver problemas socioeconômicos, tem sido uma fonte para novos problemas. Inclusive, Carr (2009) acredita que mais do que guiado por problemas ou oportunidades específicas, o desenvolvimento das tecnologias é moldado por preferências culturais, poder político e distribuição financeira.

No entendimento da apropriação social da técnica por atores sociais, estes seriam responsáveis por conferirem significado a um artefato; determinariam os desenhos dos objetos técnicos; prevalecendo aquelas formas técnicas capazes de resolver os problemas identificados pelos grupos sociais ou capazes de se adequar aos desejos destes. Segundo Hughes (1994), a ressalva está, porém, no fato de que esses grupos sociais não são representativos da sociedade, mas são tidos como relevantes em seu tempo histórico. Através da abordagem desenvolvida por Carr (2009), fica evidente a preponderância de determinados grupos sociais nesse processo, o que significa que não há necessariamente a participação da sociedade como um todo nas escolhas e caminhos da apropriação técnica. De certo modo, isso explica que o construtivismo não é ingênuo, mas acredita que por condições históricas, políticas e culturais a saliência de determinados grupos pode nortear o contexto maior, que envolve por sua vez a tecnologia.

Notadamente pendente ao construtivismo social, Carr (2009) e sua abordagem intitulada "the Social Construction of Technology (SCOT)" diferenciar-se-ia do enfoque técnico através de quatro conceitos: 1. "Interpretative flexibility": refere-se ao entendimento de que haveria alternativas para desenhar uma determinada tecnologia; 2. "Closure": A tecnologia não seria criada para resolver problemas, já que o problema só existiria na medida em que um relevante grupo social acreditasse nisso; 3. "Reverse salient": Os sistemas não seriam pré-determinados para ter sucesso ou sobrevivência; e 4. "Relevant social group": Identificaria qual é este grupo e como ele influenciaria e moldaria a tecnologia.

Sobre o papel da tecnologia nas análises das Relações Internacionais (RI), autores 
como Fritsch (2011) e Carr (2009) concordam que há certo gap na área. Ainda assim, segundo Fritsch (2011), a abordagem determinística da tecnologia tende a ser escolhida quando a tecnologia é trazida para o campo das RI: "Technology, often narrowly defined as material artifact, is considered to influence actors and interaction patterns by more or less being "added" to the structures, actors and processes that make up the study of global affairs" (FRITSCH, 2011, p. 28). Uma das razões pela qual as RI não têm assimilado completamente a emergência da perspectiva social da tecnologia está relacionada ao seu tradicional foco teórico no poder material e na centralidade do Estado (CARR, 2009).

Atualmente, o desenvolvimento de novos sistemas de tecnologia é altamente relacionado ao sistema global - não apenas local -, de tal modo que remodela questões internacionais e vice-versa, em uma concepção construtivista (CARR, 2009). Fristsch (2011) explica este papel global da tecnologia ao afirmar que:

\begin{abstract}
Although technological evolution often begins within a national context, new technologies quickly diffuse throughout the system and begin to change the system as well as the units (Deudney 1993, 2000). [...] The driving forces behind the growing interaction between members of society are means of communication and transmission, which sharply reduce time and space constraints for societal interaction processes and increase a society's over-all density (203) (FRITSCH, 2011, p. 34).
\end{abstract}

Embora a perspectiva construtivista deva ser levada em conta como um contraponto importante ao determinismo tecnológico, apontando suas fragilidades, alguns autores também identificarão uma forma de determinismo na perspectiva construtivista: O determinismo social, isto é, a ênfase de que forças sociais seriam sempre preponderantes na relação entre técnica e sociedade (HUGHES, 1994; FRITSCH, 2011) relegando o papel do artefato técnico a um plano demasiado secundário. Outras críticas direcionadas à grande parte da perspectiva construtivista são: ignorar a existência de um amplo alcance da tecnologia; representar a tecnologia como apenas um resultado materializado de estruturas políticas, econômicas, culturais e de poder (FRITSCH, 2011); enfatizar as determinantes sociais dentro do processo de invenção ou inovação, assim como no modo em que a tecnologia é usada.

Buscando solucionar os limites do determinismo, diversos autores se propõem a apontar alternativas conceituais a respeito deste debate entre construtivismo e determinismo tecnológico, justamente por acreditarem que tal dicotomia não seria suficiente para um entendimento mais completo da relação entre tecnologia e sociedade. Por exemplo, tangente 
as RI ou com foco nas tecnologias de informação, temos os conceitos de meio-termo ${ }^{5}$ (FRITSCH, 2011), da abordagem sociotecnológica ${ }^{6}$ (RADU, 2014), do ecossistema ciberfísico-social $^{7}$ (SHI; ZHUGE, 2010) como alguns dos exemplos mais proeminentes de terceiras vias. Embora todos essas abordagens tragam contribuições relevantes para o debate, em sua maioria significam, na prática, pouca variação da vertente construtivista.

Em meio a essas alternativas, o conceito de momentum tecnológico de Hughes (1994) traz algo de novo e contribui para avanços neste debate. $\mathrm{O}$ autor trata da complexa correlação entre tecnologia e sociedade, reforçados mutuamente, mas não a coloca como uma relação simétrica fixa sobre a linha do tempo, já que a evolução do sistema tecnológico e seu papel são diretamente afetados pela variável cronológica. Segundo o autor:

Technological momentum offers an alternative to technological determinism and social construction. Those who in the past espoused a technological determinist approach to history offered a needed corrective to the conventional interpretation of history that virtually ignored the role of technology in effecting social change. Those who more recently advocated a social construction approach provided an invaluable corrective to an interpretation of history that encouraged a passive attitude toward an overwhelming technology. Yet both approaches suffer from a failure to encompass the complexity of technological change (HUGHES, 1994, p. 102).

Tecnologias e seus usuários são concebidos como parte do mesmo processo, o qual embora seja uma complexa construção mútua, é possível analisar cada parte do processo sem se orientar por uma abordagem determinística, seja esta social ou tecnológica. Esta é justamente a proposta conceitual do momentum tecnológico.

Hughes (1994) considera que ambas interpretações falham em lidar com a complexidade trazida pelas mudanças tecnológicas. Esta abordagem não negligencia o papel

\footnotetext{
${ }^{5} \mathrm{O}$ meio-termo de Fritsch (2011) considera tanto a agência humana quanto a tecnologia como imperativos, portanto a tecnologia não é um valor neutro e também atua em algum nível de determinismo. "It [technology] always promotes the interests of certain social groups, while neglecting the interests or rights of others. [...] Technology is not different or distinct from any other social phenomena. It is part of our social reality and only gains meaning when described and interpreted in social terms" (FRITSCH, 2011, p. 31).

A abordagem sociotecnológica de Radu (2014) enfatiza o modo como a tecnologia é alterada através de escolhas sociais, as quais refletem, por sua vez, relações de poder. Isto enfatiza o papel condicionante do meio social sobre a tecnologia: "[...] the sociotechnologic approach has highlighted that the dynamics of technological change are potentiated by collective and individual choices and reflect underlying power relations (Law and Bijker 1992, Williams and Edge 1996)" (RADU, 2014, p. 6).

${ }^{7} \mathrm{O}$ ecossistema ciber-físico-sociedade, alternativa assim chamada por Shi e Zhuge (2010), é compreendido como um sistema dinâmico que envolve a natureza, a tecnologia da informação, e as leis culturais, econômicas e sociais: "Cyber Physical Society will execute according to social law, economic laws and information technology. Service flow, knowledge flow, information flow, energy flow, material flow and value flow implement the function of the Cyber Physical Society “(SHI; ZHUGE, 2010, p. 976).
} 
da tecnologia em sua capacidade de afetar a mudança social e também não coloca as forças sociais em postura de submissão ao poder do artefato técnico. Tal concepção está numa posição intermediária entre as duas concepções tradicionais, numa tentativa de abarcar os méritos e evitar as fragilidades de ambas as perspectivas. Tal como Hughes (1994) afirma:

Therefore, the momentum of technological systems is a concept that I can be located somewhere between the poles of technical determinism and social constructivism. The social constructivists have a key to understanding the behavior of young systems; technical determinists come into their own with the mature ones. Technological momentum, however, provides a more flexible mode of interpretation and one that is in accord with the history of large systems (HUGHES, 1994, p. 112).

Nestes termos, a concepção de momentum tecnológico é um conceito útil para compreender esta mútua influência entre tecnologia e sociedade, dando um passo adiante do debate polarizado-dualista:

Technological momentum infers that social development shapes and is shaped by technology [...] The interaction of technological systems and society is not symmetrical over time. Evolving technological systems are time dependent. [...] Technological momentum, however, provides a more flexible mode of interpretation and one that is in accord with the history of large systems [...] A technological system can be both a cause and an effect; it can shape or be shaped by society. As they grow larger and more complex, systems tend to be more shaping of society and less shaped by it (HUGHES, 1994, p. 108).

Seria possível tensionar o argumento de Hughes acusando-o de incorrer no mesmo erro que ele mesmo aponta nos construtivistas e deterministas tecnológicos: Ser essencialmente determinista. Isso ocorreria devido à interpretação de que a sua explanação recolocaria, na prática, a tecnologia novamente como ente autônomo, em um dado tempo histórico, ou a preponderância social sobre a tecnologia, em outro. Porém, segundo Hughes (1994), sua perspectiva consiste em um conceito integrado que concede igual peso entre forças sociais e técnicas. Ele aponta as diferenças entre sistemas tecnológicos novos e sistemas mais maduros, revelando serem estes últimos mais independentes de influências externas (mas não totalmente isentos destas), e portanto, mais deterministas em sua natureza em momentos específicos da história (HUGHES, 1994). Não se trata de ver os objetos técnicos como artefatos exógenos à influência social (este sim é o principal problema do determinismo tecnológico), mas como algo resultante da própria relação entre inovação técnica e influências sociais, ou seja, o objeto seria uma reificação de concepções sociais, 
políticas ou culturais que estão incorporadas no design e modos de apropriação das ferramentas. Isso não quer dizer que esteja se comportando de maneira puramente determinística uma vez que o objeto técnico e seu potencial de influência é um fenômeno configurado na fronteira da projeção e apropriação social, de um lado, e a sua maturidade técnica, do outro. Objetos que ganham em maturidade técnica passam a ser mais diluídos na prática social e podem ser mais influentes. Por exemplo, enquanto a tecnologia da Internet não atingia a sua maturidade estava restrita a um grupo delimitado de agentes (engenheiros, militares, cientistas etc.) e a sua forma estava sendo moldada pelas escolhas, descobertas e caminhos adotados por este conjunto de atores. A partir do momento que a Internet se expande para o uso social mais amplo e se torna mais madura enquanto ferramenta, esta passa a ser um importante artefato capaz de moldar a forma como nos relacionamos e agimos nos diversos campos da ação humana (social, político, cultural, econômico, estético etc.). Mas não quer dizer que a Internet será sempre um fator determinante das nossas práticas cotidianas: a própria apropriação social também pode remodelar a ferramenta e gerar novas ondas de inovação e demandas capazes de alterar o modo como esta tecnologia existe.

Considerando a discussão apresentada nesta seção e o objetivo da presente pesquisa, observa-se que a tecnologia não pode ser naturalizada como uma entidade autônoma fixa, tal qual a mais restrita ${ }^{8}$ perspectiva do determinismo tecnológico presume. É um equívoco considerar a preponderância determinística a priori, seja pelo vetor sociedade, seja pelo vetor tecnologia. Porque não se trata de uma relação mono-direcional e fixa sobre o tempo. Por outro lado, também seria ingênuo acreditar que os objetos técnicos são sempre dependentes dos nossos direcionamentos enquanto sociedade. Estes podem tanto assumir uma maturidade se transformando em sistemas semi-autônomos ao se enraizarem na cultura (influenciando-a, pois altera a nossa relação social e física com o mundo), como também podem ter seus projetos técnicos reapropriados a depender das forças e contextos sociais. Neste sentido, a concepção de "formas de uso" de Salter (2004) é bastante útil para compreendermos a relação entre projeto técnico e apropriação social:

The concept of forms of use relates to the idea that technologies are developed with a particular use in mind. The 'use' corresponds to a 'need' that the technology aims to fulfil, and the need is in turn formulated by particular interests. Often technologies are developed that can be used in ways that were not intended (p. 186)

\footnotetext{
${ }^{8}$ Vale ressalvar que a expressão "restrita" serve para não recair em generalizações, dado que há diversos autores que, apesar de colocarem a tecnologia em um papel central, não a consideram um valor neutro.
} 
Paradoxalmente, a tentativa de evitar uma visão determinista - seja de um lado, seja de outro - tem prejudicado ambas abordagens quanto à completa compreensão sobre o complexo papel da tecnologia na sociedade e vice-versa. Isto inibe avanços mais assertivos tocantes a esta relação.

Quando assumimos que tecnologia e sociedade apresentam uma relação inseparável e intrínseca, podendo haver maior ou menor influência de um sobre o outro a depender da linha do tempo, não se nega a tecnologia como um produto intrinsecamente social, embora também se reconheça a aquisição de certo grau de autonomia ${ }^{9}$ da tecnologia em momentos específicos do processo histórico. A premissa desta pesquisa é de que a tecnologia é capaz de se enraizar e influenciar as práticas sociais, culturais e políticas enquanto um produto da sociedade, e não como um elemento exógeno. Por isso, a tecnologia pode influenciar as práticas sociais e também ser influenciada por estas.

Analisar o papel das ferramentas de tecnologia da comunicação no ativismo transnacional é uma aplicação prática do momentum tecnológico. A partir desta abordagem podemos melhor compreender os usos sociais da Internet por grupos políticos. Por um lado, tal abordagem ajuda a clarear o modo no qual o domínio social influencia os usos da tecnologia em ações políticas como o ativismo transnacional. De outro lado, reconhece-se o poder da tecnologia sobre as práticas políticas durante determinado tempo específico na história. Mas a apropriação e ressignificação dessas ferramentas podem gerar um novo momentum pois não se trata de uma relação fixa no tempo.

De todo modo, quando se propõe nesta tese analisar os efeitos da comunicação digital no ativismo transnacional não estamos falando simplesmente dos efeitos do objeto tecnológico nas práticas políticas. Na verdade, a comunicação digital não é o artefato: é o fenômeno social (a comunicação) que existe através do artefato digital. Tendo isto como pano de fundo, na próxima seção buscar-se-á compreender melhor o que significa falar em comunicação digital: Como surgiu, quais os seus principais aspectos e modo de funcionamento. Isso será útil para deliminar melhor o fenômeno analisado nesta tese e propiciará insumos teóricos úteis para uma análise mais sólida sobre o fenômeno em estudo.

\footnotetext{
${ }^{9}$ Autonomia não enquanto objeto exógeno à vida social, mas enquanto objeto socialmente construído capaz de encaixar as nossas ações em parâmetros pré-definidos.
} 


\subsection{COMUNICAÇÃO DIGITAL: ORIGENS E CARACTERÍSTICAS}

$\mathrm{Na}$ órbita semântica da expressão "comunicação digital", outras terminologias serão utilizadas nesta pesquisa, tais como "ciberespaço" (cyberspace), "world wide web" (ou simplesmente web), “Tecnologias da Informação e Comunicação (TICs)”. Para avançarmos, convém agora delimitar melhor estas concepções esclarecendo-as e correlacionando-as para que possamos compreender o que significa falar no fenômeno da "comunicação digital", compreendendo seus mecanismos de funcionamento.

Para pactuar uma compreensão mais sólida sobre o que se entende por comunicação digital e quais as suas características precisamos primeiramente situar o surgimento e o modo de funcionamento daquilo que hoje chamamos de Internet.

O desenvolvimento da Internet está intimamente ligado a um contexto bastante emblemático da História das Relações Internacionais: A Guerra Fria. Ao final dos anos de 1950 e início dos anos de 1960, os Estados Unidos se engajaram no avanço científico e tecnológico que, dentre diversas razões, tinha também como motivação fazer contraponto ao Sputnik, o primeiro satélite artificial da Terra lançado pela União Soviética ao final de 1957 (KLEINROCK, 2010; CARR, 2009; CONGRESSIONAL, 2007).

A preocupação em sofisticar a tecnologia militar conduziu em 1958 ao desenvolvimento de uma agência vinculada ao governo estadunidense, inicialmente nomeada como Advanced Research Projects Agency (ARPA) ${ }^{10}$ (CARR, 2009; KLEINROCK, 2010). Alguns pesquisadores deste órgão vislumbraram o potencial de aprofundar parcerias com universidades e centros de pesquisa dos Estados Unidos, de modo que esta aproximação acadêmica foi essencial para o avanço do projeto (CONGRESSIONAL, 2007). Paralelamente, alguns pequisadores, dentre eles Paul Baran ${ }^{11}$, se envolveram em projetos para US Air Force no intuito de fortalecer a estrutura de telecomunicações no caso de um ataque nuclear pela União Soviética (CONGRESSIONAL, 2007; KLEINROCK, 2010). O modelo de rede distribuída, desenvolvido por Baran como parte da solução, ficou conhecido como "packet switching" (CONGRESSIONAL, 2007) ${ }^{12}$. A grande inovação trazida por este modelo, frente

\footnotetext{
${ }^{10}$ ARPA foi renomeado para Defense Advanced Research Projects Agency (DARPA) em 1972 (KLEINROCK, 2010).

${ }^{11}$ Paul Baran nasceu na Polônia e foi radicado nos EUA ainda criança na década de 1920. Trata-se de um dos cientistas que contribuiu para a adoção do modelo de comunicação em rede através da comutação de pacotes de dados. Ele faleceu em 2011.

${ }^{12}$ Por causa da relação com a criação e aplicação do modelo packet switching para as comunicações militares, Kleinrock (2010) explica o mito difundido de que a ARPANET teria sido criada para proteger os EUA em caso de um ataque nuclear. Embora a pesquisa no âmbito militar seja um elemento importante, a contextualização histórica desta seção demonstra que o processo foi mais amplo e só foi possível criar a tecnologia que deu
} 
ao conhecido circuit switching usado na rede telefônica, deve-se à possibilidade de ser utilizado apenas quando há envio de dados, sem criar um longo e desnecessário vácuo na estrutura quando esta se encontra inerte.

Vinton Cerf (2009, p. 1202), a quem se atribui a criação no nome Internet, explica didaticamente o packet switching através da analogia com a rotina do carteiro:

Packets are like electronic postcards with 'to' and 'from' addresses and a little text. They share communication paths the way postcards share space in a postman's van. This turns out to be more efficient for many short-lived interactions than dedicating capacity as in the telephone network with 'circuit switching'.

Tecnicamente, o packet switching descentraliza a forma como a informação é compartilhada, tornando-a mais distribuída. Ou seja, enquanto gera mais independência entre as partes, este modelo não compromete todo o sistema caso uma das conexões da rede esteja inviabilizada. Na passagem a seguir é possível observar mais especificamente este processo:

Packet switching is an approach that breaks a message down into separate, discrete pieces or packets. Each packet then moves from its point of origin to its destination over any open route, regardless of which path the other packets take. When all the packets arrive at the destination they are reassembled - and the message is delivered intact (CONGRESSIONAL, 2007, p. 35).

Para agrupar os diferentes esforços (do projeto ARPA e de outras iniciativas de centros de pesquisa) para desenvolver uma forma de comunicação em rede, deu-se origem em 1969 à rede ARPANET. A ARPANET tratava-se de um projeto financiado pelo Departamento de Defesa dos Estados Unidos e que consistia na conexão em rede entre alguns computadores através do Interface Message Processors (IMPs) (CONGRESSIONAL, 2007; KLEINROCK, 2010; NYE, 2010; BELOW, 2014).

Em outubro do mesmo ano de criação da ARPANET, a primeira mensagem "host-tohost" foi realizada a partir de Stanford Research Institute (SRI) para a University of California, Los Angeles (UCLA). O procedimento previa o envio da palavra "login", mas a conexão caiu após terem sido enviadas as letras "l"e "o" (HATHAWAY; KLIMBURG, 2012;

origem à ARPANET, e posteriormente à Internet, a partir do envolvimento de diversos atores (para além do círculo militar) e, portanto, apresenta mais complexidade do que apenas restritamente capacitar os EUA com um seguro sistema de comunicações diante de um eventual ataque militar (embora isso deva ser considerado também como parte do processo). 
KLEINROCK, 2010; CERF, 2009). O registro dessa primeira transmissão via Internet está na Figura 1:

Figura 1 - Registro da primeira mensagem transmitida pela Internet em 1969

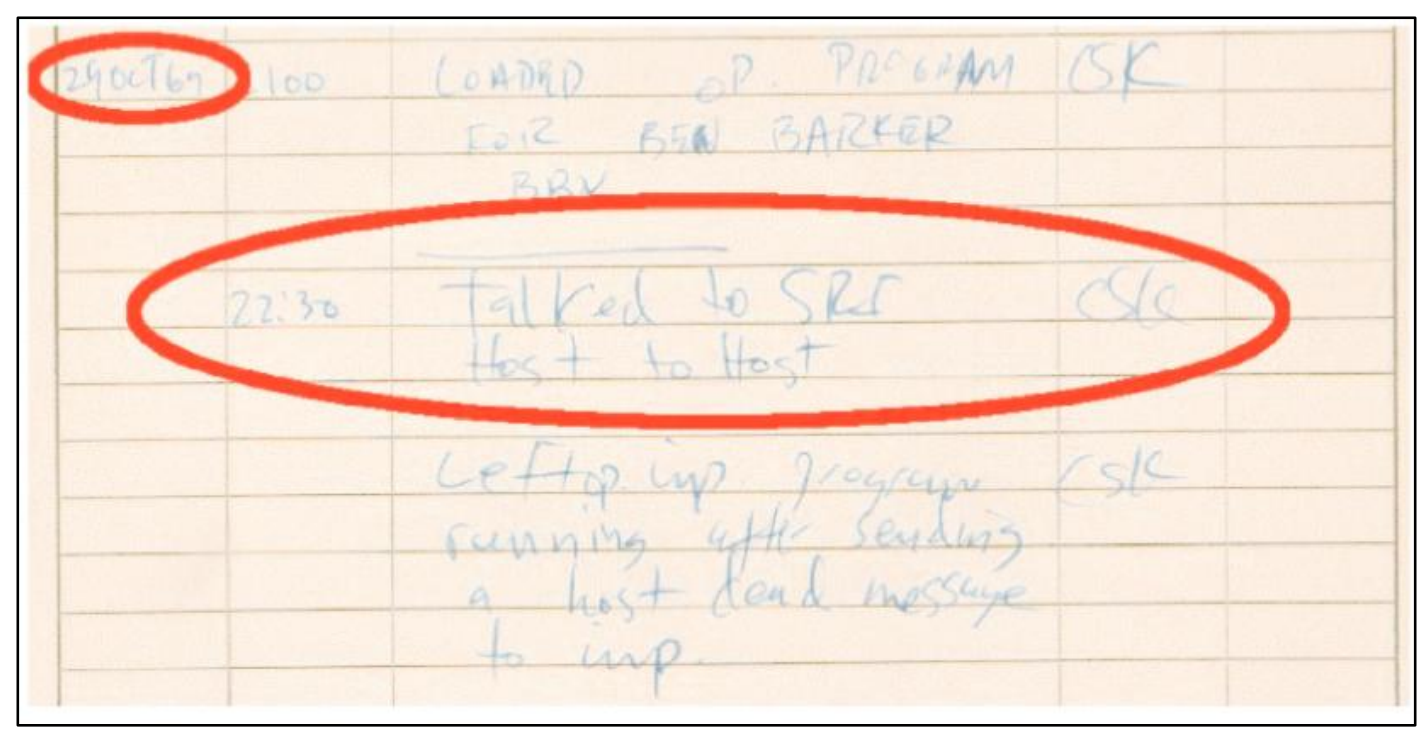

(Fonte: KLEINROCK, 2010, p. 32)

Este sistema inicial foi incrementado com o código de troca de dados chamado "Transmission Control Protocol/Internet Protocol" TCP/IP desenvolvido por Cerf e Robert Kahn em 1972 (NYE, 2010; CARR, 2009). Ainda que houvesse alternativas para o modelo de tecnologia adotado, TCP/IP foi escolhido justamente pela sua arquitetura aberta a inovações tecnológicas:

Superficially, the development and implementation of TCP/IP technology to address DARPA's priority of providing a more robust communications system can be understood within the paradigm of nation-state power. However, throughout this design phase, security of the network and accountability appear to have been low priorities - possibly due to the fact that access was restricted to defense, science and academia. TCP/IP was conceptualised from the beginning as an open and flexible architecture which ultimately provides a rich environment for both innovation and exploitation (CARR, 2009, p. 21).

Do ponto de vista operacional, a Internet funciona da seguinte maneira: A partir de um computador conectado à rede, um conteúdo a ser enviado é convertido em unidades de informação, denominados pacote de dados packets $^{13}$, que carregam em média 1000 a 2000 bytes), esses dados são enviados para um ou mais computadores destinatários também conectados a Internet (CLARK, 2004). A Internet é composta por links conectados por

\footnotetext{
13 "Packet: a unit of information, typically no more than 1000 to 2000 bytes, with a series of headers at the front, that is transmitted across the Internet from a source to one or more destination" (CLARK, 2004, p. 16).
} 
routers ${ }^{14}$, os quais determinam para onde encaminhar os pacotes de dados em trânsito. $\mathrm{O}$ processo de entrega dos dados é chamado de datagram delivery (CLARK, 2004). Geralmente usa-se um software com o intuito de "quebrar" os dados em pacotes para serem transportados um de cada vez. O Transmission Control Protocol (TCP) é o software mais comum usado para esse fim e possui um serviço chamado de circuito virtual.

A característica de best effort, ou melhor esforço, da Internet significa se comprometer em desempenhar o melhor compartilhamento de dados a depender das condições que favoreçam a qualidade deste serviço. Pode haver atrasos, perda de dados, entrega de dados fora de ordem, mas o serviço não deixará de ser fornecido:

The basic service model for packet delivery is very simple. It contains two parts: the addresses and the delivery contract. To implement addressing, the Internet has numbers that identify end points, similar to the telephone system, and the sender identifies the destination of a communication using these numbers. The delivery contract specifies what the sender can expect when it hands data over to the Internet for delivery. The original delivery contract of the Internet is that the Internet will do its best to deliver all the data given to it for carriage, but makes no commitment as to data rate, delivery delay, or loss rates. This service is called the best effort delivery model (CLARK, 2004, p. 2).

As duas grandes vantagens desse modelo são: (1) O fato de que uma variedade grande de tecnologias poder ser utilizada, apenas com um pré-requisito técnico mínimo para prestar o serviço; (2) e a garantia da prestação do serviço, ainda que de baixa qualidade (já que é melhor do que nenhum serviço), além do fato de que caberia ao sujeito determinar o que é baixa ou alta qualidade, e não a Internet ou uma máquina.

Para entender mais especificamente o funcionamento da Internet, Clark (2004) explica o exemplo simples e rotineiro de acessar uma webpage por um usuário:

When a user wants to retrieve a web page, the software must first consult the
Domain Name System (discussed above) to translate the string (for example)
"www.ana.lcs.mit.edu" into an Internet address, which will be the Web
server storing the page "papers/this-document.html". The software at the
user's computer (the so-called "browser") then opens a TCP connection to
the server machine, and sends a retrieval request that contains, among other
things, the string "papers/this-document.html". There is a protocol called
HyperText Transfer Protocol, or HTTP, that provides the rules and format
for messages requesting a Web page. The server, on receiving the HTTP
request with the name "papers/this- document.html", finds the matching file

14 "Router: the physical device (typically a computer with special software) that connects communication links together to form the Internet, and forwards packets from one link to the next" (CLARK, 2004, p. 16). 
on its disk, and passes that file through the software that implements HTTP and down to the software that implements TCP. The TCP software breaks the file into packets, as described above, and sends these packets across the Internet. These packets are then re-assembled at the receiving end-node, and the resulting file is handed to the browser software for processing (CLARK, 2004, p. 9-10).

O funcionamento da Internet hoje é resultado de uma escolha ${ }^{15}$ de modelo no momento em que foi criada. A arquitetura end-to-end, que significa relegar o complexo controle da rede para os end nodes ${ }^{16}$, foi definida em seus primeiros anos de criação, decisão crucial para impedir a centralização de seu controle (BELOW, 2014). Nas palavras de Cerf (2009) "the Internet persists because it is an architecture for interoperability rather than a fixed set of networks" (p. 1203). Trata-se, em suma, de uma rede de redes, que compartilha protocolos digitais para que computadores e diversos tipos de outros equipamentos similares (celulares, tablets etc.) se conectem remotamente. Configurou-se como um serviço de comunicações desenhado para realizar trocas de informação digital através da conexão entre computadores (CLARK, 2004).

Clark (2004) esclarece que a Internet não pode ser equiparada ao rádio ou à fibra óptica simplesmente, já que não é uma tecnologia de comunicação específica, uma vez que foi feita para abrigar novas tecnologias e diferentes fins, conforme são desenvolvidas novas pesquisas e usos:

The Internet is a network designed to support a range of applications, depending on what software is loaded into the attached computers, and what use that software makes of the Internet. Many communication patterns are possible: between pairs of computers, from a server to many clients, or among a group of co-operating computers. The Internet is designed to support all these modes (CLARK, 2004, p. 1).

O desenvolvimento da Internet como uma rede de comunicação - por onde se trafega conteúdos e através da qual se produz interações online via protocolos digitais - gerou um ambiente vivência que passou a ser denominado de ciberespaço. O ciberespaço é um termo metafórico utilizado para falar deste "lugar" de trocas simbólicas, utilizando o simbolismo do espaço de interação cibernética ${ }^{17}$. Tal ideia deve ser entendida sobretudo como uma arena

\footnotetext{
${ }^{15}$ Paralemente ao desenvolvimento da Internet no projeto ARPANET, na França outra iniciativa ganhava fôlego, portanto outros projetos paralelos estavam em andamento quando se adotou o modelo mencionado.

16 "End-node: a computer or other device that is attached to the Internet for the purpose of transmitting and receiving packets and participating in the high-level services of the Internet. A personal computer (PC) is an example of an end-node, as is a Web server" (CLARK, 2004, p. 15).

${ }^{17}$ Originalmente, o termo cyber space nasce na literatura cypherpunk com o livro Neuromance, de William Gibbson, de 1984. Nesta narrativa, aparece como o lugar abstrato de interação social em que indivíduos
} 
digital para interações sociais, políticas, econômicas e culturais acessível à experiência humana através de dispositivos eletrônicos (smartphones, computadores, tablets).

Para Nye (2010), o ciberespaço não se trata de um bem público global devido a três razões: (1) Bem público é aquele que todos podem se beneficiar e ninguém pode ser excluído, e ainda que isto possa descrever o funcionamento dos protocolos de informação da Internet, isto não descreve a infraestrutura física na qual a fonte é escassa e localizada dentro das fronteiras dos Estados e sob suas jurisdições; (2) para que haja governança efetiva do ciberespaço é necessário uma cooperação público-privada, ou seja, um esquema híbrido combinando auto-regulação, controle governamental e capacidades de enforcement; e (3) ciberespaço não é um bem comum tal qual os oceanos porque parte de sua estrutura está sob controle de soberania estatal.

Em realidade, e apesar das ressalvas, ciberespaço é em alguma medida nacional, internacional e transnacional. (a) Nacional porque a estrutura física da Internet permanece atrelada à geografia (e governos exercem soberania sobre esses espaços), de modo que localização ainda importa como um recurso no ciberdomínio (NYE, 2010). (b) Ciberespaço é inerentemente internacional: Ao menos 19 organizações globais e regionais estão ativamente envolvidas na segurança e governança do ciberespaço (CHOUCRI; GOLDSMITH, 2012; KOBRIN, 2001). O World Summit on Information Society (Genebra em 2003 e Túnis em 2005) e outros projetos similares buscam formular princípios comuns básicos, práticas, e prioridades para o ciberdomínio (CHOUCRI; GOLDSMITH, 2012). (c) Ciberespaço é um domínio transnacional, pois as trocas de informações tendem a não respeitar fronteiras dos Estados-nações. Ainda que estes tentem controlá-lo, não conseguem com total efetividade devido à própria dimensão e natureza peculiar da dinâmica deste domínio, desde o surgimento da Internet. Do ponto de vista político, trata-se de um espaço de interações entre diversos atores; um espaço de censura e violência; de tensões globais; de benefícios e oportunidades para ação política (BELLOW, 2014).

Do ponto de vista da estrutura, o ciberespaço funciona através de três camadas principais: Física (fibra óptica, cabos, backbones), lógica (protocolos, web, aplicativos) e informacional (conteúdos) (BENEDIKT, 1991; KOBRIN, 2001; SHI; ZHUGE, 2010; CHOUCRI, 2012; CHOUCRI; CLARK, 2012; HATHAWAY; KLIMBURG, 2012; KELLO, 2013; KREMER; MULLER, 2014; BELOW, 2014). Como explicam Choucri e Clark (2012):

poderiam se conectar através de máquinas (LEMOS, 2010). A partir daí, por analogia, o termo passou a ser utilizado nos estudos sobre Internet para descrevê-la como um espaço de interação social, um cyber space. 
In the layered model the upper layers depend on the functions of the lower layers, but not the opposite. This model is a useful device to (a) locate cyber actors and activities, (b) highlight significant technological changes, (c) identify the conditions under which actors operate across layers or, alternatively, chose to concentrate their activities within a layer, and (d) thus help track and represent patterns of dependencies and influence within the cyber domain (p. 3).

A natureza das camadas também serve para explicar a estrutura da Internet que podemos, grosso modo, equiparar à ideia de ciberespaço ${ }^{18}$. Convém assim situar o que cada camada corresponde.

Camada primária: Física. Tida como condicionante para o desenvolvimento das demais, a estrutura física abrange cabos de fibra óptica, "cell towers", backbones e dispositivos eletrônicos, tais como smartphones, computadores, laptops e tablets. A natureza física destes últimos devices é inquestionável e bastante familiar em grande parte do cotidiano social. Porém, no caso da estrutura dos cabos de fibra óptica ultramarinos, nem sempre é um debate comumente esclarecido. Os cabos de fibras ópticas são estáveis e robustos, capazes de carregar grande quantidade de dados, que trafegam através de países e continentes, e servem como infraestrutura para as grandes infovias conhecidas como backbones e backhauls. Em geral, os backbones são adotados para grandes distâncias e grandes volumes, devido à estabilidade e rigidez. As tecnologias empregadas na conexão last mile, isto é, as conexões entre as estações de distribuição (vinculadas aos backhauls) e os receptores finais, sustentam geralmente menor poder de transmissão, com capacidade de volume e velocidade menores quando comparados à fibra ótica. Na última milha, geralmente são empregadas tecnologias como DSL (Digital Subscriber Lines) e Cabo-modem, quando físicas; rádio, wifi, wimax, móvel $3 \mathrm{G}$ e 4G, satélite, quando sem-fio. Estas últimas, as tecnologias wireless (sem-fio) são menos estáveis, apresentando maiores predisposições a oscilações e performance. De todo modo, tanto a fibra ótica como a última milha física ou sem-fio, são tecnologias complementares, não excludentes entre si (SILVA, 2013).

Camada secundária: lógica ${ }^{19}$. Compreende protocolos, a World Wide Web, o Domain-Name System (DNS), softwares, aplicativos e plataformas de mídias sociais. Nesta

\footnotetext{
${ }^{18}$ A diferença entre Internet e Ciberespaço é muito sutil e ambos os termos podem ser equiparáveis para fins desta pesquisa. De todo modo, convém especificá-los. Internet é o conjunto de aparelhos conectados que se comunicam em rede transmitindo conteúdo simbólico através de pacotes digitais, sendo possível através de seus protocolos de transporte de dados. Para que isso ocorra, é preciso que haja as três camadas. Já a expressão "ciberespaço" se refere ao "espaço" metafórico de trocas simbólicas e interações através das tecnologias digitais (o prefixo "ciber" é uma referência à concepção de cibernética, que influenciou o densenvolvimento de computadores ainda no século XX). Assim, o ciberespaço deve ser compreendido, sobretudo como uma arena digital para interações sociais, políticas, econômicas e culturais através de dispositivos eletrônicos como computadores, smartphones, tablets etc.
} 
camada incluem os protocolos de transporte, a dinâmica do fluxo dos pacotes de dados, a própria web e também as aplicações. A palavra protocolo ${ }^{20}$ é o nome dado ao conjunto de definições que organizam o modo como as máquinas (e as próprias camadas) se comunicam através de convenções lógicas comuns pré-estabelecidas. Para que a rede dos computadores saísse do mundo restrito de pesquisadores e engenheiros de computação e pudesse ser utilizada pelo cidadão comum, foi preciso criar também na camada lógica um sistema e nomes e endereços eletrônicos: o Domain Name System (DNS), (NYE, 2010; HATHAWAY; KLIMBURG, 2012). Este sistema forneceu a base para a expansão massiva e comercial da Internet, de modo que em 1985 já haviam sido introduzidos os domínios .mil, .com, .edu, .gov (HATHAWAY; KLIMBURG, 2012). A partir daí, era possível estabelecer aquilo que hoje chamamos de Web: a World Wide Web (WWW), ou seja, o conjunto de páginas com conteúdo escrito acessíveis através da Internet $^{21}$. Isso era viabilizado através do sistema chamado de Uniform Resource Locator (URL) que consistia na possibilidade de localizar estas páginas (ou objeto online) através de endereços nominais no formato "www.nomedominio.categoria" (KELLO, 2013) e não apenas através de números (os chamados endereços IPs) ${ }^{22}$. Com o desenvolvimento da WWW, partindo da sua primeira versão estática com páginas indexáveis ${ }^{23}$, mais recentemente (principalmente no início da década de 2000), surgiu a chamada web 2.0. Esta consiste em plataformas participativas e sistemas mais interativos entre usuários, possibilitando assim a construção de redes sociais online. Estas plataformas também são denominadas de social media (mídias sociais). Dijck (2013) explica que o conceito de social media, definido por um grupo de aplicativos que constroem as bases tecnológicas da web 2.0, deu-se no final do século XX através da criação de novas plataformas digitais como blogs em 1999, Wikipedia em 2001, Myspace em 2003, Facebook em 2004, Flickr em 2004, YouTube em 2005, Twitter em 2006 (DIJCK, 2013). Essas plataformas não possuem ênfase em produzir conteúdo para que o usuário acesse (uma

\footnotetext{
${ }^{19}$ Esta camada define o modus operandi da rede por ser justamente a interface entre os produtos sociais (camada de conteúdo) e a base técnica infra-estrutural da rede (camada física).

20 "Protocol: the term used to describe the various technical specifications of the Internet. A protocol is a specification of permitted behavior by the various components of the Internet such that the resulting overall operation of the network is correct, and the participants can accomplish their intent" (CLARK, 2004, p. 15).

${ }^{21}$ O DNS foi estabelecido em 1983, já a World Wide Web iniciou-se em 1989.

${ }^{22}$ Todo o computador (e outros equipamentos de base digital) só entendem, na prática, linguagem numérica. Por exemplo, o real endereço IP do site da Universidade de Brasília (UnB) é um número de dez casas: 164.41.101.33. Para facilitar a apropriação do usuário, a URL permite dar ao usuário uma linguagem não numérica: a palavra "unb" e o "br" (de Brasil, neste caso). Por isso, a URL do site da UnB é www.unb.br. O DNS é o sistema que liga esta URL a um endereço IP.

${ }^{23}$ Também conhecida como web 1.0, pois trata-se de uma primeira versão da WWW baseada na exposição de informações em uma página e o consumo desse repositório pelo usuário.
} 
característica típica da web 1.0). Diferentemente, elas criam espaços online de interação através do qual os usuários expõem conteúdos, compartilham informações e se expressam ${ }^{24}$.

Camada terciária: Informacional. Está relacionada aos diversos conteúdos que são estocados, transmitidos e transformados no ciberespaço, seja em formato de foto, vídeo ou outro material. Ou seja, trata-se do conjunto de dados que vão além dos códigos numéricos e se consolidam como linguagem, em suas diferentes formas. É a camada das relações sociais, da estética, das produções de conteúdos culturais e políticos. É onde a rede deixa de ser apenas um conglomerado de máquinas interligadas por protocolos numéricos ou sistemas de softwares e passa a fazer sentido como espaço de interação entre os indivíduos. Por exemplo, quando se posta um vídeo em uma rede social online como o Facebook ou Twitter e se escreve um comentário sobre isso, o vídeo e o respectivo comentário são objetos da camada de conteúdo pois representam produtos socialmente inteligíveis e que fazem sentido social. Já a plataforma Facebook ou Twitter tratam-se de uma aplicação que é construída a partir de design e algoritmos operando na camada lógica. Já os cabos que viabilizam a conexão entre o aparelho (celular, computador, tablet etc.) e os computadores-servidores do Facebook ou Twitter são elementos que funcionam na camada física. Para que a comunicação digital exista é preciso que as três camadas estejam funcionando.

Em cada uma das três camadas que constituem o ciberespaço (e a própria Internet) existe, como vimos, um conjunto de elementos próprios. Essas camadas travam entre si uma relação complexa de pré-condição (por exemplo, sem a camada física não há camada lógica, nem de conteúdo) e pós-condição (por exemplo, é justamente a vida na camada de conteúdo que propulsiona o desenvolvimento das demais camadas). Para compreendemos melhor tal processo, o diagrama da Figura 2 representa graficamente como esse movimento relacional ocorre:

\footnotetext{
${ }^{24}$ Para Dijck (2013) as redes sociais podem ser classificadas de forma distintas, e ainda que as fronteiras entre as diversas plataformas se mesclem, seria possível diferenciá-las em quatro grupos básicos: Social network sites (SNSs), user-generated content (UGC), trading and marketing sites (TMSs) e play and game sites (PGS). Os SNSs são exemplificados pelo Facebook, Twitter, LinkedIn, Google+, and Foursquare, e encorajariam a criar laços, ainda que fracos, entre os indivíduos. Os UGC sites seriam YouTube, Flickr, Myspace, GarageBand, and Wikipedia, e promoveriam a troca de conteúdo por profissionais ou amadores. No caso dos TMSs, Amazon, eBay, Groupon, and Craigslist são exemplos de sites de troca e venda de produtos. Por fim, PGS são ilustrados por jogos populares, tais como FarmVille, CityVille, The Sims Social, Word Feud, and Angry Birds.
} 
Figura 2 - Diagrama do movimento relacional das camadas do ciberespaço

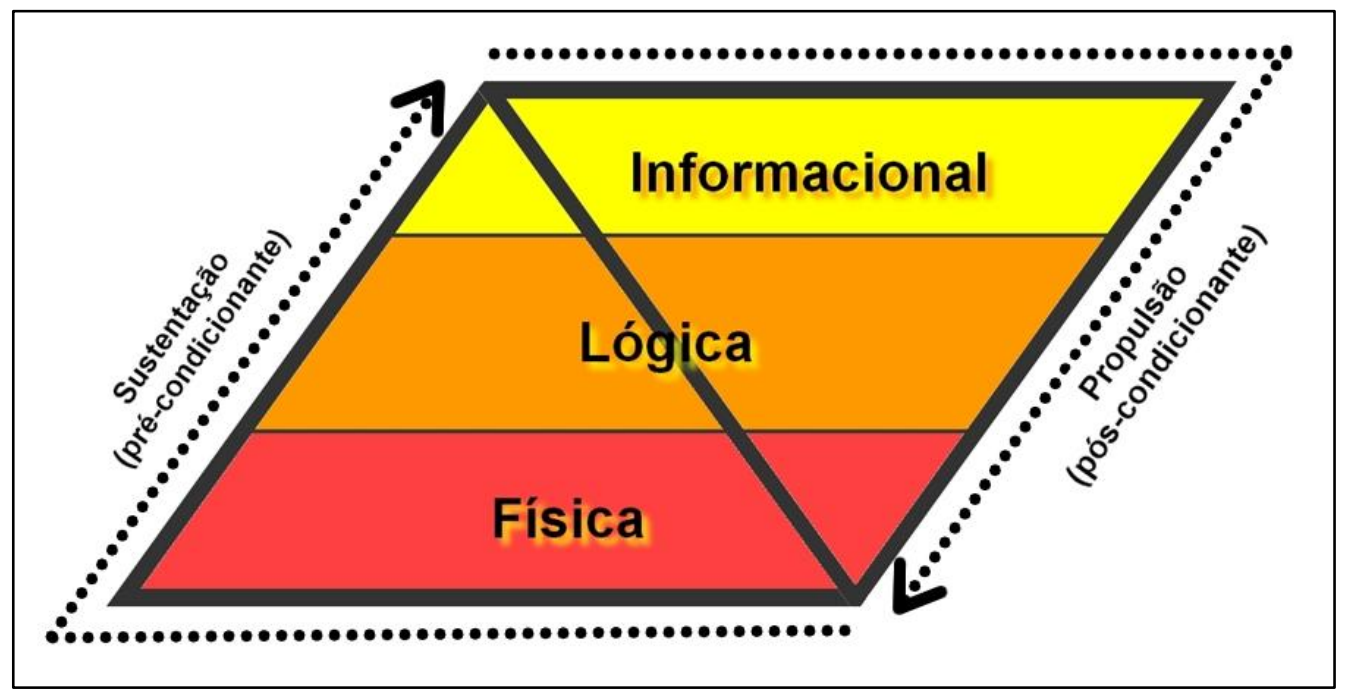

(Fonte: própria autora)

O modelo apresenta pirâmides complementares, que se apoiam e se equilibram ${ }^{25}$. Na pirâmide à esquerda a camada física é a base, enquanto na pirâmide à direita a camada informacional é a base. A pirâmide da esquerda traz as pré-condições para existência do ciberespaço. A pirâmide da direita traz as pós-condições, isto é, influencia a posteriori as demais camadas. Por exemplo, a necessidade das pessoas em compartilhar fotos, vídeos e textos sobre suas vidas em uma rede social online influencia a dinâmica da camada lógica que desenvolverá protocolos e aplicações para responder a essas demandas - e também afeta a camada física - que precisará ser mais robusta para suportar o volume de conteúdo trafegado.

Embora a estrutura física represente uma pré-condição de existência das duas subsequentes camadas, dando-lhes sustentação, não é o elemento determinante do comportamento das camadas lógica e informacional. Isto porque, considerando o papel das pessoas, grupos, instituições e governos como partícipes ativos de cada camada, a estrutura física sozinha não sustenta o sistema caso não haja uma devida apropriação social da camada informacional, por exemplo. Por isso a sustentação é mais intensa a partir da camada física e a

\footnotetext{
${ }^{25} \mathrm{O}$ modelo desenvolvido para esta pesquisa teve como ponto de partida a arquitetura do ciberespaço em camadas desenvolvido por Choucri e Clark (2012). As três primeiras camadas são similares ao modelo adotado nesta pesquisa de doutorado. A quarta camada, entretanto, apresenta os usuários. Estes são as pessoas e constituintes que moldam a experiência no domínio ciber assim como a própria natureza do ciberespaço, seja através do ato comunicativo, manuseio da informação, tomando decisões ou executando planos (CHOUCRI; CLARK, 2012). Esta compreensão dos usuários enquanto uma quarta camada, bem como a afirmação de que as camadas mais altas dependeriam do funcionamento das mais baixas, mas não o oposto, imprime, dentro da visão desta pesquisa, algum nível determinístico da tecnologia sobre os usuários. Nesta perspectiva, estes estariam na última camada com pouca margem de atuação sobre as demais camadas. Por esta razão, o modelo de camadas proposto nesta tese possui três camadas e é diferentemente representado por duas pirâmides invertidas e simétricas operando em um equilíbrio entre sustenção (pré-condição) e propulsão (pós-condição).
} 
propulsão é mais intensa a partir da camada informacional. Isto inverteria a concepção determinística de acreditar que um processo simples de adição de camadas se dá num processo unidirecional de comportamento pré-determinado pelo objeto técnico tão somente.

$\mathrm{O}$ conceito de camadas permitiu que a Internet absorvesse e incorporasse novas tecnologias conforme estas eram desenvolvidas, como os diversos aplicativos hoje existentes, assim streaming de vídeos e webpages podem ser utilizados ao mesmo tempo, já que não há uma única forma de uso da Internet (CERF, 2009).

Com a integração das camadas e seus respectivos desenvolvimentos, incluindo as facilidades da interface gráfica que permitia de modo mais simples e eficiente o compartilhamento de informações e a busca de conteúdos e serviços online, o crescimento do ciberespaço foi vertiginoso ao redor do globo, de modo que após a década de 1990 houve o chamado "Internet boom" (RADU, 2014, p. 7):

The 1990s have been marked by the so-called 'Internet boom', aided by the quick expansion of the World Wide Web and the fast integration of commerce and politics on electronic platforms; these became accessible to an ever-increasing number of people around the world in a relative short time, but currently exhibit uneven levels of development in different national contexts (RADU, 2014, p. 7).

Diante da quantidade de mecanismos usados para propor e decidir sobre padrões para a Internet, foram estabelecidas organizações oficiais para lidar especificamente com protocolos e padrões ${ }^{26}$. Criava-se assim um sistema internacional para lidar com uma rede transnacional de computadores que se configuraria a Internet a partir daí.

Se, por um lado, o ciberespaço se tornou um elemento fundamental para os fluxos de informação e para as formas contemporâneas de interação social, política, econômica e cultural potencialmente acessíveis aos diversos tipos de atores, por outro lado, nem toda troca de dados online é aberta ou indexável. Para além da Internet convencional, utililizada pelo usuário comum, a rede aberta co-existe com os sistemas fechados (como intranets de empresas e governos) e também com a chamada deep web (Internet profunda ou dark internet). Esta consiste em uma parte não convencional da Internet que opera no underground

\footnotetext{
${ }^{26}$ A primeira delas é Internet Engineering Task Force (IETF) estabelecida em 1986 e responsável por questões de engenharia relacionadas à Internet. A Internet Society (ISOC) foi criada em 1992 para alojar a IETF e a Internet Architecture Board (IAB). Em 1996, o International Telecommunications Union (ITU) adotou o protocolo de transmissão de voz trazendo inovações, tais como as videoconferências. O Internet Corporation for Assigned Names and Numbers (ICANN) foi criado em 1998, no papel de parceria público-privada, responsável para administrar e coordenar o Domain Name System (DNS), assegurando que todo endereço é único e que todos usuários da Internet possam localizar endereços válidos (NYE, 2010; CONGRESSIONAL, 2007; HATHAWAY; KLIMBURG, 2012).
} 
do sistema. Este seguimento é pouco difundido entre o usuário médio da Internet, mas amplamente conhecida entre indivíduos e grupos que, por diversas razões, buscam burlar as regras básicas do funcionamento da rede principalmente evitando protocolos de identificação. Embora não haja dados seguros sobre o tamanho desta parte da web, alguns analistas estimam que esta seja mais ampla do que o World Wide Web (WWW) em termos de volume de conteúdos trafegados (MCCORMICK, 2013).

Este é um espaço usado principalmente para consumo e veiculação de material ilícito, seja para difusão e planejamento do terrorismo, seja para movimentação de um mercado ilegal, como determinados conteúdos pornográficos envolvendo pedofilia. A respeito disso, Maccormick (2013, p.1) explica:

It's a place where drugs and weapons are openly traded, where terrorists link
up, and where assassins bid on contract killings. In recent years, the darknet
has found itself in government cross-hairs, with the FBI and National
Security Agency (NSA) cracking down on drug merchants and
pornographers. Despite a series of high-profile busts, however, this lawless
realm continues to hum along, deep beneath the everyday web.

No final dos anos de 1990, a popularização da Internet aliada à facilidade de compactar arquivos estimulou os usuários da deep web a compartilharem conteúdos protegidos por direitos autorais (como músicas e filmes, através dos chamados topsites, os quais as senhas e conteúdos só eram conhecidos pelos insiders $)^{27}$. Obviamente, contrário a este uso desenfreado e sem qualquer tipo de regulação há grandes esforços de empresas e governos. Por exemplo, as revelações de Snowden através do jornal britânico The Guardian mostraram que os EUA em 2007, através da National Security Agency (NSA), realizaram um projeto de identificar usuários do $\mathrm{TOR}^{28}$ e suas vulnerabilidades, porém o documento vazado da agência reconhece a impossibilidade de identificar o usuário deste tipo de navegação, salvo raras exceções (MCCORMICK, 2013). Isto reforça a eficácia do anonimato dos usuários neste tipo de rede.

Este uso de uma ambiência profunda do ciberespaço é datado desde os primeiros anos do funcionamento da Internet. Em realidade, poucos anos depois da primeira conexão estabelecida em rede pela ARPANET, outras redes secretas começaram a atuar

\footnotetext{
${ }^{27}$ Uma pesquisa realizada pela Wired magazine em 2005 estima que mais de meio milhão de filmes são distribuídos via darknet e os custos desse negócio é em torno de 34 bilhões de dólares, conforme estudo divulgado pela pesquisa IDC. A criação de uma moeda digital em 2009, a cryptocurrency ou bitcoins, viabilizou ainda mais este mercado marcado por obscuras e anônimas transações da deep web (MCCORMICK, 2013).

${ }^{28}$ TOR (The Onion Router) é um programa de computador, de código aberto e produzido colaborativamente através de uma comunidade hacker, que possibilita a navegação anônima na Internet através da criação de "tuneis" de navegação dificultando assim o rastreamento. Endereços com a terminação ".onion" fazem parte da chamada "Deep Web" e podem ser acessíveis através do TOR.
} 
(MCCORMICK, 2013). A partir daí, continuou a se desenvolver conforme a evolução da Internet como um todo.

Se o anonimato é um obstáculo para a identificação de ações na deep web, a persistência das práticas ilegais, mesmo quando identificadas, revela-se outro obstáculo. Quando ocorre o encerramento forçado de websites que praticam comércios ilegais neste meio, não há intimidação da atividade ilícita, já que eles geralmente reativam o site com outro nome e outro endereço:

October 2013: Tech-news site, the Verge, reports that online markets like Black Market Reloaded and Deepbay, both of which openly advertise narcotics, are seeing a surge in traffic. No doubt we will all reagroup elsewhere," one Silk Road moderator worte after the marketplace was shuttered. "I look forward to seeing all of you again... still engaging in free trade without government interference into your personal affairs." In November, a new anonymous darknet marketplace called Silk Road 2.0 was back online, just over a month after the original was shut down (MACCORMICK, 2013, p. 10).

De todo modo, seja através da web convencional, seja através da deep web, a comunicação digital representa hoje um fenômeno cada vez mais importante no cotidiano dos indivíduos nos diferentes continentes, ainda que existam níveis relevantes de exclusão digital que devem ser levados em conta ${ }^{29}$. Na busca de sistematizar esta complexa relação, a próxima seção trata justamente de identificar os efeitos da comunicação digital na vida social para que, mais à frente, possamos compreender como isso afetará os processos do ativismo.

\subsection{COMUNICAÇÃO DIGITAL E SEUS IMPACTOS NAS PRÁTICAS SOCIAIS}

No pano de fundo desta pesquisa de doutorado está a Internet e a compreensão do ciberespaço como nova arena de interações sociais, culturais e políticas. Mas o foco está justamente no "espírito" que viabiliza esta estrutura: A comunicação digital. Mais do que apenas uma definição, trata-se de um conceito analítico que permite guiar o olhar sobre este fenômeno social sem perder de vista suas dimensões técnicas. Assim, dadas as bases para o entendimento sobre a forma de funcionamento da Internet, convém agora delimitar o que se

\footnotetext{
${ }^{29}$ Principalmente em países da África, América do Sul e parte da Ásia. No Brasil, por exemplo, cerca $45 \%$ dos cidadãos não são usuários de Internet, conforme dados de 2015 do Comitê Gestor da Internet no Brasil (CGI.br): <http://cetic.br/tics/usuarios/2014/total-brasil/C2/ >. Acesso 14 nov de 2015. Tomando as estimativas de 2015, produzidas pelo Instituto Brasileiro de Geografia e Estatística (IBGE), (<http://servicodados.ibge.gov.br/Download/Download.ashx?u=ftp.ibge.gov.br/Estimativas_de_Populacao/Esti mativas_2015/estimativa_dou_2015_20150915.xls> acesso 14 nov 2015), isso corresponde a um contingente de aproximadamente 90 milhões de indivíduos.
} 
compreende por "comunicação digital" e quais impactos este fenômeno traz para as práticas sociais.

Comunicação digital consiste em um aspecto chave no domínio ciber para interações sociais, políticas, econômicas e culturais. Não se trata da ferramenta tecnológica propriamente dita (a Internet, o computador etc.). Refere-se ao fenômeno social que ocorre através dessas ferramentas. Assim, em última instância, a comunicação digital não é o "artefato técnico" em si. Trata-se, na verdade, do processo que ocorre através desses artefatos. Ou seja, a comunicação digital é uma forma de comunicação mediada por plataformas digitais. Isso é importante ter em mente pois quando se busca analisar os efeitos da comunicação digital no ativismo transnacional, foco desta pesquisa de doutoramento, não se trata de analisar os efeitos de um objeto técnico e sim os efeitos de um processo social (de base digital) em fenômenos políticos (neste caso, no ativismo transnacional).

Assim, partindo de contribuições de Gallager (2008) e Clark (2004) acerca da comunicação digital, definimos que para a comunicação digital ocorrer é necessário:

a) usuários dispostos a estabelecerem processos de comunicação;

b) conteúdo simbólico (texto, vídeo, áudio, identificação digital etc.);

c) dispositivo codificador/ decoficador (computadores, tablets, smartphones e outros);

d) infrastrutura física para transporte e processamento de dados (backbones, fibra óptica);

e) aplicativos (software, web, protocolos, blogs, mídias sociais etc.).

A popularização da comunicação digital, principalmente através da Internet e da massificação de smartphones mais recentemente, tem gerado impactos relevantes na vida de cidadãos, grupos, organizações e governos, inserindo novos ingredientes nas práticas sociais e, por consequência, nas relações políticas nacionais e internacionais. Para melhor compreender isso, sintetiza-se quatro principais conjuntos de impactos deste fenômeno sobre as práticas sociais: (1) Intensificação da conectividade midiática; (2) fomento à agregação de ideias; (3) aumento perceptivo da realidade, e (4) ampliação da difusão de poder.

A intensificação da conectividade midiática envolve o surgimento de padrões de comportamento marcados pela conexão permanente dos indivíduos a dispositivos de comunicação digital, em quase todos os lugares e em boa parte do tempo. O ciberespaço transformou o cidadão comum em um indivíduo que carrega acoplado a si um dispositivo ubíquo de mídia. Os diversos tipos de aparelhos digitais de comunicação estão cada vez mais cotidianos, alcançando status de discrição, "diluindo-se", "desaparecendo" na cultura, justamente por se tornarem parte inerente à cultura contemporânea, deixando de ser algo extraordinário ou exógeno e sim um elemento constitutivo das práticas sociais (REITAN, 
2007; MUELLER, 2010; MIARD, 2012; SEIB, 2012; BIMBER et al, 2012; DIJCK 2013; HEPP; KROTZ, 2014). Figurativamente, pode-se dizer que a comunicação digital está se tornando tão invisível e onipresente como o ar que respiramos, já que nem sempre lembramos que o ar existe justamente por ser algo que se encontra em toda a parte, naturalizado, tendendo assim a esquecê-lo. Isto significa dizer que ocorre atualmente uma tendência do cidadão comum em manter uma conexão em tempo real, o que implica em indivíduos ainda mais midiáticos e mais susceptíveis aos fluxos de informação, compartilhamentos e possibilidades de interação.

O fomento à agregação de ideias consiste na ampliação das oportunidades que os indivíduos possuem hoje à disposição para aglutinar princípios, ideologias, convicções, posições políticas, religiosas, culturais etc. Por isso, o ciberespaço amplifica a concentração de preferências e interesses (SUSTEIN, 2001; SEIB, 2012; CHOUCRI, 2012), de maneira que o indivíduo conta com a proliferação de ferramentas ágeis e de baixo custo para encontrar outros grupos ou indivíduos que possuam ideias em comum. Para autores como Jenkins (2008), isso se traduz numa nova vivência - a cultura da convergência -, onde mais importante do que a convergência tecnológica dos dispositivos multimídia seria a convergência de ideias e interesses que ocorre em um ambiente simbólico criado por comunicação digital. Na prática, esta aglutinação torna possível empreender uma série de ações concretas no mundo real: desde o aumento do consumo de bens culturais antes confinados a poucos indivíduos tornando o mercado de nicho mais importante que o mercado mainstream (ANDERSON, 2006), até a criação de comunidades online em torno de interesses comuns, que podem assim somar forças e agir coletivamente com maiores efeitos na vida social (RHEINGOLD, 1996; JENKINS, 2009).

$\mathrm{O}$ aumento perceptivo da realidade significa que o ambiente digital borra as fronteiras não apenas entre online e offline, ou público e privado, mas também entre distância geográfica e o tempo de divulgação de narrativas e informações sobre a realidade que nos cerca. A compreensão do mundo já não é baseada apenas em filtros formais (tais como mídia, escola e outros intermediários tradicionais), assim a nova maneira de obter informações dilata a visão de mundo do indivíduo. O indivíduo é exposto diariamente a uma variedade de ideias, obrigando-o a pensar ou a dar sua opinião sobre o que aparece na "tela". A comunicação digital ampliou a visão de mundo dos indivíduos através do recebimento de informações de fontes diferentes, temas, locais e níveis de complexidade (SHI; ZHUGE, 2010; CHOUCRI, 2012; RADU, 2014; MILLER, 2014). 
A ampliação da difusão de poder envolve uma redefinição das forças e agentes, e suas capacidades de ação e reação. Cyberpower é a capacidade de obter resultados (dentro do ciberespaço ou em outros domínios fora do ciberespaço) usando informações interligadas através da Internet, intranets, tecnologias celulares e comunicações baseadas no espaço (NYE, 2010). Estes recursos caracterizam o domínio do ciberespaço e são definidos pela infraestrutura, localização, redes, software e habilidades humanas. Neste contexto, o poder tende a ser cada vez mais descrito pela capacidade de conexões que determinados atores sustentam: Quem está conectado a quem, para que fins e com quais efeitos (SLAUGHTER, 2009). Embora o poder tradicional continue coexistindo, o domínio ciber cria novas arenas para o embate e oferece novas ferramentas de ataques, de pressão e de constrangimentos. É importante ressaltar que a distribuição de poder não significa necessariamente igualdade de poder (CARR, 2009; DREZNER, 2010; NYE, 2010; KELLO, 2013; FIDLER, 2014; HART, 2012; WALSH, 2012; SEIB, 2012). Determinados agentes, principalmente os Estados, continuam possuindo grande capacidade de intervenção e ação enquanto outros possuem capacidade mais limitada. O ambiente digital equaciona melhor esse desequilíbrio de recursos, mas não os equipara ou uniformiza ${ }^{30}$.

Todos esses impactos sociais elencados afetam, inevitavelmente, a forma como a política é praticada em seus diversos âmbitos. Por isso, torna-se relevante ter tal compreensão sociológica em mente já que reverberá nos processos do ativismo. Isso será retomado especificamente no Capítulo 4, na seção 4.4 (Efeitos da comunicação digital no ativismo transnacional).

Por fim, após termos as questões de base conceitual-técnicas configuradas neste capítulo, o próximo passo desta pesquisa será dedicado a afunilar a análise inserindo o debate sobre a comunicação digital no campo das Relações Internacionais. Logo, será guiado pelas seguintes questões: Qual a visão dos estudiosos da área sobre esta temática? Como as teorias tradicionais abordam tal fenômeno? Quais segmentos representam hoje as linhas mais recorrentes de análise das TICs nas RI? De que forma a difusão de poder no ciberespaço empodera atores não-estatais?

\footnotetext{
${ }^{30} \mathrm{O}$ debate sobre cyberpower será retomado e aprofundado mais adiante, no capítulo 3, apontando como este fenômeno social mais amplo afeta especificamente o lugar dos atores não-estatais na arena internacional.
} 


\section{COMUNICAÇÃO DIGITAL E RELAÇÕES INTERNACIONAIS}

O campo que envolve Relações Internacionais e o ciberdomínio tem se estruturado a partir de complexos fenômenos que envolvem diferentes atores com diferentes recursos. A intensificação de redes ágeis e globais de comunicação entre governos, empresas, ativistas e indivíduos; a configuração da diplomacia pública digital; e a ciberguerra são apenas alguns exemplos emergentes neste campo. Esse cenário tem criado novos desafios, sobretudo devido ao novo tipo de empoderamento que as ferramentas de comunicação e informação possibilitam. Historicamente, a transição e a construção de poder são elementos relevantes de análise para o campo das RI. Por isso, quando propomos estudar os efeitos da comunicação digital no ativismo transnacional, é importante contextualizar como o ciberespaço se insere neste quadro em específico.

Dito isto, este capítulo concentra-se primeiramente em compreender como os estudos ciber têm sido endereçados em RI, considerando de que modo as tradicionais correntes teóricas abordam o tema. Em seguida, busca-se configurar algumas abordagens de análise para além da filiação a uma determinada corrente teórica, apresentando uma perspectiva transversal adotada, isto é, usa-se o pluralismo como um adequado caminho teórico para esta pesquisa. Após traçarmos elementos de natureza analítica, o presente capítulo discute as características dos debates de dois segmentos específicos hoje preponderantes nas RI e que envolvem o ciberdomínio: cibersegurança e cibergovernança. Observamos neste capítulo que o novo tipo de empoderamento de atores não-tradicionais no ciberdomínio é transbordado para os demais domínios da vida social, representando uma importante contribuição para a análise do ativismo transnacional. Assim, apresentar as diferentes abordagens em RI nesta seção e situar a comunicação digital neste campo permite-nos observar as similitudes e complementaridades entre as abordagens, possibilitando assim a extração de conceitos e entendimentos adequados para fortalecer os argumentos defendidos na presente pesquisa.

\subsection{TEORIAS DAS RELAÇÕES INTERNACIONAIS E COMUNICAÇÃO DIGITAL}

Ainda que incipiente e com poucas representações de autores para as várias escolas teóricas, diferentes perspectivas tradicionais nas RI, tais como Realismo, Liberalismo, Nova Escola de Copenhagem, Níveis de análises e Construtivismo Social já buscam explicar os diversos fenômenos trazidos pelas Tecnologias de Informação e Comunicação (TICs) a partir 
de suas lentes teóricas. Isto se traduz numa tarefa complexa de análise, considerando-se que cada abordagem não é por si só homogênea. Alguns autores, como Kello (2013), acreditam que o conjunto de teorias já existentes não seria capaz de interpretar o fenômeno cyber devido à sua complexidade técnica, que exigiria uma nova abordagem. Ainda que possa haver limitações das abordagens "pré-existentes" para dar conta das nuances inerentes ao ciberespaço, esta seção busca sintetizar o debate teórico sobre as abordagens supracitadas, mostrando de forma sumarizada suas principais contribuições e avanços para entender fenômenos de natureza cyber nas RI.

Kello (2013) sumariza criticamente como a tecnologia é concebida em algumas teorias tradicionais das RI. No Realismo, segundo ele, a tecnologia é um artefato passivo e exógeno, uma fonte de poder econômico e militar. Segundo Fritsch (2011), realistas tendem a rejeitar o fato de que o progresso tecnológico tem favorecido a emergência de novos atores e novas questões internacionais, ou ainda que tenha alterado as estruturas de interação no sistema internacional. Para esta escola teórica, o poder e a influência guiariam a tecnologia, mas esta não poderia reestruturar o sistema global:

The Realist tradition's main weakness, however, derives from its static model of the global system and its instrumental understanding of technology as passive force in a country's power capabilities-mix. This undifferentiated perspective tends to neglect the reciprocal relationship between technological evolution and structural change in world politics (FRITSCH, 2011, p. 36).

Choucri (2012) chama nossa atenção para o fato de os EUA, uma superpotência militar e econômica, terem sido predominantes na criação e administração da Internet. Isto seria coerente com a teoria baseada em poder, cara ao realismo, também focada na concentração da capacidade do Estado e na garantia da segurança nacional. Dentro de uma perspectiva de segurança, Kassab (2014) acredita que o realismo estrutural é fundamental para se analisar os ciberataques, na medida em estes afetam a distribuição de capacidades, alterando o poder relativo e ameaçando a sobrevivência dos Estados no sistema internacional. Embora pareça algo novo, já que o realismo não tinha previsto outras formas de poder, Kassab (2014) acredita que seja apenas uma outra arena na qual os Estados e seus interesses colidem. Nesse sentido, as armas cyber são capazes de redefinir o significado de poder:

Power can no longer be the inflexible definition formulated by Waltz so many years ago. Rather, I recommend a more elastic concept of power borrowed from the Classical Realist, Hans Morgenthau. Power cannot be 
considered as a laundry list of state led formulations. Instead, power can be everything and anything: the control of man over man (Morgenthau 1985, p. 11) (KASSAB, 2014, p. 60).

No caso da corrente do liberalismo, tecnologia se enquadraria em um fator exógeno que impulsionaria a transnacionalização e a difusão de poder, viabilizando desde transações econômicas até destruições globais (KELLO, 2013). Assim, diametralmente oposto ao realismo, o liberalismo acredita nas influências tecnológicas sobre o sistema internacional, seja intensificando as interações econômicas, sociais e culturais, seja desacoplando a relação física entre Estado, fronteiras e bordas (FRITSCH, 2011). Nesse sentido, a tecnologia redimensionaria a configuração de poder e facilitaria a emergência de novos atores. Essa relação é tão evidente nesta perspectiva teórica, que comumente é vista como determinística:

Therefore, liberals make a strong case that globalization, to a considerable part, is caused by technology. Although the assumptions presented above could be described as leaning toward deterministic explanations, most liberals explicitly reject technological determinism (Singh 2002:11) (FRITSCH, 2011, p. 37).

Fritsch (2011) inclusive acredita que esta ênfase nas consequências da tecnologia sobre os assuntos globais irreleva a relação da reciprocidade entre tecnologia e política internacional, incorrendo no erro de desconsiderar a tecnologia como enraizada na estrutura do sistema global. Nas palavras do autor: “[...] technological evolution is at least partly driven by factors such as anarchy and competition between states" (FRITSCH, 2011, p. 41). Outro ponto a ser considerado é que o institucionalismo, também embebido na tradição liberal, possui sua âncora de análise na lógica de interações estatais, ao mesmo tempo que considera várias outras entidades e atores como reação a um protagonismo na cena do controle cyber unicamente pelos Estados (CHOUCRI, 2012).

O internacionalismo complexo de Nye e Keohane (2001) elaborado nos idos de 1980, tem relevante importância na análise de uma via intermediária entre micro-estrutura tecnológica e macro-estrutura social no entendimento do ativismo transnacional na era da Internet, na opinião de Porta e Tarrow (2005). Isto porque, os autores do internacionalismo complexo tanto focam nas novas ameaças e nas novas desigualdades trazidas neste contexto tecnológico, quanto nas oportunidades dadas a diferentes atores, entre eles coalizões transnacionais. A multiplicação de canais de conexão dentro da sociedade (não apenas relações interestatais) e a quebra de hierarquia e da predominância de assuntos militares, tudo 
isto abriu espaço para atores não-estatais operarem para além dos limites de suas fronteiras estatais (PORTA; TARROW, 2005):

We take Keohane and Nye's theory of "complex interdependence" a step further to deliberately include nonstate actors in the horizontal and vertical relations they posit among states and international institutions. By "complex internationalization," we mean the expansion of international institutions, international regimes, and the transfer of the resources of local and national actors to the international stage, producing threats, opportunities and resources for international NGOs, transnational social movements and, indirectly, grassroots social movements (PORTA; TARROW, 2005, p. 235).

$\mathrm{Na}$ visão construtivista, conforme discutida no capítulo anterior, a tecnologia seria socialmente guiada pelas forças sociais, se posicionando assim como um constructo social que influencia as estruturas políticas, incluindo aí os assuntos globais (KELLO, 2013; FRITSCH, 2011). A partir desta perspectiva, fatores não-materiais como questões normativas e de identidade devem ser incorporados quando se analisam os desenvolvimentos tecnológicos, o que significa dizer que mudanças dos assuntos globais (atribuídos ao ciberespaço) são relacionadas às mudanças de normas e identidades (FRITSCH, 2011). Igualmente, a tecnologia da informação propriamente estabelece uma nova interação social entre os diversos atores internacionais:

Often, moderate constructivists acknowledge that the diffusion of technology has increased the density of the international system. This is an important prerequisite for interaction between social actors, which in turn establishes structures. Without (technological) interaction capacities, interaction between different actors of the international system would hardly take place. This connection is often implicitly present in many constructivist arguments, but rarely mentioned explicitly (FRITSCH, 2011, p. 39).

Crítico à concepção de tecnologia enquanto um fator residual, passivo, externo e apolítico, Fritsch (2011) propõe um modelo integrativo (Figura 3) vinculando tecnologia e assuntos globais. Neste modelo, a ideia plural a partir de diferentes insights e perspectivas das RI é considerada como parte da análise:

It argued for a conceptualization of technology as an integral core part of the global system that is a fundamental prerequisite for systemic change, which in turn impacts the character and behavior of system actors and modifies existing, as well as newly emerging, policy issues (FRITSCH, 2011, p. 39). 
Figura 3 - Tecnologia e assuntos internacionais: Um modelo integrativo

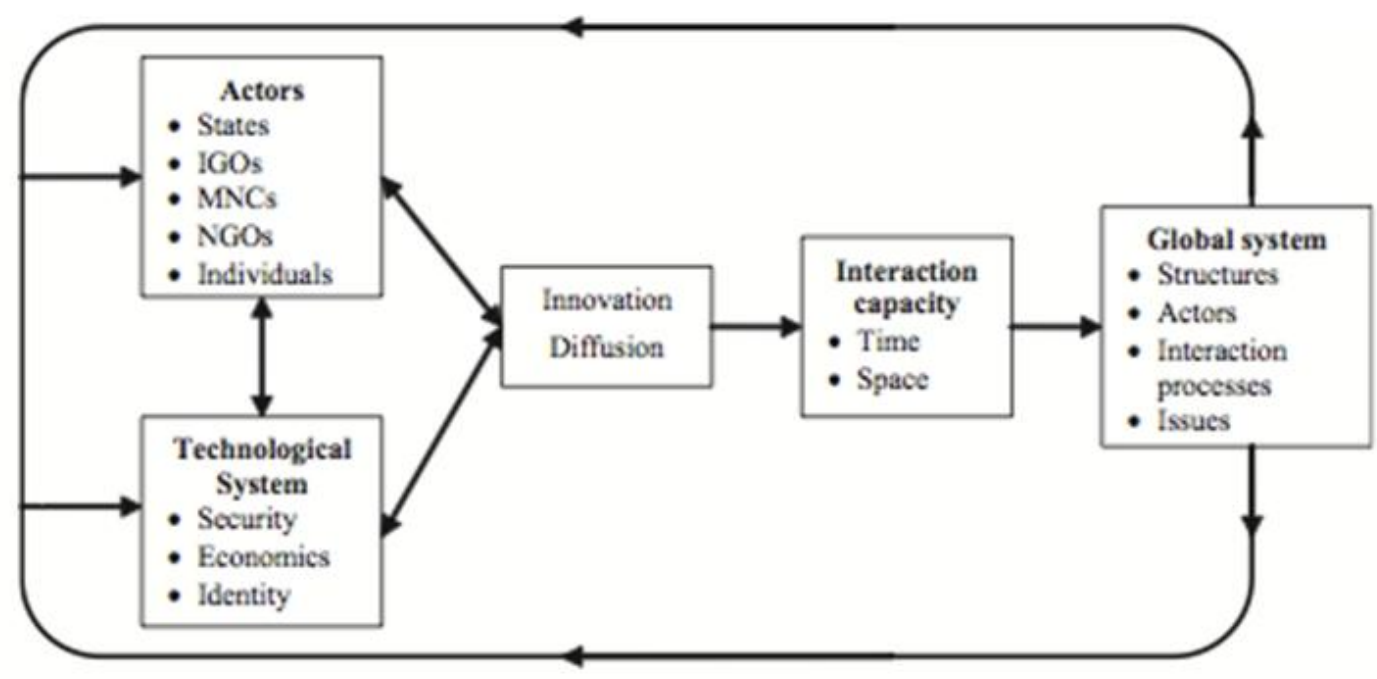

(Fonte: FRITSCH, 2011, p. 35)

Para Fritsch (2011) a Internet pode não ser um fator único para explicar mudanças nos fenômenos das RI, mas certamente é um fator potencial a ser avaliado.

Na nova Escola de Copenhagem, a compreensão de cibersegurança tal como um setor securitizado pelos atores estatais e não-estatais é uma ideia predominante (KASSAB, 2014). Para esta Escola, securitização envolve mover questões ou objetos da rotina política para tomar medidas extraordinárias (KASSAB, 2014). Primeiramente, uma dada questão é retratada como ameaça, em seguida é preciso convencer o público disto. O autor exemplifica esta securitização através do comportamento dos atores não-estatais:

Non-state actors see the internet as being attacked. They are doing their part to securitizing cyber-space as well. For example, hacktivists like Anonymous and Lolzsec see their freedom of speech and expression on the Internet under threat. Their activities are a response to what they perceive as an attempt by states and corporations to annex the Internet for their purposes (KASSAB, 2014, p. 67).

Nesta concepção de securitização, o setor cyber se torna um elemento de alta prioridade, dado que setores políticos, econômicos e de informação militar são fortemente dependentes de sistemas eletrônicos e computacionais. Esta alta dependência gera uma expectativa de manter a integridade desses sistemas, num contexto em que um ataque cyber em larga escala poderia, potencialmente, quebrar a economia em escala global (KASSAB, 2014).

Outra proposta teórica é explicar ciberespaço através do nível de análises das RI ou três imagens, baseada na perspectiva trazida por Kenneth Waltz. A primeira imagem, nível 
focado no indivíduo, mostra o impacto das novas tecnologias no comportamento humano (FIDLER, 2014). A segunda imagem centra-se na estrutura doméstica dos Estados. Fidler (2014) explica a segunda imagem enfatizando o governo e o Estado para compreender o significado do ciberespaço: "Thus, individuals and societies need to use governance mechanisms to ensure that the reliance on software, fueled by commercial interests and market forces, reflects values and interests polities deem important" (FIDLER, 2014, p. 9-10). Por fim, a terceira imagem está no nível do sistema anárquico internacional (FIDLER, 2014).

Estas três imagens são úteis em explorar o domínio cyber em RI sobretudo por auxiliar na percepção do jogo de poder a partir do enfoque das imagens. Por exemplo, déspotas souberam utilizar a nova ferramenta para ampliação de seu poder, seja internamente através do controle e da censura de seus cidadãos, seja através da cooperação com outros regimes tratando a soberania da Internet como um fator importante para a estabilidade no sistema internacional. Nas palavras de Fidler (2014): "The shift from a domestic-regime focus to an international-system perspective suits authoritarian leaders because it casts cyberspace as less of a threat to their survival and more of an instrument of their power" (FIDLER, 2014, p. 8). Segundo Fidler (2014) a conectividade transnacional exerce certa ameaça sobre regimes autoritários, porém estes estão se unindo para tratar sobre a soberania da Internet como um fator importante para a estabilidade no sistema internacional. Se a Internet é tratada como uma questão de soberania nacional, como muitos autocratas desejam, ela passa a ser uma extensão do controle do governo já existente no domínio tradicional. Choucri (2012) pontua isto da seguinte maneira:

The enabling power of cyberspace for the individual (the first image) may be limited by the strong hand of the state (the second image), which can exert control over the content of the communication as well as the behavior of the communicator. If the state seeks to manipulate access, regulate content, manage information availability, and constrain its citizens' use of cyber amenities, then control of cyber access is simply an extension of control in the real domain (CHOUCRI, 2012, p. 133-134).

Adicionando uma quarta imagem, Choucri (2012) propõe um quarto nível de análise: "[...] the individual, the state system, the international system, and the global system — and their linkages and interactions" (CHOUCRI, 2012, p 25). Em outro trabalho da autora em conjunto com Clark (CHOUCRI; CLARK, 2012) ${ }^{31}$, um dos pesquisadores envolvidos na criação da Internet nos EUA, eles reconhecem as vantagens do nível individual, porque:

\footnotetext{
${ }^{31}$ Neste trabalho, Choucri e Clark (2012) propõem a intersecção entre os níveis de análise difundidos nas RI com as camadas da Internet. Relembrando a ideia dos autores, tratam-se das fundações físicas, camada lógica, camada informacional e os usuários, conformando a arquitetura da Internet segundo o entendimento de ambos, já
} 
By using this model, we see some notable implications of cyberspace. Cyber access empowers the individual. It provides new and powerful ways to articulate and aggregate their interests and mobilize for action. The individual begins to "matter" in the state-based sovereign system of international relations. From a theoretical perspective, this means that the first level in international relations theory is as privileged as other levels of analysis, a change from traditional theory (CHOUCRI; CLARK, 2012, p. 3).

Segundo os autores, o nível de análises tradicional nas RI sofre certa mudança quando inserido no contexto cyber, pois há maior empoderamento do indivíduo, o qual fornece modos de articular e agregar interesses, mobilizando a ação. O segundo nível de análise, o Estado, quando passou a lidar com o novo elemento do domínio cyber redimensionou o complexo cálculo de segurança entre segurança interna, externa e ambiental. No terceiro nível, o qual envolve o sistema internacional como um todo, o ciberespaço passou a acelerar a formação de interesses privados com objetivos e influências no sistema como um todo. O quarto nível, por sua vez, engloba todos os outros níveis acrescidos dos níveis da natureza e ambientais. Deste modo, a comunicação digital veio desafiar mudanças sociais, regulatórias e práticas políticas (CHOUCRI, CLARK, 2012). Estes quatro níveis em vinculação com as camadas da Internet são organizados no sistema integrado situando questões e ênfases, conforme Quadro 1:

\begin{tabular}{|c|c|c|c|c|c|c|c|}
\hline & & Individual & State & International & Global & Non-profit & Profit-seeking \\
\hline & People & & $\begin{array}{l}\text { Digital } \\
\text { divide }\end{array}$ & & & Advocacy & Off-shoring \\
\hline & Information & $\begin{array}{l}\text { Privacy } \\
\text { Peer } \\
\text { production }\end{array}$ & Censorship & $\begin{array}{l}\text { Takedown; } \\
\text { IPR }\end{array}$ & spam & WikiLeaks & Aggregation \\
\hline \multirow{3}{*}{$\begin{array}{l}\overline{\widetilde{T}} \\
.0 \\
0 \\
\end{array}$} & Aplication & $\begin{array}{l}\text { Peer } \\
\text { production }\end{array}$ & $\begin{array}{l}\text { Lawful } \\
\text { intercept; } \\
\text { blocking }\end{array}$ & & & & Control \\
\hline & Services & & $\begin{array}{l}\text { Blocking } \\
\text { DNS }\end{array}$ & & $\begin{array}{l}\text { Authority } \\
\text { over DNS }\end{array}$ & & \\
\hline & Internet & $\begin{array}{l}\text { Home } \\
\text { network } \\
\text { mgt. }\end{array}$ & $\begin{array}{l}\text { Network } \\
\text { neutrality }\end{array}$ & & & & \\
\hline & Physical & $\begin{array}{l}\text { Home } \\
\text { wiring }\end{array}$ & $\begin{array}{l}\text { Facilities } \\
\text { unbundling }\end{array}$ & $\begin{array}{l}\text { Satellite orbit } \\
\text { spectrum }\end{array}$ & & & $\begin{array}{l}\text { Facilities } \\
\text { investments }\end{array}$ \\
\hline
\end{tabular}

(Fonte: CHOUCRI; CLARK, 2012, p. 5)

que não é uma concepção homogênea compartilhada na área, conforme já foi apresentado no item anterior. (CHOUCRI, CLARK, 2012). 
De acordo com a análise do modelo integrado realizada pelos autores: Quanto mais baixa a camada, mais física e facilmente regulada pelo Estado; ao contrário, quanto mais alta, maior o número de autores privados e não dominados pelo controle estatal. No caso da information layer, observa-se que quando há tentativas de controle são potencialmente frustradas. Ademais, os atores não-estatais geralmente estão envolvidos nas camadas mais altas, porém, no caso da camada física, multinacionais é que são responsáveis pela manutenção dos cabos ultramarinos, por exemplo. Organizações internacionais, ainda que algumas pouco institucionalizadas, têm lidado bem com a flexibilidade exigida para a governança do ciberespaço:

For example, inspecting and blocking packets occurs at the logical IP layer, but demanding takedown of content occurs at the information layer. As well, actions can be positioned within levels of analysis: takedown of content is normally at the domestic scope, because the laws that define the rules that govern content hosting sites and rights holders are usually specific to a country. Rights holders have had to fight more or less a country-by-country campaign to protect their property from piracy (CHOUCRI, CLARK, 2012, p. 11).

Choucri (2012), por sua vez, diz que as perspectivas teóricas utilizadas tais como o realismo, institucionalismo e construtivismo são apenas uma parte da análise das RI. De fato, representam parcialmente a miríade de ferramentas teóricas já desenvolvidas no campo deixando de mencionar outras e falhando em fazer cruzamento de perspectivas. A partir disso, a autora argumenta que as teorias do século XXI devem levar em consideração novos sistemas de interação.

Em realidade, atores não-tradicionais nas RI - como indivíduos e grupos sociais - têm aumentado seu poder através do ciberespaço. A comunicação digital, principalmente através das mídias sociais, vem impulsionando novas relações sociais (MULLER, 2010), assim como tem criado um domínio não completamente regulado de segurança nacional, menos ainda internacional (CHOUCRI, 2012). Em geral, indivíduos e coletivos buscam a Internet para se conectarem uns aos outros, se informarem e fortalecerem o networking. Por esta razão, a Internet funciona tanto como uma caixa de ferramentas, como uma nova arena que aperfeiçoa novas posições de grupos no domínio internacional. Este é um ponto importante de inflexão para os grupos sociais, uma vez que este novo contexto favorece outros players além dos Estados, e que não estão focados somente no monopólio da força ou buscando apenas resultados no ciberdomínio (MUELLER; SCHMIDT; KUERBIS, 2013).

Como um todo, estes estudos demonstram a forma das teorias de RI endereçarem o domínio cyber trazendo assim contribuições para a análise. Autores como Choucri (2012) e 
Kello (2013) demonstram algumas dificuldades de tratar o mundo político internacional conforme os modelos tradicionais das teorias. Além disso, teorias tradicionais como construtivismo, realismo e institucionalismo geram bastante debate, porém pouco interseccionam entre elas (CHOUCRI, 2012).

O resultado mais relevante, levando em conta o interesse da presente tese, diz respeito ao papel dos indivíduos e grupos sociais neste contexto digital, considerando os usos da tecnologia e seu empoderamento em escala não apenas nacional, mas também internacional. Embora o ativismo transnacional possa cruzar diferentes lentes teóricas supracitadas, para fins desta pesquisa este fenômeno não poderia ser devidamente compreendido, no atual contexto da comunicação digital, por nenhuma perspectiva teórica em específico. Por isso, as abordagens teóricas, ainda que incompletas per si, podem ser úteis apenas ao serem combinadas (extraindo o que têm de mais sólido e descartando o que há de mais frágil), adotando-se assim a perspectiva de um pluralismo teórico. Esta decisão se deve justamente ao fato de que o pluralismo teórico permite a compreensão a partir de diferentes perspectivas sobre este empoderamento dos atores sociais nas RI influenciados pelos usos da comunicação digital.

Até aqui, é possível observar que a análise da comunicação digital nas RI não ocorre de maneira uniforme. Notadamente, os estudos cyber e as RI vêm aumentando em número e em interesse dentre os pesquisadores da área. De uma maneira geral, Carr (2009) explica que os pesquisadores de RI têm buscado entender como a tecnologia tem impactado nas relações de poder entre indivíduos e Estados. O que se observa nesta relação entre a definição de um campo de estudos versus realidade dos fenômenos do mundo ciberpolítico é a tentativa do equilíbrio entre ruptura e continuum. Ruptura, porque há um elemento novo: A caracterização de um novo ciberespaço de influência e disputa de poder nas relações internacionais, de modo que tanto os cientistas quanto os policymakers estão buscando compreender em que medida as estruturas e processos das RI estão de fato se alterando substancialmente. Ao mesmo tempo, é um continuum, pois as ferramentas de análise e de ação remanescem do mundo político tradicional e muitas de suas características também. Porém, conforme já foi apontado em diversos momentos nessa pesquisa de doutorado, há necessidade de releitura dessas ferramentas de análise a fim de abarcar os novos fenômenos. Assim, este ajuste entre ruptura e continuum tem sido um desafio, que também compartilhamos, para aqueles que não se esquivam de analisar este novo elemento recente, mas já bastante enraizado no mundo social.

Segundo Kremer e Müller (2014), embora haja uma vastidão de livros e artigos que versam sobre questões relacionadas à "transnacionalização digital dos espaços sociais" 
conforme nomeiam os dois autores, ainda tem havido pouca participação da área de RI neste debate. Uma iniciativa relativamente nova, iniciada em 2009, é o esforço conjunto entre MIT e Harvard chamado MIT and Harvard Explorations in Cyber International Relations (ECIR)”. Neste projeto, o domínio cyber é pesquisado junto aos assuntos internacionais, criando uma disciplina multidisciplinar na qual se busca analisar teorias, dados e ferramentas analíticas que considerem as novas complexidades trazidas pelo século XXI, deflagrando este um contexto em que as RI não podem ser desatreladas da era cyber (CHOUCRI; GOLDSMITH, 2012).

Apesar deste cenário promissor, Kello (2013) salienta dois ceticismos comuns que influenciam os estudos de RI sobre o ciberespaço: (a) a contestação sobre o real impacto deste objeto; e (b) o questionamento da viabilidade real de estudar as propriedades deste novo domínio.

Em relação ao primeiro caso de ceticismo, há uma crença difundida de que o poder do ciberespaço em causar danos reais estaria superestimado. Nesta linha, os ciberataques não causariam danos colaterais, e assim não seriam qualificados como atos de guerra, e ainda que fossem destrutivos, não envolveriam alto custo (KELLO, 2013). Logo, considera-se os recursos materiais, financeiros e militares bem mais impactantes e concretos no jogo político da arena internacional; e a Internet, algo mais abstrato sem representar uma real ameaça hoje.

Esta visão pode ser contestada. Como argumenta Fritsch (2011), a tecnologia cria problemas específicos e tem desafiado o modus operandi da política global nas últimas décadas, possibilitando novas formas de ameaça como ciberataques cada vez mais sofisticados e a potencialização da insegurança. Para o autor, trata-se de algo complexo e que somente o conhecimento adequado dos meios tecnológicos poderia combater, mas que devem ser compreendidos à luz do ambiente sociopolítico (FRITSCH, 2011). Além disso, o grau de difusão das plataformas digitais e seu enraizamento no tecido da vida moderna tem tornado o offline e o online cada mais interligados, em simbiose crescente. Por outro lado, o argumento do baixo custo dos ciberataques também é contestável. O custo é relativo, pois depende da sofisticação em que estes ciberataques são empregados. E novos recursos são inseridos no jogo: por exemplo, a ação política sincronizada de um grupo militante hacker contém um grande capital de recursos humanos e know how capazes de fazer força frente ao alto custo da estrutura estatal similar de ciberataque ou ciberdefesa. Esta falta de importância dentro do campo de estudos é bastante influenciada, segundo Kello (2013), pela má interpretação feita pelos tomadores de decisão: 
The possibility that practitioners could be wrong in their estimation of a particular danger does not make scholars' withdrawal into the cloistered halls of academic life acceptable; on the contrary, it increases the need to challenge governing misconceptions as an essential step toward developing sensible security policy (KELLO, 2013, p. 13-14).

Ao mesmo tempo em que é um tema fascinante às RI, o ciberdomínio seria visto também como assunto neutro, revestido de caráter técnico e que por isso, não haveria nuances políticas a serem analisadas, perspectiva bastante pendente para o determinismo tecnológico debatido no capítulo anterior. Porém, como afirma Choucri (2012), este tema antes considerado técnico de "low politics" 32 não é neutro, já que é controlado política e economicamente, sobretudo por empresas privadas, além de sofrer influências dos Estados e resultar em efeitos altamente políticos.

O segundo ceticismo contesta a real viabilidade de estudar as propriedades do ciberdomínio. Esta visão tem como pano de fundo a premissa de que o ciberdomínio é de difícil apreensão in totum. Dentre as dificuldades que tais estudos enfrentariam estão as barreiras que impedem a completa coleta de dados; a defasagem de técnicas para executar coletas de dados de fato efetivas ${ }^{33}$; a falta de métrica adequada para codificar os eventos cyber; e as inadequadas perspectivas teóricas para abarcar um fenômeno de natureza digital.

É possível concordar que essas barreiras existem, mas atualmente já existem diversas outras áreas de estudo (como Comunicação Social, Ciências da Computação e Cibercultura etc.) que trazem contribuições avançadas para a produção de análises relevantes. Por isso, a melhor forma de superar tal ceticismo é concentrar-se na análise sobre cyber e RI através da interdisciplinaridade, assim seria possível formular conceitos e modelos que fortalecessem o campo, porém, muitos são os obstáculos, pois como mostra Fritsch (2011) a respeito dessa empreitada:

[...] although we have witnessed closer cooperation between practitioners, engineers, and political scientists during the last few decades, each one still prefers to concentrate on hisher own discipline and work within that discipline's set of variables, categories, and theoretical concepts (FRITSCH, 2011, p. 41).

\footnotetext{
32 Termo destinado para aquilo que seria de rotina secundária, entendido como questões econômicas e tecnológicas. Já as questões tidas como centrais eram enquadradas nas high politics, tangentes à segurança nacional e assuntos militares, englobando o sistema de decisões e interesses dos Estados, como guerras, conflitos e efetivas participações políticas.

${ }^{33}$ Por exemplo, nesta visão argumenta-se que muitos documentos importantes para análise, como aqueles sobre ciberataques, estarem circunscritos ao domínio sigiloso da diplomacia, criando um gap de acesso aos dados. Outros céticos diriam que mais do que as propriedades do ciberdomínio serem desconhecidas por grande parte dos pesquisadores, elas seriam impossíveis de serem descobertas (KELLO, 2013).
} 
Kello (2013), por sua vez, evidencia que esta interdisciplinaridade não exige necessariamente domínio da complexidade técnica sobre cyber para pesquisar em cyber studies:

\begin{abstract}
Cyber studies, however, does not require a miracle of learning; only the minimum degree of technical acuity is needed, which reveals the scope of maneuver in the cyber domain. Cyber studies require a congress of disciplines that includes not only the engineering sciences but also the political and social sciences. Certain aspects of the cyber issue, such as the analysis of code, belong to the computer specialist; others require the expertise of researchers versed in the contests of international anarchy (KELLO, 2013, p. 16).
\end{abstract}

Diversos autores apontam a necessidade de se criar instrumentos conceituais e teóricos capazes de abarcar essa realidade recente, embora já ordinária nas relações internacionais (KELLO, 2013; CHOUCRI; GOLDSMITH, 2012; RADU, 2014; CHOUCRI, 2012). A maioria das teorias das RI que foram desenvolvidas no século XX é estadocêntrica, condição que menos ainda se aplica ao contexto configurado nas últimas décadas, sobretudo com o incremento do ciberdomínio (MUELLER; SCHMIDT; KUERBIS, 2013; CHOUCRI; GOLDSMITH, 2012). Nesse sentido:

There is an enormous disconnect between the cyber realities of today and the theories of the twentieth century, which continue to guide national policy and international relations. For example, the emphasis on the state-based system of international relations is increasingly tested more by a wide range of new actors - from Wikileaks Julian Assange to the jihadist webmasters of Al Qaeda - with new cyber-enabled modes of interaction (CHOUCRI, GOLDSMITH, 2012, p. 75).

Choucri e Goldsmith (2012) demonstram que existem hoje poucos estudos sistemáticos invocando a arena cyber nas RI, sobretudo no que diz respeito à compreensão da interação entre os atores estatais e não-estatais nesta nova arena, bem como um gap no entendimento de quais atores têm gerenciado o processo de regulação neste novo espaço. Outro gap refere-se aos dados empíricos das atividades cyber, cuja coleta e refinamento têm sido infimamente pequenos quando comparados à qualidade e frequência que eventos dessa natureza acontecem (CHOUCRI; GOLDSMITH, 2012). Infelizmente, como visto, ceticismos acerca da viabilidade e relevância de estudos dessa natureza retardam ainda mais esse processo e ajudam a acentuar esses gaps. 
Apesar de o ceticismo gerar lacunas, nas RI ocorrem esforços para desenvolver pesquisas nesta interface com o ciberdomínio. Isso ocorre basicamente em duas linhas de estudos: Segurança e Governança. O primeiro segmento, que podemos chamar de Cibersegurança, é bastante influenciado pela tematização do conflito em RI. Não por acaso, a cibersegurança é um dos estudos que mais se proliferou nas RI em sua interface com o ciberdomínio. Isso pode ser explicado devido à centralidade da guerra nesta disciplina, privilegiando questões relacionadas à segurança. A segunda linha de estudo, doravante cibergovernança, é influenciado pelos debates sobre a gestão internacional da rede e as relações de poder que se estabelecem nesta arena. Estas são hoje as duas principais linhas de estudo em RI que tocam a interface com o ciberdomínio. Embora nenhuma delas consiga tratar a relação entre ciberdomínio e ativismo transnacional, ambas trazem contribuições relevantes que, para avançarmos no entendimento deste fenômeno nas RI, convém compreendermos mais especificamente alguns enfoques que estas duas abordagens oferecem.

\subsection{CIBERSEGURANÇA: ATAQUE, DEFESA E ATORES INTERNACIONAIS}

Antes de situarmos a linha de estudos em cibersegurança, é importante apresentar o marco empírico do Stuxnet: um evento que se tornou emblemático nos estudos da área. Em 2010 o programa nuclear do Irã foi prejudicado drasticamente devido a um malicious software que penetrou em seu sistema de enriquecimento de Urânio. O sofisticado vírus, denominado de Stuxnet, afetou o software e o hardware do sistema computacional vinculado ao programa iraniano, alterando a informação nele contida e comprometendo a segurança e danificando a operacionalidade das centrífugas nucleares do Irã (KIGGINS, 2014). Israel e Estados Unidos foram culpados de criarem o vírus para reverterem esse processo de desenvolvimento nuclear do Irã, embora não tenham confirmado a autoria (OPPERMANN , 2002; CHOUCRI, GOLDSMITH, 2012; SHAHEEN, 2014; KNOEPFEL, 2014; KIGGINS, 2014).

Várias questões emergiram a partir deste ataque, classificado por Knoepfel (2014) como um ato de guerra. Primeiramente, mostrou-se que o uso de ciberarmas podem causar danos e impactos que demoram para ser recuperados, e ainda que o Stuxnet tenha sido desabilitado pouco depois de descoberto (GREATHOUSE, 2014) já havia causado danos em todo o sistema. Isto significa que este tipo de ataque funciona como uma alternativa a bombas 
e mísseis comumente lançados por aviões, demonstrando que se de um lado o avanço das tecnologias da informação e comunicação têm aumentado a vulnerabilidade, por outro lado, também têm criado novas oportunidades de ataques em um novo front de embates (KIGGINS, 2014).

Segundo, no caso de um ciberataque, é bastante difícil determinar com precisão a sua origem, por conta da própria natureza abstrata e fugidia do ambiente digital. Porém, devido à sofisticação, complexidade e efetividade do Stuxnet conclui-se que ele só foi possível de ser realizado devido à capacidade de recursos, expertise e um planejamento de programa de inteligência que poucos conseguiriam administrar, apontando-se possivelmente um poderoso Estado por trás de tal ação (CHOUCRI; GOLDSMITH, 2012; SHAHEEN, 2014; KNOEPFEL, 2014).

Este caso emblemático suscita diversas análises no campo de cibersegurança e política internacional. Por cibersegurança compreende-se uma linha de estudos, emergente principalmente nas últimas duas décadas, cuja ênfase é analisar os mecanismos para proteger as operações de dados ou um sistema computacional contra possíveis perpetrações hostis (KELLO, 2013; CHOUCRI, 2012; KREMER; MULLER, 2014). Kello (2013) explica que "Crucially, the concept encompasses the safety and survivability of functions operating beyond cyberspace but still reliant on a computer host, to which they are linked at the logical or information layer" (p. 18).

Basicamente a literatura sobre cibersegurança é dividida em duas ênfases de estudos: (a) sobre os meios e motivações dos atores envolvidos; e (b) sobre os instrumentos utilizados pelo lado ofensivo no caso de um ataque (KREMER; MULLER, 2014). Kremer e Muller (2014) elaboraram um modelo para analisar stakeholders, atividades e motivos nas ações relativas à cyber segurança chamado "SAM-framework". Esse modelo não distingue entre atacante e defesa, pois acredita-se que este tipo de distinção não se aplica mais ao tipo de ciberconflito. E assim os atores são identificados independentes dos motivos e tipos de instrumentos usados. Os stakeholders são organizados em: Indivíduos, coletivos/ swarms (trata-se de um grupo de atores temporários propiciados pelo contexto da Internet e que se reúnem para um propósito definido), grupos, organizações/empresas, e Estados e organizações supranacionais e internacionais (KREMER; MULLER, 2014). As ações perpetradas pelos diversos stakeholders referem-se às atividades executadas propositadamente para atingir certos objetivos.

Devido a esta profusão de atores e devido aos diversos modos de uso e diferentes efeitos que as ferramentas digitais podem sustentar, de um modo geral, uma compreensão 
uniformizada sobre o que são ciberameaças (e a sua regulação no nível internacional) é bastante dificultosa. Isto se deve ao fato de que a Internet enquanto ferramenta pode ser usada para diversos fins e assim cria diversos entendimentos de seus propósitos. Nye (2010) pondera que Twitter e Youtube, por exemplo, são questões de liberdade pessoal na opinião norte-americana, já do ponto de vista do governo chinês ou iraniano são instrumentos de ataque.

Devido ao próprio caráter global do ciberespaço, a cibersegurança, mais do que circunscrita à segurança nacional, trata-se de uma questão transnacional que afeta usuários online de qualquer natureza, pois uma vez conectados em rede, todos estão vulneráveis a um ciberataque, de tal modo que não há uma proteção ou jurisdição assegurada por delimitações geográficas. Por isso, um ciberconflito tende a se tornar parte das preocupações em segurança.

Greathouse (2014) explica que há diversas nomenclaturas para designar o conflito no ciberespaço: Conflito de quarta geração, guerra eletrônica, guerra informacional, conflito centrado em rede, e ciberguerra. Segundo Greathouse (2014) ciberguerra é: "the use of network based capabilities of a state or non-state actor to disrupt, deny, degrade, manipulate, or destroy information resident in computers or computer networks or the computers or networks themselves of another actor (GREATHOUSE, 2014, p. 24). Isto significa que o uso de ciberarmas pode ser perpetrado por diversos atores, não apenas Estados, de modo que podem ser atores transnacionais, empresas, organizações e indivíduos. Isso ocorre devido ao fato do ambiente digital possibilitar a apropriação de suas ferramentas por esses diversos atores, o que coloca a questão para além da relação formal de agressão entre Estados, trazendo outros agentes para este jogo:

\footnotetext{
Cyber conflict, therefore, can fit four basic agent frames: (1) state-to-state, in which one state targets another state's strategic computer assets, such as in Olympic Games (this category includes the use by government of obedient civilian proxies); (2) private-to-state, which includes cyberattacks by militant groups or "patriotic" hackers such as in the Estonian case; (3) private-to-private, involving an exchange of cyber blows between nonstate entities such as private companies (a possible contingency of Secretary Napolitano's consideration); and (4) state-to-private, in which a state attacks the private computer systems of another nation, possibly for commercial or other economic gain (KELLO, 2013, p. 36).
}

Aproximando-se da análise feita sob a ótica dos Estados, os autores Hathaway e Klimburg (2012) observam particulares concepções de "ciberataque". De um modo geral, há um consenso entre os países de que esses tipos de ataque já são usados de forma militar, mas 
há uma linha muito fina entre infiltrar um computador para espiar e para atacar, o que gera grandes controvérsias (HATHAWAY; KLIMBURG, 2012). A Alemanha, por exemplo, define ciberataque como algo que torna vulnerável a cibersegurança, inclusive envolvendo questões de confidencialidade e integridade. Os Estados Unidos, por sua vez, definem o ataque na rede de computadores como tentativas de provocar interrupções e danos em computadores e sistemas alvo. A diferença entre esses dois entendimentos envolve importante questões, tal como a espionagem, já que enquanto isto é um importante caso de ataque à confidencialidade segundo o entendimento alemão, os EUA simplesmente não a incluem como ciberataque (HATHAWAY; KLIMBURG, 2012). Por isso, as tipologias podem variar na medida em que os autores criam diferentes escalas e características para enquadrar as nuances dos usos da ciberferramentas com fins estratégicos e políticos.

Além disso, os diversos mecanismos executados no ciberdomínio podem desdobrar em diferentes tipos de atividades com seus diferentes impactos, que vão desde um monitoramento até um ciberataque de proporções destrutivas. Quanto à abrangência desses ataques, Choucri (2012) tipifica as ameaças em duas macro-categorias: (a) Quando atingem diretamente os setores de comunicação e informação e (b) quando atingem outros segmentos/setores que dependem do sistema de comunicações. Alguns exemplos de ataques que podem causar o desiquilíbrio de um Estado são: Desligamento da malha energética, rompimento da comunicação, bloqueio da entrega de combustível e água, ou ainda o sequestro de drones (KASSAB, 2014). Kassab (2014) faz uma analogia desses ataques com o clássico cavalo de Tróia: Uma estratégia inovadora que enfraquece o Estado a partir da infiltração em seu interior.

A partir do cruzamento e adaptação de concepções de diversos autores, elaborou-se o Quadro 2 que traz uma tipificação considerando os principais tipos de ciberataques e algumas de suas principais características: 
Quadro 2 - Principais tipos de ciberataques

\begin{tabular}{|c|c|c|}
\hline Tipo & Descrição & Exemplo de ocorrência \\
\hline $\begin{array}{l}\text { Ataque de sobrecarga } \\
\text { no sistema }\end{array}$ & $\begin{array}{l}\text { Trata-se dos ataques capazes de bloquear ou impedir que um sistema } \\
\text { digital funcione sobrecarregando-o com acessos em grande escala. } \\
\text { Um bom exemplo é o chamado Ataque de Negação de Serviço. } \\
\text { Também conhecido por Ataques DoS (Denial of Service), este tipo } \\
\text { de ação sobrecarrega uma rede ou website através do bombardeio } \\
\text { excessivo de dados. Pode não ser destrutivo, mas paralisa a atividade } \\
\text { do sistema ou afeta a sua performance impedindo que outros usuários } \\
\text { acessem o sistema (GREATHOUSE, 2014). }\end{array}$ & $\begin{array}{l}\text { Em } 2007 \text { sites governamentais, bancos e } \\
\text { organizações de mídia da Estônia foram } \\
\text { atacados através de DoS tornando-se } \\
\text { inoperantes. Suspeita-se que o ataque tenha } \\
\text { vindo da Rússia. Este caso foi emblemático, } \\
\text { obrigando os Estados a pensarem com } \\
\text { maior preocupação em ciberconflito. }\end{array}$ \\
\hline $\begin{array}{l}\text { Ataque de infiltração } \\
\text { viral }\end{array}$ & $\begin{array}{l}\text { Um vírus de computador consiste em um software malicioso que se } \\
\text { instala no interior de um sistema operacional, com capacidade de } \\
\text { danificar, paralisar, retardar a performance do sistema, podendo } \\
\text { também capturar dados. Geralmente, os vírus têm capacidade } \\
\text { reprodutiva e podem "trafegar" de uma máquina para a outra, em um } \\
\text { movimento análogo à infecção de um corpo biológico por um micro- } \\
\text { organismo. Na mesma categoria de um ataque viral, também } \\
\text { podemos colocar o que vem sendo chamado de "bomba lógica". } \\
\text { Trata-se de um tipo de programa desenhado para ser inserido dentro } \\
\text { de uma rede e quando ativado destrói dados ou compromete a rede. } \\
\text { Por exemplo, atacar pontos centrais da rede de um alvo impedindo-o } \\
\text { de se comunicar em momento de crise (GREATHOUSE, 2014). }\end{array}$ & $\begin{array}{l}\text { Em } 2010 \text { o programa nuclear iraniano foi } \\
\text { atacado por um vírus de computador, o } \\
\text { Stuxnet, que estima-se ter destruído } 58 \% \\
\text { do projeto, atingindo software e hardware } \\
\text { (KASSAB, 2014). Acredita-se que o } \\
\text { malware tenha sido instalado através de um } \\
\text { pen drive (USB stick) (SHAHEEN, 2014). }\end{array}$ \\
\hline
\end{tabular}




\begin{tabular}{|c|c|c|}
\hline Sequestro de sistema & $\begin{array}{l}\text { Tendo em vista a ampliação do fenômeno que alguns autores } \\
\text { (LEMOS, 2013; GREENGARD, 2015) chamam de "internet das } \\
\text { coisas" (quando todo tipo de objeto passa a se conectar à rede via } \\
\text { radiofrequência, tais como celulares, geladeiras etc.) e o crescimento } \\
\text { do uso digital do espectro radioelétrico para o controle remoto de } \\
\text { objetos (como drones, veículos, máquinas de uma indústria etc.), } \\
\text { torna-se possível o sequestro remoto desses objetos na forma de um } \\
\text { ataque. Isso significa geralmente a perda (comumente temporária) de } \\
\text { domínio do objeto que passa a responder ao sequestrador, podendo } \\
\text { causar danos físicos relevantes a depender do tipo de equipamento } \\
\text { "raptado". }\end{array}$ & $\begin{array}{l}\text { Em } 2011 \text { o Irã capturou um drone } \\
\text { estadunidense RQ-170 Sentinel em seu } \\
\text { espaço aéreo. Segundo o governo iraniano, } \\
\text { a captura ocorreu com a obtenção do } \\
\text { controle digital do sistema de navegação do } \\
\text { dispositivo forçando-o a descer sem danos. } \\
\text { Na versão do governo americano o drone } \\
\text { teve uma pane mecânica. De todo modo, } \\
\text { hoje já é possível assumir remotamente o } \\
\text { controle de um aparelho através da invasão } \\
\text { do sistema de navegação. }{ }^{34}\end{array}$ \\
\hline $\begin{array}{l}\text { Sequestro de dados } \\
\text { (Ciberespionagem) }\end{array}$ & $\begin{array}{l}\text { A ciberespionagem trata do uso de capacidades eletrônicas para } \\
\text { filtrar informação não disponibilizada de um alvo. Esta ação } \\
\text { privilegia o coletor (não autorizado ou intruso) externo, na medida } \\
\text { em que traz certo anonimato, facilita a transferência de grande } \\
\text { quantidade de dados e mascara sua localização geográfica. A maioria } \\
\text { dessas atividades não é reconhecida como um ataque pelo direito } \\
\text { internacional, embora alguns Estados, quando vítimas, o classifiquem } \\
\text { como "ataque" (HATHAWAY; KLIMBURG, 2012). } \\
\text { Tradicionalmente a espionagem é uma atividade focada na obtenção } \\
\text { de informação de governos estrangeiros ou empresas concorrentes. } \\
\text { Esta prática se alastrou na Internet pela facilidade que um malicioso } \\
\text { software ou um usuário mascarado pode obter dados sigilosos. } \\
\text { Hathaway e Klimburg (2012) definem esta atividade como }\end{array}$ & $\begin{array}{l}\text { Em } 2009 \text { uma arma cyber de origem } \\
\text { chinesa chamada de "Ghostnet" roubou } \\
\text { informações confidenciais de mais de } 100 \\
\text { organizações governamentais e privadas de } \\
\text { diferentes países (SHAHEEN, 2014) }{ }^{35} \text {. }\end{array}$ \\
\hline
\end{tabular}

\footnotetext{
${ }^{34}$ Ver em <http://www.bbc.co.uk/news/world-middle-east-17805201> acesso em 22 de setembro de 2015.

${ }^{35}$ Algumas formas mistas também poderiam ser elencadas. Por exemplo, o ataque de Spear Phishing. Com características mistas entre ciberespionagem, ataque viral e sequestro remoto, o spear phishing consiste no roubo de dados sensíveis de um indivíduo ou grupo de indivíduos através do qual o agressor usurpa a identidade de uma vítima (geralmente alguém em posição de poder) e age em seu nome de forma danosa.. Em 2014 o ICANN (Internet Corporation for Assigned Names and Numbers, corporação que gerencia parte da Internet, principalmente a alocação de endereços de endereços eletrônicos na web) sofreu um ataque de spear phishing. Os agressores conseguiram tomar a identidade digital de funcionários e acessar áreas e dados privados da organização . Ver em <http://www.wired.com/2015/04/hacker-lexicon-spearphishing/> acesso em 22 de setembro de 2015 e também em <http://wap.convergenciadigital.com.br/cgi/cgilua.exe/sys/start.htm?infoid=38683\&sid=4 > acesso: 22 set. 2015.
} 


\begin{tabular}{|c|c|c|}
\hline & $\begin{array}{l}\text { "Computer Network Exploitation (CNE): enabling operations and } \\
\text { intelligence collection capabilities through the use of computer } \\
\text { networks to gather data from target or adversary automated } \\
\text { information systems or networks" (p. 16). A ciberespionagem pode } \\
\text { ocorrer através da penetração em um computador adversário ou uma } \\
\text { rede através de worm ou malware para monitorar e obter informações } \\
\text { para objetivos de estratégia. Isto não envolve destruição de dados ou } \\
\text { de rede, mas pode ser usado como um elemento para um futuro } \\
\text { ciberataque (SHAHEEN, 2014; KELLO, 2013). }\end{array}$ & \\
\hline Hacking e ocupação & $\begin{array}{l}\text { A atividade de "hackeamento" consiste na invasão de um sistema } \\
\text { digital por um indivíduo ou grupo não autorizado, sendo este ataque } \\
\text { caracterizado por uma "ocupação", geralmente seguida por uma } \\
\text { mensagem pública de protesto. Neste tipo de ataque não há roubo de } \\
\text { dados ou destruição de arquivos. Alguns autores também colocarão o } \\
\text { "cyber vandalismo" nesta mesma categoria, como uma atividade que } \\
\text { visa causar distúrbio mais do que destruição. Por exemplo, o ato de } \\
\text { colocar um conteúdo em website sem a aprovação do moderador do } \\
\text { website, predominantemente marcado por um caráter político } \\
\text { (GREATHOUSE, 2014). Embora este encaixe possa ser adotado } \\
\text { aqui, importante lembrar que a palavra "vandalismo" carrega uma } \\
\text { conotação negativa de julgamento de valor que nem sempre será } \\
\text { adequada, uma vez que diversas açães do hacktivismo estão mais } \\
\text { próximas de um protesto político (vinculadas a um valor ético ou } \\
\text { político) do que de uma ação de delinquência. }\end{array}$ & $\begin{array}{l}\text { O Ataque de } 2007 \text { na Estônia também } \\
\text { envolveu invasão e publicação de } \\
\text { mensagens de protesto em sites } \\
\text { governamentais. }\end{array}$ \\
\hline
\end{tabular}


Essas formas de ataques são hoje cada vez mais recorrentes e já fazem parte do cenário de conflitos internacionais com impactos tanto em sistemas de comunicação como em outras infraestruturas ${ }^{36}$.

Conforme mencionado, todos os usuários da rede, sejam Estados, instituições, ativistas ou indivíduos, são capazes de realizar ou sofrer ataques de natureza ciber. Isto porque, a única forma de não se vulnerabilizar ou não se envolver em ataques desta natureza é não executar qualquer tipo de transação que envolva redes digitais e tecnologia computacionais. Realisticamente, este é um método pouco provável de ser adotado efetivamente vide o enraizamento das tecnologias de informação e comunicação no mundo social. Deste modo, reconhecer que os cibermecanismos, seja para defesa, seja para ataque, são parte de um processo em rede é um dos primeiros passos para adentrar nos estudos de cibersegurança como algo relevante e necessário em qualquer estudo no campo da segurança.

Se por um lado o debate sobre cibersegurança se preocupa bastante com as formas, tipos, características e efeitos dos ciberataques no cenário internacional, também há toda uma discussão sobre as ações de defesa. De tal modo, a ideia de ciberdefesa consiste justamente na habilidade de resistir ativamente a um ataque (GREATHOUSE, 2014). Para maximizar a segurança no ciberespaço, os Estados buscam proteger suas infraestruturas críticas contra o ciberataque. Alguns países como Estados Unidos, França, China, Reino Unido e Israel já vêm investindo seriamente em programas de cibersegurança, vislumbrando o potencial de conflitos nesse domínio (SHAHEEN, 2014).

Ainda que seja difícil estabelecer o papel fixo do ofensor e defensor de forma tão delimitada no ciberespaço, podemos falar em papéis intercambiáveis e circunstanciais, de modo que todos os atores das relações internacionais podem desempenhar ambos papeis no mesmo contexto. As teorias de ofensa-defesa tratam da necessidade de desenvolver mecanismos contra ataques a fim de equilibrar esta equação. Porém, os analistas ressaltam que há uma assimetria inevitável entre ataque e defesa nesses casos: No ciberespaço, há uma tendência atual em prevalecer o poder do agressor sobre o poder de defesa. Em muitos casos, a única forma de se defender seria não estar interconectado, mas isto não é cogitado porque

\footnotetext{
${ }^{36}$ Outras tipificações e caracterizações de ciberataques, que convergem com esta proposta, também são oferecidas por outros autores. Kremer e Muller (2014), por exemplo, desenvolveram uma taxonomia focalizada no resultado de uma certa atividade mais do que uma técnica de fato implementada. São elas: Roubar, interceptar, influenciar, manipular, controlar, romper, destruir (sendo as três últimas de impacto físico direto no alvo). Os motivos são cinco: Econômico, ideológico, político, psicológico e relacionado ao poder. As técnicas e motivos se misturam, por exemplo, há certos grupos terroristas que executam ataques de caráter econômico, mas com o fim de financiarem suas agendas política e ideológica.
} 
perderia as funcionalidades de estar em rede. Exemplos de mecanismos de defesa: Criptografia, firewall ${ }^{37}$ e detecção automática de invasão (GREATHOUSE, 2014). No caso de conflitos que envolvem Estados, a vantagem do ataque é gerada pela expertise de hackers unida a suporte financeiro de governos, sendo a tentativa de se proteger mais dificultosa por ser menos ágil e nem sempre adequada a dar uma resposta ao ataque no mesmo nível (SHAHEEN, 2014).

A assimetria entre ataque e defesa ocorre ainda devido a uma série de características típicas do ambiente digital. A partir da análise de diversos autores, pode-se sintetizar as principais razões deste desequilíbrio:

a) Baixo custo - Esta é uma variável que pende a balança para uma maior facilidade do ato de atacar já que "It is inexpensive to develop and use malware, as was observed in 2011 with the 400 million unique variants and as many as eight new zero-day vulnerabilities were exploited per day" (HATHAWAY; KLIMBURG, 2012, p. 15). Porém, esta é uma questão controversa, já que para se ter um ataque de alto impacto geralmente é necessário um alto custo, dificilmente sustentado por atores pequenos e fracos. A depender do grau de potência do ataque é possível identificar os atores envolvidos: "[...] sophisticated attacks against high value targets such as defense communications systems require a higher cost of attack, which involves large intelligence agencies to intrude physically and/or crack highly encrypted codes" (NYE, 2010, p. 11). Neste caso, obviamente apenas grandes Estados ou instituições com significativo poder de desenvolvimento e pesquisa seriam capazes de executar. Além disso, é importante lembrar que, devido às características do ambiente digital, o que antes era considerado um ataque sofisticado e de alto custo, em pouco tempo é disseminado e "barateado" através de download ou replicação dos códigos e estratégias utilizadas.

b) Abstração de fronteiras - Esta variável diz respeito ao aspecto poroso da geolocalização no ciberespaço. Como aponta Shaheen (2014) "[...] it is difficult to discuss offense-defense balance in terms of conventional understanding of territory because the cyberspace does not define borders for every state" (p. 87). Isso significa em termos práticos que a intensa conectividade dos sistemas entre o atacante e o alvo faz com que a penetração seja mais fácil,

\footnotetext{
${ }^{37}$ Firewalls são dispositivos cibernéticos que funcionam como uma barreira passiva para negar acesso nãoautorizado. Ajuda a defender contra vírus e worm atacks. Não é plenamente seguro, pois pode ser infiltrado por um mecanismo de encapsular dados, de modo a permitir a infiltração em um banco de dados supostamente protegido por firewall (KASSAB, 2014).
} 
já que é um espaço sem fronteiras. A mobilidade permite que uma arma esteja bastante distante e indetectável pelo alvo e que haja maior conhecimento da vulnerabilidade do alvo, até melhor do que o próprio alvo (embora depois de expostos ao ataque, os programadores e engenheiros de softwares conseguem cessar aquela vulnerabilidade, ou até mesmo desenvolver mecanismos de retaliações no futuro) (SHAHEEN, 2014).

c) Anonimato - Devido aos mecanismos de navegação criptografada ou anônima, torna-se difícil identificar o agressor (KASSAB, 2014; GREATHOUSE, 2014; KIGGINS, 2014). A inabilidade de identificar ciberatacantes é chamada de problema de atribuição (KIGGINS, 2014). O defensor tem que estar sempre pronto para se defender ainda que não conheça seu atacante.

d) Tentativa-erro - O defensor não pode cometer erros nenhuma vez. Já o atacante precisa acertar apenas uma vez. Por isso, o atacante pode tentar inúmeras vezes sem sucesso até atingir o seu objetivo, uma vez que: "It is also probable that the number of pathways to enter target's computer network is more than the target's system administrators can possible protect" (SHAHEEN, 2014, p. 90).

Embora haja esta assimetria entre ataque e defesa, paradoxalmente o ato de atacar tem seus efeitos colaterais e nem sempre é o mais bem-sucedido. Isto ocorre principalmente em função de duas razões: (a) devido à possibilidade de fácil reapropriação da ciberarma por terceiros e replicada, saindo assim do controle de seus criadores; (b) devido à capacidade do atacado em se transformar em atacante (numa ação de represália) e causar danos ainda maiores àquele que iniciou a ofensiva.

No primeiro caso, na prática, a vítima de ciberataque pode desenvolver suas próprias armas e copiar armas de seus adversários estimulando a proliferação desse tipo de recurso, consequentemente, aumentando o perigo de instabilidade no sistema internacional (SHAHEEN, 2014). As ciberarmas são relativamente baratas e manipuláveis facilmente por atores não-estatais (expandindo para diferentes atores as opções de estratégia ofensiva). Ao mesmo tempo, esses recursos são fugidios e nem sempre identificáveis e controláveis pelos sistemas convencionais de defesa (KELLO, 2013).

No segundo caso, o debate sobre o que vem sendo chamado de teoria de deterrence é bem ilustrativo. Este conceito, que considera os Estados como atores centrais nas relações 
internacionais, explica que o potencial ofensor é dissuadido do ataque quando a ameaça da punição excede os ganhos que se obteria com o ataque (KIGGINS, 2014). Além disso, Kiggins (2014) explica que tal teoria envolve a credibilidade do defensor de ser capaz de executar a punição, a qual envolve três elementos: Identificar o perpretador, selecionar o tipo de resposta mais apropriado, e executar a resposta. A análise de Kiggins (2014) aponta que o sistema de cibersegurança dos EUA, apesar de todo o avanço, não consegue seguir estes critérios:

The US has the luxury of superlative technical skill among its cyber operators in government service and the experience to execute cyber operations as evidenced by Stuxnet. What the US lacks, as all other cyber operators, is the technology to identify whom or what perpetrated a cyber attack beyond identifying where a computer used to initiate an attack is located geographically (KIGGINS, 2014, p. 166).

Nesta perspectiva, os atores estatais seriam mais cautelosos no uso de ciberarmas, como o caso de os EUA decidirem em 2003 não atacar sistemas de computação no Iraque com receio de causar efeitos sem precedentes e causar reações catastróficas, não apenas no âmbito governamental, mas também no domínio privado, afetando negócios e economia.

Isso ocorre principalmente nos casos em que o Estado possui uma capacidade de contra-ataque capaz de provocar um prejuízo desproporcional ao ofensor. Porém, para punir, é preciso identificar o agressor, o que é uma das maiores dificuldades neste meio, conferindo à deterrence um efeito limitado (GREATHOUSE, 2014). Apesar desta dificuldade de atribuir o perpetrador dos ataques, a deterrence pode existir e evitar o ataque, já que pode causar denial do atacante (NYE, 2010). Autores como Kassab (2014) veem um efeito positivo da "cyber-deterrence" como uma fenômeno que pode ser capaz de evitar ciberconflitos:

\footnotetext{
States must make cyber-attacks more expensive than advantageous, and thus, impossible. Currently, states are attacking one another through the cyber realm because it is cheap, easy and hard to detect. My argument, the use of cyber-deterrence, hopes to end cyber-warfare by making it too expensive and difficult, not to mention easier to detect as a nation's cyber infrastructure would be knocked out (KASSAB, 2014, p. 74).
}

Porém, ainda é cedo para confirmar esta hipótese mais otimista. Pode-se dizer hoje que o ciberataque é uma ferramenta mais exequível quando comparada com as armas tradicionais, empoderando diversos atores (estatais e não estatais), mas prevalecendo ainda um relevante desequilíbrio de recursos disponíveis e capacidade de ação (seja para agredir ou se defender) entre os atores: permanece o maior poder de fogo dos atores estatais, na maioria 
dos casos. Alguns países estão desenvolvendo potentes instrumentos de ciberguerra, seja no modo preventivo para invadir sistemas no futuro (como a criação de backdoors ${ }^{38} \mathrm{em}$ aparelhos exportados ou no próprio sistema de defesa de países que ainda estão vulneráveis), seja no desenvolvimento de firewalls, criptografia e outros sistemas de defesas. Há hoje um real desequilíbrio destas forças. Além disso, importante lembrar que não há leis internacionais devidamente consolidadas e pactuadas capazes de punir os Estados, e por conseguinte, os demais atores que realizam ciberataques.

\subsection{CIBERGOVERNANÇA: REGULAÇÃO E GERENCIAMENTO}

Se por um lado as questões de segurança têm sido o tema que mais define os estudos das Relações Internacionais no campo das tecnologias digitais de comunicação, a própria característica transnacional da Internet, sua regulação e gerenciamento também é uma segunda abordagem que ganha atenção de estudiosos da área. Do ponto de vista dos atores, cibergovernança está relacionada ao debate feito entre pesquisadores e policymakers, sobretudo após a Guerra Fria, sobre como a Internet é administrada (registros de endereços e domínios na Internet, por exemplo), considerando políticas públicas e privadas em nível nacional e internacional (MUELLER, 2010; CHOUCRI, GOLDSMITH, 2012; KIGGINS, 2014; FIDLER, 2014; MUELLER; SCHMIDT; KUERBIS, 2013; OPPERMAN, 2012; NYE, 2010).

Nye (2010) relembra o esforço de alguns governos nacionais em controlar o ciberespaço, principalmente no que tange problemas relacionados à segurança, espionagem e crime. Porém, segundo o autor, a utilização de estruturas legais tradicionais para este fim não funciona num ambiente fluido como este. Em realidade, Nye (2010) destaca que ao invés de ser um ambiente selvagem e anárquico, trata-se de um domínio que envolve diversas áreas de governança pública e privada:

\footnotetext{
${ }^{38}$ Backdoors ("porta de fundo") é um termo utilizado em informática para definir mecanismos instalados em sistemas computacionais (hardware ou software) que permitem a "invasão" de terceiros, viabilizando assim um ciberataque, danificando ou controlando o referido sistema. Por exemplo, a criação de backdoors em smartphones reivindicada pelas forças de segurança dos EUA despertou protestos de empresas e organizações civis por ser considerado um ataque à privacidade e uma ação potencialmente autoritária de Estado. Sobre o exemplo, ver mais detalhes:

$<$ http://convergenciadigital.uol.com.br/cgi/cgilua.exe/sys/start.htm?infoid=39642\&sid=18>. Acesso: 10 jan. 2016.
} 
A non-governmental World Wide Web Consortium develops standards for the Web. The Internet Corporation for Assigned Names and Numbers (ICANN) has the legal status of a non-profit corporation under American law, though its procedures have evolved to include government voices (though not votes). In any event, its mandate is limited to domain names and routing management, not the full panoply of cyberspace governance. National governments control copyright and intellectual property laws, though they are subject to negotiation and litigation, sometimes within the frameworks of the World Intellectual Property Organization and the World Trade Organization. Governments also determine national spectrum allocation within an international framework negotiated at the International Telecommunications Union (ITU) (NYE, 2010, p. 14).

Kobrin (2001) defende a cooperação triparte público-privada-sociedade civil como um requerimento para efetivar a governança do ciberespaço, isto porque, segundo o autor, o setor privado e autoridades públicas devem se envolver na cooperação sobre questões sensíveis, tais como privacidade dos dados, censura e proteção do consumidor, as quais já envolvem vários setores da sociedade civil. $\mathrm{O}$ autor atenta-se para o fato de que aplicar um atrelamento geográfico em transações da Internet é bastante complicado, questionando se um país poderia regular o que uma empresa como o Google, ao disponibilizar conteúdo nos EUA, deveria responder à jurisdição imposta por outro país, como a França.

Entretanto, a maioria das iniciativas de governança são emergentes e descentralizadas, de modo que a solução viável na opinião de Mueller (2010) é a governança em rede conectando instituições nacionais e a internacionais, tal como corroboram grande parte dos autores de que "The extreme transnational interdependence in Internet operations requires globalized institutions to be effective" (MUELLER; SCHMIDT; KUERBIS 2013, p. 100).

Muito embora o caminho natural seja a governança conjugada entre instituições de natureza distintas, ainda se observa a crença de que devido à tradicional função do Estado como mantenedor da segurança, o aumento de insegurança no ciberdomínio conduziria à extensão da soberania do Estado neste domínio através do auxílio de meios tecnológicos (NYE, 2010). Os principais perigos enfrentados neste quesito de segurança internacional, segundo Kello (2013), são: a potencialidade das armas cyber, as complicações relacionadas à ciberdefesa e os problemas de instabilidade estratégica.

A forma como a Internet foi criada e configurada não foi uma decisão internacional, mas sim oriunda da potência dominante daquele período, os EUA, os quais delegaram ao setor privado a administração do ciberespaço (CHOUCRI, 2012). Ainda que não esteja concentrada a regulação da Internet nas mãos de um único Estado, é bom ter em mente que os 
EUA ocupam um lugar privilegiado por ter sido precursor na criação. Tal como Choucri (2012) explica: "[...] in the context of the United States, they have implications in the world cyber arena. As is said of politics broadly defined, those who make the rules control the game" (CHOUCRI, 2012, p. 128). Segundo os autores Mueller, Schmidt e Kuerbis (2013), o controle de segurança da Internet está concentrado nos Estados Unidos:

While Internet security has the characteristics of a public good in some situations, the ingredients necessary to create it certainly are not. The response team was almost exclusively based in the United States and appears to have followed US-centered security considerations. In this regard, the response team was more akin to a US-based club than a neutral global community of technically interested experts (MUELLER; SCHMIDT; KUERBIS, 2013, p. 98).

Por isso, não é por acaso que Mueller (2010) pontua que mais do que o debate se a Internet pode ser governada, é se ela deveria ser feita de uma maneira diferente desta que vigora hoje como parte natural da rotina. O mesmo autor complementa que é importante estar consciente das forças políticas, legais, institucionais, econômicas e culturais que moldam as mudanças da política global no que tange à governança da Internet e não apenas focar nas novas relações sociais impulsionadas pela Internet. Ademais, também é importante não se ater apenas às redes físicas e técnicas de conexão formada através da Internet, pois embora sejam análises que se interseccionam, muitas vezes elas escondem o papel de Estados que impõem a hierarquia sobre como a governança das comunicações deve ocorrer no âmbito global (MUELLER; SCHMIDT; KUERBIS, 2013).

Há uma questão interessante no papel da Internet aos olhos dos governantes: Mais do que uma questão doméstica, estaria relacionada às questões da anarquia entre as nações (FIDLER, 2014). Kassab (2014) sugere que:

Cyberspace is the new anarchy, a new battle ground with no overarching authority to place limits on an actor's behavior. Within this new anarchy, new forms of capabilities can be found, but not as we expect. Cyberwarriors, state sponsored hackers, can now break into state institutions and compromise the national security of that state (KASSAB, 2014, p. 60).

O acesso e o uso das ciberferramentas são caracterizados como caóticos, reforçando a anarquia global, sendo este um entendimento esperado nas relações internacionais sobretudo no prisma do realismo estrutural; por outro lado, a expansão de participação no ciberespaço 
tem estimulado a busca por novos padrões de governança, tanto no processo quanto na estrutura, para além da preocupação apenas da soberania territorial (CHOUCRI, 2012).

Kiggins (2014) sugere que a natureza interdependente de cibersegurança mostra que a mesma deve ser tratada como um assunto transnacional numa política coordenada de cooperação entre atores estatais. Desse modo, segundo o autor:

In effect, transnational cyber security is a problem for global governance where states cooperate to eliminate and reduce cyber threats to achieve decreased and more manageable risks thereby providing certainty to users that the Internet is a stable, reliable, and secure medium for global information and economic exchange (KIGGINS, 2014, p. 163).

Ao mesmo tempo em que se observa uma busca por cooperação em nível internacional, resguardando as estruturas e preservando uma Internet livre e aberta, já no campo doméstico, em nome da segurança, observam-se medidas que limitam o potencial de conectividade através de filtros, bloqueios, vigilância etc. (RADU, 2014).

De um modo geral, por conta da natureza da Internet, os governos estão sendo dissociados de sua tarefa de controlar o comportamento de seus cidadãos (no meio online), implicando numa ruptura entre localização geográfica e soberania estatal (CHOUCRI, 2012). Os autores Mueller, Schmidt e Kuerbis (2013) acreditam que para efetivar a interdependência das operações da Internet são necessárias instituições globais operantes. Este mesmo grupo de autores enfatiza que cooperação nesse nível internacional não é contrário às tradicionais preocupações de segurança dos Estados e nem incompatível com a soberania territorial estatal. Porém, os Estados devem estar abertos a um ambiente moldado por práticas definidas por multistakeholders e assim ceder parte de sua autonomia decisória (MUELLER; SCHMIDT; KUERBIS, 2013).

Concretamente, algumas iniciativas já são vistas quanto à cibergovernança global. Os autores Choucri e Goldsmith (2012) citam a Convenção sobre Cibercrime adotada pelo Conselho de Segurança da ONU em 2001 e ratificada por 32 países (excluindo países como China e Rússia) como uma iniciativa na linha de governança internacional. O foco desta convenção é violação de copyright e redes de segurança, além da espionagem da Internet. Outra iniciativa é o CERT (Coordination Center), do US Defense Advanced Research Projects Agency, estabelecido na Carnegie Mellon University em 1988. O projeto incluía mais de 250 organizações envolvidas o fim de criar mecanismos para apoiar a cibersegurança em nível global (CHOUCRI; GOLDSMITH, 2012). 
Responsáveis em formular princípios para o ciberdomínio têm-se o World Summit on Information Society (Genebra em 2003 e Tunis em 2005) e com pelo menos 19 organizações globais atuantes. Em 2011 a London Conference on Cyberspace buscou dialogar em prol de práticas e prioridades no ciberespaço (CHOUCRI; GOLDSMITH, 2012; RADU, 2014). Além disso, instituições transnacionais como Internet Corporation for Assigned Names and Numbers $(\mathrm{ICANN})^{39}$ e o Internet Governance Forum $(\mathrm{IGF})^{40}$ têm emergido ainda mais forte neste cenário (RADU, 2014).

Choucri (2012) esboça quatro modelos diferentes que podem ilustrar o futuro da governança, e todos eles devem se atentar às questões fundamentais relacionadas à jurisdição, legitimidade, autoridade e accountability:

[...] The first model is a future anchored in high sovereign control over cyber venues in the context of a high level of international conflict and violence. [...] Countries like Saudi Arabia, Myanmar, North Korea, and China may become candidates. The second model of cyber futures proposes a world of high conflict and violence worldwide in the absence of sovereign control or any centralized authority. We refer to this future as one of cyber anarchy. [...] The third cyber future issues from international cooperation and coordination in a world dominated by non-state actors, agents, and entities. [...] Civil society, local and global, would be the main supporters and constituencies of this model. The fourth model of cyber futures is a world managed by sovereign states and characterized by a high degree of international cooperation and collaboration (CHOUCRI, 2012, p. 234).

Choucri (2012) foi uma das primeiras autoras a trabalhar neste campo interdisciplinar de ciberpolítica e RI, desde então ela chama a atenção para a relevância de analisar as novas características trazidas pelo ciberdomínio nas relações internacionais. Para a autora, ciberpolítica é um aspecto importante do campo no século XXI, e não pode evitar analisar as propriedades fundamentais deste novo domínio: "For instance, —many features of cyberspace

\footnotetext{
${ }^{39}$ A ICANN foi fundada em 1998 com a função de gerenciar e alocar a tribuição de identificações nominais à WWW. É uma entidade sem fins lucrativos que está oficialmente subordinada ao Departamento de Comércio do governo dos EUA. Embora seja considerada uma entidade dos EUA, diante das inúmeras críticas e pressões que sofreu nos últimos anos (em prol da criação de uma nova entidade internacional), a ICANN tem se reformulado e hoje tenta abarcar a participação de diversos representantes dos diversos países em seus quadros colegiados. Não pode ser considerada uma organização multilateral, mas hoje pode ser categorizada como uma entidade estadunidense que tem em sua estrutura um nível razoável de participação de representações internacionais.

${ }^{40} \mathrm{O}$ IGF é um fórum multissetorial e multilateral para discussão sobre os rumos da governança da Internet, criado pela ONU em 2006. Desde então tem realizado encontros anuais em diferentes cidades do mundo. Como explica documento de seu website oficial: "The Internet Governance Forum (IGF) serves to bring people together from various stakeholder groups as equals, in discussions on public policy issues relating to the Internet. [...] The Internet Governance Forum is an open forum which has no members. It was established by the World Summit on the Information Society in 2006. Since then, it has become the leading global multi-stakeholder forum on public policy issues related to Internet governance. Its UN mandate gives it convening power and the authority to serve as a neutral space for all actors on an equal footing". Disponível em: < http://www.intgovforum.org/cms/2011/press/Backgrounder_What_is_IGF_final.pdf> Acesso: 12 jan. 2016.
} 
are reshaping contemporary international relations theory, policy, and practice. Those related to time, space, permeation, fluidity, participation, attribution, accountability, and ubiquity are the most serious" (CHOUCRI, 2012, p. 3-4).

Para muitos autores, os aspectos relacionados à segurança que interseccionam RI e Internet seriam os mais relevantes (MUELLER; SCHMIDT; KUERBIS, 2013). Muito se dá por conta do próprio campo das RI centrado em questões de segurança, mas também pela explícita ameaça que questões como ciberterrorismo e cibercrime sucintam. Nesse sentido, é comum o entrelaçamento entre cibergovernança e cibersegurança no intuito de privilegiar pesquisas e políticas que tenham como foco assuntos de segurança na governança da Internet (MUELLER; SCHMIDT; KUERBIS, 2013). Por isso, a compreensão desses dois campos (cibersegurança e cibergovernança) e a identificação das questões que envolvem a relação entre o ativismo transnacional e a comunicação digital são questões relevantes para responder às indagações desta tese. Isso envolve temas como a capacidade de ataque; dinâmica da defesa; o empoderamento dos atores envolvidos; ciberespionagem; regulação e gerenciamento do ciberdomínio como ambiente de interação e conflitos. Assim, para avançarmos neste ponto e nos aproximarmos ainda mais do ativismo transnacional, a próxima seção traz uma análise mais específica sobre como os atores não-estatais estão se inserido neste contexto de cyberpower, tendo como pano de fundo o cenário internacional.

\subsection{ATORES NÃO-ESTATAIS, ARENA INTERNACIONAL E CYBERPOWER}

Na disciplina de Relações Internacionais, que já completa quase um século ${ }^{41}$ desde sua consolidação, o escopo dos estudos e pesquisas incidiu em grande parte sobre assuntos relacionados a guerras, conflitos e acordos entre Estados, os quais eram comumente tratados como principais atores no cenário internacional. Conforme pincelado nas seções anteriores, esta abordagem estadocêntrica perpassa diversas vertentes teóricas, uma vez que "a ideia inicial de relações internacionais está vinculada com a ideia de Estado nacional histórica e etimologicamente" (OLSSON, 2011, p. 144), onde as relações que eram travadas para além das fronteiras das nações implicavam em pressupostos e interesses estatais. Assim, o

\footnotetext{
${ }^{41}$ Os autores Messari e Nogueira (2005) explicam que o início das Relações Internacionais enquanto disciplina deu-se em 1917, logo após a primeira Guerra Mundial na universidade escocesa de Aberystwyth, com o intuito de estudar a guerra e suas consequências para evitá-las.
} 
surgimento e o reconhecimento de outros atores não-estatais - a exemplo das empresas multinacionais, organizações internacionais intergovernamentais, organizações internacionais não-governamentais ou transnacionais - no último quarto do século $\mathrm{XX}$, marcado por um contexto crescente do processo de globalização ${ }^{42}$, conduziu a uma revisão de conceitos atrelados ao Estado, tais como legitimidade, autonomia, poder e monopólio legítimo da força, política interna e política externa.

Indubitavelmente, a literatura sobre globalização é relevante para entendermos o ciberespaço, devido ao foco na fluidez de bens, serviços e pessoas além das fronteiras:

We define twenty-first-century globalization as a process that is (1) generated by uneven growth and development within states, which (2) leads to the movement of goods, services, ideas, and effluents across national borders, such that (3) globalization contributes to transformations of socioeconomic and political structures within and across states, and also (4) creates pressure on prevailing modes of governance, thus (5) generating demands for changes or expansion of the modes of governance. We stipulate, however, that cross-border movements of people, goods, services, influences, and so forth lead to globalization if, and only if, they alter the fundamental characteristics of state and society and result in the loss of discretion over decision making proportions (CHOUCRI, 2012, p. 45).

A partir desse novo e recente contexto globalizado no final do século $\mathrm{XX}$, foram reconhecidas diferentes formas da atuação da vida política internacional envolvendo temas como meio ambiente, Direitos Humanos, novas ameaças de segurança internacional, processos de integração, cooperação multilateral, diplomacia pública etc., que redimensionaram as relações internacionais refletindo na evolução da própria disciplina, e realocando o papel do Estado nesse processo (OLIVEIRA, 2010; OLSSON, 2011). O sistema internacional e suas recentes formas de organização da sociedade, como a cooperação e a interdependência, abrem as lacunas que existem dentro da limitação dos atores centrados somente nos Estados, buscando por outras vias e conceitos explicar a complexidade das relações no mundo político contemporâneo.

\footnotetext{
${ }^{42} \mathrm{O}$ termo é polissêmico, já definido por diversos autores, inclusive com comparações aos termos "internacionalização" e "mundialização". Olsson (2011) entende "globalização" enquanto "fenômeno peculiar e distinto, e não apenas como simples projeção do processo de expansão e internacionalização do capitalismo" (OLSSON, 2011, p. 90), onde a intensificação dos fluxos e relações econômicas, políticas, sociais, jurídicas e culturais redimensionou a relação do Estado com outros protagonistas emergentes, tornando-se ainda mais complexa mediante um ambiente de avanços tecnológicos da informação e da comunicação. Tarrow (2006), por sua vez, acredita que o mais adequado é pensar em internacionalização. As ameaças à soberania, igualdade, diversidade têm sido bem tratadas na literatura da globalização, porém "internationalism also offers an opportunity space into which domestic actors can move, encounter others like themselves, and form coalitions that transcend their borders, and this process has been less well understood" (TARROW, 2006, p. 25).
} 
Entende-se que a qualidade de se comportar como um ator internacional envolve três elementos gerais: (a) Exercer funções no sistema internacional; (b) influenciar os responsáveis pelas ações na política exterior; e (c) possuir relativa autonomia para tomar decisões. Particularmente, compreende-se por atores não-estatais aqueles grupos com autonomia política e financeira em relação ao Estado, oriundos da sociedade civil, da economia de mercado ou de impulsos políticos além do controle do Estado (JOSSELIN; WALLACE, 2001). Por sua vez, para estes atores não-estatais se enquadrarem na atuação transnacional bastariam cruzar as fronteiras de dois ou mais Estados. Observa-se que os atores não-estatais têm avançado nos últimos 40 ou 50 anos, e a sua significância não pode mais ser desconsiderada no mundo político internacional (JOSSELIN; WALLACE, 2001).

Tão logo, os atores não-estatais têm protagonizado, sobretudo nas últimas duas décadas, uma série de acontecimentos de natureza econômica, cultural, militar e ambiental independentes das ações e posições estatais, os quais podem se manifestar, sendo ainda capazes de enfraquecer ou potencializar essas ações. Sabe-se que os Estados e seu uso de força material ainda representam definitivos instrumentos em dados momentos da política internacional, como Bobbio (1986) já endossava:

Ao lado dos Estados, desempenham também um papel importante atores não estatais, se é verdade que tais atores têm um papel decisivo e a iniciativa num grande número de crises e de conflitos internacionais (pense-se nas empresas multinacionais), também é verdade, por outro lado, que, quando se chega às provas de força, não são eles que as levam a efeito, mas os Estados, que monopolizam a força, e os resultados dessas provas são afinal avaliados segundo a influência que eles têm na vida dos Estados envolvidos. O que indica que os Estados são, se não os únicos, certamente os atores decisivos no contexto das Relações Internacionais (BOBBIO, 1986, p. 1090).

Realmente é preciso reconhecer que nos deparamos ainda com diversos casos em que os poderios econômicos e militares estatais sobressaem em prol dos interesses dos envolvidos, pois sistemas de coerção asseguram bons efeitos, ainda que questionáveis pela forma em que são utilizados numa controvérsia. Seria ingênuo, portanto, reduzir a importância que o emprego do uso da força por parte do Estado ainda representa nos estudos de relações internacionais. Porém, é ainda mais ingênuo desconsiderar a força que os atores não-estatais têm exercido cada vez mais no cenário internacional.

Outro elemento importante acrescentado a este debate sobre globalização é o papel do novo ciberespaço e a Internet. Segundo Mueller (2010) a Internet redimensionou a relação do 
Estado a partir de diferentes maneiras: Globalizou a comunicação dissociando-a de uma base territorial; aumentou a escala de trocas e armazenamento de informação, modificando o processo governamental; distribuiu o controle a partir da descentralização dos protocolos da Internet, os quais não estão vinculados a unidades políticas; estimulou novas instituições transnacionais responsáveis pelo gerenciamento da Internet (IETF, ICANN).

Hallams (2013) relembra que o uso de tecnologia moderna tem impactado as relações internacionais já no século XIX (o telégrafo catalisou movimentos de escravos e ajudou a redefinir regras coloniais), no período entre-guerras (empreenderam-se as estratégias de propaganda com o rádio e o telefone), na Segunda Guerra Mundial e na Guerra Fria (aperfeiçoaram-se as armas bélicas e de destruição de massa). Particularmente no século XXI, a autora avalia que o período é marcado por um mundo conectado sem precedentes, empoderando atores não-estatais e desafiando as noções tradicionais de poder e influência.

Com o advento das novas tecnologias, esta passagem além das fronteiras passa a ocorrer não somente através do tradicional meio físico, caracterizado pelo transporte de serviços, mercadorias e pessoas, a exemplo de locomotivas, navios e aviões. Este processo, doravante, passa a ser incorporado no meio virtual através do ciberespaço propiciado pela Internet. Claro que, como visto no capítulo anterior, a estrutura da Internet possui sua natureza física, mas sem dúvida o ciberespaço é formado por uma materialidade bastante diferente daquela já vista até então, criando novas relações de âmbito transnacional e incitando questionamentos sobre as jurisdições geográficas devido aos novos espaços virtuais em que as relações são estabelecidas.

Diante desse cenário seria negligente não reconhecer outros mecanismos de ação que vêm ganhando força política e angariando bons resultados. Radu (2014) enfatiza que ainda que Estados continuem a tentar exercer controle sobre infraestruturas físicas e conteúdos online, cada vez mais atores não-estatais desafiam esta posição. Por isso, o ciberespaço se tornou, segundo este mesmo autor, um novo domínio de poder, mas sem o monopólio dos governos. Desse modo, os Estados seriam um ator dentre outros, revelando a inabilidade deles, e também de outras organizações relacionadas à segurança internacional, em agir com o monopólio da força e assim, serem capazes de determinar resultados no ciberespaço (MUELLER; SCHMIDT; KUERBIS, 2013).

Por outro lado, Choucri (2012) chama a atenção para os limites dos atores não-estatais ao lembrar que eles podem até participar de fóruns internacionais, porém ainda não possuem direito a voto. Isto parece evidenciar o tradicional perfil estadocêntrico no cenário 
internacional sem grandes mudanças. Porém, se grupos não-estatais ainda são desprovidos das tomadas de decisões formais, isto não significa que o poder não seja exercido de outras maneiras. É nessa linha de pensamento que grande parte das teorias das RI demonstram quando se adentram aos estudos do ambiente cyber. Choucri (2012) explica, por exemplo, como o modo de os atores não-estatais se articularem e perseguirem seus objetivos no ambiente online é capaz de influenciar as prioridades e o desempenho das organizações internacionais. A autora ainda evidencia a visibilidade, empoderamento e influência do indivíduo, seja sozinho ou em grupos, como um novo traço do sistema internacional:

The dynamics of conflict and warfare, traditionally framed in the context of state interactions, must now be reassessed to take into account non-state groups and attendant networks. This reassessment will become increasingly critical if the frustration of the population is channeled into support for nonstate groups that are sources of terrorist recruitment (CHOUCRI, 2012, p. 43).

As tecnologias mediadas pelo computador adicionam novos elementos nas relações já existentes entre grupos ou redes não-estatais e Estados, por exemplo. O perigo do apoio a grupos terroristas por parte da população suscetível devido a frustrações políticas, enfatiza que a ferramenta pode servir a variados objetivos, evidenciando seu uso a partir de táticas e estratégias de diferentes vieses e níveis (CHOUCRI, 2012; RADU, 2014).

Assim, uma das principais alterações provenientes da nova estrutura do ciberespaço não é a emancipação de novos atores não-estatais, uma vez que estes já vinham desempenhando um papel cada vez mais crescente ao longo do século XX, mas sim a alteração na distribuição de vozes, demandas e capacidades para agir nas relações internacionais (CHOUCRI, 2012).

Esta alteração pode ser considerada um ponto crucial no entendimento do papel da comunicação digital nas relações internacionais, já que abre margem para um novo tipo de poder que emerge neste contexto: O cyberpower. Tradicionalmente na Escola das RI, o poder, quando não é visto como um elemento central nos estudos, é tratado com bastante relevância.

Grosso modo, poder é a capacidade de fazer coisas. Politicamente, poder é a habilidade de afetar outras pessoas a realizarem aquilo que é do seu interesse. Alguns podem definir isto apenas como influência e distinguir de poder, mas segundo Nye (2010), isto apenas traria confusão para o entendimento do conceito (NYE, 2010). Definir o poder envolveria apenas relacioná-lo ao objetivo, domínio e contexto, segundo Nye (2010). Por isso, 
para compreendermos este novo tipo de poder, não adentraremos na conceituação complexa de poder e política, mas sim tomaremos como ponto de partida a conceituação desenvolvida por Nye $(2002 ; 2008 ; 2010)$ para tratar deste novo poder trazido pelo ciberespaço.

Em sua análise mais ampla, Nye (2008) procurou delimitar conceitualmente esse debate na relação entre hard power e soft power, ou, em português, poder duro e poder brando. Durante os anos de 1990, Nye (2008) desenvolveu essas duas facetas para o poder político, diferenciando o poder duro, aquele poder de coerção, ameaça e imposição, em oposição ao poder brando, de persuasão e atração.

O hard power é um exercício direto de natureza econômica e/ou militar. Guerras e diplomacias coercitivas são exemplos de emprego do poder duro na área militar aplicado por políticas governamentais. Uma forma de ação é obrigar uma parte a realizar um comportamento conforme deseja a outra parte, envolvendo ameaça e consequente punição no caso de descumprimento, infligindo no uso da hard power para fazer prevalecer interesses próprios. Há também as sanções, o apoio financeiro e subornos, todos utilizados para se obrigar e condicionar a outra parte a agir conforme um determinado comportamento e não outro.

Se, no poder duro a ameaça substitui a confiança, no poder brando é o contrário, e, em prol do consenso e de cooptação argumentativa, torna-se secundário o uso da força (NYE, 2004). Para o autor não é mais estratégico, num ambiente de interdependência entre os países e na era da informação global fazer uso da hard power, dado que as informações extravasam as fronteiras e atingem a opinião pública internacional com uma facilidade que nunca havia ocorrido antes. E assim o poder brando é tanto mais intenso pela facilidade que encontra nas condições materiais atuais de alcance, quanto mais legítimo quando uma determinada ação torna-se plausível e aceitável frente aos outros pares políticos. Isso significa fazer uso da cooptação ao invés de coação. Compartilhamento de políticas governamentais, instituições ou valores culturais são alguns meios de cooptar atores fazendo uso do poder brando. Para Nye (2002) o soft power basicamente funciona como uma habilidade política capaz de provocar comportamentos sem o uso da força bruta. Pois o intuito é o de "atrair aliados de ideologias semelhantes, sem o uso de ameaças. O poder brando, quando bem utilizado, reduz os custos da liderança, por criar afinidades entre as nações, baseadas na imagem que lhes é transmitida pela nação que deseja ser líder" (SOUZA; ZACCARON, 2006, p. 220). Uma forma clara de distinguir soft de hard power é: "If this is against their will, it is an aspect of hard power; if it is accepted as legitimate it is an instance of soft power" (NYE, 2010, p. 8) 
Rocha (2009) traz uma leitura interessante sobre o soft power, dividindo-o em duas acepções principais. A primeira, mais próxima da definição clássica de poder entre os politólogos, coloca o poder brando a serviço do hard power, como ferramenta para auxiliar no poder de coação. A segunda, mais próxima do entendimento de Nye (2002), é vista "como sendo um efetivo e independente poder informal, por assim dizer, que reside nos meios de comunicação social, nos organismos não governamentais, nos movimentos sociais, entre tantos outros exemplos" (ROCHA, 2009, p. 7).

Para Nye (2008) o uso da força ainda é legítimo quando realmente imprescindível, mas ele esclarece que o equilíbrio entre os dois poderes é ainda mais necessário. Assim, o termo smart power relaciona os usos tanto da hard, quanto da soft power, de forma adequada, estratégica e integrada para atingir interesses e resultados (NYE, 2008; WILSON III, 2008).

Especificamente no que se refere à mídia, Nye (2005) mostra que os principais resultados conquistados com a soft power é tornar a opinião pública mais favorável e aumentar a credibilidade estrangeira. A reputação e credibilidade são, na realidade, questões chaves do ator internacional para tornar sua soft power mais influente. Camargo (2009) traz uma entrevista de Nye realizada em 2004 explicando que os meios de comunicação (no sentido de instituições midiáticas) são um ator transnacional nas relações internacionais, na medida em que atravessam fronteiras tanto pelo seu conjunto de leitores, quanto pelo conteúdo das notícias que veiculam sobre fatos internacionais. Mas deve-se ter cautela para não se resumir a mídia a um caráter meramente coadjuvante, ou uma soft power de manipulação da opinião pública, como alguns estudos costumam reduzi-la. Lembrando que o soft power não se trata apenas de ser capaz de influenciar, já que com hard power é possível também ser influente através de ameaças e subornos (NYE, 2008).

Em perspectiva paralela, Oliveira (2010) explica que, para a mídia, “o seu poder de agir potencialmente, em certas circunstâncias, se transforma em poder real na medida em que com rapidez e eficiência obtém certas informações e as divulgam como um produto vendável de interesse global” (p. 259). Em nível nacional, a mídia mobiliza a opinião pública, já em nível externo pode mostrar a maneira como define o problema ou uma dada questão interna (OLIVEIRA, 2010). Esta potencialidade da mídia nas mãos de atores políticos pode ainda ser explorada enquanto capacidade de convencimento público. E, sem dúvida, para que a amplitude de uma dada opinião pública tenha considerável alcance internacional, de alguma maneira precisa atravessar os meios de comunicação. No caso da mídia na função de ator 
internacional $^{43}$, como explica Camargo (2009), ela tem uma identidade mais variável e menos definida do que outros atores tradicionais, cujas identidades constantes permitem que se prevejam seus comportamentos. Mas ainda assim ela é capaz de criar mecanismos de confiança para que suas informações sejam levadas em conta num domínio público e político de maior alcance e interferência, exercendo, como vimos, o soft power.

Para Nye (2010), esse poder baseado em fontes de informação e meios de comunicação não é novo, mas o cyberpower é, já que este último está condicionado a um novo contexto midiático: O ciberespaço. Assim, o cyberpower é conceituado a partir de duas dimensões, física e virtual, conforme o Quadro 3. Para o autor, o exercício deste tipo de poder está bastante relacionado aos alvos, tanto dos instrumentos físicos quanto os informacionais, com reflexos dentro e/ou fora do ciberespaço. Interessante observar que as expressões de poder neste novo domínio tanto podem ser de natureza soft ou hard:

Quadro 3 - Dimensões físicas e virtuais do cyberpower

Targets of Cyber Power

\begin{tabular}{|r|l|l|}
\cline { 2 - 3 } \multicolumn{1}{c|}{} & \multicolumn{1}{c|}{ Intra cyber space } & \multicolumn{1}{c|}{ Extra cyber space } \\
\hline $\begin{array}{r}\text { Information } \\
\text { Instruments }\end{array}$ & $\begin{array}{l}\text { Hard: Denial of service attacks } \\
\text { Soft: Set norms and standards }\end{array}$ & $\begin{array}{l}\text { Hard: Attack SCADA systems } \\
\text { Soft: Public diplomacy campaign to sway } \\
\text { opinion }\end{array}$ \\
\hline $\begin{array}{r}\text { Physical } \\
\text { Instruments }\end{array}$ & $\begin{array}{l}\text { Hard: Government controls over companies } \\
\text { Soft: Infrastructure to help human rights } \\
\text { activists }\end{array}$ & $\begin{array}{l}\text { Hard: Bomb routers or cut cables } \\
\text { Soft: Protests to name and shame cyber } \\
\text { providers }\end{array}$ \\
\hline
\end{tabular}

(Fonte: NYE, 2010, p. 5)

Deste modo, retomando a ideia de cyberpower já especificada no capítulo 2 (inserida numa das categorias de efeito), este conceito trata da habilidade de obter resultados (sejam estes dentro ou fora do ciberdomínio) através do uso de informações interconectadas pela Internet, por isso estrutura-se cultural e politicamente através do ciberespaço, permeando níveis individuais, sociais e imaginários coletivos (CARR, 2009; DREZNER, 2010; NYE, 2010; KELLO, 2013; FIDLER, 2014; HART, 2012; WALSH, 2012; SEIB, 2012; JORDAN, 1999).

\footnotetext{
${ }^{43}$ Oliveira (2010) discorre sobre cinco possibilidades de atuação da mídia, baseando-se na taxonomia criada por Gilboa (2002), acrescidos de conceitos trazidos por Camargo (2009) e Diodato (2004): Controladora, constrangedora, interventora, instrumental, conflituosa, controladora da construção da agenda política internacional. Partindo do pressuposto, já defendido em tese por Oliveira (2010), de que a mídia comporta-se como um ator emergente nas Relações Internacionais, permite avançarmos no papel que ela tem desempenhado na área e não mais apenas debater se atua ou não como ator.
} 
Carr (2009) enfatiza o impacto da tecnologia nos aspectos sociais de poder nas relações internacionais, tais como legitimidade e soft power. Para a autora, a infraestrutura tecnológica é importante para compreender o poder industrial dela derivado, porém é preciso também adicionar o papel da informação, cultura, identidade e conhecimento no centro da análise sobre a Internet. Somente assim é possível engajar em uma conceitualização mais ampla e que aborda a complexidade do século XXI (CARR, 2009). Quando ela propõe a articulação entre novas tecnologias e poder, a autora sofre críticas por considerar a tecnologia como apenas uma forma de expressão cultural, tal como a arte e a literatura. Ela contraargumenta que ser alvo de críticas é parte do processo ao se envolver em questões de desenvolvimento da tecnologia sem se preocupar em determinar se seus efeitos são positivos ou negativos, mas sim em apresentar como isso recoloca o poder do Estado de modo mais complexo (CARR, 2009).

Os Estados estão acompanhando as mudanças trazidas pela "revolução da informação", de modo que a arquitetura da Internet tem deixado brechas para a regulação pelos governos: "Discriminating governments have the capacity to decide which elements of digital information they choose to let in and which elements they can screen out" (DREZNER, 2010, p. 31). Pelo fato de a infraestrutura física ainda estar atrelada a questões geográficas e os governos possuírem soberania sobre elas, a localização ainda importa enquanto um importante recurso de poder no ciberespaço (NYE, 2010).

Um dos dilemas discutido por Drezner (2010) é se a Internet predominantemente empodera os governos que controlam de forma coercitiva ou se empodera mais os ativistas cidadãos. O argumento de Drezner (2010) é de que esta equação depende do ambiente político e que apenas reforça a dinâmica já existente:

In open societies, there is no question that the Internet has enhanced the power of civil society vis-à-vis the state. However, in dealing with totalitarian governments or international governmental negotiations, the information revolution does not fundamentally affect the state's ability to advance its interests (DREZNER, 2010, p. 32).

Below (2014) também acredita que a Internet empodera mais aqueles atores nãoestatais em sociedades democráticas do que em sociedades marcadas por governos totalitários. Em sistemas democráticos, onde os direitos políticos individuais são articulados, compreendidos e protegidos, indivíduos e grupos são capazes de transpassar o poder do Estado e lutar pelos seus próprios objetivos, assim blogs e mídias sociais são ferramentas de agregação e formação de uma massa crítica política (CHOUCRI, 2012). Ao mesmo tempo, a 
realidade tem mostrado que em países politicamente repressivos o discurso online também pode representar importante manobra para alguns grupos (CHOUCRI, 2012; DREZNER, 2010). Nesse sentido, não é possível afirmar uma relação direta quanto ao empoderamento de atores não-estatais vis a vis estatais, somente a partir do regime político vigente, já que outros fatores devem ser considerados no processo. Esta é uma relação complexa, sobretudo porque também envolve, além dos usuários e seus respectivos governos ao qual estão juridicamente submetidos, o subjugo das empresas e aqueles que controlam a forma como as ferramentas são produzidas e disponibilizadas:

Cyberpower will emerge as a complex form of power in which a digital
grassroots find and use tools to gain greater choice of action in their lives but
whose use of tools also fuels the increasing domination of a virtual elite over
the nature of cyberspace and its capabilities. The power and paradox of
cyberspace is its ability to liberate and dominate simultaneously (JORDAN,
1999, p. 2).

Se há, de um lado, formas de escape às constrições governamentais por parte da sociedade, ao mesmo tempo, há maiores recursos, tecnológicos e não tecnológicos, por parte do Estado, para controlar a informação dentro da estrutura tecnológica. Os principais recursos tecnológicos usados são a criação de firewalls e proxy servers, softwares que filtram e bloqueiam conteúdos inapropriados; dentre os não tecnológicos têm-se a identificação e prisão de indivíduos relevantes no ativismo político, o alto preço do acesso à Internet e a pressão nos Internet Service Providers (ISPs) (DREZNER, 2010). Logo, se a Internet facilita para os ativistas se organizarem, também favorece o monitoramento por parte dos governos, seja para censurar, seja apenas para antecipar protestos (DREZNER, 2010).

Uma forma bastante comum de controle de informações pelo governo é através de técnicas de filtro, e, embora não sejam facilmente distinguidas de problemas técnicos, tais bloqueios de conteúdos geralmente ocorrem em momentos cruciais de eventos políticos, como o ataque DoS (Denial of Service) ocorrido durante a disputa entre Rússia e Estônia em 2007 (BELOW, 2014). Esta coincidência de falhas na Internet em momentos de grande agitação política marca as tentativas governamentais de atenuarem a animosidade que emana dentro das redes, e possivelmente minimizar os impactos que extravasam do ciberespaço e atingem as ruas.

Por isso, este tipo de bloqueio de conteúdo ocorre para impedir a troca de informações e restringir a possibilidade de ação, ou seja, minar o empoderamento, porque, como afirma 
Below (2014, p. 108) "power is not only about persuading and discussing, but also about being aware of its own situation. And this awareness requires the freedom of expression as well as the freedom of information and thus the access to media websites with even opposite opinions". Assim, a busca por websites alternativos, blogs e redes sociais funciona para driblar casos de controle governamental tanto da mídia tradicional, como televisão e jornal, quanto dos bloqueios de conteúdo online (DREZNER, 2010).

Nye (2010) menciona dados da Open Net Initiative a respeito do controle exercido pelos Estados. Pelo menos 40 países usam algum tipo de filtro restritivo e firewall, de modo que alguns deles são motivados por censura política, como é o caso da China, Vietnã, Irã, Líbia, Etiópia e Arábia Saudita. Além do próprio controle estatal exercido dentro de suas fronteiras no que diz respeito ao fluxo de informações da Internet, líderes de regimes autoritários também se beneficiam desse contexto para fazer propaganda e levantar bandeiras tradicionais nas relações internacionais, como soberania, não-intervenção, ameaça à segurança nacional e equilíbrio de poder (FIDLER, 2014). Invocar a Internet como questão de soberania nacional provoca um retrocesso na liberdade de expressão e à forma em que a Internet é gestada, criando apoio para a cobertura de ações repressivas no ciberespaço. A coexistência de sistemas privados e Estados soberanos no setor das TICs cria uma relação não-hierárquica entre atores transnacionais e Estados (NYE, 2010; RADU, 2014). Em realidade, os regimes autoritários desejam retomar a hierarquia. Tudo isto configura um comportamento paradoxal por parte desses regimes: enquanto expandem o acesso da Internet para a população, aumentam o controle sobre o seu uso, censura e vigilância (FIDLER, 2014). Trata-se da contradição de ciberespaço como algo referente à liberdade e controle simultaneamente (BELOW, 2014):

Authoritarian leaders' increasing use of social media is not only propaganda, but also a statement that they do not fear cyberspace because they have learned how to operate in this realm. The strategy involves creating individual, social, and economic dependence on the internet while developing the capacity to exploit dependence for the preservation of power. For opponents of authoritarian regimes, cyber dependence means vulnerability which creates problems if, as proclaimed in the West, internet access leads to transformative political chance (FIDLER, 2014, p. 15).

Na opinião de Drezner (2010), embora Estado e sociedade se beneficiem com a Internet, a distribuição de poder no meio cyber favorece os atores não-estatais na medida em que os tradicionais recursos coercitivos historicamente usados colocavam estes em desvantagens com relação aos Estados. Nesse sentido, as recentes mudanças tecnológicas 
alteraram os domínios do poder de tal modo que os líderes políticos ainda estão buscando acompanhar estes passos (NYE, 2010). O baixo custo de participação, o anonimato, as assimetrias quanto à vulnerabilidade favorecem os atores menores, sobretudo não-estatais, na capacidade de exercerem hard e soft power no domínio cyber, mais do que no domínio tradicional (NYE, 2010). As transformações tecnológicas empoderaram atores desconhecidos com causas subversivas, como grupos religiosos extremistas, e isso contrariou interesses de alguns governos (KELLO, 2013). Mais do que isso, grupos independentes e dotados de conhecimento para roubar e manipular dados sigilosos são capazes de ameaçar e colocar Estados em risco, causando insegurança e resultando em grandes mudanças de poder (KREMER; MULLER, 2014). Porém, é preciso reconhecer que o empoderamento acontece não apenas da perspectiva do indivíduo:

By providing ever more powerful tools to the individual, cyberspace seems to offer power in various virtual possessions. Yet, the reliance on these tools ensures individuals become ever more dependent on an expertise based elite who create and maintain those tools. Cyberpower is a cartography of power in cyberspace that makes clear that the virtual lands host a constant, complex conflict between grassroots and elites (JORDAN, 1999, p. 7).

Apesar da via de mão dupla, compreende-se que o tipo de empoderamento dos indivíduos se dá de uma maneira diferente, através da comunicação, percepção, organização e preparação para a ação, desafiando conceitos tradicionais de soberania do Estado, e delegando aos indivíduos um papel privilegiado, invertendo as teorias tradicionais das RI (CHOUCRI, 2012). O conhecimento passa a ser um dos principais traços do mundo econômico no século XXI e as vias cyber são importantes canais pelos quais os indivíduos expressam sua visão de mundo ao mesmo tempo em que são expostos a uma multiplicidade de vozes, apesar dos diferentes níveis de acesso, conhecimento e habilidades que estão inseridos (CHOUCRI, 2012): "If knowledge is power, as is commonly said, then the global economy at the beginning of the twenty-first century is increasingly reliant on cyber-based facilities to accelerate the transformation of knowledge into power" (CHOUCRI, 2012, p. 72). Assim, a importância da organização dos indivíduos, e seus agrupamentos, nesse meio digital é fundamental para a eficiência e efetividade do conhecimento, pois como Shi e Zhuge (2010, p. 978) esclarecem: "Knowledge itself is power. Knowledge flow is the power of a team".

Em relação à conectividade e poder, Drezner (2010) e Seib (2012) explicam que a sociedade civil global ao estabelecer redes, intensificar a troca de informações a partir de 
novas ferramentas de mídia, aumentar a consciência sobre a realidade doméstica e internacional, e diversificar participantes, consegue ser mais efetiva no empoderamento político de poder por se organizar em torno de grupos ou redes não-estatais, quando comparado com um Estado. O fato de a nova estrutura baixar o custo final de transporte e comunicação é decisivo para o seu empoderamento (DREZNER, 2010). Alguns grupos de atores não-estatais, como o Anonymous, que possui conhecimento de alto nível sobre computadores e atividades na rede, excedem as capacidades de muitos Estados, por exemplo (WALSH, 2012). Por conta desta crença na redistribuição de poder no meio cyber, Walsh (2012) afirma:

As a consequence, this complex environment promises a new set of winners and losers whose means of acquiring power, prestige, and wealth are not inextricably tied to traditional gaps in military and economic capabilities. Computer network operations thus provide a means for both state and nonstate actors to alter the current distribution of power within the international system (WALSH, 2012, p. 233).

Embora grandes potências angariem estender seu domínio também nessa nova arena, assim como já o fazem no ar, na terra, no mar e no espaço, os resultados ainda estão distantes pois não detêm total controle sobre este domínio (NYE, 2010). Seib (2012) aponta a inabilidade dos tomadores de decisões em política externa em acompanhar as grandes mudanças trazidas pela nova ecologia da informação. Nas palavras dele:

Governments around the world were caught unaware because they did not understand how media were changing national and global political dynamics by empowering citizens to the point at which they could do something about the circumstances that were making their lives miserable (SEIB, 2012, p. 56).

Os elementos dispersos das redes devem ser incorporados nas estruturas hierárquicas dos Estados para que não fiquem defasados nesse novo contexto (SEIB, 2012). As redes não seriam restritas ao fenômeno tecnológico, mas a conectividade amplifica as redes sociais, transpassando fronteiras tradicionais dos Estados:

Networks, however, are more complex often not as visible or tangible as a street-based political operation. Networks rely on virtual and offline interpersonal connections that are sometimes local, sometimes global, and that typically involve multidimensional linkages between people, institutions, and parallel networks. A diagram of a network is multidimensional and often very intricate in the representations of these linkages (SEIB, 2012, p. 125). 
Por isso, incorporar e entender o funcionamento das redes nas decisões dos tomadores de decisão em política externa é fundamental, já que a diplomacia tradicional apenas entre Estados passa a ser apenas uma parte da complexa rede dos assuntos exteriores (SEIB, 2012).

Ao mesmo tempo, ainda que os atores não-estatais tenham ganhado gradativo espaço neste novo domínio e a maior difusão de poder seja um fator que os beneficia, reduzindo parcialmente a diferença entre eles, isto não significa que o poder está mais equilibrado entre atores estatais e não-estatais, de tal modo que os governos e as suas jurisdições geográficas ainda seriam os atores mais poderosos no mundo político, embora não estejam mais tão sozinhos quanto antes (NYE, 2010; KELLO, 2013).

What is distinctive about power in the cyber domain is not that governments are out of the picture as the early cyber libertarians predicted, but the different power resources that different actors possess, and the narrowing of the gap between state and non state actors in many instances. But relative reduction of power differentials is not the same as equalization. Large governments still have more resources (NYE, 2010, p. 9).

Em realidade, os Estados têm a seu favor novas formas de exercício de poder, como a militarização do ciberespaço, o domínio de técnicas como criptografia, o desenvolvimento de indústrias na área de TICs. A militarização do ciberespaço vem sendo encabeçada pelos Estados Unidos, enfatizando a ciberinteligência militar, ao mesmo tempo que este país, paradoxalmente, impulsiona o discurso sobre a liberdade da Internet (FIDLER, 2014). Segundo a polêmica visão de Fidler (2014), devido ao viés militarizado, os EUA veem o ciberespaço através das lentes da power politics (política de poder), de modo não muito diferente dos governos autoritários.

A capacidade de recursos físicos relacionados às TICs é também uma forma de poder, pois um país que possui equipamentos robustos de computação e telecomunicações estimula o crescimento e a produtividade da economia; logo, desenvolver redes de informação disponíveis para os cidadãos coloca o país em posição privilegiada perante os demais (HART, 2012). Conforme afirma Choucri (2012): "Many governments have used cyber venues to exert their power and influence and extend their reach as well as their instruments of sanction and leverage - and to pursue their own security by increasing the insecurity of their critics or detractors" (CHOUCRI, 2012, p. 230).

Hart (2012) explica haver o poder relacional e o poder estrutural quando se trata da Internet. No poder relacional há duas abordagens, a primeira anarquista, que acredita na autoregulação da Internet, e aqueles que acreditam na Internet como mais um campo de 
concentração de poder, consolidando tradicionais atores que exercem poder sobre outros, como governos e grandes corporações. No poder estrutural o país que detém a fonte das novas tecnologias, como microprocessadores e softwares, tem o poder de impor seus modelos institucionais e culturais para os demais:

For example, Microsoft and Intel now dominate the personal computer market with the Windows operating systems on computers using Intel microprocessors. Apple currently dominates the markets for portable audio devices and smart phones. Google dominates the market for search engines and on-line advertising (HART, 2012, p. 211).

E apesar desse tipo de poder ser menos destrutivo do que outros concentrados em territórios ou valores econômicos, ele está marcado por conhecimentos e artefatos culturais que enraízam no coração e mente das pessoas, comportando-se como uma fonte de poder altamente ameaçadora quando concentrada (HART, 2012). Isto pode ser compreendido como soft power.

Alguns especialistas governamentais acreditam no aperfeiçoamento de criptografia e administração da identidade como fatores capazes de reduzir a ameaça de ciberataques em poucos anos (NYE, 2010). Isto sugere a dianteira dos Estados nesse processo, o que limitaria a ação de outros atores não-estatais, embora estes também se beneficiem da maior difusão de poder neste domínio:

While cyberspace may create some power shifts among states by opening limited opportunities for leapfrogging by small states using asymmetrical warfare, it is unlikely to be a game changer in power transitions. On the other hand, while leaving governments the strongest actors, the cyber domain is likely to increase the diffusion of power to non-state actors, and illustrates the importance of networks as a key dimension of power in the 21st century (NYE, 2010, p. 19).

Buscando entender esta nova cadência entre os atores, Nye (2010) distingue entre três tipos de atores internacionais nesse contexto, embora reconheça haver ramificações em cada um deles: (a) governos, (b) organizações com alto grau de estruturação da rede e (c) indivíduos ou redes pouco estruturadas. Kremmer e Mueller (2014) por sua vez, criticam a distinção de Nye (2010) entre diferentes tipos de atores e suas respectivas fontes de poder, já que específicas fontes de poder não poderiam ser atribuídas a apenas uma categoria de ator.

A distribuição de poder nas relações internacionais afeta sobretudo o nível da relação sociedade e Estado e tem menos vínculo com a tecnologia da informação por si só do que com o poder das normas. Isto é, mais do que se relacionar com a implementação ou 
esquivamento de filtros de conteúdo, trata-se do impacto trazido pela imposição e controle de normas, que os governos podem ditar quais e como as vozes são ouvidas (DREZNER, 2010; BELOW, 2014). A autora Dijck (2013) relembra que o poder das normas na área de sociabilidade é muito mais influenciado pelo poder da lei e ordem, mais do que a punição, o controle.

Segundo Joyce (2010a) há basicamente três tipos de perspectiva sobre o valor do ativismo digital e a distribuição de poder: os otimistas, os pessimistas e os persistentes. As duas primeiras perspectivas dizem respeito ao potencial da tecnologia digital em alterar a distribuição do poder político. Os positivos acreditam no uso para alterar hierarquias políticas e empoderar cidadãos, já os pessimistas acreditam no uso igualmente possível para instituir o caos, seja para objetivos construtivos e destrutivos. Os persistentes não fazem esse tipo de valoração positiva ou negativa, e acreditam que a distribuição da política de poder e suas estruturas não se alteram significantemente com o advento da tecnologia digital. Pois a mobilização, organização e disseminação de mensagem embora mais efetivas, não mudariam a natureza do ativismo, apenas aperfeiçoariam práticas já usadas. Por conta das redes propiciarem maior difusão e possibilidade de horizontalidade, os otimistas acreditam que esta estrutura pode alterar a mudança de poder no mundo político na medida em que as redes digitais vão se tornando mais integradas (JOYCE, 2010a).

Nesta pesquisa, compartilha-se a ideia de que a forma como a rede de atores se organiza, não necessariamente igualitária, é decisiva para criar e distribuir poder entre eles (MUELLER; SCHMIDT; KUERBIS, 2013). O aumento de poder das redes é um dos imperativos observados nas relações internacionais, de modo que o ciberespaço é o epicentro de uma nova face do poder, que envolve governança, comunicação, diplomacia e operação militar (BELOW, 2014; CHOUCRI, 2012).

De forma congruente com a discussão, Slaughter (2009) aponta que a real medida do poder no século XXI não se dá mais apenas por capacidades militares ou econômicas estatais, mas é dimensionada pelo nível de conexão que cada ator (governamental ou nãogovernamental) é capaz de estabelecer. Nesse sentido, para a autora iniciativas colaborativas, como os empreendimentos chamados "wikis", são responsáveis por uma participação política bastante estratégica e de impacto nas demais conectividades políticas e sociais. Isto porque, são capazes de criar mecanismos muito mais complexos na medida em que são realizados não apenas por um poder central ou um corpo organizacional, mas a partir da colaboração de 
qualquer interessado. Algo que aumenta a probabilidade de acerto da empreitada, seja esta de que natureza for. Nas palavras de Slaughter (2009):

The power that flows from this type of connectivity is not the power to impose outcomes. Networks are not directed and controlled as much as they are managed and orchestrated. Multiple players are integrated into a whole that is greater than the sum of its parts - an orchestra that plays differently according to the vision of its conductor and the talent of individual musicians (p. 4).

O mundo conectado e em rede mobiliza as esferas públicas e privadas de forma cooperativa e conciliadora de interesses, potencializando também o poder destrutivo de redes terroristas e de vigilâncias por parte do Estado. É claro que o Estado continua com o seu importante papel, tendo doravante que lidar com outras ameaças ou concorrências que vem abaixo, acima ou através dele (SLAUGHTER, 2009).

Na opinião de Choucri (2012), ciberespaço é mais do que apenas viabilizador de poder e influência, é em realidade um endereçador de um novo realinhamento nas relações internacionais, é o meio pelo qual os atores têm perseguido seus objetivos. Desse modo, a autora sintetiza novos desafios e vulnerabilidades para as questões de segurança e uma potencial mudança na natureza das relações internacionais, sobretudo quanto às novas assimetrias entre Estados e outros atores:

First are the unmistakable new challenges to national security, with new sources of vulnerability (cyber threats), new dimensions of national security (cyber security), and new drivers of fear and uncertainty. Second are new types of asymmetries, such as the unprecedented potential for weaker actors to influence or even threaten stronger actors (e.g., by penetrating the U.S. government' s computer systems). Conversely, we observe the emergence of new symmetries (e.g., the ability of states to penetrate the computers of other states). In either case, we are witnessing a potentially powerful shift in the nature of the game (CHOUCRI, 2012, p. 223-224).

Todo este cenário adiciona novos ingredientes na dinâmica do ativismo transnacional, que é afetado diretamente por estas complexificações da difusão de poder. Para aprofundarmos isso, no próximo capítulo a análise está centrada especificamente na relação entre a comunicação digital e o ativismo transnacional. Primeiramente compreendendo este fenômeno de forma conceitual para, em seguida, identificar o que e como tem sofrido alterações em sua dinâmica, e qual o impacto disso em alguns fenômenos emblemáticos das relações internacionais recentes. 


\section{ATIVISMO TRANSNACIONAL E COMUNICAÇÃO DIGITAL}

No capítulo anterior, analisou-se a relação entre comunicação digital, política e relações internacionais, partindo de questões conceituais e teóricas no campo das Relações Internacionais até culminar com o dimensionamento de como os atores não-estatais se posicionam atualmente sob a perspectiva do cyberpower nos embates inerentes ao cenário internacional contemporâneo. Neste capítulo 4, o estudo está concentrado justamente em aprofundar o modo como esses atores não-estatais atuam sob a perspectiva do ativismo em geral, e do ativismo transnacional em específico, levando em conta as possibilidades que o ciberdomínio suscita e as questões sociais e políticas que emergem com a apropriação da comunicação digital.

Se o ativismo transnacional não é novo enquanto um fenômeno político, os usos da comunicação digital em suas ações, como veremos, têm trazido novos elementos para sua dinâmica. Entender este fenômeno conceitualmente, apropriar-se do seu campo de estudos e delinear os principais elementos que o caracterizam é parte do foco deste capítulo. Nesse percurso, a visão histórica do fenômeno é trazida, bem como a multidisciplinaridade que atravessa seu estudo.

Para isso, o presente capítulo busca apresentar primeiramente o debate conceitual sobre o ativismo, considerando as discussões que envolvem este tema em sua dinâmica, assimilando as contribuições do debate teórico sobre movimentos sociais e ação coletiva, com ênfase nas correntes contemporâneas. Em seguida, o capítulo analisa os principais elementos que constituem o modus operandi do ativismo transnacional, condensando os aspectos-chaves que enquadram este fenômeno. Por fim, a análise adentra nos efeitos da comunicação digital na dinâmica do ativismo transnacional contemporâneo, possibilitando-nos vislumbrar o seu lugar nas relações internacionais do século XXI.

\subsection{DELIMITANDO O ATIVISMO E SUAS DIMENSÕES FUNDAMENTAIS}

Embora o ativismo transnacional possua peculiaridades e nuances próprias, como veremos mais à frente, este deve ser compreendido sociologicamente e politicamente como parte de um fenômeno maior que é o ativismo político em geral. Por isso, para compreendê- 
lo, devemos levar em conta a literatura sobre teorias da ação coletiva e dos movimentos sociais, bem como outras teorizações correlatas.

Três termos precisam ser esclarecidos pois serão bastante citados e, por vezes, intercambiados: Ativismo, ação coletiva e movimentos sociais. São terminologias que possuem um cerne em comum, mas que carregam sutis diferenças. A noção de movimentos sociais esteve historicamente vinculada a análises de movimentos de trabalhadores ou organizações operárias, principalmente na perspectiva da esquerda. A partir do século XX essa expressão sofreu alguma ampliação servindo para designar o agir de atores sociais que buscavam romper os processos de alienação e se movimentavam coletivamente para combater opressões, carregada de um certo valor moral positivo. Não por acaso, a utilização da expressão "movimento social" é incomum para denominar movimentos fascistas, racistas etc. Já a expressão "ação coletiva" se difundiu geralmente como parte dos processos de movimentos sociais ou como uma forma de falar da mobilização de um conjunto de pessoas em prol de uma causa, geralmente numa perspectiva um pouco mais ampla e nem sempre carregada da premissa da existência de classes sociais ou proletariado - mas mantendo a perspectiva do confronto - estando mais acoplada a bandeiras que envolvem direitos civis, advocacy ou inserção social de minorias (ALONSO, 2009; GOHN, 2010; MEDEIROS, 2012; NUNES, 2014).

De um modo ou de outro, mesmo esta tentativa de distinção não é exata, pois diversos analistas irão intercambiar esses termos e tanto autores liberais quanto autores de influência marxista farão uso de ambas as expressões em diversas passagens, de forma não muito diferenciada. Na verdade, não há um consenso sobre um conceito amplamente aceito sobre movimentos sociais ou sobre a ideia de ação coletiva. Para Melucci (1989):

O que é empiricamente chamado de "movimento social" é um sistema de ação que liga orientações e significados plurais. [...] Eu defino analiticamente um movimento social como uma forma de ação coletiva (a) baseada na solidariedade, (b) desenvolvendo um conflito, (c) rompendo os limites do sistema em que ocorre a ação (MELUCCI, 1989, p. 56).

Portanto, um movimento social é uma forma de ação coletiva mais estruturada. E como afirma o autor, "uma ação coletiva não pode ser explicada sem levar em conta como os recursos internos e externos são mobilizados, como as estruturas organizacionais são constituídas e mantidas, como as funções de liderança são garantidas” (Melucci, 1989, p. 56). 
Somando-se a isso devemos colocar as variáveis contextuais que também interferem no surgimento e emergência de uma ação coletiva.

E o ativismo é justamente a postura pró-ativa de indivíduos que agem conjuntamente e sistematicamente em prol de uma causa, seja através de ações coletivas pontuais e menos estruturadas, seja através de um movimento coletivo estruturado mais perene. Por isso, o foco desta pesquisa é o ativismo (em sua forma transnacional) e não apenas movimentos sociais globais. Pois considera-se que, para ser importante na arena internacional, uma ação coletiva não precisa necessariamente ocorrer apenas na forma de um movimento social ou a partir de um formato organizacional tradicional. Atualmente, o ativismo, enquanto fenômeno político relevante, não está restrito à formação de movimentos sociais, mas também tem sua relevância em ações coletivas contenciosas capitaneadas por grupos mais ou menos estruturados (como ONGs, coalizões etc.), e ainda por mobilizações em rede pontuais menos estruturadas. Neste sentido, incorpora-se a contribuição de Sidney Tarrow, Doug McAdam e Charles Tilly (2001) em Dynamics of Contention quando abordam a discussão dos movimentos sociais e da ação coletiva enquanto fenômeno de confronto político. Como explica Tarrow (2012), em entrevista sobre a obra e sua recepção nos dois lados do Atlântico:

É verdade que tínhamos uma postura crítica em relação à pesquisa norte-
americana por concentrar sua atenção nos movimentos, enquanto nós nos
interessávamos pelo fenômeno mais geral, que viemos a chamar de "política
confrontacional". Muitos dos nossos críticos acreditavam erroneamente que
estávamos apenas dando um nome novo a algo que eles já estavam
estudando os movimentos sociais. Mas, na verdade, estávamos tentando
estender as fronteiras da disciplina para abarcar a política confrontacional de
todos os tipos. Creio que esperávamos demais dos nossos leitores
americanos ao exigir que acreditassem que poderiam usar o mesmo
enquadramento analítico para entender movimentos, greves, guerras civis,
revoluções etc (TARROW, 2012, p. 13).

Ou seja, embora as expressões como movimentos sociais, ação coletiva, ativismo recebam usos terminológicos com sutis peculiaridades, como vimos, todas tratam, na prática, do alinhamento coletivo de indivíduos que agem ou se mobilizam politicamente em prol de um objetivo comum, com alguma estruturação e tendência ao confronto por objetivarem mudar a realidade.

Feita essa delimitação geral, um segundo esclarecimento conceitual se refere ao recorte sobre o tipo de ativismo que está sendo estudado. O fenômeno do ativismo que será 
objeto desta pesquisa adota um recorte de três premissas delimitadoras: Ativismo enquanto ação (a) coletiva, (b) política e (c) não definida por preceitos morais. $\mathrm{O}$ adjetivo transnacional deve ser considerado uma forma, um modo de ativismo e não um novo tipo a ponto de ser conceitualmente independente. Por isso, grande parte da análise aqui proposta trata do ativismo enquanto fenômeno político contencioso e levará este para a sua forma na arena internacional.

A dimensão coletiva é aquilo que transcende o indivíduo, isto é, que envolve pelo menos um grupo de indivíduos. Para efeitos desta pesquisa, considera-se que um indivíduo isoladamente não é suficiente para constituir uma ação coletiva e não serão analisadas ações de cunho meramente individuais. A título de delimitação, estipula-se que três ou mais indivíduos podem constituir minimamente um grupo, ao passo que apenas um ou dois seria insuficiente para tanto. Ou seja, para que um grupo se forme é preciso haver alguma triangulação, sendo insuficiente a existência de um binômio. Mas a questão quantitativa é menos importante para determinar o grupo ativista. A cumplicidade entre militantes em prol de uma causa é um elemento fundamental para que uma mera aglomeração quantitativa de indivíduos se torne uma ação ativista, como aponta Jordan (2012, p. 12):

Activism is essentially something done together by many people, but we
must be careful with the sense of group or collective that is employed here.
What is essential to activism is not simply being more than one, as we are in
a cinema, but a sense of solidarity in pursuit of transgression. There has to be
a sense of shared identity, which can best be understood at this stage as
people recognizing in one another the anger, fear, hope or other emotions
they feel about a transgression.

Ainda que muitos movimentos nasçam a partir da ação de um indivíduo ou que tenham como símbolo uma figura individual, nestes casos, a própria ideia de liderança pressupõe que haja um movimento coletivo através do qual um conjunto de outros indivíduos seguem um líder, compartilhando valores entre si e agindo de forma conjunta. A noção de indivíduo será citada no decorrer do texto sempre no sentido figurativo, isto é, indivíduo não como ente independente mas como componente da ação coletiva mais ampla.

Já o recorte da dimensão política implica em excluir, por exemplo, mobilizações de cunho estritamente religioso, cultural, comportamental, folclórico etc. Porém, importante ressalvar que uma mobilização coletiva de caráter religioso, por exemplo, pode tornar-se um ativismo político quando ultrapassa a fronteira do privado e almeja mudanças na vida pública, 
passando a agir neste sentido. Neste caso, ainda que tenha origem espiritual, trata-se de ativismo político de inspiração religiosa. Portanto, a denominação "política" não está na origem do movimento ou em suas inspirações e sim na perspectiva ideológica e em suas aspirações. Ou seja, quando os seus objetivos se configuram como bandeira que visa mudar a organização social, as relações de poder e o sentido dos bens públicos, temos um ativismo político, independente de suas origens.

Se as dimensões coletiva e política podem ser definidas a título de recorte delimitador através das estipulações descritas acima, a terceira dimensão - não definir o ativismo por preceitos morais - requer um debate teórico e uma justificativa mais prolongada. Isso ocorre pois o caráter moral como pressuposto definidor do ativismo envolve uma discussão conceitual de fundo, sendo o mecanismo da estipulação insuficiente neste caso. Atualmente, é possível encontrar autores qualificando como ativismo diversos tipos de movimentos, seja de extrema-esquerda, antissistema, extrema direita, xenófobos, fascistas, redes ativistas religiosas, grupos racistas, ONGs de advocacy etc. Mas é recorrente a vinculação da ideia de ativismo a movimentos sociais de esquerda, libertários ou que pressupõe bandeira e métodos considerados minimamente legítimos. Para Reitan (2007), por exemplo, o ativismo consiste em um papel assumido por indivíduos ou atores coletivos para resistir ao que é considerado politicamente errado ou para agir em nome de uma mudança política através de táticas pacíficas ou transgressivas. Embora esta seja uma definição razoável em alguns de seus aspectos, nota-se que se exclui qualquer tipo de violência como expressão de ativismo, o que pressupõe, enquanto conceito de ativismo, um valor moral como premissa. Esta linha de raciocínio também influenciou o ativismo transnacional principalmente quando este tema se tornou mais recorrente nas Ciências Sociais a partir dos anos de 1960. O enfoque neste momento se deu a partir da perspectiva de estudos dos movimentos sociais, os quais eram considerados ético-moralmente guiados e não-violentos. Em outras palavras, tais análises excluíam grupos que utilizavam táticas ilegais ou terroristas, por exemplo. Os estudos sobre as práticas terroristas eram realizados por uma outra seara de pesquisadores, concentrada na temática do terror. Logo, tanto autores que trabalhavam com a temática do terrorismo internacional, quanto autores relacionados aos estudos dos movimentos sociais em âmbito internacional, em geral não comungavam da mesma área.

Moore (2012) e Asal (2012) realizaram separadamente uma experiência de levantamento de tópicos relacionados ao terrorismo e movimentos sociais em um conjunto de periódicos acadêmicos. Através de métodos diferentes, os resultados são convergentes. No 
caso de Asal (2012), a consulta foi realizada por meio da palavra-chave "social movements". Os primeiros 1000 artigos foram selecionados e foi feita uma triagem da palavra "terror" no título resultando em pouquíssimas correspondências, o mesmo ocorreu inversamente. No caso de Moore (2012), a procura foi realizada em revistas acadêmicas tradicionais do campo dos movimentos sociais, tais como American Journal of Sociology, American Sociological Review, and Mobilization referente às publicações do período 1960-2012. A tendência de ambas as pesquisas aponta o não estudo de terrorismo por parte dos movimentos sociais e vice-versa.

Asal (2012) relata ser problemática esta separação de ramos de estudos, já que para ele a única diferença entre terrorismo e as chamadas redes de ativismo transnacional se daria pela uso da violência pelo primeiro:

On more than one occasion I have had the unpleasant experience of being yelled at for suggesting that $\mathrm{Al}$ Qaeda is just as much of an activist network as the International Campaign to Ban Landmines. Indeed if you compare different transnational activist networks (TANs) across a wide spectrum of policy areas to a variety of terrorist organizations across an equally wide variety of policy areas according to their behavior and strategic use of contentious behavior (as opposed to their policy objectives which you might like or dislike) the one key difference between the groups labeled as terrorist and those that are referred to as TANs or social movements are that the terrorist groups use violence and the "traditional" TANs do not (ASAL, 2012, s/p).

Outro fator que pode contribuir para esta separação se dá ao fato de os estudiosos de movimentos sociais trabalharem com movimentos de grande mobilização de apoiadores, o que não ocorre geralmente em grupos violentos. Assim, excluir-se-ia grupos de terrorismo (MOORE, 2012). Porém, observa-se que a cadeia trazida por grupos que usam o terror também cresce em escala e extensão, possivelmente menos visíveis publicamente.

Estas similitudes de um grupo enquadrado como terrorista com os movimentos sociais é também apontada por outros autores. Muitos pesquisadores compreendem que o estudo focado em terrorismo tem contribuído para o entendimento de violência política. Porém, nem todos se convencem de que os estudos focados em movimentos sociais são melhor compreendidos quando separados dos estudos de terrorismo, como é o caso do autor White (2012), o qual observa que muitos grupos terroristas seguiam antes o curso do ativismo político tradicional até que assumiram a luta armada após sofrerem violência do Estado. Diferentes pesquisadores consideram um avanço para os estudos de ações coletivas, 
resultantes de uso de violência ou não, a aproximação de métodos de análise dos movimentos sociais com a empiria focada do terrorismo. Por exemplo, a securitização do ambiente internacional encabeçado pelos EUA, e aderido por diversos países ao redor do mundo após o 11 de setembro, alerta sobre a ameaça de um outro tipo de difusão do ativismo transnacional já que sua securitização afeta outros grupos não terroristas, como imigração por exemplo (OLESEN, 2011). Deste modo, uma análise mais ampla permite fazer cruzamentos entre o terrorismo e a imigração sem ser barrado por fronteiras engessadas de áreas de conhecimento.

Esta distinção de ramos de estudos é justificada em grande parte pelo fato de que autores que trabalham com o terrorismo são geralmente orientados por estudos de segurança firmados em estratégias de contraterrorismo. Já os autores focados nos movimentos sociais são comumente envolvidos com as causas nas quais eles apoiam e simpatizam, de tal modo que são influenciados por comprometimentos normativos (ASAL, 2012; GOODWIN, 2012; MOORE, 2012).

Com base nesta segmentação, questiona-se se o terrorismo é o domínio de um grupo especializado em violência (que não seria ativismo) ou se o terrorismo é uma tática/estratégia que alguns grupos ativistas lançam mão (YOUNG, 2012). Questionar se um movimento que utiliza táticas terroristas pode ser enquadrado como um grupo ativista envolve justamente a concepção do que é ativismo, ou seja, definir se há ou não uma premissa moral embutida na ideia do ativismo. Por isso, adentrar um pouco mais na discussão sobre o que é terrorismo e como isso se relaciona com o ativismo nos servirá para delinear as linhas conceituais que serão adotadas neste trabalho. Oberschall (2012, s/p) resume a definição de terrorismo da seguinte maneira:

There is no agreed-upon definition of terrorism, but most agree that it is collective, not individual; it is political, not criminal (although some terrorists morph into criminal); it is covert; and it is violent, the violence striking without warning and often victimizing indiscriminately officials, combatants and non-combatant civilians alike, including those belonging to groups the terrorists stand for. In the confrontation between insurgents and states, between challengers and regimes, terrorism is one of several modes of confrontation ranging from peaceful and conventional political action to extremes of collective violence.

Esse entendimento amplo de terrorismo é bastante controverso. Por exemplo, o Código $^{44}$ dos Estados Unidos define terrorismo como uma violência premeditada, motivada

\footnotetext{
${ }^{44}$ Trata-se do Código dos EUA, Título 22, Cap. 38, Parágrafo 2656f(d) (BRYM, 2012).
} 
politicamente contra alvos não combatentes e perpetrada por grupos subnacionais ou agentes clandestinos (BRYM, 2012). O fato de excluir Estados dessa definição, como aponta Brym (2012), legitima ações estatais violentas contra alvos não combatentes, sendo muitas vezes apenas enquadradas como um ato de manutenção da segurança contra insurgentes. Notadamente o uso da violência política pode ser realizada por entes estatais ou não-estatais, porém, no caso de estudos de terrorismo comumente exclui-se os Estados ou foca-se apenas em ativistas não-estatais, apesar de muitos reconhecerem o Estado como potencial perpretador deste tipo de violência (WHITE, 2012).

É comum dentre os argumentos que denominam certos grupos como terroristas a presença de traços morais, de Direito e de regras de guerra. Porém, Porta (2012) esclarece que as ações terroristas em si seriam menos determinadas por esses traços e mais por questões ideológicas e políticas. Nesse caso, as formas da ação coletiva determinariam o terrorismo, mais do que seus fundamentos de ação (PORTA, 2012). É por isso que autores como Asal (2012) e Goodwin (2012) definem terrorismo como o ato de usar civis como alvo para prejudicá-los, seja em nome de uma causa amplamente simpatizada ou não. Tais atos, como vimos, podem ainda ser protagonizados por um governo ou ator não-governamental. Importante ressaltar que esse atos tidos como terroristas não são definidos como tais pelos agentes que os praticam, tratando-se, na realidade, de uma adjetivação vinda de fora (ASAL, 2012; WHITE, 2012).

Na análise da Global Terrorism Database (GTD) ${ }^{45}$, o terrorismo é frequentemente uma ação sem a identificação do perpretador, permitindo até três possibilidades de preenchimento para este campo em cada ataque (MILLER; LAFREE, 2012). Este é um indicativo de que as ações terroristas podem ser perpetradas por grupos muitas vezes não identificados. Ao reconhecer a dificuldade em atribuir o responsável por ataques terroristas, este estudo reforça a necessidade de se trabalhar com a ação terrorista enquanto prática de um grupo ao invés de ser definidora do grupo ou determinante para o entendimento da ação coletiva como um todo.

Observa-se que os ataques suicidas são considerados uma última ferramenta de um grupo que se acredita carente de poder tradicional frente a uma força militar estatal, sendo comumente identificada como uma tática empregada por ativistas para incitar uma resposta de

\footnotetext{
${ }^{45}$ A instituição coletou informações de aproximadamente cem mil ataques terroristas ocorridos entre 1970 e 2010 - dados incluíam quando, onde, e como os ataques ocorreram, assim como as possíveis informações dos perpetradores (MILLER; LAFREE, 2012).
} 
autoridades (BRYM, 2012). Esse é um exemplo do uso de práticas terroristas como última alternativa frente a outras opções de baixo impacto. No caso do ataque suicida, "Apparently, strategic thinking, cultural forces, public opinion, and emotional responses combine to incite some movement members to engage in suicide attacks" (BRYM, 2012, s/p). Moore (2012) menciona um estudo sobre o terror enquanto tática usada por grupos que propagam uma causa política com limitado apoio popular e com uma pequena base de apoiadores para mobilizar. Assim, de um lado a prática do terror seria menos atraente para grupos de amplo apoio popular, assim como o protesto em massa seria mais atraente neste caso. O poder popular tem um forte apelo, enquanto aqueles que têm menor número de apoiadores precisariam ampliar o seu poder, e a violência pode ser um artifício de ampliação deste poder (MOORE, 2012).

Miller e LaFree (2012) são categóricos ao afirmar que terrorismo é uma ferramenta de movimentos sociais objetivando realizar um objetivo comum. A dupla reconhece que identificar o perpetrador respeitando as informações obtidas a partir das fontes documentais (meios de comunicação, documentos governamentais abertos) não é uma tarefa simples, já que accountability, atribuição e responsabilidade não são características desse tipo de ação terrorista: "For just over $40 \%$ of all attacks in the GTD there is no perpetrator information available. Although perpetrators of terrorism frequently seek attention for their actions, there are times when it is not in their best interest to do so" (MILLER, LAFREE, $2012 \mathrm{~s} / \mathrm{p}$ ). Assim, apenas metade dos ataques terroristas são atribuídos a um grupo específico. Miller e Lafree (2012) comentam sobre a dificuldade de se atribuir responsabilidade aos ataques terroristas de alto impacto baseando-se em fontes midiáticas. Isto porque, geralmente estes meios buscam explicar o acontecimento antes mesmo de existir um quadro interpretativo razoável e também há a tendência de responsabilizarem indivíduos no intuito de personificar o ataque. Outro ponto que dificulta a identificação é a subdivisão de grupos formais em novos grupos, ou a criação de alianças, ou ainda a relocação de membros, mudança de liderança e até mesmo mudança de nomes (MILLER; LAFREE, 2012). Isto confirma o caráter não-estático dos grupos perpetradores de ataques terroristas, revelando um traço de movimento, inclusive com limiar tênue entre certos grupos. A observação desses movimentos permitiu aos autores compreenderem os padrões da atividade terrorista entre diferentes organizações. Também chamados de "clusters", estes movimentos são agrupamentos de entidades perpetradoras de terror que dividem objetivos comuns ainda que não compartilhem de mesma liderança ou táticas e podem ter se desenvolvido independentemente umas das outras (MILLER; LAFREE, 2012): 
This, along with supplemental research on the groups, organizations, and causes, allowed us to cluster together those that share common objectives, even if they do not agree on leadership or tactics, or if they have evolved over time, or simply developed independently. This work on the data is still ongoing, however our preliminary efforts identified 60 movements responsible for over 36,000 terrorist attacks between 1970 and 2007, or 44\% of all attacks during this time period. These movements are born of various causes including particular political ideals such as the leftist movements in several countries in Latin America, Europe, and South Asia, and nationalistseparatist movements such as Irish Republicans and Loyalists, as well as Palestinian, Tamil, and Basque separatists. Some, like the Salafi-jihadist groups, are based on religious beliefs, while others represent "single issues" like animal rights and environmentalism. A typical movement in the GTD is comprised of a mixture of organizations of all sizes and structures as well as generic groupings that are identified as perpetrators (MILLER; LAFREE, 2012, s/p).

Munson (2012) evidencia a resistência dos estudos de movimentos sociais em englobar o terrorismo em suas análises. Para o autor, ambas ações coletivas são orientadas em prol da mudança política e social, ainda que através de meios de ação diferentes:

Many people resist recognizing groups engaged in terrorism as social movement organizations. This is perhaps because social movement research is so often conducted by scholars personally sympathetic to the movements they study - and most scholars aren't sympathetic to terrorist activity. But sympathetic or no, most terrorism is conducted by groups that fit any common definition of a social movement organization. Suicide bombings, airplane hijackings, and butyric acid attacks are used by groups oriented toward social and political change in much the same way as protest marches, boycotts, letter-writing campaigns, and civil disobedience.

A pesquisadora de estudos de movimentos sociais, Donatella Porta (2012), ressalta o problema em se taxar um grupo coletivo somente pelos meios usados em suas ações em si: "Even when means are easily definable as terrorist, it is tricky to talk of a terrorist organization, as this would hypostatize the use of one means over others that that organization will very likely be using as well" (PORTA, 2012, s/p). Asal (2012) acredita não haver uma natureza tão distinta que separe terrorismo dos movimentos sociais apesar de estudos de um modo geral não pautarem os dois segmentos coletivos de forma nivelada. Para ele o terrorismo é uma tática que pode ser empregada por movimentos sociais, portanto, um tipo de comportamento a ser estudado por todos que analisam os grupos sociais. As ações violentas, 
assim como os protestos, são parte das escolhas estratégicas de uma organização social, seja esta em nome de uma causa que simpatizamos ou não, e não são mutuamente excludentes (ASAL, 2012). Young (2012) ironiza a lógica de restringir a definição de um grupo a partir de uma de suas ações ao descrever a analogia com os protestos: Haveria então uma coerente classe de atores (manifestantes) que são especializados em uma forma única de ação política (protesto) estabelecendo uma específica forma de atividade política (protestism/protesting)? Com esta ironia o autor mostra a inconsistência ao se utilizar o terrorismo como uma prática isolada de um grupo particular e propõe um esquema de segmentação especializado em três tipos de atores: Especialistas em não-violência; especialistas em estratégias misturadas violentas e não violentas - ou múltiplos atores; e especialistas em violência (YOUNG, 2012). Em realidade, nem sempre o ativismo luta contra o status quo, enfatizam Piper e Uhlin (2004), de modo que os estudos do ativismo transnacional deve cobrir um espectro desde objetivos democráticos até antidemocráticos. Estratégias, violentas ou não-violentas, são em geral reações de atores coletivos frente a estratégias de Estados, elites ou outros atores coletivos (GOODWIN, 2012).

Porta (2012) inclusive reconhece a utilidade de se trabalhar com as mesmas ferramentas dos estudos dos movimentos sociais para entender melhor grupos violentos clandestinos, uma vez que até mesmo no caso de clássicos protestos sociais pode haver expressões de violência política. Esta radicalização dentro do movimento gera ramificações de grupos clandestinos dissidentes, confirmando suas raízes e experiências em movimentos sociais. Isto significa que há terroristas que antes eram envolvidos com a forma de luta reconhecida na política tradicional e, após serem vítimas de violência estatal ou outro tipo de opressão, alteraram sua luta para ações violentas (WHITE, 2012). Isto mostra que se pode fomentar a violência deslegitimando o movimento (WHITE, 2012).

Assim, a mesma caixa de ferramentas já desenvolvida para analisar movimentos sociais pode ser utilizada para compreender a origem, o desenvolvimento, e eventualmente, a derrocada de um grupo violento:

Clandestine organizations are in fact political actors that address various strategic dilemmas, trying to adapt their organizational forms and strategies to mobilize their potential bases and win concession by the adversary. Resources are mobilized, political opportunities assessed, and framing processes are as important here as elsewhere. As other political organizations, clandestine political organization act, however, under various 
types of constraints: their choices are limited by external conditions, but also by the internal availability of resources and by collective norms (PORTA, 2012, s/p).

Por isso, acredita-se que segmentar os estudos prejudica o diálogo de literatura e de método, provocando lacunas na compreensão de ações coletivas de maneira geral. Compreender a razão que conduz um grupo a utilizar ou não a violência contra civis é uma das lacunas que isso pode gerar (ASAL, 2012). Por outro lado, alguns autores como Tarrow (2006) já apontaram a natureza das dinâmicas de interação como a chave para identificar a escolha de terror por alguns atores sociais (GOODWIN, 2012). Assim, estender a literatura de movimentos sociais para estudar o terrorismo ajuda a evitar duas armadilhas: Fanatismo e racionalismo (MUNSON, 2012). A primeira diz respeito a estudos que buscam entender o que leva as pessoas a agirem como fanáticas e se vincular a tais grupos, sendo pobreza, frustração sexual, humilhação cultural e antiglobalização os principais desencadeadores e que muitas vezes são ofuscados pelo argumento do fanatismo. A segunda armadilha diz respeito ao tratamento racionalista de grupos engajados em terrorismo, que embora complexos são analisados como indivíduos calculistas que avaliam estratégias baseadas em custo-benefício, quando em realidade os fatores desencadeadores desse tipo de ação podem ser a falta de opções políticas, a intenção de provocar danos governamentais, ou até mesmo a alteração de opinião pública a respeito de uma intervenção militar (MUNSON, 2012). Estudos compartilhados permitiriam analisar padrões mais amplos de diferentes campanhas terroristas e grupos de movimentos sociais no que diz respeito à origem, mobilização, dinâmica e impacto potencial (MUNSON, 2012).

Assim, compreendendo este debate mais amplo, para efeito desta pesquisa, considerase que as diversas linhas de grupos políticos (sejam grupos rotulados como terroristas, grupos de direita, movimentos sociais, organizações liberais, grupos de esquerda etc.) devem ser consideradas formas de ativismo político. Esta afirmativa possibilita analisar o fenômeno do ativismo de forma adequada, evitando recortes metodológicos baseados em julgamentos morais como premissas, o que causaria uma perda na análise mais complexa e completa do fenômeno. Ou seja, as formas de ação, táticas e estratégias de grupos ativistas devem ser compreendidas como métodos e não como elementos definidores sobre o que é, ou o que não é, ativismo. 


\subsection{ATIVISMO TRANSNACIONAL, ESTADO E PODER}

Conforme discussão anterior, em linhas gerais, podemos definir a concepção de ativismo como uma ação sistemática de indivíduos ou grupos que agem deliberadamente em prol de uma causa. Quando se acopla o adjetivo transnacional a este termo, estamos falando desta ação ativa se expandindo para além das fronteiras nacionais, repercutindo em dois ou mais países. Esta é a linha que será adotada nesta pesquisa, porém há diversas nuances, debates e peculiaridades que precisam ser devidamente esclarecidos para que esta definição possa ser considerada uma diretriz conceitual consistente.

Se o ativismo transnacional é hoje um elemento de crescente importância no cenário político contemporâneo, este não é um fenômeno novo. A partir das explanatórias pesquisas de Tarrow (2006), o ativismo transnacional pode ser encontrado anterior ao século XX com o transbordamento além das fronteiras, explicitado no movimento antiescravidão do século XIX ou da campanha de Primeiro de Maio dos trabalhadores da América e Europa. Igualmente, Pipa Norris (2001) reforça que:

Global protest movements and direct action demonstrations spreading across national borders have existed for decades, such as the anti-nuclear movement in the 1950s and the anti-Vietnam protests of the 1960s, or even further back the antislavery and the suffrage movements in the 19th century. The phenomenon is far from new but these movements are facilitated in an environment of minimal-cost instantaneous global communications where technology can be used by a diverse coalition to challenge the legitimacy of international organizations and the authority of national governments (NORRIS, 2001, p 21).

Embora não seja um fenômeno novo, os padrões, escala e a dinâmica são hoje bem distintas do que foi no passado. O alcance e grupos envolvidos também se tornaram bem mais complexos, além de numerosos:

What appears novel is that transnational organizations have become far more numerous and geographically diverse in just the past few decades. But beyond this quantitative change, we should also expect important qualitative changes in transnational organizing (SMITH, 2003, p. 69). 
Quando falamos hoje de ativismo transnacional estamos discutindo, além da concepção de ativismo, outro aspecto paralelo: O seu caráter transnacional. E isso envolve questões como o sentido da transnacionalidade, a relação com a ideia de nação ou Estado, e o poder do ativismo em agir no além fronteiras.

Primeiro, para compreendermos o significado do adjetivo "transnacional" é preciso pontuar também termos correlatos como "globalização" e "internacionalização". Tarrow (2006) acredita que o uso de internacionalização seria o mais adequado, ao invés de globalização. O autor reconhece que a rapidez da comunicação eletrônica, a facilidade e o barateamento das viagens internacionais, a difusão da língua inglesa, a ampliação de novos atores e também de novas desigualdades têm a globalização como componente de fundo. Ao mesmo tempo, Tarrow (2006) também menciona uma mudança na estrutura internacional de poder, mas que não é reduzida a uma questão de globalização. Por isso, ele prefere utilizar o conceito de internacionalização: “[...] a dense, triangular structure of relations among states, nonstate actors, and international institutions, and the opportunities this produces for actors to engage in collective actions at different levels of this system" (TARROW, 2006, p. 25).

Apesar desta divergência de nomenclatura com Tarrow (2006), é comum associarmos os avanços trazidos pelas TICs à globalização. Isto porque entendê-la enquanto "fenômeno peculiar e distinto, e não apenas como simples projeção do processo de expansão e internacionalização do capitalismo" (OLSSON, 2011, p. 90), onde a intensificação dos fluxos e relações econômicas, políticas, sociais, jurídicas e culturais redimensionou a relação do Estado com outros protagonistas emergentes, é marcado por um ambiente de avanços tecnológicos da informação e da comunicação. Porém, para compreender o ativismo transnacional, tal como defende Tarrow (2006), é preciso avançar mais do que simplesmente associar ao contexto da globalização.

No campo das RI, o debate sobre globalização tem suas intersecções com o transnacional por tratar de atividades, fluxos e repercussões políticas, econômicas e culturais que vão além das fronteiras nacionais. Neste campo, busca-se relacionar os estudos de política doméstica, por exemplo, bem como o papel dos atores não-estatais no mundo político no âmbito internacional (JOSSELIN; WALLACE, 2001). Porém, mudanças no ambiente global, como aquelas preconizadas pelos teóricos da globalização, não seriam suficientes para desencadear ou explicar a ação coletiva transnacional, na opinião de Porta e Tarrow (2005): 
Cognitive change within and relational changes between actors must be the active forces for such a fundamental change. The former can best be seen the changing perspective of nonstate actors active on the international scene, while the latter can be observed in the formation of sustained networks of transnational activists (PORTA; TARROW, 2005, p. 8).

Conscientes deste debate, usamos o termo transnacionalização como mais adequado do que globalização e internacionalização para explicar o ativismo que atinge mais de um país, porque globalização é um processo que envolve cruzar o mundo todo, conforme Piper e Uhlin (2004) reforçam. Nesta perspectiva, o ativismo além-fronteiras não se caracteriza como um movimento global in totum e sim um fenômeno que transpassa um conjunto de realidades nacionais e muitos dos casos podem não ter dimensão global e serem restritos geograficamente. Por exemplo, um movimento político que atua em toda a América Latina pode ser transnacional e não ser global. Assim, o termo transnacional é mais preciso por envolver tanto as interações globais (nos casos de ativismo que hipoteticamente envolve todas as partes do globo), quanto as redes limitadas geograficamente a uma região específica que envolve mais de um país (PIPER; UHLIN, 2004). Deve-se considerar além do cruzamento de fronteiras o envolvimento de pelo menos um ator não-estatal, porque caso contrário seria simplesmente interestatal e não transnacional (PIPER; UHLIN, 2004). Ademais, internacionalização prevê um enfoque maior nas relações entre os Estados, enquanto transnacional trata de fluxos materiais e imateriais que atravessam as fronteiras, sendo relações econômicas, culturais ou políticas entre entes de diferentes naturezas; seja propriamente Estados, sejam atores individuais, coletivos institucionalizados ou informais.

Se a transnacionalização do ativismo é um fenômeno cada vez mais comum no atual cenário, este processo nem sempre ocorre de maneira uniforme. Porta e Tarrow (2005) identificam três modos em que isso pode ocorrer:

More recently, a growing stream of research on social movements has identified three important processes of transnationalization: diffusion, domestication, and externalization. By diffusion, we mean the spread of movement ideas, practices, and frames from one country to another; by domestication, we mean the playing out on domestic territory of conflicts that have their origin externally; and by externalization, we mean the challenge to supranational institutions to intervene in domestics problems or conflicts (PORTA; TARROW, 2005, p. 2).

Quando se observa o alvo do ativismo, a ideia de transnacionalidade também deve ser compreendida como ações coordenadas internacionalmente por parte das redes de 
engajamento contra atores internacionais, outros Estados ou instituições (KECK; SIKKINK, 1998; BENNETT, 2003; PORTA, TARROW, 2005; TARROW; McADAM, 2005; REITAN, 2007). Nota-se que não está restrito a organizações internacionais ou multilaterais apenas. $O$ ativismo transnacional é uma ação que perpassa as fronteiras do Estado de diversas maneiras tanto nos processos de engajamento quanto nos fluxos da ação. Por exemplo, indivíduos de diferentes nacionalidades podem ter como alvo um único país. Von Bülow (2014), ao estudar como as organizações da sociedade civil ${ }^{46}$ buscam influenciar negociações internacionais, define ação coletiva transnacional como "o processo pelo qual indivíduos, grupos e/ou organizações não estatais se mobilizam conjuntamente em torno de temas, objetivos e alvos que vinculam as arenas doméstica e internacional" (p. 14-15).

A fim de explicar como o ativismo tem caminhado para a sua dimensão alémfronteiras, Reitan (2007) mostra através de pesquisas empíricas de outros autores a presença deste movimento contra específicos aspectos da política neoliberal. Ainda que tenha um contexto neoliberal demarcado, a ideia do autor pode ser expandida de forma genérica para o ativismo como um todo. Primeiramente, aquilo que estimula a necessidade de expansão global do movimento pode estar relacionado com frustração ou pouco avanço do objeto de luta ao nível local ou nacional. A difusão do ativismo começa a se estender internacionalmente a partir da troca de informação em redes e da criação de laços com novos atores para revigorar o movimento. Neste processo três tipos de atribuição podem envolver os ativistas além das fronteiras: (a) Atribuição de merecimento (aqueles grupos distantes que realizam um merecido esforço de luta); (b) atribuição de interconectividade (aqueles grupos que possuem objetivos distintos, porém são lutas relacionadas de grupos autônomos mas articulados); e (c) atribuição de similaridade (aqueles grupos que se identificam com outros além das fronteiras dividindo as mesmas questões, como camponeses, indígenas, trabalhadores, juventude ameaçados por questões neoliberais) (REITAN, 2007). Estas três diferentes formas de atribuição produzem solidariedade e impactos na coesão das redes, conduzindo de diferentes maneiras para a ação coletiva transnacional, segundo explica Reitan (2007). Essas redes devem também ser construídas a partir de baixo, isto é, nível local, pois ativistas que operam na arena internacional têm responsabilidade e devem considerar as

\footnotetext{
${ }^{46}$ Sociedade civil implica numa categoria heterogênea de movimentos sociais, ONGs, organizações profissionais e associações empresariais: "Assim, OSCs não são, por definição, forças benignas (ou malignas) que atuam na arena internacional. Eu as vejo de forma ampla, como atores políticos institucionalizados que buscam moldar as regras que governam a vida política e social, de fora dos partidos políticos e do Estado" (VON BÜLOW, 2014, p. 17).
} 
consequências de suas atividades para aqueles que trabalham em nível local ou nacional (PIPER; UHLIN, 2004).

Piper e Uhlin (2004) explicam que o ativismo pode ser motivado por diversas razões e para ser considerado transnacional basta ter um destes pontos: 1. Focar em questões de natureza transnacional (como o meio ambiente, por exemplo); 2. Envolver atores transnacionais, seja pela estrutura transnacional de não estar circunscrita num só país com participantes de diversas nacionalidades, seja por envolver questões circunscritas por país outro que não o mesmo que os ativistas sejam cidadãos (como grupos solidários apoiando o movimento de independência de um país estrangeiro); 3. Aplicar métodos e estratégias transnacionais (como participação em rede); 4. Envolver como alvo dos ativistas de um outro país que não seja o mesmo de origem dos ativistas, criando uma interação além da fronteira; 5. Considerar os ativistas como cidadãos-globais e manter visões de mundo transnacionais. Ademais, a intensidade e velocidade dos links transnacionais entre os ativistas variam criando grupos distintos: Laços não-formais, laços difusos, laços de rotina, e organizações formais.

Numa outra categorização, Olesen (2011a) propõe uma concepção que abarque o ativismo transnacional a partir de três elementos inter-relacionados:

[...] sensitivity to (1) the way the conditions for transnational framing change over time, (2) how these changes are related to and defined by powerful states and world political events and (3) how they affect the discursive opportunities available to transnational activists in their framing efforts (OLESEN, 2011a, p. 5).

Situando historicamente, Porta e Tarrow (2005) explicam que houve três mudanças no cenário internacional desde os anos de 1980 decisivas para a transnacionalização das ações coletivas: O colapso do bloco soviético, permitindo ações não-estatais que antes eram bloqueadas durante a Guerra Fria; a facilitação na circulação de pessoas e de comunicação; o fortalecimento de instituições e corporações internacionais. A busca pela transnacionalização do ativismo está relacionada a diversos fatores: expansão do movimento, maior empoderamento do grupo, busca de apoio internacional. É claro que a mudança de escala para o nível transnacional não invalida os movimentos sociais locais.

Estratégias políticas e governamentais frente às ações dos ativistas têm obrigado os mesmos a elaborarem novos planos de ações coletivas, que por sua vez são reforçados com o apoio de uma estrutura transnacionalizada envolvendo ativistas ao redor do globo (PORTA; TARROW, 2005). Através da orientação e influência da opinião pública, os ativistas criam 
espaços públicos autônomos transnacionais de interferência dos partidos políticos e da mídia comercial (PORTA; TARROW, 2005).

O sentido do que é transnacional no ativismo envolve também entender a relação com o Estado, incluindo aí regimes e contextos políticos. Os estudos do ativismo transnacional nas RI têm encontrado espaço sobretudo junto à análise dos atores não-estatais (PIPER; UHLIN, 2004). Este paradigma da política internacional não centrado nos Estados foi inicialmente proposto por Nye e Keohane na década de 1970 (PIPER; UHLIN, 2004).

Para Piper e Uhlin (2004) há algumas falácias relacionadas ao ativismo que precisam ser esclarecidas. A primeira diz respeito ao papel do Estado. Geralmente a definição de ativismo é dada como conflito de interesses, mas não se deveria subentender que é sempre pautada entre ativistas e atores estatais, ou seja, que é sempre para desafiar o status quo, já que alguns ativistas simplesmente apoiam a estrutura de poder elitista e vigente (PIPER, UHLIN, 2004). A segunda falácia é o ativismo em prol de interesses privados. Uma vez que o ativismo está relacionado às estruturas de poder, isto implicaria em objetivos públicos e não privados, por isso os autores são taxativos ao dizer que promover interesse privado próprio não é ativismo (PIPER, UHLIN, 2004). A terceira falácia é acreditar que são apenas atores não-estatais que se envolvem em ativismo, porém, a maioria das ONGs que agem como ativistas não é totalmente autônoma em relação ao Estado, podendo sofrer em alguma medida interferência e controle estatal. Além disso, embora a maioria do ativismo político tenha como alvo instituições políticas formais, muitos ativistas entram na arena política formal, mas complementam suas ações e protestos fora dessa esfera (PIPER; UHLIN, 2004). Estes elementos ponderados pelos dois autores é importante para não caracterizar de maneira ingênua e mascarada o ativismo.

Outro ponto a se levar em consideração na conceituação de ativismo transnacional é o tipo de contexto nacional ao qual o processo está inserido. Isto porque a compreensão de ativismo é diferente em democracias ou autoritarismos. Conforme explica Wakefield (2008), nas democracias o ativismo tido como "benigno", isto é, embasado por valores justos e democráticos, é legítimo e ocupa um papel vital para garantir a ética e a transparência das organizações, por exemplo. Já em regimes autoritários, devido ao freio do debate público pelo governo, estes mesmos ativistas possuem pouca margem de manobra e de ação (WAKEFIELD, 2008). Além disso, países com grandes distanciamentos de poder, como a Índia, ou com pouco espaço político e cultural para críticas públicas, como o Japão, também criam uma atmosfera pouco propícia para o ativismo, segundo Wakefield (2008). Portanto, o 
contexto nacional e o sistema político vigente ao qual o grupo está submetido influencia o desenvolvimento de ativismo, como já visto em outras passagens desta pesquisa de doutorado, sendo capaz inclusive de estimular, por diferentes razões, a mudança de escala do âmbito doméstico para o transnacional.

Os contextos políticos são importantes, porém, não se trata de uma equação simplificada de reação determinada dos atores frente a um tipo de comportamento ou mudança, pois como adverte Von Bülow (2014) "Os atores reagem às mudanças no ambiente político, mas muitas vezes não o fazem da mesma maneira" (p. 20). Se no caso dos governos democráticos, o incentivo ao ativismo é parte do plano de expansão de participação política, sendo esta uma das razões para explicar o fato de que a maioria dos ativistas transnacionais é oriunda de países democráticos; já, em um ambiente marcado por um sistema autoritário, há também o estímulo à mudança da escala para o ativismo transnacional, na medida em que a falta de oportunidades nas políticas domésticas pode forçar os ativistas a buscarem apoio no além-fronteiras (PIPER; UHLIN, 2004). Porém, os autores relembram, se o país é muito fechado e repressivo, como o caso da Coreia do Norte, há pouco espaço para ativismo de qualquer natureza, seja doméstica, seja internacional. Já o grau de democracia no Estado molda a extensão e a forma do ativismo transnacional influenciando a capacidade dos ativistas em engajamento (PIPER; UHLIN, 2004).

Piper e Uhlin (2004) mostram a interdisciplinaridade dos estudos do ativismo transnacional a partir de diversos campos, tais como a Economia Política Internacional, Sociologia, Antropologia, Ciência Política e Direito Internacional. Estudos a partir do campo da Economia Política Internacional, com foco no poder e no exercício da autoridade no sistema internacional, tende a tratar o ativismo transnacional como uma resistência à globalização neoliberal. Sociólogos também estenderam seus estudos sobre os movimentos sociais para o nível global. Estudos focados em ONGs e seus casos empíricos em diversas áreas foram objeto de estudos transnacionais. Pesquisas antropológicas no nível da base popular têm contribuído para explicar a perspectiva a partir dos grupos ativistas. A teoria política também tem adicionado novas versões para a análise do ativismo transnacional, desde a perspectiva liberal até a marxista, tocando em questões como cidadão global e democracia cosmopolita. O Direito Internacional, por sua vez, também tem direcionado sua atenção para este processo. Devido à sua complexidade: "Transnational political activism challenges conventional understanding of civil society and social movements as well as international relations" (PIPER; UHLIN, 2004, p. 3). 
Grugel (2003) salienta que as abordagens da sociedade civil global sobre ativismo são marcadas por fundamentos democráticos, já os estudos transnacionais são denotadamente mais plurais, envolvendo questões de democracia e Estado, crime, terrorismo e trabalhadores, por exemplo. Ambos, por sua vez, têm um tronco comum, sobretudo no que diz respeito à formação de redes entre indivíduos e grupos. Na opinião de Grugel (2003), estes estudos podem exagerar quanto à capacidade transformativa do ativismo global e esquecer que o lugar onde a maioria do ativismo social ocorre é dentro das fronteiras. Os dois tipos de estudos sociedade civil global e estudos transnacionais - oferecem consideráveis informações sobre como as redes transnacionais operam. Porem ambos falham em considerar o Estado e as instituições globais seriamente. Uma abordagem alternativa é a oferecida por Tilly e Tarrow (2007) sobre a teoria dos movimentos sociais. O transnacional não seria uma alternativa à esfera da política nacional, mas sim um complemento para enraizar políticas nacionais (GRUGEL, 2003). Nota-se que esta intersecção ainda precisa ser melhor explorada nas RI e o ativismo transnacional melhor tratado enquanto assunto multidisciplinar. Aliás, as bordas entre ativismo nacional e transnacional não são tão definidas (como vimos anteriormente), já que podem ser trocas e interações de grupos de organizações domésticas que desenvolvem movimentos que variam entre o doméstico e o internacional de forma intermitente, ou ocorrer a partir de trocas entre entidades já totalmente transnacionalizadas.

Um ambiente de incertezas políticas no nível nacional que vislumbra um exemplo externo de realização de uma ação libertadora em condições semelhantes, por exemplo, pode influenciar este ambiente gerando a cascata informacional: "an information cascade demonstrates the power of peer pressure - many individuals will choose actions based on what they observe others doing" (DREZNER, 2010, p. 40). Especialmente importante é no caso de governos coercitivos com alto poder de repressão, como explica Drezner (2010), isto porque a coordenação e mobilização é inversamente provável em razão do alto risco. Porém, se os cidadãos se asseguram que todos irão agir, a probabilidade da cascata é maior, sobretudo se for desencadeada por algo que desequilibre o sistema, como desastre natural ou um levante no país vizinho (DREZNER, 2010). Nas palavras de Drezner (2010): "This explains why repressive societies often appear stable for years and yet without warning can face a massive scaling up of protests and civic action" (DREZNER, 2010, p. 40). Isto demonstra que os movimentos sociais não atuam de forma isolada, mas representam em seus comportamentos a influência dos governos ou contexto que eles desafiam (PORTA; TARROW, 2005). 
Conforme observado nas diferentes abordagens do ativismo transnacional, a escola voltada para os estudos dos movimentos sociais associa de forma bastante enfática a dinâmica do ativismo transnacional com a democracia, o papel do Estado e o poder. Piper e Uhlin (2004) explicam que a dimensão internacional da democratização não tem sido mais negligenciada havendo estudos sobre como os ativistas têm promovido a democratização em diferentes países, especialmente na América Latina, enfocando questões de direitos humanos, por exemplo. Para Smith (2003), as organizações transnacionais de movimentos sociais não são os únicos atores transnacionais, porém são importantes para coordenar os esforços de uma causa reunindo ativistas além das fronteiras seja para troca de experiências, seja para construir valores comuns. Por isso, esses movimentos estão diretamente e geralmente relacionados à abertura democrática e à integração internacional. A autora avalia que o ativismo transnacional está mais relacionado aos níveis de democracia e integração política global do que diferenças culturais ou regionais (SMITH, 2003).

O fato de o ativismo transnacional contemporâneo ter sido ativado por críticas ao Estado e fermentado por valores de mobilização e participação é outro ponto salientado por Grugel (2003). Segundo este autor, ainda que o modelo estatocêntrico esteja se esvaziando, o poder do Estado deve ser considerado uma variável importante nas estratégias ativistas transnacionais. Isto porque, o Estado seria, em última instância, um instrumento de dominação social, afinal seria o próprio Estado capaz de desenvolver poder de coerção e violência, possuindo enforcement sobre os seus cidadãos (GRUGEL, 2003).

Deste modo, Grugel (2003) propõe considerar a centralidade do Estado para a análise do ativismo transnacional considerando a tarefa deste último fazer do Estado um efetivo e eficiente instrumento para a sua comunidade. Segundo o autor:

The state remains the central actor in the enactment and implementation of progressive policies of transformation - as well as the principal barrier to participation and equity. Activism, whether transnational or national, requires engagements with states to bring about change, especially when activism aims to promote eminently political tasks such as deepening democracy or furthering human rights (GRUGEL, 2003, p. 39).

Apesar de importante, o poder do Estado é subestimado em pesquisas sobre ativismo transnacional. Para minimizar este gap nos estudos de ativismo, Piper e Uhlin (2004) sugerem mapeá-lo no macro e micro níveis: Investigar como o poder estrutural do Estado e a economia moldam o ativismo transnacional; e a análise do poder discursivo e o emaranhado complexo 
de poder no nível micro. Os autores inclusive salientam que os Estados podem não apenas moldar as formas de ativismo transnacional, como podem determinar uma pré-condição para o ativismo ocorrer. Porém, Chandler (2011) explica que o ativismo global busca criar métodos de protestos, de aumento de consciência e de engajamento que passam ao largo das restrições e limites políticos de um Estado. Com a intensificação da globalização, o poder do Estado tem alterado, mas não enfraquecido, de modo que os Estados asseguram ainda suas posições dominantes de poder, enquanto os ativistas transnacionais não têm influenciado de maneira significativa as políticas das instituições econômicas multilaterais (PIPER; UHLIN, 2004).

Um dos aspectos fundamentais para que um ativismo tenha um caráter transnacional é justamente o poder de agir atravessando fronteiras. E isso é potencializado pelo poder de comunicação que conseguem arregimentar (PIPER; UHLIN, 2004). O poder comunicativo dos ativistas é manifestado quando eles conseguem afetar o debate público moldando normas, valores, opiniões e agendas (OLESEN, 2011). O poder de resistência estaria a ele vinculado, pois viabilizar poder pelas redes do ativismo transnacional usa estrategicamente a informação num modo persuasivo, configurando-se no poder discursivo (PIPER; UHLIN, 2004). É recorrente na literatura sobre ativismo transnacional que a principal fonte de poder para estes ativistas é a habilidade de iniciar e moldar debates públicos sobre questões políticas e morais e arregimentar apoio em prol da causa. Interessante exemplo é análise do telefone móvel como potencial espalhador de uma ação ativista feita por Miard (2012). O autor revisa três tipos de teorias para seu estudo quantitativo: Teoria da ação coletiva; Teoria da mobilização e difusão; e Teoria da sociedade em rede. Na teoria da ação coletiva os laços sociais fazem as decisões individuais sobre participação da ação coletiva de maneira interdependente, estimulando e influenciando outros a agirem em prol da causa. Envolve o conceito de visibilidade das manifestações públicas frente ao confronto de autoridades políticas. A teoria de mobilização e difusão enfatiza aspectos estruturais, de modo que fontes como dinheiro e tempo são tidos como centrais para a expansão do movimento. Os laços sociais influenciam no recrutamento. Por fim, a teoria da sociedade em rede. Esta é desenvolvida previamente ao desenvolvimento da tecnologia, embora tenha ficado amplamente marcada pelas novas tecnologias conforme será melhor desenvolvido na última seção deste capítulo. A descentralização das decisões e o estreitamento de laços para recrutamento e mobilização em nome de causas políticas são a chave para a criação de redes sólidas (MIARD, 2012). 
Além disso, desde os anos de 1990 muitos autores têm sido otimistas ao tratar do ativismo transnacional, mas devido à importância e papel deste tipo de ativismo, deve-se ter uma reflexão mais crítica sobre o caráter de seu poder de influência (OLESEN, 2011). Piper e Uhlin (2004) partem do princípio de que os ativistas transnacionais são tradicionalmente carentes de capacidade de poder convencional, como força militar e recursos econômicos. Decorrente disso, as causas ativistas são geralmente vinculadas ao soft power, o qual muitas vezes é mal interpretado e subestimado enquanto um poder real das redes ativistas (PIPER; UHLIN, 2004).

Por fim, um outro elemento que caracterizaria o poder do ativismo transnacional é a geopolítica. Como já mencionado, o lugar geográfico influencia o poder dos ativistas transnacionais (localizar-se em Washington ou Genebra pode ter mais efetividade para influenciar o Banco Mundial, por exemplo) (MOORE, 2012). Este é um fato até então pouco refutável nas Relações Internacionais. Porém, essa e outras questões vinculadas ao poder e à dinâmica do ativismo transnacional têm sofrido mutações diante da ubiquidade midiática trazida pelo meio digital. Veremos que os efeitos do ciberespaço nas práticas sociais afetam a dinâmica do ativismo atingindo em eixos-chaves como engajamento, organização e ação. Em última instância, isso traz novas questões para o lugar do ativismo transnacional nas relações internacionais.

\subsection{ATIVISMO: TEORIAS E DINÂMICA}

Com as delimitações conceituais e de recorte configuradas, convém agora compreender o debate teórico em torno do ativismo, com foco no seu modus operandi. $\mathrm{O}$ estudo mais sistemático do ativismo, do ponto de vista clássico, inicia com a temática dos movimentos sociais ainda no século XIX, confundindo-se com o próprio surgimento da Sociologia. Não por acaso, sofreu a influência de escolas tradicionais e correntes sociológicas marcantes ao longo do século XX (GOHN, 2010; ALONSO, 2009). Atualmente, a literatura sobre teorias da ação coletiva e movimentos sociais tem sido dividida em duas linhas: Os paradigmas clássico e o contemporâneo ${ }^{47}$.

\footnotetext{
${ }^{47}$ Analistas como Gohn (2010) farão ainda uma subdivisão entre escolas europeia e norte-americana. Embora considera-se que tal classificação seja útil e válida (principalmente para fins de análises sociológicas mais
} 
No âmbito das teorias clássicas, a tradição funcionalista foi uma das primeiras a esboçar uma concepção sobre o lugar das ações coletivas na dinâmica da vida social. Emile Durkheim (2007), um dos principais expoentes desta Escola, concebia movimentos sociais como greves, por exemplo, uma arritmia, uma patologia, uma anomalia vista como um sintoma de mal funcionamento do corpo social. Nesta perspectiva, ações coletivas que rompiam com o bom andamento da sociedade eram consideradas expressões desordenadas de insatisfações individuais que não foram devidamente incorporadas e tratadas pelas instituições.

O marxismo também imprimiu sua visão clássica sobre a ação coletiva. Agir coletivamente com consciência de classe marcaria o processo de transformação da realidade. A classe trabalhadora era, por definição, o ente universal que sustentaria e justificaria essa metamorfose. Por isso, a conscientização do proletariado enquanto classe (ente coletivo), visando ação conjunta para subverter o modelo de dominação vigente através de mudanças nas condições materiais ${ }^{48}$ levaria à subversão do status quo do sistema capitalista e transformaria as estruturas políticas até então existentes (MARX; ENGELS, [1848] 2011; [1846] 1989). No fundo, Marx, Engels, Lenin e outros marxistas viam ações coletivas (mobilização e participação política) como parte de um fenômeno maior: A luta de classes. Tudo isso tendo como cenário de fundo uma concepção materialista sobre métodos e meios para tal (GOHN, 2010).

Uma outra escola clássica importante que também influenciou o debate inicial sobre a dinâmica do ativismo, e também uma das primeiras a tratar da ação coletiva de forma mais científica, foi a Escola de Chicago. Esta abordagem estava baseada em uma perspectiva interacionista e sócio-psicológica para explicar a ação coletiva que pode ser bem sintetizada nos seguintes termos:

Os movimentos e as ações sociais eram compreendidos como ciclos evolutivos, que se manifestavam, desde sua origem, através de processos comunicativos utilizados como atrativos. A procura por tais grupos acontecia, na maioria das vezes, devido a situações de desespero emocional e instabilidade financeira gerados por transformações nos processos produtivos e industriais. Nota-se a preocupação com questões de cunho psicológico e social, fato que justificava a utilização de metodologias

\footnotetext{
epistemológicas), para fins desta pesquisa acrescentaria pouco e desviaria o foco, que é compreender as principais correntes em suas perspectivas, mas centradas na dinâmica do ativismo.

${ }^{48}$ Posse de bens de capitais (bens que produzem outros bens, como máquinas, por exemplo), propriedade privada, distribuição de riqueza são alguns elementos que exemplificam as condições materiais.
} 
sociopsicológicas na tentativa de alcançar as reações individuais dos participantes dos grupos sociais (MELO JUNIOR, 2007, p. 67-68).

Somando-se a isso, esta tradição pressupunha um certo cenário de conflito onde o papel das lideranças era a chave para transformar a ação coletiva em algo benéfico. Como explica Gohn (2010):

A interação entre o indivíduo e a sociedade era o enfoque básico. A mudança
social passava portanto, pela perspectiva da reforma social. [...] Os agentes
básicos nesse processo de mudança eram as lideranças. Isso acontecia pois o
binômio indivíduo-sociedade tendia a privilegiar, ao final do processo, o
primeiro termo e, consequentemente, a individualização. [...] Os líderes não
seriam causas - estopins - dos movimentos, mas sim agentes apaziguadores.
Suas tarefas seriam desmobilizar o conflito, dissolver o movimento. Como?
Transformando-os em instituições sociais por meio do equacionamento das
demandas em questão (GOHN, 2010, p. 27-29).

Autores como George Mead (2013) e Hebert Blumer (TURNER, 1970) foram nomes marcantes desta Escola ao situarem as ações coletivas a partir da perspectiva interacionista entre indivíduo e sociedade. Principalmente Blumer buscou desenvolver uma teoria do comportamento coletivo, com tipificações e elementos que influenciaram linhagens teóricas posteriores.

Embora influentes nas décadas seguintes - direta ou indiretamente - boa parte das abordagens clássicas (seja o funcionalismo, o marxismo ou o interacionismo da Escola de Chicago) foram incipientes e insuficientes para explicar a complexidade da dinâmica das ações coletivas de forma mais completa. Em parte devido às próprias limitações dos fenômenos em seus contextos históricos, às próprias tradições teóricas em suas fragilidades epistemológicas e também pelo fato destas Escolas não serem necessariamente teorias voltadas especificamente para explicar tal fenômeno, na verdade, tratavam-no como um componentes de uma estrutura analítica maior.

Já mais centradas no fenômeno da ação coletiva em sua dinâmica interna, as teorias contemporâneas tentaram sanar alguns dos limites das escolas clássicas e por isso são mais adequadas para os objetivos desta pesquisa. Três vertentes podem ser consideradas fundamentais e que hoje sustentam boa parte deste debate: a Teoria da Mobilização de Recursos (TMR); a Teoria do Processo Político (TPP) e a Teoria dos Novos Movimentos Sociais (TNMS).

A Teoria da Mobilização de Recursos surge como uma resposta direta às limitações do funcionalismo, radicalizando uma percepção racionalista que teve dentre seus principais 
inspiradores Marcus Olson (1965). Embora este autor tenha sido a base para esta corrente, sua análise estava concentrada nos grupos de interesse e outros autores posteriores é que levaram tais dimensões para o campo da ação coletiva do ponto de vista mais amplo, configurando de fato uma corrente:

McCarthy e Zald (1977) são os epígonos da Teoria de Mobilização de Recursos (TMR), que fizeram perante as explicações das mobilizações coletivas em termos de emoções coletivas, exacerbando o extremo oposto: sua racionalidade. Contra o funcionalismo, defenderam que, longe de expressão caótica de insatisfações individuais não canalizadas pelas instituições, movimentos, como o por direitos civis nos Estados Unidos, tinham sentido e organização. Contra as versões economicistas do marxismo, argumentaram que descontentamentos e motivos para a mobilização, sejam eles privações materiais ou interesses de classe, sempre existem, o que os tornariam inócuos para explicar a formação de mobilizações coletivas. Assim, mais importante que identificar as razões seria explicar o processo de mobilização. Longe de emotiva, a decisão de agir seria ato de deliberação individual, resultado de cálculo racional entre benefícios e custos (ALONSO, 2009, p. 52).

Trata-se de uma análise com foco na organização, com influência de teorias da Economia (de linha não-marxista), onde os movimentos sociais eram vistos analogicamente como uma corporação na qual se rejeitava a psicologia como foco explicativo básico das ações coletivas (ALONSO, 2009; GOHN, 2010). Isso explica a preocupação de McCarthy e Zald (1977) com a redução de custo, a estrutura e os benefícios por considerarem variáveis importantes para se compreender a ação coletiva:

The resource mobilization perspective adopts as one of its underlying problems Olson's (1965) challenge: since social movements deliver collective goods, few individuals will "on their own" bear the costs of working to obtain them. Explaining collective behavior requires detailed attention to the selection of incentives, cost-reducing mechanisms or structures, and career benefits that lead to collective behavior (see, especially, Oberschall 1973) (McCARTHY; ZALD, 1977, p. 1216).

Não por acaso, na Teoria da Mobilização de Recursos a viabilidade da ação coletiva está intimamente vinculada à disponibilidade e uso racional de recursos materiais, financeiros e humanos (ativistas, apoiadores) além de um nível necessário de organização como pressuposto para o bom gerenciamento destes ativos.

Embora trouxesse novos e importantes aportes específicos para a análise da dinâmica da ação coletiva, rompendo com algumas limitações do funcionalismo, o excesso de racionalismo economicista e a baixa conexão da ação coletiva na macroestrutura sociopolítica 
foram algumas das principais críticas endereçadas à Teoria da Mobilização de Recursos. Por isso, as outras duas correntes contemporâneas buscavam chaves alternativas (e, de algum modo, complementares) de entendimento. Como explica Alonso (2009, p. 53-54):

O enquadramento macro-histórico do fenômeno aparece nas duas outras
teorias sobre os movimentos sociais. A Teoria do Processo Político (TPP) e
a Teoria dos Novos Movimentos Sociais (TNMS) nasceram dos debates
sobre a revolução, ou melhor, da exaustão dos debates marxistas sobre as
possibilidades da revolução. Ambas se insurgiram contra explicações
deterministas e economicistas da ação coletiva e contra a ideia de um sujeito
histórico universal. As duas constroem explicações macro-históricas que
repelem economia como chave explicativa e combinam política e cultura na
explicação dos movimentos sociais. Contudo, a TPP investe numa teoria da
mobilização política enquanto a TNMS se alicerça numa teoria da mudança
cultural.

No caso da Teoria do Processo Político (TPP), Charles Tilly, Sidney Tarrow e Doug McAdam são referências fundamentais (TARROW, 1996; McADAM; TARROW, TILLY, 2001; TILLY, 1978; 2006; 2008). Para esses autores, em obra conjunta intitulada "Dynamics of Contention" de 2001, embora reconheçam as contribuições da Teoria da Mobilização de Recursos (TMR) eles apostam em outra ênfase:

Resource mobilization models emphasized the significance of organizational
bases, resource accumulation, and collective coordination for popular
political actors. They stressed similarities and convergences between social
movements and interest group politics. Read twenty or thirty years later,
early resource mobilization models exaggerate the centrality of deliberate
strategic decisions to social movements. They downplay the contingency,
emotionality, plasticity, and interactive character of movement politics. But
at least they draw attention to the significance of organizational processes in
popular politics (McADAM; TARROW; TILLY, 2001, p. 15).

Como se pode notar na afirmativa, a TPP não nega todos os elementos postos na TMR e ambas podem ser consideradas correntes de base racionalista, onde a análise dos recursos disponíveis e seu uso são aspectos importantes na compreensão da dinâmica da ação coletiva. Porém, uma das principais linhas distintivas da Teoria do Processo Político (TPP) é o olhar para o entorno, isto é, vão além do foco na organização (característico da TMR), dando certa centralidade do ambiente político na compreensão deste fenômeno e da ação coletiva como uma interação contenciosa: 
Enquanto a TMR enfatiza recursos materiais disponíveis para ativistas individuais, a TPP prioriza uma estrutura de incentivos e/ou constrangimentos políticos, que delimita as possibilidades de escolha dos agentes entre cursos de ação. Esta perspectiva afeta a compreensão das instituições políticas. A mobilização baseia-se num conflito entre partes, uma delas momentaneamente ocupando o Estado, enquanto a outra fala em nome da sociedade. Essas posições são variáveis, os atores migram entre elas. Por isso, a análise tem de suplantar as barreiras convencionais que definem "Estado" e "sociedade" como duas entidades coesas e monolíticas. Assim, em vez de definir a equação como movimentos sociais versus Estado, a TPP opõe "detentores do poder" (os membros da polity), que têm controle ou acesso ao governo que rege uma população (incluídos os meios de repressão), e "desafiantes", que visam obter influência sobre o governo e acesso aos recursos controlados pela polity (ALONSO, 2009, p. 55-56).

Por isso, para autores como Tilly (1977), as oportunidades que se apresentam no contexto político é um elemento tão importante quanto a organização da ação coletiva.

Por fim, no caso da Teoria dos Novos Movimentos Sociais (TNMS), cultura e identidade serão termos-chaves, basilares para a formação dos movimentos sociais. Como sintetiza Alonso (2009, p. 59) em perspectiva comparada com as correntes anteriores:

Embora não constituam uma escola coesa, como a TPP e a TMR, há um ar de família dentre os principais teóricos dos Novos Movimentos Sociais: Alain Touraine, Jürgen Habermas, Alberto Melucci. São todos críticos da ortodoxia marxista, mas mantêm o enquadramento macro-histórico e a associação entre mudança social e formas de conflitos. Nisso não diferem da TPP. A especificidade está em produzir uma interpretação efetivamente cultural para os MS [movimentos sociais].

Nesta linha, analistas como Melucci (1996) criticam tanto as perspectivas de ênfase materialista, onde a ação coletiva é tratada no plano da disputa material de âmbito econômico (o marxismo clássico), quanto as perspectivas mais difusas que veem a ação coletiva como uma aglutinação baseada em crenças e representações que visam responder a disfunções do sistema social. Para o autor (e esta é uma característica bastante recorrente na TMNS) é preciso ir além, pois "analysis cannot simply identify action with that which the actors report about themselves, without taking into account the system of relationships in which goals, values, frames, and discourses are produced (MELUCCI, p. 14, 1996). Não por acaso, esta corrente nega a visão funcionalista da cultura como "um conjunto fixo e predeterminado de normas e valores herdados do passado" (GONH, 2010, p. 121) e se interessa pelo aspecto relacional entre indivíduos: 
Este modelo auto-reflexivo contribui com a compreensão de como os movimentos se constroem e porque os indivíduos criam laços de solidariedade, mesmo quando não serão diretamente afetados pelos benefícios alcançados. Neste sentido, a luta dos atores coletivos não se restringe a sua inclusão no sistema de organização política ou a obtenção de benefícios materiais, mas envolve a construção de novas identidades, culturas, linguagens e hábitos (CARLOS, 2009, p. 2).

Além disso, o fato de ser considerada uma vertente de aproximação neomarxista, não significa que todo aspecto do marxismo tenha sido incorporado, inclusive temas caros ao marxismo, como a noção de ideologia e classe passam a ser subvertidos. Para Gohn (2010) apesar de trabalharem com as bases marxistas do conceito (como a visão da cultura como ideologia) esta vertente descartou o marxismo clássico por este tratar da ação coletiva apenas no nível das estruturas, da ação das classes.

Em linhas gerais, todas estas abordagens, principalmente as mais contemporâneas, trazem elementos específicos úteis para uma boa compreensão da dinâmica do ativismo hoje. Embora cada uma tenha suas limitações e embates próprios, é possível combinar suas contribuições naquilo que são complementares. Neste sentido, propõe-se analisar a dinâmica do ativismo através de cinco eixos fundamentais em torno dos quais os processos do ativismo podem ser mais especificamente sintetizados sob a luz destas teorizações: (1) Configuração, (2) engajamento, (3) estruturação, (4) planejamento e (5) ação ${ }^{49}$.

\subsubsection{Configuração}

O primeiro eixo trata da configuração da causa, isto é, a formação das bandeiras, das reivindicações, dos objetivos e argumentos que darão a forma conceitual, teórica e ideológica do movimento em questão ${ }^{50}$. A existência de uma causa é determinante para que se configure

\footnotetext{
${ }^{49}$ Estes eixos tratam de uma síntese considerada mais adequada para organizar a análise e a literatura sobre o tema. Outros autores trazem seus próprios eixos de análise do ativismo e buscou-se incorporá-los dentro desta estrutura proposta. Por exemplo, Tilly propõe um conjunto similar de cinco elementos: "The analysis of collective action has five big components: interest, organization, mobilization, oportunity and collective action itself” (TILLY, 1977, p. 11). Outros, como Oberschall (2012), propõem outras linhas de análise, neste caso, o autor fala em fases da ação coletiva: (1) descontentamento; (2) ideologia para a insatisfação; (3) capacidade de se organizar; (4) oportunidade política. Como se verá no texto, a análise proposta tenta levar em conta estas contribuições prévias, readequando-as ou combinando-as quando preciso.

${ }^{50}$ No eixo da configuração da causa também deve-se abarcar eventuais processos de re-configuração de bandeiras. É possível que determinado movimento ou grupo passe por momentos de reestruturação ideológica ou política na qual as próprias bandeiras e finalidades possam ser reconfiguradas. Portanto, a ideia de configuração
} 
o ativismo que, por definição, pressupõe um horizonte reivindicatório ou, no mínimo, um intuito de reivindicação ainda que minimamente pactuado.

Como explica Oberschall (1993), muitos movimentos começam na forma de uma reação a uma mudança ou a uma nova política que afeta negativamente os interesses e os modos de vida de um contingente relativamente grande de pessoas, diante disto, os ativistas se organizam para reverter tal mudança. Porém, um movimento ativista também pode surgir sem configurar-se necessariamente como uma reação a uma nova política, já que pode se basear no desejo de alteração nas condições pré-existentes (como status quo), cujo objetivo é conquistar novos direitos ou concretizar benefícios não disponibilizados (OBERSCHALL, 1993). O autor aponta quatro aspectos relevantes que tendem a influenciar o surgimento (ou ressurgimento) de um movimento ativista: a) Mudanças nas condições básicas de vida, capazes de produzir descontentamento e percepção de ineficácia de autoridades; b) Mudanças nas crenças e valores, aspirações e expectativas utilizadas para filtrar, enquadrar e responder a uma circunstância de vida; c) Mudanças na capacidade de agir coletivamente, como crescimento de um grupo, aumento na liberdade para organizar-se, melhoria nos processos de comunicação e maior coesão entre os membros do grupo; d) Mudanças na oportunidade para a ação bem sucedida, como fragilidade da oposição, apoio de aliados poderosos, e o sucesso de outros movimentos sociais.

Quanto à temática das causas, antes do século XX, as bandeiras do ativismo nasciam basicamente em torno de duas razões mais recorrentes: Lutas contra o autoritarismo e lutas contra a escassez material. No primeiro caso, preponderava a luta contra Estados autoritários (como regimes absolutistas ou impérios colonialistas, por exemplo) ou políticas autoritárias (como a escravidão, ausência de direitos políticos). No segundo caso, tratava-se dos movimentos de trabalhadores marcados pela exploração do sistema capitalista emergente, geralmente aglutinados em torno de reivindicações por melhores salários, jornadas e condições de trabalho mais justas. Neste conjunto, também podemos incluir os cidadãos marcados pela privação material que se organizavam para reivindicar melhorias nas condições básicas de vida. Durante o século XX as causas mobilizatórias se diversificaram e, principalmente na década de 1960, ocorre um “boom" quanto à pluralidade destas pautas para temas e atores novos:

deve ser tratada aqui como a gênese da causa, ainda que esta gênese seja resultado de uma reformulação de uma bandeira precedente. 
Eram jovens, mulheres, estudantes, profissionais liberais, sobretudo de classe média, empunhando bandeiras em princípio também novas: não mais voltadas para as condições de vida, ou para a redistribuição de recursos, mas para a qualidade de vida, e para afirmação da diversidade de estilos de vivêla (ALONSO, 2009, p. 51).

Movimentos ecológicos, feministas, étnicos, homoafetivos e culturais de um modo geral são algumas das inovações neste cenário. Os mais diversos temas passaram a ser legítimos objetos de ação coletiva. Isso não significou o fim das demandas materialistas: Bandeiras baseadas na escassez material e contra o autoritarismo continuaram existindo e coexistindo, porém como constituinte de uma ecologia maior. Esses temas, em seus objetivos, também são marcados por duas propriedades intrínsecas, isto é, têm caráter público e são ambivalentes (positivos e negativos), como afirma Oberschall (1993, p. 20):

Movement goals have two properties. They are collective goods, not private goods, and for some they are "bads", not goods. [...] Because what is a good or benefit to one group is a "bad" (or negative good) to another, movements will be met by opposition [...].

Do ponto de vista do processo, geralmente a configuração de uma causa pressupõe etapas anteriores à sua eclosão para o público mais amplo. As concepções de "latência" e "visibilidade" de Alberto Melucci $(1995,1989)$ são úteis neste sentido. A fase de latência consiste na estruturação interna de um grupo, quando a articulação ainda é inicial e a configuração dos aspectos chaves que caracterizará o ativismo estão em fase de gestação. A identidade coletiva e desenvolvimento do senso de pertencimento são algumas das ênfases neste momento. Há também baixa capacidade de mobilização. Já a fase de visibilidade é quando o grupo está voltado para o externo, com maior capacidade de mobilização e com seus parâmetros identitários e ideológicos melhor delimitados. Porém, é importante perceber que não se tratam de momentos isolados e não-relacionados. Estão claramente vinculados pois, como observa Melucci (1989), a latência forma as bases para a visibilidade que, por sua vez, reforça as redes submersas de potenciais ativistas diante da publicidade das ações, podendo repercutir assim no recrutamento de novos engajados ou na reativação de militantes até então adormecidos. 


\subsubsection{Engajamento}

O segundo eixo que estrutura a dinâmica do ativismo é justamente o engajamento de indivíduos que constituirão a base de recursos humanos necessária para a concretização da ação coletiva. Isso envolve os modos de filiação, participação e pertencimento que viabiliza o ativismo enquanto uma ação que aglutina indivíduos em prol de um objetivo comum. Não existe ativismo sem indivíduos engajados ${ }^{51}$.

Há duas formas preponderantes de engajamento de um indivíduo em uma causa: (a) Formal, como membro devidamente filiado ou vinculado, ou (b) Informal, como alguém que apoia uma causa e atua em prol de sua concretização através de processos mobilizatórios não permanentes. Seja formalmente ou informalmente, um ponto importante de convergência dos atores na ação coletiva é a constituição da identidade coletiva de um grupo. Não devemos, pois, compreender a noção de identidade coletiva como algo fixo, imutável. Também não se trata de uma concepção compartilhada de posições puramente racionais no sentido mais extremo da palavra. Trata-se de algo que possui uma certa estabilidade, porém é fundamentalmente um constructo dinâmico, envolvendo também elementos subjetivos que atravessam a base cognitiva de valores sobre a qual os argumentos estão erguidos enquanto bandeira. Como aponta Melucci (1995, p. 44-45):

Collective identity is an interactive and shared definition produced by several individuals (or groups at a more complex level) and concerned with the orientations of action and the field of opportunities and constraints in which the action takes place. By "interactive and shared" I mean a definition that must be conceived as a process because it is constructed and negotiated through a repeated activation of the relationships that link individuals (or groups). First, collective identity as a process involves cognitive definitions concerning the ends, mean, and field of action. [...] Second, collective identity as a process refers thus to a network of active relationships between the actors, who interact, communicate, influence each other, negotiate, and make decisions. Forms of organizations and models of leadership, communicative channels, and technologies of communication are constitutive part of this network of relationships. [...] Finally, a certain degree of emotional investment, which enable individuals to feel like part of a common unity, is required in the definition of a collective identity (MELUCCI, 1995, p. 44-45).

\footnotetext{
${ }^{51}$ Embora a configuração da causa deva ser pensada também como um pressuposto para que haja o ativismo, isso não significa dizer que o surgimento da bandeira é necessariamente o primeiro elemento que surge, do ponto de vista cronológico, na estrutura daquilo que será o ativismo político. O engajamento pode já estar configurado previamente por outras razões, nem sempre políticas (no caso de comunidades de bairro, grupos recreativos, grupos religiosos etc.). Ou seja, é possível que haja, antes da causa, o engajamento cívico, social em um grupo sobre o qual uma causa de teor político pode ser acoplada.
} 
Também é preciso frisar que a identidade coletiva é um processo relacional, por isso está tão umbilicalmente ligada ao engajamento. Por isso, para McAdam, Tarrow e Tilly (2001), a criação de identidades políticas envolve mudanças na consciência das pessoas envolvidas, mas também envolve alterações nas conexões entre as pessoas e grupos. Essas conexões entre ativistas são motivadas tanto por um cálculo racional que envolve o custo de engajamento, as vantagens decorrentes do engajamento e os recursos disponíveis para a sua efetividade (MCCARTHY; ZALD, 1977), quanto pela dimensão afetiva que também atravessa o ativismo:

A ação coletiva não está toda no agir, mas também no sofrer e no
compartilhar. Ela tem uma dimensão de afeição e paixão coletiva. Mais do
que serem propulsados em direção a um ponto estratégico, os membros que
se engajam são afetados por situações em que contribuem para definir e
dominar; eles são passíveis, expostos a eventos que os abalam e os tiram da
rota, remanejando seus critérios de compreensão e reorganizando seus
horizontes de inteligibilidade (CEFAÏ, 2009, p. 30-31).

Por ser relacional, o ativismo também envolve o antagonismo. Os constrangimentos externos também são elementos importantes que impulsionam o engajamento e reforçam identidades coletivas pois a identificação de um opositor comum ajuda um grupo ativista a se unir e se expandir, como afirma Gerlach (2001). Além disso, a existência de uma oposição também é um elemento importante para a criação de um senso de solidariedade do "nós" contra "eles" (GERLACH, 2001, p. 300).

Do ponto de vista mais amplo, a dimensão cultural, onde a identidade e as trocas simbólicas ocorrem, passa a ser cada vez mais um espaço importante para o engajamento de pessoas devido ao compartilhamento de determinadas crenças ou realidades em comum, o que também aumenta as possibilidades de conflitos com o "externo":

O "ambiente cultural" de cada sujeito (indivíduo ou sociedade) é, pois, a condição de possibilidade de produção 'da história' correspondente ao respectivo meio. Por essa razão o referencial cultural de meios distintos pode acarretar incompreensões, conflitos e choques não apenas entre grupos geograficamente distantes mas aproximados, por exemplo, pelos processos de colonização, mas igualmente entre grupos internamente a uma mesma sociedade formal, como ocorre com as comunidades de imigrados em sociedades formais dominantes (MARTINS, 2002, p. 48-49). 
Vale ressalvar que, embora o engajamento baseado em uma formação identitária forte seja um elemento importante no ativismo contemporâneo, nem sempre isso ocorrerá. Indivíduos podem aglutinar-se em ações coletivas e se tornarem ativistas baseados em fracos laços identitários, principalmente através de interesses comuns conjunturais, provisoriamente amarrados por um objetivo compartilhado. De todo modo, seja através da construção de identidades ou da conexão transitória de interesses comuns, é imprescindível notar que os processos de comunicação são recursos fundamentais pois funcionam como uma espécie de "liga" que viabilizaria a continuidade do engajamento, uma vez que renova os laços (sejam fortes ou fracos), possibilitando assim a ocorrência de ações conjuntas para além do domínio burocrático ou estatal, fomentando aquilo que Habermas (1981) chama de "mundo da vida"52.

\subsubsection{Estruturação}

O terceiro eixo na dinâmica do ativismo diz respeito ao modo como o grupo está estruturado, a forma de organização, o design sobre o qual o movimento está arquitetado. Se partirmos do pressuposto de que a ação coletiva requer, ainda que minimamente, a utilização de recursos para atingir seus objetivos, a forma em que essa ação está estruturada influencia no modo como esses recursos são utilizados ou apropriados, bem como seus efeitos. Para autores como MacCarty e Zald (1977) a organização seria um elemento central neste sentido:

Because resources are necessary for engagement in social conflict, they must be aggregated for collective purposes. Second, resource aggregation requires some minimal form of organization, and hence, implicitly or explicitly, we focus more directly upon social movement organizations than do those working within the traditional perspective (McCARTHY; ZALD, 1977, p. 1216).

Concorda-se que o nível de organização afeta os modos de utilização dos recursos e sua efetividade. Porém, para além do que propõe os autores, podemos compreender

\footnotetext{
${ }^{52}$ Para Habermas, nos processos de interação social, onde a ação comunicativa se desenvolve, existe o domínio dos sistemas (política, economia etc.) que é regido pela razão instrumental. Por outro lado, há o domínio do mundo da vida (o mundo do intersubjetivo). Como sintetiza Riviera (1995): "A teoria da modernidade de Habermas se baseia no diagnóstico, de um lado, da progressiva racionalização do mundo da vida (que coloca restrições estruturais à evolução sistêmica da sociedade) e, de um outro, do desengate progressivo do sistema a partir do mundo da vida, dando lugar à autonomização sistêmica e ao subseqüente fenômeno da colonização do mundo da vida. A penetração da lógica sistêmica no mundo da vida explica em grande medida as patologias da sociedade moderna, o que sugere que a reprodução simbólica do mundo da vida também pode ser afetada pelo sistema da reprodução material" (p. 63).
} 
"organização" não apenas como algo formal, mas enquanto arcabouço no qual uma ação coletiva ou um grupo ativista está assentado, ou minimamente ordenado. Como acrescenta Cefaï (2009), organizações “constituem conjunturas práticos-sensíveis, que fixam hábitos de cooperação e de conflito e que fornecem parâmetros de experiência cognitiva e normativa" ( $p$. 15). A ação coletiva, explica o autor, estrutura-se organizando seus ambientes, produzindo experiências que possibilitam aos seus atores terem uma orientação, uma compreensão acerca daquilo que fazem e, ao mesmo tempo, daquilo que as circunstâncias fazem deles. São vetores onde se assentam capitais materiais e humanos, onde redes de ativistas se desenvolvem e são também capazes de produzir energia simbólica e servir como instâncias de representação coletiva (CEFAİ, 2009). Indo um pouco mais além, implica também em afirmar que a estruturação organizativa de um grupo ou uma ação coletiva nem sempre ocorre apenas na forma corporativa. Uma ação coletiva pode não ser organizada por uma ONG ou sindicato e sim por um conjunto de protocolos (sociais ou comunicacionais) através dos quais indivíduos se organizam em redes autogestionadas e sem uma estrutura formal delineada.

Esta perspectiva de ação coletiva organizada na forma de redes é hoje bastante discutida, principalmente com o advento das ferramentas de comunicação como a Internet, porém não se trata de um fenômeno meramente tecnológico. A própria noção de "redes de indivíduos" já existia antes das redes digitais. Portanto, este é um campo de análise que vem ganhando força gradativa nas últimas cinco décadas. Como explica Diani (2003, p. 1):

Since the 1970s, analysts of social movements and collective action have tried hard to make sense of these structures and their dynamics. That collective action is significantly shaped by social ties between prospective participants is not a recent discovery (e.g. Pinard 1968; Booth and Babchuk 1969; Oberschall 1973; Pickvance 1975; Tilly 1978; Snow et al 1980); nor is the view of social movements as networks linking a multiplicity of actors (e.g. Gerlach and Hine 1970; Curtis and Zurcher 1973). More recently however, interest in the relationship between social movements and social networks has grown both in the rage of the topics addressed and the depth of the research results.

Dentre os primeiros estudos a tratar da estruturação de movimentos na forma de rede, o livro People, Power, Change: Movements of Social Transformation, de Luther Gerlach e Virginia Hine, publicado em 1970, é uma referência recorrentemente citada ${ }^{53}$. Após

\footnotetext{
${ }^{53}$ Melucci (1989), Diani (2003), Bennet (2003), Tufte (2013).
} 
analisarem empiricamente o modus operandi do Movimento Pentecostal e do Movimento Black Power nos EUA, os autores perceberam que:

One of the most significant and least understood aspects of a movement is its
organization, or "infrastructure". We have found that movement organization
can be characterized as a network - decentralized, segmentary, and reticulate.
Most people, even those participating in movements, are not able to imagine
an organization of this type. There is a marked tendency in our society to
identify an organization as something which has clear-out leadership and
which is centrally directed and administered in a pyramidal, hierarchical
pattern. [...] If there is no observable bureaucratic organization, a single
charismatic leader or a very small elite is assumed to be controlling the
movement. [...] there is a third type of organization characterized by
decentralization, segmentation, and reticulation. Decentralization has to do
with the decision-making, regulatory functions of the movement.
Segmentation has to do with the social structure - the composition of parts
that make up the movement as a whole. Reticulation has to do with the way
these parts are tied together into a network (GERLACH; HINE, 1970, p. 33-
34).

Para que esta estrutura exista, é preciso haver processos de comunicação relativamente eficientes pois, como apontam Keck e Sikkink (1998), "Networks are forms of organization characterized by voluntary, reciprocal, and horizontal patterns of communication and exchange" (p. 8). Portanto, os modos de estruturação do ativismo podem alcançar um espectro que vai desde as formas mais rígidas e centralizadas, baseadas em uma organização formal, até as formas menos informais e mais descentralizadas. Em ambos os casos, há existência de alguma forma de estruturação preexiste à ação coletiva (CEFAÏ, 2009), ainda que seja em forma embrionária. Em todas elas a comunicação estará de algum modo presente, mas poderá ter significados, formas e efeitos distintos.

\subsubsection{Planejamento}

O quarto elemento que compõe a dinâmica do ativismo trata do planejamento, isto é, da elaboração racionalizada dos passos que a ação percorrerá em seu processo de execução. De antemão, importante ter como premissa que o planejamento nem sempre existe. Ações coletivas podem ser executadas sem um plano prévio, podem eclodir de forma não organizada, passional e não planificada. A existência de um caminho previamente delineado que precede a ação está intimamente ligada ao nível de organização (estruturação) que o 
movimento sustenta (MEYER; STAGGENBORG, 2012). Quanto mais estruturado estiver o movimento, maior será a frequência de planejamento.

O objetivo do planejamento é criar um roteiro teórico prévio para tornar a ação exequível. Ou seja, estipulam-se previamente métodos e meios capazes de prever erros e evitar desvios no percurso da execução da ação. O planejamento também serve para sincronizar o engajamento, definindo papeis e dirimindo desgastes entre ativistas no interior do movimento.

Para se consolidar sua efetividade, o planejamento de uma ação coletiva pressupõe duas faces importantes e intrinsicamente relacionadas: (a) estratégia e (b) conhecimento. Embora a discussão mais geral sobre estratégia seja bastante popular em outras áreas (como Administração, Marketing, por exemplo), o debate teórico sobre estratégia no ativismo não é um tema largamente abordado, como lembra Meyer e Staggenborg (2012). Em linhas gerais, estratégia é o plano direcionado a uma ação mais ampla não imediata (de médio ou longo prazo) que visa guiar ações. Assim, um planejamento estratégico significa calcular, dimensionar, prever desvios, guiando a ação no plano de forma mais ampla possível para maximizar impactos, minimizando custos e aumentando as probabilidades de efetividade dos objetivos. De acordo com Meyer e Stagenborg (2012) pode-se elencar três elementos basilares que são levados em conta na composição da estratégia de uma ação coletiva: A demanda, a arena e as táticas. São fundamentos para se traçar uma estratégia ativista:

Collective action demands, arenas, and tactics are three key elements of strategy. Each involves the selection of targets, decisions about timing, and various types of relationships and strategic dilemmas. These choices are naturally related, and each decision opens up some strategic possibilities while foreclosing others. Once activists are drawn into particular venues, they learn to formulate demands and devise tactics appropriate to them. Activists who prefer particular tactics and demands are also likely to be attracted to venues where they could work (MEYER; STAGGENBORG, 2012, p. 6-7).

Como explicam os autores, a demanda significa aquilo que o movimento anseia e está intimamente ligada aos objetivos da causa. As demandas de um movimento podem ser múltiplas ou amplas, por isso, em alguns casos haverá priorização de demandas centrais, de médio ou longo prazo, sobre a qual os ativistas irão concentrar suas ações por considerarem mais urgentes ou fundamentais (ainda que no plano mais amplo seja parte de seus objetivosfins). Por isso, toda estratégia estará voltada para uma demanda considerada de algum modo 
importante, que pode ser tanto a realização dos objetivos do movimento como também pode ser delimitada em objetivos específicos prioritários de médio ou longo prazo. No caso das arenas, consistem no campo de ação onde a estratégia será desenhada:

Movement actors need to select arenas or venues in which to press their claims. Major arenas include legislatures, courts, electoral politics, mass media, and the public. Each venue provides access to different targets and audiences, and each requires different skills and styles of rhetoric and action (MEYER; STAGGENBORG, 2012, p. 8).

A decisão sobre quais arenas serão adotadas na estratégia está inevitavelmente vinculada ao poder dos ativistas de agir sobre determinados espaços de luta, ao potencial de impacto destes na realização da ação e às competências do movimento em dominar seus códigos e recursos. Isso também implica em escolhas estratégicas, pois o foco em uma arena pode levar à negligência de outras (MEYER; STAGGENBORG, 2012). As arenas nem sempre são iguais e podem possuir lógicas próprias: podem ser formais ou informais; configuram-se por um conjunto de regras e recursos através do qual ocorre a disputa; exigem certas habilidades e know how; oferecem determinados tipos de recompensas e resultados e, ao mesmo tempo, implicam em determinados riscos e também suscitam determinadas ameaças (JASPER, 2004). No caso das táticas, trata-se dos microplanos direcionados a uma ação concreta mais localizada e imediata ${ }^{54}$. São execuções específicas de uma estratégia. São micro-ações capazes de ativar a dinâmica de uma estratégia, ao definir formas de ação para metas que formam os objetivos. Táticas "are the specific means of implementing strategy, the forms of collective action taken by movement actors" (MEYER; STAGGENBORG, 2012, p. 8). A escolha das táticas não se dá de forma aleatória e, embora possa seguir padrões levandose em conta o repertório de performances disponíveis (TILLY, 2006), a definição sobre quais táticas serão usadas em uma ação coletiva depende da experiência prévia do movimento na relação com outros atores (seja no embate ou no angariamento de apoio) e o quanto o uso de determinadas táticas demonstrou efetividade no passado (McCARTHY; ZALD, 1977).

O estabelecimento de uma boa estratégia em seus três componentes-chaves (demanda, arena e tática) requer a obtenção de informação e dados capazes de subsidiar e embasar as

\footnotetext{
${ }^{54}$ Turner (1970) aponta três estratégias alternativas utilizadas por movimentos socias: Persuasão, barganha e coerção. Considera-se esta divisão útil, porém avalia-se que o autor está tratando, na verdade, de táticas. Assim, podemos encaixar tais elementos como exemplos de táticas. De todo modo, para fins da discussão aqui proposta, a ideia não é elencar todas as táticas possíveis ou classificá-las, mas esclarecer o lugar da tática na estratégia do ativismo, ambas situadas no plano maior do planejamento da ação coletiva. Exemplos específicos de táticas serão abordados na próxima seção, já com foco nas táticas propiciadas pela comunicação digital.
} 
escolhas e caminhos que a compõe. Por isso, o conhecimento sobre o adversário, sobre seus recursos, suas fraquezas, suas habilidades é a outra face do planejamento. O conhecimento é a matéria-prima da estratégia. E a informação é a matéria-prima do conhecimento. A informação isoladamente nada mais é do que dados sobre eventos, atores e fatos. Porém, quando combinamos os diferentes tipos de informação disponíveis pode-se gerar conhecimento que será fundamental para as escolhas dos elementos que compõem uma boa estratégia:

For activists, strategy refers to choices about claims, issues, allies, frames, identity and presentation of self, resources, and tactics. They act as though these choices matter, and we generally assume that they do, but the accumulation of activist knowledge is inevitably ad hoc (MEYER; STAGGENBORG, 2012, p. 4).

Por isso, a capacidade de coletar, armazenar, esconder e cruzar informações é tão importante para a efetivação de um plano, já que esses elementos estarão diretamente ligados à qualidade da estratégia desenhada.

\subsubsection{Ação}

O quinto e último eixo do ativismo é a execução da ação, a concretização de iniciativa que busca atingir determinado intuito, seja uma meta ou a própria realização de determinada causa. Ou seja, trata-se das atividades especificamente direcionadas para realizar objetivos previstos. A ação coletiva em si é o fenômeno resultante da combinação de vários elementos como interesse, organização, mobilização (TILLY, 1978) e também, a delineação da estratégia, quando esta ocorre. Vimos nos parágrafos anteriores o interesse (na configuração da causa), a organização (na estruturação), a mobilização (no engajamento) e a delineação da estratégia (no planejamento). Naturalmente todos esses itens convergem para a ação por que o agir está claramente vinculado aos objetivos que precedem a realização da própria causa. Mas o que caracterizaria a dinâmica da ação em si? O que determina a sua forma? A análise de três elementos é bastante útil neste sentido: (a) A ideia de oportunidade; (b) o conceito de repertório; (c) e a noção de recursos.

Diversos autores vêm reafirmando as oportunidades políticas como elemento importante na dinâmica das iniciativas de uma ação coletiva (TILLY, 1978; MELUCCI, 1989; OBERSCHALL, 1993; McADAM; McCARTHY; ZALD, 1996; TARROW, 1996; PORTA, 1996). O que podemos chamar de "oportunidade" pode ser sintetizado como as 
janelas políticas - na forma de circunstâncias, conjunções, situações, eventos - que propiciam contextos adequados ou virtualmente profícuos para que uma ação seja executada e seus objetivos concretizados. Envolve diretamente a relação de um grupo, de uma causa, de um movimento com o seu entorno, isto é, o cenário político mais amplo.

Para Tarrow (2009) as oportunidades delineiam os horizontes possíveis para uma ação e a própria ação, ao ser executada, também pode repercutir em novas oportunidades, gerando assim um movimento potencialmente ${ }^{55}$ cíclico. Um outro elemento que deve ser levado em conta no surgimento de oportunidades para a ação é o contexto no qual o movimento está inserido, principalmente o tipo de regime político. Tilly e Tarrow (2007) veem tal contexto na forma de estruturas de oportunidade política e apontam seis aspectos de um regime político que afetam as oportunidades de ação, bem como as ameaças que um movimento está submetido:

General features of a regime affect the opportunities and threats impinging on any potential maker of claims, and changes in those features produce changes in the character of contention. We can sum up crucial features of regimes as political opportunity structure. Political opportunity structure includes six properties of a regime: 1 . The multiplicity of independent centers of power within it; 2 . Its openness to new actors; 3 . The instability of current political alignments; 4. The availability of influential allies or supporters for challengers; 5 . The extent to which the regime represses or facilitates collective claim making; 6 . Decisive changes in items 1 to 5 (TILLY; TARROW, 2007, p. 57).

Isto implica em dizer, na prática, que o tipo de regime no qual um grupo está inserido, ou contra o qual um grupo ativista está em conflito pode influenciar o horizonte das oportunidades para a ação. Mas não significa dizer que o regime determina em stricto sensu ou fecha as oportunidades possíveis. Ou seja, nas entranhas de um regime autoritário não significa que seja impossível surgir ações de cunho democrático pelo fato deste contexto inibir oportunidades democratizantes. Ações democratizantes podem ocorrer em regimes autocratas justamente através de janelas de oportunidades suscitadas por uma ação autoritária que gerou, como efeito colateral, um contexto propício para uma ação (ou reação) de cunho revolucionário, por exemplo.

Simultaneamente, as oportunidades não são capazes por si só de suscitar e sustentar as ações do ativismo. Precisam reagir com outras variáveis que, ao serem combinadas, podem surtir ou não efeito prático, como ressalvam McAdam, McCarthy e Zald (1996, p. 5):

\footnotetext{
${ }^{55}$ Frisa-se "potencialmente" porque nem sempre uma ação tem a capacidade de repercutir em novas oportunidades, já que pode acabar em si e não alimentar tal ciclo.
} 
If the combination of political opportunities and mobilizing structures affords groups a certain structural potential for action, they remain, in the absence of one other factor, insufficient to account for collective action. Mediating between opportunity, organization, and action are the shared meanings and definitions that people bring to their situation. At a minimum people need to feel both aggrieved about some aspect of their lives and optimistic that, acting collectively, they can redress the problem. Lacking either one or both of these perceptions, it is highly unlikely that people will mobilize even when afforded the opportunity to do so.

O outro elemento útil para analisar a ação é o conceito de repertório, principalmente a partir das contribuições de Tilly $(1978,1995,2006,2008)$. O autor tratou do tema em diversas obras ao longo de sua trajetória acadêmica e o tema sofreu algumas mutações neste percurso (ALONSO, 2012). Inicialmente, a ideia de repertório surgiu como o cardápio de rotinas assimiladas e compartilhadas que são colocadas em ação por grupos ativistas no confronto político. Em suas obras mais maduras, Tilly vinculou tal conceito à ideia de performance, usando a metáfora do palco teatral:

We can capture some of the recurrent, historically embedded character of contentious politics by means of two related theatrical metaphors: performances and repertoires. Once we look closely at collective claimmaking, we can see that particular instances improvise on shared scripts. Presenting a petition, taking a hostage, or mounting a demonstration constitutes a performance linking at least two actors, a claimant and an object of claims. Innovation occurs incessantly on the small scale, but effective claims depend on a recognizable relation to their setting, to relations between the parties, and to previous uses of the claim-making form. Performances clump into repertoires of claim-making routines that apply to the same claimant-object pairs: bosses and workers, peasants and landlords, rival nationalist factions, and many more (TILLY, 2006, p. 34-35).

Este conceito é importante pois demonstra que o ativismo se utiliza de um leque de performances pré-configuradas a partir do qual lança mão e faz adaptações a depender do contexto político no qual está inserido, visando também o objetivo que busca alcançar. De forma complementar, paralelamente à concepção de repertórios, Snow e colegas (1986) também introduzem o conceito de framing como um elemento importante na orientação da ação. Nesta perspectiva analítica, a execução de uma ação coletiva também está inserida em um enquadramento maior no qual os atores estão inseridos. Isso envolveria o 
compartilhamento de sentidos, significados, crenças, pressuposições que influenciam o tipo e a forma que a ação tomará ${ }^{56}$.

Ao mesmo tempo que há um repertório comum com significados compartilhados e frames, também devemos lembrar que este não é imutável ou fixo: É adaptado e reinventado com o tempo, não devendo ser compreendido como algo estático e sim como algo dinâmico e vivo. Inovações nos processos de comunicação podem ampliar esse leque de performances, como veremos na próxima seção. Para o autor esta capacidade de reinvenção e flexibilidade no repertório é mais comum em grupos ativistas, isto é, grupos desafiantes. Estados ou outras instituições que concentram poder tendem a replicar performances, principalmente aquelas que tiveram sucesso em manter determinado status quo, por isso, tendem a manter repertórios menos inovadores, mais fixos no tempo.

Da mesma forma como ocorre com as oportunidades, como vimos, os repertórios também são influenciados pelos contextos políticos. A baixa ou alta capacidade $^{57}$ de um governo, o fato de ser um regime democrático ou um regime não democrático, são variáveis que, ao serem cruzadas, podem limitar ou expandir as possibilidades de repertórios disponíveis para ativistas (TILLY, 2006).

Paralelamente à existência de oportunidades e repertórios, um terceiro elemento que compõe a execução da ação é a existência de recursos. A ação em si só pode ser exequível se levar em conta os recursos que os ativistas têm em mãos para torná-la efetiva no plano real. Devemos entender por recursos os elementos materiais (tangentes) e imateriais (intangentes) que o ativismo detém (ou precisa se apoderar) para efetivar uma ação tais como dinheiro, logística, legitimidade, força de trabalho, tecnologia, capital social etc. (McCARTHY; ZALD, 1977). Uma das principais características dos recursos é a sua escassez. Por isso, há disputas não apenas contra adversários centrais (como Estados, autoridades, corporações), mas também entre ativistas de grupos diferentes para a obtenção de recursos considerados valiosos (McCARTHY; ZALD, 1977). Assim, muitas estratégias e ações que precedem as finalidades de um movimento podem ser voltadas para a obtenção de recursos estratégicos necessários para serem utilizados no plano maior do movimento.

Por fim, do ponto de vista mais amplo, vale ressaltar que, embora a ação seja um fenômeno prático que geralmente visa um objetivo específico, isso não significa que seja algo

\footnotetext{
${ }^{56}$ O debate trazido por esses autores é inspirando nos trabalhos de Erving Goffman (2006).

${ }^{57}$ Como explica o autor: "Governmental capacity (degree to which governmental actions affect distributions of populations, activities, and resources within the government's jurisdiction, relative to some standard of quality and efficiency): low (0) to high (1)" (TILLY, 2006, p. 21).
} 
que está sob o pleno controle dos ativistas e nem que tenha real efetividade, dado que podem tomar rumos inesperados:

O curso da ação não é uniforme. Ele é semeado de arapucas, interrompido por peripécias e giros imprevisíveis, é exposto a maquinações e armadilhas, é relançado por manobras e projetos. Com frequência toma direções imprevistas, sai do rumo das expectativas de seus agentes, bifurca-se em várias possibilidades, impõe que se pesem prós e contras (CEFAÏ, 2009, p. $34)$.

Assim, as estratégias tentam justamente minimizar os riscos e esta perda de controle, de modo que os recursos disponíveis (dinheiro, legitimidade, logística, tecnologia etc.) é que tornam os repertórios possíveis de serem executados na prática. Vale lembrar que nem toda a ação é precedida de um plano e nem sempre o planejamento consegue ser totalmente executado, como vimos anteriormente.

\subsection{EFEITOS DA COMUNICAÇÃO DIGITAL NO ATIVISMO TRANSNACIONAL}

Se difusão e mobilização do ativismo transnacional, aos moldes de como o definimos na seção anterior, não é uma exclusividade do século XXI, pode-se apontar elementos novos no ativismo transnacional hoje? Afirma-se que sim. Há mudanças relevantes na dinâmica do ativismo transnacional propiciadas pelos usos da comunicação digital a ponto de colocá-lo cada vez mais como um importante e emergente fenômeno na balança de poder da arena internacional. Paralelamente a isso, é preciso compreender que a comunicação digital tem seus limites e a análise de seus efeitos no ativismo transnacional deve ser acompanhada de três asserções que podem ser defendidas com base nas argumentações e análises discutidas nesta pesquisa: (a) Não se trata de um novo e radical ativismo baseado no cyberpower; (b) o uso da comunicação pelo ativismo transnacional não é uma inovação do ambiente digital; (c) o uso da comunicação digital pelo ativismo transnacional não é apenas positivo.

Sobre a primeira asserção, não se pode negar o uso da comunicação e seus efeitos nas práticas políticas contemporâneas. Ao mesmo tempo, ainda é bastante comum o outro extremo: Análises que tratam estas ferramentas como elementos divisores de uma grande ruptura. Joyce (2010b) acredita, por exemplo, que o ativismo digital pode se configurar menos 
como uma grande inovação, do ponto de vista conceitual, e sim como uma mera extensão das práticas já existentes, uma mudança de grau, mas não de tipo, pois:

Many activists simply recreate pre-digital forms of activism using digital tools: the protest march is organized by social network instead of clandestine meetings, the mass mailing becomes a mass email. Because deep understanding of the potential of digital infrastructure for activism is lacking, so is sophistication and successful implementation (JOYCE, 2010b, p. 212).

A afirmativa é correta ao ponderar que o ativismo lança mão de repertórios (no sentido "tillyano") pré-existentes e que muitas vezes reproduzem performances antigas no ambiente digital. Mas falha ao esquecer que novas vias de ação, empoderamento e mobilização surgem a ponto de repercutirem em novas possibilidades antes não existentes que, se não significam rupturas radicais a ponto de surgir um ativismo radicalmente reformulado, certamente trazem elementos inovadores que estão alterando a forma de funcionamento do ativismo e consequentemente o seu posicionamento nas arenas de embates políticos. Sobretudo é importante compreender que a comunicação digital isoladamente não é suficiente para o sucesso da política ativista. O poder é construído pelos ativistas através dos diversos recursos disponíveis (incluindo recursos oriundos dos processos de comunicação) balanceado pelas oportunidades existentes (TILLY, 1978; MELUCCI, 1989; OBERSCHALL, 1993; McADAM; McCARTHY; ZALD, 1996; TARROW, 1996; PORTA, 1996). Há um desvio de interpretação a partir de casos excepcionais que usam ferramentas digitais e um amplo desconhecimento do ativismo político como um todo (NIELSEN, 2010). Por isso, Nielsen (2010, p. 182) aposta que:

[...] we need to give up the idea that digital and networked technologies will bring about a radical break - for good or ill — with the past. Instead, we should look at how new tools and old practices are combined in modular and only sometimes innovative ways.

Ainda que a essência do ativismo não tenha se alterado ao longo do tempo, há ferramentas e táticas constantemente sofrendo mudanças e estes mecanismos são padrões que devem ser analisados pontualmente (JOYCE, 2010a).

A outra asserção que precisa ser incorporada na análise é que o uso da comunicação pelo ativismo não é específico do mundo digital. Tradicionalmente, a mídia tradicional analógica (TV, rádio, jornal impresso etc.) tem sido usada como forma não apenas de informação e comunicação, mas também a serviço da organização e mobilização para grupos 
e pessoas, haja vista, por exemplo, o papel do jornal em ações coletivas como agitador e propagandista na clássica descrição de Lenin (GERBAUDO, 2012). Para Gerbaudo (2012, p. 4) "Social media can be seen as the contemporary equivalent of what the newspaper, the poster, the leaflet or direct mail were for the labour movement". Ainda que esta equiparação direta seja controversa, já que as novas mídias permitem uma interação espaço-tempo-escala inéditas, isto ajuda a demonstrar a continuidade da mídia moderna em desempenhar um papel importante na mobilização e estruturação de grupos sociais num novo contexto histórico e político. E a comunicação digital deve ser compreendida como um passo adiante nesta linha que vem a somar e integrar os meios de comunicação pré-existentes.

Por fim, como terceira asserção, devemos perceber que, ontologicamente, o uso das ferramentas de comunicação digital tem caráter diverso, isto é, podem ser tanto positivos quanto negativos. As TICs são avaliadas de diferentes formas pelos pesquisadores sociais, considerando seus usos e potencialidades. Muitas vezes a tecnologia é vista de forma neutra ou naturalmente positiva, capaz de trazer apenas avanços e benefícios, conforme debatido amplamente no capítulo 2 a partir da visão do determinismo tecnológico. Para Castells (2012), por exemplo, a Internet é tida como um espaço de autonomia, fora do controle de empresas ou de governos. Nesse ponto, fica claro o papel libertário trazido na apropriação social das TICs, que faz parte dos argumentos dos ufanistas tecnológicos. Outros pesquisadores, menos empolgados, defendem que a Internet é passível de controle e manipulação (DEAN, 2003; WOLTON; 2001; LANIER, 2010), seja de governos, seja de empresas, e regimes políticos podem ser capazes de regular as atividades dos cidadãos nesse ambiente, se assim desejarem.

Apostar todas as fichas na hipótese de que a comunicação digital primariamente auxilia grupos com "boas iniciativas" criaria uma bolha que excluiria a miríade de grupos que utilizam a Internet (DREZNER, 2010). Acreditar somente nos aspectos apenas positivos das novas mídias, segundo Kluver (2002), é um erro que incorrem muitos pesquisadores:

Much public discussion of the role of the internet remains dominated by cheerleaders and hyperbole, with little critical appraisal of how it actually is used and how the logic of the medium both encourages and inhibits serious discussion of foreign affairs. [...]. What is troubling is that this naive reasoning, and the presumption that improved communications technologies will reduce misunderstandings and avert political conflict, has an inordinate and perhaps unjustified role in interpreting the impact of communications media on government policymakers, as well as average citizens (p. 508). 
É importante compreender também que a ferramenta digital não carrega por si só a possibilidade de emancipação política pacífica, mas tem também o potencial de ser instrumentos poderosos nas mãos de células que aplicam a violência, como o caso de terroristas que planejam e executam ataques.

De um modo ou de outro, para o bem ou para o mal, são faces de um mesmo problema que estão inseridos no campo de estudo do ativismo, do ponto de vista mais amplo (conforme discutido na primeira seção deste capítulo) enquanto fenômeno político. Portanto, devem ser analisados como tal, levando-se em conta as questões sociais e políticas relacionadas.

Por isso, para identificar os efeitos da comunicação digital no ativismo transnacional contemporâneo convém retomar a discussão sobre as repercussões da comunicação digital nas práticas sociais (conforme discutido no final do capítulo 2$)^{58}$ e vincular como isso repercute na dinâmica do ativismo em seus pilares de funcionamento (conforme discutido na seção 4.3). Assim, todos os cinco eixos que compõem a dinâmica do ativismo - configuração, engajamento, estruturação, planejamento e ação - são direta e indiretamente afetados por mudanças sociais que a comunicação digital tem repercutido.

Tendo em mente estas duas discussões anteriores, o diagrama da Figura 4 busca sintetizar como as mudanças sociais trazidas por essas novas tecnologias da comunicação afetam a dinâmica do ativismo em seus eixos fundamentais, gerando efeitos específicos:

\footnotetext{
${ }^{58}$ Revisitando os quatro principais efeitos da comunicação digital sobre as práticas sociais tem-se: (1) a intensificação da conectividade midiática; (2) o fomento à agregação de ideias; (3) o aumento perceptivo da realidade, e (4) a ampliação da difusão de poder.
} 
Figura 4 - Impactos sociais da comunicação digital e seus efeitos na dinâmica do ativismo

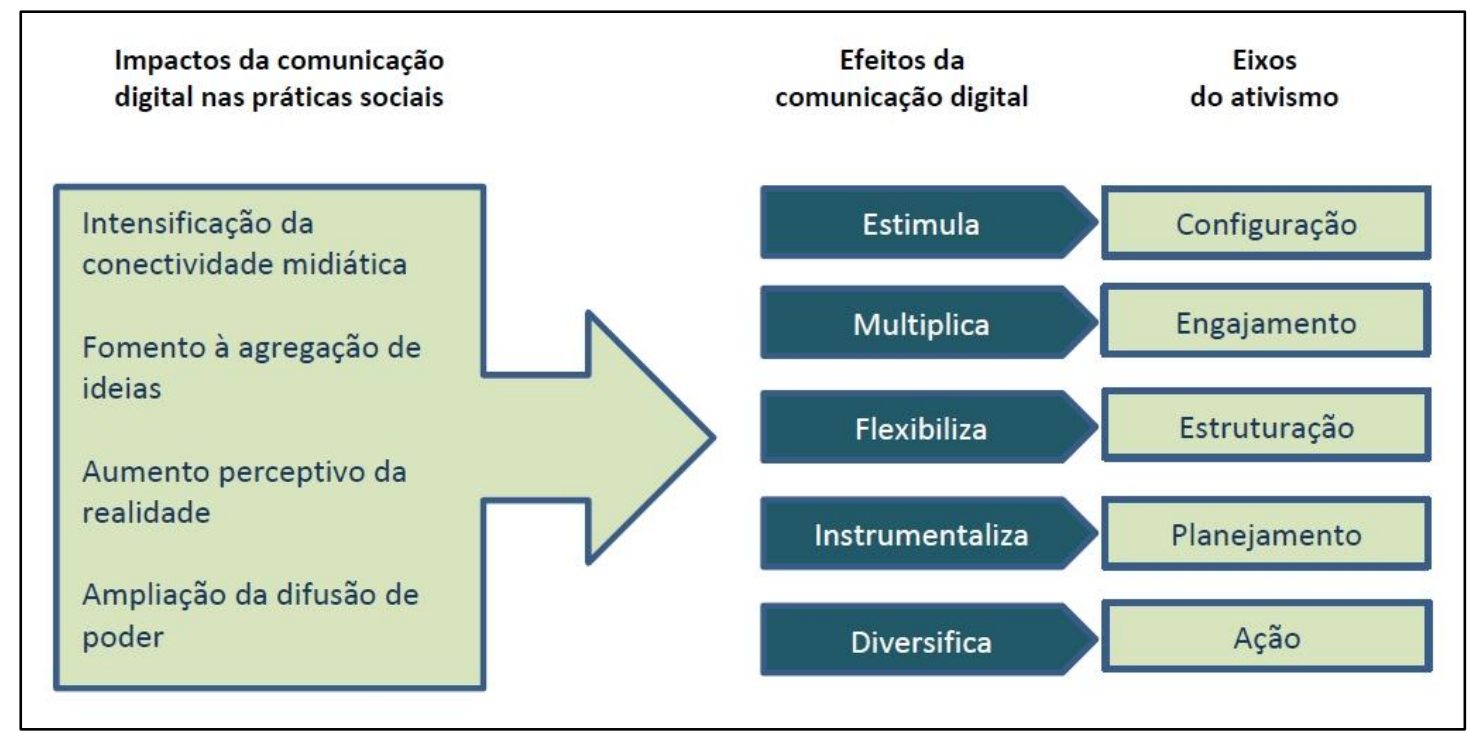

(Fonte: própria autora)

Assim, a partir da percepção de que tais repercussões são concretas e trazem implicações políticas e, com base nas análises e discussões precedentes, é possível identificar cinco categorias de efeito fundamentais da comunicação digital no ativismo transnacional:

a) Estímulo à configuração da causa

b) Multiplicação do engajamento

c) Flexibilização da estruturação

d) Instrumentalização do planejamento

e) Diversificação da execução de ações

$\mathrm{Na}$ intenção de contribuir para uma perspectiva útil sobre ativismo transnacional contemporâneo, convém agora especificar o que significa cada um desses efeitos, sob a forma de categorias analíticas, aprofundando seus reais impactos, limites e elementos que os constituem no espectro político mais amplo.

\subsubsection{Estímulo à configuração da causa}

A configuração do ativismo transnacional se dá em torno de uma causa inicial, uma ideia política através da qual será erguida uma bandeira ou um conjunto de reivindicações. A comunicação digital acelera processos de convergência de ideias (JENKINS, 2009) e, 
paralelamente, também pode aumentar as rotas de atrito. Os dois efeitos distintos, seja agregacionista ou agonístico, criam um mesmo ambiente de estímulo para o discurso político e a defesa de ideias comuns, incentivando o surgimento de bandeiras.

Em linhas gerais, as TICs são responsáveis por facilitar a comunicação entre os indivíduos, de modo que permitem tanto aproximar pessoas com interesses e preferências semelhantes, quanto mediar a construção de uma ideia compartilhada e defendida por indivíduos geograficamente distantes. Dentre as características mais anunciadas da comunicação online estão a possibilidade do contato instantâneo, da aproximação de diferentes culturas e ideologias, bem como a transposição das tradicionais fronteiras físicas (RHEINGOLD, 1996; LEMOS, 2010; JENKINS, 2009).

De fato, o acesso à Internet permite estimular o contato entre indivíduos com afinidades e interesses similares dispersos que podem fazer força e convergir ideias e ações, com uma sinergia que seria impossível sem a mediação digital como elemento catalisador. Isto é o que o autor Henry Jenkins (2009) caracterizou de "cultura da convergência" para demonstrar que convergência é mais do que um processo tecnológico de agregar diferentes funções nos mesmos aparelhos, pois envolve um processo de aglutinação cultural. Embora o autor tenha se concentrado em entender a sociedade de consumo em massa e questões da indústria cultural, seu insight é bastante apropriado para se pensar a participação política nas redes online. A convergência é definida por ele como:

[...] fluxo de conteúdos através de múltiplas plataformas de mídia, à cooperação entre múltiplos mercados midiáticos e ao comportamento migratório dos públicos dos meios de comunicação, que vão a quase qualquer parte em busca das experiências de entretenimento que desejam (JENKINS, 2009, p. 29).

Em outras palavras, a convergência da rede permite aproximar indivíduos com objetivos e reivindicações comuns, acompanhar conteúdos que tenham afinidade e interesse, de modo a estreitar vínculos, sejam culturais, políticos ou religiosos. Isto significa que, muitas vezes, mais do que expor o outro a opiniões e valores diferentes do seu, a convergência reforça as suas próprias convicções. As interações da mídia contemporânea permite agregar pessoas em torno de símbolos comuns, ao mesmo tempo em que dispersa e fragmenta o espaço urbano real criando solidariedade e senso de identidade coletiva não restrita à territorialidade (GERBAUDO, 2012; KAVADA, 2010). A Internet facilita a interação de igual pra igual no grupo construindo um senso de identidade coletiva. 
Por isso, crenças e descontentamentos, antes dispersos, podem se definir em uma causa através da convergência de ideias e interesses dentro do ciberespaço, ainda que seus agentes estejam distantes geograficamente. O conhecimento de diferentes realidades empodera os indivíduos de uma maneira nova, informando-os e os unindo:

As the venues of mass communication become more diverse and pervasive, individual citizens become intellectually and politically empowered. They know more about what is going on around them and they use media tools to form communities of interest that enhance political activism (SEIB, 2012, p.1).

Esse espaço de interação viabiliza pessoas like-minded a se convergirem através das redes sociais, blogs e plataformas de compartilhamento de conteúdo, apesar da distância geográfica, dividindo perspectivas, fornecendo informação e mobilizando recursos (ROSENAU apud LAI, 2003; SCHUMANN, 2015). Por serem conexões descentralizadas não significa que estejam isoladas de uma proposta coletiva, de maneira que a interação gera uma construção de identidade de baixo para cima (SCHUMANN, 2015).

Nesse sentido, a visibilidade é um elemento importante para a configuração de uma causa, pois a Internet ajuda os ativistas a disseminarem o seu conteúdo e a chamarem a atenção para suas reivindicações. Os grupos têm a possibilidade de transmitir sua mensagem sem necessariamente passar por má-interpretação ou foco em sensacionalismos, muitas vezes comuns à mídia tradicional. Assim, websites, listas de e-mails, mídias sociais são deflagradores de informação, criando uma representação digital potente para endereçar uma ampla audiência com maior rapidez e custos reduzidos (SCHUMANN, 2015). A troca de informações, a publicidade e a integração das redes de comunicação eficientes aumentaram exponencialmente a velocidade com que uma causa se espalha (SEIB, 2012; PORTA; TARROW, 2005).

A comunicação digital trouxe justamente maiores possibilidades de visibilidade para além dos canais formais dos meios de comunicação analógicos, afetando assim, a velocidade da roda do engajamento. Durante todo o século XX predominou-se um modelo de visibilidade baseada no mass media. Significa dizer que para determinados fatos, atores ou eventos ganharem conhecimento público precisariam passar por estas mídias que são, predominantemente, grandes corporações que controlam os recursos sobre o que será transmitido no noticiário e que ajudará a compor o imaginário do público sobre determinadas questões políticas. A concepção de gatekeeper, bastante discutida em Teorias do Jornalismo, 
sintetiza justamente esta característica dos meios de comunicação e seus agentes como filtros, moderadores ou guardiões do portão da visibilidade midiática (WHITE, 1993; TRAQUINA, 2005; WOLF, 2008), que em última instância afeta o próprio processo de formação da opinião pública. Muitos analistas apontam que o surgimento da Internet tem provocado um rearranjo neste formato até então predominante. Para Lemos (2002) o ambiente digital marcou a libertação do pólo de emissão, isto é, a difusão de informação e mensagens em larga escala passou a não ser mais um oligopólio restrito apenas às corporações de mídia, já que agora também é dividido com indivíduos e organizações online que, embora não tenham o mesmo poder, têm causado abalos na preponderância histórica dos meios tradicionais enquanto intermediários.

A histórica primazia de meios como o rádio ou a televisão em dar as notícias em primeira mão também sofreu modificações. Diversos exemplos já demonstraram que muitos eventos têm sido noticiados primeiramente nas timelines de mídias sociais e somente horas depois é que passam a ser objeto de publicação nos meios tradicionais (KLUVER, 2002) ${ }^{59}$. Mas isso não significa superioridade das novas mídias ou mesmo que tenham melhor qualidade que os meios tradicionais:

For motivated participants, the database logic of new media can have an
overwhelming political impact. There are literally hundreds of instances in
which new media empowered motivated constituencies and enabled them to
achieve political force. Likewise, for an interested observer, the logics of the
database and the conversation are very valuable, and new media clearly
enhance this. However, my argument has been more modest: for influencing
public opinion generally, new media do not demonstrate any inherent
superiority over traditional media forms (KLUVER, 2002, p. 514).

O mass media passou a ser também mais desafiado com informações paralelas que circulam nas mídias sociais sobre versões diferentes quanto à cobertura de um fato, ou a revelação da ausência de cobertura de determinadas questões, bem como a crítica ao noticiário quando há erros de informação ou análise (DELWICHE, 2005; WOODLY, 2008). São todos elementos que existiam basicamente nas cartas dos leitores, espaços controlados pelos editores, mas que agora ganham em escala e fogem do gatekeeping. Para Axel Bruns

\footnotetext{
${ }^{59}$ Vale lembrar que, apesar desta relevância e agilidade das TICs, a televisão ainda continua sendo o meio com maior audiência em diversos países. De todo modo, a própria TV tradicional tem perdido audiência uma vez que o uso da Internet ocupou parte do tempo de consumo de mídia que era dedicado à televisão.
} 
(2011), entra em cena o fenômeno do gatewatching, isto é, a própria audiência passa também a ser um guardião que determina a visibilidade (popularidade) de um tema:

[...] a mídia on-line especialmente possibilitou que as audiências - ou mais exatamente, os usuários - pulassem por cima das publicações noticiosas para conectar diretamente com as organizações, as instituições e os indivíduos que lhes interessam - para acompanharem em primeira mão os comunicados à imprensa e as afirmações públicas dos governos, dos políticos, das empresas, das ONGs e de outras figuras da vida pública. Além disso, estes usuários ativos podem atualmente compartilhar com outros aquilo que observam enquanto estão observando, através de uma ampla gama de plataformas variando das ferramentas colaborativas [...] (BRUNS, 2011, p. 123).

Os indivíduos online também passaram a influenciar de forma mais contundente, inclusive no agendamento do noticiário. Quando um tema se torna um "viral" ou entra no topo dos índices de menções das mídias sociais (como trending topics do Twitter) isso tem se tornado, com bastante frequência, tema de matérias na imprensa formal. Como analisa Jenkins (2009), se o paradigma da revolução digital presumia que as novas mídias substituiriam as antigas, o emergente paradigma da convergência presume que novas e antigas mídias irão interagir de formas cada vez mais complexas: “o poder da mídia alternativa é que ela diversifica; o poder da mídia de radiodifusão é que ela amplifica” (p. 341). Ou seja, o ambiente digital passou a compor o universo de elementos que influencia a pauta jornalística, e o próprio ambiente digital, composto por sujeitos interconectados, tem se tornando um novo espaço da visibilidade pública. Algo que tem sido usado de forma estratégica pelo ativismo contemporâneo transnacional para gerar repercussões na opinião pública internacional e angariar novos militantes dispostos a engajar-se em suas bandeiras (SILVEIRA, 2009; ZAGO; BATISTA, 2011).

De modo prático, o novo ativismo tem percebido que para alcançar a opinião pública sua ação precisa ser multimídia. Compreende que a dinâmica da visibilidade neste século XXI não está mais tão centrada no mass media e que o ambiente digital é uma nova face para se disputar publicidade, para se conquistar ou impactar a opinião pública, para ser conhecido, permeando o imaginário do público. Para Castells (2012) a contínua transformação da tecnologia da comunicação na era digital amplia o alcance dos meios de comunicação para todos os domínios da vida social, numa rede que é simultaneamente global e local, genérica e personalizada. E o ativismo transnacional contemporâneo tem se configurado para passear cruzando estas fronteiras. 
Como aponta Neil Postman (2000) um meio é uma tecnologia através da qual a cultura cresce e tanto as organizações quanto os indivíduos incorporam a gramática do meio, o que poderia ser equiparado metaforicamente como uma "ecologia" onde as coisas crescem e se equilibram. Portanto, não se trata apenas de um ativismo que atua em mídias online, mas um ativismo que tem compreendido que o meio digital não suplantou o sistema de comunicação pré-existente, mas o tornou diferente e busca justamente explorar esta nova ecologia e suas potencialidades para ações que rompem as barreiras nacionais de forma natural, porque é uma característica inerente ao modo de funcionamento das Tecnologias de Informação e Comunicação (BIMBER et al, 2012).

Choucri (2012) explica que o espaço virtual cria mecanismos de fala e de visibilidade que no espaço físico era até então inexistentes ou dificultosos. E isso facilita a articulação de demandas comuns, aumentando a audiência para determinadas ideias antes pouco observadas. Não por acaso, redes sociais digitais (seja redes de indivíduos, de páginas, blogs, de organizações etc.) propiciam a intensificação das conexões culturais e políticas, que são na verdade canais adicionais ao sistema pré-existente.

Embora a comunicação digital deva ser compreendida como um "ambiente de trocas simbólicas" através do qual as bandeiras podem surgir, não deve ser tratada como a própria máquina produtora do ativismo. A comunicação opera como um ingrediente a mais em uma engrenagem maior que envolve elementos de contextos políticos, sociais, econômicos, culturais e históricos. Portanto, não basta comunicação digital para haver ativismo. É preciso existir uma combinação de fatores e um gatilho consistente, como aqueles colocados por Oberschall (1993) na primeira seção deste capítulo.

Uma importante forma de reunir pessoas em torno de uma causa é a sensibilização coletiva. Isso pode ocorrer a partir de um evento que desencadeia o despertar do movimento e a Internet age na viralização deste tipo de narrativa ou estopim. Vídeos e imagens compartilhadas são cruciais para construir um senso de identidade coletiva, já que são elementos vívidos e concretos que conseguem traduzir o senso de envolvimento em ânsia por ação (KAVADA, 2010; SCHUMANN, 2015). Redes sociais e e-mails facilitam a viralização da informação (KAVADA, 2010). Ativistas enviam conteúdo para membros das redes sociais e apoiadores do movimento, e contam com a capacidade de espalhamento, que é potencialmente forte dentre aqueles que se conhecem e se confiam: "They are also more likely to participate in a protest when they know that their friends will also attend" (KAVADA, 2010, p. 108). 
Essa viralização não ocorre de forma aleatória. Berger (2014) explica que o fenômeno do viral é uma combinação de alguns fatores (que o autor chama de princípios) que, ao serem combinados, geram os surtos de disseminação online de um evento, fato, imagem, conteúdo. O chamado efeito viral:

Depois de analisar centenas de mensagens, produtos e ideias contagiantes, notamos que os mesmos seis "ingredientes" ou princípios, com frequência estavam ativos. Seis passos-chave, como eu chamo, que fazem com que as coisas sejam faladas, compartilhadas e imitadas. [1] Moeda Social [...]; [2] Gatilhos [...]; [3] Emoção [...];[4] Público [5] Valor Prático; [6] Histórias. (BERGER, 2014, posição 421-461).

Nesta mesma lógica de raciocínio, Gerbaudo (2012) também aponta que a sensibilização para este engajamento online assume dinâmicas específicas no ambiente digital. Para o autor, as mídias sociais reúnem grupos fragmentados através de um complexo processo simbólico e de mediação técnica, que chama de "choreography of assembly". O termo coreografia é útil porque sintetiza o caráter simbólico e mediado: "on the fact that media practices intervene in preparing the terrain, or setting the scene, for people coming together in public space" (GERBAUDO, 2012, p. 40). A coreografia dos encontros públicos mediados por mídias sociais não são apenas um espaço de circulação de informações práticas ou de logísticas para organizar eventos ou protestos, são a construção de uma narrativa cultural própria criando uma coletividade comum, envolvendo comprometimento emocional. É fundamental o aspecto emocional para a ação coletiva, pois a construção da identidade do grupo é continuamente remodelada, questionando a ideia de a organização já ser um ator formado, e essa constante remodelação leva em consideração o conteúdo produzido no grupo e as práticas concretas (SCHUMANN, 2015). Isso ocorre não apenas através dos repertórios disponíveis em contextos de regimes democráticos ou estáveis. Também se dá em zonas de conflito, instáveis ou autocráticos, onde o processo de narrativa e sensibilização também encontra seus caminhos (GHEIDARY, 2012) ${ }^{60}$.

\footnotetext{
${ }^{60} \mathrm{O}$ autor descreve o passo-a-passo do caminho da informação para a sensibilização coletiva num contexto de zona instável e de violência. Primeiramente, a informação circula entre aqueles que estão na zona de crise. Se um dos pares é atingido, outros pares e grupos locais registram a cena através de dispositivos móveis para circular de maneira fidedigna o fatídico ocorrido. Na sequência, outros pares envolvidos e afetados na cena poderão colaborar com informações primárias fazendo upload em mídias sociais assim que tiverem acesso a Internet e então poderão mostrar aos que estão do lado externo o acontecimento. Estas informações alcançarão redes de comunidades virtuais efêmeras formada em diversos pontos geográficos. O terceiro caminho da informação é traçado entre os atores envolvidos diretamente no acontecimento e membros de mídias formais globais que estavam acompanhando os acontecimentos pelas mídias sociais daqueles que estavam de fora. $\mathrm{O}$
} 
Segundo Wheeler (2012), a cultura e o contexto moldam o significado das práticas das novas mídias, tanto em seus usos, quanto nos impactos desses usos. Isto significa que, a depender do tipo de sociedade e de governo vigente, o mesmo uso de uma ferramenta social pode ter impactos diferentes, pois pode haver variáveis contextuais que irão interferir no seu desempenho final. Por exemplo, um elemento contextual em como a forma que um governo reage ao ativismo pode impactar no surgimento de uma causa ativista e no tipo de ativismo desenvolvido naquela sociedade (GLAISYER, 2010) e, consequentemente, nos usos e impactos que esses ativistas fazem da comunicação digital para fazer florescer a causa. Mais especificamente, democracias e autocracias se comportam de maneira distinta frente ao surgimento de bandeiras do ativismo. Notadamente, em democracias onde prevalece maior liberdade de expressão e associação, a configuração de uma bandeira encontra menos resistência para florir pois coexistem diferentes canais para o fluxo de ideias:

In some parts of the world, notably democratic countries and aspiring democracies, political blogs have become mechanisms for the articulation of interests and for the aggregation of individuals or groups into a critical mass. This kind of activity is possible when the political rights of individuals are articulated, understood, and protected by the social contract and the principles of the political system. (It should also be noted that online speech and organizing appear to be effective in some politically repressive countries) (CHOUCRI, 2012, p. 29-30).

Em todo o mundo, governos democráticos ou organismos multilaterais (como OECD e sistema ONU), têm percebido na comunicação digital uma oportunidade para fortalecer a dimensão cívica, estimulando a participação e o ativismo através destas ferramentas (DREZNER, 2010; GLAISYER, 2010). Do mesmo modo, o governo dos Estados Unidos também tem agido nessa direção:

The U.S. State Department has begun to invest serious resources into the use of online technology to promote civic activism. In November 2009, Secretary of State Hillary Clinton announced the Civil Society 2.0 Initiative to build the capacity of grassroots organizations through the use of blogs, social networks, and other Web 2.0 technologies. In her announcement, she pledged the United States would "send experts in digital technology and communications to help build capacity" for civil society groups worldwide. In January 2010, Clinton gave a follow-up speech on internet freedoms in which she charged that a "new information curtain" was being imposed by repressive governments. She further acknowledged the complex effects of

quarto caminho da informação provavelmente se dá entre os atores que estão diretamente envolvidos in loco e aqueles que estão envolvidos, mas do lado de fora à zona de crise, principalmente através das comunidades das mídias sociais visando combater as atividades dos grupos de oposição (GHEIDARI, 2012). 
Web 2.0 technologies: "while it is clear that the spread of these technologies is transforming our world, it is still unclear how that transformation will affect the human rights and the human welfare of the world's population (DREZNER, 2010, p. 41- 42).

Em muitas realidades, os governos continuam a operar como hierarquias burocráticas apesar do desafio dos movimentos em rede. Outros governos buscam responder a esse modus operandi, visando estabelecer uma relação mais horizontal com os movimentos (GLAISYER, 2010), criando assim um ambiente fecundo para a configuração do ativismo.

Mas não basta combinar um contexto democrático e intensos fluxos de comunicação digital para fazer florir ativismo em sua forma benéfica. Se a comunicação digital tende a ser catalisadora de ativismo em geral, este mesmo elemento também pode suscitar bandeiras consideradas não democráticas ou moralmente condenáveis, em torno das quais se aglutinam outsiders. Apesar do desincentivo estatal para este tipo de ativismo e apesar do poder de controle que um Estado pode exercer, a comunicação digital sustenta múltiplos pontos de fugas ao domínio total de governos, possibilitando o funcionamento de ambientes comunicacionais autônomos não colonizados pelo mundo do sistema, no sentido habermasiano (HABERMAS, 1981), seja para o bem, seja para o mal. Por outro lado, uma hipotética eficiência de regimes democráticos ao utilizar a comunicação digital para estabilizar e institucionalizar a participação política do cidadão, incorporando-o na rotina institucional do Estado, também pode acarretar em um efeito distinto: pode significar menor combustão para efervescência de ideias e embates, esfriando o surgimento de novas causas políticas autônomas, justamente devido ao nível de colonização aplicado.

Paralelamente, é preciso compreender que o papel das TICs e sua eficiência na aglutinação de ideias não é líquido e certo e, a depender do contexto social, a comunicação digital pode ter efeitos colaterais distintos. Por exemplo, ainda que acredite no potencial da Internet para empoderamento do ativismo, Tarrow (2006) ressalta que esta nova forma de comunicação permite também a dispersão, isto é, pode fomentar a fragmentação a ponto de enfraquecer a configuração de uma bandeira, por propiciar a ramificação em interesses difusos diversos, não unificados. Nas palavras do autor:

Moreover, when it comes to building a unified movement, ease of access to communication is a mixed blessing, because every activist who is capable of building a website can challenge established organizers and disperse a unified movement into a number of separate campaigns. Finally, states and 
countermovements have proved adept at using their information channels to infiltrate and oppose them (TARROW, 2006, p. 210).

Em que pese uma valoração, no que se refere à dispersão de uma causa em diferentes "microcausas", isto não é necessariamente ruim para o surgimento de um movimento, considerando-o como um processo histórico, já que pode significar sementes que germinam paralelamente, com alguma potencialidade de serem unificadas no futuro, sob um mesmo 'guarda-chuva' e culminar com mudanças estruturais relevantes no longo prazo e que atendam às demandas dos grupos.

Já no contexto de regimes autocráticos, o fomento da comunicação digital ao surgimento de causas ativistas também ocorre, porém, através de outras vias, pois há outros ingredientes envolvidos. O argumento de que as ações vinculadas à liberdade de expressão só ocorrem na ausência de constrangimentos externos (STEEN-THORNHAMMAR, 2012a, 2012b), como regimes ditatoriais, é meia-verdade, já que muitas vezes a reação em nome da liberdade de expressão ocorre precisamente diante de um governo autoritário, sendo esta situação um combustível para o exercício, ainda que reprimido, de liberdade de expressão. Wheeler (2012) acredita que as mídias sociais são ferramentas que permitem ao público maior habilidade de se organizar e de mobilizar números expressivos de pessoas críticas com margem de tempo até que a repressão do Estado venha a ocorrer.

Ao mesmo tempo, em sociedades autoritárias e fechadas prevalece a repressão aos movimentos de oposição (GLAISYER, 2010) e é importante lembrar que as TICs possibilitam novos aparatos tecnológicos disponíveis aos governos permitindo o monitoramento e até mesmo censura por parte dos Estados do uso dessas ferramentas pela população em geral. Se a estrutura física da Internet ainda existe em territórios, permitindo que governos possam controlar e monitorar cidadãos, até mesmo bloqueando acessos, a tecnologia pode mais prejudicar do que necessariamente ajudar os ativistas (JOYCE, 2010a). E assim, a ação governamental em repreender e monitorar os cidadãos pode ser eficiente e conseguir desarticular causas ativistas ${ }^{61}$.

De acordo com a OpenNet Initiative, o número de países que têm censurado digitalmente seus cidadãos vem aumentando consideravelmente através do bloqueio ao acesso de websites ou filtros de termos, retirada de conteúdo de websites, ou intimidação direta de

\footnotetext{
${ }^{61}$ Por exemplo, Glaisyer (2010) diz que no "Moldovan case" em 2008 a vigilância do Estado egípcio conseguiu minar o uso da tecnologia dos ativistas, mais especificamente o Facebook, provocando nos ativistas o medo de serem identificados e presos.
} 
ativistas devido às suas atividades online (BRODOCK, 2010). As razões argumentadas pelos países envolvem direito de propriedade, segurança nacional, bloqueio de pornografia e diminuição da exploração. Na China, por exemplo, o Twitter e o Facebook são proibidos, já em outros países como Irã e Tailândia, a censura não se restringe somente à Internet, já que o governo conseguiu agir bloqueando o uso de SMS (Short Message Service) por um certo período antes das eleições (BRODOCK, 2010). Mas isso não significa uma eficiência total do aparelho de censura, pois nestes diversos países o uso de aplicações ${ }^{62}$ (como proxy, VPN, criptografia etc.) tem sido uma forma cotidiana de driblar as normas estatais por ativistas e cidadãos comuns. No Irã, por exemplo, a utilização de proxy para acessar conteúdo e redes sociais oficialmente bloqueadas, embora seja ilegal, é uma prática bastante disseminada (principalmente entre jovens) e o governo não consegue conter tal apropriação devido ao volume do uso (teria de monitorar e punir milhões de jovens ao mesmo tempo) e devido à rápida disponibilização de uma nova aplicação quando uma é bloqueada, muitas delas produzidas e disseminadas por ativistas estrangeiros ${ }^{63}$.

De fato, a tecnologia digital forneceu métodos de controle melhores do que aqueles existentes offline: "All in all, the technological dimension of the movement, particularly with respect to devices that are easy to track (mobile phones, for example), provided more opportunities for comprehensive surveillance than had the tools not been used" (GLAISYER, 2010, p. 88).

Mas concomitantemente (e paradoxalmente) o ativismo também ganha novos insumos para surgir. Drezner (2010) indica que a difusão das tecnologias da informação em governos autoritários aumenta a probabilidade de informações em cascata vazarem e assim fragilizarem o aparente controle autoritário. É fato que as inquietações políticas frente a um governo autoritário vigente sejam mais difíceis de serem contidas, já que a nuvem de ativistas têm expostos os abusos e maus-tratos de forma mais ampla e externa (WAKEFIELD, 2008). Isto ocorre porque as tecnologias da web 2.0 estão cada vez mais capazes de driblar o controle de informação imposto pelo governo:

At moments when a critical mass of citizens recognizes their mutual dissatisfaction with their government, the ability of the state to repress can evaporate. In some cases of "people power" mobilization, governmentcontrolled media outlets have often switched sides and supported activists

\footnotetext{
${ }^{62}$ Aplicações é um nome genério para software ou sistemas de computador. Ou seja, aplicações lógicas sobre a camada física. Já aplicativo tem sido muito vinculado a aplicações para celular.

63 Ver em: <http://www.bbc.com/portuguese/noticias/2009/06/090616_iranianosinternetts.shtml> Acesso: 16 dez. 2015.
} 
against repressive governments (DREZNER, 2010, p. 40).

Se por um lado os governos repressivos têm mais aparatos coercitivos para brecar a configuração de uma causa, dificilmente conseguirão conter o florescimento de inquietações políticas em contextos de intensa contestação ou efervescência política em um cenário de capilaridade da comunicação digital nas diversas classes sociais. Terão maior dificuldade em efetivar um controle totalizante dos processos de comunicação online devido à própria natureza distribuída do meio digital. Isso porque o lugar de desafiante, típico do ativismo, tende a explorar mais as propriedades fugidias da rede:

In the short run, digital activists, who often have few options when opposing governments, tend to exploit technology more quickly than those they challenge, who are constrained by bureaucratic decision-making structures. Whether, in the long run, power will shift from repressive governments to activists is unclear. An argument can be made that as long as the Internet is open and permits people to connect using ever-changing technology, its infrastructure will favor those who can adapt quickly (GLAISYER, 2010, p. 97).

Por outro lado, a depender do nível e da eficiência de repressão e da capacidade de resistência e de contestação, a comunicação digital pode ter pouco efeito como agente catalisador de causas ativistas, mesmo em sociedades de alta ubiquidade midiática (MIARD, 2012). Nestes casos hipotéticos, significa que o Estado conseguiu desenvolver um eficiente aparato repressivo (tecnológico) para anular o adubo que o ambiente digital propicia. Ou, em outros casos, simplesmente não são dadas as condições culturais e sociais suficientemente pujantes em termos políticos a ponto de favorecer este florescimento, tendo pouco efeito uma intensidade comunicativa online.

Assim, do ponto de vista metodológico, a análise sobre a importância da comunicação digital no surgimento de causas ativistas deve ser compreendida como algo contextual, processual e histórico. Por exemplo, a emergência do ativismo em contextos autoritários pode levar um longo período de maturação ou de incubação, no bojo de processos de comunicação online. O uso dessas novas tecnologias pode gerar mudanças no "DNA" social e repercutir em pequenas fissuras ao longo do tempo, capazes de culminar em processos revolucionários a depender das oportunidades e contextos. Por isso, deve-se olhar para os ativistas e os usos da comunicação digital na ação política não apenas no âmbito restrito do poder institucionalizado 
e na produção da decisão política mais imediata. Alterações sociais e políticas lentas, na estrutura do corpo social e no nível da cultura, podem ser determinantes para a prática política, pois "In user accounts of how Internet use has changed their lives, their thinking and their activism, we see nascent forms of political change, not observable if we keep our eyes firmly fixed upon formal institutionalized power and policy-making” (WHEELER, 2012, p. 161).

Em qualquer um dos contextos, seja uma democracia ou autocracia, o que se pode afirmar é que a comunicação digital tornou o controle institucional (seja governamental ou multilateral) de ações coletivas duplamente difícil de se lidar, pois o ativismo se tornou mais propenso a existir e mais custoso de se conter.

\subsubsection{Multiplicação do engajamento}

Os indivíduos e grupos possuem hoje, a sua disposição, maiores possibilidades para o engajamento político do que havia há duas décadas atrás, antes da Internet. A expansão dos meios digitais não causou a extinção dos canais tradicionais de participação política, ao contrário, vieram para somar novas formas de engajamento nesta ecologia pré-existente, trazendo suas peculiaridades. Isso pode ser explicado com base em três efeitos da comunicação digital sobre engajamento, enquanto fenômeno político: (a) o aumento da visibilidade dos grupos políticos, que por sua vez, tende a afetar o volume do engajamento; (b) o aumento das oportunidades para o engajamento político, gerando um contexto de múltiplos estilos e graus de envolvimento disponíveis; (c) o aumento do nível de personalização do engajamento político, expandindo-o até o grau das relações interpessoais e subjetivas.

O aumento da visibilidade de um grupo, já apresentado na categoria anterior, tende a afetar também o volume do engajamento. Tendo como premissa que a visibilidade repercute em todos os eixos da dinâmica do ativismo, enquanto um vetor transversal, um de seus efeitos mais imediatos é a alteração no fluxo do engajamento, seja nos casos de perda de adeptos, seja no casos de ganho de novos militantes. Isso ocorre porque a imagem do grupo tende a ser um recurso fundamental na sua capacidade de angariar apoios.

Se observarmos todo esse contexto de mudanças nas formas de visibilidade aliado ao fato de que uma das premissas para se recrutar novos militantes e angariar apoios é tornar-se conhecido, naturalmente temos um cenário propício para o engajamento político. A 
comunicação digital permite expandir justamente o campo de influência de uma ação coletiva, tornando-a mais visível e aumentando a oferta de potenciais apoiadores (SCHUMANN, 2015). A relação entre visibilidade e engajamento passa pela disseminação de notícias políticas (tanto no new media como na mídia tradicional), tematização de uma causa específica na agenda pública e percepção de que há um movimento sendo ativado (SCHUMANN, 2015). Trata-se de um processo cumulativo: O alcance da informação por segmentos mais amplos da sociedade permite penetrar em maior número de potenciais adeptos, a um custo mais baixo. Isso facilita o engajamento transnacional, uma vez que diminuem tanto os custos de envolvimento à distância, quanto potencializa a visibilidade internacional de um grupo, possibilitando receber apoio ou até mesmo angariar engajamentos de outros países. Para que esse quadro se concretize, é preciso que o público internacional tenha acesso a uma determinada narrativa e as respectivas questões políticas que dela emergem. Kluver (2002) sintetiza:

[...] the internet successfully communicated a narrative that transcended political, cultural and linguistic borders, and demonstrated the power of new media to draw international attention. However, this is an example of a motivated political agency reaching out to a motivated audience of politically aware individuals, many of whom then communicated the narrative through traditional media. In the case of a largely unconcerned audience, or a less astute political organization, the same is unlikely to occur (p. 514).

Para alguns grupos, a presença virtual tem a importante função de dar visibilidade externa angariando apoio estrangeiro - um recurso que pode ser fundamental para ativistas em contextos políticos altamente opressivos (SCHUMANN, 2015). As tecnologias permitem aos ativistas online fazer apelos diretamente à esfera pública global, aumentando sua exposição internacional. Em sociedades reprimidas politicamente há maior liberdade de expressão através de fontes alternativas de mídia, descreve Drezner (2010). Para evitar as constrições da mídia tradicional, diversos grupos têm preferido cada vez mais produzir e disseminar conteúdo online através das mídias alternativas que não filtram a informação de maneira tradicional. As tecnologias das mídias sociais são mais difíceis de serem controladas do que televisão ou jornal. Quando ativistas nestas sociedades têm conexão com comunidades diaspóricas baseadas em outros países podem, através do reforço destas comunidades, tentar influenciar a mídia estrangeira (DREZNER, 2010). Esta extensão das mídias alternativas para 
o exterior é chamada pelos autores Keck e Sikkink (1998) como "efeito bumerangue", já que a pressão sobre o regime pode vir de fora.

Por fim, a visibilidade também pode gerar um efeito dominó onde publicização gera engajamento e o engajamento pode gerar mais publicização, que por sua vez pode redundar em mais engajamento, e assim por diante. Por exemplo, em casos de visibilidade positiva ou impactante do grupo, isso tende a trazer mais engajamento. A depender do volume deste engajamento, uma parcela de indivíduos poderá se sentir propenso a se juntar a uma causa justamente por conta de um "boom" de participantes, o qual pode ser interpretado por alguns como um indicativo de sucesso da causa (MIARD, 2012).

Quanto ao aumento das oportunidades de engajamento, a comunicação digital propiciou um inevitável crescimento das opções de participação política através das diversas plataformas, aplicativos e nos diferentes níveis de comprometimento com um grupo ou organização. Tarrow (2006) defende que a grande novidade do ativismo recente é o aumento em número de pessoas e grupos que realizam suas atividades para além de suas nacionalidades ou localidades. E a comunicação digital é um elemento importante neste fenômeno. Mensurando este crescimento, a Union of International Associations estima que o número de organizações internacionais não-governamentais cresceu $700 \%$ entre 1980 e 2007 (DEVILLART; WANIEWSKI, 2010). Este crescimento é acompanhado pelo contínuo aumento no contingente de usuários online e no número de gadgets, como aparelhos celulares ${ }^{64}$. Toda essa conectividade influenciou o fluxo internacional de comunicação e favoreceu ações coletivas organizadas em nível internacional (DEIBERT, 2000; BENNETT, 2003). O acesso a essas ferramentas online permite aos grupos e indivíduos cruzar as fronteiras de maneira mais fluida e capilar.

Mas o aumento das oportunidades de engajamento político nem sempre se traduz em aumento do engajamento em si. O primeiro trata de oferta, o segundo, de demanda. Em outras palavras, no plano geral há um aumento da oferta de meios e formas disponíveis para o engajamento, principalmente através do ciberespaço. Já o aumento quantitativo de pessoas engajadas de fato, enquanto demanda social, depende dos contextos políticos e culturais nos quais a comunicação digital estará inserida. Em alguns contextos, essa oferta de

\footnotetext{
${ }^{64}$ Conforme dados da União Internacional de Telecomunicação (UIT) em 2005 havia 2,1 bilhões de assinaturas de telefones celulares no mundo. Em uma década, em 2015, esse número triplicou chegando a cerca de 7,1 bilhões. Já o número de indivíduos usuários de Internet era 1 bilhão em 2005, de maneira que o número também triplicou em uma década indo para 3,2 bilhões em 2015. Ver em: <http://www.itu.int/en/ITUD/Statistics/Documents/statistics/2015/ITU_Key_2005-2015_ICT_data.xls>. Acesso em 9 jan 2016.
} 
possibilidades de engajamento será respondida com demanda à altura, resultando assim em um aumento real do ato de engajamento em si.

Esse aumento de oportunidades também passa pela multiplicação das formas possíveis de envolvimento online. Bimber et al (2012) apontam que organizações e grupos ativistas oferecem hoje um leque maior de modos de participação política através da comunicação digital:

Rather, it implies a continual negotiation of boundaries in different ways as various members act on their own styles and preferences, rather than being so tightly constrained by those of the organization. As technology use changes expectations and weakens various boundaries, individuals are better able to negotiate them on their own terms and to shape their experiences of organizations to a substantial degree. This does not imply that all people will make the same choices about which boundaries to cross or how to situate themselves in organizational contexts that are more flexible. Rather, it implies a continual negotiation of boundaries in different ways as various members act on their own styles and preferences, rather than being so tightly constrained by those of the organization (BIMBER et al, 2012, posição 611).

$\mathrm{Na}$ prática, isso resulta na potencialização do ativismo ao se otimizar novas oportunidades de engajamento através (a) de uma maior flexibilização nos processos de filiação; (b) da melhoria logística para o engajamento remoto; (c) da criação de novas arenas para o engajamento em mobilização específica; (d) e do surgimento de novos recursos para o engajamento de apoio.

O processo de filiação ou de pertencimento a um movimento se tornou menos rígido, aberto e suscetível a gradações. A Internet facilitou o recrutamento a partir de uma definição de membro mais informal, mais fluida e flexível (KAVADA, 2010). Lai (2003, p. 105) exemplifica que "Cyberspace (for novices as well as veteran activists) is a learning-by-doing, action-oriented medium at both individual and collective levels. People can act with just a few clicks, sending support and appeal letters or animated e-cards to their targets".

Os usuários buscam na Internet informação que é consistente com seus sentimentos e ideias, reforçando suas crenças e evitando dissonâncias, reforçando a ideia de pertencimento (SCHUMANN, 2015). Por isso é tão importante reunir pessoas em torno de um argumento aceito na comunidade ou construindo-o a partir de elementos socialmente compartilhados:

Activists can circulate images, stories, and statements that convey the movement's mission, commemorate its landmark events, and name its allies and opponents. The Internet further allows activists to discuss and interact around these issues and to reflect on common experiences. Email lists, 
discussion groups, comments on Facebook and YouTube all contribute to this process of defining and identifying with the movement (KAVADA, 2010, p. 111).

A flexibilidade de filiação passa inclusive pelo pertencimento no nível simbólico, fortalecendo o autorecrutamento. Isto é bastante visto nos casos de terrorismo, onde o lugar chave para desenvolver a radicalização é a solidária experiência de uma comunidade virtual (NYE, 2010). Narrativas e histórias inclusivas, informação clara de seus objetivos, missão e eventos seminais permitem ampla interpretação e assim podem ser assimiladas por um número maior de apoiadores, aumentando a escala de filiação, reenergizando o movimento com novos ativistas.

A outra frente de oportunidade importante de engajamento possibilitado pela comunicação digital é o ativismo remoto. Hoje, através da Internet, é possível contribuir e participar de uma causa sem precisar se deslocar fisicamente ou estar presencialmente comprometido com um movimento. É possível ser um ativista contra a ocupação do Tibet pela China sem precisar estar no Tibet. Uma das formas mais efetivas de engajamento remoto, com repercussões reais na ação coletiva, é o engajamento de doação. Isto é, quando um ativista contribui não necessariamente com sua força de trabalho (e de mobilização) mas com recursos monetários que serão utilizados pelo movimento. A Internet tem sido bastante eficiente e cada vez mais central para recrutar a arrecadação de fundos financeiros (NYE, 2010).

Uma outra frente de oportunidade se dá no nível das arenas de mobilização disponíveis. No ambiente digital, os custos de engajamento são reduzidos e a participação em eventos mobilizatórios pode ser potencializada. Ao mesmo tempo, a mobilização online não depende necessariamente de uma cultura digital hiperdesenvolvida. Choucri (2012, p. 142) demonstra que a falta de tradição cibernética num país não é pré-requisito para a eclosão do engajamento político online:

There is no long tradition of cyberbased discourse, social networking, blogging, or other forms of cyber interaction. By contrast, the revolutions in Tunisia and Egypt were accompanied by unexpected and surely unprecedented effective uses of cyber venues, social media, and other forms of communication to challenge the authority and legitimacy of the regime.

As aglutinações em torno de arenas de mobilização podem não ser necessariamente espontâneas, como afirma Gerbaudo (2012), mas não necessariamente pre-existem identidades e redes comuns: "In the absence of embedded identities and thick social networks 
to sustain collective action, these elements need to be created pro-actively and ad-hoc in the course of the process of mobilisation" (GERBAUDO, 2012, p. 36).

Além da filiação mais flexível, melhor logística para o engajamento remoto, e o surgimento de novas arenas de mobilização, também não devemos ignorar a abertura de oportunidades para os modos mais simplificados de engajamento político como a demonstração pública de aval à causa, que chamaremos aqui de engajamento de endosso ou de apoio. O engajamento online permite aos interessados que possam participar de forma rápida e não onerosa, ainda que desprovidos de recursos como tempo, dinheiro ou habilidades específicas, geralmente pré-requisitos para a forma tradicional de participação offline. Compartilhar um website do grupo, assinar uma petição online, "curtir" a página do Facebook são exemplos factíveis de expressar endosso à causa e estão disponíveis ao usuário comum (SCHUMANN, 2015). Por isso, o baixo custo, baixo risco e a facilidade propiciados pelo engajamento online podem atrair aqueles que não podem se envolver offline, assim como também pode expandir a atuação dos apoiadores já engajados nas práticas offline, através de uma nova dinâmica nas práticas digitais (SCHUMANN, 2015).

Se para estes analistas há uma maior facilidade para o engajamento de baixo custo na forma de endosso, para outros estudiosos esse tipo de envolvimento no ciberespaço é considerado de baixo impacto na política. Para alguns analistas, nem sempre curtir uma página no Facebook de um grupo ativista significará um engajamento efetivo em direção ao objetivo coletivo. Por isso, as redes baseadas em mídias sociais são bastante criticadas já que a adesão de novos membros é facilmente exequível e não requer um comprometimento sólido, sendo o movimento muitas vezes independente da motivação e responsabilidade de quem adere (SEIB, 2012). Como sintetiza Scholz (2010), alguns autores afirmam que o ativismo digital é reduzido por "click activism" ou "slacktivism", ou seja, cria a impressão de o indivíduo estar envolvido em determinadas causas, quando na verdade seria apenas uma ação online sem efeito no mundo offline. Eles acreditam, que por se tratar de uma atividade sem impacto social ou político, cria-se a ilusão de ter impacto em escala global apenas fazendo parte de um grupo do Facebook, por exemplo: "[...] the fact that people can join a social movement with one click means that they can leave just as easily" (KAVADA, 2010 p. 113). Para Gladwell, (2010) as mídias sociais promovem laços fracos e portanto não seriam suficientes para uma ação revolucionária, configurando um "modismo" pensar na revolução desta maneira à luz deste autor. E assim, apenas poucos que se unem a grupos no Facebook, e partilham fotos e vídeos em blogs ou redes sociais, por exemplo, se envolveriam de fato em 
campanhas políticas de longa data (MOROZOV, 2008; SCHOLZ, 2010; KAVADA, 2010, SEIB, 2012).

Porém, questionamos se para ser efetivo o engajamento precisaria de um envolvimento a longo prazo por parte do participantes, desqualificando as ações fáceis, rápidas e que envolveriam poucos riscos. Acredita-se que não. Embora o tempo seja um fator importante, este não é decisivo quanto à efetividade de um engajamento coletivo, pois um envolvimento efêmero de milhões de indivíduos pode ser intenso a tal ponto de ser revolucionário, ainda que dure algumas horas. Como bem pondera Schumann (2015), laços fracos - frutos de relações com baixa intensidade emocional, intimidade e reciprocidade - têm um grande impacto no engajamento político, de modo que a visão do slacktivismo como apenas um tipo de ativismo inócuo de uma geração preguiçosa pode ser incompleta. $\mathrm{O}$ ativismo de sofá pode ser mais potente do que se imagina:

Moreover, low-threshold online collective actions affect offline engagement,
because both practices address the same needs. In turn, it can be concluded
that low-cost and low-risk online collective actions are viewed as legitimate
tactics (Gil de Zúñiga, Veenstra, Vraga, \& Shah, 2010), as part of
individuals' repertoire of contention. The medium of action - the Internet-
should not be confounded with the level of commitment of those who act. In
conclusion, online and offline behaviour should be understood as integrated
and coordinated, not distinguished as set in the digital and the "real" world
(SCHUMANN, 2015, p. 44).

Dito isto, compreende-se que as ações coletivas baseadas na Internet são igualmente válidas e potentes como o engajamento offline (SCHUMANN, 2015). Além disso, observa-se que uma atividade online conduz a outra: Assinar uma petição em nome de uma causa facilita a doação de dinheiro para uma causa similar no futuro (SCHUMANN, 2015), pois o participante já ficaria mais propenso a participar de outras causas similares ou ainda avançar em participações mais densas na mesma causa.

Por fim, o terceiro efeito da comunicação digital sobre engajamento, enquanto fenômeno político, é o aumento da personalização e subjetivação, e consequente expansão do ativismo para as redes interpessoais. Bennet (2012) afirma que:

[...] communication technologies may put individuals at the center of their own networks, but the reach of those networks often enables the coproduction and distribution of multimedia content with a surprisingly large number of others. [...] The more diverse the mobilization, the more personalized the expressions often become, typically involving communication technologies that allow individuals to activate their loosely 
tied social networks. There are still plenty of conventional politics based on identification with parties, ideologies, and common causes. However, the rise of a more personalized politics has become a notable trend (BENNETT, 2012, p. 21-28).

Tal como Bennet (2012), Schumann (2015) explica que os caminhos de mobilização e razões de participação não são definidos somente por grupos políticos formais, mas também por redes pessoais pré-existentes. O engajamento pode se dar através de redes não necessariamente políticas, já que a participação na Internet permite aos cidadãos engajar-se em uma causa acionando seu perfil em mídia social, expandindo e tornando mais inclusivas as ações coletivas, inclusive para os não-militantes:

Thereby calls for actions reach individuals who never would have attended a protest or sit-in - either because they would not want to commit to a fixed organizational agenda or because they would not have been targeted by the mobilizing efforts of formal groups (SCHUMANN, 2015, p. 18).

As redes preexistentes possuem laços que promovem a integração social dentro de um potencial grupo de recrutas, facilitando também a formação de pontes com outras redes (MIARD, 2012). Assim, mais do que somente recrutar indivíduos dispersos, as redes podem também "recrutar" outras redes, isto é, podem compor-se de outras redes já organizadas, a partir da coparticipação de outros grupos de maneira solidária.

A partir do momento que o engajamento político se personaliza mais, expandindo-se para as redes interpessoais, aumenta-se naturalmente o grau de importância do elemento subjetivo na política, pois: "social media platforms and its interactive tools may shape the nature of collective actions by shifting the focus from centralized, group-driven engagement to personalized participation" (SCHUMANN, 2015, p. 17). Gerbaudo (2012) acredita no aspecto crucial do papel das emoções brotado dentro das mídias sociais, embora negligenciado em estudos de movimentos sociais e novas mídias. Na teoria de movimentos sociais, a questão sobre como as pessoas são agrupadas a partir de uma condição de dispersão espacial é comumente endereçada. No jargão militar, mobilização é a concentração de participantes no espaço e tempo (anterior ao combate). A experiência de agrupamento varia de acordo com o grau de dispersão social para ser mobilizada e agrupada, ou seja, é diferente mobilizar grupos já agrupados em torno de pólos como comunidades e vizinhanças. O processo de construção identitário e motivações emocionais dão coerência para a participação 
no protesto espontâneo (GERBAUDO, 2012). Para engajar num grupo é preciso entender a causa do grupo, seu passado, seus objetivos, sua relação com outros grupos, características dos membros, regras e sanções. Se os indivíduos se identificam, o comportamento passa a ser em consonância com o grupo, por isso a criação de um senso de identidade e de membros de um grupo é facilmente construída através da Internet (SCHUMANN, 2015).

Porém, essa personalização e subjetivação da política que caracteriza o engajamento através de plataformas digitais pode não significar somente a existência de laços societais fortes, mas repercutir simultaneamente em ligamentos efêmeros e transitórios. Portanto, defende-se que os diversos estilos de participação, formas de engajamento e níveis de envolvimento devem ser levados em conta como componentes de uma mudança importante na ecologia do ativismo transnacional, possibilitado pelo uso cada vez mais crescente da comunicação digital.

\subsubsection{Flexibilização da estrutura}

Com uma causa devidamente configurada e a existência de um grupo mínimo de pessoas engajadas neste entorno, o ativismo também desenvolve uma estrutura de organização interna que é afetada pela comunicação digital. Na prática, as ferramentas online permitem conectar de uma maneira inédita movimentos políticos transnacionais levando a concepção de organização em rede a cabo (HART, 2012; CASTELLS, 2012; MIARD, 2012; GHEIDARY, 2012).

Enquanto o ator é definido por possuir um papel e status claros, as redes descaracterizam esta identificação pré-definida, tornando muito mais difusa e fluida sua definição e materialização. Porém, nem por isso perde importância ou materialidade, pelo contrário, este tipo de organização social vem tendo cada vez mais impacto justamente devido à sua flexibilidade e potencialidade de operar de modo transnacional, capaz de assumir diferentes formatos, seja uma estrutura informal e descentralizada, seja em reforço ao caráter formal e centralizado de uma organização, por exemplo. Na prática:

Networks were characterized as relying on lateral as opposed to hierarchical channels of communication, which made it possible to more efficiently 
exploit complementary skills and knowledge dispersed among multiple actors (MUELLER; SCHMIDT; KUERBIS, 2013, p. 88).

Em realidade, o conceito de redes não é necessariamente novo e não nasceu com a Internet, como vimos na seção anterior, sendo gradativamente inserida principalmente a partir dos anos de 1960. Com o surgimento da Internet, esta concepção ganhou mais concretude e encontrou nos processos de comunicação digital uma base adequada para se expandir.

Embora a estrutura em forma de redes represente um fenômeno real e relevante, Choucri (2012) observa que nas Relações Internacionais elas não são sempre bem explicadas, ainda que mencionadas: "The relevance of networks - social, computational, and political, among others - is generally recognized in international relations but has not been fully exploited” (p. 77). Além disso, os autores Mueller, Schmidt e Kuerbis (2013) atestam que na grande área que engloba RI e Ciência Política, as redes são geralmente tratadas como a definição de algum tipo de entidade ou nó, numa relação que gera uma espécie de link e não um modo de organização por si só. Nesse caso, há pouco refino desta forma de estruturação, reduzindo e simplificando a complexa relação de redes.

Os primeiros estudos de redes em nível internacional mostravam a importância de redes transgovernamentais, isto é, redes de troca de informações internacionais e de cooperação entre agências governamentais de menor escalão sobre problemas comuns, sem tratar necessariamente de acordos formais (MUELLER; SCHMIDT; KUERBIS, 2013).

De acordo com Braga (2011) as redes podem promover princípios, causas e normas ainda que se comportem de forma mais fluidas, não diferenciando seus planos de ação entre doméstico e internacional como tradicionalmente se faz nas RI, e podem advogar em nome de atores que não se representam perante as estruturas estatais sozinhos, e assim criam instrumentos de pressão e aumentam os canais de acesso ao sistema internacional.

Com o surgimento da Internet, o termo passou a ter uma conotação bastante vinculada à descentralização: "Used to express the idea of increasing flexibility and de-centralization, the concept quickly became a standard reference point for many authors studying the impact of new media on contemporary activism" (GERBAUDO, 2012, p. 21-22). O conceito de redes inicialmente se baseava num contexto de estruturas flexíveis e adaptáveis, sem necessidade de uma coordenação central. É oposto ao conceito de massa, ou sociedade de massa, a qual implicaria numa relação autoritária e hierarquizada (GERBAUDO, 2012). 
Trabalhando nas escalas doméstica e internacional, Castells (1999; 2003; 2013) se tornou um acadêmico bastante reconhecido pela sua teoria das redes e a sua vinculação à Internet. Para o autor, a constituição de redes é operada pelo ato da comunicação, ou seja, a natureza da rede é definida a partir do compartilhamento de significados dados pela troca de informações. Esta nova forma social baseada na troca de informações entre atores que não estão localizados no mesmo espaço físico passa a ser determinante para o fortalecimento social, político e econômico desses atores. Castells (2013) é bastante enfático sobre a liberdade de uma comunicação autônoma através das redes da Internet, possibilidade permitida pela plataforma e que não ocorreria em outro meio. $\mathrm{Na}$ opinião do autor, os movimentos sociais ocupam hoje um espaço híbrido entre redes sociais e o espaço urbano.

Uma das características mais arraigadas ao conceito de redes na era digital, inclusive partilhado por Castells (2013), é a descentralização interna: Ferramentas digitais borram as linhas que separam organizações altamente estruturadas em redes e indivíduos levemente estruturados em redes (NYE, 2010).

A estruturação em redes digitais não elimina o papel das organizações como entes aglutinadores da ação coletiva, mas as torna menos detendoras deste papel possibilitando que indivíduos se organizem através do ciberespaço sem um centro hierárquico de onde emanam as diretrizes de ação, mas com algum nível de coordenação diluído nos protocolos de comunicação. É por isso que Morozov (2008) explica a crença de que a mudança social seria mais encabeçada por indivíduos do que instituições tradicionais com sedes físicas.

Instituições como ONGs, governos e think tanks estão sendo desafiadas pela mudança do equilíbrio de poder entre indivíduos e organizações no contexto da Internet, já que indivíduos não-afiliados e apenas munidos de computador e conexão podem influenciar e provocar ações até mesmo maiores do que organizações com sedes físicas (MOROZOV, 2008). Isto indica que a estrutura de rede não precisa ser solidamente definida em uma organização, mas manter minimamente os laços que unem os indivíduos no interior do grupo. Através da Internet, as redes aqui estudadas criam canais regulares de comunicação (mensagens de e-mail, chats, fóruns online etc.) de forma a aglutinar interessados, propiciando uma forma de estruturação que é capaz de funcionar de modo bastante ágil em um cenário transnacional. Alguns especialistas vão mais longe ao afirmarem que a Internet representaria em si uma forma de organização, pois "the internet is more than a form of communication; it is at the core of a new movement form" (TARROW, 2006, p. 136). Porém, a organização propiciada pela Internet não é uma organização similar àquela experienciada 
offline, já que muitas vezes não exige consolidação plena do grupo para se construir e se constituir em rede, bem como necessita de pouca organização formal, muitas vezes bastando a manutenção simples de uma página na web. Assim, com a facilidade da web em fornecer acesso para a busca de materiais, mobilizar apoiadores e levantar dinheiro, o papel da sede física perde em importância, embora continue co-existindo. O uso versátil e amplo da ferramenta digital permite que se desenhem diversas formas de ativismo. A web 2.0 desempenha um papel importante nesse processo ao promover alto grau de interatividade, operacionalizando as concepções de "participatory culture" de Jenkins (2009) e "self-mass communication" de Castells (2009).

Ao mesmo tempo em que a mobilização de indivíduos através da Internet facilita a formação de redes de caráter volátil, temporário e instável, esta mesma rapidez de espalhar informações e organizar ações também pode significar um rápido desaparecimento da mobilização em si (KAVADA, 2010). Ao contrário de isto ser desestimulador da causa ativista, essa volatilidade da mobilização online pode significar maior autonomia de ação para os membros pois "the internet offers individual activists the opportunity for do-it-yourself ideological production, when those at the summit of their 'organizations' might prefer to move in another or end campaign" (TARROW, 2006, p. 138).

Ainda que tenham curta duração, ações políticas baseadas em laços interpessoais não devem ser desprezadas, pois ainda que esses laços não repercutam em mobilizações perenes, são potencialmente acionáveis, podendo ser reativados para um novo projeto quando necessário (KAVADA, 2010). No caso de um grupo já ter se estabelecido, o senso de pertencimento é reforçado através de discussões e deliberações online, ainda que os membros permaneçam anônimos, facilitando assim a interação entre os apoiadores e os representantes do grupo ativista, criando conexão e definindo identidades (SCHUMANN, 2015). Constrói-se assim um espaço de contato e encontro entre membros novos e os já existentes, além de um lugar de memória para a continuidade das atividades, e ainda que websites tenham sido criados para um evento específico, permanecem ativos como manutenção histórica do grupo (KAVADA, 2010).

Mas nem todas as redes são efêmeras ou baseadas apenas no indivíduo. A difusão transnacional pode ser uma das formas de fazer as redes prevalecerem ao longo do tempo. Um dos incentivos para isso é criar uma espécie de rede das redes, em que outras comunidades gravitam em torno de uma rede específica. Choucri (2012) explica estas outras relações em rede da seguinte forma: 
Because of the diffusion of social networking systems, cyberspace has enabled and empowered virtual communities across national boundaries. Virtual communities may reinforce communities on the ground, create new political entities, or extend the reach of political influence and political discourse (p. 191).

Esta difusão está próxima daquilo que Choucri (2012, p. 191) chama de comunidade virtual, a qual é "composed of those who engage in e-based interactions motivated by shared values, affinities, and other linkages". Além de cruzar as redes já existentes, a Internet ajuda a estabelecer novas redes que permitem aos interessados no movimento ter acesso, muitas vezes direto, aos principais ativistas coordenadores da causa (KAVADA, 2010).

Como vimos, grande parte das pesquisas sobre ativismo e os impactos das novas mídias mostra como as ações facilitadas pelas inovações tecnológicas criaram uma nova estrutura para a ação coletiva: Descentralizada, horizontal e espontânea (SHIRKY, 2008; BIMBER et al 2012; BENNETT, 2013). O próprio modelo trazido por Keck e Sikkink (1998) considera as redes de ativismo transnacional como formas de organização, formais ou informais, marcado por padrões horizontais de comunicação e troca:

The drive toward more decentralized forms of organizing has been attributed
both to the low cost of the Internet and its capacity for interactive and
multimodal communication: Internet communication can range from
synchronous to asynchronous, from mass to interpersonal, from local to
global. Unlike other means of communication, the Internet cannot be
centrally controlled. This facilitates the development of transnational,
diverse, and loosely connected activist networks that are now able to
organize protests and wage campaigns without a formal membership base,
physical headquarters, or identifiable leaders (KAVADA, 2010, p. 104).

Gerbaudo (2012), por sua vez, questiona se esta é mesmo a forma que melhor sintetiza as dinâmicas de mobilização nos movimentos sociais contemporâneos e o papel das mídias sociais nesse processo. Por trás do entusiasmo do horizontalismo, tão difundido entre os autores da área, ele acredita que há hierarquias de engajamento ainda que em organizações informais (GERBAUDO, 2012). Isto é, há uma assimetria entre aqueles que mobilizam e os que são mobilizados, entre os que lideram o processo e os que seguem, denotando um caráter não estático aos movimentos, natureza da própria palavra "movimento" (GERBAUDO, 2012). Frente à aparente consensual tomada de decisão coletiva, o autor acredita que a política informal é nutrida por ações de grupos diretos e a ideia de não se ter uma estrutura hierárquica na rede apenas mascararia o líder, já que o mesmo existiria, ainda que se mantendo invisível 
(GERBAUDO, 2012). Segundo o autor, os conceitos de abertura e horizontalidade da rede são entraves ideológicos para a compreensão de como realmente funciona a participação interna dos grupos em redes online no espaço contemporâneo. Gerbaudo (2012) acredita na importância na liderança para dar coerência aos grupos, um senso comum de unidade, de lugar e de direção para a ação coletiva. A sua teoria pode ser organizada em torno de três níveis: organizacional (há os coreógrafos do encontro público, aqueles que iniciam e guiam o encontro), temporal (iniciação, condensação das pessoas em torno de uma identidade comum e a sustentação, materialização ao longo do tempo no espaço público) e espacial (o modo no qual conecta participantes dispersos em lugares específicos de encontro) (GERBAUDO, 2012).

Von Bülow (2014) reconhece que a forma hierárquica ou horizontal que as redes podem tomar depende da análise empírica da rede e não é algo dado a priori (VON BÜLOW, 2014). Assim, a autora contraria a ideia corrente de que a ação coletiva transnacional, quando vista como redes, tende a apresentar um aspecto relacional informal, difuso, horizontal, menos hierarquizado e flexível (VON BÜLOW, 2014). A autora inclusive chama a atenção deste tipo de concepção: "No entanto, esse tratamento metafórico do conceito de "redes" estabelece a priori uma forma superior de organização e, por conseguinte, desvia nossa atenção das relações de poder, assimetrias e conflitos entre os atores" (p. 48).

Por isso, acreditar na horizontalidade e reciprocidade de trocas comunicativas como característica inerente das redes transnacionais incorre em não considerar outros tipos viáveis de configuração. Estas estruturas não são estáticas, são modeladas e remodeladas ao longo do tempo, com níveis de horizontalidade e verticalidade que não interferem na difusão e complexidade de seus elementos.

Ainda que uma das maiores características das redes a partir do uso da Internet seja o seu caráter não-territorial, sendo capaz de unir indivíduos com interesses similares em nome de objetivos políticos, porém distantes geograficamente, Lai (2003, p. 101) atenta que localização importa para a estrutura das grandes organizações: "Although the activism derived from and through the internet/cyberspace can be described as borderless in many ways, the networks are sometimes geographically confined to cities of the developed world". Isto porque, no argumento do autor, regiões desenvolvidas com alta concentração de informação e conhecimento atraem mais ONGs e possui vantagens quanto à disponibilidade e funcionalidade das TICs. Gerbaudo (2012), por sua vez, critica autores que negligenciam o peso da localização geográfica para as redes online. 
Assim, formação e estrutura em redes no ativismo transnacional não obedece a uma característica pré-definida pelas tecnologias da informação e comunicação. Em realidade, as redes se constituem de acordo com a construção do próprio ativismo e encontram no ambiente digital uma ferramenta que facilita a flexibilidade de configuração. Assim, tendo como vetores de um mesmo espectro a centralidade versus não-centralidade, hierarquia versus horizontalidade, territorialização versus desterritorialização; espontâneo versus orquestrado, nota-se que a flexibilização trazida pelas redes online está justamente nas diversas possibilidades de construir e organizar o ativismo para além de estruturas rígidas, como um ingrediente que tende a fortalecer o segundo vetor desses binômios, mas sem descartar o primeiro.

\subsubsection{Instrumentalização do planejamento}

Através da comunicação digital, os ativistas têm mais ferramentas para reunir informações, avaliar cenários e desenhar táticas e estratégias. O planejamento se tornou mais instrumentalizável, isto é, com maiores ferramentas e insumos a seu dispor a um custo menor, que pode repercutir na qualidade da ação coletiva: cyberplanning, coleta de informações estratégicas e capacitação online são as principais inovações neste campo.

O cyberplanning envolve a criação de estratégias e diretrizes que guiam as ações da causa/grupo. A coleta de informações é parte desse processo. A Internet possibilita maior acesso a publicações e relatórios, e também permite o acompanhamento e monitoramento da evolução de uma dada situação. Miard (2012) explica que o monitoramento se tornou mais barato e mais efetivo com as tecnologias digitais. Nesse sentido, ferramentas e plataformas como Google Alerts, Technorati, Digg, StumbleUpon, Del.icio.us são grandes aliadas (KAVADA, 2010).

Ferramentas online ajudam na colaboração, coordenação e divisão de tarefas dentre os ativistas para organizar uma campanha, protesto ou outras ações (sejam estas executadas no ambiente online, seja no ambiente físico-espacial). Isso pode envolver criar lista de afazeres numa Wikipage e trocar mensagens de mobilização, usar calendários online para reuniões, aplicativos de interação, seja e-mail, Facebook ou Skype, para tomadas de decisão, e outras ferramentas para organizar votação online ou agregar ideias dando forma às preferências 
(KAVADA, 2010). No caso do ativismo transnacional, a Internet desempenha um papel fundamental na coordenação além das fronteiras:

The strategic use of information, in particular, seems to be central in transnational activism. The development of new communication and information technology has reshaped 'the repertoire of contention', adding activities like 'e-mobilization' and cyber-activism' [...] (PIPER; UHLIN, p. 7, 2004).

Alguns grupos criam suas próprias plataformas e personalizam suas necessidades através dos mecanismos online (KAVADA, 2010). Outros conseguem mapear o terreno político ao identificar nas diversas plataformas sociais quais são os lados do debate, seus apoiadores e os mais influentes, muitas vezes com o auxílio de softwares (HWANG, 2010).

A mobilidade e a ubiquidade midiática possibilitada pela comunicação digital é uma outra dimensão que desempenha um papel importante no planejamento estratégico. Ainda que instrumentos como celulares, tablets e outros microdispositivos digitais possam ser utilizados para captar imagens, produzir narrativas, aumentar a visibilidade, também são bastante usados para produzir comunicação tática e coletar informação estratégica em tempo real. Os aparelhos celulares permitem uma conexão instantânea na rede de apoiadores de modo a aperfeiçoar e expandir campanhas, melhorar atividades coordenadas e protestos, e aumentar a consciência sobre assuntos sociais (CULLUM, 2010). As mensagens de texto e ligações de voz são as funções mais básicas do aparelho. Já aliado à Internet, permite uma mobilização política taticamente orquestrada com base no monitoramento e na mobilidade que o aparelho permite, despontando sua característica multimodal (MIARD, 2012). Cullum (2010) observa que ativistas nem sempre abandonam métodos tradicionais, mas incorporam tecnologias avançadas de celulares para suas táticas.

Além da coleta de informação estratégica, monitoramento e cyberplanning, a comunicação digital também instrumentaliza o ativismo através da capacitação ou instrução de seus militantes. O treinamento prévio, como forma de antever situações e preparar para ação, ganha um importante impulso no ambiente digital pois tende a qualificar o ativistas em sua capacidade de ação, minimizando riscos e erros. Por isso, cada vez mais ativistas usam os aplicativos e plataformas online para esse fim:

The effectiveness of nongovernmental organizations and the abilities of citizens to run and participate in advocacy campaigns and activism can be 
improved if activists and others get training to develop their skills and knowledge of various applications, platforms, and devices. Activists should strive to stay at the front of the learning curve by experimenting with the latest mobile security and privacy tools (CULLUM, 2010, p. 68).

Importante lembrar que o planejamento ativista através da comunicação digital deve ser visto com algumas ressalvas. Primeiro, em realidade, o planejamento de ações não é algo necessariamente novo no ativismo, pois antes já existia a possibilidade de identificar o melhor momento para publicar informação e rastrear atores influentes. O que a comunicação digital traz de novo é justamente um melhor aparato de ferramentas que significam, em última instância, instrumentalização que pode resultar em empoderamento. Ou seja, há uma maior quantidade de volume de informação coletada e melhor qualidade em seu processamento (HWANG, 2010). Segundo, o planejamento através do ambiente digital também tem seus riscos. Aumenta-se a possibilidade de monitoramento (por governos, corporações, organismos multilaterais, outros grupos adversários) nas trocas de informações do grupo que, se vazadas ou utilizadas de forma descontextualizada, podem ter efeito negativo:

\begin{abstract}
Although digital messages can easily be transmitted, this may result in the loss of context or a level of distortion, and therefore the generation of an opportunity for subversive voices. In fact, in this case, two or more social networks that were meant to be separate collided. Government sympathizers could enter from a point (i.e an open group) and access the information generated by opposing groups, then reproduce them, distort them and disseminate them from scratch. Evidence of this can be traced through many English-language blogs, where each of them have provided a different version of one specific story that was supposedly initially from Social network sites SNS (GHEIDARY, 2012, p. 218).
\end{abstract}

Terceiro, os usos das ferramentas digitais para o planejamento estratégico não é automático e totalmente isento de custos: Também dependem de cultura política, habilidades, know how e alguma infraestrutura mínima disponível (computadores, servidores, conexão etc.). Quarto, o planejamento também serve para todas as táticas ativistas, inclusive violentas. Aos grupos terroristas estão disponíveis as ferramentas virtuais, assim como para quaisquer outros grupos. Quinto, o planejamento colaborativo intensifica a interatividade e isso tende a aumentar as rotas atrito, embates ou disputas internas. No bojo desta intensificação, pesquisas demonstram que algumas formas de interações online (como listas de discussão, por exemplo) tendem a ser mais conflituosas que as interações face-a-face (KAVADA, 2010; WILHELM, 
1999). Isso ocorreria devido a questões como a perda de linguagem gestual (no caso de fóruns online baseados em texto, que gera ruídos de comunicação e incompreensões); ao anonimato ou ao próprio design ${ }^{65}$ da ferramenta que pode favorecer animosidades. Sexto, o ambiente digital também é composto por um turbilhão de informações falsas ou de baixo valor estratégico. O excesso de informação pode gerar má-interpretação e ações equivocadas, ou até mesmo uma apatia dentre os integrantes do grupo diante de grande quantidade de dados circulantes. Esses excessos podem dificultar a comunicação interna do grupo, camuflando a discussão mais importante e desviando o foco daquilo que de fato seria relevante (HWANG, 2010; NIELSEN, 2010). Para Nielsen (2010) isso ocorre geralmente quando organizações se preocuparam mais em adotar as tecnologias digitais do que necessariamente se adaptar a elas.

\subsubsection{Diversificação da ação}

Uma das questões mais importantes trazidas pela comunicação digital é o empoderamento de indivíduos, reforçando-os em grupos e dando-lhes instrumentos de informação e ação, que antes das TICs eram bastante dificultosos de serem alcançados. Kluver (2002, p. 504) menciona a instantaneidade de resposta que a Internet permite junto à audiência, aumentando o poder do indivíduo para agir politicamente: "By being able to instantaneously respond to any message to the same audience, individuals had far greater power to influence policy. The widening of the 'feedback loop' thus gives new media a democratizing bias over other media formats". Através da comunicação digital ativistas têm hoje diferentes modos para realizar seus objetivos.

As características do ciberdomínio, conforme análise no capítulo 2, desaguam em mudanças relevantes na capacidade da ação coletiva: surgem novas arenas para o embate político, há uma maior probabilidade de eventos ganharem escala transnacional, há maior capacidade de romper fronteiras físicas, o poder e controle estão mais distribuídos, surgem novos atores (MUELLER, 2010). Como afirma Mueller (2010) a Internet altera os custos e a capacidade de ação de um grupo na medida em que facilita a interatividade da comunicação. Assim, a comunicação digital pode mudar a natureza e escala das ações coletivas,

\footnotetext{
${ }^{65}$ Por exemplo, a existência de botões ou etiquetas que possibilitam expressar discordâncias com apenas um clique pode estimular a ocorrência de atritos.
} 
encorajando a auto-organização e ações descentralizadas, reunindo informação e aproximando pessoas like-minded, bem como impulsionando ações offline. Na prática, o ciberespaço diversifica o repertório de ação (SCHUMANN, 2015). Ciberataques próprios, ações coordenadas colaborativas, ações de constrangimento público e execução de eventos coletivos online são algumas dessas novas formas de ação hoje disponíveis para o ativismo contemporâneo através do ambiente digital.

Com o processo de informatização de instituições, governos, organizações e corporações a partir dos anos de 1980 e com a popularização da Internet como um dos meios de comunicação mais influentes do século XXI, o ciberdomínio possibilitou novas formas de ataque e também criou novas arenas para a disputa política. Grupos ativistas têm hoje em suas mãos diferentes instrumentos online para pressionar autoridades ou desestabilizá-las como nos casos de ciberataques: Ataque de Negação de Serviço (DDoS), ataque viral, infiltração de dados (ciberespionagem), hacking, sequestro remoto ${ }^{66}$.

A comunicação digital impulsiona a execução de ações online do ativismo, porém estas atividades não são inerentes ao uso das ferramentas em si, já que dependem da devida forma de apropriação dos ativistas (SALTER, 2004; KAVADA, 2010). Por exemplo, uma mesma ferramenta pode ser utilizada para diferentes ações ou finalidades de um grupo. Se o uso do Twitter pode ser valioso para comunicar entre os pares sobre um evento ou partilhar uma nova informação para a campanha ativista em um determinado grupo, isto pode não se aplicar a outro. Portanto, o significado que uma ferramenta terá para a prática ativista dependerá do que o grupo intenta realizar com ela (KARPF, 2010). Nesta mesma linha de raciocínio, para Seibe (2012) os meios de comunicação são apenas ferramentas, as quais dependem da ação dos indivíduos para se efetivar o movimento social:

Media are just tools, nothing more. Whether the carbon copies of samizdat writings that were circulated surreptitiously in the Soviet Union or the YouTube videos that were produced by young Egyptians, media manifestations of resistance and rebellion can inform and encourage, but the actions that bring about change must be undertaken by individuals, and lasting change requires reform, and sometimes rebirth, or institutions (p. 3).

\footnotetext{
${ }^{66}$ Ver discussão sobre formas de ciberataque em quadro no capítulo 3.
} 
Igualmente, para diversos autores (SALTER, 2004; SEIBE, 2012; PORTA; TARROW, 2015) o design da ferramenta digital em si não determina seu uso nem garante a materialização da ação:

Moreover, neither globalization nor the Internet explains, per se, the passage from structure to action. Social movement studies confirmed long ago that grievances are not sufficient to produce mobilization; both macroeconomic and microtechnological change must be processed by actors in social networks who respond to concrete threats and avail themselves of opportunities and resources they can perceive and cope with (PORTA; TARROW, 2005, p. 230).

Ao mesmo tempo, há diferentes níveis de impacto e de habilidades necessárias para que o uso de uma ferramenta alcance toda sua potencialidade na prática. Neste sentido, Nielsen (2010) traz uma tipologia das ferramentas online para discernir esses diferentes usos demonstrando que nem todos os meios digitais são usados de maneira equânime por ativistas. Segundo ele há três tipos de ferramentas: Mundanas, emergentes e especializadas:

I refer to these as "mundane tools," a set of technologies that are widely available, almost universally used, and familiar to most. Many activists also experiment with social networking sites, video sites, and photosharing services - tools I refer to as "emerging" because they, while in principle available to everyone, are used only by some and are unfamiliar to many. Finally, most campaigns also use campaign websites and dedicated onlineintegrated software for various, more specific managerial tasks, such as managing voter databases. I call these "specialized tools" because they are not meant for general use but developed (and often sold) to handle very specific tasks and are usually known to only a few professionals (NIELSEN, 2010, P. 187).

Embora a tipologia de Nielsen (2010) seja aplicável, ela pode ser melhorada devido a duas fragilidades: (1) escapou ao autor algumas gradações importantes; e (2) o autor está demasiadamente concentrado na tipologia das ferramentas, e não na tipologia dos usos, que seria conceitualmente mais preciso. Pode-se melhorar esta taxonomia considerando quatro (e não três) tipos e inserindo alguns deslocamentos conceituais a fim de tirar o foco nominal nas ferramentas (como faz o autor) e colocar o foco no conceito de uso ${ }^{67}$.

\footnotetext{
${ }^{67} \mathrm{Ou}$ seja, uma ferramenta não nasce em uma categoria. Em seu histórico de desenvolvimento até a sua estabilização ela pode passar por várias tipologias. Então o mais importante não é afirmar que o Facebook é uma ferramenta mundana. O mais importante é afirmar que hoje o Facebook é uma ferramenta mudana, mas ela já foi uma ferramenta de vanguarda em seus primórdios. Ao mesmo tempo, não significa que uma ferramenta passa por todas as fases. Esta percepção está alinhada com aquilo que Lee Salter (2004) denominou de "formas de uso", conforme discutido anteriormente no capítulo 2 desta tese.
} 
Assim, readaptando esta taxonomia, existem diferentes usos das ferramentas digitais para a ação ativista: (a) Mundano (quando o uso é amplamente disseminado e popularizado no cotidiano do cidadão comum), (b) especializado (quando o uso ocorre a partir de um know how mais específico, voltado para tarefas peculiares que estão mais próximas de rotinas profissionais), (c) emergente (quando o uso nem sempre está plenamente disseminado e muitas vezes se restringe às rotinas profissionais, e geralmente a apropriação é inicial e de vanguarda, muito comum em pessoas aficionadas por tecnologia ou que fazem acompanhamento sistemático de inovações e são as primeiras a testá-las, como geeks); (d) avançado (quando o uso ocorre em um patamar elevado de conhecimento técnico das camadas que compõem o ciberespaço, seu funcionamento e suas linguagens de máquina, o que envolve códigos de programação e expertise hacker). Dito isso, as ferramentas podem ter diferentes usos. Por exemplo, uma rede social pode ser utilizada de forma mundana por um indivíduo comum ao postar uma foto de um protesto que participou em sua timeline. A mesma rede social pode ser objeto de um uso avançado por um hacker ativista que conseguiu invadir o sistema a ponto de alterar os algoritmos que determinam a timeline fazendo com que todos vejam um post (ou uma foto) sobre o mesmo protesto.

No geral, o ativismo tem feito o uso mundano como premissa. Isso ocorre pois as ferramentas visivelmente marcadas pelo uso mundano (como aplicativos de celular, redes sociais online, websites, chats etc.) são aquelas que mais sustentam capilaridade política justamente por fazerem parte da vida cotidiana dos indivíduos, antes de enquadrá-los como ativistas: "Activists would be fine without their campaign website or Facebook page, but would have a harder time without more ordinary Internet tools" (NIELSEN, 2010, p. 190). Isto significa que se a ferramenta já é amplamente usada para tarefas diárias, naturalmente o emprego para a estratégia ativista é uma decorrência previsível. As mídias sociais como Facebook, Twitter, YouTube etc. oferecem usos extremamente úteis para as ações coordenadas e são amplamente difundidas nas diversas camadas sociais.

O uso especializado da ferramenta também é bastante difundido no ativismo, principalmente para executar ações com algum nível mais apurado de profissionalismo, que exige dos ativistas algum know how para utilizá-la em ações em prol da causa (como produção de peças de propaganda mais sofisticadas, produção de campanha, uso viral da rede etc.). $\mathrm{O}$ uso emergente existe no meio ativista, mas ainda não é uma regra geral (como ocorre nas formas mundana e especializada). Isso se explica pelo fato do uso emergente (a) requerer intenso acompanhamento do grande volume de inovações hoje existentes e (b) por estar na 
fronteira da inovação, a sua performance é carregada de incertezas, o que aumenta os riscos de falhas no uso prático de uma ação. Mas é possível, hipoteticamente, que o uso emergente cresça com o tempo, uma vez que o domínio e conhecimento antecipado de uma nova ferramenta pode ser um diferencial para o grupo ou uma ação justamente por se tratar de um elemento surpresa, ou seja, uma arma ainda pouco conhecida e nem sempre prevista pelos adversários ou que pode chamar a atenção justamente por sua capacidade de aumentar o repertório de ações.

Já o uso avançado é muito restrito a grupos ativistas enraizados no ciberespaço cujos participantes são, em sua maioria, experts em tecnologia. Grupos como Anonymous ou o Movimento Software Livre são exemplos de grupos ativistas que fazem uso avançado das ferramentas digitais.

Essa gradação de usos é importante para esclarecer que a ação pode ser marcada por diferentes níveis de apropriação da ferramenta. E esses níveis podem ter diferentes efeitos. Significa que nem todos os grupos de ativistas farão uso avançado das potencialidades de ação das ferramentas digitais. A maioria mantém-se nos usos mundanos e especializados. Mas não significa que o uso avançado fique apenas restrito às áreas de atuação de grupos hackers, já que a própria natureza da Internet estimula e facilita a interação, de modo que uma das características do cyberpower é justamente a possibilidade de ações colaborativas que aumentem seu impacto. Então, ainda que um grupo não possua em seus quadros nenhum ativista com conhecimento de programação, este grupo pode fazer um uso avançado da ferramenta digital em uma ação de sua autoria através do apoio ou colaboração de grupos que possuam esta expertise. Para Gerbaudo (2012) ferramentas digitais, como mídias sociais, são canais que primeiramente servem para construir identidades comuns, estabelecer vínculos de solidariedade e confiança, para depois viabilizar uma ação coletiva, e não um facilitador da ação a priori.

A própria possibilidade de ação colaborativa também é um elemento importante no aumento do repertório de ação. A comunicação digital possibilita ações coletivas sinérgicas, isto é, executadas coletivamente de forma sincronizada como um ator coletivo unificado (LEVY, 1995; JONHSON, 2003; HARDT; NEGRI, 2004; GERBAUDO, 2012; CASTELLS 2003; 2013; SCHUMANN, 2015). As ações na forma de swarms são um exemplo. Este debate é trazido por Hardt e Negri (2004) para falar das multidões como uma nova classe social. As características da multidão são: multiplicidade irredutível, poder desterritorializado, agir em conjunto, mas não reduzido a uma identidade ou a um lugar (GERBAUDO, 2012). 
Autores como Hardt e Negri (2004) e Castells (2003) consideram a não-centralidade e nãoespacialidade como características fundamentais dessas redes e swarms. Porém, a empiria mostra que há uma busca por construção de centralidade e espacialidade fixa, contrariando a ideia da rede apenas difusa. Por isso Gerbaudo (2012) trata da importância da mobilização como um processo mais do que um estado, mas com uma reunião espacial e coreografia próprias (GERBAUDO, 2012).

Há também outras formas de ações específicas colaborativas como smart mobbing (grupo de pessoas que cooperam e coordenam suas ações através de celulares; geralmente sem controle centralizado, ainda que grupos ativistas sejam responsáveis por guiar a ação), election monitoring (ajuda a combater fraude de votos e rumores), reporting (casos de violência, de violações de direitos humanos e outros abusos), sousveillance (para capturar atividades ilegais ou imorais e monitorar governos, fazer valer o direito); tuitaço (mobilização online através do Twitter em dia e horário sincronizados para fazer o tema subir no trend topics e ganhar visibilidade política), além de outras formas de eventos online de protestos (CULLUM, 2010; CASTELLS, 2013). A comunicação digital promove uma guinada elevando participantes a agirem coletivamente em eventos e campanhas no ciberespaço de forma mais colaborativa e inclusiva quando comparado ao espaço físico (SCHUMANN, 2015).

Paralelamente, se o ciberespaço disponibiliza hoje novas ferramentas de ação (e seus respectivos usos), que significam na prática novos modos de performances, que são somados aos repertórios pré-existentes, isto significa que a própria natureza digital do ciberespaço também tem criado novas oportunidades para a ação política no nível das trocas simbólicas. A comunicação digital lida com informação e a informação é uma espécie de poder, especialmente quando usada como meios de argumentos e interações entre usuários conectados (SCHUMANN, 2015). Ativistas criam hiperlinks a partir de fontes alternativas, que são usadas para transmitir mensagens de campanha em redes sociais pessoais, ações que antes estavam restritas a panfletos de baixa tiragem ou aos filtros do mass media. Embora a produção de conteúdo seja um potencial disponível para qualquer participante, na prática, é uma parcela pequena que realmente produz, organiza e reúne informação relevante (SCHUMANN, 2015).

Além disso, a própria natureza abstrata que compõe a camada lógica e a camada física do ciberespaço - a primeira caracterizada por números binários e a segunda por circuitos elétricos cada vez mais disseminados, potentes e portáteis - também cria novas oportunidades 
para a ação ativista. Isso porque os governos, corporações e organizações em geral se tornam cada vez mais informatizados e dependentes da comunicação digital. Toda informação que produzem (incluindo aquelas estratégicas ou sigilosas) não estão mais em papeis físicos, trancados em cofres de aço. Estão em computadores, em nuvens de dados, conectados a intranets e na maioria das vezes, também com link a Internet. Tendo em vista que a imagem pública dessas instituições é fundamental para sua existência, poder e legitimidade, a maior vulnerabilidade a transparências "indesejadas" pode afetar sua performance. E a ciberespionagem é uma ação que se beneficia desse contexto. Vazamentos tendem a se tornar cada vez mais frequentes e as diferentes informações vazadas podem servir para diferentes propósitos de ação, afetando governos e instituições. Isso vai desde o constrangimento público, que pode resultar em perdas de capital econômico, político ou social, até servir como arma de barganha no jogo de pressões políticas. Grupos terroristas, por exemplo, oportunamente investigam informações dentro de sistemas fracos de segurança para extrair dados úteis para fins políticos (KIGGINS, 2014).

Embora se deva reconhecer e não subestimar o poder político das ferramentas digitais para a ação ativista, também devemos atentar para algumas limitações em seu uso. Primeiramente, as ferramentas digitais permitem, paradoxalmente, um maior poder de monitoramento dos Estados, como já mencionado anteriormente. O controle estatal, incluindo acessos a dados privados de indivíduos e organizações ativistas, é justificado em nome da segurança para proteger os interesses nacionais (STEEN-THORNHAMMAR, 2012). Segundo Columbus (2010, p. 165) "Although the Internet allows activists greater access to the tools of mass communication and coordination, it does not protect them from persecution".

Segundo, ainda que plataformas digitais (como mídias sociais, blogs etc.) possam ser um facilitador do ativismo, boa parte destas são desenhadas por corporações e usam códigos, algoritmos, design e outras bases pré-estabelecidas e geralmente não compartilhadas (SHIRKY, 2011; DIJICK, 2013), portanto fora do controle ou decisão do ativista. Jungherr e Schultz (2010) lembram, por exemplo, que as mídias sociais não são espaços neutros, já que alguém controla as características e o funcionamento do serviço, em geral uma entidade comercial, além de ter pouca privacidade e controle dos dados ali confiados. Por isso, os dados expostos num aplicativo online envolvem riscos de diferentes naturezas. Estes riscos podem ser de perda de privacidade, pois todo site, ainda que seguro, tem um potencial risco de sofrer vazamentos, de modo que arquivar o material offline seja a maneira mais certeira de manter uma informação sensível em segurança. Outro risco é a perda de acesso, quando o site 
sai do ar ou o conteúdo é removido, sendo o mais adequado manter o material em diferentes sistemas. Há ainda a perda de conteúdo, seja por causa de uma invasão, um bug ou uma ruptura física, por isso a necessidade de realizar backup do material depositado. Pode ainda ocorrer mudança dos termos de serviço de um website, como por exemplo a alteração das características de uma ferramenta que já se utilizava e a sequente prestação de um serviço não-confiável, com falhas e riscos de continuidade (JUNGHERR; SCHULTZ, 2010).

Por outro lado, há métodos que ajudam a proteger o conteúdo online. Os métodos de criptografar estão mais sofisticados e o tempo de criar novos códigos é mais rápido do que o tempo para decifrá-los (STEEN-THORNHAMMAR, 2012). E ainda, a tecnologia está mais sob controle privado do que governamental, alterando a estrutura de poder: "Companies such as Google have improved their encryption methods, making it harder for governments to intercept and monitor messages" (STEEN-THORNHAMMAR, 2012, p. 229).

Terceiro, os ciberataques são capazes de alcançar caráter destrutivo de alto impacto, acarretando em prejuízos físicos (ainda que sejam raros, atualmente ${ }^{68}$ ), ou gerando alto custo econômico e impactos políticos e sociais relevantes, podendo afetar a vida de cidadãos comuns. Isso pode inclusive enquadrar o ativismo ao rótulo criminal, prejudicando sua imagem perante o público como perpetrador deste tipo de ação. Muitas dessas ciberarmas foram desenvolvidas por criminosos para objetivos financeiros, ou por geeks ou outros hackers para demonstração de capacidade, ou simplesmente diversão. Porém, essa mesma tecnologia quando apropriada por ativistas possui propósitos bem distintos dos originais, já que ativistas usam as ferramentas desenvolvidas por criminosos ou hackers para ações politicamente motivadas (MURDOCH, 2010).

Apesar dessas práticas não-éticas estarem sujeitas a ocorrer também no meio online, geralmente são justificadas pelos ativistas, dentre os argumentos estão: A rejeição da validade do direito/lei, de modo que a ação seria justamente uma forma de desafiar este status quo; os benefícios suplantariam os efeitos negativos; rejeição da legitimidade ética dos efeitos

\footnotetext{
${ }^{68}$ Os prejuízos perpretados em meio online são em geral indiretos, e para prejudicar fisicamente necessita de uma ação offline. Interferir na infraestrutura crítica pode causar prejuízo físico direto. Embora ativistas ainda não estejam usando a tecnologia digital para causar prejuízos físicos, Estados já têm executado ataques em conflitos com outros Estados e através de operações militares (MURDOCH, 2010). Como explica o autor: "Nowadays, as more critical infrastructure is connected to the Internet, the need for privileged access is diminishing, opening up vulnerabilities to criminals, terrorists, and activists alike. Indeed, while examples of more recent cyber-attacks remain classified, U.S. government departments have disclosed that they regularly have their computer systems breached by foreign entities, with government intelligence agencies suspected. Given such access, officials believed attackers could seriously disrupt distribution of food and electricity" (MURDOCH, 2010, p. 145).
} 
negativos; ou não acreditam que haja uma ação ruim que precise ser justificada (MURDOCH, 2010).

Por fim, uma quarta limitação é que nem toda ação online alcança seu objetivo. Quanto à efetividade das ações propiciadas pelo ambiente digital, Karpf (2010) questiona se estas novas plataformas fazem do ativismo político mais efetivo e bem-sucedido do que antes. A ferramenta carrega um alto potencial de uso, mas são as formas de uso (SALTER, 2004) combinadas com os contextos políticos, culturais e sociais que determinarão a sua efetividade. Por isso, métricas isoladas não funcionam para compreender todos os impactos de ações online por diferentes grupos e contextos. Karpf (2010) explica que, para ser válida a comparação das métricas, é preciso entender a estrutura de poder existente e como a ação ativista intende afetar aquela estrutura:

New technologies offer an expansive suite of tools for engaging our fellow citizens, but some forms of engagement are more effective than others. Would an America-based blog with one million visits have more impact in Egypt than an Egyptian blog whose five hundred visitors were all key journalists or fellow digital activists? Seems unlikely. Tactical metrics, then, are only truly impressive when placed in context (KARPF, 2010, p. 162).

Por isso não se pode afirmar que haja relação direta entre ação e efeitos. Ainda que os avanços do ativismo através do ambiente digital tenham disseminado as melhores práticas de determinadas táticas, nem sempre uma ação terá o mesmo efeito em conjunturas distintas:

Tactical knowledge, while extremely important to improving activism practice, has its shortcomings. Each tactic is highly contextual: a given practice, using a specific tool, was successful in achieving a given goal by targeting a given audience within an equally specific political, economic, and social context. Reproducing tactics is common, yet blueprint copying is impossible. Even in the same country, the context always changes from campaign to campaign (JOYCE, 2010b, p. 210).

O problema reside no fato do conhecimento tático não ser algo reproduzido facilmente, pois táticas e contextos mudam constantemente e assim dependem de uma série de fatores menos controláveis pelos ativistas. 


\section{INDICADORES E TRÊS ESTUDOS DE CASO: AL-QAEDA, WIKILEAKS E PRIMAVERA ÁRABE}

A partir das abordagens teóricas, conceituais e analíticas apresentadas nas seções anteriores, este capítulo final tem o objetivo de observar como essas questões se desenvolvem na prática. Para isso, optou-se por uma análise de três estudos de caso, especificamente três fenômenos recentes e emblemáticos de ativismo transnacional que representam importantes eventos do cenário internacional contemporâneo. Para tanto, o capítulo está organizado em cinco seções. Primeiramente, realiza-se uma explanação sobre os parâmetros metodológicos utilizados para a análise dos estudos de caso (o porquê dos casos analisados; quais as ferramentas de coleta de dados; quais as ferramentas de análise utilizadas e a importância dos indicadores para este método). As segunda, terceira e quarta seções são dedicadas a uma abordagem específica sobre cada um dos estudos de caso com base nos parâmetros metodológicos levantados. A quinta seção traz uma análise transversal sobre os três estudos de caso, situando-os em um cenário mais amplo.

\subsection{PARÂMETROS METODOLÓGICOS}

É possível identificar mudanças importantes na dinâmica do ativismo transnacional desde o final do século passado, quando o acesso a Internet para o uso do público mais amplo (não restrito a universidades ou a órgãos governamentais) ainda era um evento recente. Os protestos antiglobalização, como a Batalha de Seattle em 1999 e outros casos similares que se seguiram no século que nascia, traziam à tona uma forma de ativismo transnacional visivelmente afetada pelo uso da Internet em suas diversas fases. Isso apontava para um campo que clamava por estudos mais específicos.

Uma década depois de Seattle, o fenômeno foi ganhando em escala, em complexidade e em importância. As ações de ativistas no além-fronteiras e a apropriação que se tem feito das novas ferramentas de comunicação digital repercutiram em mudanças importantes nos eixos vertebrais da dinâmica ativista contemporânea, conforme discutido nesta pesquisa. Para testar tal argumento, a metodologia do estudo de caso foi utilizada como o caminho mais natural e adequado. 
Esta escolha se deve pelas principais razões a seguir: (a) trata-se de um fenômeno social e político com a ocorrência de casos emblemáticos, e por si só complexos em suas estruturas internas; (b) a riqueza dos casos disponíveis também é marcada por sua heterogeneidade: os usos da comunicação digital têm servido para formas de ativismo distintas (movimentos potencialmente antagônicos, em alguns casos); (c) a metodologia de estudo de caso possibilita uma análise transversal nas diferentes formas de ativismo, permitindo observá-los de forma sistêmica, sem perder as suas respectivas complexidades inerentes.

Por isso, trata-se de um método qualitativo amplamente aceito e que tem se demonstrado como uma forma eficiente de análise de fenômenos sociais e políticos complexos. Como defende o estudioso em metodologia Robert Yin (2015):

Como método de pesquisa, o estudo de caso é usado em muitas situações, para contribuir ao nosso conhecimento dos fenômenos individuais, grupais, organizacionais, sociais, políticos e relacionados. Naturalmente, o estudo de caso é um método de pesquisa comum na psicologia, sociologia, ciência política, antropologia, assistência social, administração, educação, enfermagem e planejamento comunitário.[...] Seja qual for o campo de interesse, a necessidade diferenciada da pesquisa de estudo de caso surge do desejo de entender fenômenos socias complexos [...] (p. 4).

Para o autor há uma grande força nos estudos de caso devido à sua múltipla capacidade de trabalhar com diferentes evidências - documentos, artefatos, entrevistas e observações (YIN, 2015). Com esta percepção em mente, optou-se por testar as teorizações produzidas no decorrer desta pesquisa de doutoramento a partir da análise de três casos ${ }^{69}$ impactantes de ativismo transnacional e que se tornaram amplamente conhecidos no século XXI:

1) Al-Qaeda - Trata-se de um movimento islâmico internacional cuja bandeira principal consiste na crítica à influência ocidental no mundo árabe e na busca por criação de Estados muçulmanos baseados em uma visão fundamentalista do Islã. É caracterizado pelo uso da violência e métodos terroristas para fazer pressão política. Tornou-se mundialmente conhecido como responsável pelo ataque do 11 de Setembro nos EUA em 2001.

\footnotetext{
${ }^{69}$ Uma descrição mais aprofundada dos três casos ocorrerá nas seções específicas de cada um, no desenvolvimento deste capítulo. Neste momento, trata-se apenas de uma breve delimitação sobre cada caso, retomando e relembrando o que já foi apontado na Introdução.
} 
2) WikiLeaks - É uma organização nascida no bojo das articulações do movimento hacker que tem a bandeira da transparência radical (ou transparência total) como seu principal objetivo. A organização estimula e recebe importantes vazamentos de teor político e/ou econômico com o objetivo de revelar ações irregulares de players poderosos (como governos e corporações).

3) Primavera Árabe - Envolve uma série de levantes populares questionando diversos governos em países do Oriente Médio e Norte da África, de modo que alguns casos culminou com quedas de regime. Dentre as principais reivindicações dos protestos estavam o desejo por mais justiça social, justiça política e mudanças nos regimes vigentes.

A escolha destes três fenômenos se deu a partir de três pré-requisitos que todos preenchiam: (a) são casos emblemáticos e representativos do uso da comunicação digital no desenvolvimento de suas dinâmicas, repercutindo em eventos importantes no cenário internacional contemporâneo; (b) são três formas distintas de ativismo, seja no teor ideológico, nos métodos, na estrutura e nos objetivos-fins, isso possibilita uma riqueza de análise capaz de melhor tencionar e explorar as categorias teóricas propostas; (c) embora muitos dos atores envolvidos diretamente nestes casos sejam de difícil acesso, tratam-se de casos com vasta documentação e registro de diferentes fontes analíticas, o que permite segurança na coleta e cruzamento de informações relevantes.

Estes três casos não devem ser pensados como "entes" ativistas no sentido estrito do termo. Devem ser compreendidos como epicentros em torno dos quais o fenômeno do ativismo transnacional ocorre. Por isso, o estudo não está restrito a uma abordagem hermenêutica da narrativa desses casos, com foco apenas em suas lideranças ou estrutura. Isso será levado em conta, naturalmente, porém, a proposta é analisar os casos trazendo os contextos políticos, sociais e históricos sob os quais se basearam; as suas características ideológicas, bem como aquilo que se ergue ao seu redor (como redes de apoiadores, embates com adversários etc.).

A análise dos casos visa a demonstrar como ocorrem os impactos da comunicação digital no ativismo transnacional, conforme categorias elencadas no capítulo anterior ${ }^{70}$.

\footnotetext{
${ }^{70}$ Doravante, o conjunto de impactos ou efeitos da comunicação digital no ativismo transnacional será citado apenas como "Categorias de efeitos".
} 
Assim, busca-se identificar formas de apreender essas mudanças no campo da realidade e aferi-las qualitativamente em casos concretos como estes.

Como premissa metodológica, a análise destes três estudos de caso está inserida no modelo de método qualitativo. Devido à própria complexidade do fenômeno e dos objetos em análise, métodos quantitativos seriam insuficientes e incompletos. Uma pesquisa qualitativa possibilita um olhar dos casos em seus contextos de ocorrência, de modo a trazer uma visão mais completa e contextual do fenômeno. Pois, como explica Jha (2008):

Qualitative research is multimethod in focus, involving an interpretive, naturalistic approach to its subject matter. This means that qualitative researchers study things in their natural settings, attempting to make sense of, or interpret, phenomena in terms of the meanings people bring to them. Qualitative research involves the studied use and collection of a variety of empirical materials case study, personal experience, introspective, life story, interview, observational, historical, interactions, and visual texts - the described routine and problematic moments and meanings in individuals' lives (JHA, 2008, p. 45).

Para organizar esta pesquisa qualitativa e adentrar nos estudos de caso, optou-se pela elaboração de um quadro de indicadores que constitui cada categoria de efeitos. Ou seja, para cada efeito da comunicação digital no ativismo transnacional elencado será desenvolvido um conjunto de indicadores. Estes serão prospectados, checados e analisados. O modo de ocorrência do indicador representa a forma como tal categoria se desenvolve. Para compor o quadro de análise guiado pelos indicadores que estão devidamente estabelecidos no Quadro 4, também adotou-se o método da observação sobre os fatos, uma vez que se tratam de casos relativamente delineados no passado, mas que ainda continuam em desenvolvimento. Como explica Kothari (2004):

Under the observation method, the information is sought by way of investigator's own direct observation without asking from the respondent. For instance, in a study relating to consumer behaviour, the investigator instead of asking the brand of wrist watch used by the respondent, may himself look at the watch. The main advantage of this method is that subjective bias is eliminated, if observation is done accurately. Secondly, the information obtained under this method relates to what is currently happening; it is not complicated by either the past behaviour or future intentions or attitudes (2004, p. 96).

Os indicadores se comportam justamente como um parâmetro-guia, estabelecendo elementos analíticos relevantes dentro do processo de coleta e sistematização deste processo de observação dos fenômenos em análise. Na prática, indicadores são elementos utilizados 
para operacionalizar um conceito abstrato e serve como um sinal, um indício, um apontamento concreto de sua existência na realidade. São hoje largamente empregados em diversos estudos, em diversas áreas como uma abordagem metodológica para qualificar e compreender determinados fenômenos. Nas Ciências Humanas, especificamente nas Ciências Sociais Aplicadas, o uso de indicadores serve como um elemento para medir, identificar, qualificar e quantificar um determinado fator ou característica que compõe um fenômeno social. Ajuda a compreender os caminhos que este fenômeno toma e que elementos compõem o seu desenvolvimento:

In general terms, an indicator is a quantitative or a qualitative measure derived from a series of observed facts that can reveal relative positions (e.g. of a country) in a given area. When evaluated at regular intervals, an indicator can point out the direction of change across different units and through time (OECD, 2008, p. 13).

Nesta pesquisa, o emprego deste método tem o intuito de caracterizar um conjunto de indicadores qualitativos. Informações quantitativas também são utilizadas, desde que inserida numa moldura de pesquisa qualitativa. Isso nos permite desmiuçar e observar melhor a microfísica que compõe as categorias de efeitos. Cada indicador representa um elemento ou uma característica da categoria em questão e para cada um deles foram pensados elementos práticos que comprovam a sua existência (ou inexistência) e a forma como ocorre. Embora os indicadores sejam específicos, os exemplos factuais podem ser multifacetados e, por isso, referirem-se a mais de um indicador simultaneamente, até porque tratam-se de complexos fenômenos sociais.

Para que tenhamos uma devida clareza sobre o que os indicadores representam, o Quadro 4 traz uma síntese sobre cada categoria de efeito, seu respectivo indicador e o que este representa:

Quadro 4 - Categorias de efeitos e seus respectivos indicadores qualitativos

\begin{tabular}{|c|c|c|}
\hline $\begin{array}{c}\text { CATEGORIA DE } \\
\text { EFEITO }\end{array}$ & INDICADOR & DESCRIÇÃO \\
\hline $\begin{array}{l}\text { 1. Estímulo à } \\
\text { configuração da } \\
\text { causa }\end{array}$ & 1.1 Articulação & $\begin{array}{l}\text { Qualifica qual o papel da comunicação digital } \\
\text { na gênese da causa/ grupo. A articulação da } \\
\text { causa é o processo que compreende o } \\
\text { surgimento das bandeiras, reivindicações ou } \\
\text { elementos ideológicos. }\end{array}$ \\
\hline & 1.2 Difusão & Qualifica o papel da comunicação digital no \\
\hline
\end{tabular}




\begin{tabular}{|c|c|c|}
\hline & & $\begin{array}{l}\text { desenvolvimento da causa/grupo através da } \\
\text { sua propagação para um público maior, ou } \\
\text { seja, quando começa a "dar-se a ver", } \\
\text { difundindo-se. }\end{array}$ \\
\hline & 1.3 Massificação & $\begin{array}{l}\text { Qualifica o papel da comunicação digital na } \\
\text { expansão da causa, atravessando diferentes } \\
\text { mídias e se tornando conhecida pelo grande } \\
\text { público, para além do ambiente digital. }\end{array}$ \\
\hline \multirow{3}{*}{$\begin{array}{l}\text { 2. Multiplicação do } \\
\text { engajamento }\end{array}$} & 2.1 Coordenação & $\begin{array}{l}\text { Qualifica a importância da comunicação digital } \\
\text { no processo de engajamento de coordenação, } \\
\text { isto é: o engajamento daqueles que exercem } \\
\text { papel de liderança nos processos; aqueles } \\
\text { indivíduos responsáveis pelo start e } \\
\text { coordenação das ações mais cotidianas e } \\
\text { perenes da causa. "Coordenação" deve ser } \\
\text { compreendida aqui no sentido lato da palavra: } \\
\text { Isto é, ordenar em conjunto (o que inclui tanto } \\
\text { lideranças mais centralizadas, quanto } \\
\text { lideranças mais horizontalizadas, } \\
\text { descentralizadas ou distribuídas). }\end{array}$ \\
\hline & 2.2 Adesão & $\begin{array}{l}\text { Qualifica a importância da comunicação digital } \\
\text { no processo de engajamento de adesão, isto é, } \\
\text { o engajamento de apoiadores. Trata-se do } \\
\text { conjunto de indivíduos que não estão à frente } \\
\text { do processo, mas compactuam e oferecem } \\
\text { apoio (seja na forma de apoio político, de força } \\
\text { de trabalho, de expertise). }\end{array}$ \\
\hline & 2.3 Colaboração & $\begin{array}{l}\text { Qualifica a importância da comunicação digital } \\
\text { no engajamento colaborativo oriundo de entes } \\
\text { coletivos ou institucionais (como movimentos } \\
\text { sociais, grupos políticos, associações, } \\
\text { fundações, outras organizações etc.) nas } \\
\text { atividades do caso em análise. Trata-se de } \\
\text { averiguar de que forma a comunicação digital } \\
\text { potencializa a solidariedade e a colaboração } \\
\text { intergrupos ou intermovimentos. }\end{array}$ \\
\hline \multirow{3}{*}{$\begin{array}{l}\text { 3. Flexibilização da } \\
\text { estrutura }\end{array}$} & 3.1 Virtualização & $\begin{array}{l}\text { Qualifica a importância da comunicação digital } \\
\text { na estruturação do movimento ou da } \\
\text { organização. Significa qualificar o grau de } \\
\text { virtualização, de "digitalização", a ponto de } \\
\text { suplantar a infraestrutura física (como } \\
\text { escritório, sede etc.), ou pelo menos afetar a } \\
\text { relevância dada a esta. }\end{array}$ \\
\hline & 3.2 Descentralização & $\begin{array}{l}\text { Qualifica o papel da comunicação digital na } \\
\text { descentralização da estrutura organizativa do } \\
\text { movimento ou da organização em relação às } \\
\text { tomadas de decisão e produção de diretrizes. }\end{array}$ \\
\hline & $\begin{array}{l}3.3 \\
\text { Transnacionalização }\end{array}$ & $\begin{array}{l}\text { Qualifica o papel da comunicação digital na } \\
\text { transnacionalização do movimento ou da } \\
\text { organização, possibilitando-o operar através } \\
\text { de uma estrutura que rompe fronteiras e se } \\
\text { coloca presente através de diferentes cenários }\end{array}$ \\
\hline
\end{tabular}




\begin{tabular}{|c|c|c|}
\hline & & e contextos nacionais. \\
\hline \multirow{3}{*}{$\begin{array}{l}4 . \\
\text { Instrumentalização } \\
\text { do planejamento }\end{array}$} & 4.1 Elaboração & $\begin{array}{l}\text { Qualifica o papel da comunicação digital como } \\
\text { ferramenta para os processos de elaboração } \\
\text { de planos, estratégias ou táticas. }\end{array}$ \\
\hline & 4.2 Datificação 71 & $\begin{array}{l}\text { Qualifica o papel da comunicação digital como } \\
\text { mecanismo de aglutinação, obtenção e } \\
\text { tratamento de dados estratégicos que servirão } \\
\text { como insumos para os processos de produção } \\
\text { e planejamento de ações. }\end{array}$ \\
\hline & 4.3 Instrução & $\begin{array}{l}\text { Qualifica o papel da comunicação digital nos } \\
\text { processos de orientação, instrução ou } \\
\text { capacitação de apoiadores, simpatizantes e } \\
\text { outros participantes. }\end{array}$ \\
\hline \multirow[t]{2}{*}{$\begin{array}{l}\text { 5. Diversificação da } \\
\text { ação }\end{array}$} & 5.1 Cibereventos & $\begin{array}{l}\text { Qualifica o papel da comunicação digital na } \\
\text { realização de ações de mobilização que se } \\
\text { configuram como um evento online voltado } \\
\text { para uma ação. "Eventos coletivos online" são } \\
\text { ações realizadas especificamente no ambiente } \\
\text { digital que possuem caráter público e que } \\
\text { pedem o envolvimento coletivo de indivíduos. } \\
\text { São ações coletivas que visam reforçar, } \\
\text { defender ou atingir os objetivos da causa. }\end{array}$ \\
\hline & 5.2 Ciberataque $^{72}$ & $\begin{array}{l}\text { Qualifica o papel da comunicação digital no } \\
\text { empoderamento de ações de ciberataque. } \\
\text { Note-se que o termo "ciberataque" } \\
\text { compreende um guarda-chuva de ações } \\
\text { conforme discussão sobre o tema no Capítulo } \\
3 \text {. }\end{array}$ \\
\hline
\end{tabular}

Para analisar cada um desses indicadores, a pesquisa qualitativa foi realizada através da coleta de informações, dados e relatos de fatos oriundos de fontes variadas. Assim, foram utilizadas quatro formas ${ }^{73}$ de coleta de dados (em ordem de importância):

\footnotetext{
${ }^{71} \mathrm{O}$ termo "datificação" trata-se de um neologismo cuja origem está na palavra em inglês "data" (dado). O termo tem sido usado principalmente na discussão sobre Big Data (MAYER-SCHONBERER; CUKIER 2013) para descrever o fenômeno da produção de informação sobre eventos, fatos, documentos etc. a partir de diversos aparelhos e sensores que passam a "datificar" grande volume de eventos e fatos, ou seja, traduzi-los ou registrálos através de dados digitais.

${ }^{72}$ Importante delimitar a diferença entre ciberataque e ciberevento. O primeiro ocorre especialmente direcionado a uma ação online que possui algum grau de agressão (como invasão, ocupação, hacking, sequestro remoto, ciberespionagem etc.) e que está no limiar da ilegalidade ou ultrapassando esta fronteira. Já os cibereventos são ações que não se configuram como um ato de agressão direta e que geralmente são aceitos como ações dentro da fronteira da legalidade nos parâmetros de países de regimes democráticos. Exemplos de cibereventos são protestos online, tuitaços, campanhas online etc.

${ }^{73}$ Inicialmente, a metodologia também lançou mão de entrevistas semi-estruturadas como uma forma complementar de fonte de informação. O objetivo era suplementar eventuais lacunas ou produzir confirmações de fatos ou questões polêmicas. O recurso da entrevista seria utilizado através de questões pré-estruturadas direcionadas. O lugar secundário das entrevistas era justificado a partir de duas questões inerentes aos objetos em análise: (a) primeiro, devido à riqueza de registros e descrições disponíveis sobre cada caso, a partir de fontes variadas, e isso, por si só, já se configurava como uma base consistente para a análise dos indicadores; (b) segundo, a própria natureza dos casos dificultava a aproximação de atores e militantes, principalmente lideranças que se tornaram de difícil acesso e nem sempre dispostas a responder questionários enviados, ou ainda, alguns
} 
a) Pesquisa bibliográfica ${ }^{74}$ - devido à importância e impacto dos três eventos, há um grande volume de literatura recém produzida, principalmente em língua inglesa e espanhola. Através da cobertura do estado da arte em livros e periódicos científicos, obteve-se o cerne das informações necessárias para compor, identificar e qualificar cada indicador elencado.

b) Relatos de fatos - também foram produzidos relatos sobre os fatos, a partir de diversas fontes, seja na forma de páginas online independentes (como blogs) ou ainda através de matérias ou reportagens jornalísticas que relatam os episódios no curso dos acontecimentos. No caso de matérias jornalísticas, tomou-se o cuidado metodológico de confirmar o fato em mais de uma fonte, analisando apenas aquelas fontes de ampla credibilidade pública.

c) Pesquisas quantitativas - sondagens de opinião, pesquisas quantitativas na forma de relatórios etnográficos de websites também foram somados para compor os indicadores.

d) Registro de depoimentos - eventuais testemunhos, entrevistas ou depoimentos que ativistas ou especialistas tenham proferido sobre os fatos e eventos estudados. Isso inclui entrevistas para veículos jornalísticos, vídeos de militantes, posts em blogs etc.

O desenvolvimento e aplicação dos indicadores qualitativos são úteis para a análise dos estudos de caso principalmente por duas razões fundamentais. Primeiro, os indicadores sintetizam o aprofundamento das categorias de efeitos elencadas e dão maior segurança no processo de observação dos casos. Possibilita pensar e olhar tais categorias em suas nuances e dimensões internas. Segundo, também servem como parâmetros transversais a todos os casos possibilitando assim um olhar comparativo e sistematicamente mais analítico. Considera-se que tais parâmetros também possam ser úteis como uma das contribuições da pesquisa para o avanço em estudos da área, podendo ser aplicados ou readaptados para outros estudos similares futuros.

Por fim, as análises sobre cada um dos casos serão ordenadas nas próximas três seções levando-se em conta o sentido cronológico de eclosão de eventos-estopins considerados linhas-divisoras de seus respectivos surgimentos. Será produzido uma espécie de "preâmbulo" ou "introdução" no início de cada seção, antes da análise propriamente dita dos indicadores

\footnotetext{
operam no âmbito da clandestinidade. Em razão disso, foram contatados ativistas, ex-ativistas, jornalistas especializados e alguns estudiosos, totalizando 12 fontes selecionadas. As poucas respostas obtidas, mesmo após um segundo reenvio, demonstraram dificuldade em obter feedback aos questionamentos, seja por evitar falar sobre o tema que se tornou sensível para as mesmas, seja por não cumprimento do deadline de entrega das respostas.

${ }^{74}$ Essa base de dados foi viabilizada através da intensa pesquisa em acervos bibliográficos na Universidade de Brasília (UnB), periódicos Capes, Ebrary e outras bases acadêmicas, além da aquisição de obras recém-lançadas. Um grande volume de informações foi coletado especialmente durante o estágio doutoral nos acervos das bibliotecas do MIT e Harvard University.
} 
(que seguirão a ordem do Quadro 4), cujo objetivo é dar elementos mínimos de delineamento de cada caso situando-os no contexto de seus surgimentos e familiarizando o leitor com o tema. $\mathrm{Na}$ análise dos indicadores foi priorizada a identificação da ocorrência ou não do indicador em discussão. Em seguida, uma vez localizado, este é qualificado na forma descritiva de como ocorreu e como se desenvolveu. Procurou-se produzir tal descrição contextualizando-a com elementos que estão no entorno do fenômeno para tentar abarcar a sua complexidade. Tendo em vista que os indicadores podem ser mais desenvolvidos ou menos desenvolvidos, a depender do caso, porém sem exaurir os exemplos, a descrição dos mesmos não tem a obrigação de ser equilibrada em termos de volume de discussão. Significa dizer que alguns indicadores podem ter uma discussão mais extensa devido à riqueza de sua ocorrência naquele caso em específico, enquanto outro indicador poderá ser descrito em poucos parágrafos, devido à própria natureza de sua existência menos avançada. Embora haja análises durante a descrição dos indicadores, a última seção do capítulo é que terá a função mais analítica e buscará fazer uma síntese mais transversal das categorias de efeitos, tendo como base os dados levantados nas seções e também retomando temas teóricos dos capítulos precedentes.

\subsection{AL-QAEDA: ESTRATÉGIA ONLINE E TERRORISMO}

O dia 11 de setembro de 2001 ficou marcado na história pelo sequestro de quatro aviões norte-americanos por 19 terroristas da rede Al-Qaeda (BURKE, 2007; DEMANT, 2001). Dois aviões colidiram com as Torres Gêmeas na cidade de Nova York. Um destes caiu sobre o Pentágono e o quarto, planejado para chocar-se com a Casa Branca, foi desviado e caiu no Estado da Pensilvânia. Os ataques no território estadunidense causaram cerca de três mil mortes e foram considerados a maior ação terrorista da história (BURKE, 2007).

Em linhas gerais, o principal objetivo da Al-Qaeda é pressionar mudanças no cenário político do Oriente Médio, exigindo a retirada da influência ocidental (principalmente dos EUA) na região e apostando no resgate e solidificação de valores fundamentalistas islâmicos, visando refundar aquilo que consideram verdadeiros Estados muçulmanos. Visando a 
concretização deste horizonte almejado, passaram a empreender a jihad ${ }^{75}$ : uma guerra religiosa, política e militar em nome de Deus (Alá) cujo principal método seria o uso da violência através de ataques terroristas a alvos que consideravam emblemáticos e potencialmente impactantes, causando danos materiais e perda de vidas.

Amplamente noticiado e ainda mais explorado por pesquisadores de diversas áreas, o fatídico acontecimento do 11 de Setembro é, sem dúvida, um marco das relações internacionais contemporâneas. Uma das razões mais notórias para se afirmar isto se deve ao rearranjo internacional causado pela forma como um ator não-governamental conseguiu criar mecanismos capazes de desafiar a segurança da maior potência militar em vigor:

O atraente e poderoso videoclipe pré-gravado por Bin Laden, entregue antes dos ataques aéreos dos Estados Unidos no Afeganistão e mostrado pela AlJazira horas depois da consagração norte-americana no país, simbolizou a inadequação da resposta que o Estado mais poderoso do mundo conseguiu apresentar em face do bom uso dos recursos oferecidos pela moderna tecnologia de telecomunicações (BURKE, 2007, p. 57).

Como consequência direta dos ataques, os EUA iniciaram aquilo que chamaram de “Guerra ao Terror”, sob a presidência de George W. Bush. Para o governo estadunidense não havia dúvidas da responsabilidade da Al-Qaeda nos atentados. E proclamou assim uma caçada aos seus membros, principalmente aquele que considerara o líder do grupo: Osama bin Laden $^{76}$. Para atingir seus fins, os americanos e seus aliados ${ }^{77}$, invadiram o Afeganistão, país até então dominado pelo Talibã ${ }^{78}$ e que desde a década de 1990 estava apoiando atividades da Al-Qaeda, hospedando a principal base operacional do grupo em seu território ${ }^{79}$.

A Al-Qaeda demonstrou como redes transnacionais e clandestinas podiam fazer frente aos tradicionais atores estatais. Neste contexto, também estão outras redes, tais como

\footnotetext{
${ }^{75}$ Embora seja normalmente vinculado a ideia de "guerra santa" ou "guerra religiosa", o termo jihad significa na verdade "esforço", "luta", "empenho". Um dos pilares da fé islâmica. A conotação política é dada justamente à interpregação ao sentido de "luta" e "obrigação" de defender a fé islâmica contra infiéis.

${ }^{76}$ Osama bin Laden nasceu na Arábia Saudita, filho de uma rica família sediada naquele país. Entrou para o ativismo islâmico ainda na juventude, no início da década de 1970. Com a invasão da União Soviética no Afeganistão, bin Laden liderou sauditas que lutaram na libertação afegã do domínio soviético. É considerado um dos principais fundadores da Al-Qaeda e se tornou um símbolo do grupo, principalmente após os ataques de 11 de setembro. Em 2011, os EUA anunciaram a sua captura e morte no Paquistão.

${ }^{77}$ Dentre estes: Reino Unido, Alemanha, França, Canadá, Itália e Austrália (e outros países).

${ }^{78}$ Movimento nacionalista islâmico, de viés fundamentalista, que governou o Afeganistão entre 1996 e 2001 .

${ }^{79}$ Após a Guerra do Afeganistão, os EUA e seus aliados também invadiram e ocuparam o Iraque em 2003. Neste caso, a justificativa principal já não era a caçada a Al-Qaeda e sim a acusação de que o governo iraquiano se configurava como uma ameaça à segurança estadunidense e estaria produzindo armas de destruição em massa.
} 
guerrilhas, militantes antiglobalização, máfias, narcotraficantes que, embora com táticas, lógicas e intuitos distintos, ameaçam "enfraquecer e até inviabilizar os fluxos comerciais e de informações" (DEMANT, 2001, p. 363). Sem dúvida, havia uma estrutura que viabilizava as ações da Al-Qaeda:

No final de 2001, Bin Laden e os homens à sua volta tinham acesso a enormes recursos, tanto simbólicos quanto materiais, que podiam usar para projetar internacionalmente seu poder e influência. Tinham até um país que praticamente podiam chamar de seu [Afeganistão] (BURKE, 2007, p. 31).

Diversos autores apontam como elemento chave neste processo os sistemas de comunicação e informação mais recentes, como é o caso da Internet (HALLAMS, 2013; JACOBSON, 2010; BURKE, 2007). Trata-se de um elemento central, porém não provocaram algo necessariamente novo, pois como pondera Jacobson (2010), os ataques apenas colocaram em evidência as manobras terroristas que já ocorriam online antes do 11 de Setembro, embora a intensificação do uso da comunicação digital, no caso da Al-Qaeda, se dará após as repressões ao atentado. Nas palavras de Burke (2007, p. 243) "os ataques do 11 de Setembro não foram tanto uma ruptura radical com a marcha dos acontecimentos precedentes, mas uma soma de todos eles".

\subsubsection{Estímulo à configuração da causa}

\section{a) Articulação}

A Al-Qaeda, enquanto organização, tem suas origens na década de 1980 em um complexo cenário que envolve fundamentalismo religioso, reafirmação de uma identidade pan-islâmica e disputa por influência geopolítica e econômica de potências no contexto da Guerra Fria. O gatilho para configuração da causa ocorre com a invasão do atual Afeganistão pela antiga União Soviética em 1979. Como explica Weimann (2006):

Al Qaeda (Arabic for "The Base") traces its roots to 1980s Afghanistan. Three years following the 1979 Soviet invasion of the country, Osama bin Laden traveled to Afghanistan to join the anti-Soviet resistance. Shortly after, he established his own military camps, and then in 1988 established al Qaeda, at first not as a terrorist organization but as a network of foreign soldiers who had come to Afghanistan, so that the soldiers' relatives could track them. Al Qaeda also channeled money to the Afghan resistance (p. 65). 
Os Estados Unidos tiveram papel importante no apoio material aos combatentes da resistência contra a invasão soviética, fornecendo treinamento e equipamentos com o objetivo de barrar o avanço russo, pois uma eventual vitória soviética implicaria no aumento da influência do bloco comunista na região.

Em 1989, quando os soviéticos se retiraram do Afeganistão, Osama bin Laden retornou para a Arábia Saudita (seu país de origem). Devido aos acirramentos das suas discordâncias e embates contra a família real saudita (considerada por ele como ocidentalizada e corrupta) chegou a ficar em prisão domiciliar após o seu retorno. Já na década de 1990, mudou-se para o Sudão, morando neste país entre 1991 e 1996, onde desenvolveu atividades comerciais e, paralelamente, atividades políticas. Durante sua estada, bin Laden encontrou mais militantes de outras nacionalidades que também atuavam naquele território, oriundos principalmente do Egito, Paquistão e Tunísia (WEIMANN, 2006), ampliando assim a sua rede de contatos e reforçando o caráter transnacional do grupo.

Porém, com a ocorrência dos primeiros atentados atribuídos a Al-Qaeda - somando-se ao discurso que caminhavam entre o fundamentalismo islâmico e a crítica à presença norteamericana na região - houve novas pressões, desta vez sobre o governo sudanês, que expulsou bin Laden e seus militantes. Assim, o grupo retornou para o Afeganistão, que serviu como um país-base até o início deste século:

In 1996, under U.S. pressure, Sudan forced bin Laden and other members of al Qaeda to leave, and they rnoved to Afghanistan, where they openly lived until the U.S. attacks on the Taliban in 2001" (WEIMANN, 2006, p. 65).

É neste cenário que os ataques do 11 de Setembro ocorrem. Cada um dos passageiros terroristas trazia consigo uma carta esclarecendo que participavam de uma batalha em nome de Alá, de tal que modo que deveriam proferir como últimas palavras a seguinte frase: "Alá é o único Deus e Maomé é o Seu mensageiro” (BURKE, 2007, p. 259).

De modo geral, os muçulmanos acreditam que seguir as instruções de Alá (presentes no Corão e que o profeta Maomé teve a função de passar diretamente aos homens) garante uma sociedade justa e pacífica, transmitindo certa superioridade cultural, militar e política do mundo islâmico sobre outros valores (BURKE, 2007). Porém, é a interpretação mais radical 
do Corão que se baseia o fundamentalismo ${ }^{80}$ islâmico e se desdobra nos conhecidos ataques terroristas, pois "Assim, tal como toda a prática e crença islâmicas, a doutrina da jihad é produto de várias leituras e aplicações dos princípios contidos nos textos sagrados em contextos históricos e políticos específicos” (BURKE, 2007, p. 49). E a Al-Qaeda vai justamente nesta linha.

Nota-se que o surgimento da Al-Qaeda enquanto organização não dependeu da Internet. Tem origem em articulações que não se basearam no uso de ferramentas online de comunicação, uma vez que estas ainda eram embrionárias e pouco disponíveis nos anos de formação do grupo. Logo, não é possível afirmar que a comunicação digital desempenhou algum papel relevante na configuração da causa em suas origens, uma vez que esta articulação se deu através de um tipo de ativismo armado paramilitar e pan-islâmico, com bases espaciais físicas.

Mas isso não significa total ausência da comunicação digital no processo de rearticulação posterior do grupo. Com a abertura da Internet para o uso civil, a partir de meados da década de 1990, esta ferramenta significou um elemento importante para a articulação global da causa que passou por processos de reconfiguração, reforçando bandeiras e redirecionando finalidades, ganhando adeptos através da comunicação online (THOMAS, 2003; BERNER, 2006; JACOBSON, 2010). Isso ocorreu principalmente depois do 11 de Setembro, diante da reação estadunidense que culminou com a invasão do Afeganistão sob a alegação de destruir a base física da Al-Qaeda, a qual recebia apoio do então governo afegão.

$\mathrm{O}$ ataque dos Estados Unidos a Al-Qaeda no Afeganistão alterou significativamente a configuração do grupo, como aponta Berner (2006). Muitas das características preponderantes até então, tais como paramilitarismo de articulação e ação em espaços físicos geograficamente localizados, praticamente desapareceram, deixando de ser um lugar para ser um "programa secreto y un emprendimiento de martirio esparcido por todo el mundo. En consecuencia, la destrucción de AL Qaeda se ha vuelto una misión imposible" (BERNER, 2006, p. 17). Não é por acaso que Thomas (2003) afirma que "al Qaeda loves the Internet" (p. 112), já que a própria existência do grupo atualmente depende das Tecnologias de Informação e Comunicação (TICs). Isso significa afirmar que, apesar do meio digital não ter sido utilizado para o surgimento do grupo, foi fundamental para a sua reconfiguração posterior que ocorreu justamente com base no uso da comunicação digital.

\footnotetext{
${ }^{80}$ É adequado pontuar que o fundamentalismo pode existir nas mais diversas religiões, como o próprio cristianismo, de modo que não é característica exclusiva do islamismo.
} 
Logicamente, na hipotética ausência do meio digital, o grupo poderia encontrar outras opções de articulação analógicas. Mas dificilmente sustentariam a dimensão alcançada. Sem a Internet, o grupo enfrentaria sérios constrangimentos para continuar existindo. A comunicação digital possibilitou manter articulações vivas e ganhar novos adeptos e visibilidade, driblando assim o poderio militar hard power da maior potência do globo, mesmo diante da invasão do Afeganistão. Trata-se de um elemento fundamental para a própria manutenção da bandeira em sua forma ideológica, possibilitando a sua existência até os dias de hoje, mesmo após a anunciada captura e morte de bin Laden em 2011 pelas forças estadunidenses ${ }^{81}$.

\section{b) Difusão}

Após o 11 de setembro, com a ação militar e a tomada do Afeganistão pelas tropas estadunidenses, houve uma desmobilização das bases físicas de treinamento e planejamento da organização no Afeganistão, conforme já mencionado. Como consequência direta, a saída foi buscar medidas alternativas de sobrevivência e expansão que seriam mais viáveis através do auxílio do sistema moderno de comunicação digital:

Perhaps the most obvious reason, however, as to why terrorist groups, cells, and operatives have increasingly turned to the Internet is for the security it offers. As the United States and the international community have cracked down on $\mathrm{Al}$ Qaeda and affiliated terrorist organizations, the terrorists have tried to find new ways to avoid detection (JACOBSON, 2010, p. 357).

Ainda que mostre indícios de derrocada, o grupo pôde, além de se rearticular como vimos, também se difundir a partir da comunicação online. Um indicador disso é o número exponencial de crescimento de websites terroristas vinculados à organização, que acompanhou a própria expansão da Internet a partir dos anos de 1990 (WEIMANN, 2006).

Kremer e Muller (2014) argumentam que a Internet tem sido um meio fundamental para a difusão da Al-Qaeda enquanto movimento. De modo geral, o conteúdo de um site terrorista abarca a história da organização e suas atividades, biografias de seus líderes, os

\footnotetext{
${ }^{81}$ O presidente estadunidense Barack Obama anunciou em 2 de maio de 2011 que uma operação executada por grupo de elite das forças armadas do país haviam encontrado, capturado e morto Osama bin Laden no Paquistão. Segundo as autoridades americanas, seu corpo teria sido jogado ao mar. Ver em < http://www.bbc.com/news/world-us-canada-13256676 >. Acesso 13 abr. 2014.
} 
principais objetivos políticos e ideológicos, além de notícias atualizadas que abarquem as lutas, explicadas à luz da própria organização ${ }^{82}$. Além disso, os fatos demonstram que a possibilidade de difusão da informação através da Internet tem servido também como uma arma ideológica. Thomas (2003) explica que, no caso dos ataques do 11 de Setembro, a AlQaeda aproveitou-se do meio para lutar pelos corações e mentes do mundo islâmico, de modo que websites da organização como alneda.com e drasat.com argumentavam a legalidade dos ataques. Para Hallams (2013) as armas hoje disponíveis não são mais apenas as tradicionais bombas caseiras, mas também aquelas que funcionam com o auxílio de webcam e equipamentos tecnológicos, capazes de difundir a imagem do grupo, editando e enfatizando a sua performance de luta. Imagens do ataque ao World Trade Center registradas em câmeras e celulares alcançaram o público através da Internet e logo foram usadas para explicar sua causa e significados pelos terroristas online, conferindo seu próprio sentido para o acontecimento (HALLAMS, 2013).

Figura 5 - Reprodução da home do website Alneda

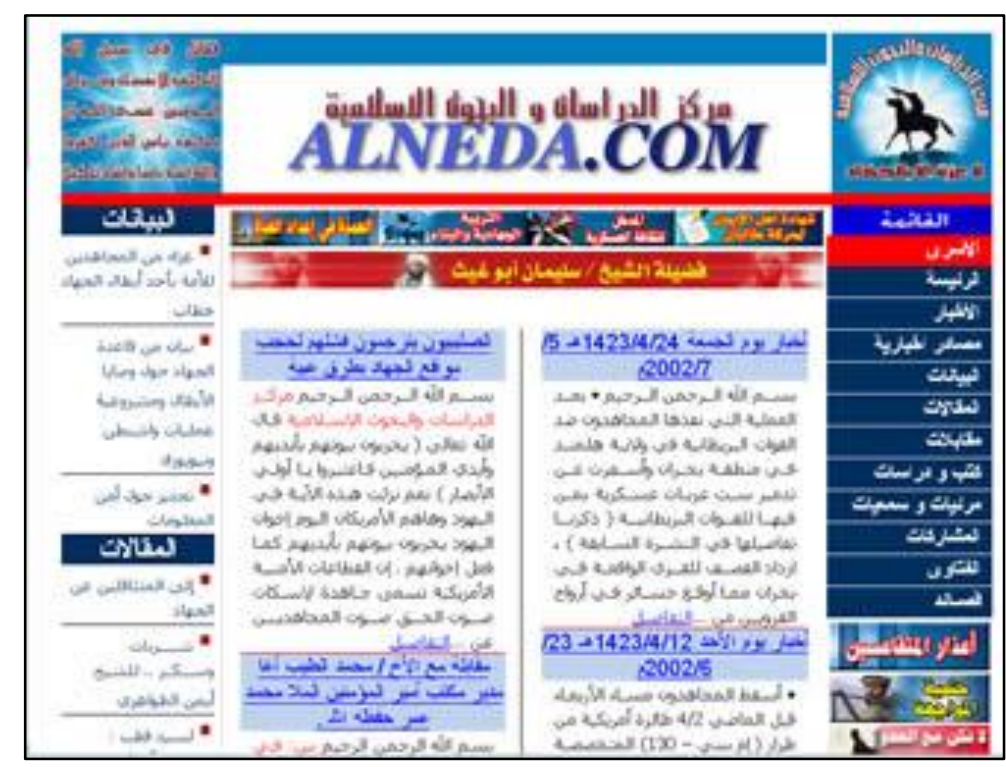

(Fonte: Google imagens)

\footnotetext{
${ }^{82}$ Interessante notar que esses websites tentam se resguardar do uso indevido de suas informações por terceiros, eximindo-se de responsabilidades, como aponta a transcrição feita por Berner original do próprio grupo (2006, p. 84): "Para cumplir con nuestra responsabilidad de informar a la comunidad musulmana, declaramos a todo el mundo que tenemos nuestros canales especiales de comunicación y que transmitimos información a través de páginas Web designadas. En nuestras declaraciones nos adjudicamos total responsabilidad por las operaciones que realizamos contra los norte-americanos y sus colaboradores en el ejército y las fuerzas policiales. También queremos aclarar que no nos adjudicamos ninguna responsabilidad por otras operaciones y por aquellos que no reciben directamente estas declaraciones realizadas a través de nuestros medios regulares. Al Qaeda en Irak, 13 de mayo de 2005."
} 
Como reforça Soriano (2013), o uso da comunicação digital por grupos jihadistas em geral (especialmente a Al-Qaeda) tem alcançado um nível de expansão bastante relavante a ponto de se equiparar, ou mesmo superar, o uso feito por estruturas governamentais:

Así por ejemplo, un estudio de 2007 publicado en International Journal of Human-Computer Studies destacaba como las webs yihadistas mostraban un de dominio de las potencialidades de Internet similar al de las agencias gubernamentales de los Estados Unidos. De hecho, las 86 webs analizadas mostraban un mayor y más sofisticado uso del entorno multimedia, que las webs de su enemigo occidental, haciendo un uso profuso de herramientas interactivas como foros y chats (Qin \& otros, 2007) (SORIANO, 2013, p. 289)

A Al-Qaeda incentiva a difusão e utilização do material disponibilizado nos websites de confiança que formam a sua rede para um círculo ainda maior através de outros websites. Como transcreve Weimann (2006), em 2002 o grupo manifestou abertamente a importância da propaganda através da Internet ao afirmar:

Therefore, we urgently recommend any Muslims that are interested in our material to copy all the articles from our site and disseminare them through their own Web sites, discussion boards and e-mail lists. This is something that any Muslim can participare in, easily, including sisters. This way, even if our sites are closed down, the material will live on with the Grace of Allah (p. 66).

Na prática, o ciberespaço se tornou um ambiente comunicacional onde os terroristas puderam dar mais materialidade discursiva às suas aspirações mais antigas, através de um contato direto com um público global que significava um percentual extremamente alto da propaganda do movimento (SORIANO, 2013):

Internet es una herramienta básica para cumplir esta función, como lo demuestra el hecho de que el $93 \%$ de toda la propaganda producida durante el periodo comprendido entre 2001 y 2005 utilizase el ciberespacio como canal de difusión, sin que ninguna otra vía de difusión pudiese rivalizar en importancia (Torres, Jordán y Horsburgh, 2006) (SORIANO, 2013, p. 298).

Não por acaso, como apontam Rabasa e colegas (2006), o uso da comunicação digital ajudou a Al-Qaeda a se difundir rapidamente na comunidade muçulmana: 
As a result of this media strategy, al-Qaeda's messages have penetrated deeply into Muslim communities around the world. Indeed, only the most advanced of modern states equal al-Qaeda's capability to spread sophisticated propaganda quickly and globally (p.15)

Na prática, a Internet é usada como arena de visibilidade para a Al-Qaeda dentro de diferentes perspectivas: proselitismo, contra-contraterrorismo ${ }^{83}$, propagação da causa e justificativa da violência. Todas elas tratam de apresentar a luta jihadista e buscam contemplar as variadas audiências.

Figura 6 - Banner de Internet com propaganda da Al-Qaeda intitulada Winds of Paradise

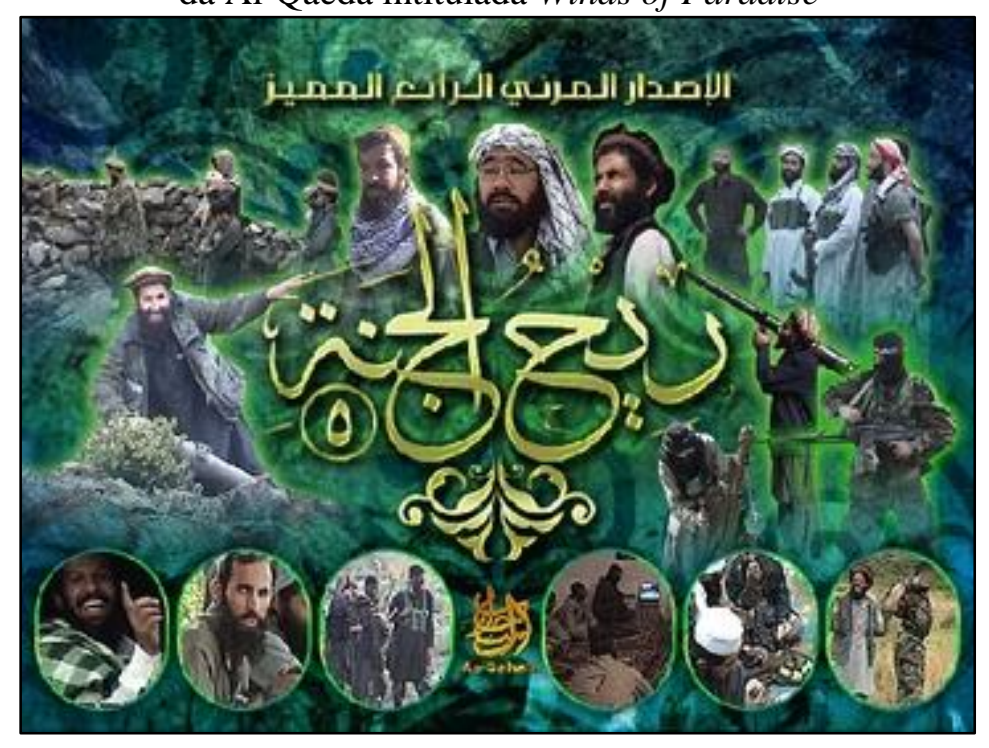

(Fonte: The Long War Journal)

Segundo Weimann (2004) são três tipos de público-alvo dos sites da Al-Qaeda: (1) Apoiadores atuais e potenciais; (2) Opinião pública internacional, não diretamente relacionada, mas interessada ${ }^{84}$; (3) Inimigos públicos. Estes últimos são geralmente desmoralizados, recebem ameaças de ataques, são apontados como culpados. Há certo estímulo por parte da Al-Qaeda para debates que busquem enfraquecer os argumentos adversários e provocar mudança da opinião.

E essa difusão ocorre levando em conta a gramática do tipo de público em cada ferramenta de comunicação digital. Por exemplo, o Twitter é hoje um espaço para divulgação

\footnotetext{
${ }^{83}$ Trata-se de ações contraofensivas de grupos terroristas reagindo às ações governamentais contraterroristas. Este termo será melhor explicado adiante.

${ }^{84}$ Nesse caso os sites se preocupam com a tradução para outras línguas. Mais especificamente para atender aos jornalistas estrangeiros, é possível também encontrar releases de imprensa com o ponto de vista da organização.
} 
entre jovens que não acessam sites da Al-Qaeda, enquanto o Facebook alcança um número e tipo mais generalista de pessoas, e embora muitas vezes os jihadistas sejam banidos da plataforma, nada os impedem de criar um novo perfil após a exclusão (BRACHMAN, 2010).

Quanto às estratégias de argumentação política em prol da causa, a comunicação digital significa o principal canal de voz do grupo, prevalecendo a tese da "legítima defesa", ou seja, a causa é difundida como uma reação ou um ato de defesa de modo que o uso da violência seria um recurso necessário na medida em que o povo muçulmano sofreria da mesma violência perpetradas por potências ocidentais como os EUA.

Weimann (2004) também explica que, no processo de difusão da causa, os terroristas lançam mão de três estruturas retóricas para justificar a violência: (1) Não há outra opção além da violência, além de enfatizar a diferença de forças: de um lado, um Estado ou inimigo poderoso, e de outro, a organização fundamentalista, o oprimido; (2) Desligitimação do adversário, qualificando o inimigo como assassino e violento agressor, enquanto o pequeno grupo jihadista luta pela liberdade; (3) Demonstração de que preferem soluções pacíficas, apesar de serem grupos violentos, e que buscam ajuda da pressão internacional contra um governo repressivo. Por isso, na maioria dos websites vinculados a Al-Qaeda, as ações de violência não são sobressalientes mas, quando são mencionadas, justifica-se como uma defesa moral e legítima às agressões ocidentais (WEIMANN, 2004).

Nota-se que, embora nos meios tradicionais, como o jornalismo formal, a bandeira e a imagem do grupo apareçam intrinsecamente vinculadas à violência (especialmente abordando as repercussões dos atos terroristas), nos canais online o movimento foca em outra direção e não está necessariamente interessado em propagandear a violência do grupo ${ }^{85}$, mas focar em revelar pontos negativos de seu inimigo que são usados para combater o terrorismo: restrições de liberdade de expressão, métodos antidemocráticos, torturas dos militantes que viraram prisioneiros políticos (WEIMANN, 2004).

As próprias reações do inimigo são utilizadas como peças de propaganda online, que ajudam a construir a imagem do grupo e difundir suas bandeiras. Após os atentados, houve um levante contraterrorista liderado pelos Estados Unidos (a chamada "Guerra ao Terror), e a Al-Qaeda, por sua vez, incitou o chamado contra-contraterrorismo online. Como explica Brachman (2010) o contra-contraterrorismo é um processo de desconstrução da ação ou discurso do outro reagindo com uma outra versão dos fatos. Isto funciona da seguinte

\footnotetext{
${ }^{85}$ Embora o enaltecimento de atos violentos também ocorra em determinados casos, mas, no geral, não é a ênfase preponderante no discurso online.
} 
maneira: o governo dos EUA, ao divulgar alguma ação antiterror, como por exemplo uma nova estratégia militar no Afeganistão, imediatamente ganha cobertura da mídia tradicional e repercussão internacional. Algum membro de inteligência ${ }^{86}$ da Al-Qaeda analisa e espalha a notícia enfatizando de forma pejorativa a atitude dos EUA de tentar minar a luta jihadista. $\mathrm{O}$ monitoramento norte-americano antiterror acompanha esta resposta da Al-Qaeda e deslegitima o discurso jihadista através de seus próprios canais de mídia. Com esta atitude dos EUA, os jihadistas têm a certeza de que são monitorados e se aproveitam da situação para espalhar informações que lhes interessam, inclusive ameaças ao próprio governo estadunidense. O monitoramento é mútuo entre o governo norte-americano e a Al-Qaeda (BRACHMAN, 2010). Assim, para a organização, o importante no contra-contraterrorismo online é a difusão de um conteúdo jihadista que, ao mesmo tempo que exorta a luta, deslegitima e desvaloriza as ações do inimigo.

Brachman (2010), com base em consulta de especialistas da Al-Qaeda, sistematiza algumas narrativas utilizadas nesse sentido: (a) abafar quando os EUA parecem ter feito algo com sucesso contra Al-Qaeda e enfatizar os erros americanos; (b) no caso da morte de um militante, deslocar a atenção para as substituições de outros membros para a luta; (c) desqualificar o inimigo no contexto real, com base em fatos verídicos; (d) espalhar vídeos de americanos mortos, pois na mentalidade dos jihadistas, a imagem desumaniza-os; (e) publicar estatísticas de quantos muçulmanos têm sido mortos por americanos; (f) usar imagens positivas da Al-Qaeda, como por exemplo realizando caridade, ou então incentivando garotas a frequentarem a escola; $(\mathrm{g})$ enfatizar rixas diplomáticas entre os inimigos da Al-Qaeda, para enfraquecê-los: por exemplo, publicar ações de Israel contrárias aos interesses norteamericanos, ou encorajar a desunião entre as partes políticas do Ocidente; (h) publicar e comentar relatórios de contraterrorismo estadunidenses, que costumam ser uma das melhores propagandas da Al-Qaeda.

Publicar conteúdos dessa natureza mostra como os terroristas têm se aproveitado da comunicação digital para recontextualizar as ações contraterroristas dos EUA em prol de sua própria luta, propagando-a. A partir disso, busca difundir narrativas jihadistas que são compartilhadas online ganhando escala. Isso demonstra como os recursos propiciados pela

\footnotetext{
${ }^{86}$ Há especialistas da Al-Qaeda que monitoram o sistema contraterrorista dos EUA. Brachman (2010) descreve o caso de Zachary Adam Chesser, jovem que entrou para Al-Shabab, um grupo terrorista próximo à Al-Qaeda e cujo papel na organização era disseminar a ideologia radical islâmica e inspirar pessoas, chamado de "CounterCounterTerrorism". Sua página no YouTube aumentou de visibilidade em 2010, com mais de um milhão de acessos por ano, sendo que $80 \%$ dos visitantes estão lotados nos EUA, Reino Unido e Canadá.
} 
comunicação digital possibilitam a construção do próprio discurso para além da interferência ou filtro de intermediários (como veículos jornalísticos e outros), tornando esse jogo de poder que envolve a formação da imagem da causa bem mais complexo. Com os recursos online em mãos, os terroristas têm maior controle sobre o conteúdo que veiculam, tanto para manipular sua própria imagem, quanto a de seus inimigos (WEIMANN, 2004; THOMAS, 2003).

A Internet também possibilitou a difusão de mensagem através do processo de viralização online e este elemento tem sido bastante utilizado por redes terroristas como a AlQaeda. Hallams (2013) conta que o vídeo postado do Bin Laden, exortando seus seguidores momentos depois do choque dos aviões, evidencia a habilidade da rede terrorista de minimizar discursivamente o impacto da ação de terror na nação mais poderosa naquele contexto, ou seja, os Estados Unidos. Weimman (2006) aponta que fevereiro de 2004 marca um momento importante da propagação destes grupos vinculados à rede Al-Qaeda, ilustrando assim o sucesso das campanhas de difusão da causa através da Internet. Trata-se da divulgação online do vídeo intitulado "Badr al-Riyadh". Pesquisa desenvolvida pelo SITE Institute (Search for International Terrorist Entities Institute) ${ }^{87}$ demonstrou que o vídeo foi baixado por aproximadamente 400 mil pessoas em menos de 5 dias.

Figura 7- Imagem de trecho do vídeo Badr Ar-Riyadh

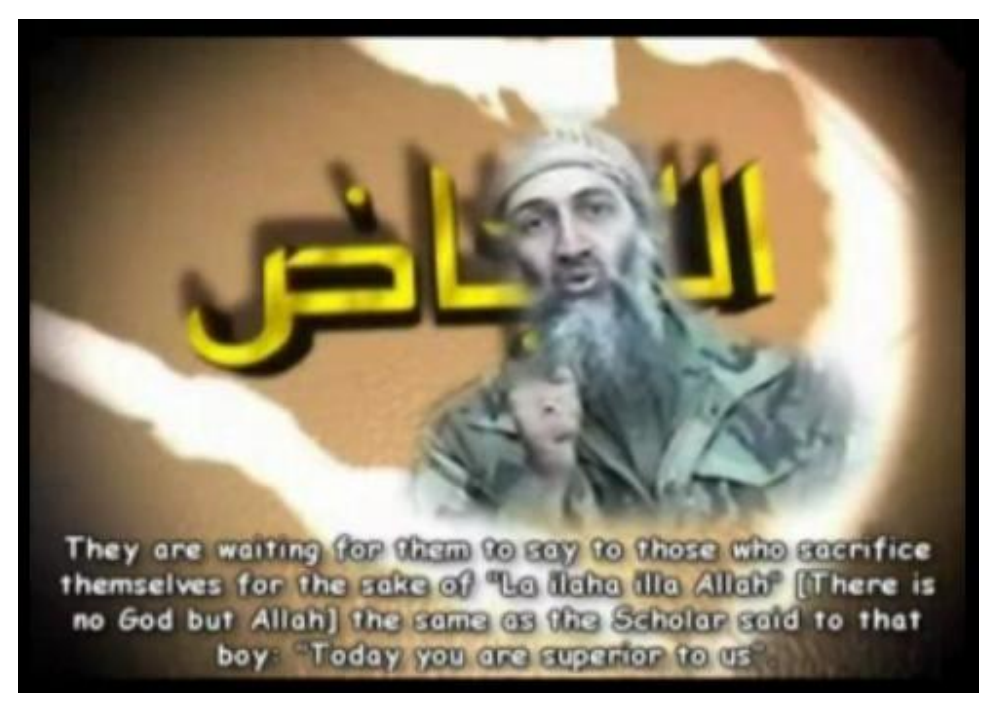

(Fonte: archive.org)

\footnotetext{
${ }^{87} \mathrm{O}$ Instituto foi criado nos EUA em 2002 como um projeto de pesquisa sem fins lucrativos que visava monitorar as atividades terroristas na Web. Em 2008 o projeto foi descontinuado e parte de seus integrantes fundaram o SITE Intelligence Group, uma organização com fins lucrativos que presta serviços similares mediante assinatura: <http://www.siteintelgroup.com/>. Acesso: 07 nov. 2015.
} 
Brachaman (2010) esclarece que a preocupação com a audiência faz parte das táticas da Al-Qaeda, que procuram conhecer o seu público para o qual produzem conteúdos, de modo que a mensagem possa levar em consideração o grau de simpatia, ou rejeição, em relação a Al-Qaeda. A propaganda online é importante nesta difusão, pois conforme enfatiza Rabasa e colegas (2006):

What makes al-Qaeda's propaganda distinctive is the relentlessly global
nature of its dissemination and the quality of its production. As a result of
this media strategy, al-Qaeda's messages have penetrated deeply into
Muslim communities around the world, preying on those Muslims who have
a sense of helplessness both in the Arab world and in the Western Muslim
diaspora. Al Qaeda appears to have had an impact by offering a sense of
empowerment to those uninitiated in Islamic texts and history (p. xviii).

Sabendo manejar a luta jihadista, a Al-Qaeda tem na Internet um sistema que funciona para aproximar a comunidade islâmica, ao mesmo tempo que facilita a difusão do fundamentalismo muçulmano em rede. Realiza, portanto, o proselitismo ${ }^{88}$ entre grupos muçulmanos dentro e fora do Oriente Médio (DEMANT, 2001). Hallams (2013) relata a participação de programadores de software a fim de criarem um navegador particular para realizar busca de sites particulares fornecendo uma livraria online de mais de 3000 livros de pensadores jihadistas para serem baixados inclusive em celulares.

A abertura de canais de conversação também tem sido importante para a difusão da causa. Uma iniciativa ocorrida em 2007 em conjunto com a plataforma Al-Fajr Media Center criou uma chamada de "Encontro aberto com Al Zawahiri" (SORIANO, 2013). O líder jihadista se colocou a disposição para responder perguntas do público em geral num formato de áudio de duas horas com transcrições em árabe e em inglês. Em dois meses o impacto disto foi grande, contando com quase 2000 perguntas a partir de diversas regiões do globo (SORIANO, 2013). Outros meios ainda usados para espalhar sua mensagem é o uso de SMS pelo celular, com mensagens e informações em prol do movimento e suas bandeiras.

\footnotetext{
${ }^{88}$ O proselitismo pode ser entendido como a articulação de um discurso de convencimento para a causa jihadista, apelando para a fé islã como amálgama entre os muçulmanos espalhados ao redor do mundo. Com essa narrativa argumentativa, o proselitismo jihadista dá visibilidade e compartilha informações menos preconceituosas, enviesadas a seu modo, conteúdo a respeito do fundamentalismo islâmico.
} 


\section{c) Massificação}

Um dos pressupostos do método terrorista de ataque é justamente causar comoção pública que, em última instância, gere pressão sobre governos para atender suas reivindicações (WEIMANN, 2006; RABASA et al 2006). O próprio atentado do 11 de Setembro ocorre nesses termos, com aviões se chocando contra prédios em intervalo de tempo suficiente para que todos os aparelhos de registro e câmaras de TV fossem ligadas para transmitir ao vivo a segunda explosão. Sobretudo, o ataque de 11 de Setembro foi produzido e repercutido pela mídia tradicional em escala maciça:

[...] the Black September terrorists' attack was watched live by an estimated audience of 800 million viewers all over the world. The advances in communication technology in the ensuing three decades and the staggering visual images of the events on September 11 combined to make the al Qaeda attacks on the United States the most- watched terrorist spectacle ever (WEIMANN, 2006, p. 41).

Na fase pós-11 de Setembro, quando a Al-Qaeda passou a utilizar a Internet com mais intensidade devido às ações de opressão principalmente dos EUA, não houve abandono do uso da mídia tradicional (como a TV) para dar visibilidade à causa. Há na verdade uma sinergia de uso entre a nova e a antiga mídia. Como demonstram Rabasa e colegas (2006):

In addition to its own media sources, al-Qaeda has made use of the international media to spread its propaganda. This includes Arab media such as the satellite stations al-Jazeera and al-Arabiya. But it also includes Western media sources, particularly CNN, the BBC, ABC news, MSNBC, and other major news networks that have broadcast al-Qaeda's audio and videotapes - particularly those claiming to be of bin Laden - along with other materials such as its training videos. It is perhaps no accident, therefore, that when CNN reporter Peter Arnett asked bin Laden in his 1997 interview what his future plans were, bin Laden answered: "You'll see them and hear about them in the media, God willing" (p. 20).

A cobertura na mídia, aliada ao conteúdo difundido pela Internet, tem uma participação significativa na guerra psicológica empreendida virtualmente pela Al-Qaeda. Thomas (2003) descreve que a imagem do bin Laden que apareceu na Al Jazeera ${ }^{89}$

\footnotetext{
${ }^{89}$ Al Jazeera é uma emissora de televisão criada em 1996 e sediada no Qatar. Ergueu-se inicialmente com foco na cobertura e transmissão em países do mundo árabe. Tem ênfase em noticiário internacional e hoje possui mais de 60 escritórios ao redor do mundo que se estendem por seis continentes diferentes, incluindo canal em língua inglesa. Maiores informações em <http://www.aljazeera.com>. O autor Seib (2012) esclarece que seu
} 
transparecendo estar vivo e bastante saudável pode ter sido manipulada na divulgação online, uma vez que naquele ano de 2003 sabia-se que ele estava bastante machucado:

Al Qaeda combines multimedia propaganda and advanced communication technologies to create a very sophisticated form of psychological warfare. Osama bin Laden and his followers concentrate their propaganda efforts on the Internet, where visitors to al Qaeda's numerous websites and to the sites of sympathetic, aboveground organizations can access prerecorded videotapes and audiotapes, CD-ROMs, DVDs, photographs, and announcements. Despite the massive onslaught it has sustained in recent years - the arrests and deaths of many of its members, the dismantling of its operational bases and training camps in Afghanistan, and the smashing of its bases in the Far East-al Qaeda has been able to conduct an impressive scare campaign. Since September 11, 2001, the organization has festooned its websites with a string of announcements of an impending "large attack" on U.S. targets. These warnings have received considerable media coverage, which has helped to generate a widespread sense of dread and insecurity among audiences throughout the world and especially within the United States (WEIMANN, 2004, p. 5).

Um outro exemplo dessa sinergia entre nova e velha mídia é o vídeo "Badr alRiyadh", citado no indicador anterior desta seção. Pesquisa desenvolvida pelo SITE Institute demonstrou que essa produção, após ser intensamente acessado online, atingiu outras formas de mídia: além da reprodução em canais de TV, também foi compilado para outros suportes analógicos, como vídeo cassete, por toda a Arábia Saudita (WEIMANN, 2006, p. 65).

Figura 8- Tela do site da Al Jazeera com vídeo de Osama bin Laden

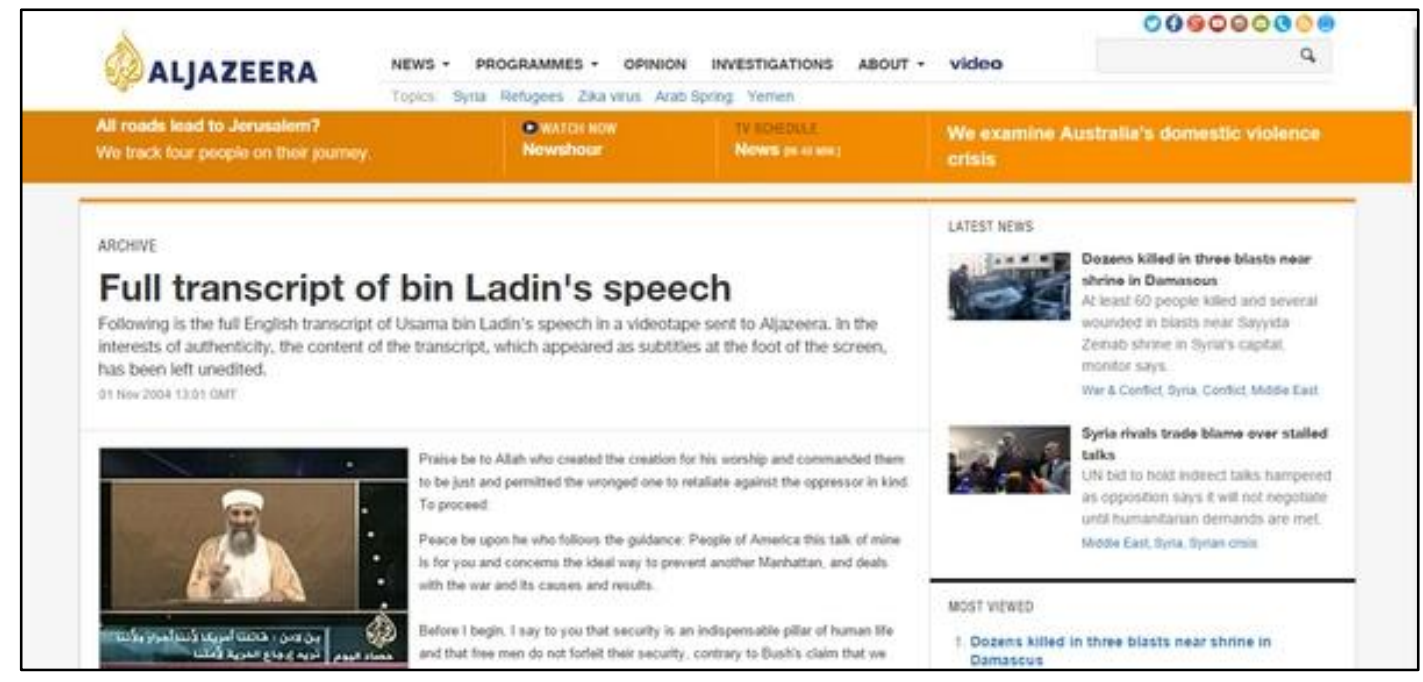

(Fonte: Al Jazeera)

empreendimento foi provocado por interesses de diplomacia pública por parte do emir do Qatar, Hamad bin Khalifa Al Thani, o qual gostaria de atuar no jogo internacional para além da produção de petróleo e gás natural. 
Os pronunciamentos sobre ações presentes e ataques futuros influenciam as percepções midiáticas sobre suas capacidades e trajetórias futuras, consolidando-se como uma fonte importante usada por jornalistas estrangeiros (RABASA et al, 2006). Na prática, a AlQaeda sabe que a Internet é uma fonte certa para jornalistas na busca por informações sobre o grupo e a utilização da comunicação digital acaba servindo como um mediador que facilita também a conexão entre a clandestinidade do movimento e a sua visibilidade na mídia de massa, que por sua vez atinge um público mais amplo, seja comunidades internacionais distantes como o Ocidente, seja comunidades islâmicas que utilizam a TV e rádio como principais fontes de informação.

\subsubsection{Multiplicação do engajamento}

\section{a) Coordenação}

A Al-Qaeda tomou a forma de um grupo transnacional com cerca de 20 mil homens espalhados entre afegãos e células secretas no Oriente Médio, Europa e África. O 11 de setembro foi preparado por uma liderança poderosa e de elite: o milionário homem de negócios saudita Osama Bin Laden, o médico-cirurgião egípcio Ayman al Dhawahiri, o PhD Mohammad Atta, e Ziad Jarrah que era fluente em quatro línguas (MOHAMEDOU, 2011). Sobretudo liderado pelos dois primeiros, inicialmente o grupo era hierárquico: o líder Bin Laden era conhecido como "Abu Abdallah" por seus colegas; o segundo homem era Ayman al Dhawahiri que recebia recomendações de 31 membros de um conselho consultivo separado em 5 comitês operacionais: militar (que também coordenava células internacionais), assuntos religiosos, assuntos financeiros, meios de comunicação e publicidade e logística (MOHAMEDOU, 2011). Esse núcleo de lideranças históricas não se formaram através do uso da comunicação digital, conforme já descrito anteriormente. Porém, já neste século, no processo de desenvolvimento das ações que culminaram com o 11 de Setembro, a Internet serviu como um importante meio de interação e coordenação das ações entre os membros deste núcleo principal e os sequestradores dos aviões sobretudo do ponto de vista operacional (THOMAS, 2003; WEIMANN, 2004; HALLAMS, 2013).

No cyber domain, a comunicação digital também tem possibilitado o surgimento de outras lideranças. Um dos nomes mais ativos e pioneiros no uso da Internet para promover o 
grupo foi Abu Musab al-Zarqawi ${ }^{90}$. Como explica McGrath (2011), al-Zarqawi ganhou notoriedade em capitanear para si o movimento através da comunicação online. Isto inspirou outros grupos e células (vinculadas ou não a Al-Qaeda) que perceberam a relevância desta forma de comunicação e também adotaram tais padrões, ainda que isso contrariasse certos dogmas, como foi o caso do grupo Taliban:

The Taliban, who had banned all human images, for example, developed a video department. Al-Zarqawi also diversified and fragmented global jihadism. As a frontline leader, his cyber-world legend rivaled that of bin Laden, who, while respected, remained in hiding. Al-Zarqawi became a de facto threat to bin Laden's previously unilateral putative dominance in captaining the jihadist movement (McGRATH, 2011, p. 100).

Soriano (2013) traz um outro exemplo: Adam Gadahn, conhecido como "Azzam, o americano". Ele também se tornou um dos nomes mais conhecidos da Al-Qaeda no processo de promoção do grupo, atuando na organização, tradução e distribuição de conteúdo digital para além do mundo islâmico:

Esta implicación de Adam explicaría el salto cualitativo que supuso la difusión, en el año 2000, del vídeo de Al Qaeda La destrucción del USS Cole. Este vídeo de dos horas, perfectamente subtitulado al inglés, incluía un numeroso metraje sobre Bin Laden y su organización pero, ante todo, daba muestras de seguir una estructura inspirada en los guiones cinematográficos. El vídeo tuvo una enorme repercusión en los ambientes yihadistas, reforzando el papel de Adam como propagandista de Al Qaeda. (SORIANO, 2013, p. 331)

O surgimento de lideranças que atuam online e coordenam ações de suporte também ocorre em apoio a outras organizações islâmicas similares à Al-Qaeda, como é o caso do jovem cidadão inglês Babar Ahmad (nascido no Reino Unido, mas de origem paquistanesa). Ele atuou desde o final da década de 1990 coordenando ações online que visavam o levantamento de recursos financeiros e divulgação de movimentos jihadistas (JACOBSON, 2010). Em 1997 criou uma entidade chamada Azzam Publications para arrecadar e espalhar a causa jihadista através de websites. O argumento era simples: para aqueles que não podem lutar presencialmente, podem contribuir de outras maneiras, doando recursos por exemplo. Nas palavras de Jacobson (2010) "To persuade individuals to donate, Babar used a familiar argument on his website - that supporting the jihad in some fashion was an obligation incumbent upon every Muslim" (p. 354).

\footnotetext{
${ }^{90}$ Trata-se de um militante jihadista de origem jordaniana que se autoproclamou "líder da Al-Qaeda no Iraque". Foi morto em 2006 pelas forças norte-americanas através de um ataque aéreo no Iraque (MOHAMEDOU, 2011).
} 
Assim, a Internet tem possibilitado que antigas lideranças se mantenham conhecidas (seja espalhando vídeos ou relatos em websites), ativas e articuladas (seja coordenando ações) através da comunicação online. Ao mesmo tempo, também têm se portado como palco fértil para que outras lideranças atuem e mantenham o movimento dinâmico com novos engajados.

\section{b) Adesão}

Segundo relatos do grupo e de outros membros, para aderir a Al-Qaeda, um ativista deve ser muçulmano, capaz de suportar traumas psicológicos como prisões e mortes, fiel à organização e aos demais membros, mas sem revelar encontros e conversas com os demais membros da organização (BERNER, 2006). Este é o pressuposto geral para o engajamento no movimento. Na prática, a Internet deu espaço a uma gama mais variada de ativistas e mobilizadores, que além de estarem espalhados pelo globo, podem se comprometer em graus e maneiras diferentes, seja dando suporte financeiro e material, seja compartilhando nas redes online manifestações da organização, uma vez que "any terrorist websites stop short of enlisting recruits for violent action but they do encourage supporters to show their commitment to the cause in other tangible ways" (WEIMANN, 2004, p. 9).

Em se tratando de métodos considerados ilegais ou criminosos pela maioria da comunidade internacional (principalmente governos), a adesão a Al-Qaeda não segue os padrões normais de uma organização política tradicional. $\mathrm{O}$ engajamento se torna inviável na forma de assinatura ou entrada oficial em uma organização formal (como é o caso de sindicatos, ONGs, associações multilaterais etc.). Por isso, a comunicação digital se tornou elemento basilar para a filiação ao grupo. Sem o ambiente digital, as chances de engajamento seriam bem mais dificultosas e localizadas, com menor capacidade de internacionalização e expansão. Dados do FBI, trazidos por Hallams (2013), parecem corroborar esta importância: cerca de $80 \%$ do recrutamento terrorista se dá através da Internet. Soriano (2013) também demonstra potentes indicadores de utilização da comunicação digital pelos movimentos jihadistas no ato de recrutamento em países como a Arábia Saudita:

En mayo de 2007, un alto funcionario del Ministerio de interior saudí llegaba a declarar al periódico Asharq Al Awsat que el $80 \%$ de todos los jóvenes saudíes que habían sido reclutados por los yihadistas en su país, lo habían sido utilizando Internet (SORIANO, 2013, p. 312). 
Segundo dados do International Institute for Strategic Studies, em 2003 estima-se que a Al-Qaeda contava com aproximadamente 18.000 membros distribuídos em mais de 60 países e com uma capacidade de recrutamento em trajetória ascendente (SORIANO, 2013).

Em linhas gerais, podemos notar que o envolvimento de pessoas comuns com a AlQaeda ocorre em um movimento duplo (a) a partir da interação por parte de já engajados em aproximar interessados na luta, com esclarecimentos em chats e divulgações de material em sites (b) através do autorrecrutamento.

Um exemplo trazido pelo autor é o caso do estudante de ciências da computação no Columbia College (Missouri). Ziyad Khalil chamou a atenção de bin Laden com suas atividades na Internet como ativista muçulmano e apoiador do Hamas $^{91}$. Logo se tornou um membro da Al-Qaeda e um estratégico ponto de apoio para comunicação nos EUA. Citando outro estudo, Weimann (2006) explica como esta dinâmica interativa do engajamento online funciona:

According to Zanini and Edwads: Using some of the same marketing techniques employed by commercial enterprises, terrorist servers could capture information about the users who browse their web sites, and then later contact those who seem most interested. Recruiters may also use more interactive Internet technology to roam online chat rooms and cyber cafes looking for receptive members of the public, particularly young people. Electronic bulletin boards and user nets can also serve as vehicles for reaching out to potential recruits. Interested computer users around the world can be engaged in long-term "cyber relationships" that could lead to friendship and eventual membership (WEIMANN, 2006, p. 118).

Na avaliação de MacGrath (2011) a Al-Qaeda encontrou na web uma excelente ferramenta de recrutamento e "Compared to their Afghan jihad predecessors, the newest generation of Al Qaeda members is far more technologically sophisticated. The Web's anonymity masks ancient prejudices and offers a " 'virtual sanctuary' on a global scale to propagandize" (p. 72). Na mesma linha, Weimann (2006) conclui que "Without recruitment terrorism cannot survive and develop. "Recruitment provides the killers, the suicide bombers, the kidnappers, the executioners, the engineers, the soldiers, and the armies of modern terrorism" (p. 117). O autor cita dados do SITE Institute apontando que:

\footnotetext{
${ }^{91}$ Hamas trata-se de uma organização muçulmana atuante principalmente na Palestina e em Gaza, de influência sunita. O nome "Hamas" significa "Movimento de Resistência Islâmica". O grupo é considerado uma organização terrorista por diversos países ocidentais como os EUA e países da União Europeia, bem como por Israel (este último, considerado seu maior inimigo, devido à ocupação israelense nos territórios palestinos).
} 
[...] al Qaeda's Internet communications, has provided chilling details of a high-tech recruitment drive launched in 2003 to recruit fighters to travel to Iraq and attack U.S. and coalition forces there: "potential fighters are bombarded with religious decrees and anti-U.S. propaganda as well as training manuais on how to be a terrorist. Willing recruits are also being given specific instructions on how to go to Iraq through a maze of secret chat rooms" (WEIMANN, 2006, p. 120).

Apesar dos indícios, dados e fatos sobre engajamento online, o pesquisador Thomas Hegghammer (2013) contesta que haja de fato recrutamento digital efetivado pelo grupo. Segundo este autor, embora a Internet seja central principalmente no esforço de propaganda, não há registros de pessoas recrutadas online:

Nevertheless, there are no accounts in [al-Qaeda on the Arabian Peninsula] QAP literature of people being recruited online. Instead, QAP leaders explicitly apologized for not being able to accept joining offers submitted over the Internet and encouraged people to form independent cells instead (HEGGHAMMER, 2013, p. 7).

Ele menciona o caso de uma pessoa frustrada devido à dificuldade de se tornar um membro, motivo pelo qual precisou realizar o seu ataque terrorista de forma independente da organização, sem nenhum tipo de auxílio. Para Hegghammer (2013), assim como não se tem evidências de recrutamento nas mesquitas, sobretudo depois de 2002, devido ao risco do recrutador ser flagrado na atividade, o mesmo receio ocorre frente ao ambiente online:

The virtual world was somewhat safer for recruiters to frequent, but it was not used for recruitment, presumably because digital signal costs are harder to verify. [al-Qaeda on the Arabian Peninsula] QAP is not unique in this respect. Jihadi Internet propaganda has inspired individuals to approach organizations, but there are very few known cases of established groups soliciting new recruits online (Taarnby, 2005: 39; Watts, 2008: 2). For the most part, initial contact between QAP recruiters and recruits seems to have been established in two types of places: social gatherings in private homes and private lectures by radical preachers (p.8).

A afirmativa de Hegghammer deve ser considerada como correta apenas se entendermos "recrutamento" no sentido estrito formal, ou seja, de uma organização filiando engajados através de inscrições via website. Nesta perspectiva, isso de fato não ocorre. Por outro lado, indo além do que afirma o autor, não devemos entender recrutamento neste sentido reduzido e formalístico. De fato, compreender a atividade de recrutamento como um anúncio explícito da Al-Qaeda não é totalmente defendida nem por aqueles autores que 
reconhecem o recrutamento online como parte das atividades da organização. Ainda que Rabasa e colegas (2006, p. 18) destaquem a existência de anúncios de "chamados" que podem ser interpretados como recrutamento: "The jihadist Internet even has job advertisements. A Global Islamic Media Front posting in October 2005 advertised open positions for 'electronic mujahideen'". Percebe-se que estudiosos como Brachman (2010) e Weimman (2004) entendem o recrutamento como um conjunto de ferramentas de atração e cooptação, voltado para um público simpatizante com a causa, mas não propriamente mobilizado. Por isso, boa parte da propaganda online produzida pelo movimento, incluindo produção imagética, tem sido focada no recrutamento, como demonstra Seib (2012):

\begin{abstract}
Al Qaeda has its own production company, As Sahab, that creates videos for online viewing. Anwar al-Awlaki, who was head of Al Qaeda in the Arabian Peninsula before being killed in a US drone attack, had been called by some "the Bin Laden of the Internet" and had adherents including three of the 9/11 hijackers, the perpetrators of the failed 2009 Christmas Day airliner bombing and the 2009 shootings at Fort Hood, and others. Awlaki, who was born in the United States and held US and Yemeni citizenship, disseminated his sermons, in Arabic and English, through numerous websites. US counterterrorism officials had been particularly worried about him because his English-language Internet videos were designed to recruit American Muslims to stage attacks within the United States (p. 61).
\end{abstract}

Além disso, o próprio exemplo descrito por Hegghammer (2013) deve ser compreendido como um ato de recrutamento ou, melhor dizendo, de "auto-recrutamento", indo além do sentido meramente formal. Visto por Burke (2007) como uma vantagem que fortalece a Al-Qaeda, ao invés de ser um fraco e superficial engajamento, como alguns acreditavam, o uso das modernas tecnologias da comunicação pode alcançar um grande número de pessoas sem o pressuposto do contato face a face. A Internet se tornou um meio plenamente capacitado para servir como ferramenta de mobilização da comunidade muçulmana espalhada ao redor do mundo. Isto porque, esse novo contexto tecnológico remodelou a própria ideia de recrutamento, potencializando-o para uma dimensão das interações simbólicas.

Assim, o aparentemente inofensivo fato de alguém se auto-recrutar online - no nível das interações simbólicas - não significa algo abstrato e sem efetividade na vida real: um homem-bomba, autorrecrutado online, é capaz de fazer um estrago significativo. Tanto quanto aquele que entrou por vias tradicionais no movimento.

Mas como todo esse contingente engajado se articula e se reconhece como parte de um 
mesmo movimento ativista? A resposta é: protocolos de segurança e interação online. Para criar certos parâmetros de identidade através da comunicação digital, a própria característica do meio possibilita recursos para proteger os engajados. Certas práticas de segurança em websites jihadistas utilizam ferramentas de criptografia, uso de navegação anônima ou TOR ${ }^{92}$ na deep web. Todos esses instrumentos possibilitam a construção de identidade e o engajamento transnacional (SCHUMANN, 2015). Nesta mesma linha de análise, Seib (2012) aponta que:

The Internet binds together the amorphous cloud of jihadist groups, spreads the ideology, weaves together the 'single narrative' that Islam is under attack, popularizes militant acts, and distributes terrorist know-how. Because Al Qaeda is so dispersed, the fight against it has strained an international order still based on sovereign states (138139).

Já a interação online se dá a partir de uma estrutura em rede, com teor mais horizontalizado. Como demonstra alguns autores (SAGEMAN, 2004; RABASA et al, 2006), o engajamento neste tipo de ativismo está mais próximo de um processo com vetor de baixo para cima (bottom-up) do que de cima para baixo (top-down). As redes pessoais também agem paralelamente como elemento importante nesta dinâmica de engajamento, reafirmando esta difusão horizontalizada. Ao estudar as características de 150 terroristas vinculados a AlQaeda, Marc Sageman (2004) descobriu que 68\% desses tinham amigos jihadistas e 20\% tinham parentes jihadistas. Esse engajamento é marcado também por um sentimento difundido de irmandade sendo comum a utilização do termo "família" entre os ativistas para designar células que atuam em determinada região ou país, como "família egípcia", "família tunisiana" etc. (GUNARATNA, 2002). Ou seja, redes pessoais e redes online se fundem gerando sinergia para o engajamento.

Weimann (2006) aponta que, diferentemente de outros grupos islâmicos terroristas que conseguem manter seu próprio website oficial, a Al-Qaeda depende de uma rede de colaboradores que gerenciam websites considerados semi-oficiais para difundir suas mensagens:

AI Qaeda's sites are maintained by group members and by supporters who are in direct contact with the members. [...] Many sites are registered or hosted in Europe, Asia, or even the United States. The use of American hosts should not surprise anyone: according to a July

\footnotetext{
92 O TOR é um software que viabiliza a comunicação e navegação anônima principalmente na chamada Deep Web.
} 
2004 survey, 76 percent of Islamic terrorist Web sites are hosted by U.S. companies. Many of these Web sites are openly anti-American and anti-West (WEIMANN, 2006, p. 67).

Isso só se tornou possível devido às características fugidias da comunicação digital e a possibilidade de estruturação em rede que este meio possibilita. Diante do aparato de repressão hoje existente, dificilmente esses grupos apoiadores conseguiriam se multiplicar caso utilizassem apenas métodos e formas tradicionais de interação.

A fim de angariar seguidores para a Al-Qaeda, observa-se que membros têm desvinculado a imagem de violência em seus websites de propaganda jihadista e, desse modo, buscam espalhar a ideologia de forma mais receptiva através da Internet. Outro método incorporado é o debate aberto através de fóruns de discussão online, agregando indivíduos dentro do chamado like-minded, isto é, colocar em contato aqueles que partilham da mesma crença e interesses criando uma rede entre eles (BRACHMAN, 2010; COUTINHO, 2012). Há ainda estratégias para alcançar a geração mais jovem, como por exemplo vídeo games de conteúdo radical islâmico, cujo objetivo é matar forças militares americanas, judeus e outros "infiéis" (qualificação dada pelo islamismo a quem não é do islã) para se estabelecer um califado global islâmico (HALLAMS, 2013).

É importante notar que há uma forte relação entre "visibilidade" e "recrutamento". No caso do engajamento de adesão, o objetivo do uso da comunicação digital é claro: criar condições favoráveis para que indivíduos propensos à causa jihadista se utilize de meios factíveis para que realize a sua participação mais ativa através dos diversos estilos de participação e graus de envolvimento. Isso vai desde a mobilização de apoio à causa, através do compartilhamento de notícias favoráveis ao movimento, até ações de apoio mais esporádicas e de caráter técnico:

Al Qaeda has used its websites to urge its followers to make full use of the Internet. This message was on one of the sites: "We strongly urge Muslim Internet professionals to spread and disseminate news and information about the Jihad through e-mail lists, discussion groups, and their own Web sites. If you fail to do this, and our site closes down before you have done this, we may hold you to account before Allah on the Day of Judgment" (SEIB, 2012, p. 138).

É o caso dos "terroristas caseiros", assim definido por Coutinho (2012), que abrangem entusiastas ocidentais que tomam conhecimento da causa via Internet e se engajam sem sair de casa. Um bom indicador da dimensão dessa rede de engajamento é Global Islamic Media 
Front $(\mathrm{GIMF})^{93}$ - um dos principais grupos online de apoio às ações da Al Qaeda - que chegou a ter mais de 7.400 membros em 2004:

Al Qaeda's GIM online group had more than 7,400 members in 2004, and al Qaeda used this group to communicate with members and sup- porters throughout the world. Postings, which use an IP address in Ottawa, Canada, include the major online publications of al Qaeda, such as Sawtal-jihadand AlBattar. Additionally, messages taking credit for terrorist attacks are often posted on this Web site (WEIMANN, 2006, p. 228).

Mesmo websites abertos e populares que disponibilizam chats, e-mails e grupos de discussão (como o Yahoo!) têm um papel importante como instrumento para o engajamento. Nesses espaços os apoiadores têm acesso a vídeos de tortura, operações de carros-bombas, sermões de jihadistas, homenagens a bin Laden etc. Se um desses grupos é removido, são criados novos grupos pelo livre e ilimitado acesso fornecido pelas plataformas digitais (WEIMANN, 2006).

Os pesquisadores Lutz e Lutz (2004) chamam de "part-time activists" os terroristas que muitas vezes participam do planejamento e financiamento de ataques, ao mesmo tempo em que se dedicam a outras atividades além da luta, e nem sempre participam de uma organização permanente, o que lhes renderia um status de dedicação temporária ou pouco formal, mas que não implicaria em menos comprometimento com a causa:

La oportunidad de participar y realizar una contribución personal a la «yihad en la red», mediante la réplica y edición de contenidos, la discusión, o la aportación de ideas, constituye una importante fuente de reafirmación personal y reforzamiento de la conducta (SORIANO, 2013, p. 308).

Há também os "jihobbyists" definidos por Brachman (2010), que realizam atividades técnicas e de alto nível ligadas à tecnologia em prol da Al-Qaeda. Alguns criticam tal termo, por acreditarem que subestimaria a ação online bastante ativa dos jihadistas, e traria visão equivocada de menor comprometimento, tal qual um hobby, minimizando a importante tarefa de repostar vídeos, artigos, criar contas no Facebook, Twitter etc. (BRACHMAN, 2010).

Outro tipo de engajamento de adesão bastante importante é o doador. Burke (2007) lembra que a organização possuía significativos recursos financeiros oriundos de uma rede

\footnotetext{
${ }^{93}$ No decorrer das discussões desta seção, o nome da organização aparecerá descrito por alguns autores apenas como "Global Islamic Media" e a sigla (GIM). Ou seja, sem a palavra "Front" e o respectivo "F" ao final, conforme consta no nome oficial. Em ambos os casos, trata-se da mesma organização.
} 
global vinculada à difusão do terrorismo - tanto de indivíduos, quanto de organizações. Para os atentados de 11 de Setembro foi necessária a quantia de 500 mil dólares (BURKE, 2007). Não há dúvida de que as tecnologias de informação e comunicação ampliaram as possibilidades de arrecadamento financeiro para a Al-Qaeda. O amplo alcance transnacional, a eficiência nas transações bancárias, o anonimato e a segurança para doadores e receptores são alguns desses fatores (RABASA et al, 2006; JACOBSON, 2010). Um exemplo trazido por Weimann (2006) demonstra cifras relevantes recebidas por organizações jihadistas através da Internet:

Until it was modified, the Islamic Assembly of North America (IANA) had a Web site (Islamway.com) "that offered Arabic-language videos with graphic scenes of jihadist combat and called for contributions. IANA has received $\$ 3$ million since 1995, according to FBI court filings; much of the contributions came from abroad. U.S. government officials are tracing the finances of IANA (WEIMANN, 2006, P. 135).

Com a descentralização da Al-Qaeda, principalmente após a repressão estadunidense, Jacobson (2010) ressalta que o movimento já não conseguia angariar fundos para os ataques do mesmo modo que ocorria até o 11 Setembro. Diferentes frentes de engajamento de doadores online foram desde então abertas. Dentre elas têm-se as doações diretas de pessoas físicas para o grupo. Soriano (2013) afirma que qualquer pessoa tem à sua disposição ferramentas para apoiar financeiramente a Al-Qaeda. Como aponta Weimann (2006), a comunicação digital "allow terrorists to identify users with sympathy for a particular cause or issue", e possibilita assim a viabilização deste tipo de engajamento de doação. Devido às possibilidades de convergência que o meio digital possibilita, esses fragmentos de recursos acabam atingindo somas relevantes. Weimann (2004) explica ainda que a Al-Qaeda consegue filtrar e mapear usuários identificados à causa para estimulá-los a fazer doações. Diversos ativistas são encarregados apenas de levantar fundos online para a organização (JACOBSON, 2010).

A prática de atividade criminosa também faz parte das alternativas para angariar fundos pelos terroristas, como fraudes, roubos, transações ilegais e tráfico de drogas (BURKE, 2007; JACOBSON, 2010; THOMAS, 2003; WEIMANN, 2004). Um exemplo é o engajamento do jovem inglês Younis Tsouli, conhecido como o rei do terrorismo na Internet (JACOBSON, 2010). Ao começar a postar vídeos sobre o terrorismo, Tsouli percebeu que precisava de dinheiro para alocar em sites de qualidade, por isso passou a usar cartões de crédito roubados 
para realizar sua tarefa, atividade em que foi muito bem-sucedido, inclusive com reconhecimento dos líderes da Al-Qaeda no Iraque (JACOBSON, 2010). O caso do Tsouli não é isolado, pelo contrário, a prática comum de hackear sites de cartão de crédito é divulgada para outros membros da rede terroristas realizarem com segurança, isto é, com proteção de sua identidade e total eficácia de resultados (JACOBSON, 2010). Na ação de levantamento de fundos de forma ilícita, "[...] al-Qaeda uses various security measures, such as "anonymisers" that replace the IP address assigned by an Internet service provider with an "anonymiser" address that cannot be tracked" (RABASA et al, 2006, p. 57). Além disso, o movimento também tem usado websites de apostas para lavagem e recebimento de dinheiro (McGRATH, 2011). O mais curioso é que os sites mais cotados para serem utilizados como hospedagem são os norte-americanos, por serem de boa qualidade e com preços reduzidos.

Segundo Jacobson (2010) "Terrorists use of the Internet to raise and transfer funds is also part of a broader global shift toward the use of technology in international commerce" (p. 356). Por isso diversas facilidades encontradas para qualquer organização política traz benefícios para a Al-Qaeda. Dentre elas, tem-se a possibilidade de mascarar a identidade de quem angaria fundos pela Internet, de utilizar as transações financeiras instantâneas como PayPal e o M-payments (transações pelo celular), de usar meios técnicos (softwares e proxy servers) para trazer anonimato no usuário e proteger o endereço do IP (Internet Protocol) (JACOBSON, 2010).

\section{c) Colaboração}

No nível do engajamento de colaboração a Al-Qaeda tem se utilizado da Internet para receber apoio, tanto financeiro, de organizações que funcionam como atravessadores na captação de recursos, quanto político (de outros grupos terroristas islâmicos). Weimann (2006) traz alguns exemplos dessas redes de apoiadores e demonstra que, mesmo que haja uma repressão ${ }^{94}$ para desativá-la, continua se replicando:

\footnotetext{
${ }^{94}$ Ressalvando que essa repressão existe, é substancial e não significa que os websites consigam manter-se intactos a todo o tempo ou que tenham conseguido se sofisticar a ponto de estancar as ações de sabotagem, como demonstra Soriano (2013): "Según Aaron Weisburd, el creador de Internet Haganah, una organización dedicada a monitorizar la presencia yihadista en el ciberespacio: el $80 \%$ de las principales webs que aparecieron entre 2002 y 2004, han desaparecido, incapaces de soportar el hostigamiento continuo de organismos como los que él mismo preside. Según relata este activista en un artículo colgado en su propia página, aunque todas estas webs han ido mejorando progresivamente su apariencia gráfica, técnicamente continúan presentando las mismas
} 
The UK-based Muslim al-Muhajiroun organization has a Web site affiliated with al Qaeda, run by Sheikh Ornar Bakri Moharnmed. On its Web site, the organization calls itself "the voice, the eyes, and the ears of the Muslim people. [...] Although the text claims that Muslims could not have been behind the 9/11 attacks, it then praises the hijackers: "For them [nonMuslims], attacks such as the September 11th Hijackings is a viable option in Jihad [...]. One of al Qaeda supporting organizations, S.O.S. (Supporters of Shareeah), has a very modern and sophisticated Web site. [...] Numerous Web sites are used by, linked to, or associated with al Qaeda, and despite all attempts to ban or destroy the Internet presence of bin Laden and his supporters, their presence and activities on the Net have only become more conspicuous, more significant, and more sophisticated (p. 72-75).

Porém, após o 11 de Setembro, instituições dessa natureza têm sido bastante monitoradas:

The U.S. government has also frozen the assets of three seemingly legitimate charities that use the Internet to raise money-the Benevolence International Foundation, the Global Relief Foundation, and the Al-Haramain Foundation - because of evidence that those charities have funneled money to al Qaeda" (WEIMANN, 2004, p. 8).

Como explica o autor, nos EUA, três websites atuavam neste sentido: Benevolence Internacional Foundation (BIF), the Global Relief Foundation (GRF) e Al-Haramain Foundation. Todos foram bloqueados por receberem caridades e encaminharem para o grupo:

According to the FBI, the BIF raised millions of dollars for bin Laden. It also reportedly sent $\$ 600,000$ to Chechen extremists trained by Al-Qaeda. In addition, the BIF was linked to the 1993 World Trade Center bombing [...] The third lslamic foundation whose assets the U.S. government has seized is the al-Haramain Foundation, based in Saudi Arabia and active in more than fifty countries (WEIMANN, 2006, p. 139).

Porém, mesmo com o bloqueio norte-americano, muitas organizações reabriram seus escritórios, conforme relato de Rabasa e colegas (2006): "[...] illegitimate organizations posing as charities and nongovernmental organizations are reopening offices - virtual or real- after having been targeted and shut down by the United States and its allies" (p. 57). Corroborando este indicador, Soriano (2013) afirma que uma parte significativa do

deficiencias que las hacen vulnerables a las actividades de sabotaje" (p. 343). Embora Weimman (2006), na citação anterior, afirme a sofisticação do website Supporters of Shareeah (vinculado à Al-Qaeda), significa dizer que, no geral, os sites jihadistas não adquiriram a sofisticação necessária para impedir a repressão, mas já há exemplos de melhorias que pode ser uma tendência conforme os ativistas percebem novas formas de driblar sabotagem e utilizar ferramentas de segurança contra ataques. 
financiamento do terrorismo jihadista vem de fundos desviados por instituições de caridade muçulmanas e intermediários financeiros, especialmente oriundos do Oriente Médio.

O estudo sobre análise de redes desenvolvido pela pesquisadora Barber (2015) apresenta um resultado interessante acerca da forma como a Al-Qaeda se comportou ao longo do tempo em relação às redes afiliadas e à formação de uma rede global. Houve uma expansão dos grupos afiliados para além dos objetivos da Al-Qaeda, de modo que a Al-Qaeda foi gradualmente perdendo controle. A pesquisadora demonstra que até o 11 de Setembro a organização conseguiu manter os demais grupos afiliados sob sua influência, a exemplo do Islamic State (IS), Hamas (Islamic Resistance Movement) e Boko Haram (o estudo analisou as relações de rede entre 56 organizações afiliadas a Al-Qaeda). Porém, após os ataques, esses grupos passaram a conectar-se entre si, não mais tendo apenas a Al-Qaeda como horizonte ou direção. Por isso, a ideia de uma vasta rede altamente controlada pela Al-Qaeda pode ser falha:

Ultimately, the image of a vast and tightly controlled network of organizations with Al Qaeda Core pulling all the strings does not seem to be realistic. While that may have been the case on a smaller scale, during the group's time "under the radar", its leap to infamy with the September 11th attacks appears to have marked the end of that structure. Indeed, it never fully met the requirements of a strong network, as defined within this project. Rather, we have a large, increasingly regionalized network that, while at least inspired and sometimes aided by Al Qaeda, does not maintain the idea of a unified, globalized movement. In the end, with great networks comes a great lack of control (BARBER, 2015, p. 24).

Mesmo sem o controle direto das redes que se expandiram, tais organizações mantém algum nível de solidariedade em sua relação a Al-Qaeda, ainda que divergências de meta ou de método sejam hoje bastante comuns e ainda que haja casos de rompimentos declarados ${ }^{95}$. De um modo ou de outro, a Internet tem sido uma ferramenta importante na manutenção desta solidariedade e da conexão entre estas redes colaborativas.

\footnotetext{
${ }^{95}$ Como é caso de Ayman al-Zawahiri, uma das lideranças da Al-Qaeda, que passou a criticar os caminhos e a liderança do Estado Islâmico. Ver em < http://www.mirror.co.uk/news/world-news/al-qaeda-declares-war-isis$\underline{6422015}>$ > Acesso: dez 2015.
} 


\subsubsection{Flexibilização da estrutura}

\section{a) Virtualização}

Atualmente, a sede de fato da Al-Qaeda é o vasto espaço virtual que tem coesão pelos usos de ferramentas digitais e novas mídias mais do que definido pelas fronteiras de um território (SEIB, 2012). O crescimento de websites jihadistas ao longo do tempo é um forte indicador deste fenômeno. A pesquisadora Hallams (2013) apresenta dados que mostram o salto de apenas dois sites em 1998 para mais de 4.700 em 2005. Além disso, a pesquisadora também estima, citando dados do Federal Bureau of Investigation (FBI), que há entre 5 mil e 10 mil websites radicais atualmente em funcionamento (HALLAMS, 2013).

A pesquisa Dark Web Terrorism Research, iniciada em 2003 pelo Laboratório de Inteligência Artificial da Universidade do Arizona (Artificial Intelligence Laboratory), acentua ainda mais estes números na medida em que contabilizou também conteúdo na chamada Internet oculta, que não aparece nos sites de busca convencionais e contam com acesso restrito, identificando assim a tendência do aumento da presença de grupos terroristas na Web:

El resultado fue la recopilación manual efectuada por Gabriel Weimann hasta 2006 (unas 5.000 webs terroristas), habían quedado ampliamente superados. De hecho, según los datos obtenidos por este grupo de investigación, la presencia terrorista en la red en el año 2007 podía cifrase en unos 50.000 sites elaborados en más de quince lenguas distintas (SORIANO, 2013, p. 299-300).

Em uma contagem mais geral de conteúdos através de softwares de rastreamento (spidering) os pesquisadores detectaram volumes significativos de atividade online:

[...] sus ordenadores han almacenado hasta el momento 500 millones de páginas, archivos y comentarios, procedentes del contenido parcial de solo un quinto de las cincuenta mil sites detectados. Algunas de esas páginas webs llegaban a albergar individualmente más diez mil páginas de contenidos y archivos. En cuanto a los foros, su volumen supera los trescientos. Algunos de los más importantes tienen más de 30.000 miembros registrados y un millón de mensajes alojados. En cuanto al contenido multimedia, la información recopilada hasta el momento, abarcaba más de un millón de imágenes de temática terrorista y más de 15.000 archivos de vídeo, la mitad de ellos con imágenes de la explosión de artefactos explosivos caseros (IED) (SORIANO, 2013, p. 300). 
Esta tendência também se aplica a Al-Qaeda, a qual certamente não é o único grupo terrorista que utiliza a rede, mas é emblemática na conduta de atividades neste meio como seu espaço-mor de interação (MCGRATH, 2011; RABASA et al). Trata-se de um tipo de estrutura que possibilita a interação em rede, inclusive servindo como locus para o diálogo entre lideranças, engajados e apoiadores:

Otra prueba de la creciente vinculación de los administradores de estos foros y los operativos de las organizaciones yihadistas la podemos encontrar en una iniciativa conjunta de del foro yihadista Al Fajr y del brazo mediático de Al Qaeda, Al Sahab, difundida el 16 de diciembre de 2007. Bajo el nombre de «Encuentro abierto con Al Zawahiri», este portal difundía un anuncio donde se mostraba la predisposición del líder terrorista a responder a las preguntas enviadas previamente por los internautas. En anuncio establecía que las preguntas debían ser «breves y concretas», y que estas deberían ser enviadas a través de algunos de los siguientes foros: Al Ekhlass, Al Hesbah, Al Boraq y Al Firdaws. Según este comunicado, los administradores de estas páginas tenían instrucciones de cómo hacer llegar las cuestiones al núcleo de Al Qaeda (SORIANO, 2013, p. 301-302).

Em um outro exemplo, Soriano (2013) lembra que a plataforma pró-Al-Qaeda Global Islamic Media (GIM) lançou em 2007 o que denominou de "primeiro software islâmico para trocas seguras na internet" (SORIANO, 2013, p. 342). Tratava-se de um programa de computador capaz de criptografar (codificar) mensagens de forma fácil e portátil, através de um pendriver (via USB) sem precisar de instalação, especialmente útil para os ativistas usarem em cibercafés e outros lugares de acesso público para utilizar a Internet com segurança (SORIANO, 2013). Por isso, o uso e a posse de computadores por membros da AlQaeda se tornou tão recorrente e importante para a própria subsistência do movimento:

As the Taliban collapsed and Al Qaeda lost its Afghan sanctuary, Osama bin Laden biographer Hamid Mir watched 'every second Al Qaeda member carrying a laptop computer along with a Kalashnikov' as they prepared to scatter into hiding and exile. On the screens were photographs of September 11th hijacker Mohamed Atta (McGRATH, 2011, p. 71).

Na prática, a Internet se configurou como o $h u b^{96}$ (que ocupa as funções de uma sede física) onde os ativistas se "encontram", interagem e determinam ações:

\footnotetext{
${ }^{96}$ Em informática, um " $h u b$ ” consiste em um aparelho através do qual diversos computadores e outras máquinas se conectam, possibilitando assim a formação de uma rede.
} 
Al-Qaeda has perfected the use of information technology (IT), particularly the Internet, as a terrorist tool, and has made use of the mass media to spread its propaganda. Part of what makes al-Qaeda and its affiliates such a difficult challenge is that they are able to "hide in plain view." Jihadist groups in Western Europe are embedded in the broader Muslim communities and have used the services and infrastructure available on the continent for propaganda, indoctrination, recruitment, and operations on the scale of the March 2004 Madrid terrorist attack (RABASA et al, 2006, p. xxvii).

Vale lembrar que a Al-Qaeda chegou a possuir um website oficial chamado Alneda (que significa "o chamado") e que funcionava no endereço www.alneda.com. Seu funcionamento foi retirado em 2002, porém, o movimento passou a contar com uma rede de outros websites semi-oficiais que em 2003 chegavam a 50 (WEIMANN, 2006), que desde então cumpriam o mesmo papel da Alneda, porém de forma menos centralizada.

\section{b) Descentralização}

A destruição física dos assentamentos de treinamento no Afeganistão não impediu que os militantes de várias partes do mundo quando retornaram aos seus lugares de origem sustentassem a rede de cooperação (LUTZ; LUTZ, 2004). Como lembra Weimann (2004) tratam-se de células independentes sem comando hierárquico, compartilhando entre grupos terroristas maneiras de como construir bombas, estabelecer núcleos de terror e conduzir ataques. Este formato de organização também possibilitou a formação de redes de engajados que nem sempre se envolvem diretamente em ataques, mas que endossam a causa através de diversos níveis de envolvimento, como vimos no indicador anterior. Organizando-se em rede via Internet, o movimento pôde mobilizar a participação tanto individual, como outros grupos, criando redes de apoiadores em sua estrutura, sendo possível colocar em contato e criar solidariedade entre grupos islâmicos terroristas de diversas vertentes (THOMAS, 2003).

Esta última característica trata da comunicação interna que se expande para outras redes, estabelecendo o chamado "networking" (WEIMANN, 2004) ou "rede de redes" (BURKE, 2007). Neste mesmo sentido Lutz e Lutz (2004) afirmam que "Such modern technology [internet] obviously has permitted antigovernment groups to work together without necessarily always coming together" (p. 83). Gustavo de Aristegui, político espanhol e especialista em terrorismo, citado por Seib (2012), identificou quatro tipos de redes na qual a Al-Qaeda está estruturada: 
He reported that "first, there is the original network, the one that committed 9/11, which uses its own resources and people it has recruited and trained." Second is the "ad-hoc terrorist network, consisting of franchise organizations that al Qaeda created - often to replace ones that weren't bloody enough - in countries such as the Philippines, Jordan, and Algeria." Third, said Aristegui, is an umbrella network, "a strategic union of like-minded companies" tied to Al Qaeda by common purpose and funds provided by bin Laden. In the fourth network are the "imitators, emulators" who agree with Al Qaeda's program but have fewer financial connections to bin Laden. Members at this level, said Aristegui, carried out the 2004 Madrid bombings (SEIB, 2012, p. 138).

Nota-se que há uma variação e gradação nas formas de participação, incluindo as redes de apoiadores que são parte da estrutura de funcionamento do movimento.

Burke (2007) menciona que o velho estilo dos grupos fundamentalistas islâmicos, hierarquizado e estruturado de forma mais ou menos centralizada, pronto para usar métodos violentos - ou seja, aquele modelo que deu maior visibilidade a Al-Qaeda no final dos anos de 1990 - permaneceu inalterado até um pouco depois da invasão do Afeganistão (quando os EUA desmantelaram todas as manobras táticas daquela região). A partir daí, houve uma mudança na estrutura do movimento em duas direções principais: (a) Passou a operar sob a lógica das redes e (b) passou a aplicar hierarquização online de seus militantes no âmbito dessas redes.

Operar sob a lógica das redes consistiu em se estruturar a partir daquilo que Gerlach e Hine (1970) chamaram de descentralização, segmentação e reticulação ${ }^{97}$. A descentralização tem a ver com tomada de decisão. Segmentação se refere à estrutura social - a composição das partes que compõem o movimento como um todo. Reticulação diz respeito à forma como essas partes estão amarradas umas às outras em uma rede (GERLACH; HINE, 1970). A partir do uso das redes digitais, a Al-Qaeda se formatou nesta estrutura. Significou abandonar a forma físico-espacial tradicional, que era centralizada em uma base no meio do deserto com um comando rígido visível, e passar a operar algum nível de descentralização através do espraiamento de células ${ }^{98}$ terroristas independentes, em uma estrutura organizativa segmentada (em diversas micropartes) e articulada (como uma teia) por uma identidade e bandeira compartilhadas (GUNARATNA, 2002; BRACHMAN, 2010; COUTINHO, 2012; SORIANO, 2013). Como descreve Seib (2012):

\footnotetext{
${ }^{97}$ Conforme discutido na seção 4.3.3.

${ }^{98}$ The membership of an Al Qaeda cell varies from two to fifteen, a cellular network that draws heavily on the conspiratorial model of the Islamic Group of Egypt and the Egyptian Islamic Jihad introduced by alZawahiri, who had restructured and professionalised the latter after a series of setbacks (GUNARATNA, 2002, p. 97).
} 
A RAND study reported that before the US invasion of Afghanistan, Al Qaeda featured a combination of a hub-and-spoke structure, in which cells of operatives communicated with Osama bin Laden and his lieutenants in Afghanistan, and a wheel structure, where operatives communicated with each other without necessarily going through the leadership (p. 137).

Mas isso não significou o abandono total de estruturas pré-existentes. A organização em rede se fundiu com os modos mais tradicionais de formação de redes de irmandade onde as células se tornaram parte de uma família maior que é o movimento. Gunaratna (2002) explica que a Al-Qaeda tem praticado claramente um movimento em escala mundial, apesar disso se constrói em torno de costumes locais e laços de irmandade. O movimento está organizado em torno de linhas de grandes clãs baseados em famílias (a broad-based family clan) com seus membros de multinacionalidades e designados como "irmãos", um termo comumente usado por religiões muçulmanas para referir-se uns aos outros. Essa estrutura não significa dizer que só há membros entre famílias. Significa afirmar que esta estrutura é bastante comum e prepondera na estrutura do movimento. Não por acaso, o termo "família" ganha conotações políticas de grupos originários de determinados países, ainda que estejam espalhados em outras nações, inclusive não muçulmanas:

Hence its North African "family" (exclusively Algerians, Egyptians, Tunisians, Moroccans, Libyans) is responsible for activities in Europe, its Southeast Asian "family" (Malaysians, Indonesians, Filipinos, Singaporeans) for operations in the Far East, and its Central Asian "family" for the region from Turkey across Muslim Central Asia into Xingjiang in China (GUNARATNA, 2002, p. 96).

O sentimento de identidade, na forma de uma irmandade, significa hoje uma linhamestra que guia as ações da rede, dando-lhe unidade:

Que los integrantes del movimiento yihadista compartan una misma visión sobre el papel que cada uno debe desempeñar como miembro de esa unidad, les permite actuar como un todo coherente, independientemente de que carezcan de conexión y conocimiento entre ellos. Este relato compartido permite que exista una centralización en lo estratégico (la consecución de un mismo fin) a través de una descentralización en lo táctico (qué acciones se emprenderán para lograrlo y quiénes se encargarán de llevarlas a cabo) (SORIANO, 2013, p. 147)

Para Seib (2012) a "Al Qaeda is a supranational network that relies on a mix of connectivity and geographical autonomy to accomplish its goals. Because of its relative 
permanence, Al Qaeda might be considered a mutation of a network, a « virtual state »." Este "estado virtual" teria suas tropas organizadas em redes, como explica Seib (2012), funcionando através de células ao invés de divisões. Na analogia feita por este autor, seria algo como uma confederação, com seus respectivos afiliados ao redor do mundo, capazes de gerenciar as suas próprias operações de forma mais ou menos autônoma, enquanto consideram-se partes de um todo maior e compartilham um propósito comum:

Al Qaeda is not a corporation or a club. It is a political entity with a
population - dispersed as it may be - that engages in financial transactions,
communications activity, and paramilitary operations. With these
characteristics and its global reach, Al Qaeda should be analyzed as a virtual
state (SEIB, 2012, p. 137).

Embora a existência e a ação de células ativistas ocorra de forma bastante horizontalizada, sem um centro de comando como ocorria no passado, a comunicação online voltada para o público mais amplo ocorre através da hierarquização das fontes e formação de redes de distribuição visando inibir ruídos e mensagens falsas. Como explica Soriano (2013):

Entre las principales dificultades a las que ha tenido que hacer frente la estrategia propagandística de Al Qaeda, se encuentra la confusión que generaba en su audiencia, la presencia en la red, de mensajes incoherentes entre sí, la multiplicidad de supuestos «portavoces oficiales», y las decenas de comunicados procedentes de grupos de dudosa existencia. Si por un lado, la falta de jerarquización ha permitido garantizar la presencia del mensaje en el ciberespacio, ese mismo esquema, ha generado un verdadero problema de confianza entre sus partidarios. La ausencia de un sistema fiable de verificación de informaciones concernientes a la yihad, ha dejado un terreno abonado para multitud de «operaciones de desinformación» (p. 306).

A solução deste problema foi encontrada na própria característica da Internet, que possibilita a formação de redes online:

Para solventar esta dificultad, más que recurrir a la puesta en marcha de nuevas y efímeras «webs oficiales», que son rápidamente hackeadas; la solución intermedia ha sido recurrir a un grupo reducido de «distribuidores». Una serie de plataformas completamente virtuales (las cuales ni si quiera gestionan una web propia), cuyo cometido es recibir los materiales procedentes de los grupos que combaten la yihad, editarlos y distribuirlos a través de una red de webs y foros de confianza. Se trata de un sistema trasparente, que permite a su audiencia distinguir rápidamente los comunicados y mensajes auténticos, de los falsos en función de cual haya sido el canal de distribución utilizado. Por otro lado, este nuevo sistema 
también está basado en una estructura en red, con un liderazgo difuso, y sin elementos imprescindibles (SORIANO, 2013, p. 307).

Para garantir que a rede não tenha ruídos e produza comunicação e informação úteis, o movimento tem usado o ambiente digital para estruturar e classificar os agentes responsáveis por checar e circular informação 99 . Gunaratna (apud SORIANO, 2013) aponta que isso ocorre em três círculos:

[1] el primero y más pequeño estaría compuesto por un pequeño grupo de dirigentes «senior» de esta organización. Se trataría de un nivel prácticamente imposible de penetrar [...] ${ }^{100}$ [2] El segundo círculo estaría compuesto por lo que los servicios de inteligencia han bautizado como Obelisk: una red de sites de acceso protegido con contraseña y ubicados en una amplia red de discretos servidores, muchos de ellos hackeados, lo que implica que sus legítimos dueños desconocen el tipo de contenidos que alojan sus terminales. Este nivel es usado por operativos de medio y bajo nivel del universo yihadista. [...] Este sistema de autentificación permite que los contenidos elaborados con una finalidad persuasiva puedan a su vez ser replicados en otros websites del tercer nivel. [...] Por último, el tercer nivel estaría compuesto por aquellas webs destinadas a replicar y hacer llegar el mensaje yihadista al mayor número posible de personas. La ausencia de filtros de acceso le convierte en un entorno mucho más vulnerable, ya que estás páginas se ven sometidas a las acciones de sabotaje e infiltración de los hackers y de las agencias contraterroristas (SORIANO, 2013, p. 305-306).

Esse uso em rede com algum nível de hierarquização ocorre através de uma estrutura de comunicação entre os ativistas cercando-se de procedimentos e recursos que visam evitar o rastreamento digital, uma vez que todo tipo de comunicação (incluindo aparelhos de telefone) passaram a funcionar em uma base digital monitorável. Isso vai desde o uso de criptografia,

\footnotetext{
${ }^{99}$ Por exemplo: "El grupo mediático más representativo es, sin duda, el llamado Global Islamic Media (GIM), transformado posteriormente en Global Islamic Media Front (GIMF). Originalmente constituía uno de los grupos o espacios virtuales que la compañía Yahoo ofrece a los usuarios de sus cuentas gratuitas de correo electrónico. Dicho grupo atesoraba las direcciones de e-mail de casi 7.500 usuarios afiliados, los cuales recibían regularmente información sobre nuevos materiales, vídeos, enlaces, etcétera. A diferencia de otros «grupos mediáticos», es posible presuponer Al GIM algún tipo de vinculación con organizaciones terroristas «reales». De hecho, en su momento Al Qaeda no dudó en advertir a su «audiencia» de que no confiase en la credibilidad de ningún material procedente del grupo que no hubiese sido previamente anunciado y validado por Global Islamic Media." (SORIANO, 2013, p. 303). O autor também lembra do caso de "Abu Maysara Al Iraqi portavoz mediático de Al Qaeda en Iraq, el cual ha utilizado los foros para dar a conocer los nuevos comunicados del grupo, al tiempo que ha recomendado no otorgar ninguna credibilidad a cualquier otro material procedente de otro usuario que proclamase representar a este grupo yihadista" (SORIANO, 2013, p. 301).

${ }^{100}$ Ainda que tenha ocorrido alguma penetração no passado como explica Noah Shachtman (2007) ao relatar entrevista de Gunaratna no site Wired: "America, Britain, and Pakistan had a successful operation that penetrated Al Qaeda's most secretive Web communications for a period in 2004. Then, after one of the founders of Al Qaeda's Internet system, Mohammed Naeem Nur Khan, had been arrested in secret by Pakistani intelligence in July 2004, allied intelligence services were able to monitor the communications of this leadership group for about five weeks [...] 〈http://www.wired.com/2007/10/inside-al-qaeda > acesso 14 dezembro 2015〉.
} 
deep web, mudança de endereços eletrônicos, até a adoção de procedimentos de uso de aparelhos digitais como celular (BERNER, 2006).

Uma das vantagens da organização em rede está em permitir a interação entre os pares de forma mais dinâmica, reduzindo os custos da comunicação e ampliando a complexidade da informação compartilhada através de uma estrutura menos rígida (WEIMANN, 2004). A AlQaeda tem demonstrado qualidade adaptativa, principalmente devido à sua estrutura descentralizada (WEIMANN, 2006). Para McGrath (2011), a "al-Qaeda appears to be functioning as a systemic organization, not a uniquely contrived amalgam of irreplaceable personalities, with troop losses being regenerated and replacement leaders appointed" (p. 66). Implica, na prática, no fortalecimento da estrutura ao torná-la mais flexível e adaptável, já que a destruição de importantes membros não significa a destruição da rede.

Como vimos, há uma descentralização no nível da tomada de decisões quando se passou a utilizar a comunicação digital para operar em uma estrutura em rede, com alguns mecanismos de validação e hierarquia. Isso significou que a centralidade de lideranças em tomar decisões ficou diluída nesta nova forma de organização. Não por acaso, como bem lembra Seib (2012), a morte de bin Laden já não significou um impacto real na dinâmica do movimento que não dependia mais de sua liderança na prática:

The world's best-known terrorist group, Al Qaeda, owes its survival partly to its ability to resist relying on a formal, hierarchical structure and instead to develop a much less vulnerable network model. Because Al Qaeda's operational leadership and the ranks of its adherents are well dispersed, a case can be made that the killing of Osama bin Laden in 2011 was useful but was more a symbolic accomplishment than a devastating blow to Al Qaeda's capabilities (SEIB, 2012, p. 134).

Apesar de o 11 de Setembro ter causado saliência na liderança de bin Laden, que continuou a ser uma figura representativa do movimento, transmitindo via Internet mensagens e instruções de ação, isso não significou uma centralização na tomada de decisões. Ao invés disso, a produção da decisão foi diluída entre as células.

As lideranças tradicionais da Al-Qaeda - como Osama bin Laden e Ayman alZawahiri - desempenhavam um papel duplo: líderes intelectuais, estimulando e divulgando a causa, e líderes operacionais, planejando e agindo junto às ações concretas em seus círculos de militantes mais próximos, porém essa liderança se tornou cada vez mais diluída e menos central na estrutura da organização (MCGRATH, 2011). Antes, o grupo tendia a uma estrutura de pirâmide hierárquica semelhante às organizações militares ou corporações. Com a 
mudança, as redes segmentadas passaram a permitir uma estrutura transnacional multicelular que se remodela com o passar do tempo e é menos hierárquica e mais horizontal, inclusive no processo de tomada de decisão.

$\mathrm{Na}$ prática, o uso da Internet para tomada de decisões ocorre em dois níveis mais fundamentais: (a) diretriz geral na tomada de decisão a partir de uma avaliação de conjuntura entre as diferentes células através dos canais online de interação (entre militantes) e subsequente divulgação de conteúdo com uma direção a ser seguida (para apoiadores no círculo mais amplo), principalmente a partir de eventos-chaves ${ }^{101}$. Como ilustra Soriano (2013):

Los yihadistas han hecho acto de presencia en comunidades virtuales como Friendster, MySpace y, sobre todo, Orkut. Esta última, creada por Google, es la más popular de todas y también, aquella donde más presencia tiene la comunidad radical. En 2006 existían en esta plataforma un mínimo de diez comunidades cuyos puntos de unión eran la admiración hacia Bin Laden, Al Qaeda y la necesidad de extender la yihad armada. Algunos de estos grupos han llegado a tener dos mil miembros. Sus usuarios no solo intercambian de manera abierta y accesible fotografías, textos y opiniones, sino también informaciones de interés como las nuevas direcciones webs de grupos yihadistas reales (p. 303-304).

E (b) no nível intracelular, isto é, como parte do aparato comunicativo utilizado pelos ativistas para troca de informações estratégicas.

Nota-se que, devido ao próprio caráter clandestino no movimento, em função dos métodos e ações terroristas adotados, o uso da comunicação digital para deliberação online e tomadas de decisão (na forma de um fórum com representantes ou lideranças) torna-se mais difícil de ocorrer, uma vez que há o risco de monitoramento, prisão e morte desses militantes pelas forças de segurança de governos contrários a Al-Qaeda.

\footnotetext{
${ }^{101}$ Por exemplo, recentemente, após a execução de 43 membros vinculados à organização pelo governo da Arábia Saudita, Ayman al-Zawahri (considerado uma das principais lideranças em atuação) convocou militantes, através de uma gravação de voz, a atacar o país em retaliação às condenações. Ver em < http://noticias.uol.com.br/ultimas-noticias/reuters/2016/01/14/chefe-da-al-qaeda-convoca-ataques-em-reposta-aexecucoes-da-arabia-saudita.htm > Acesso: 15 jan. 2016. Em um outro exemplo, de 2014, Ayman al-Zawahiri conclama para luta contra o presidente sírio Bashar al-Assad. Ver em < http://www.huffingtonpost.com/2014/04/26/ayman-al-zawahiri-tape_n_5217738.html > acesso 12 mar. 2015. Em ambos os casos, os áudios são difundidos principalmente via Internet.
} 


\section{c) Transnacionalização}

A Al-Qaeda tem em seu DNA o caráter transnacional desde a sua formação ainda na década de 1980. Pode-se apontar três fases neste sentido e situar o papel da comunicação digital especificamente na terceira fase. A primeira fase seria a própria articulação inicial do grupo que, como vimos, surge a partir de uma articulação paramilitar no Afeganistão que envolveu voluntários de diversos países (principalmente do mundo islâmico) que fizeram frente na resistência à invasão russa. Esse caráter multinacional também continuou a crescer em uma segunda fase, pós retirada da URSS, com os exílios de bin Laden e seus seguidores no Sudão e, depois, quando de volta ao solo afegão com apoio do governo Taliban, em seus campo de treinamento onde se reuniram mais militantes de diversas nacionalidades. Nota-se que até aqui já era um grupo de formação e ação transnacional e não dependeu da comunicação digital para atingir estas características.

O uso da comunicação digital no processo de transnacionalização ocorrerá numa terceira fase que ocorre justamente após o 11 de Setembro, quando o grupo se tornou conhecido mundialmente. A ação estadunidense em resposta ao ataque - com a invasão estadunidense de países como Afeganistão (em 2001) e Iraque (em 2003) - gerou uma forma de "diáspora" forçando a luta jihadista a procurar outras formas de articulação internacional. E a Internet se tornou fundamental neste momento enquanto estrutura para ampliar seu caráter transnacional. É possível afirmar que a transnacionalização do grupo de forma mais global se deu a partir do uso do ambiente digital pois, até a segunda fase, o movimento estava nitidamente circunscrito a alguns países islâmicos (GUNARATNA, 2002; MOHAMEDOU, 2011). Com o uso da Internet o cerne continuará sendo este nicho (principalmente Oriente Médio e Norte da África) mas a causa ganha escala global passando a ter voluntários e apoiadores espalhados em diferentes continentes, incluindo participações significativas de países ocidentais. Dados sobre a origem do acesso de websites jihadistas podem ilustrar este cenário:

Así por ejemplo, dos investigadores del Center for Political Violence and Terrorism Research de Singapur (Givner-Forbes y Shwery, 2007), introdujeron la dirección web de lo que en 2007 se consideraban los diez principales portales yihadistas de Internet. Los resultados demostraban cómo el gran grueso de estas visitas (78,1 de cada 100) procedía de Oriente Medio y del Norte de África, aunque existían visitas procedentes de otros cuarenta países distintos. El continente europeo albergaba solo el 4,8 por ciento de estas visitas. Los resultados por países eran muy significativos: los Territorios Palestinos eran el territorio que efectuaba el mayor número de 
visitas a estas páginas (15,72 de cada cien), lo cual es un resultado iluminador teniendo en cuenta la escasa población de Palestina, la escasa penetración de Internet y la ausencia en esta región de una facción de Al Qaeda. Los siguientes niveles de actividad se ubicaban en Jordania, Qatar, Kuwait, Bahrain, Arabia Saudí, los Emiratos Árabes, Yemen y Argelia; curiosamente, algunos de los países cuyos Gobiernos mantienen buenas relaciones con los Estados Unidos. Este último país y el Reino Unido mostraban registros individuales significativos: 3,97 y 0,97 respectivamente, aunque en el caso de Estados Unidos, debe matizarse el volumen de los recursos que la comunidad de Inteligencia utiliza para monitorizar el trafico yihadista en Internet (SORIANO, 2013, p. 314).

Na prática, a Internet permitiu ampliar o leque de participação na organização, tanto espacial, uma vez que terroristas não são apenas envolvidos com causas do Oriente Médio, mas podem ser provenientes de qualquer lugar do planeta (LUTZ, LUTZ, 2004), quanto abarcando diversos níveis de comprometimento com a causa, desde simpatizantes, passando por mobilizadores, até ativistas. A Internet conecta redes de diferentes grupos terroristas em apoio à jihad em diversos lugares: Afeganistão, Indonésia, Iraque, Turquia, Filipinas, Líbano etc. (WEIMANN, 2006), potencializando e facilitando o engajamento para além das fronteiras físicas.

A estrutura transnacional característica da Internet possibilitou a existência da organização, pós-11 de Setembro, "By converting al Qaeda into a set of guiding principles, an ideology, it transcends all national boundaries and makes affiliation or enfranchisement exceptionally easy" (SEIB, 2012, p. 135). Desde modo, o engajamento transnacional de um simpatizante não requer necessariamente sair do seu país de origem, já que pode atuar de forma discreta e viajar dentro de seu próprio país para efetivar ações, o que dificultaria o controle das forças de segurança uma vez que nem sempre se tratará de um estrangeiro agindo de fora para dentro (RABASA et al, 2006).

\subsubsection{Instrumentalização do planejamento}

\section{a) Elaboração}

Em se tratando de um movimento que se tornou cada vez mais clandestino, sendo perseguido pelos serviços secretos de diversos países (principalmente das grandes potências ocidentais), reunir membros para planejar ações se tornou um evento perigoso. Diante disso, a 
comunicação digital desempenhou um papel fundamental no planejamento e elaboração de estratégias e táticas que precedem as ações do grupo.

Isso se torna possível devido às próprias características da ferramenta que se configuram apropriadas para os projetos de grupos como a Al-Qaeda. Weimann (2004, p. 3), em poucas palavras, sintetiza a especificidade que a torna tão atrativa e necessária:

By its very nature, the Internet is in many ways an ideal arena for activity by terrorist organizations. Most notably, it offers easy access; little or no regulation, censorship, or other forms of government control; potentially huge audiences spread throughout the world; anonymity of communication; fast flow of information; inexpensive development and maintenance of a web presence; a multimedia environment (the ability to combine text, graphics, audio, and video and to allow users to download films, songs, books, posters, and so forth); and the ability to shape coverage in the traditional mass media, which increasingly use the Internet as a source for stories (WEIMANN, 2004, p. 3).

Claramente, a Internet traz importantes vantagens, tais como anonimato, flexibilidade da rede, poucos mecanismos de controle e comando, capacidade de mobilizar ativistas e servir como plataforma eficiente para comunicação estratégica:

O islamismo atual seria impensável sem a tecnologia moderna. Fitas disseminam os sermões de pregadores; manifestações são coordenadas por telefone, fax e e-mail; vídeos perpetuam a imagem do mártir que se tornou homem-bomba, e a mais terrível organização fundamentalista de todas é assim denominada em função do banco de dados digitais de militantes internacionais elaborado por seu líder, um engenheiro com educação ocidental: a al-Qaeda, que significa database (DEMANT, 2001, p. 313).

A comunicação estratégica é aquela que se realiza internamente à organização, entre seus membros, seja simplesmente para trocar informações relevantes, seja para compartilhar estratégias de ataque e técnicas de bombas, ou ainda planejar atentados. A comunicação estratégica engloba também o chamado networking, em que grupos ou redes de terroristas interagem em nome da mesma causa, conforme já foi trazido no indicador sobre o engajamento dos colaboradores.

Para elaborarem os ataques do 11 de Setembro os terroristas se comunicavam via email e chats, usando também códigos criptografados (HALLAMS, 2013; THOMAS, 2003). Weimann (2004) descreve como se deu esse processo: 
$\mathrm{Al}$ Qaeda operatives relied heavily on the Internet in planning and coordinating the September 11 attacks. Thousands of encrypted messages that had been posted in a password-protected area of a website were found by federal officials on the computer of arrested al Qaeda terrorist Abu Zubaydah, who reportedly masterminded the September 11 attacks. The first messages found on Zubaydah's computer were dated May 2001 and the last were sent on September 9, 2001. The frequency of the messages was highest in August 2001. To preserve their anonymity, the al Qaeda terrorists used the Internet in public places and sent messages via public e-mail. Some of the September 11 hijackers communicated using free web-based e-mail accounts (p. 10).

Thomas (2003) desenvolve um interessante estudo em que ele define cyberplanning como uma tática mais importante do que ciberterrorismo. Enquanto ciberterrorismo é uma ação ilegal de destruição de propriedade digital para intimidar ou coagir pessoas, o cyberplanning é definido como "the digital coordination of an integrated plan stretching across geographical boundaries that may or may not result in bloodshed" (THOMAS, 2003, p. 113). A importância do cyberplanning está justamente nas características trazidas pela Internet para os grupos terroristas, tais como anonimato, comando, controle e coordenação de ataques. Segundo o autor é possível identificar os elementos de cyberplanning em websites ${ }^{102}$ ligados a Al-Qaeda a partir de monitoramentos realizados pelos EUA. No agrupamento de características realizado pelo autor, identificam-se algumas que tocam a presente categorização de comunicação estratégica. São elas:

(a) A Internet pode ser usada de forma anônima. Há sites (spammimic.com) que oferecem ferramentas para escamotear mensagens em spams comerciais. A criação de novos emails é simples, além da possibilidade de entrar em chats com registros temporários. $\mathrm{O}$ acesso à rede de conexão pode ocorrer de computadores públicos, como cibercafés e universidades.

(b) A Internet independe de mecanismos de controle e comando. Forças militares americanas não conseguem prejudicar a coordenação e o comando de ataques terroristas, que não são impedidos nem pela distância geográfica, nem pela falta de equipamento de comunicação sofisticado. Nas palavras de Thomas (2003): "The average citizen, the antigovernment protester, and the terrorist now have access to command and control means, limited though they may be, to coordinate and plan attacks" (p.117). No site alneda.com há apoio da AlQaeda dando suporte às causas jihadistas ao redor do mundo e ensinando os seguidores a agir de forma independente, inspirados por argumentos teológicos, mas sem a necessidade de um

\footnotetext{
102 Alguns exemplos apontados por Thomas (2003) são: alneda.com, assam.com, almuhrajiroun.com, qassam.net, jihadunspun.net (traz vídeos do bin Laden), 7hj.7hj.com (ensina a conduzir ataques nos computadores), aloswa.org, (justifica os ataques terroristas), drasat.com (traz notícias da Al-Qaeda), jehad.net.
} 
comando central para ditar os ataques.

(c) A Internet distancia aqueles que planejam o ataque dos seus alvos. A rede restringe os riscos que terroristas teriam com o uso de telefones e celulares, mais fáceis de serem rastreados e identificados. Há diversas formas de enviar mensagens escondidas, como camuflando-as em gráficos. O curioso é que a Al Jazeera noticiou que a mensagem ${ }^{103}$ final de direcionar o ataque às torres gêmeas foi bem simples e aberta.

Mas esse uso não ocorre livremente. Assim como facilita a interação, a comunicação online também possibilita o monitoramento de rastros digitais capaz de desmantelar grandes organizações (THOMAS, 2003; LUTZ, LUTZ, 2004; COUTINHO, 2012). Por isso, para fins de comunicação interna, o cuidado com o monitoramento e vigilância é uma constante nas atividades do grupo. Na mensagem abaixo emitida pelo grupo em 2004, compilada por Berner (2006), observam-se as orientações e precauções para a comunicação online a partir de computadores disponíveis em cibercafés:

Para utilizar Internet deben ir a un caber café...nunca visiten un sitio que pueda revelar vuestra identidad, como los que pertenecen al FBI, Al Qaeda o los Muyahidín....al abrir una cuenta de correo electrónico, vayan a un caber café, nunca lo hagan en casa, nunca utilicen el mismo caber café una y otra vez... antes de partir del caber café, retiren toda evidencia, nunca dejen pistas... al enviar un e-mail nunca utilicen lenguaje que pueda revelar vuestro compromiso ideológico. Escriban vuestros mensajes en un procesador de texto, ármenlo, corten, peguen y envíen. Y luego desconéctese. Nunca deje su e-mail abierto para escribir un mensaje. Al Qaeda, enero de 2004 (BERNER, 2006, p. 84).

Soriano (2013) explica que isso tem levado aos jihadistas a utilizar programas de telefonia por IP (Internet Protocol) - como Skype, Paltalk, Voipbuster e outros - que permitem ser acessados de qualquer computador para realizar de forma gratuita, chamada de âmbito internacional. Isso significaria criar um ambiente mais seguro para o seu território de comunicações já que governos e agências de segurança têm dificuldades para fazer um controle efetivo devido a questões jurídicas e tecnológicas (como proteção à privacidade, por exemplo). Mas nem sempre é preciso de um grande aparato tecnológico para manter um ambiente relativamente seguro para o planejamento de ações. Soriano (2013) demonstra que o

\footnotetext{
${ }^{103}$ Segundo Thomas (2003): "Al-Jazeera television reported that Mohammmed Atta's final message (another advantage of the Internet - the impossibility of checking sources) to direct the attacks on Twin Towers was simple and open. The message suportedly said, 'The semester begins in three more weeks. We've obtained 19 confirmations for studies in the faculty of law, the faculty of fine arts, and the faculty of engineering.' The reference to the various faculties was apparently the code for the buildings targeted in the attacks" (p. 119).
} 
uso mais comum desse recurso de comunicação tem sido mais rudimentar, mas extremamente imaginativo e eficaz:

Así por ejemplo, las investigaciones policiales han podido detectar como los terroristas utilizaban cuentas preasignadas de correo electrónico con nombres de usuario y contraseñas compartidos. Siguiendo este procedimiento las células operativas se comunicaban de manera segura alojando en la «bandeja borrador» los mensajes que debían ser leídos. El hecho de que nunca se produjese envíos ni recepción de e-mails reducía enormemente la «huella digital» y dificultaba su monitorización por los servicios de inteligência (SORIANO, 2013, p. 294).

Também são utilizados códigos pré-estabelecidos em determinados websites - os chamados "semáforos eletrônicos" como a mudança na cor de um banner, de um ícone em específico, no fundo de uma fotografia ou em uma frase em um chat - que servem como sinalização para troca de informações, isto é, um sinal que na verdade traz outro significado como a ordem para um ataque, a data e lugar para uma reunião etc. que possibilitam o planejamento e a comunicação interna (WEIMANN, 2006; SORIANO, 2013). Um exemplo disso é a descoberta do plano para assassinar o ministro do Interior da Arábia Saudita (o príncipe Nayef bin Abdel Aziz), cujos detalhes (como hábitos, itinerário, informações sobre segurança pessoal, método de ataque) estavam “escondidos” em uma edição ${ }^{104}$ específica de uma publicação online (WEIMANN, 2006).

Um outro exemplo de planejamento via Internet descrito por Weimann (2006) foi o atentado à bomba de Madri (em 2004), que matou 201 pessoas e feriu 1.240. O plano que precedeu esta ação foi encontrado na Internet:

Brynjar Lia, a researcher at the Norwegian Defense Research Establishment (FFI), had come upon the original online document in December 2003, three months before the bombings, on the al Qaeda Web site Global Islamic Media. Lia read the text and, interpreting it as a strategy document intended for the Islamic resistance within Iraq, filed it. Only after the Madrid bombings did FFI researchers recall the document and analyze it in more Detail (WEIMANN, 2006, p. 133).

Ainda fazendo uso da comunicação digital, mas diversificando a ação para além da Internet, têm-se os usos de SMS. Em março de 2006 foram difundidas de forma clandestina mensagens de texto para organizar flash mobs de protesto referente à caricatura do Profeta Muhammad (RABASA et al, 2006).

\footnotetext{
${ }^{104}$ Especificamente na edição n. 11 da Camp al Barrar, um conhecido manual militar de treinamento referenciado por terroristas, com publicações regulares.
} 
Todos esses fatos são indicadores de que o uso da comunicação digital para o planejamento de ações se tornou parte importante da elaboração, disseminação e execução de planos e estratégias pelo grupo, no nível global.

\section{b) Datificação}

A quantidade de dados disponíveis na rede virtual é imensa e quase imensurável pois trata-se de um quantitativo que muda a cada dia. Esta é uma das principais vantagens (ou desvantagens, a depender do uso que é feito com a informação) trazidas com as novas tecnologias. Sabe-se que é possível identificar distâncias e rotas exatas entre cidades, ter acesso a projetos de engenharias de potenciais alvos, coletar informações atualizadas de voos comerciais, observar escala de funcionários numa dada empresa, enfim, como dito, há uma gama de dados disponíveis para qualquer um acessar, e em tempo real. É por esta razão que em 2003, o próprio secretário de Defesa estadunidense Donald Rumsfeld informou, em uma intervenção pública, que os manuais de treinamento da Al-Qaeda encontrados no Afeganistão chamavam a atenção de militantes sobre a possibilidade de acessar online até $80 \%$ da informação necessária sobre o inimigo para planejar um ataque. Isso utilizando apenas plataformas públicas abertas e sem precisar recorrer a meios ilegais (SORIANO, 2013; THOMAS, 2003; COUTINHO, 2012).

Isto significa que, aliada a um bom filtro de informações e planejamento estratégico, a Internet se transforma em um recurso impactante na construção dos ataques com maior precisão. Coutinho (2012) reforça isto ao dizer que: "Like all Internet users, terrorists also have access to maps, diagrams, schedules, pictures and exact location so fall sorts of potential targets such as transportation facilities, nuclear power plants, government buildings, airports or ports" (p. 16).

Estrategicamente, Weimann (2004) explica que a Al-Qaeda opera através do Data Mining, ou prospecção de dados, analisando diversos alvos dos EUA e cruzando informações em softwares que são capazes de calcular até mesmo os impactos que pode gerar nos sistemas econômicos caso os ataques venham a se efetivar:

Specific targets that al Qaeda-related websites have discussed include the Centers for Disease Control and Prevention in Atlanta; FedWire, the moneymovement clearing system maintained by the Federal Reserve Board; and facilities controlling the flow of information over the Internet. Like many other Internet users, terrorists have access not only to maps and diagrams of 
potential targets but also to imaging data on those same facilities and networks that may reveal counterterrorist activities at a target site. One captured al Qaeda computer contained engineering and structural features of a dam, which had been downloaded from the Internet and which would enable al Qaeda engineers and planners to simulate catastrophic failures. In other captured computers, U.S. investigators found evidence that al Qaeda operators spent time on sites that offer software and programming instructions for the digital switches that run power, water, transportation, and communications grids (WEIMANN, 2004, p. 7).

Igualmente, Thomas (2003) reconhece que a Internet ajuda a filtrar informações de potenciais alvos, incluindo aqueles que podem colocar em xeque sistemas de infraestrutura básicos e causar um enorme prejuízo. Assim, a Al-Qaeda capacita engenheiros e outros especialistas a realizar catastróficas simulações e planos: "Imaging data can also allow terrorists to view counter terrorist activities at a target site" (THOMAS, 2003, p. 118). Conforme visto, o próprio ataque do 11 de Setembro de 2001 foi planejado pela Internet e fez uso de informações abertas a qualquer um, inclusive terroristas. Thomas (2003) explica que em computadores apreendidos dentre os terroristas há registros de que no Afeganistão se coletava informações dos alvos para enviar de forma criptografada via Internet aos demais envolvidos com os referidos ataques.

Como relata Soriano (2013), o FBI rastreou várias inspeções em profundidade de sites americanos a partir de fontes suspeitas de pertencer a Al-Qaeda na Arábia Saudita, Indonésia e Paquistão. Parte dessas visitas estavam claramente direcionadas para estudar sistemas vitais como telefonia, abastecimento de água, oleodutos, barragens, redes de energia, centrais nucleares e usinas de gás. Este é um claro indício do uso da Internet para coletar informações potencialmente relevantes para a elaboração de planos de ataque. $\mathrm{O}$ autor também relata que em um computador da Al-Qaeda apreendido em Cabul, foram encontrados softwares de engenharia que simulavam as consequências de uma falha catastrófica de uma barragem (SORIANO, 2013). Ou seja, para que esses programas funcionem é preciso alimentá-los com dados obtidos online.

O uso da ameaça como estratégia de coleta de informações, que embasarão planos futuros, também é apontado por Thomas (2003). Falsas ameaças podem tanto ser usadas para desviar a atenção de um cenário de ataque real, quanto o alarme falso pode gerar uma resposta imediata dos EUA, facilitando os estudos da organização sobre a reação dos EUA perante uma ameaça, facilitando assim a coleta e análise de informações para os terroristas desenvolverem táticas mais efetivas. 


\section{c) Instrução}

Antes do 11 de Setembro a preparação física e mental dos membros geralmente era realizada em territórios que agregavam diferentes jihadistas de várias partes do mundo. Com a destruição da base no Afeganistão e a extrema atenção de países como os Estados Unidos voltada para aniquilar qualquer campo terrorista, tem sido uma constante o uso de treinamentos online (JENKINS, 2002; RABASA et al, 2006; WEIMANN, 2006; McGRATH, 2011; COUTINHO, 2012; SORIANO, 2013). Por uma questão de viabilidade, inclusive. Além disso, passou a fazer parte da narrativa da Al-Qaeda dar autonomia e empoderamento aos interessados na luta, acentuando o caráter descentralizado da rede terrorista. Como retrata Rabasa e colegas (2006):

Since the loss of its extensive training complex in Afghanistan, al-Qaeda and its offspring have had to invent new ways of teaching their operational tradecraft to the next generation of jihadists. In Afghanistan, al-Qaeda under the patronage of the Taliban - was able to train thousands of new recruits from a variety of backgrounds in both guerilla warfare and terrorist tactics ranging from small arms training to counterinterrogation techniques with relative impunity. The creation of the 11-volume Encyclopedia of the Afghan Jihad, acquired by U.S. intelligence in 1999, was designed to serve as a step-by-step do it-yourself guide for the up-and-coming terrorist to augment what he learned in the Afghan training camps, and to educate those who could not make it to the camps. This publication has served as the primary text for training new recruits in an era when training camps are harder to set up. It includes sections on how to blow up a plane and threaten with a knife and has been widely circulated on the Internet. Also on the Internet are online courses offered by Islamist Web sites on how to build explosive devices (RABASA et al, 2006, p. 41).

Coutinho (2012) explica que a Al-Qaeda dá os instrumentos para que qualquer um possa ser um terrorista, independente de onde esteja. A autora lista os seguintes instrumentos usados através da rede digital: Treinamentos para aqueles que não precisam ser convencidos, apenas guiados; informações sobre armas convencionais, explosivos, táticas, segurança operacionais e preparação física. Ela menciona que alguns autores não acreditam que a Internet possa ser convincente por si mesma para persuadir as pessoas. Porém, a Internet não age sozinha, ela é um meio utilizado para facilitar indivíduos propensos a agarrar a causa e lutar dentro do seu contexto, seja local, seja transnacional.

Weimann (2006) pesquisou em maio de 2005 referências no Google sobre livros terroristas instrutivos e encontrou 7900 sites relacionados. Há casos como a revista online Al Battar publicada bimestralmente por ativistas vinculados a Al-Qaeda, que traz informações 
detalhadas de como sequestrar pessoas relevantes do meio político e econômico, como disparar granadas e outros tutoriais relacionados, desenvolvendo um verdadeiro campo de treinamento virtual (RABASA et al, 2006; WEIMANN, 2006; HALLAMS, 2013; SORIANO, 2013). Weimann (2006) transcreve um trecho publicado neste manual:

Oh Mujahid [hofy warrior] brother, in order to join the great training camps you don't have to travel to other lands. Alone, in your home or with a group of your brothers, you too can begin to execute the training program. You can all join the AL Battar Training Camp - A L Battar (the online manual of al Qaeda) (WEIMANN, 2006, p. 111).

É claro que o monitoramento de países engajados na luta contraterrorista é bastante incisivo e eficiente, por isso muitos desses websites de treinamento são retirados do ar. Porém, o próprio sistema permite que o endereço eletrônico seja copiado e retransmitido em outra página logo em seguida, criando-se espelhos sob diversos endereços, um método de replicagem difícil de controlar (WEIMANN, 2004).

A comunicação digital também ajuda no planejamento da segurança dos ativistas. Em muitos sites, os militantes analisam as prisões de companheiros e tentam pensar em meios e métodos para evitar que isso aconteça novamente. Compartilhar e instruir usuários com técnicas para alcançar um maior anonimato e segurança na Internet tem sido também uma preocupação recorrente (SORIANO, 2013). A exemplo disso tem-se a citação da própria AlQaeda transcrita por Berner (2006):

Utilicen teléfonos celulares sólo cuando sea necesario y cuando no exista un medio de comunicación alternativo... es mejor no utilizar para nada teléfonos celulares... si deben utilizar un teléfono celular, utilicen uno obtenido con un nombre y dirección falsos...nunca utilicen un teléfono celular provisto por vuestros líderes para llamar a un amigo o pariente...si le solicitan a vuestros amigos que los llamen, brinden un momento específico y mantengan vuestros teléfonos encendidos sólo cuando esperan esa llamada...no reciban llamadas en vuestros hogares, háganlo en una tienda o en un espacio abierto y apaguen los teléfonos y desconecten las baterías tan pronto como terminen la conversación. Al Qaeda, enero de 2004 (p. 137).

Mohamedou (2011) relata um manual de treinamento para soldados sobre aspectos de guerrilhas, explosivos, protocolos de vigilância e ataques kamikaze, chamado de Enciclopédia da Jihad, feita no Afeganistão em 1996 e transferida para um CD-ROM em 1999. Isto mostra que a comunicação digital foi além do uso da Internet, utilizando de meios que complementassem a difusão da instrução. 


\subsubsection{Diversificação da ação}

\section{c) Ciberevento}

A natureza clandestina da Al-Qaeda e a imagem de um grupo terrorista capaz de provocar mortes em ataques a civis são elementos que dificultam a ocorrência de cibereventos públicos como petição, protestos online ou outros que requerem apoio em larga escala. $\mathrm{O}$ movimento de contenção antiterrorista exerce um alto monitoramento deste tipo de atividade. Há manifestações públicas online de apoio à organização principalmente em países do Oriente Médio, como vimos no decorrer da análise. Mas não foram identificados eventos online de dimensões significativas e com formato claramente definido enquanto "ciberevento", conforme estipulado nesta pesquisa.

Além das inúmeras páginas na web de propaganda e da rede de apoiadores do grupo, é possível localizar campanhas e ações online mais ou menos orquestradas (sem um claro contorno de ciberevento), principalmente em redes online. Porém, nesses casos, muitas vezes há dúvidas sobre a veracidade dos perfis participantes. Por exemplo, na Arábia Saudita, a atividade online da Al-Qaeda tem aumentado principalmente através de microblogs como o Twitter, no intuito de gerar campanhas em prol da organização. Observa-se que autoridades de segurança do país:

[...] has monitored a large number of fake accounts on social networking sites, under Saudi and Gulf names, and that these accounts incite public opinion. The campaign inspected the identity of these accounts, and found out that most of them are managed from Iran and Iraq ${ }^{105}$.

Ainda que levemos em conta este tipo de ação (seja ou não a partir de perfis falsos), notadamente, a produção de ciberventos não é um elemento central no uso da comunicação digital pelo grupo.

\section{b) Ciberataque}

Os serviços secretos governamentais já encontraram indícios de ciberataques realizados por membros filiados a Al-Qaeda (SORIANO, 2013; MCGRATH, 2011). Como aponta Weimann (2006) é natural que a Internet seja em muitos modos uma arena ideal para

\footnotetext{
${ }^{105}$ Conforme descreve reportagem publicada no site jornalístico Almonitor, que faz cobertura de países do Oriente Médio. Disponível em: < http://www.al-monitor.com/pulse/security/2014/04/al-qaeda-twitter-mobilizesaudi-youth.html\# > . Acesso em: 6 dez. 2016.
} 
atividades de organizações terroristas. No Paquistão foi detectado um campo de treinamento destinado exclusivamente para capacitação operacional dos membros sobre como fazer penetração de computadores e técnicas de sistemas de guerra cibernética. Uma espécie de "Cyber University" estava dedicada à formação de hackers para ataques online (SORIANO, 2013).

Há também jihadistas vinculados à Al-Qaeda que atuaram na direção do ciberataque. Um dos mais conhecidos é chamado de "Irhabi 007", cujo nome real é Younis Tsouli ${ }^{106}$. Como relata Soriano (2013), Tsouli foi um dos primeiros "ciberjihadistas" que oferecia links para revistas eletrônicas emblemática como A voz da Jihad e Al Battar, as principais plataformas para a propaganda da Al-Qaeda na Arábia Saudita. No início de 2004, Irhabi se uniu a fóruns jihadistas e criou um sistema unificado com acesso protegido por uma senha onde os "ciberjihadistas" mais comprometidos poderiam encontrar um espaço discreto e seguro para trocar informações sobre como fazer ciberataques (SORIANO, 2013) ${ }^{107}$.

Embora esteja claro que ações de ataques no cyber domain já ocorram, não há consenso sobre a efetividade da Al-Qaeda em produzir ciberataques propriamente dito. Para alguns analistas como Green (2002), não há evidências que o cibeterrorismo seja algo que de fato tenha causado danos e acredita que há uma super-estimação do problema:

There is no such thing as cyberterrorism - no instance of anyone ever having been killed by a terrorist (or anyone else) using a computer. Nor is there compelling evidence that al Qaeda or any other terrorist organization has resorted to computers for any sort of serious destructive activity (online) ${ }^{108}$

Porém, é importante afirmar que a relevância de ataques e a concepção de terrorismo não está necessariamente vinculada à potencialidade de causar mortes. A crescente informatização das atividades modernas e a centralidade que os sistemas digitais ganham a cada dia são um horizonte factível de impacto futuro. E ainda que um eventual ataque cibernético não cause mortes, pode causar insegurança, distúrbios e danos que vão desde a inoperabilidade de serviços online até a interrupção de serviços básicos como rede elétrica ou

\footnotetext{
${ }^{106}$ De origem marroquina, mas com residência no Reino Unido, foi condenado em 2007 neste país. Ver mais em < http://news.bbc.co.uk/2/hi/americas/7191248.stm > Acesso em: 16 nov. 2015.

${ }^{107}$ Por exemplo, como descreve Soriano (2013): "En una ocasión, colgó un documento de veinte páginas de elaboración propia titulado Seminario sobre cómo hackear páginas web, con numerosa información sobre cómo manipularlas y ofreciendo un listado de webs vulnerables en las cuales era posible colgar material sin el conocimiento de sus administradores" (SORIANO, 2013, p. 322).

${ }^{108}$ Disponível em <http://www.washingtonmonthly.com/features/2001/0211.green.html>. Acesso em: 2 dez. 2015.
} 
sistemas de transporte. Mas para chegar a este nível, é necessário uma expertise e a posse de equipamentos que consigam atingir tamanha dimensão, o que não é comum ainda para grupos terroristas em geral.

Apesar de já existirem indícios de ataques cibernéticos próprios produzidos por apoiadores ou filiados a Al-Qaeda - ataques sem impactos de mortes diretas - é possível afirmar que a prática de ações de ciberterrorismo ${ }^{109}$ não é uma especialidade deste grupo. Como é possível averiguar nos indicadores anteriores, o grupo utiliza a comunicação digital principalmente para a difusão da causa, recrutamento e planejamento.

Existem ativistas fundamentalistas islâmicos que operam no ciberespaço em apoio ao movimento da Al-Qaeda, em defesa da causa, promovendo ciberataques. Além de casos isolados de autorrecrutamento hacker, há também redes muçulmanas de programadores e especialistas em sistemas que apoiam o grupo. É o caso do Muslim Hackers Club. Segundo agências de segurança estadunidense, trata-se de um grupo que tem como objetivo desenvolver ferramentas de software para o lançamento de ataques cibernéticos contra alvos ocidentais (WEIMANN, 2006).

Não é possível afirmar que haja um poder de fogo realmente significativo, por enquanto. Mas já foram detectadas ações colaborativas que se não considerados ataques cibernéticos na acepção mais formal do termo, são pelo menos prelúdios ou insumos para que ataques online possam ser um novo campo de ação com relevância para a Al-Qaeda no futuro.

Uma outra forma de ataque cibernético é o chamado cyberfear. Embora possua traços de outras categorias de análise aqui apresentadas, sustenta uma característica fundamental: Provocar medo e insegurança em seus inimigos através de ações no ciberespaço. Ou seja, objetivo e público-alvo explicitamente definidos. É a chamada guerra psicológica tratada por Weimann (2004): Consiste em espalhar informações, imagens e ações entendidas como ameaça e construção do medo sobre o outro. No cyberfear há uma ampliação do real, como por exemplo tratar dos potenciais ataques cibernéticos até que se acreditem neles. Outro exemplo é anunciar que irá derrubar aviões a partir do desligamento do sistema de controle de tráfico aéreo (WEIMANN, 2004). São ameaças que indubitavelmente provocam pânico e desestabilização social, ainda que não venham a ser levadas a cabo. Um exemplo concreto de cyberfear, amplamente difundido por jihadistas online, foi de que a Al Qaeda ascendia como a

\footnotetext{
${ }^{109}$ Isto é, ataques terroristas que ocorrem especificamente dentro do ciberespaço, conforme discussão do capítulo 3.
} 
primeira organização terrorista a dominar o poder nuclear, algo que não se confirmou com evidências físicas de armas nucleares (JENKINS, 2012).

Thomas (2003) também aponta a Internet como uma atmosfera de construção de medo virtual. Segundo o autor, ferramentas online empoderam grupos e os fazem parecer mais capazes do que realmente são. As ameaças podem ganhar amplitude ainda que os grupos sejam totalmente impotentes. E o iminente ataque a um computador estratégico pode causar danos sérios de infraestrutura, para a economia e caos social. "In effect, the Internet allows a person or group to appear to be larger or more important or threatening than they really are" (THOMAS, 2003, p. 116). Além disso, elas podem ser parcialmente reais, já que as mensagens refletem muitas vezes apenas um lado e tem enviesamento político muito claro: "The internet can thus spread rumors and false reports that many people, until further examination, regard as facts" (THOMAS, 2003, p.116). Boa parte das ações de cyberfear ocorre com a ajuda de redes online de apoiadores.

As recomendações quanto à proteção de dados online de militares e diplomatas emitidas por serviços de segurança de alguns países também demonstram que todo tipo de dado está sendo utilizado para planejar ataques, de modo que a Al-Qaeda estaria também envolvida nisto. Trata-se de um outro tipo de ciberataque que é a ciberespionagem. Por exemplo, em 2008 o serviço de inteligência britânico (o MI5) distribuiu um comunicado aos soldados lotados no exterior para retirarem todos os tipos de informações pessoais de redes sociais online (SORIANO, 2013). O aviso se deu após a descoberta de numerosos acessos suspeitos a informações pessoais dos militares (como nomes, locais de nascimento, carreiras, fotografias, parentes etc.) postadas abertamente em sites como Facebook. As visitações estavam relacionadas a membros da Al-Qaeda (SORIANO, 2013). Em um outro exemplo similar, trazido pelo autor, detectou-se que a Al-Qaeda conseguiu, através de um software de espionagem, compilar informações pessoais de um diplomata dos EUA que atuava na região do Oriente Médio. Os invasores "crackearam" ${ }^{110}$ dados de conta de e-mail, extratos bancários, localização e rotina de deslocamento físico (SORIANO, 2013).

Outro caso que nos serve como indicador disso é o cracking e a divulgação pelo website do Muslim Hackers $C l u b^{111}$ de informações confidenciais, como nomes de código e

\footnotetext{
${ }^{110}$ O neologismo anglofônico vem do verbo "crack" que significa, grosso modo, "quebrar". Em informática, o termo é utilizado quando algum especialista em programação consegue quebrar o sistema de segurança de um arquivo ou software.

${ }^{111}$ Trata-se de um grupo que o serviço de inteligência dos EUA acredita desenvolver ferramentas de software para serem usadas em ciberataques contra alvos ocidentais (WEIMANN, 2006).
} 
frequências de rádio usadas pelo Serviço Secreto dos Estados Unidos (WEIMANN, 2006). O site do grupo oferecia ainda tutoriais na criação e disseminação de vírus e elaboração de estratagemas de hacking, que envolve sabotagem de rede e desenvolvimento de códigos maliciosos.

\subsection{WIKILEAKS: VAZAMENTO DIGITAIS E REDES COLABORATIVAS}

Vazamentos de informações sigilosas com exposição de segredos de Estado foram emblemáticos para a política internacional nos últimos anos. Principalmente a partir de 2010, pode-se destacar quatro importantes momentos: Em abril a publicação do vídeo "Collateral murder" $" 112$ demonstrou o ataque das forças armadas norte-americanas a civis desarmados a partir de um helicóptero de guerra no Iraque, apontando o uso excessivo e injustificado da força; o Afgan War Diaries ${ }^{113}$, registros da guerra do Iraque com mais de 90 mil documentos relevaram ações ilegais ou contestáveis dos militares estadunidenses durante a ocupação do Afeganistão; e o chamado "Cablegate",114, conjunto de telegramas trocados entre embaixadas e o departamento de Estado norte-americano, tornaram públicos segredos diretos da diplomacia ainda corrente, causando uma série de tensões na arena internacional. Todos vazamentos foram difundidos pelo WikiLeaks e marcaram a entrada desta organização no centro de acalorados debates políticos. Como descreve Quian (2013):

El primer gran impacto mundial de WikiLeaks en los medios de comunicación, la opinión pública y la esfera política se produjo el 5 de abril de 2010 con la publicación del dramático vídeo grabado el 12 de julio de 2007 desde un helicóptero Apache estadounidense en Irak, en el que se ve cómo soldados estadounidenses acribillan al fotógrafo de la agencia Reuters Namir Noor-Eldeen, a su ayudante y a nueve personas más. Para difundirlo, WikiLeaks creó ex profeso el sitio web Collateral Murder (http://collateralmurder.com) y eligió estratégicamente el National Press Club de Washington para su presentación mundial en conferencia de prensa. La cadena árabe Al Jazeera y el canal Russia Today fueron los primeros que le dieron una amplia atención, además de Reuters, obviamente por su relación con dos de los asesinados. A estos medios les siguieron The Washington Post, BBC, The New York Times, CNN, The Guardian y El Mundo, entre otros (p. 32-33).

\footnotetext{
${ }^{112}$ Disponível em: <https://collateralmurder.wikileaks.org/ >. Acesso: 4 de out. 2015.

${ }_{113}$ Disponível em: <https://wikileaks.org/afg/>. Acesso: 4 de out. 2015.

${ }^{114}$ Disponível em: <https://wikileaks.org/plusd/?qproject[]=cg\&q=\#result>. Acesso: 4 de out. 2015.
} 
A existência do WikiLeaks e a sua repercussão nos dias atuais só é possível por ser uma organização cujas estruturas estão sedimentadas nas Tecnologias da Informação e Comunicação (TICs), embora, como veremos, faça paralelamente uso dos meios de comunicação tradicionais. O WikiLeaks se tornou, na verdade, a organização especializada em publicação de informação governamental sigilosa mais importante do mundo atualmente, sendo responsável pelos maiores vazamentos de informações militares, em termos de volume, já registrados na história.

Passou a ser tema de debates acirrados sobre os seus métodos, sendo visto por alguns como uma organização criminosa e irresponsável que põe em risco a vida de diplomatas, militares e tenciona a relação entre países e, por outros, como o símbolo do ativismo em prol de um mundo mais transparente, inibindo a ação secreta e ilegal de grandes potências militares e econômicas, como os Estados Unidos.

Para compreender melhor este fenômeno, será preciso, primeiramente, situar o WikiLeaks em suas origens, sintetizar sua trajetória, apontando suas principais características.

O WikiLeaks foi criado oficialmente em outubro de 2006, como uma organização civil sem fins lucrativos. Seu website foi lançado publicamente em 2007, juntamente com a promessa de disponibilizar mais de 1,2 milhões de documentos secretos. Embora o grupo esteja comumente vinculado à Internet, não se trata apenas de um site: consiste em organização especializada em receber e circular informações governamentais sigilosas que consideram necessárias de serem publicizadas a título do que chamam de "transparência total”. O uso da Internet, como veremos, é apenas uma parte deste processo. Como explica a própria organização em seu website oficial:

WikiLeaks is a multinational media organization and associated library. It was founded by its publisher Julian Assange in 2006. WikiLeaks specializes in the analysis and publication of large datasets of censored or otherwise restricted official materials involving war, spying and corruption. It has so far published more than 10 million documents and associated analyses ${ }^{115}$.

Embora o WikiLeaks seja uma organização que conta com diversos participantes ao redor do mundo, como veremos, o nome mais conhecido e seu fundador, é o australiano

\footnotetext{
${ }^{115}$ WIKILEAKS WEBSITE. Disponível em: <https://wikileaks.org/What-is-Wikileaks.html〉. Acesso em: 23 nov. 2015.
} 
Julian Assange ${ }^{116}$. Em entrevista ao jornal Der Spigel, Assange explica o que é a organização e fala também sobre a repressão que o grupo sofre, principalmente em países como os EUA, que tiveram conteúdos secretos vazados:

WikiLeaks is a giant library of the world's most persecuted documents. We give asylum to these documents, we analyze them, we promote them and we obtain more. [...] WikiLeaks is still a taboo object for some parts of the government. Firewalls were set up. Every federal government employee and every contractor received an e-mail stating that if they read something from WikiLeaks including through the New York Times website, they have to remove this from their computer immediately and self-report. They had to cleanse and confess. That's a new McCarthy hysteria (ASSANGE, 2015, online).

É preciso compreender o surgimento de grupos como o WikiLeaks como parte de um contexto maior de inovações tecnológicas estruturais que reverbera em importantes mudanças na esfera econômica, social e política. Trata-se de um fenômeno que tem ganhado centralidade desde o surgimento da Internet e seus protocolos digitais de comunicação, e que afeta hoje a forma como os indivíduos estão se relacionando (socialmente, economicamente e politicamente) e também tem ampliado o tráfego global de dados e os pontos de conexão entre diversos atores:

\begin{abstract}
Vê-se uma nova geração de cidadãos organizada em boa medida online contra regimes autoritários comandados por uma geração que cresceu sem acesso à internet. [...] Embora o fenômeno WikiLeaks nada tenha a ver com esses desenvolvimentos, a reação pública deve ser vista no contexto de novos e reforçados argumentos segundo os quais o acesso livre à informação e à internet tem poder de emancipação (SPEKTOR, 2011, p. 21).
\end{abstract}

Se uma parte da reação do grande público agraciou o compromisso de transparência da informação defendido pela organização e seu caráter anarquista, compactuando com o apoio dos ataques hackers, outra parte dividiu junto com alguns governos a condenação do ato. Como lembram Curran e Gibson (2012), o porta-voz do Departamento de Estado dos EUA

\footnotetext{
${ }^{116}$ Iniciado como hacker aos 17 anos, em 1991 já era um reputado hacker e fundou junto com outros colegas (conhecidos como Prime Suspect and Trax) a revista International Subversive. Sob o codinome de Mendax, Assange ascendeu como o mais importante hacker da Austrália e teve que responder judicialmente por uma série de delitos informáticos: "[...] haber accedido ilegalmente al terminal central de la empresa de telecomunicaciones canadiense Nortel, a la sede del 7. ${ }^{\circ}$ Grupo de Mando de las Fuerzas Aéreas estadounidenses en el Pentágono, al Naval Surface War Center de Virginia, a la planta de Sistemas Técnicos Aeroespaciales de Lockheed Martin en California y a MILNET, la red de datos secretos del ejército estadounidense [...]" (QUIAN, 2013, p. 23). Assim, Assange se tornou o principal alvo de governos que tiveram seus arquivos vazados pelo grupo. Atualmente, está exilado na embaixada do Equador em Londres e é considerado refugiado pelas autoridades britânicas em razão do processo que o acusa de práticas de pedofilia, impetrado pela Justiça sueca que pede a sua extradição. Para o próprio Assange e ativistas do grupo, as acusações seriam inverídicas e o real interesse por trás de sua prisão seria político. $\mathrm{O}$ ativista teme que uma eventual prisão possa se reverter em extradição para os EUA, que o acusam de espionagem.
} 
disse que ao invés de jornalista, Julian Assange era um "whistleblower", atuando com uma agenda política e com foco claro nos Estados Unidos.

Importante notar que as dimensões de uso das tecnologias digitais de comunicação pelo WikiLeaks têm despertado análises distintas sobre sua real natureza. Spektor (2011) polariza o debate a partir de dois argumentos: (1) primeiro, um grupo que acredita nas novas tecnologias a serviço da emancipação política (sob a égide de princípios como transparência, democracia, e no intuito de mitigar a hegemonia americana nas relações internacionais); (2) segundo, um outro conjunto de analistas acredita que os responsáveis pelos vazamentos são criminosos que desestabilizam relações bilaterais entre países e prejudicam as relações internacionais. É possível ainda acrescentar outro argumento; (3) terceiro, um grupo que abrange aqueles que revelam a pouca efetividade de atuação da organização, de modo que o WikiLeaks não teria trazido impactos significativos, apesar da grande repercussão no mundo político.

Cotejando esses três posicionamentos, fica evidente que a atuação da organização gera impactos, ainda que sua qualificação tenha gradações. Estas vão desde a reafirmação do status quo e a criação de atalhos para minimizar os impactos dos vazamentos; passa por outro nível que notifica um mínimo ajuste na burocracia interna para lidar com a transparência forçada; sob outra matiz resvala no crescimento da opinião pública internacional imbuída a criar medidas de enforcement e não mais tolerar infrações e vantagens de comunicações sigilosas; até chegar num nível de remodelamento das relações entre governos, onde a transparência pode vir a ser uma medida de aperfeiçoar a relação entre discurso e prática e também empoderar outros atores em prol de uma verdadeira emancipação política.

Em sua causa o WikiLeaks defende a transparência nas atividades do governo e de grandes corporações como princípio capaz de reduzir a corrupção, melhorar o governo e fortalecer democracias.

\subsubsection{Estímulo à configuração da causa}

\section{a) Articulação}

O WikiLeaks é uma organização que atua em prol da bandeira da transparência radical para governos e grandes corporações com influências ideológicas hacktivistas, principalmente 
de linha cypherpunk ${ }^{117}$. Um lema cypherpunk resume bem a causa defendida pelo grupo: "Privacidade para os fracos, transparência para os fortes" ${ }^{118}$. Como explica a própria organização:

The organization strongly believes that such transparency is vital to holding governments, corporations, and other intitutions accountable for their actions. WikiLeaks believes that publishing information obtained by "principled leaking" -leaks based on moral conscience or the information's importance to society -has the potential to not only expose corruption but to even save lives. WikiLeaks has broken numerous stories in the world press and has been awarded several prestigious journalism (WIKILEAKS.ORG, 2013, p. 11).

A organização nasceu a partir de diálogos online entre ativistas de diferentes partes do globo preocupados com questões como educação, saúde, fome acentuadas pela corrupção de governos: "The founding people behind WikiLeaks thought long and hard about how this problem could be fixed, and particularly about how information technologies could amplify the fix on a world wide scale" ${ }^{119}$. Assim, com o intuito de atuar contra regimes autoritários expondo dados sensíveis e demonstrando à opinião pública mundial seus abusos de poder tinham o objetivo de sensibilizar mudanças políticas efetivas. Porém, houve uma mudança de foco e a bandeira da transparência - com ênfase em grandes potências, mesmo aquelas consideradas democráticas como os EUA - passou a ser incorporada de forma mais central:

Another problem with WikiLeaks as a model of transparency activism is that it is not clear what Assange's ultimate goals are, or whether his methods are the best way to achieve them. At first, the site said that its "primary interest is in exposing oppressive regimes in Asia, the former Soviet bloc, Sub-Saharan Africa and the Middle East, but we also expect to be of assistance to people of all regions who wish to reveal unethical behaviour in their governments and corporations." Now it describes itself "as a non-profit media organization dedicated to bringing important news and information to the public. We provide an innovative, secure and anonymous way for independent sources around the world to leak information to our journalists." But it's far from clear that Assange is just interested in exposing oppressive and unethical behavior (SIFRY, 2011, p. 174).

Como explica Silva (2013), a concepção contemporânea de transparência e a sua respectiva guinada para o digital, embora tenha suas origens e precedentes em debates anteriores sobre publicidade (principalmente Kant e Bentham), é uma bandeira recente que

\footnotetext{
${ }^{117}$ Como explicam Assange et al (2012) "What is a cypherpunk? Cyberpunks adovocate for the use of cryptography and similar methods as ways to achieve societal and political change. Founded in the early 1990s, the movement has been most active during the 1990s "cryptowars" and following the 2011 internet spring. The term cypherpunk, derived from (cryptographic) cipher and punk, was added to the Oxford English Dictionary in 2006" (posição 3)

118 "Privacy for the weak, transparency for the powerful".

${ }^{119}$ WikiLeaks, Website official. Disponível em https://wikileaks.org/wiki/Draft:About . Acesso: 3 jan. 2016.
} 
vem sendo bastante difundida e defendida tanto por ativistas, como por governos. Trata-se de um meio para garantir controle público e justiça política, inibindo abusos de poder e corrupção $^{120}$. O autor explica que há quatro princípios fundamentais que estão nas bases desta noção: (1) previsibilidade (regras previamente estabelecidas e compartilhadas possibilitam maior controle cognitivo de condutas); (2) Publicidade (atividades de determinados agentes devem se realizar com alto grau de franqueza, honestidade e conhecimento público, pois aquilo que não pode ser submetido ao domínio público tende a ser injusto); (3) inteligibilidade (o que não é compreensível não pode ser controlável, logo, compreender significa identificar patologias como crimes, corrupção e outros desvios); (4) exigibilidade (saber sobre o que afeta a todos é um direito).

Na prática, o WikiLeaks radicaliza esta concepção de transparência digital, levando-a para a arena internacional. Spektor (2011) complementa esta percepção ao afirmar que: “o episódio WikiLeaks encontra raiz em uma dimensão mais profunda e importante da política internacional contemporânea, qual seja o embate acirrado pelo acesso à informação governamental no início do século XXI" (SPEKTOR, 2011, p. 20). Como explana Seib (2012):

\begin{abstract}
"Transparency" has moved from being a distant ideal to becoming an expectation, and its absence will increasingly trigger public protest. The desire for transparency can be fulfilled by a combination of the efforts of traditional journalists and independent diggers such as those who retrieved the WikiLeaks documents (p. 154).
\end{abstract}

Neste ponto, a visão do WikiLeaks é contribuir com elementos para que atores nãoestatais possam se empoderar e tomar conhecimento de irregularidades para entrar no jogo político de entidades poderosas. Acredita-se que os dados abertos em rede permitem uma maior circulação e liberdade de informação, corroborando para o desenvolvimento de princípios democráticos, por outro lado, podem criar contextos de vulnerabilidade, sobretudo para instituições que são marcadas por dados sigilosos, secretos e não-transparentes, traduzidos em caixas pretas de alguns Estados em determinados aspectos de suas relações domésticas e externas, incluindo aí a rotina diplomática. Como descreve QUIAN (2013) sobre a manifestação pública de Assange na abertura do Wikileaks em 2007:

\footnotetext{
${ }^{120}$ As Assange has always insisted, transparency is not a goal, it is a method of achieving 'justice': 'It is not our goal to achieve a more transparent society; it's our goal to achieve a more just society. And most of the times, transparency and openness tends to lead in that direction, because abusive plans or behavior get opposed" (BECKETT; BALL, 2012, p. 145-146).
} 
Assange de WikiLeaks para su lanzamiento público, el 3 de enero de 2007: «WL [WikiLeaks] puede convertirse en la agencia de inteligencia más poderosa del mundo, una agencia de inteligencia de la gente... WL será un yunque en el que golpea el martillo de la conciencia colectiva de la humanidad... WL, esperamos, será una nueva estrella en el firmamento político de la humanidad». En su declaración fundacional, WikiLeaks se definía de forma ambigua como una organización formada por disidentes, periodistas, matemáticos y tecnólogos de todo el mundo. Y definía como su misión publicar en su página web y en otros sitios de Internet informes filtrados por fuentes anónimas sobre comportamientos poco éticos y delitos de gobiernos, ejércitos y grandes corporaciones financieras de todo el mundo (p. 31).

Assim, é possível afirmar que a abertura e divulgação de dados oficiais governamentais podem ser usadas tanto por Estados para fortalecimento de suas instituições democráticas, como o exemplo brasileiro recente da Lei de Acesso à Informação ${ }^{121}$, quanto por movimentos ativistas, como o caso do WikiLeaks, que pregam a radicalização da transparência total de dados e informações.

Os princípios de autonomia e liberdade, luta contra a mediação das instituições, sua centralização e hierarquização, e o acesso à informação para todos são bandeiras defendidas pelo WikiLeaks que, para alguns analistas, compõem uma natureza ideológica complexa e multifacetada, de base anarquista. Esta aproximação é explicada por Curran e Gibson (2012): "At the outset we identified the championing of an informational commons-committed to the free access to and exchange of information which an anarchical Internet renders possible — as a central component of WikiLeaks' anarchism” (p. 307).

A associação à ideologia anarquista é também muito vinculada ao WikiLeaks devido ao apoio que recebe de grupos anarquistas, pois segundo Burns e Sumaiya (2010, s/p) "The Internet assaults underlined the growing reach of self-described 'cyberanarchists', antigovernment and anticorporate activists who have made an icon of Mr. Assange".

Apesar do fato apontado pelos autores de que o princípio anarquista pode ser atrelado ao caráter originário do WikiLeaks, isto não é endossado pela própria organização, até mesmo pelo simbolismo negativo que de algum modo está atrelado ao termo. Curran e Gibson (2012) explicam que o uso dos rótulos de anarquista para Julian Assange e, consequentemente para o WikiLeaks, serve para deslegitimar o grupo, afirmando que isso seria mais uma característica

\footnotetext{
${ }^{121}$ Trata-se da Lei no 12.527 , de 18 de novembro de 2011, conhecida como LAI (Lei de Acesso à Informação). É a principal legislação brasileira sobre transparência e obrigações dos agentes governamentais em ceder informações públicas para qualquer requerente. A Lei também estabelece que tipo de informações podem ser consideradas secretas e por quanto tempo podem ficar sob sigilo. Ver texto integral em <http://www.planalto.gov.br/ccivil_03/_ato2011-2014/2011/lei/112527.htm>. Acesso 23 jun. 2015.
} 
pessoal de Assange, que nega publicamente o papel de anarquista, talvez mais por uma estratégia defensiva, do que por rejeitar de fato os princípios anárquicos, como explicam os autores. Curran e Gibson (2012) também lembram que a cultura hacker, movimento da cibercultura de influência anarquista, está na base da formação do grupo. O hacktivismo compartilha a crença no caráter libertário e anárquico da Internet, em que os hackers contribuem para a renovação tecnológica de forma colaborativa, diferentemente dos crackers - denominação pejorativa para aqueles que usam as habilidades junto ao sistema operacional para invasão de sistema e para fins comerciais ou pessoais, entendidas estas dentro de uma prática criminosa (CURRAN; GIBSON, 2012; MILAN, 2013). Serra (2012) acrescenta que tecnologicamente, a prática do WikiLeaks prega o intercâmbio anônimo de informações, com uma atitude política de acesso a todos da informação, traços em perfeita harmonia com a ética hacker. Notadamente, o grupo foi gestado no últero da cultura hacker. O movimento hacktivista pregava a penetração de sistemas de informações para extrair dados de empresas ou governos ${ }^{122}$, de modo que os ativistas eram motivados pelo desafio político, como era o caso de Assange (BECKETT; BALL, 2012). O DNA do WikiLeaks está justamente neste ambiente hacker. Suas bandeiras foram configurada desde os tempos do jovem Assange no hacktivismo, ainda na Áustralia, passando posteriormente por outros movimentos hackers, como o Chaos Computer Club. Como explicam Beckett e Ball (2012) sobre o grupo inicial:

It consisted largely of Assange and individuais from the 'Chaos Computer Club', a German group of pro-transparency hackers. WikiLeaks' claimed membership was rather larger than reality, and its inicial impact was also more modest than its publicity had suggested (p. 18).

Não por acaso, ao registrar em 1999 o domínio leaks.org, Assange já antevia as primeiras ideias básicas do que seria o WikiLeaks, que veio a surgir sete anos mais tarde, em 2006, como organização. Começou a operar online em janeiro de 2007 em um provedor sueco, já que o país protege o anonimato. Configurou-se atrelado a uma outra articulação de

\footnotetext{
${ }^{122}$ Importante nestes casos não confundir "hackers" com "crackers", conforme brevemente mencionado. Hackers são indivíduos com alto grau de conhecimento em linguagem de máquina e programação de softwares que, a partir da influência da contracultura ainda na década de 1970, levantaram a bandeira do empoderamento das pessoas comuns pela tecnologia para evitar serem dominado por estas, através das grandes corporações ou governos. O hacktivismo também prega a falibilidade dos sistemas buscando demonstrar que nenhum sistema é completamente perfeito e que nem sempre devemos viver dependentes destes. Nota-se que há um teor ideológico e político na cultura hacker. No caso do cracker trata-se de indivíduos também com um alto grau de conhecimento em informática porém sem esta ética hacker. De modo prático, crackers invadem bancos e usufruem dos dividendos furtados e o fazem por interesse particular. Hackers invadem bancos por uma questão ideológica e política.
} 
Assange, desta vez com um coletivo chamado The Sunshine Press (QUIAN, 2013). Segundo Assange, a iniciativa de fundar a organização foi uma resposta contra a guerra do Iraque, que considerou ser o resultado de uma manipulação midiática que só teria se tornado possível graças à ignorância pública que prevaleceu sobre fatos (QUIAN, 2013).

É possível afirmar que a configuração da causa do grupo e seu nascimento se dá justamente a partir de articulações com ativistas envolvidos em duas áreas paralelas: o hacktivismo e o jornalismo. Além de Assange, um outro co-fundador importante do grupo, Daniel Domscheit-Berg, também provia das mesmas bases cypherpunks. Com a configuração da organização, práticas hackers perderam a força e preponderou a ênfase de vazamentos não necessariamente através de ciberataques diretos, mas através de vazamentos digitais resultantes de vazamentos colaborativos recebidos pela organização: "WikiLeaks founder Julian Assange and colleagues like Daniel Domscheit-Berg emerged from a 'hacker' culture, but WikiLeaks itself soon moved away from the idea of penetrating other people's systems" (BECKETT; BALL, 2012, p. 16).

Nota-se que toda a formação dos princípios ideológicos que constituem hoje o WikiLeaks foi visceralmente influenciada pela existência de redes digitais de comunicação e de movimentos neste campo como o hacktivismo ou a corrente cypherpunk. A digitalização de dados de todas as espécies (inclusive informações secretas governamentais ou empresariais) criou um jardim fértil para o surgimento de um tipo de ativismo que pressupõe a existência de redes digitais. Ou seja, o processo que começa com o sequestro de dados sigilosos (por apoiadores) e o subsequente envio digital para divulgação na plataforma da organização só é possível devido ao uso da comunicação digital como recurso capaz de viabilizar tal procedimento.

\section{b) Difusão}

No começo de sua operação na web, o WikiLeaks não atingiu uma grande audiência online. A causa ficou restrita a nichos de usuários específicos, principalmente restritos ao seu website. A difusão da organização ocorre justamente com a sinergia entre Internet e veículos formais do jornalismo ${ }^{123}$ como parceiros para o vazamento de dados de grande impacto, principalmente aqueles vinculados a governos poderosos como os EUA. A partir daí, a organização ganha o noticiário e seu nome passa a ser conhecido pelo grande público:

${ }^{123}$ Isto será melhor detalhado no indicador seguinte: Massificação. 
La existencia de WikiLeaks plantea nuevos escenarios de acceso universal y masivo a la información en bruto por parte de los ciudadanos, sin que los datos pasen por el filtrado de los medios de comunicación tradicionales, cuestionando así su papel de mediadores informativos y poniendo en duda el modelo de mercantilización de la información que impera. Sin embargo, WikiLeaks renunció a sus principios con motivo del caso Cablegate, cuando Julian Assange decidió que los medios tradicionales de masas deberían jugar un papel clave en la difusión del mensaje de WikiLeaks, concediéndoles legitimidad como intermediarios necessários (QUIAN, 2013, p. 30).

Ao mesmo tempo que ganha o noticiário, a visibilidade de seu website também cresce na mesma velocidade. Isso tem grande importância para a organização, pois leitores online tendem a servir também como canais de divulgação da causa e das suas ações. $O$ ato de compartilhar histórias e segredos e o papel da comunicação digital em estimular este fenômeno através das redes sociais é um aliado da organização:

Readers exponentially amplify the distribution of stories in a highly efficient way, because generally they will be connected to people who will tend to share their interests and pass on material to their networks in turn. So readers act as publisher, filter, gatekeeper, and curator of news. They will sometimes re-version, adapt or dissect that news. In addition, they might comment, critique or analyse that information. They can also reverse the flow and interact back to the originator - in this case, WikiLeaks (BECKETT; BALL, 2012, p. 131).

Isso repercutiu não apenas em um alcance de um grande número de leitores desses jornais, mas também se consubstanciou em indicadores de viralização online do grupo. A publicação de vazamentos com o apoio de veículos do jornalismo formal gerou uma sinergia que repercutiu em um grande número de acessos, buscas ou menções sobre WikiLeaks no mundo virtual, que viralizou conteúdo online em diversos índices, trazidos aqui como exemplificação o buscador online Google e o microblog Twitter.

Quian (2013) explica como os resultados da busca pelo nome "WiliLeaks" na popular ferramenta online Google mantiveram-se relativamente baixos antes de 2010. Isto embora o grupo já divulgasse informações muito relevantes há pelo menos três anos, porém apenas pela via online em seu próprio website (QUIAN, 2013, p. 102): 
Gráfico 1 - Tendências de busca do termo WikiLeaks no Google

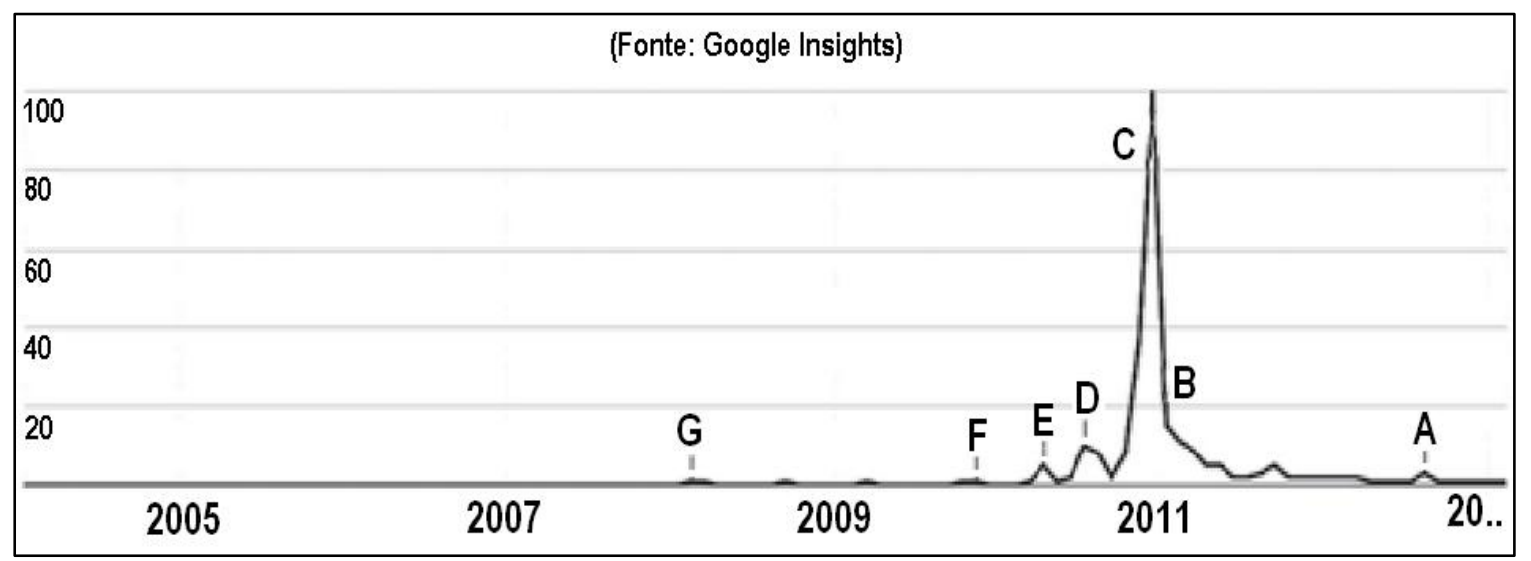

O Gráfico 1 demonstra um pico (a letra "C") justamente no caso Cablegate ${ }^{124}$ que teve grande repercussão através da divulgação de diversos telegramas oriundos das embaixadas americanas, em novembro de 2010. Esse vazamento marca o auge da relação sinérgica entre o WikiLeaks e a mídia tradicional. Após este pico, o gráfico começa a perder força e Quian (2013) atribuiu isso aos desgastes entre essas duas partes:

El primer pico importante (E) coincide con la publicación en abril de 2010 del vídeo Collateral Murder de la guerra en Irak, alcanzando las búsquedas el valor 5 en Irak, alcanzando las búsquedas el valor 5. Hasta esa fecha, el valor obtenido en la escala de 0 a 100 fluctúa entre 0 y 1 , siendo 0 el más repetido. En julio de 2010 las búsquedas logran el valor 10 (D) coincidiendo con el anuncio de la publicación de los papeles del Pentágono sobre la guerra en Afganistán [...] Las búsquedas alcanzaron el valor máximo de la escala 0-100 a finales de noviembre y en diciembre de 2010 (C), en el inicio del Cablegate. Luego, poco a poco el número de búsquedas en Google sobre WikiLeaks se fue reduciendo a medida que las filtraciones fueron pasando a un segundo plano, la atención de los medios se iba centrando en Julian Assange y su relación con los medios se iba deteriorando, aunque desde entonces el volumen de búsquedas de «wikileaks» sobre el total se ha mantenido por encima de los valores registrados hasta abril de 2010 (QUIAN, 2013, p. 102-103).

\footnotetext{
124 "Cablegate" é o nome dado a um dos maiores vazamentos realizados pelo grupo que consistiu em um volume expressivo de telegramas da diplomacia americana: "In September 2011, the master file containing the entire collection of 251,000 American diplomatic cables became available online. It included everything from the private phone number of the Queen of the Netherlands to information about China's nuclear power plants. Once again, US diplomats needed to repair damaged relationships" (SEIB, 2012, p. 153).
} 
Em um outro indicador, desta vez no microblog Twitter, o WikiLeaks também tem uma viralização de menções, conforme demonstra o Gráfico 2, que vai atingir picos expressivos em 2010 e em 2012 (QUIAN, 2013, p. 106):

Grafico 2- Menções ao WikiLeaks no Twitter

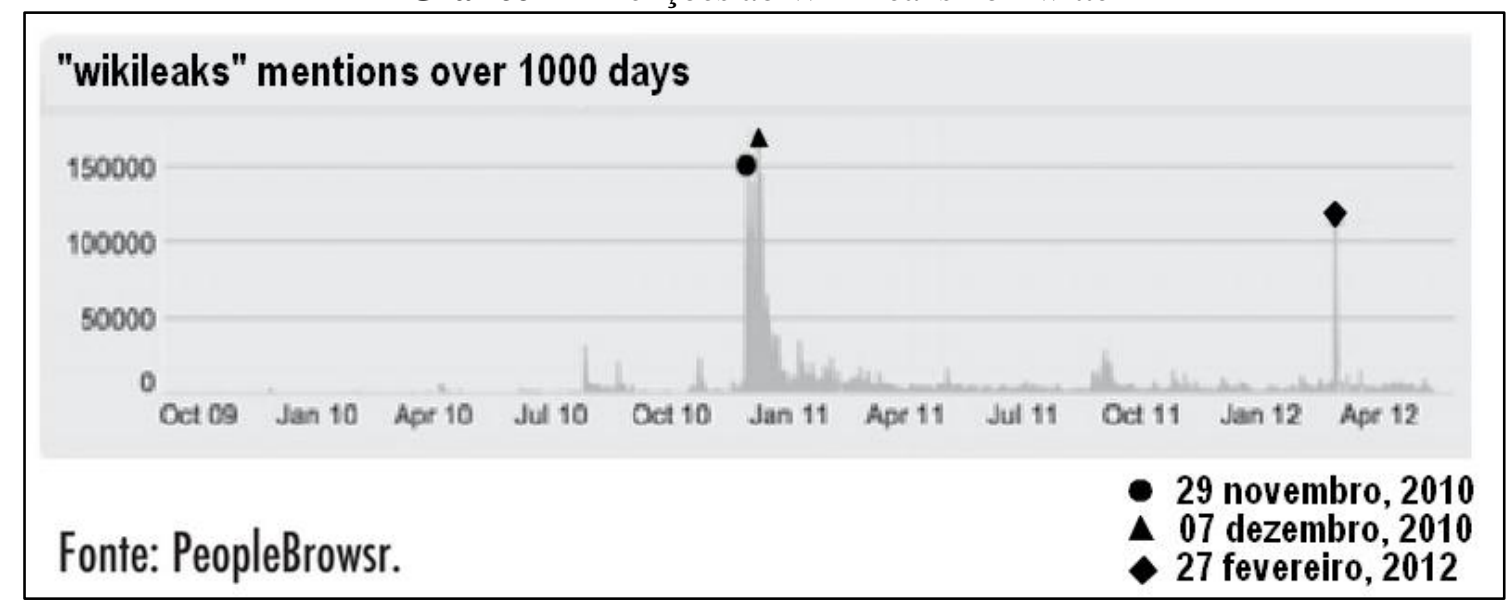

Pode-se perceber, novamente, que esses indicadores também apresentam padrões similares de viralização em relação ao nome do grupo, principalmente em 2010. A Tabela 1, a seguir, traz um detalhamento dos principais picos de menções no referido microblog: 
Tabela 1 - Dias de maior impacto no Twitter - por menções ao WikiLeaks

\begin{tabular}{|c|c|c|}
\hline Día & Menciones & Acontecimientos \\
\hline $\begin{array}{l}7 \text { de diciem- } \\
\text { bre de } 2010\end{array}$ & 161.776 & $\begin{array}{l}\text { Detención de Julian Assange en Londres. Visa y } \\
\text { MasterCard suspenden los pagos a WikiLeaks. }\end{array}$ \\
\hline $\begin{array}{l}9 \text { de diciem- } \\
\text { bre de } 2010\end{array}$ & 144.650 & $\begin{array}{l}\text { Twitter cancela la cuenta de Anonymous y } \\
\text { Facebook, la página de Operation Payback. } \\
\text { Amazon sufre ataques DDoS. Lula da Silva } \\
\text { defiende a WikiLeaks. }\end{array}$ \\
\hline $\begin{array}{l}29 \text { de } \\
\text { noviembre } \\
\text { de } 2010\end{array}$ & 140.816 & $\begin{array}{l}\text { Día después del inicio de la filtración de } 251.287 \\
\text { cables de la diplomacia estadounidense. Assange } \\
\text { anuncia que a principios de } 2011 \text { prevé difundir } \\
\text { material sobre un gran banco norteamericano. }\end{array}$ \\
\hline $\begin{array}{l}3 \text { de diciem- } \\
\text { bre } 2010\end{array}$ & 139.291 & $\begin{array}{l}\text { WikiLeaks toma el nombre de dominio } \\
\text { WikiLeaks.ch suizo después de que su provee- } \\
\text { dor estadounidense, EveryDNS, le retire su } \\
\text { servicio. Un día antes, la Corte Suprema sueca } \\
\text { se niega a examinar el recurso de Assange y con- } \\
\text { firma la orden de detención internacional. }\end{array}$ \\
\hline $\begin{array}{l}8 \text { de diciem- } \\
\text { bre } 2010\end{array}$ & 133.102 & $\begin{array}{l}\text { Ataques DDoS de hacktivistas partidarios de } \\
\text { WikiLeaks contra la fiscalía sueca, los servi- } \\
\text { cios de Visa y MasterCard, y la página web de } \\
\text { Claes Borgstrom, abogado de las dos muje- } \\
\text { res que acusan a Assange de presuntos abusos } \\
\text { sexuales. }\end{array}$ \\
\hline $\begin{array}{l}27 \text { de febre- } \\
\text { ro de } 2012\end{array}$ & 107.745 & $\begin{array}{l}\text { WikiLeaks inicia la filtración de } 5 \text { millones de } \\
\text { correos electrónicos de Stratfor. }\end{array}$ \\
\hline $\begin{array}{l}1 \text { de diciem- } \\
\text { bre de } 2010\end{array}$ & 107.363 & $\begin{array}{l}\text { El jefe de la Comisión de Seguridad Nacional } \\
\text { del Senado de Estados Unidos, el demócrata } \\
\text { Joe Lieberman, insta a las empresas que prestan } \\
\text { servicios a WikiLeaks a que finalicen su rela- } \\
\text { ción con esta organización. Amazon expulsa } \\
\text { a WikiLeaks de sus servidores, en los que se } \\
\text { alojaba desde el } 29 \text { de noviembre. Interpol con- } \\
\text { firma que emitió el } 20 \text { de noviembre una alerta } \\
\text { roja contra Assange (petición internacional de } \\
\text { búsqueda y detención). }\end{array}$ \\
\hline
\end{tabular}

(QUIAN, 2013, p. 106-107)

Nota-se que quatro dos sete eventos com maior volume $\left(1^{\circ}, 2^{\circ}, 4^{\circ}\right.$ e $6^{\circ}$ eventos $)$ não tratam dos vazamentos em si, mas da repercussão política de ações de repressão realizadas contra o grupo, o que amplia a difusão da causa da organização, mobilizando e se fazendo conhecer para uma audiência cada vez maior. Os outros dois eventos $\left(3^{\circ}\right.$ e $\left.5^{\circ}\right)$ se referem especificamente à viralização devido à repercussão de vazamentos.

Estes dados mostram como a mudança de comportamento do WikiLeaks frente à mídia tradicional afetou a sua própria difusão online. Como explica Domingos e Couto (2011), por se tratar de uma organização sem fins lucrativos e sem compromisso com os 
critérios de noticiabilidade que regem os meios de comunicação tradicionais, apresentaria uma lógica diferente destes. Porém, o maior problema enfrentado pelo grupo para alcançar seu objetivo de provocar mudanças substantivas do cenário político, através da transparência e difusão de informações, foi administrar a grande quantidade de material que lhe chegava em segredo e torná-lo público. Neste ponto fica clara a diferença entre "transparência" e “publicidade". Como esclarecem Lindstedt e Naurin (2010), a partir de um debate mais geral sobre o conceito de transparência:

The concept of transparency captures the accessibility of information. [...] Publicity on the other hand means that the existing information is actually communicated to and received by the principal. With respect to citizens and political leaders, transparency implies that documentation of the actions of the political leaders is released, while publicity means that the content of this information has also become known by citizens. Clearly, transparency will most often increase the chances of publicity. In most cases information that is relatively easily accessible would stand a greater chance of also reaching a broader public. But the link is not an automatic one (p. 303-304).

Deste modo, é importante entender que, no início dos vazamentos do grupo, ainda em 2007, era privilegiada a publicação na íntegra dos documentos no website oficial da organização, porém sem qualquer tratamento direto das informações por grandes empresas de mídia. Significa dizer que havia transparência da informação, porém não necessariamente publicidade da mesma. O processo de publicidade foi advindo a partir da sinergia com os meios de comunicação tradicionais.

Paradoxalmente, a difusão da organização e o crescimento da sua audiência online aumentam também os ataques de governos e represálias que passaram a ocorrer tanto de forma direta, quanto de modo indireto, através de empresas como Amazon e PayPal ${ }^{125}$. Por isso, a estratégia para manter a organização viva foi continuar investindo nas redes de apoiadores, divulgando os pacotes de vazamentos de tempos em tempos e reforçando seus recursos online (seja criando espelhos do site em vários países para driblar os ataques, seja simplificando e sofisticando os modos de envio de conteúdo de vazamento através de tecnologias como criptografia ${ }^{126}$ etc.).

\footnotetext{
${ }^{125}$ No caso do do PayPal (empresa que intermedia pagamentos online), em 2010 os fundos e as doações do Wikileaks foram congeladas, tal como um embargo econômico imposto contra uma nação hostil (THOMPSON, 2013). No caso da Amazon, o serviço de hospedagem do website foi bloqueado. Ambos os casos por pressão do governo dos EUA.

${ }^{126}$ Criptografia implica em sistemas de segurança que "codificam" dados impossibilitando que sejam "lidos" ou "inteligíveis" para outrém não autorizado: "WikiLeaks uses a form of encryption known as 256-bit AES, similar
} 


\section{c) Massificação}

Como se pôde perceber, o processo de difusão da causa ocorreu acoplado a um processo de massificação atravessando outras mídias, justamente devido à sinergia com os veículos de comunicação de massa tradicionais (através do jornalismo formal). Assim, para entender esse processo transmídia é preciso ter em mente as nuances da relação entre o WikiLeaks e os veículos jornalísticos parceiros no processo de massificação dos vazamentos.

Enquanto disseminadores de informação, a organização costuma se identificar como uma organização de mídia cuja função é produzir um tipo de jornalismo específico, intitulado por Assange de "jornalismo científico":

WikiLeaks strongly self-identifies as a media organization whose mission is
to keep governments accountable by fearlessly publishing facts that need to
be made public. WikiLeaks practices "scientific journalism," in which
readers may view the original source documents on which articles are based
so that they can make up their own minds about the truth of a story.
WikiLeaks has adopted new technologies to help it tell the truth in a new
format, but the function of the organization is the same as other major media
outlets. The media helps keep governments honest, and WikiLeaks's unique
methods do much to ensure government transparency. The health of a
democracy depends on the media being able to report things freely, and
WikiLeaks is wrongfully being targeted for doing just that (ASSANGE,
2013, p. 64).

Na prática, é possível afirmar que o WikiLeaks pode e deve ser considerado uma organização de mídia por tratar de divulgar informação cobrindo um nicho específico, mas isso não retira o seu caráter ativista que fica evidente em suas origens, trajetória, modus operandi baseado no engajamento colaborativo e suas bandeiras de influência cypherpunk, como vimos anteriormente. Assim, em concordância com o argumento de Beckett e Ball (2012):

Those who argue that WikiLeaks is not 'journalism' are defining the term to exclude forms of news mediation that they do not wish to give an official stamp. Those who argue that WikiLeaks easily fits into their definition of journalism are in danger of ignoring how it challenges the validity of those categories. The debate about 'WikiLeaks as Journalism' is really a debate about what journalism is or is becoming (p. 26).

Além disso, o grupo também não encontra eco em todos os parâmetros que guiam a

to that used by online banking sites, and the military and intelligence agencies themselves. With a sufficiently strong and well-protected password, breaking in to such a file would take several million times longer than the life span of the universe" (BECKETT; BALL, 2012, p. 20) 
forma de existência, organização e operação de meios de comunicação convencionais: não estariam sob o mesmo padrão de códigos de conduta (MILLIGAN, 2013). O que se pode afirmar é que o grupo "cambia las reglas del juego de los medios de comunicación, atacando al corazón de su negocio: la exclusividad y la intermediación" (GUTIÉRREZ-RUBÍ, 2011, p. 29).

De todo modo, seja como grupo ativista, como intermediário de fontes ou como organização de mídia, o WikiLeaks estabeleceu um papel importante para mídias convencionais em compilar o material e processar aspectos relevantes para os cenários nacional e internacional, e por fim, divulgá-los. Por isso, a massificação do WikiLeaks para o público mais amplo não é totalmente inovadora: trata-se de um típico caso de hibridismo e integração transmídia: "When examined critically, WikiLeaks itself is not a revolutionary idea. It is best seen as a radical new hybrid combining 'hacktavism' with some of the traits of more tradicional investigative journalism" (BECKETT; BALL, 2012, p. 3).

Esta porosidade mostra como a efetividade de impactos político e social pretendidos pelo WikiLeaks se completa plenamente na medida em que a mídia tradicional e outros veículos de comunicação, como importantes portais de notícias online, são capazes de divulgar amplamente as informações previamente disponibilizadas online pelos ativistas. Inicialmente, este círculo estava restrito a grandes jornais na Europa e EUA:

WikiLeaks decidió aliarse con cinco grandes medios de información escritos
de Occidente, globales y tradicionales, para publicar aquellos cables. The
New York Times (Estados Unidos), The Guardian (Reino Unido), Der
Spiegel (Alemania), Le Monde (Francia) y El País (España) trabajaron
conjuntamente para sacar a la luz la mayor filtración de documentos secretos
jamás revelados sobre la diplomacia de Estados Unidos (QUIAN, 2013, p. 9-
10).

Porém nem sempre foi assim. Conforme tratado no indicador "articulação (item "a" desta seção), no surgimento do WikiLeaks o papel de grandes corporações midiáticas ainda não estava delineado: inicialmente, tratava-se de uma ação preponderantemente online. Para sair deste nicho, difundir-se e massificar-se para públicos mais amplos, a organização entendeu que o interesse dos grandes jornais estrangeiros no material sigiloso obtido seria a chave para que a informação vazada chegasse a todos os recantos do mundo e exercesse seu papel político equilibrando a balança de poder (uma vez que tratavam de vazamentos de potencial interesse para diversos cidadãos em diversos países, empoderando-os contra poderosos). Assim, conferir o papel de parceria a uma rede de agentes independentes tornou 
possível distribuir os documentos por todo o globo (VIANA, 2010), aumentando inclusive a importância da sua plataforma online como "repositório" de informação pública relevante sobre transparência no mundo. Como analisam Beckett e Ball (2012):

Just like any mainstream mass media organization, WikiLeaks clearly wanted a wide audience and to have an impact on society. [...] The main way to support it - apart from donations - is to share the information it reveals through links across email, websites and social networks like Twitter and Facebook. It is a good example of the new networked effects of the Internet on the dissemination of journalism. The online public does more than simply consume news (BECKETT; BALL, 2012, p. 26 e 131).

Na divisão de tarefas, o WikiLeaks se responsabilizava pelo recebimento do material e pela checagem de dados e fontes, passando a delegar a realização de um discurso compreensível, em nome da visibilidade, a alguns meios de comunicação de renome global. Segundo Schlosberg (2013) a cobertura midiática no início dos vazamentos dos telegramas, isto é, na primeira semana de dezembro de 2010, não marginalizou o conteúdo dos vazamentos em razão das fontes governamentais darem ênfase ao caráter não legítimo do grupo, e nem focou o conteúdo apenas em sensacionalismo ou escândalo. A cobertura pautou notícias relacionadas ao interesse público como questões de controvérsias políticas, ameaças de segurança, corrupção e criminalidade (SCHLOSBERG, 2013). E isto já gerou uma grande repercussão para a organização. Por exemplo, no dia 14 de dezembro de 2010 o sistema de medição de tráfego online do The Guardian, registrou 9,4 milhões de consultas de usuários sobre o grupo, resultado direto do vazamento dos telegramas (cables) publicado neste dia (QUIAN, 2013).

A escolha dos jornais pelo grupo vislumbrava o potencial alcance de circulação destes, já que a amplificação potencializaria o impacto, conforme explica Daniel (2011), o braço direito de Assange enquanto ainda trabalhava pelo WikiLeaks:

Aprendemos com o tempo também com quais jornalistas podíamos trabalhar
em conjunto para conseguir a maior atenção possível em relação a uma
notícia. Na dúvida, escolhíamos jornais ou programas televisivos que
garantissem para nós um círculo de leitores maior e mais variado do que as
mídias que estavam mais bem informadas e proporiam as questões mais
inteligentes, mas que fossem lidos e vistos por pessoas que não
precisávamos mais tentar convencer (DOMSCHEIT-BERG, 2011, s/p).

Além da audiência e do número de leitores dos jornais escolhidos, também havia o pressuposto da replicação por outros jornais no mundo que citavam as matérias ou replicavam 
trechos, uma vez que o impacto político possuía alto grau de valor-notícia (SEIB, 2012). Boa parte dos documentos vazados estavam categorizados como "secretos" e isso tinha um potencial impacto político relevante. Por isso, os jornais tentaram também se resguardar sobre o seu papel de "mediadores" e fizeram "edições", omitindo algumas informações potencialmente perigosas para a segurança nacional:

On the first day on which it published WikiLeaks material, the New York Times also published a "Note to Readers" explaining its decision to reveal the material. It said: "The Times believes that the documents serve an important public interest, illuminating the goals, successes, compromises and frustrations of American diplomacy in a way that other accounts cannot match." Noting that about 24,000 of the documents were marked "secret" and/or "noforn," meaning not to be shared with other countries, the Times said it had excised material "that would endanger confidential informants or compromise national security." In addition, the newspaper said it had allowed US officials to review the material before publication and had acceded to some of the government's requests to cut out particular items mechanisms (SEIB, 2012, p. 152).

Sabe-se, porém, que os grandes jornais estão preocupados basicamente com um tipo de notícia: Aquelas que satisfazem o seu critério de noticiabilidade (SERRA, 2012). Por esta razão, o WikiLeaks recebe críticas por ter se sujeitado aos filtros convencionais das grandes mídias e criado uma falsa ideia de transparência, quando na verdade mais revelou os obstáculos disso (ROBERTS, 2012; QUIAN, 2013). Neste sentido, Spektor (2012) afirma que "A falta de accountability do site representa, talvez, uma de suas maiores fraquezas e deve servir de alerta para aqueles que acreditam ser o seu serviço algo que veio para ficar" (p. 25).

Embora o papel do jornalismo formal tenha se configurado como um pilar relevante para a dimensão atingida dos vazamentos, importante perceber que a existência da Internet possibilitou que esses vazamentos ocorressem de forma menos filtrada do que poderia ter ocorrido em tempos de vida sem comunicação online. Isso porque o próprio meio digital representava um elemento novo nesta relação entre "fontes" e "mídia", pois gerou-se um maior constrangimento do ato do intermediário-editor, isto é: "não publicar" ou de "fazer cortes" de conteúdos politicamente relevantes (a ponto de distorcer ou esconder fatos) passou a significar um risco para os veículos jornalísticos pois, em paralelo, existia o próprio site do WikiLeaks que também publicava o mesmo conteúdo vazado em modo mais integral, como explica Seib (2012): 
The journalists understood, however, that their decision making about what the public would and would not see was limited, because they knew that WikiLeaks intended to publish the entire archive on its own website, where it would be available to everyone who had Internet access (p. 153).

Keller (2013), diretor executivo do The New York Times, revela que essa relação da mídia tradicional com o WikiLeaks não era tão harmoniosa. Em relação a um dos vazamentos, Assange ligou pessoalmente para ele criticando posturas adotadas pelo jornal na edição do War Logs. Segundo Keller (2013) a edição ocorreu para resguardar nomes lá contidos que poderiam ser alvo do Taliban. O enfoque dado pelo jornal ao perfil do informante Bradley Manning - que teria enfatizado de modo desproporcional seu perfil psicológico em detrimento do seu intuito - também foi motivo de desavença. Como complementa Quian (2013):

El tema más recurrido y más conflictivo en las reuniones fue la protección de las identidades de las personas que aparecían en aquellos documentos secretos, por motivos de seguridad personal. Mientras los periodistas se aferraban a sus principios éticos y deontológicos tradicionales para proteger a esas personas, la ética hacker de Assange le hacía colocarse en una posición radicalmente opuesta: la información debía ser liberada en bruto, sin suprimir datos, sin editar el contenido de los documentos, porque para él eso era lo correcto. Toda la información debía estar al alcance de cualquier individuo (p. 34).

Na prática, havia percepções de papeis nem sempre convergentes entre a organização WikiLeaks e seus parceiros da mídia: para Assange, os veículos jornalísticos eram colaboradores; porém, para jornalistas como Keller (2013), o WikiLeaks consistia apenas em uma fonte.

Diante da recorrência de atritos dessa natureza entre o grupo e seus parceiros iniciais de mídia, principalmente em torno da discordância de certas edições realizadas pelos jornais antes da publicação, o WikiLeaks decidiu ampliar a sua rede de distribuição para outros jornais $^{127}$. A partir daí a organização intensificou esta diretriz e passou a ampliar seu leque de

\footnotetext{
${ }^{127}$ Deterioradas las relaciones con los cinco grandes medios colaboradores en el Cablegate, WikiLeaks recurrió para esta filtración masiva a 28 organizaciones mediáticas de todo el mundo, más repartidas geográficamente, culturalmente más heterogéneas y de naturaleza diversa, pero, en general, menos populares e influyentes mundialmente que sus aliados en el Cablegate: ABC Color (Paraguay). Al Akhbar (Líbano). Al Masry Al Youm (Egipto). Asia Sentinel (Hong Kong). Bivol (Bulgaria). Carta Capital (Brasil). CIPER (Chile). Dawn Media (Pakistán). L’Espresso (Italia). La Repubblica (Italia). La Jornada (México). La Nación (Costa Rica). Malaysia Today (Malasia). McClatchy (Estados Unidos). Nawaat (Túnez). NDR/ARD (Alemania). Owni (Francia). Página 12 (Argentina). Plaza Pública (Guatemala). Pública (Brasil). Público (España). Rolling Stone (Estados Unidos). Russia Reporter (Rusia). Sunday Star-Times (Nueva Zelanda). Ta Nea (Grecia). Taraf (Turquía). The
} 
veículos parceiros (ou distribuidores) triplicando este número até o final de $2015^{128}$, ou seja, atualmente essa rede contém cerca de 100 veículos, conforme dados oficiais da organização:

WikiLeaks has contractual relationships and secure communications paths to more than 100 major media organizations from around the world. This gives WikiLeaks sources negotiating power, impact and technical protections that would otherwise be difficult or impossible to achieve. Although no organization can hope to have a perfect record forever, thus far WikiLeaks has a perfect in document authentication and resistance to all censorship attempts ${ }^{129}$.

Atualmente, a organização tem se reafirmado como uma causa que vem se consolidando no imaginário de um público amplo, em diversos países. Hoje o WikiLeaks é conhecido tanto no meio online, incluindo os submundos da deep web, quanto no noticiário de telejornais tradicionais. Ou seja, tem conseguido alcançar públicos vastos operando em duas frentes integradas: (a) via Internet, como banco de dados primário para aqueles que desejam obter documentos de vazamentos em textos mais integrais (menos editados) e (b) via mídia de massa, através do conjunto de veículos jornalísticos que o tomam como fonte, massificando as informações, porém, com um nível de edição maior.

\subsubsection{Multiplicação do engajamento}

\section{a) Coordenação}

O WikiLeaks é uma organização formada por um número não muito volumoso de associados. Conforme palavras de Assange, em janeiro de 2010, havia em torno de 5 pessoas trabalhando diariamente, que se autofinanciavam, e cerca de 800 que trabalhavam esporadicamente (MEY, 2010).

Os responsáveis por manter o dia-a-dia das operações do grupo sempre foi um número reduzido e centralizado no entorno de Julian Assange, formado por alguns voluntários e

Hindu (India). The Yes Men (dúo de activistas formado por Andy Bichlbaum y Mike Bonanno) (QUIAN, 2013, p. 45-46).

${ }^{128}$ No interstício desde caminho, como também descreve Lynch (2013), outras empresas de mídia localizaram nos documentos já vazados informações importantes que ainda não tinham ganhado notoriedade pública (2013). "By mid-2011, these new WikiLeaks media partners would include the Sunday Star Times (New Zealand), Folha de São Paulo and O Estado de Sao Paulo (Brazil), Novaya Gazeta (Russia), RUV (Iceland), AI Akhbar (Lebanon), Al-Masry AI Youm (Egypt), El Comercio (Peru), L'Espresso (Italy), Daily Nation (Kenya), CIPER (Chile), and over 70 other media outlets [...]" (p. 56-57).

${ }^{129}$ Conforme contabilizava o website oficial da organização, com post datado de 3 de novembro de 2015. Disponível em: < https://wikileaks.org/What-is-Wikileaks.html >. Acesso: 10 jan. 2016. 
outros ativistas remunerados: "The effective work of checking and verifying the data submitted and administering the day-to-day running of the site is done by a small team of permanent staff, and although some agreed to work for free for several months in 2010 " [...]. (BREVINI; MURDOCH, 2013, p. 49).

Daniel Domscheit-Berg (2011), um dos fundadores do grupo, explica que quando o WikiLeaks revelava um número substantivo de voluntários, isto significava que se tratavam mais de números do que de pessoal disponível para trabalhar, já que um grande número de assistentes que apoiavam o grupo em realidade apenas assinaram a mailing list.

O grupo possui oficialmente um Conselho composto por nove membros, incluindo Assange ${ }^{130}$. Segundo dados da organização em seu website, pelo menos até 2016 "has more than one hundred other staff accross the Americas, Africa, Eurasia and the Asia Pacific" Ainda conforme o website, a organização justifica não divulgar detalhes sobre os membros em razão das ameaças de morte, a fim de proteger a integridade da equipe. Entretanto, informam que:

Our core staff come from four different continents. Gender balance is important for us, exactly half of our staff members are women. We are young and old, and come from different cultural backgrounds. Our core staff speak at least ten different languages fluently. Each of us have studied or lived abroad for significant periods of time. All of us have university degrees and most of us have completed Master or PhD studies in top universities. ${ }^{132}$

Os membros não estão aptos a receber informações ou documentos secretos, com exceção de Julian Assange and Kristinn Hrafnsson, conforme esclarece texto institucional no website da organização.

Na prática, a comunicação digital sustentou até agora uma função dupla: propiciou o contato e o engajamento de seus principais fundadores e instrumentalizou o engajamento do núcleo coordenativo. Os dois principais fundadores do WikiLeaks, Assange e DomscheitBerg, se conheceram em ambientes hackers. Já o núcleo duro da organização opera hoje em diversos países sem uma sede física efetiva, operando através da comunicação digital nas atividades de coordenação e tarefas práticas.

Isso significa dizer que a comunicação digital não tem sido utilizada para inserir ou engajar novas lideranças, embora seja através dela que o grupo se reune, e nem tem sido um

\footnotetext{
${ }^{130}$ Disponível em: <https://wikileaks.org/wiki/WikiLeaks:Advisory_Board>. Acesso 22 dez. 2016

${ }^{131}$ WikiLeaks, Website oficial. Disponível em <https://wikileaks.org/What-is-Wikileaks.html>. Acesso: 5 jan. 2016.

${ }^{132}$ Disponível em: <https://wikileaks.org/Press.html>. Acesso: 5 fev. 2016
} 
elemento aberto neste sentido. O engajamento de lideranças no WikiLeaks sempre foi pouco permeável, formando-se em torno de articulações diretas de Assange com parceiros (seja online, seja offline), que acaba sendo o elemento mais determinante na incursão no engajamento de coordenação. Isso se explica pelo próprio formato da organização, fundada por Assange, concentrada e liderada por este.

\section{b) Adesão}

Ao analisarmos o modo de engajamento do WikiLeaks percebemos a importância da rede de apoiadores que atuam nas bases da organização através de mediações digitais: "We are a young organisation that has grown very quickly, relying on a network of dedicated volunteers around the globe" (WIKILEAKS.ORG, 2013, p. 12). Isso ocorre porque a comunicação digital possibilita uma cultura da convergência, conforme conceitua Jenkins (2009), o que permite ao grupo operar um modo inovador agregando ideias e engajamentos online sob a bandeira de construir um repositório crowdsourcing ${ }^{133}$ a partir do engajamento colaborativo em rede (DUNN, 2013).

Para além do núcleo da organização (composto por suas lideranças), a atividade de captação de dados sigilosos depende da rede de apoiadores ao redor do globo. O potencial destes apoiadores está justamente na capacidade da comunicação digital que transformou a figura do informante isolado em uma rede colaborativa e poderosa de investigadores e denunciantes. Pode-se perceber que há duas redes paralelas de apoiadores que dão suporte direto ao staff da organização: (a) a rede de "informantes" (whistle-blowers) e (b) a rede de "simpatizantes".

A rede de informantes é composta por indivíduos que atuam em grandes corporações, governos ou em órgãos que detêm informação estratégica e sigilosa (de impacto político) e que se arriscam para "sequestrar" informação relevante e repassar para o banco de dados da organização.

By offering a high-security anonymous drop box supported by cutting-edge cryptography that rendered the original source untraceable, the founders

\footnotetext{
${ }^{133}$ Crowdsourcing é um termo utilizado para explicar uma forma de atividade coletiva baseada no princípio da colaboração e sinergia de esforços na produção de conhecimento. Busca somar informação e produzir uma inteligência coletiva a partir da participação individual onde cada constituinte se soma sinergicamente para obter um resultado maior que a simples soma das partes. $\mathrm{O}$ uso de foruns digitais, chats e redes sociais online voltados para aglutinar e processar coletivamente informação sobre um tema específico têm sido exemplos atuais de atividade de crowdsourcing em expansão.
} 
aimed to encourage whistle-blowers working for corporations and government agencies to submit restricted and classified material uncovering deception and malpractice (BREVINI; MURDOCH, 2013, p. 40).

Devido aos perigos e às possíveis represálias comumente imputadas àqueles que fazem vazamento de informação confidencial, sempre houve zelo pela proteção das fontes de informação (QUIAN, 2013, p. 34). Inclusive, a organização disponibiliza uma rede de advogados para defender as fontes e o próprio trabalho do grupo. Todo o processo de envio de vazamentos foi arquitetado para ocorrer online da forma mais segura e anônima possível, com avançados mecanismos de criptografia acoplados à plataforma:

With its anonymous drop box, WikiLeaks provides an avenue for every government official, every bureaucrat, and every corporate worker, who becomes privy to damning information that their institution wants to hide but the public needs to know (WIKILEAKS.ORG, 2013, p. 20).

Assim, um informante se sentia livre e seguro para obter dados online ou coletar manualmente informações sigilosas em diferentes formatos (vídeos, cartas, documentos secretos, telegramas, imagens, planos, números etc.) e transmiti-los digitalmente para o crowdsourcing de dados da organização. Este ato deve ser entendido, sobretudo, como uma ação política realizada por indivíduos que, somados, compõem uma ação coletiva onde cada um tem uma função específica. Algo que seria possível de ser executado individualmente, mas que teria repercussões imediatas ao denunciante, o que tende a inibir este tipo de prática $^{134}$. Essa rede de informantes age junto ao WikiLeaks como parte de um processo de colaboração com horizonte político em prol da bandeira da transparência, como explica o próprio Assange (2013), e eles têm segurança e respaldo ao contribuirem como fontes:

We make a promise to sources that if they give us material of diplomatic, critical, ethical or historical significance, that is not published and under some sort of threat, we will publish it. And that actually is enough (ASSANGE, 2013, p. 254).

\footnotetext{
${ }^{134}$ Por exemplo, os vazamentos de Edward Snowden, ex-analista de inteligência que prestava serviços para a CIA. O tipo de vazamento que Snowden executou se assemelha em vários pontos aos vazamentos do Wikileaks, principalmente por se tratar de dados digitais. Porém, ao realizar de forma não anônima e se expor como aquele que executou o vazamento, isso significou para Snowden optar por levar uma vida de fugitivo. Os EUA pressionam para efetivar sua prisão. O ex-analista está hoje exilado na Rússia sem poder retornar aos EUA ou passar por outros países que são capazes de extraditá-lo para América do Norte. A importância de plataformas colaborativas como o Wikileaks está justamente em viabilizar os vazamentos tornando-os mais exequíveis por serem menos custosos para aqueles informantes que desejam contribuir, mas preferem ficar protegidos contra represálias pelo anonimato.
} 
Um dos exemplos mais conhecidos deste tipo de apoiador foi o então soldado Bradley Manning que vazou 700 mil arquivos secretos para o WikiLeaks - documentos e vídeos sobre ações das forças de segurança estadunidense ${ }^{135}$. Manning conseguiu coletar tais informações sigilosas enquanto trabalhava como analista em Bagdá. O WikiLeaks publicou a contribuição de Manning em 2010. Embora tenha enviado anonimamente, o soldado foi posteriormente descoberto pelas autoridades americanas ${ }^{136}$. Foi preso e condenado a 35 anos de prisão ${ }^{137}$.

Ao se referir aos informantes, Assange disse em entrevista que eles geralmente agem motivados por questões morais, porém ele não veria problemas em remunerar o trabalho dos chamados whistleblowers, desde que considerando estratégias seguras de manter o anonimato entre os jornalistas e suas fontes através de transferências bancárias:

Usually they are incensed morally by something. Very rarely actually they want revenge or just to embarrass some organisation. So that's their incentive, to satisfy this feeling. Actually we would have no problem giving sources cash. We don't do that, but for me there is no reason why only the lawyers and the journalists should be compensated for their effort. Somebody is taking the risk to do something and this will end up benefiting the public (MEY, 2010).

Já a rede de simpatizantes são aqueles que atuam na retaguarda da organização, dando suporte a ataques, contra-ataques e melhorando a infraestrutura para viabilizar a comunicação digital da organização. Como descreve Milan (2013):

The pressures enacted on the whistle-blower website spurred the mobilization of hundreds of people not directly linked to its core group. These people provided technical support to the WikiLeaks cyberinfrastructure. They mirrored the site when it was taken offline, contributing to the spread and visibility of WikiLeaks content, and they mobilized in support of the organization, for example by attacking (i.e., taking down, defacing, making temporarily unavailable) the websites of companies that had taken action against the whistle-blower website. Most of this kind of activism existed long before WikiLeaks started making the news in 2010 (p.

\footnotetext{
${ }^{135}$ Como descreve Quian (2013): “Assange disponía de cientos de miles de documentos secretos que le habría filtrado, presuntamente, Bradley E. Manning, un imberbe analista de inteligencia del ejército de Estados Unidos destinado en Irak y detenido allí el 26 de mayo de 2010, acusado de sustraer documentos clasificados de las redes secretas del Pentágono y de entregárselos a WikiLeaks. A Manning se le atribuyó la responsabilidad de las filtraciones del vídeo del caso Collateral Murder y de miles de otros documentos secretos sobre las guerras de Irak y Afganistán y de la diplomacia estadounidense" (p. 34).

${ }^{136} \mathrm{Na}$ verdade, foi denunciado por Adrian Lamo (ex-hacker e analista de inteligência), funcionário de uma empresa que prestava serviço para as forças de segurança estadunidense, após ter confessado para o mesmo ser o responsável pelo vazamento para o Wikileaks.

137 Para saber mais sobre o caso: < http://g1.globo.com/mundo/noticia/2013/08/entenda-o-caso-de-bradleymanning-condenado-por-vazar-segredos.html > Acesso: 8 jun. 2015.
} 
193).

Conforme o website da organização, a página ${ }^{138}$ relativa aos apoiadores é bastante instrutiva sobre como a pessoa simpatizante deve proceder para integrar ao grupo. Primeiramente, deve-se tornar um membro dos amigos do WikiLeaks na página wlfriends.org e assinar o Facebook e Twitter para acompanhar as notícias. A seguir, sugerem atividades diferentes a depender do perfil do interessado: usuários de blogs e Internet (adicionar o banner de levantamento de doações em seu site ou perfil e se conscientizar sobre as ações perpretadas pela organização); especialistas em Tecnologia da Informação (realizar pesquisas de conteúdo, estrutura de conteúdo e funções de busca); designers gráficos (criar ilustrações e padrões de database); advogados (interar-se sobre os processos judiciais da organização e entrar em contato por email); acadêmicos (analisar material e divulgar impacto da organização); pesquisadores (pesquisar nos arquivos disponíveis pelo website); especialistas de finanças (compreender os papeis de doações e levantamentos de fundos); promotores de campanhas de levantamento de fundos (realizar atividades em prol da organização e angariar fundos); jornalistas (analisar e filtrar o material vazado online pela organização).

Esse grupo de simpatizantes online é fundamental para manter o grupo funcionando em suas estruturas básicas diante da grande pressão e represálias que têm sofrido após importantes vazamentos governamentais. Ou seja, atuam como uma camada de defesa e, como todo ativista, também incorrem em riscos e quebra de seus anonimatos:

The WikiLeaks case, too, has problematized the widespread public use of social networking and its increasing integration into surveil lance regimes. In their quest to contain the WikiLeaks phenomenon and learn more about its supporters, US authorities turned to social media companies. Twitter was forced to hand over the account data of known WikiLeaks activists and their followers, and one can only speculate which other online services received the same requests and complied quietly [...]. Google publishes the numbers of requests by state authorities for the disclosure of its user data in its Transparency Report, and it reports that it received 5,950 such requests from the US government in the first six months of 2011 alone (i.e., 1,000 a month or 33 a day), a number that is up 70 percent from 2010. Google has complied in 93 percent of the cases (Google, 2011) (HINTZ, 2013, p. 154).

\footnotetext{
${ }^{138}$ Disponível em: <https://shop.wikileaks.org/donate>.
} 
Apesar disso, os simpatizantes operam com a ajuda de hackers ou gerenciadores de plataformas e sites para espelhar (duplicar) o website do grupo diante dos ataques e suspensão de acesso:

\begin{abstract}
WikiLeaks también ha contado con el soporte de cientos de sitios que han creado en todo el mundo mirrors de la página web de la organización (sitios web espejo que contienen una réplica exacta de http://wikileaks.org para contrarrestar los ataques a la página de WikiLeaks). El 15 de diciembre de 2010, en pleno apogeo del fenómeno WikiLeaks tras la publicación del Cablegate, el site de Information Clearing House había listado 2.194 sitios web espejos de WikiLeaks (QUIAN, 2013, p. 48).
\end{abstract}

Além do apoio técnico-estrutural, esta rede também viabiliza campanhas online em defesa do grupo em redes sociais e outras plataformas (BECKETT; BALL, 2012).

É preciso reconhecer que as redes usadas pelo WikiLeaks têm alargado o debate público apontando o caráter poroso do Estado e provocando o aumento de instâncias paraestatais na resolução de conflitos públicos:

A lógica, aplicada ao Wikileaks, sugere tratar-se de um fenômeno cada vez mais comum: redes autônomas e autorreguladas promovidas por ativistas sociais cujo objetivo é ressaltar a importância de determinados temas ou aspectos da política internacional. Seu alvo seria denunciar um ou outro aspecto da política dos Estados a fim de cercar oficiais governamentais e impedir-lhes a atuação impune sob o véu do segredo e da confidencialidade (SPEKTOR, 2012, p. 26).

Paralelamente, simpatizantes também conseguem se engajar nas ações do WikiLeaks através da doação de recursos financeiros. Certamente, como sabemos, este não é um método novo e diversas organizações ao longo da história (mesmo antes da Internet) já lançavam mão deste tipo de engajamento, voltado principalmente para receber apoios daqueles que não conseguiam se envolver diretamente em ações do grupo, mas que estavam dispostos a doar dinheiro para causas políticas coletivas.

O que a comunicação digital possibilitou de novo foi justamente a facilidade da logística para este tipo de engajamento que então poderia ser realizado online, sem a necessidade de trocas físicas ou utilização de sedes físicas de bancos. Porém esta forma de envolvimento não foi desenvolvida desde o nascimento do grupo. $\mathrm{Na}$ verdade, iniciou-se de modo bastante amador e somente com o tempo é que houve uma delimitação melhor dos meios e métodos para tal.

Como revela um dos fundadores do grupo, Domscheit-Berg (2011), a forma de receber auxílio de colaboradores era bastante informal. Por exemplo, o ex-membro do WikiLeaks 
descreve que a conta do PayPal para receber doações foi registrada por um repórter americano de 60 anos que trabalhava num jornal local do meio oeste estadunidense:

Por meses, ele nos perguntara se poderia fazer algo por nós. E como ele não
se oferecera espontaneamente para cuidar das finanças, demos a ele
exatamente esse serviço. Naquela época, nossa lógica era: quem não
interessasse por nossas contas seria o mais adequado para administrá-las.
Quem não se interessasse por sua influência sobre a opinião pública
administraria o chat - e assim por diante. Nosso voluntário era muitíssimo
ocupado e não tinha a menor ideia do que deveria fazer e onde estava
exatamente o problema (DOMSCHEIT-BERG (2011, posição 721-723).

Já em 2008 o grupo detinha três contas no PayPal, que poderiam receber dinheiro transferido pelos doadores, acumulando 5 mil libras em marços de 2008. Em junho de 2009 já contavam com 35 mil libras, porém a conta foi bloqueada pelo PayPal, que exigia um documento provando que se tratava uma organização sem fins lucrativos, conforme WikiLeaks havia se declarado. Para reaver o dinheiro, o grupo se recadastrou como empresa, mas ainda enfrentava problemas, sobretudo porque aquele voluntário designado pouco sabia lidar com a situação (DOMSCHEIT-BERG, 2011).

Segundo Domscheit-Berg (2011), Assange pensou em fundar empresas próprias para proteger as doações em dinheiro de ataques externos, além de utilizar organizações sem fins lucrativos como fiscal sponsors ou patrocinadoras fiscais, de modo que os doadores transfeririam dinheiro sem pagar impostos. Em abril de 2008 o grupo abriu uma conta no Moneybookers, para o qual os doadores, sobretudo americanos, eram capazes de transferir dinheiro online. Porém, Assange centralizou o controle dessa conta e outros membros não tinham acesso (DOMSCHEIT-BERG, 2011) ${ }^{139}$.

As grandes dificuldades de conseguirem ajuda financeira por projetos consistia na falta de organização do grupo, falta de sede própria, e a dispersão e pouco envolvimento do conselho (dos oito membros, apenas um deles Daniel e Assange conheciam pessoalmente) (DOMSCHEIT-BERG, 2011).

Apesar das limitações iniciais para angariar fundos, o engajamento de doadores se tornou a principal fonte de sustentação ${ }^{140}$ do grupo. As doações recebidas eram apenas

\footnotetext{
${ }^{139}$ Outra forma de arrecadar dinheiro seria leiloar o acesso exclusivo ao material do WikiLeaks, que foi inviabilizada pelo fato de que o grupo estaria tentando fazer dinheiro com o trabalho das fontes, sendo que a mídia teria o material em primeira mão por ser a mais dotada para pagar o valor, além da própria inviabilidade técnica de o grupo implanta o leilão (DOMSCHEIT-BERG, 2011).

${ }^{140}$ Assange em janeiro de 2010 ainda contabilizava apenas $10 \%$ das doações através do modo online, porém vislumbrava o crescimento desta participação online em pouco tempo (MEY, 2010).
} 
privadas, principalmente oriundas de jornalistas e advogados envoldidos com a causa, já que o grupo recusava doações governamentais ou de corporações (MEY, 2010). Nos tempos de maior fluxo de doações isso ocorreu predominantemente via online, através de serviços como Amazon, PayPal:

WikiLeaks' funding model has at its core a German foundation, the Wau Holland Foundation, which processes the personal donations coming into the site. In 2010, €695,000 came through general bank transfers and $€ 635,000$ through Wau Holland's account with PayPal, which since 2002 has been owned by eBay, the other major Internet retailer alongside Amazon (Wau Holland Foundation, 2010) (BREVINI; MURDOCK, 2013, p. 44).

Importante notar que este fluxo de engajamento e o volume de doações não é estável: variava com o tempo, apresentando picos a depender dos períodos de intensa atividade do grupo, principalmente em torno de eventos como vazamentos ou repressões. O Gráfico 3 (BREVINI; MURDOCK, 2013, p. 45) demonstra esta dinâmica entre 2010 e 2011:

Grafico 3 - Fluxo de doações para o WikiLeaks 2010-2011

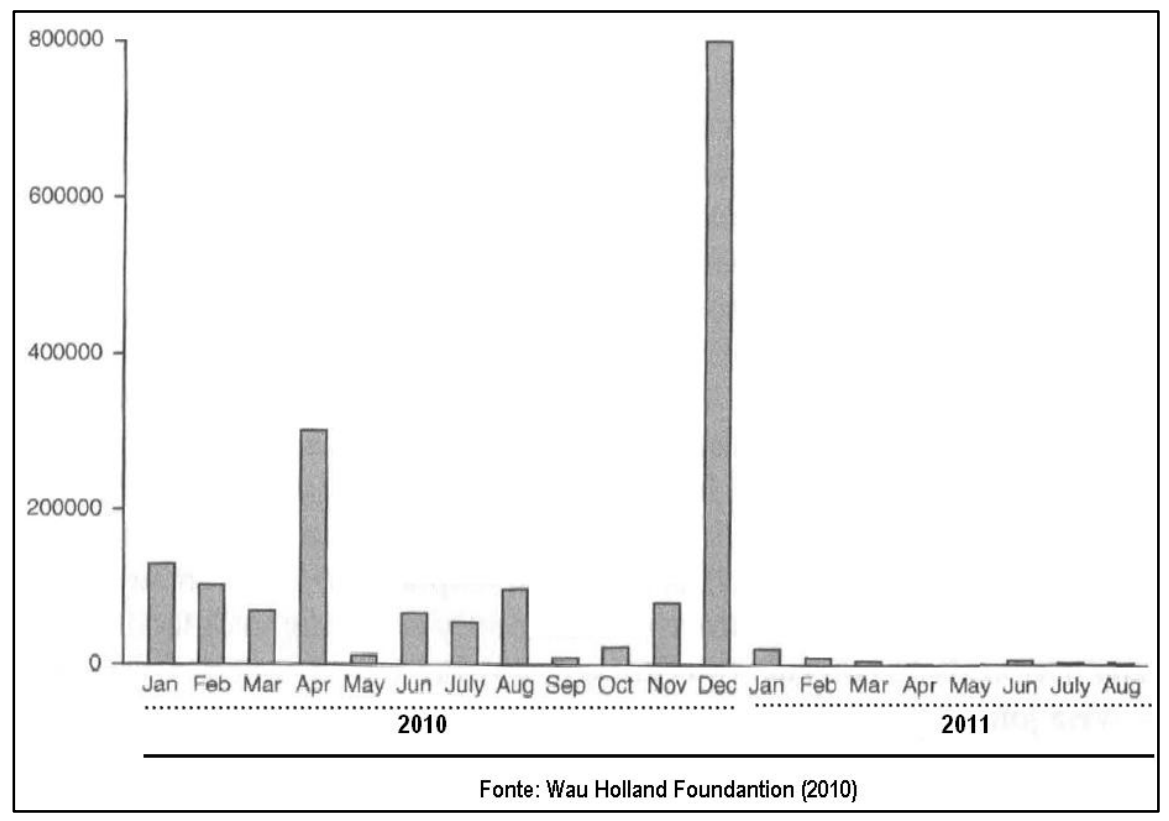

Notemos que 2010 é o ano onde são registrados maiores volumes donatários. Em todo o período há dois principais picos de doações online: ambos em 2010. O primeiro em abril e o segundo em dezembro deste ano. O primeiro pico ocorre no entorno de três vazamentos importantes, sendo o primeiro deles (no dia 5 de abril) o vídeo Collateral Murder. O segundo 
e o terceiro foram Carter Cables ${ }^{141}$ e o Guantánamo Leaks (respectivamente 24 e 25 de abril). Principalmente o vídeo teve grande repercussão e impacto, alcançando um número maior de pessoas primeiramente se tornando viral na Internet para posteriormente ser reproduzido em telejornais. Já o segundo pico é o mais significativo de todos e ocorre em dezembro. Essa alta de doações pode ser explicada a partir da combinação de cinco ingredientes:

1. Acumulado de intensa visibilidade jornalística no ano de 2010. Desde o Collateral Murder foi um período de acentuada atividade, chegando o WikiLeaks ao final daquele ano como uma organização conhecida mundialmente (dentro e fora da Internet);

2. Vazamento Cablegate, em 28 de novembro, sobre telegramas das embaixadas estadunidenses teve grande impacto na comunidade internacional e no noticiário em diversos países;

3. Ataques ao website em 3 de dezembro de 2010. O website do grupo precisou mudar de endereço devido a ataques cibernéticos. Além disso, a Justiça da Suécia pediu a prisão de Assange por crime sexual;

4. Ataque financeiro em 4 de dezembro de 2010. O PayPal congelou os recursos do WikiLeaks recebidos via Internet por doações. A empresa também vetou o envio de doações para o WikiLeaks através da sua plataforma;

5. Prisão de Assange em 7 de dezembro de 2010. Finalmente a polícia britânica acata o pedido da Justiça sueca e prende Assange em Londres, acusado de crimes sexuais. Ele nega as acusações e afirma ser pretexto para prendê-lo pelos vazamentos do WikiLeaks e extraditá-lo para os EUA.

Essa sequência de eventos, culminando com a prisão do principal líder da organização, gerou protestos de apoio e mobilizações impactando assim no aumento considerável do volume de doações neste mês. Os apoiadores foram acionados e uma das formas deste engajamento em prol do movimento que o WikiLeaks representava era engajar-se como um doador. Nota-se que o volume de doações está intimamente vinculado à visibilidade que o grupo consegue adquirir, principalmente em momentos chaves de grande repercussão, tais como vazamentos impactantes e repressões diretas ao grupo e suas lideranças.

Não é possível afirmar que a comunicação digital isoladamente propiciou o engajamento de doadores. Mas é possível observar que o ambiente online (a) facilitava este tipo de engajamento; (b) não significava uma regularidade no volume de doações; (c) acabava

${ }^{141}$ Disponível em < https://wikileaks.org/WikiLeaks-releases-the-Carter.html > Acesso: 13 out. 2015. 
sendo um mecanismo instável. Facilitava tanto o fluxo de doações (antes do bloqueio financeiro), quanto os picos eram realizados basicamente a partir da logística online de doações. No caso do WikiLeaks, esta logística online era fundamental para manter algum fluxo de doações. Não por acaso, o bloqueio dos serviços online para recebimento de doações (como o PayPal) causou uma grande queda no volume de recursos ${ }^{142}$ que dependia das redes de apoiadores que se engajavam de forma rápida, ágil e segura doando através da Internet, oriundos de diferentes países:

[...], the comprehensive financial blockade had a devastating impact on the flow of donations after December 2010, with Assange claiming that the site had lost 95 percent of its income (Guardian, 2010). Faced with this severe squeeze, the platform was forced to temporarily suspend its publishing activities in October 2011; it stated "In order to ensure our future survival, Wikileaks is now forced to temporarily suspend its publishing operations and aggressively fundraise in order to fight back against this blockade and its proponents" (WikiLeaks, 2011). (BREVINI; MURDOCK, 2013, p. 46-47).

Não significava uma estabilidade no volume de doações pois a oscilação das doações é percebida no próprio Gráfico 3. Em 2 anos de amostra (sendo 2010 o principal ano de atividades do grupo) não há um volume médio estável. Além disso, a própria organização ansiava por volumes maiores de doadores, mas isso ainda não se realizou como planejaram. Como descreve Beckett e Ball (2012): "By January 2007, a WikiLeaker, believed to be Assange, had posted that 'it is our goal to raise pledges of $\$ 5 \mathrm{~m}$ by July', a goal the site is still far from reaching" (p. 21).

Por fim, o engajamento de doações online se demonstrou instável, pois dependia de empresas formalmente estabelecidas e sujeitas a pressões político-econômicas:

Further, the actions by Amazon, Paypal, etc., demonstrated the vulnerability of these services to political interventions, as they coincided with pressure from members of the US political elite, both inside and outside government (Benkler, 2011) (HINTZ, 2013, p. 152).

Além do Paypal, diversas empresas que faziam essa mediação online foram pressionadas e cederam como Amazon, eBay, MasterCard, Serviço Postal Suíço, Visa e Apple, suspendendo qualquer tipo de doação direcionada para o grupo através de seus

\footnotetext{
${ }^{142}$ O Gráfico 3 mostra claramente, após dezembro de 2010, quando há o bloqueio, e daí por diante durante todo o ano de 2011 será marcado pelo baixo nível de doações.
} 
sistemas digitais $^{143}$. No caso da Apple, esta chegou a oferecer para o WikiLeaks uma ferramenta para angariar fundos online através de um aplicativo para iPad e iPhone (1 dólar para cada instalação do aplicativo). Porém "The application was launched on December 17, 2010, but three days later Apple removed it from its Apple store on the grounds that "it violated our developer guidelines. Apps must comply with all local laws and may not put an individual or targeted group in harm's way" (BBC News, 2010). (BREVINI; MURDOCK, 2013, p. 46).

Apesar das restrições sofridas neste período, a organização restabeleceu a parceria com algumas dessas empresas mediadoras, recebendo doações a partir de diferentes plataformas online. Conforme a página ${ }^{144}$ oficial da organização relativa a doações, observase diversas opções para a realização de doações, a maioria online: cartão de crédito; Paypal; Bitcoin; Litecoin; Google checkout, cheque (neste caso, conta com remessas de envio postal a diferentes países, como Alemanha, Austrália e França) e Transferência Bancária. As doações são realizadas via Wau Holland Foundation, porém com deduções de impostos da União Europeia, ou através da Freedom of the Press Foundation, com deduções de imposto nos Estados Unidos.

\section{c) Colaboração}

Além dos engajamentos de adesão, o WikiLeaks também tem recebido apoio online de diversas entidades. Este engajamento colaborativo ocorreu principalmente nos episódios de repressão à organização, especialmente no bloqueio de contas financeiras e prisão de Assange em Londres.

Alguns analistas acreditam que empresas que prestavam serviço ao WikiLeaks possam ter sido pressionadas diretamente pelo governo estadunidense para suspender o serviço, a exemplos de empresas como PayPal, Amazon, Visa.com, Facebook (SPEKTOR, 2011). Estas empresas tinham função fundamental junto à organização, pois cumpriam o papel de receber e encaminhar as doações destinadas ao grupo. Por esta razão, Assange chamou tais atitudes de

\footnotetext{
${ }^{143}$ Como detalha cronologicamente Winseck (2013): "As Amazon, OVD, and everyDNS took out partof WikiLeaks' technical infrastructure, several other companies moved in to disable is financial underpinnings. Over the course of four days, Paypal (eBay; December 4), MasterCard, and the Swiss Postal Office's PostFinance (December 6), and Visa (December 7) suspended payment services for donors to the site" (p. 170).

${ }^{144}$ Disponível em: <https://shop.wikileaks.org/donate>.
} 
"censura econômica", anunciando perda de 3/4 de milhão de dólares em doações (ROBERTS, 2010).

Diante deste cenário, as respostas de dezenas de organizações na Internet em solidariedade ao WikiLeaks foi imediata. A reação adveio de diversos grupos hackers, dentre eles o coletivo Anonymous. A atitude se transformou no lema "Operation Avenge Assange", configurando-se numa espécie de infoguerra (ROBERTS, 2012). Eles concatenaram invasões aos websites de diversas companhias e empresas que hostilizaram o WikiLeaks, deixando-os inacessíveis ou lentos (BURNS; SOMAIYA, 2010). O PayPal, uma empresa que administra pagamentos online, justificou o bloqueio ao WikiLeaks pelo fato de que a organização estaria violando a política da empresa ao desempenhar atividades ilegais. Para os apoiadores de Assange ficou evidente as mãos invisíveis dos EUA para evitar o financiamento e o funcionamento da rede de servidores de computadores que viabilizavam a atividade da organização (BURNS; SOMAIYA, 2010) ${ }^{145}$. Mas pairam dúvidas sobre o real envolvimento do governo nestes casos de suspensão de serviços:

There is no evidence that the American government directly instigated the actions of these companies against WikiLeaks. The office of Senator Joe Lieberman admitted that publicity following his remarks may have played a part in the corporate decisions to stop hosting WikiLeaks servers and fundraising systems. Certainly one of his aides had contact with Amazon. However, it is claimed that there was no direct communication between government and the companies (BECKETT; BALL, 2012, p. 93).

Além das ações online, as organizações colaboradoras como AP, Los Angeles Times e The National Newspaper Association compartilham seus advogados mas não teriam colaboram com doações, conforme Assange, que afirma que a organização apenas recebe doações de fontes privadas (MEY, 2010).

Como aponta Slaughter (2009), não é possível definir e nem coordenar os resultados dentro de uma rede horizontal de colaboradores, que depende de outras organizações e não há um maestro da orquestra definido. Nesse ponto, possivelmente o resultado da atuação do WikiLeaks não foi exatamente como preconizaram seus objetivos iniciais, porém isto se deve menos por falha de percurso, e mais pela própria estrutura desta rede de colaboração.

O WikiLeaks tinha a clara intenção de promover uma movimentação social e política em prol de transformação das bases políticas, porém isto não foi factível, devido à

${ }^{145}$ Este tema será retomado na sub-seção 5.2.5, ibem “b” (Ciberataques), no final desta seção. 
impossibilidade de coordenar os resultados, ao menos até o momento. Mas a sua atuação tem gerado a mobilização transnacional relevante de diversas organizações online, principalmente não-governamentais e isso tem sido um elemento central na subsistência e visibilidade.

\subsubsection{Flexibilização da estrutura}

\section{a) Virtualização}

Oficialmente, o WikiLeaks está sediado na Suécia. Mas na prática, o grupo encara desafios jurídicos ao adotar uma forma institucional de uma organização que rompe com o locus nacional e especializado de existência de uma organização tradicional, geralmente com sedes físicas, com escritórios operantes em territórios específicos. Segundo afirmou o próprio Assange em entrevista: "Because we are not in one location, it doesn't make sense for us to have headquarters. People have their own offices across the world" (MEY, 2010). Por ser um grupo desterritorializado, divulga informações fora do alcance de governos, empresas ou organizações. Esta estrutura apátrida garante a segurança dos colaboradores e a permanência do site (QUIAN, 2013).

O nível de virtualização da estrutura do grupo também pode ser comprovado pela atual situação de sua principal liderança: mesmo fisicamente exilado na embaixada equatoriana em Londres, Assange continua operando de lá através da comunicação digital, inclusive dando entrevistas e participando de conferências online. O locus de existência do grupo é fundamentalmente online:

Even the most diffuse global multi-national corporations and organizations have some kind of geographical base. Assange and WikiLeaks remain of no fixed abode. WikiLeaks looks set to continue with its model of an independent organization that enters into collaboration with other media to process and publish classified information - transnational, if not transitory (BECKETT; BALL, 2012, p. 147)

Para Milan (2013), organizações como o WikiLeaks "is the manifestation of a wave of movement activity that is virtual, distributed, and individualized” (p. 203). Segundo a autora, a Internet já não é apenas uma ferramenta para formação de redes de mobilização: Tornou-se uma plataforma para ação, recrutamento e agregação de interesses comuns. Plataformas como a do WikiLeaks torna possível o envio (através de informantes anônimos) e a distribuição de 
conteúdo sigiloso, protegendo o deflagrador da informação ao mesmo tempo que permite o compartilhamento de conteúdo sigiloso (KAVADA, 2010). O grupo possibilita aos colaboradores-informantes no ato do envio-recebimento de material sigiloso, tanto a opção via Internet, quanto pessoalmente. Porém, o grupo faz questão de demonstrar preferência pelo locus digital. Como explicam: "We accept leaked material in person and via postal drops as alternative methods, although we recommend the anonymous electronic drop box as the preferred method of submit-ling any material” (WIKILEAKS.ORG, 2013, p. 13).

A importância desta plataforma online é incontestável quando comparada a qualquer espaço físico que o grupo já teve ou que mantém. Não por acaso, no site da instituição não há um endereço físico oficial, como geralmente ocorrem em organizações ativistas deste tipo. Há e-mails de contatos, endereços de páginas e números de telefones de membros ou colaboradores de diversos países ${ }^{146}$. A estrutura para interação das redes de colaboradores e o sistema de recebimento de vazamentos é preponderantemente online:

Its cross-national servers and network of thousands of 'mirrored' sites duplicating its content have created a new kind of publisher of last resort. [...] As well as its basic 'drop box' function, it used novel online practices such as Wikis, crowd-sourcing, forums, and email lists. Implicit in the use of these was a production philosophy that was participatory and open source (BECKETT; BALL, 2012, p. 27).

Mas o fato de ser online não significa que a organização está isenta de ações de repressão ou do poder de corporações e governos. Após a série de vazamentos em 2010, o grupo precisou migrar os sistemas e melhorar suas formas de defesa para continuar existindo:

The WikiLeaks website has been hosted by multiple servers and under various domain names. At the beginning of its activity in 2006, it was hosted by a server based in Sweden called PeRiQuito AB, but it later moved its servers to Amazon Web Services (AWS), which rents computer infrastructure on a self-service basis. On December 1, 2010, Amazon suspended WikiLeaks' service (Davidson, 2010). AWS does not prescreen its customers but it does have Terms of Service, and it gave WikiLeaks' breaching of these terms as the reason for its decision.[...] On December 2, 2010, EveryDNS, the company responsible for mapping WikiLeaks' domain names, withdrew its services, claiming that the domain name had been subject to multiple Denial of Service (DoS) attacks, which were affecting the overall quality of service the company could offer its clients (BREVINI; MURDOCK, 2013, p. 42- 43).

\footnotetext{
${ }^{146}$ Disponível para ser visto neste link: <https://wikileaks.org/Enquiries-and-Contact.html〉. Acesso: 4 de jan. 2016.
} 
Por outro lado, se o locus digital não é inviolável e também está sujeito às repressões, devido à própria natureza fugidia e colaborativa da rede - que permite espelhamento de conteúdos -, a plataforma do WikiLeaks existe até hoje, apesar dos ataques, o que seria impossível se dependesse de uma sede física. E como bem sintetiza Milan (2013), o ativismo não está se transformando em algo totalmente online, porém - como é caso do WikiLeaks há uma tendência em existir com uma forte base digital, onde a Internet não é apenas uma plataforma para networking e troca de informações ou um espelho de ações offline, mas um lugar onde narrativas, solidariedade, identidades e empoderamento co-existem e são reproduzidos e reforçados, complexificando e complementando aquilo que continua ocorrendo nas interações face-a-face.

\section{b) Descentralização}

Em sua estruturação inicial (que vai da sua fundação até o intenso ano de 2010 com os grandes vazamentos), a organização contou com duas importantes figuras, Julian Assange como um grande porta-voz e personificação do grupo - e o seu principal colaborador, Daniel Domscheit-Berg ${ }^{147}$. Os dados trazidos por Brevini e Murdock (2013) demonstram onde estão os principais gastos da organização em 2010 e pode nos servir como uma pista mais concreta para entender a organização da estrutura do grupo naquele momento:

Tabela 2 - Despesas do WikiLeaks em 2010

\begin{tabular}{|l|c|c|}
\hline & $\%$ & Euros $(€)$ \\
\hline Campanhas & 35.7 & 143.305 \\
\hline Remuneração & 26.0 & 104.477 \\
\hline Viagens & 15.4 & 62.053 \\
\hline Infraestrutura & 14.7 & 59.044 \\
\hline Serviços jurídicos & 8.2 & 32.944 \\
\hline
\end{tabular}

(Fonte original: Wau Holland Foundation)

O fato do WikiLeaks alocar quase 36\% da sua receita em campanhas no ano de 2010 e $26 \%$ com seu staff (Tabela 2) demonstra que mais da metade dos recursos estão voltados para

\footnotetext{
${ }^{147}$ Domscheit-Berg se desvinculou do WikiLeaks ainda em 2010. Sua saída se deu devido a divergências sobre os métodos e a forma de gestão de Julian Assange.
} 
manter uma estrutura mínima funcionando para garantir recebimento e tratamento de dados e publicizar suas ações. "These have been aimed at extending the site's international reach, with the double intention of increasing 'the global impact of the leaks' (Assange, 2010) and making it more resilient to pressure from individual states and corporations" (BREVINI; MURDOCK, 2013, p. 44).

Em sua estrutura, o grupo possui um "advisory board" $" 148$ composto por nove membros espalhados ao redor do mundo (incluindo brasileiro, australiano, chineses, norte-americano, dentro outros), cuja função seria conceder credibilidade e estrutura para a organização, ao mesmo tempo em que forneceria exposição, porém como os membros não eram expostos publicamente, o que parecia contradizer a própria função do corpo de membros. ${ }^{149} \mathrm{~A}$ centralização excessiva de Assange em conjunto com a pouca participação efetiva dos membros do Conselho conduziram a um cenário menos cooperativo coletivo:

In its earliest days, an 'advisory board' was constantly under discussion, with attempts made to recruit, but this was never expected to have any overall ultimate control over the collective. There is no mutual ownership or control so it seemed more like an anarchist cell than a co-operative collective (BECKETT; BALL, 2012, p. 27).

A existência deste "conselho" é pouco publicizada por questão de proteção aos membros, segundo Assange, porém, é possível visualizar na subpágina ${ }^{150}$ oficial do grupo a descrição de cada um deles. Segundo Domscheit-Berg (2011), alguns membros negaram participação do Conselho:

O conselho consultivo era uma ideia fantástica, formada antes da minha época de WL. Das oito pessoas que chamávamos de nosso conselho, conhecíamos pessoalmente apenas uma única pessoa, e era CJ Hinke, um internauta ativista da Tailândia. No decorrer do tempo, os jornalistas descobriram cada um dos supostos membros do conselho. Os chineses negaram imediatamente sua participação, o que Julian ignorou com as seguintes palavras: É claro que eles não podem admitir publicamente o que são. Ben Laurie recusou diversas vezes ter participado do nosso conselho. Philip Adams ainda disse que, em algum momento, ele aceitou o posto, mas, por motivos de saúde, não pôde contribuir com nada (posição 783-787).

\footnotetext{
${ }^{148}$ Disponível em: <https://wikileaks.org/wiki/WikiLeaks:Advisory_Board>. Acesso em: 23 jan. 2016

${ }^{149}$ WHITTAKER, Zack. Wikileaks: How the organization functions and operates. iGeneration. June 21, 2011. Disponível em: <http://www.zdnet.com/article/wikileaks-how-the-organization-functions-and-operates/>. Acesso: 07 jan. 2016.

${ }^{150}$ Disponível em: <https://wikileaks.org/wiki/WikiLeaks:Advisory_Board>. Acesso em: 23 jan. 2016.
} 
Mesmo com a existência do conselho, a organização sempre foi bastante personificada e centralizada na figura de Julian Assange desde a sua fundação. A partir de 2011 isso se torna mais evidente, embora outros ativistas continuassem a atuar no entorno de Assange (como Kristinn Hrafnsson que atua na função de porta-voz da organização e Sarah Harrison, editora-investigativa). Como explica Hintz (2013), conflitos internos no final de 2010 afetaram a estrutura da organização:

WikiLeaks has implicitly emphasized the centrality of infrastructure access through its practice of using decentralized server networks and by placing servers in countries with beneficial laws that prevent or reduce the risk of censorship and surveillance. Its successes in keeping its published information open and available attest to the importance of this strategy, and so do its failures. As internal conflicts led to the departure of several members in late 2010, the availability of both technical skills and secure infrastructure was affected, and WikiLeaks' effectiveness was compromised (p. 150).

Isso reforçou a ideia de uma organização personificada em seu fundador que se tornou sinônimo do próprio grupo, muitas vezes ofuscando outros ativistas envolvidos. Para Lovink e Riemens (2013) seria o típico caso de uma “organização de uma única pessoa”:

WikiLeaks is a typical SPO (Single Person Organization) or UPO (Unique Personality Organization). This means that the initiative taking, decision making, and execution are largely concentrated in the hands of a single individual. Like small and medium-sized businesses, the founder cannot be voted out, and, unlike many collectives, leadership does not rotate. This is not an uncommon feature within organizations, irrespective of whether they operate in the realm of politics, culture, or the "civil society" sector. SPOs are recognizable, exciting, inspiring, and easy to feature in the media. Their sustainability, however, is largely dependent on the actions of their charismatic leader, and their functioning is difficult to reconcile with democratic values. This is also why they are difficult to replicate and do not scale up easily. Sovereign hacker Julian Assange is the identifying figurehead of WikiLeaks, and the organization's notoriety and reputation merge with Assange's own. What WikiLeaks does and stands for becomes difficult to distinguish from Assange's rather agitated private life and his somewhat unpolished political opinions (p. 248-249).

Deve-se ressaltar que há um grau de centralização e personificação na estrutura da organização, em torno de Assange. Porém, a análise mais atenta e a forma na qual a organização está estruturada permite contestar a concepção dos autores quando afirmam que "WikiLeaks is a typical SPO (Single Person Organization)". Trata-se de algo mais complexo: de fato é uma organização que possui um fundador (não se trata de um coletivo horizontalizado, embora em seu início isso tenha sido mais ambíguo). Por outro lado, não é 
tão típica assim: é verticalizada e centralizada no nível da tomada de decisões e, ao mesmo tempo, convive com uma estrutura horizontalizada e em rede no nível da execução de ações. Algo não muito típico em organizações de um "homem só", onde tomadas de decisões e ações ocorrem a partir de uma figura personalizada. E, no caso do Wikileaks, isso ocorre como aponta Benkler (2013): “And like so many other projects on the Net, it uses a combination of volunteerism, global presence, and decentralized action to achieve its results" (p. 16). Assange, isoladamente, não conseguiria manter as atividades do grupo funcionando. Para isso, necessita de ativistas no núcleo mais operacional da estrutura (que tendem a estar sob sua subordinação direta) e, ao mesmo tempo, também precisa de outros colaboradores no nível mais amplo da coleta de material sigiloso, manutenção técnica das estruturas online, tratamento de dados e divulgação (estes não estão simplesmente sob seu comando), além do grupo mais amplo de colaboradores em redes e a partir de outras organizações pré-existentes.

Para Sifry (2011), WikiLeaks é um modelo de ativismo da transparência que apesar do controle autocrático de Assange, também passou por diversas fases. A primeira do modelo, entre 2006 e 2009, marcada pela divulgação de material cru em seu website. Neste período, tem-se o trabalho voluntário e a organização possui traços um pouco mais coletivizados enquanto "grupo". A segunda fase, de controle editorial e produção rígidos, como o exemplo de realização e promoção do vídeo Collateral Murder. A última fase é marcada pela negociação com maior número de empresas de mídia para a divulgação dos dados, considerando um processo mais devagar e cauteloso, sobretudo colaborativo. Em todas essas etapas, permanece o poder de decisão concentrado na figura de Assange (em maior ou menor grau, a depender do período), com um núcleo muito pequeno de ativistas diretos em seu entorno. Mas em todas essas etapas, a estrutura de ação depende de uma forma mais rizomática, isto é, que pode se ramificar a partir de diferentes pontos, fugindo assim do modelo de uma estrutura meramente centralizada:

By its very nature, a 'rhizomatic' form of alternative media is not necessarily static. WikiLeaks embraces the uncertainty principle. By adopting different aspects of various media/ political organizations, WikiLeaks appears in this phase to have created a hybridized, multi-faceted media entity combining elements of the following models: hacktavist network; transparency organization; political sect; stateless group uncensorable outlet (BECKETT; BALL, 2012, p. 32).

Nesta linha de argumento, Lovink e Riemens (2013) apontam que o termo "organized network" tem sido utilizado para tipificar este formato de estrutura organizacional. Para Quian 
(2010) a possibilidade de existência de um personagem como Julian Assange e a estrutura do seu grupo é um fenômeno somente possível devido à convergência midiática, a cultura participativa e a inteligência coletiva que a comunicação digital propiciou.

\section{c) Transnacionalização}

Atravessando todos os níveis da estrutura, a natureza transnacional do WikiLeaks é evidente. Isso está claro na própria autodefinição do grupo que se considera uma organização global independente, composta por indivíduos de diferentes profissões engajadas na bandeira da transparência radical (WIKILEAKS, 2013).

Adicionalmente, a organização acredita que não apenas pessoas do seu próprio país, mas de outros países, devem acompanhar os governos em âmbito global para garantir a transparência:

We believe that it is not only the people of one country that keep their government honest, but also the people of other countries who are watching that government. That is why the time has come for an anonymous global avenue for disseminating documents the public should see. ${ }^{151}$

A rede de informantes foi desenhada para ser transnacional, com informações oriundas de qualquer fonte politicamente relevante do globo (governos, corporações etc.). A rede de apoiadores técnicos também é composta por cidadãos de diferentes países e a rede de doadores também é transnacional; além dos colaborares, sobretudo os meios de comunicação, estarem espalhados ao redos do globo para maior visibilidade.

A estruturação transnacional opera, no interior da dinâmica da organização, através da comunicação digital. Este modo de comunicação foi fundamental para o próprio nascimento, relevância e viabilidade do grupo, que potencializou o horizonte de sequestro de dados digitais em escala global, possibilitando serem enviados de forma segura através do meio digital, de qualquer país; criando assim uma rede de ativistas operando a partir de diversos territórios. Ao entrar em sinergia com uma rede global de veículos jornalísticos (hoje em torno de 100 veículos em diversos continentes, como a organização informa em seu website) isso fortaleceu a ideia de uma esfera pública internacional, como aponta Dunn (2013):

$151<$ https://www.wikileaks.org/wiki/WikiLeaks:About> Acesso em: 2 jan.2016 
In relation to the WikiLeaks story, this notion of a transnational public sphere creates an interesting dynamic between traditional media and the new-media platform. Under anonymous cover, people all over the world can secretly upload information to the whistle-blowing site. WikiLeaks in turn depends on the traditional outlets at the national level to analyse and extract meaning and purvey that meaning and conclusion to audiences within their national domains (p. 92).

Essa natureza transnacional também é reforçada pelo próprio conteúdo dos vazamentos que impactam nas relações entre países e repercutem nas mídias locais. Um exemplo emblemático é o vazamento Cablegate - publicação dos 220 telegramas confidenciais de embaixadas em 28 de novembro de 2010.

The Wikileaks releases of highly sensitive classified information, such as the Iraq war logs and diplomatic cables, were an issue at the information layer of the internet architecture. It might initially be seen as a domestic (state) issue with respect to levels of analysis. However, it was in fact an international issue, since the Wikileaks operator was overseas (CHOUCRI, CLARK, 2012, p. 5).

Para Steen-Thornhammar (2012a), o WikiLeaks se tornou uma plataforma transnacional importante, criando uma estrutura que viabilizava o monitoramento global de autoridades e corporações, reforçando o compromisso com a democracia e a proteção à liberdade de expressão em nível internacional (STEEN-THORNHAMMAR, 2012a). Para Choucri e Clark (2012) este tipo de engajamento transnacional só foi possível em razão da própria estrutura da Internet, que possibilitou ações de ativistas que operaram em nível internacional.

\subsubsection{Instrumentalização do planejamento}

\section{a) Datificação}

A dimensão dos vazamentos realizados pelo WikiLeaks seria logisticamente impossível se a base desses documentos fosse analógica, isto é, se acaso tratasse de suportes físicos como papel, fita-cassete ou outras bases pré-digitais. A possibilidade da coleta nas fontes demandaria o sequestro físico desses conteúdos em salas de arquivos fortemente 
vigiadas ou protegidas e necessitaria de uma ação de transporte de um volume considerável de material sigiloso. Ainda que pressupuséssemos que poderiam ser utilizadas câmeras fotográficas (mesmo analógicas) no fotocopiamento dos documentos, isso demandaria um trabalho e tempo que inviabilizaria o processo de vazamento na prática. O informante até poderia copiar algumas páginas, mas não conseguiria fazê-lo na íntegra e, em todos os casos de material analógico, o risco de ser apanhado durante o processo de coleta seria imensamente maior, o que desestimularia a ação e ainda haveria o complicador do envio do material coletado para um agente publicador, que pudesse ocorrer de forma segura e anônima. A dimensão dos dados vazados pelo WikiLeaks são bons exemplos disso, como explica McCurdy (2013):

Whereas the volume of information may have presented an issue in the past again, think of the time needed to photocopy, "declassify," and collate the 7,000-page Pentagon Papers - digital informatlon can easily be encoded onto multiple media simply and instantly, and shared across computer networks worldwide at minimal cost. To help gain some perspective on this point imagine this: if Cablegate were released as an analogue leak, and assuming each cable is a page or less, it would take 41.8 hours of straight printing ata rate of 100 pages a minute. The print job would use almost 503 reams of paper. Yet, in a digital age, the Cablegate and related files were not printed but were digitally distributed. Each trave was eventually made available on the Internet as a reasonable-sized torrent: Cablegate (1.61 GB), Afghan War Diaries (75.7 MB), Iraq War Logs (354.18 MB), and the Collateral Murder vídeo and raw Apache footage (249.19 MB). Given that the average CD-RW holds around $700 \mathrm{MB}$, these files could fit, likely with room to spare, on 4 CDs or on a single USB flash drive (p. 136).

A digitalização de documentos secretos, o seu depósito em computadores e a facilidade de cópia de grandes volumes de dados em compartimentos cada vez mais miniaturizados (como um pendrive) foram condições materiais fundamentais para a coleta de dados. O papel da comunicação digital nesta possibilidade de coleta de dados é ressaltado pelo próprio grupo ao afirmar que:

Scrutiny requires information. Historically, information has been costly in terms of human life, human rights and economics. As a result of technical advances - particularlly the internet and cryptography - the risks of conveying important information can be lowered (WIKILEAKS, 2013, p. 14)

Se por um lado as plataformas digitais possibilitaram a coleta e o envio de grandes volumes de dados de forma relativamente fácil e segura, analisar e extrair conhecimento relevante de uma quantidade enorme de documentos tem sido um desafio para o WikiLeaks, que se depara, em grande parte, com arquivos desorganizados e em muitos dos casos 
informação irrelevante (SERRA, 2012). O excesso de informação significa o mesmo que ausência de informação e pode ser inclusive uma tática de invisibilidade utilizada por corporações ou governos para escamotear o conhecimento ao mesmo tempo em que se apresentaria "aparentemente" transparente.

Apesar destas limitações, os mecanismos de coleta, estocagem, e processamento de informação em volumes cada vez maiores têm evoluído nos últimos anos, no caminho do que vem sendo chamado "big data":

Big data starts with the fact that there is a lot more information floating around these days than ever before, and it is being put to extraordinary new uses. Big data is distinct from the Internet, although the Web makes it much easier to collect and share data. Big data is about more than just communication: the idea is that we can learn from a large body of information things that we could not comprehend when we used only smaller amounts. [...] With big data, instead of trying to understand precisely why an engine breaks down or why a drug's side effect disappears, researchers can instead collect and analyze massive quantities of information about such events and everything that is associated with them, looking for patterns that might help predict future occurrences (CUKIER, SCHOENBERGER, 2013, s/p).

Neste sentido, o WikiLeaks segue esta tendência e os dados vazados em grandes quantidades têm sido analisados e incorporados neste cenário mais amplo de cruzamentos complexos, com diversas outras bases de dados, e que podem, atualmente, ser realizados por microcomputadores pessoais e programas avançados de classificação e cruzamentos estatísticos que estão hoje em plena fase de expansão, como explica a própria organização:

We use traditional investigative journalism techniques as well as more modem technology-based methods. Typically we will do a forensic analysis of the document, determine the cost of forgery, means, motive, opportunity, the claims of the apparent authoring organisation, and answer a set of other detailed questions about the document. We may also seek external verification of the document. For example, for our release of the Collateral Murder video, we sent a team of journalists to Iraq to interview the victims and observers of the helicopter attack. The team obtained copies of hospital records, death certificates, eye witness statements and other corroborating evidence supporting the truth of the story (WIKILEAKS, 2013, p. 15).

Ou seja, o processamento digital da informação coletada, em última instância, providencia os insumos que definirão a tomada de decisão - no âmbito do planejamento que 
precede a publicação - sobre o que será ou não vazado, já que parte do material, após coletado e analisado, é descartado por irrelevância.

\section{b) Instrução}

A utilização de ferramentas digitais de comunicação para orientar as ações do grupo ocorre basicamente em torno das instruções sobre os modos de envio de dados através da plataforma online. Essas orientações estão fundamentalmente na sub-página sobre "submissões", como demonstra a Figura 9:

Figura 9 - Tela de submissões de arquivos no website do WikiLeaks

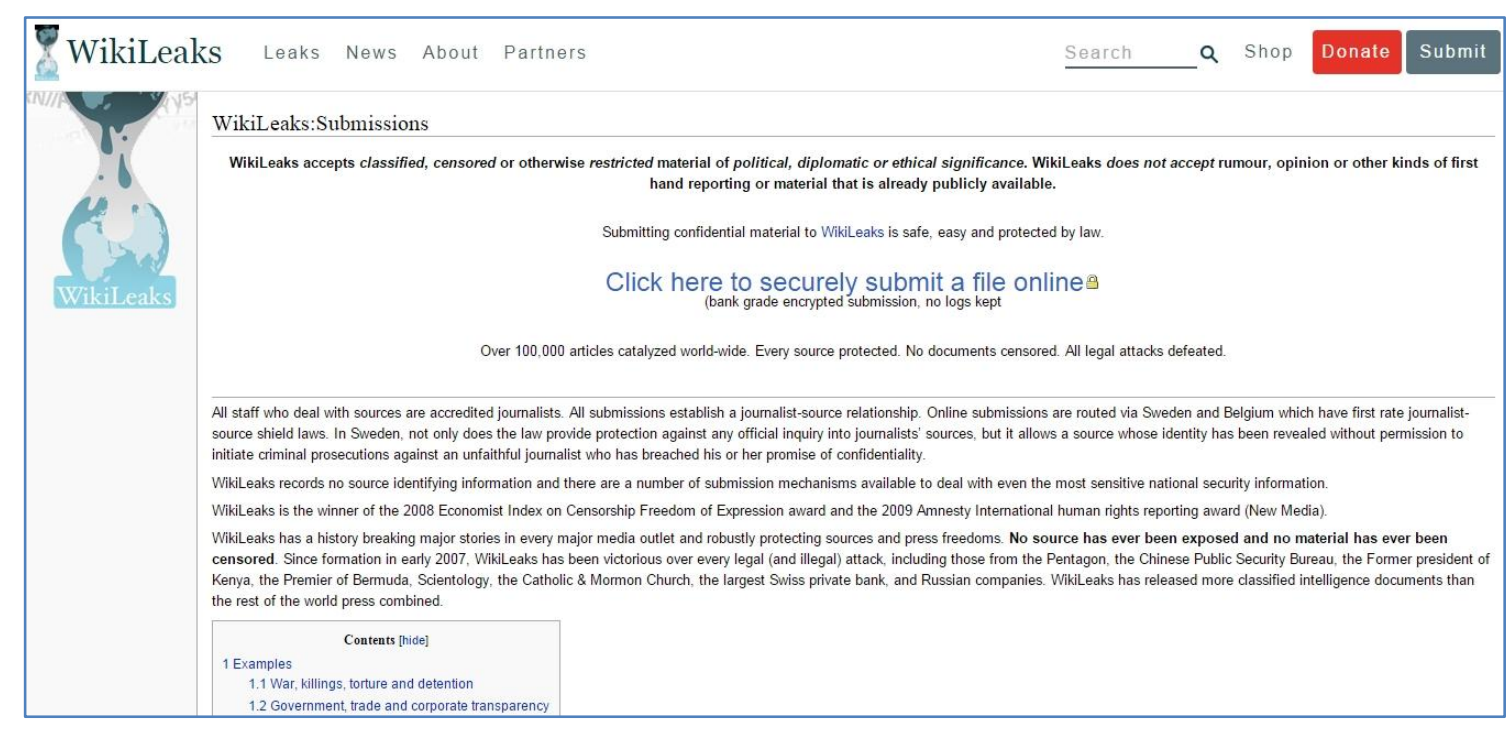

(Fonte: Website WikiLeaks) $^{152}$

No website, explica-se qual o tipo de material o grupo está apto a receber, exemplos de categorias de informação a serem vazados, a importância dos mecanismos de segurança e como um informante deve proceder. No site é fornecida instrução sobre como postar informações a partir de cibercafés ou wireless hotspots, garantindo o anonimato ainda que o WikiLeaks esteja infiltrado por uma agência governamental de inteligência. Inclusive, a depender da fonte, o mais indicado pelo grupo é o envio do material a partir de um computador não pessoal, ou ainda, combinando postagem pelo correio com técnicas

${ }^{152}$ Disponível em: <https://wikileaks.org/wiki/WikiLeaks:Submissions >. Acesso: 17 jan. 2016. 
eletrônicas. O objetivo é proteger os informantes, evitando que sofram repressão das organizações vazadas:

However, we also provide instructions on how to submit material to us, via net cafes, wireless hot spots and even the post so that even if WikiLeaks is infiltrated by an external agency, sources can still not be traced. Because sources who are of substantial political or intelligence interest may have their computers bugged or their homes fitted with hidden video cameras, we suggest that if sources are going to send WikiLeaks something very sensitive, they do so away from the home and work. A number of governments block access to any address with WikiLeaks in the name. There are ways around this. WikiLeaks has many cover domains, ... that don't have the organisation in the name. It is possible to write to us or ask around for other cover domain addresses. Please make sure the cryptographic certificate says wikileaks.org (WIKILEAKS, 2013, p. 17).

Paralelamente, também no website oficial grupo, há links para outras plataformas instrutivas que reúnem informações e orientações de como utilizar a Internet de forma segura para efetivar os envios de dados sensíveis, como é o caso do Projeto Tor (tails.boum.org) que se trata de:

[...] a group of volunteer-operated servers that allows people to improve their privacy and security on the Internet. Tor's users employ this network by connecting through a series of virtual tunnels rather than making a direct connection, thus allowing both organizations and individuals to share information over public networks without compromising their privacy (TOR PROJECT, online). ${ }^{153}$

Ou a plataforma Tails (www.tails.boum.org) que ensina a usar a Internet de forma anônima, apagar rastros digitais remanescentes do uso de um computador e como usar sistemas de cripografia para envio e recebimento de materiais criptografados (https://tails.boum.org). Ambos os casos são parceiros do WikiLeaks, constando inclusive suas logormarcas na base da página inicial do website do grupo.

Ainda, o website oficial fornece orientações sobre como driblar bloqueios governamentais, alguns facilmente executados.

\section{c) Elaboração}

Devido à sua própria natureza desterritorializada e intensamente virtualizada, o WikiLeaks pressupõe a comunicação digital como instrumento inevitável de seus processos

\footnotetext{
${ }^{153}$ Disponível em: <https://www.torproject.org/about/overview.html.en〉. Acesso: 16 dez. 2016.
} 
de planejamento no nível da elaboração de estratégias. O uso de ferramentas interativas como chats, webconferências, e-mails e outros sistemas similares compõe o cotidiano e cultura da organização.

Quando um material é recebido no website, automaticamente é distribuído um backup nos seus computadores-servidores. Em seguida todos os documentos ficam organizados por ordem de chegada e são acessados pelos editores da organização para avaliarem se preenchem os critérios previamente estabelecidos que caracterizam material relevante para ações de vazamentos. O resumo dos vazamentos são preparados em conjunto pelo staff, utilizando a comunicação digital como parte do processo, uma vez que aqueles que irão tratar os dados estão espacialmente distantes. Historicamente, as sínteses que apresentam os vazamentos são geralmente produzidas pelo próprio Assange e, eventualmente, em colaboração com o informante que forneceu o material. Sempre através de sistemas de comunicação criptografados e protegidos contra vigilância indesejada, conforme descreve o website da organização.

$\mathrm{O}$ uso de ferramentas digitais ${ }^{154}$ para processar e classificar informações e decidir o que será publicado (KELLER, 2013), bem como a definição e elaboração de formatos e modos de publicação de material, como é o caso da edição do vídeo Collateral Murder (BECKETT; BALL, 2012), também são exemplos deste uso mais instrumental na elaboração dos vazamentos.

Embora seja preponderante um formato centralizado e instrumental de uso da comunicação digital para a elaboração de seu planejamento, a organização já chegou a utilizar a Internet para atividades de co-elaboração mais horizontais. Quian (2013) traz um exemplo: a partir dos atritos sobre a forma de edição e publicação dos documentos vazados pelos veículos jornalísticos, o WikiLeaks decidiu colocar a questão em consulta. Diante da polêmica, a decisão de vazar toda esta documentação foi compartilhada com seus seguidores, ao convidar a partir de seu website e do Twitter oficial a uma votação online, que ocorreu no Twitter no dia 01 de setembro de 2011. O objetivo era decidir se deveria publicar novos vazamentos de telegramas sem ocultar nada e sem passar pelo filtro dos meios de comunicação (QUIAN, 2013). Segundo o The Guardian: "WikiLeaks appeared likely to use the Twitter responses, which it said favoured disclosure at a ratio of 100 to one, to pave the way for imminent

${ }^{154}$ Neste caso, não apenas a comunicação digital, mas também softwares de data mining, big data entre outros. 
disclosure of the remaining material from its cable archive"155. Porém, a decisão provocou críticas por parte dos meios de comunicação envolvidos no Cablegate:

En una nota conjunta publicada el 2 de septiembre, The New York Times, The Guardian, Der Spiegel, Le Monde y El País lamentaron y condenaron la publicación de la totalidad de los 250.000 cables en bruto por considerar que «la revelación de la identidad de los informantes podría poner en peligro a las citadas fuentes» (QUIAN, 2013, p. 42-43).

Embora possa lançar mão deste tipo de planejamento mais colaborativo, indo além do staff, seja na forma de consultas ou enquetes públicas, este não deve ser compreendido como um elemento caracterizador da forma de uso da comunicação digital para a elaboração de planos. Pelo menos até o momento este tipo de elaboração não é usual nem cotidiano no planejamento da organização.

\subsubsection{Diversificação da ação}

\section{a) Ciberevento}

A intensa visibilidade online do WiliLeaks tem propiciado a ocorrência de alguns cibereventos em torno da organização. A prisão de Assange em 2010 e o bloqueio das contas do WikiLeaks em serviços financeiros e de hospedagem geraram uma série de manifestações online, incluindo uma petição no site Avaaz ${ }^{156}$ cujo chamado dizia:

The U.S. and other governments and corporations involved in the crackdown on WikiLeaks: We call on you to stop the crackdown on WikiLeaks and its partners immediately. We urge you to respect democratic principles and laws of freedom of expression and freedom of the press. If WikiLeaks and the journalists it works with have violated any laws they should be pursued in the courts with due process. They should not be subjected to an extrajudicial campaign of intimidation. ${ }^{157}$

A petição, intitulada "Stop the Crackdown on WikiLeaks" alcançou cerca de 650 mil

\footnotetext{
${ }^{155}$ WikiLeaks prepares to release unredacted US cables. The Guardian. 01 set. 2011. Disponível em: <http://www.theguardian.com/media/2011/sep/01/wikileaks-prepares-unredacted-us-cables>. Acesso: $10 \mathrm{dez}$. 2015.

${ }^{156}$ Trata-se de uma plataforma mundial voltada para a criação e divulgação de petições online.

${ }^{157}$ Disponível em: <https://secure.avaaz.org/en/wikileaks_petition/?rc=fb>. Acesso: 29 nov. 2015.
} 
assinaturas de pessoas oriundas de diversos países, conforme é possível averiguar na lista de assinantes. Cerca de 300 mil endossos ocorreram em menos de 24 horas após o lançamento.

Figura 10 - Tela com petição pró-WikiLeaks

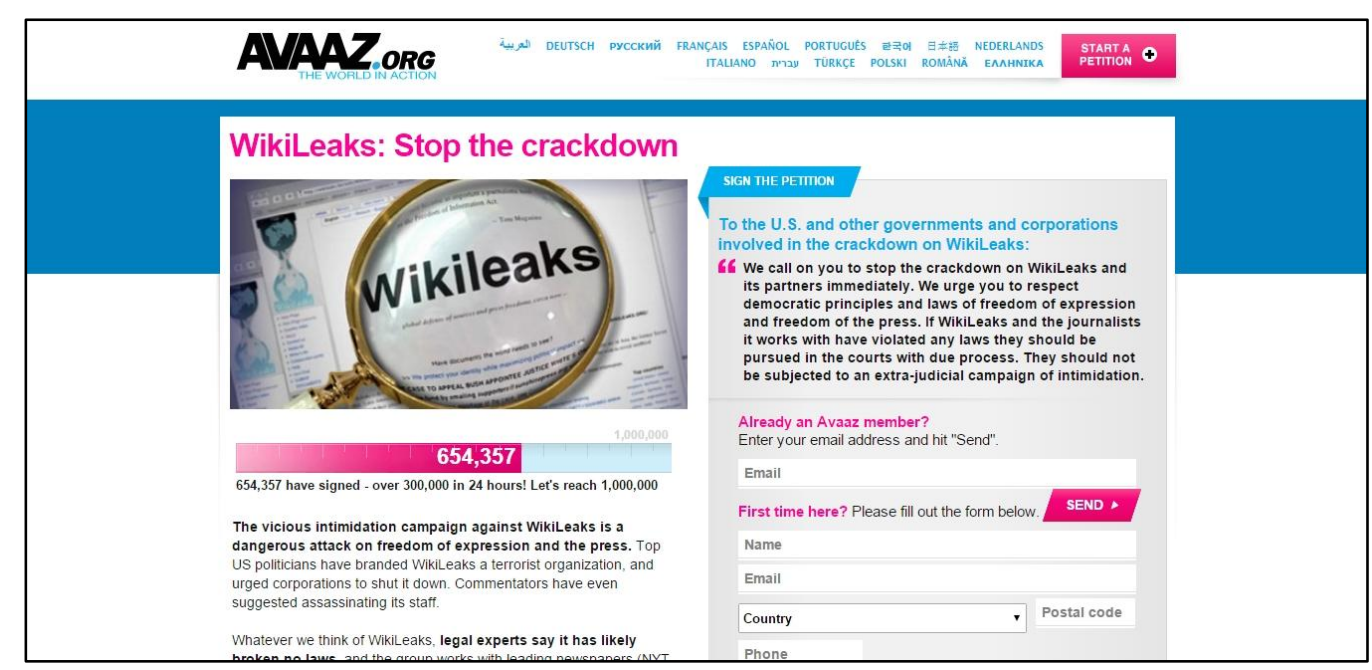

(Fonte: Avaaz.org)

Nota-se que o número de "assinaturas" atingidas não foi baixo, mas também não se pode afirmar que consistiu em um quantitativo substancial, tendo em vista ser um ciberevento que se propunha de caráter internacional. Isso pode ser também medido pela diferença entre a meta dos organizadores e o valor atingido: buscava-se atingir 1 milhão de endossos. Conseguiu-se cerca de $60 \%$ desta meta conforme Figura 10.

Diversas outras petições similares surgiram em diversos países. No Brasil, por exemplo, houve petição online pedido para o governo do Equador conceder exílio político a Assange em decorrência de seu refúgio na embaixada do país em Londres ${ }^{158}$; petições online pedindo a liberdade de Julian Assange; e outras de organizações de imprensa em defesa política às ações do WikiLeaks ${ }^{159}$. Na prática, essas petições e outras similares variam no volume de "assinaturas" e não têm valor jurídico de fato. Trata-se de uma mobilização online coletiva cujo principal intuito é demonstrar uma manifestação coletiva de apoio ao grupo e de desaprovação às repressões sofridas. Tem um papel mais simbólico.

Outra campanha protagonizada pela organização, que também podemos considerar um

\footnotetext{
${ }^{158}$ Disponível em < http://www.peticaopublica.com.br/pview.aspx?pi=ASSANGE > Acesso: 04 jan. 2016.

${ }^{159}$ Disponível em < http://abraji.org.br/?id=90\&id_noticia=1309 > Acesso: 04 jan. 2016.
} 
ciberevento, ocorreu em junho de 2011 quando o Wikileaks encabeçou uma campanha ${ }^{160}$ com um vídeo online para arrecadar dinheiro para a organização, que já sofria 6 meses de bloqueio de suas contas pelas entidades financeiras norte-americanas. Promovendo a organização e sua causa, ao mesmo tempo em que expunha os gastos extratosféricos devido à prisão domiciliar de Assange e às despesas jurídicas, o vídeo protagonizado pelo próprio Assange era uma paródia ao comercial da Mastercard, uma das empresas envolvidas no bloqueio, e estimulava as doações online através de métodos alternativos presentes no website oficial.

Mais recentemente, o WikiLeaks lançou uma outra campanha para mobilizar sua rede potencial de informantes e colaboradores em um projeto coletivo de vazamento pré-definido: coletar e publicar documentos privilegiados sobre o secreto acordo de comércio livre entre a União Europeia e os Estados Unidos. A mobilização prevê uma ação de crowdfunding ${ }^{161}$ (financiamento coletivo online) iniciado em agosto de 2015 visando somar e oferecer uma recompensa de 100 mil euros para o informante que obter informações relevantes sobre o tema. Até janeiro de 2016 a organização já havia arrecadado $56 \%{ }^{162}$ da quantia estimada.

\section{b) Ciberataque}

Embora seus fundadores - e muitos de seus colaboradores - tenham suas origens em movimentos hackers, não é uma característica do WikiLeaks, pelo menos não até o momento, efetivar ciberataques próprios, isto é, ataques online executados por membros ligados diretamente ao próprio grupo. Ao mesmo tempo, a rede de colaboradores que está no entorno do grupo tem utilizado deste tipo de ação online, levando o embate político para o domínio ciber. Isso ocorreu principalmente na forma de ciberataques colaborativos executado por apoiadores em defesa do grupo, principalmente na forma de contra-ataque, em resposta às ações de repressão pós-vazamentos.

Como já mencionado anteriormente, em dezembro de 2010, PayPal suspendeu o processo de doações ao WikiLeaks devido ao grupo violar as políticas de uso do PayPal, justificando que seus serviços de pagamento não podiam ser usados para estimular, promover,

\footnotetext{
${ }^{160}$ REDAÇÃO. Olhar digital. 01 jul. 2011. WikiLeaks cria vídeo para pedir doações e faz paródia à campanha da MasterCard Disponível em: <http://olhardigital.uol.com.br/noticia/wikileaks_cria_video_para_pedir_doacoes_e_faz_parodia_a_campanha_d a_mastercard/19012>. Acesso: 03 nov. 2015.

${ }_{161}^{161}$ Disponível em: <https://wikileaks.org/WikiLeaks-goes-after-hyper-secret.html>.

${ }^{162}$ Disponível em: <https://wikileaks.org/pledge/>. Acesso: 31 jan. 2015.
} 
facilitar ou instruir pessoas a engajar em atividades ilegais (BREVINI; MURDOCK, 2013). Nesse mesmo sentido seguiram outras empresas: Bank of America, Visa, and MasterCard que também decidiram interroper seus serviços para o WikiLeaks sob a alegação de que o grupo desenvolvia atividades ilegais e isso seria uma quebra de contrato.

Figura 11 - Tela com chamado de mobilização para Operação PayBack

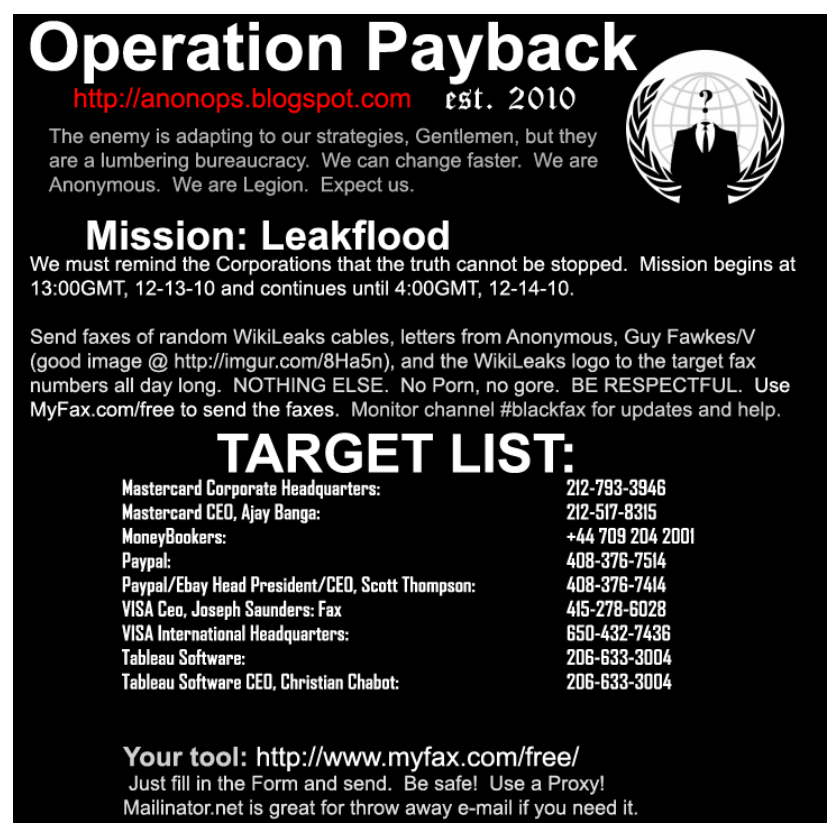

(Fonte: Google Imagens)

Isso desencandeou a chamada "operação Payback", organizada pelo grupo Anonymous em apoio ao WikiLeaks, que chegou a paralisar o acesso a sites de empresas como MasterCard, como sintetiza trecho de reportagem no dia 8 de dezembro de 2010:

Co-ordinated attacks by online activists who support the site and its founder Julian Assange - who is in UK custody accused of raping two Swedish women - have seen the websites of the alleged victims' Swedish lawyer disabled, while commercial and political targets have also been subject to attack by a loose coalition of global hackers. The Swedish prosecution authority has confirmed its website was attacked last night and this morning. MasterCard was partially paralysed today in revenge for the payment network's decision to cease taking donations to WikiLeaks.In an attack referred to as Operation Payback, a group of online activists calling themselves Anonymous appear to have orchestrated a DDoS (distributed denial of service) attack on the financial site, bringing its service to a halt.Attempts to access www.mastercard.com have been unsuccessful since shortly after 9.30am (THE GUARDIAN, 2010) ${ }^{163}$

163 Disponível em: <http://www.theguardian.com/media/2010/dec/08/operation-payback-mastercard-websitewikileaks>. Acesso: $12 \mathrm{dez} .2015$. 
Para Greathouse (2014) a reação do grupo Anonymous em defesa do WikiLeaks demonstra o potencial de atores não-estatais no domínio ciber e acredita que este tipo de ação pode se ampliar no futuro, pois ainda que não tenham paralisado totalmente os sites e empresas como MasterCard, Visa e PayPal, foram suficientemente potentes para parcialmente inviabilizá-los ou causar distúrbios funcionais significativos por algumas horas: “A more focused and drawn out denial of service attack would have significant potential to disrupt economic activities within an information dependent economy (GREATHOUSE, 2014, p. 26).

Uma das formas que os ativistas usaram para promover a campanha de ataque foi através de contas no Facebook e Twitter, locais onde também usavam para discussão da ação. Porém, ambas as contas foram banidas ${ }^{164}$ das respectivas redes sociais, justificada pelo Facebook que tais páginas promoviam um ataque distribuído de negação de serviço, considerado uma forma ilegal de congelar sites.

Um outro modo de ciberataque diz respeito à atividade que viabiliza a matéria prima dos vazamentos de dados publicados pela organização: a ciberespionagem. Primeiro, é importante esclarecer que não há indícios ou provas de que o WikiLeaks realiza ciberataques ou sequestro de dados digitais. A organização recebe, trata e publica esses dados resultantes de espionagem e ciberespionagem. Espionagem quando os informantes copiam dados físicos; ciberespionagem quando esses informantes copiam dados invadindos sistemas digitais (seja via internet, seja via terminal ou servidor que dá acesso ao banco de dados digitais). Essa atividade de sequestro de dados é realizado não pelo grupo em si mas por colaboradores ou voluntários. Esses desenvolvem ciberespionagem e só podem realizar tal façanha, em muitos casos, porque os arquivos são digitais. Arquivos físicos são bem mais difíceis de serem vazados.

Um bom exemplo desta forma de ação é o já mencionado informante Bradley Manning (que vazou 700 mil arquivos secretos para o WikiLeaks). McCurdy (2013) explica como Manning conseguiu copiar o material sigiloso burlando as barreiras de segurança do governo americano:

It is alleged that Bradley Manning installed the open-source, data-mining software Wget on his SIPRNet computer and used computer scripts to download information from the military network onto his workstation

\footnotetext{
${ }^{164}$ ISAAC, Mark. Facebook and Twitter Suspend Operation Payback Accounts. Forbes. 8 dez. 2010. Disponível em: <http://www.forbes.com/sites/mikeisaac/2010/12/08/facebook-and-twitter-suspend-operation-paybackaccounts/\#5d0ec11c4713>. Acesso: 13 dez. 2015.
} 
(Zetter, 2011c). Information would then be transferred to a rewritable compact disk (CD-RW). This process was described by Bradley Manning (bradass87) as follows: "bradass87: I would come in with music on a CDRW ... labelled with something like "Lady Gaga" ... erase the music ... then write a compressed split file ... no-one suspected a thing I lipsyncehd to Lady Gaga's Telephone...i didnt even have to hide anything" (Hansen, 2011) (McCURDY, 2013, p. 31)

Se não é o WikiLeaks que produz diretamente a ação de ciberespionagem, a organização é sem dúvida o "curador", em uma metáfora "museológica" desta ação pois estimula e faz com que tal ação tenha um efeito real nos cenários políticos. Não por acaso, segundo suas lideranças, a ciberespionagem produz transparência que, por sua vez equilibraria o jogo de poder:

As Julian Assange argued as recently as the middle of January 2011, "Transparency should be proportional to the power that one has. The more power one has, the greater the dangers generated by that power, and the more need for transparency. Conversely, the weaker one is, the more danger there is in being transparent." In other words, information is power, then what the transparency movement is trying to do is correct an asymmetric power relationship (SIFRY, 2011, p. 165).

Embora os vazamentos tenham se tornado temas de grande debate político em todo o mundo, o pesquisador Alasdair Roberts (2012) acredita que os objetivos do WikiLeaks sobre a transparência radical tem sido malograda. Para Spektor (2011), do ponto estritamente substancial, o barulho causado pelos vazamentos em muito supera seu significado real:

Afinal de contas, em que pese a cor, detalhe e textura granular dos materiais,
não há ali revelações chocantes. Aquilo que se aprende lendo os documentos
geralmente é do conhecimento dos observadores mais atentos da cena
internacional (p. 20)

Por outro lado, ao contrário do que propõe o autor, defende-se que há hoje uma importância crescente dos vazamentos digitais como uma nova forma de ação política que não deve ser subestimada. O vazamento de novembro de 2010, cujo teor tratou das trocas de telegramas realizados entre os Estados Unidos e suas embaixadas, estremeceu as relações bilaterais norte-americanas. Se antes, nos casos da guerra do Iraque e do Afeganistão, a opinião pública geral, doméstica e internacional, foi interpelada, sobretudo no que diz respeito à violação de Direitos Humanos e exagero do uso da força, no caso do vazamento dos telegramas as relações bilaterais entre diversos países se viu diretamente afetadas e expostas. Hillary Clinton, então no papel de Secretária de Estado dos Estados Unidos, descreveu em 
novembro de 2010 as revelações de WikiLeaks como um "ataque à comunidade internacional", e não apenas aos interesses da política externa norte-americana:

Nevertheless, these cables could compromise private discussions with foreign governments and opposition leaders, and when the substance of private conversations is printed on the front pages of newspapers across the world, it can deeply impact not only US foreign policy interests, but those of our allies and friends around the world. ${ }^{165}$

Ross (2010) aponta que o WikiLeaks é um ataque à forma como a atual diplomacia se conduz, isto é, baseada em telegramas secretos que, quando revelados, demonstram a incoerência entre discurso e prática. A estratégia estadunidense em nomear os vazamentos como um ataque à política internacional como um todo escamoteia o fato de que o país mais atingido, neste caso, foi os Estados Unidos. Porém, ainda que a maior potência militar do planeta tenha sido a principal afetada, os vazamentos geraram reações da comunidade internacional, repudiando os atos revelados com base em informações concretas, ainda que o conteúdo, em linhas gerais, possa não ser novidade nos bastidores da diplomacia, dos serviços secretos e dos círculos jornalísticos e militares. Ao mesmo tempo, a ação do WikiLeaks não se tratou de uma problema doméstico, pois serviu como alerta para outros governos agirem, se precavendo:

The Wikileaks episodes of 2010 and the tight coupling of the kinetic and virtual domains - regarded by the United States as a major security crisis - showed in unambiguous ways the politicization and disruptiveness of cyberspace. Responses to the cable leaks varied across the international landscape, but in general, most countries viewed this episode as a threat to their sovereignty and security - even if they were not the target of the leaks - and recognized the importance of developing preventative measures (CHOUCRI, 2012, p. 224).

Uma contradição apontada por Spektor (2012) trata do fato de que outros tipos de vazamentos e informações de bastidores são comumente explorados em livros (inclusive best sellers), porém tais jornalistas ou ex-políticos não são enquadrados na envergadura de criminosos que violaram a lei e difundiram informações sigilosas do país, demonstrando que seriam as "acusações ao WikiLeaks uma hipocrisia fundamental: a divulgação é legítima sempre e quando for realizada por porta-vozes do establishment" (SPEKTOR, 2012, p. 22).

\footnotetext{
${ }^{165}$ Disponível em: <http://www.telegraph.co.uk/news/worldnews/northamerica/usa/8169040/WikiLeaks-HillaryClinton-states-WikiLeaks-release-is-an-attack.html>. Acesso em 12 ago. 2013.
} 
É compreensível o fato de que a boa diplomacia requer comunicação livre e confiança mútua e de que toda negociação complexa se utiliza de segredos e sigilos fundamentais para concessões para os dois lados, porém, como diz Spektor (2012) "Oficiais de governo de todo o mundo tendem a conhecer bem as vicissitudes da comunicação entre países. O uso parcial de informações e o uso estratégico de vazamentos são moeda corrente" (p. 23). Nesse ponto, é possível dizer que vazamentos e informações estratégicas também são de uso na diplomacia, e o WikiLeaks catalisaria determinados comportamentos e contribuiriam com novas variáveis nas relações em jogo. Tal como afirma Roberts (2012): "A generation ago, leaking was limited by the need to physically copy and smuggle actual documents. Now it is a matter of dragging, dropping, and clicking send" (p. 117).

Porém, esta apropriação não é perfeita. Este mesmo autor ressalta dois aspectos que problematizam esta aparente fluidez da informação. Primeiro, na idade digital, os conteúdos são vastos e embora o material vazado tenha um tamanho significativo, ainda é infimamente menor do que a informação total produzida sobre o assunto. Logo, o vazamento pode tratar apenas de uma parcialidade do fenômeno. Segundo ponto refere-se ao tratamento dado ao material para ser compreensível pelas pessoas em geral, pois além da grande quantidade de informação, há o alto teor técnico do conteúdo, que pode muitas vezes tornar-se incompreensível para a maioria das pessoas. Quando o WikiLeaks revelou informações da contrainsurgência militar em 2008, Domscheit-Berg (2011) disse que o esperado era um grande alvoroço, entretanto devido à complexidade do conteúdo, poucos de fato compreenderam.

Mas não seria exato afirmar que a transparência digital radicalizada pelo WikiLeaks é inócua, pois os vazamentos desencadeiam tensões reais nas relações internacionais. Até mesmo nos casos em que os efeitos são tidos como menores do que se preconizava, pois ao se conceber que o status político permanece igual, à revelia da abertura de expressivos sigilos de um Estado, diz muito sobre o diagnóstico do que são as relações internacionais contemporâneas, pois a inércia da permanência pode ser igual ou mais revelador do que a ruptura. De todo modo, é negligência afirmar que o efeito da atuação do WikiLeaks é ínfimo, ao mesmo tempo que é utópico pensar que a bandeira da transparência será capaz de destituir práticas seculares, ainda que estas não sejam tão publicamente defensáveis. Seib (2012) acredita que esta pode ser uma possibilidade de mudança nas práticas de fazer política: 
However security might be enhanced, diplomats must recognize that even the newest versions of communication are unlikely to be totally secure. A whole generation of hackers will, for a variety of purposes, seek- and most probably find-ways to penetrate what had been thought to be private diplomatic dispatches. Openness will be forced upon the diplomatic process, requiring changes in the way business is done and perhaps also making hypocrisy less affordable. Disingenuous public praise for corrupt foreign officials might become less frequent if diplomats know that frank evaluations of that corruption could become public (p. 102).

Por outro lado, na outra ponta do processo, não significa dizer que governos e corporações estão totalmente vulneráveis e permanecerão despreparados para lidar com vazamentos digitais. Um dos efeitos mais imediatos aos grandes vazamentos como do WikiLeaks em 2010 e de outros vazamentos similares, como o de Edward Snowden em 2013, é a mudança nos sistemas de armazenamento e acesso a documentos sigilosos, seja melhorando os sistemas digitais de defesa/proteção, seja evitando que determinadas informações sejam digitalizadas, o que pode dificultar (mas não extirpar) a coleta deste tipo de dado:

For cautious policymakers, every electronic conversation that was once thought to be private must now be expected to become public. That means many such conversations will no longer take place, or if they do they will have little value. Confidential sources will no longer come forward if they think their identities might leak out. Overall, information could be much harder to come by (SEIB, 2012, p. 102).

Embora boa parte dos vazamentos tenham atingido diretamente os EUA, a preocupação com este tipo de ataque, baseado em ciberespionagem, também passou a preocupar outros governos ${ }^{166}$.

Isso demonstra que, devido ao alto grau de globalização característico do século XXI, o vazamento de dados sensíveis de um país tende a afetar outras nações, seja diretamente (quando se trata de informações de teor bi-laterais ou multi-laterais), seja indiretamente (quando há impactos econômicos ou políticos desestabilizando uma região do globo, por exemplo).

\footnotetext{
${ }^{166}$ Inclusive houve bloqueio quanto ao acesso para o site do WikiLeaks por diversos países: "Soon after the first cables were released, some governments simply blocked access to WikiLeaks itself or to publications discussing cables related to their countries. WikiLeaks' media partner in Lebanon, the Ieft-wing newspaper Al-Akhbar, was hacked and taken offline in response to reporting on cables relating to Saudi Arabia (Kenner 2010). Saudi authorities also blocked access to this site, as well as to the London-based Arab news outlet Elaph. In Morocco, El País and Le Monde were blocked after publishing articles on cables (Black 2010). The Chinese government blocked access to the WikiLeaks website after the New York Times reported that a cable had linked China's Politburo to the December 2009 hack of Google's computer systems (Kan 2010), and Chinese government officials directed local media outlets to stop reporting on the cables (Smith 2010)" (LYNCH, 2013, p. 67).
} 


\subsection{PRIMAVERA ÁRABE: MOBILIZAÇÃO ONLINE E LEVANTES DE RUA}

Uma sucessão de levantes populares em dezembro de 2010 e início de 2011 se propagou em países do Oriente Médio e Norte da África, repercutindo inclusive com a queda de governos na Tunísia e no Egito. Rapidamente, a chamada "Primavera Árabe"167, assim cunhada pelos jornalistas, ganhou as manchetes dos noticiários internacionais. No meio acadêmico também se tornou um emblemático objeto de estudo político, ainda que o referido termo "Primavera Árabe" não fosse considerado o mais adequado entre alguns pesquisadores.

Esta nomenclatura geralmente é questionada em duas vias: primeiro, por que o termo reduz o fenômeno a uma visão restrita de luta pela democracia, quando está atrelado, em suas origens, também a problemas econômicos e sociais, os quais os países da região vêm enfrentando nas últimas décadas. A segunda razão é que ao se denominar "Primavera Árabe" para o conjunto dos levantes sociais de diferentes países - Tunísia, Egito, Líbano, territórios palestinos, Jordânia, Iraque, Kuwait, Emirados, Omã, Arábia Saudita, Sudão (Norte), Argélia, Marrocos, Síria, Iêmen e Líbia -, coloca-se no mesmo bojo realidades distintas, "com problemas econômicos e sociais diferentes oriundos dos diferentes legados deixados pelo colonialismo europeu e pelas diferentes formas de domínio de regimes únicos que governaram esses países por décadas" (FERABOLLI, 2012, p. 107). No intuito de categorizar os países, Roche (2012) divide-os em três diferentes blocos considerando os avanços políticos naquele contexto:

a) Tunísia e Egito: evolução rumo a uma democracia, mas lentamente; b) Líbano, territórios palestinos, Jordânia, Iraque, Kuwait, Emirados, Omã, Arábia Saudita, Sudão (Norte), Argélia e Marrocos: movimentos sem realizações imediatas; c) Síria, Iêmen e Líbia: movimentos violentos, reações conservadoras, intervenções estrangeiras (Líbia), verdadeiras guerras civis (ROCHE, 2012, p. 55).

Reconhecendo estas ressalvas e diferenças, o termo é utilizado nesta pesquisa entendose que ele se tornou rotineiramente difundido para denominar tais eventos que também sustentam traços comuns, apesar de suas peculiaridades. Desse modo, tais levantes podem ser

\footnotetext{
${ }^{167}$ Segundo Ferabolli (2012) a denominação "primavera" é historicamente derivada dos eventos ocorridos em 1968, chamados na ocasião de "Primavera de Praga". Naquele episódio, o primeiro secretário do partido comunista da antiga Tchecoslováquia promoveu reformas, apoiado por intelectuais e pelo povo, para descentralizar a economia e aumentar as liberdades individuais. $\mathrm{O}$ intuito era de desvincular o Estado do jugo soviético, porém, a euforia com as mudanças durou apenas alguns meses, quando então a invasão militar de forças do Pacto de Varsóvia restituiu a antiga ordem.
} 
estudados enquanto um conjunto, sem que revele algum problema de ordem analítica para os objetivos desta pesquisa, pelo contrário, uma vez que o intuito é justamente entender este despertar árabe como um processo transnacional.

Sem perder de vista as peculiaridades de cada país, dentre as principais características comuns da Primavera Árabe podem-se elencar: (a) existência de governos autocráticos; (b) existência de regimes fechados ou semi-fechados; (c) restrições democráticas crônicas; (d) altos índices de corrupção; (e) abusos nos serviços de segurança; (f) grau elevado de desigualdades sociais; (g) privatizações em benefícios de minorias (LYNCH, 2011). Para esta análise, não se tratará especificamente da particularidade de cada país com profundidade, tendo-se fincado a maior parte dos exemplos em países como Egito e Tunísia por conta do volume de material encontrado e do emblemático papel que tiveram estes dois regimes durante a Primavera Árabe. Além disso, o fenômeno resultou em diferentes desdobramentos:

Every unhappy country is unhappy in its own way, and so the stories of the Arab states' upheavals vary. Some leaders, such as King Abdullan in Jordan and Marocco's King Mohammed, proved agile enough to survive the initial surge of emotion in the region. In Tunisia and Egypt, the army made clear that it would not go to war against its fellow citizens. In Libya, however, chaos prevailed as events reflected the vicious lunacy of that country's leader, Muammar Qaddafi (SEIB, 2012, p. 5).

O início das mobilizações ocorre na Tunísia, com uma série de manifestações de rua contra o governo após um vendedor ambulante tocar fogo em si próprio (autoimolação de Mohamed Bouazizi) em protesto ao confisco de seus produtos. A partir daí, a mobilização cresce em escala: tanto em volume (de ocorrências e de manifestantes), quanto em área de abrangência, replicando-se em outros países como um efeito em cascata. Mason (2012, p. 25) relata a sequência dos levantes:

President Zine El Abidine Ben Ali fled Tunisia on 14 January 2011. By 11 February, Hosni Mubarak was gone, and protests were spreading across the region: to Yemen, where the first 'day of rage' took place on 27 January; to Bahrain, where protesters occupied the Pearl Roundabout on 14 February. Then, on 17 February, security forces started shooting marchers in Bahrain and the Libyan people rose up against Gaddafi. On 25 March the long, tortured battle for freedom in Syria began. 
A partir daí a questão da autoimolação do vendedor tunisiano já não era mais o foco e ficava claro que algo maior movia os levantes nos diversos países. A questão da identidade muçulmana e seu viés político estava no pano de fundo:

One of the issues at the heart of Muslims' dissatisfaction with their own state of affairs is the persistent lack of prosperity in predominantly Muslim countries. Government corruption and US and Western policies receive a large part of the blame, but Muslims increasingly cite the absence of democracy as a major factor 2006 and 2011, the percentage of respondents who said "lack of democracy" was responsible for Muslim states' lack of prosperity rose from 32 to 48 percent in Egypt, from 28 to 42 percent in Jordan, and from 35 to 49 percent in Indonesia (with smaller percentages in other Muslim nations (SEIB, 2012, p. 161-162).

Um outro elemento importante, também no pano de fundo desses eventos, é o papel da comunicação digital. As ações diretas como campanhas, greves, manifestações de rua foram permeadas pela apropriação de mídias sociais, a exemplo do Facebook, Twitter e YouTube. Como apontam Beckett e Charlie (2012):

Media, especially networked communications, were critical to making this happen. This is new. Levels of Internet penetration and mobile telephony in the Middle East have increased rapidly in the last few years. This has given people new tools for political expression and activism. What is significant is that these new tools are different because they are networkable (p. 137-138).

Se por um lado é possível afirmar que há algum consenso sobre o uso da comunicação digital como um elemento importante no desenrolar dos fatos (embora o grau de importância possa ser mais controverso entre autores), a efetividade dos levantes também é tema de debate. Para alguns analistas, no final das contas, houve mudanças e quedas de regimes em alguns países, mas em outros pouca coisa mudou de fato. Para Salem (2015):

[...] while social media has proven to be extremely effective in mobilising protesters, it has been less effective in grassroots organization [...] in the aftermath of the revolution, social media has proven ineffective in building organizations and institutions". Moreover, the nature of social media means that dramatic, sensational news travels faster than more mundane news. While the uprising itself was riveting and followed by millions across the globe, the aftermath and the struggles of rebuilding a new state have not been able to attract the same interest (p. 185).

Na avaliação de Seib (2012), embora tenha ocorrido a queda de regimes, seria exagerado denominar todo o processo da Primavera árabe como um evento no mesmo 
patamar que uma revolução pois, para ele, uma revolução requer uma substancial reestruturação institucional, não apenas mudanças de regime.

De um modo ou de outro, o fato de os países terem tido diferentes resultados políticos não diminui o importante papel das mídias digitais na Primavera Árabe (HOWARD; HUSSAIN, 2013). Até porque, a medição de uma efetividade depende de uma análise maior e a longo prazo, podendo ir para além do atual contexto pois os impactos políticos são complexos e podem ter desdobramentos históricos que ainda não somos capazes de captar totalmente. O que se pode afirmar é que a comunicação digital foi um elemento novo nos levantes e em seu processo de transnacionalização. Como isso ocorre, a partir da conjuntura de quais outras variáveis, em que grau e qual o seu real papel são questões ainda em debate.

\subsubsection{Estímulo à configuração da causa}

\section{a) Articulação}

A chave de ignição dos protestos se deu a partir da ocorrência de atos autoritários de repressão praticados pelos regimes, capturados e catalisados pela comunicação online, rompendo a barreira da visibilidade da mídia mainstream (que em alguns países estavam controladas pelo Estado) e se articulando na forma de um compartilhamento generalizado em redes pessoais online, alcançando o âmbito de discussões entre familiares, amigos e likeminded (HOWARD; HUSSAIN, 2013).

Na Tunísia, é o caso da imolação de Mohamed Bouazizi: um vendedor ambulante de frutas e legumes, de 26 anos, que em dezembro de 2010 teve seus produtos confiscados por autoridades governamentais da Tunísia por considerarem sua atividade ilegal. Após reivindicar a devolução de seus pertences na sede da administração regional e ver seu pedido negado, jogou líquido inflamável em seu próprio corpo e ateou fogo. Bouazizi foi socorrido e levado ao hospital, mas faleceu após pouco mais de 2 semanas, no dia 5 de janeiro de 2011, devido complicações dos ferimentos.

A narrativa da morte de Bouazizi na Tunísia revelava, na verdade, outras questões regionais para além do radicalismo islâmico: condições econômicas e sociais extremamente desiguais que vivem grande parte da população árabe (FERABOLLI, 2012). A reverberação da morte de Mohamed inclusive é tida como o estopim dos levantes: 
Bouazzi's death triggered the revolt in Tunisia, serving as a "last straw" for thousands of Tunisians who saw in his frustration a mirror-image of their own lives. Social media were the initial amplifiers of this frustration. Facebook became the town square a relatively protected zone where dissent could be expressed to a largely sympathetic audience without the same level of fear of the state security apparatus that might have muted protests in physical, rather than cyber, space (SEIB, 2012, p. 4).

A forte imagem da autoimolação de Bouazizi foi gravada em celulares por diversas testemunhas na rua e se difundiu via redes sociais online, impressionando os olhos principalmente dos tunisianos e do mundo islâmico. O compartilhamento viral ultrapassou fronteiras e atingiu não apenas a Tunísia mas também obteve grande audiência de outros países muçulmanos.

Como foi apontado, os citados países envolvidos possuíam dentre as principais características comuns a existência de Estados autocráticos de regimes fechados, restrições democráticas, altos índices de corrupção, abusos nos serviços de segurança e privatizações em benefícios de poucos, notadamente guiadas por princípios neoliberais (LYNCH, 2011). O descontentamento amplo, ainda que houvesse quem concordasse com o status quo, em combinação com um compartilhamento em tempo real dos acontecimentos para além de suas fronteiras possibilitou que os levantes da Primavera Árabe fossem resultados de um efeito cascata. Este efeito representa um amplo movimento de protesto que foi ao encontro de reformas econômicas e políticas, bastante sintetizada por liberais como sendo revoluções pela democracia que revelariam o despertar de um grupo de pessoas que tem sido esmagado por regimes despóticos durante décadas (LYNCH, 2011). Por isso a auto-imolação de Mohamed Bouazizi na Tunísia atiçou e unificou sentimentos de opressão e injustiça comuns em um ambiente similar de privações no qual vivem grande parte da população árabe (FERABOLLI, 2012; SEIB, 2012).

No one is quite certain about the route of the path to the tipping point. Bouazizi's suicide in itself was a sad act that might have attracted little notice had the reasons behind it not seemed so familiar to so many. Bouazizi was saying "Kifaya" (Enough) as had been said by so many others in the Arab states, and ignored by so many governments. But, finally, people took note. His voice, through his action, increased the volume of this cry to the point at which it could no longer be dismissed as inconsequential background noise. People listened and moved from a complaint, "Enough," to a demand, "The regime must go!" (SEIB, 2012, p. 164-165). 
A forte imagem de Bouzazizi e sua narrativa ganhou contornos políticos pan-islâmicos e desencandeou uma série de levantes começando pela Tunísia, contra regimes circulou amplamente no mundo árabe através de vídeos amadores gravados em celulares e espalhados em redes sociais online. Uma vez que as mídias sociais estavam além do controle do Estado (ou pelo menos com menor controle do que o espaço físico), pessoas conseguiram desenvolver estratégias para ação e delimitar o objetivo coletivo: depor o déspota (HOWARD; HUSSAIN, 2013).

The critics of Ben Ali, president of Tunísia, dominated virtual spaces, but after Bouazizi's death, these critics began occupying public spaces. Shamseddine Abidi, a 29-year-old interior designer, posted regular videos and updates to Facebook, and Al Jazeera used the content to carry news of events to the world. Images of Bouazizi, hospitalized with burns, passed along networks of family and friends, and eventually strangers. An aggressive internet campaign called on fellow citizens and unions to set up committees to support the uprising in Sidi Bouzid. Lawyers and student unions were among the first to move into the streets in an organized way (HOWARD; HUSSAIN, 2013, p. 19).

Toda esta articulação culminou com a queda do então presidente Ben Ali após duas décadas no poder. O efeito viral das imagens de Bouzazizi, seguido dos protestos de países vizinhos que também sofriam da mão de ferro dos regimes autocratas foram uma sequência de elementos catalisadores da articulação da causa e sua subsequente expansão para além das fronteiras, ainda que em cada país fizesse ao seu modo e com suas prioridades de reivindicações. A circulação de vídeos, a produção de relatos, a criação de perfis de protestos e páginas em redes sociais reforçou o sentimento de levante e a própria repressão se tornou também um elemento político importante, como combustão no processo, empurrando ainda mais a articulação dos levantes para as redes sociais online que possibilitavam recursos para fugir e denunciar os atos de opressão.

Um exemplo emblemático deste tipo de articulação online foi no caso egípcio da fan page "Somos Todos Khaled Said", no Facebook, criada pelo executivo da Google, Wael Ghonim, em 2010. Tratava-se de uma página de protesto pela morte de um jovem chamado Khaled Said. Ele foi retirado de um cibercafé e assassinado pelas autoridades egípcias (PAVLIK, 2011; HOWARD; HUSSAIN, 2013; SALEM, 2015). Na época, o crime alegado foi a recusa de mostrar o documento de identidade quando indagado por forças policiais, porém há indícios de que ele tenha veiculado um vídeo que mostrava policiais envolvidos na venda de drogas (SALEM, 2015). 
Figura 12 - Versão em inglês da página no Facebook We are all Khaled Said

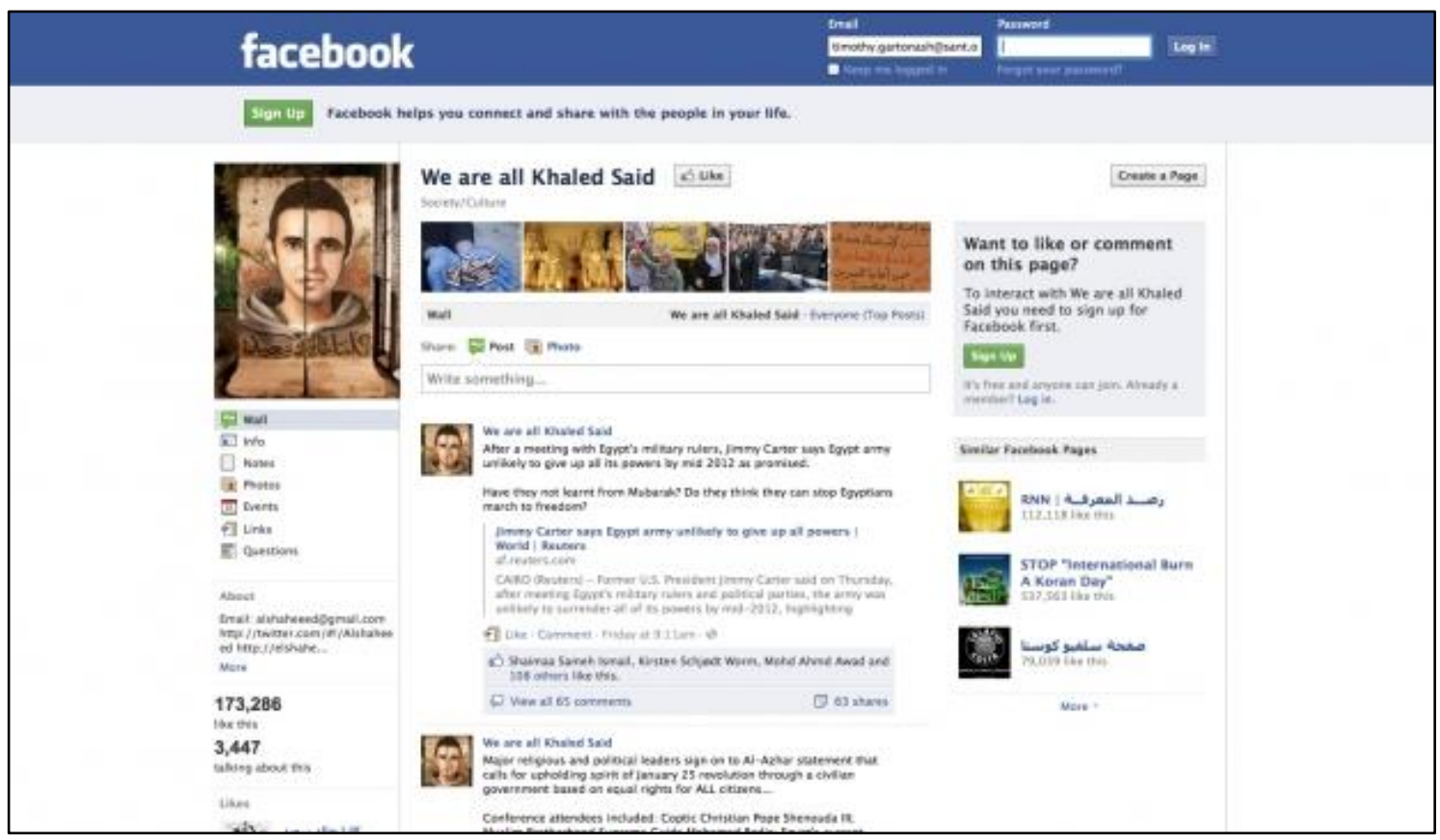

(Fonte: Facebook)

A página foi um recurso de crítica ao regime do Egito, que levou muitos egípcios a tomarem conhecimento dos abusos de Mubarak e a corrupção de seu governo, fomentando protestos e revoltas. A repercussão foi bem-sucedida, como afirma Pavlik (2011), dado que propagou as atrocidades vividas sob o regime autoritário no Egito. As imagens do rosto de Khaled ferido foram transmitidas de celular para celular até que milhares de pessoas tomaram conhecimento e começaram a desenvolver estratégias de protesto online, transformando o portal de memória de Said como um portal de sensibilização coletiva. Para diversos analistas o papel de aglutinação política de páginas como esta foram elementos que impulsionaram a articulação e fomento dos protestos em diversos países (CASTELLS, 2012; SEIB, 2012; SALEH, 2013)

O descontentamento de grande parte da população tunisiana frente ao regime ganhou adensamento e contaminou outros países, que também intensificaram suas manifestações públicas contrárias aos seus respectivos regimes autoritários. Este adensamento contou com a difusão de informações através de mensagens em aparelhos móveis e redes sociais, tais como Facebook, Twitter e Blog, os quais foram conduzidos por cidadãos comuns e articularam uma atmosfera para os levantes, gestada no ambiente digital (SEIB, 2012). 
Nesse contexto, protestar, difundir informações sobre os levantes, incitar as pessoas de seus círculos sociais a reclamarem do regime e contestar a ordem que estavam obrigados a seguir foram em grande medida impulsionados por redes de contato através do uso de plataforma online. É exatamente como explica Castells (2012) sobre a Primavera Árabe: a união possibilitada pela Internet fez superar o medo e alcançou o espaço público real. No Egito, inspirados pelo evento na Tunísia, um grupo de like-minded desempregados e fervorosos por mudança política encontraram solidariedade online e usaram seus celulares para chamar suas redes sociais para as ruas, exponenciando os protestos rapidamente (HOWARD; HUSSAIN, 2013).

Outro papel importante nesta articulação inicial da Primavera árabe é conferido aos vazamentos digitais de informações sigilosas e a sua difusão pelas redes digitais. Como foi o caso de informações vazadas pelo WikiLeaks sobre documentos diplomáticos. Telegramas do embaixador americano para a Tunísia revelavam a corrupção e relacionava metade dos membros da elite comercial do país ao então presidente Ben Ali, e isto ocorreu dias antes do início dos levantes (SEIB, 2012; KELLER, 2013; SALEH, 2013; SCHLOSBERG, 2013). Cidadãos e ativistas utilizaram a Internet para revelar as compras em Paris da primeira dama usando transporte aéreo privado do presidente (LYNCH, 2011).

A publicização desses fatos não trazia uma informação necessariamente nova para esses cidadãos que conheciam o modus operandi dos regimes autocratas. Porém, a recorrente visibilidade online $^{168}$ de escândalos de corrupção, ostententação com dinheiro público, pobreza no país e subserviência frente a potências estrangeiras, causava vergonha e estimulava a articulação de uma causa (SEIB, 2012; YORK, 2013). Julian Assange (figura central do WikiLeaks) disse em entrevista que a preocupação em fazer parcerias com jornais francófonos e árabes foi importante para a difusão dos vazamentos sobre os regimes corruptos naquela região (ASSANGE; ZIZEK, 2013b). O fato de as pessoas saberem que os EUA tinham conhecimento das atrocidades era um indício de que os EUA e outros Estados não deveriam apoiar o governo de Ben Ali, além de suscitar a animosidade do povo em larga escala (ASSANGE; ZIZEK, 2013b). Ademais, a convergência com o fato de Bouazizi e a cobertura da mídia foram elementos decisivos para o processo na opinião de Assange: "So, people becoming aware of what their beliefs are, what each other's beliefs are, is something that introduces that truly democratic shift" (ASSANGE; ZIZEK, 2013b, p. 268).

\footnotetext{
${ }^{168}$ Que também se espalhou para outras mídias tradicionais, como foi o caso do papel da TV Al Jazeera, como discutiremos mais a frente.
} 
Se para esses diversos analistas há uma inevitável importância da comunicação digital na articulação dos levantes, para Ferabolli (2012) o papel das redes sociais digitais foi supervalorizado: "O estopim da crise não teve nada a ver com o ativismo online de uma pequena parcela da juventude árabe com acesso a tais tecnologias, embora essas tenham servido como fonte de encorajamento e informação no decorrer dos processos" (FERABOLLI, 2012, p. 108). A autora está correta quando afirma que não foi o ativismo online o estopim do processo: o acúmulo de opressões sociais, políticas e econômicas que marcavam a história desses países, cada uma à sua maneira, são elementos que precedem a influência da comunicação online. Mas como a própria autora admite, é preciso reconhecer que a comunicação digital foi um elemento encorajador, um estímulo à articulação da causa. Analogicamente, ferramentas como redes sociais online funcionaram como um catalisador relevante nesses sentimentos acumulados propiciando assim a criação de uma oportunidade política para surgimento da causa e sua articulação.

\section{b) Difusão}

Como vimos, o uso das mídias sociais para difusão e tomada de consciência das atrocidades, corrupção, supressão de direitos que a população da região estava exposta foi determinante no processo da Primavera Árabe. O potencial de circular informação em nível nacional e transnacional diz respeito à propagação de informações e opiniões sobre os regimes fechados relacionando-os à corrupção e abusos de poder, que até então estavam escamoteados e abafados pelos regimes. Esta difusão de informações de abusos por parte dos regimes aglutinou o descontentamento, pois se antes já existia o desejo por mudança, não havia um enredo que conduzisse a isso (SULLIVAN, 2011).

Segundo Lynch (2011) a publicização dos levantes foi inovadora (uploading de vídeos através de câmeras de celulares para divulgação nas mídias sociais como o Facebook e Twitter), porém não introduziram nenhuma ideia particularmente nova. Isso porque, as críticas do status quo, o desejo por mudança política, a ânsia por liberdades democráticas, a identificação intensa de um mundo árabe já eram partilhados no mundo árabe há pelo menos dez anos e, em geral, os levantes clamaram por independência, soberania nacional, e respeito pelo desejo do povo. Ao mesmo tempo, outros autores defendem que a mídia social e as tecnologias móveis desempenharam um papel central na difusão dos levantes entre os 
cidadãos de todos estes países e da região (HOUNSHELL, 2011; PAVLIK, 2011; SULLIVAN, 2011; TUFEKCI e WILSON, 2012).

Figura 13 - Egipcios e o uso de telefones celulares nos levantes em 2011

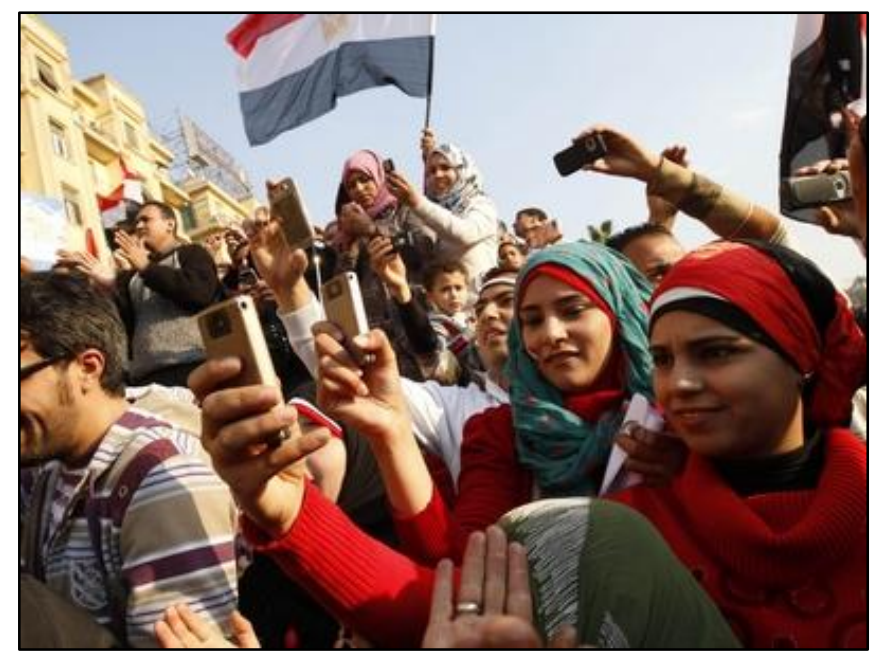

(Fonte: Mohammed Abed/AFP/Getty Images)

Howard e Hussain (2013) descrevem casos emblemáticos de viralização no Egito que impactaram a Primavera Árabe como um todo:

We found four major types of content that typified Egyptian viral vídeos: raw protest and mobilization footage; citizen commentary; political punditry; and "soundtracks for the revolution." Raw protest and mobilization footage the most common, totaling nearly 5.5 million views from 23 videos. One video featured a detailed 20-minute dialogue between a religious scholar and political philosopher about the future of Egypt, totaling 100,000 views. Another video featured a homemade video with a young girl's commentary about political events, totaling 275,000 views. But the most popular video, a music video, was heralded as a soundtrack to the revolution and served as a rallying cry of support for the Egyptian people's protests. This music video, uploaded on January 27, was the single most popular viral vídeo for the Egyptian revolution, and it accounted for 25 percent of the top-20 video views (HOWARD; HUSSAIN, 2013, p. 62).

Algumas pesquisas quantitativas realizadas com os manifestantes de diversos países durante os levantes registraram o uso de smartphone, Facebook e Twitter tanto como meios fundamentais de tomada de conhecimento dos protestos pela população em geral, sobretudo a mais jovem, quanto do compartilhamento dos abusos de poder dos governantes e dos problemas políticos e econômicos enfrentados (TUFEKCI e WILSON, 2012; HOUNSHELL, 2011). Nas palavras de Tufekci e Wilson (2012): "In the case of protests in Egypt, it appears 
that social networks, often mediated through the new online platforms in the emergent networked public sphere, played a crucial role" (p. 376).

Hounshell (2011) contextualiza o Twitter como uma ferramenta essencial, mas não a única, para acompanhar e entender as mudanças na região árabe. Ele exemplifica citando um pesquisador que trabalhou com quase 6 milhões de tweets em 7 países (Argélia, Bahrain, Egito, Líbia, Marrocos, Tunísia e Iêmen). A pesquisa mostra que o Twitter era uma plataforma para que pessoas externas discutissem as notícias, sejam estas sobre a resignação de Mubarak, seja sobre os discursos retóricos e insanos de Kadafi, ou para começar um grande protesto (HOUNSHELL, 2011). Uma característica interessante é que o Twitter era utilizado para divulgação externa, por isso mais comum no idioma inglês, enquanto o Facebook era basicamente utilizado na língua árabe pelos participantes diretos das manifestações que compartilhavam informações no círculo pessoal de contatos. Pesquisadores da Arab Social Report entrevistaram centenas de pessoas envolvidas nos protestos tanto na Tunísia, quanto no Egito, e o resultado mostrou que o Facebook foi pioneiro em tornar as pessoas conscientes sobre os movimentos civis em seu país e nos vizinhos, de modo que apenas $15 \%$ acreditava que a função principal do Facebook era entretenimento (HOWARD; HUSSAIN, 2013).

Embora as vozes de jornalistas eram importantes para relatar sobre o que estava ocorrendo em relação aos protestos, os ativistas tinham maior capacidade de registrar o acontecimento e contribuir na circulação do conteúdo através de tweets e re-tweets, blogs e posts no Facebook, inclusive as fontes dos tweets enviados em Janeiro de 2011 durante os protestos na Tunísia e no Egito foram provenientes de blogueiros, jornalistas e ativistas autodeclarados (SCHUMANN, 2015).

No caso da Síria, em que o controle das notícias era bastante restrito, o papel das mídias sociais foi essencial na divulgação. Seib (2012) explica que o conteúdo registrado por celulares usavam programas como Qik para enviar para fora do país e amigos pudessem fazer upload no YouTube. Em Junho de 2011 já contabilizavam mais de 250 vídeos no canal do YouTube chamado Freedom4566 e já tinha sido visto mais de 220 mil vezes (SEIB, 2012).

Na potencialização da divulgação e a fim de eliminar barreiras, as ferramentas online também fizeram adaptações para se adequar ao que ocorria junto aos dissidentes, como foi o caso do Youtube: "YouTube had to develop a special waiver to its usual policy of not publicizing culturally offensive gore to allow the shocking user content being submitted by usersin the field of action to go live" (HOWARD; HUSSAIN, 2013, p. 29). 
Segundo Seib (2012) "One lesson of 2011 is that the pace of events increases along with the rate of information flow" (SEIB, 2012, p. 157). De fato, a velocidade das informações foi potencializada pela capacidade viral ${ }^{169}$ que alguns eventos apresentaram. A replicabilidade de narrativas significa que diversas formas de testemunhos e depoimentos passam a ser compartilhadas de forma viral, criando assim uma narrativa que reforça a mobilização dos levantes em diferentes lugares. Para vislumbrar melhor este fenômeno, convém primeiramente compreender o sentido do termo "viral":

Para a biologia, um vírus é um microrganismo que se multiplica usando a célula do seu hospedeiro. Na computação, o vírus é um programa malicioso que vem dentro de outro programa, que faz cópias de si mesmo e tenta se espalhar pelos demais computadores. No cenário dos negócios, o marketing viral é a propaganda boca a boca. No mundo das redes, a idéia da comunicação viral passa pela formação de uma rede que utilize cada computador nela conectado como hospedeiro e reprodutor do fluxo de comunicação (SILVEIRA, 2007, p. 89).

Quando se fala especificamente em cultura ou sociabilidade, a repercussão viral de uma informação ocorre quando um conteúdo (seja na forma de texto, vídeo, foto, áudio etc.) é intensamente replicada e compartilhada através de e-mails, celulares mas principalmente através de redes sociais online como Facebook, Twitter e YouTube. Essa replicabilidade, pode prevalecer no âmbito dos usuários da rede de um mesmo país como pode, em diversos casos, também ultrapassar fronteiras. É o caso das narrativas online em torno dos levantes árabes que se espalharam por diversos países.

A capacidade de amplificar acontecimentos de forte sensibilização coletiva refere-se ao efeito de tornar um evento dramático ou trágico em um símbolo de mobilização política.

O cerceamento da comunicação digital também foi um elemento intensificador do protesto. A Internet no Egito era utilizada por dissidentes liberais, minorias, grupos religiosos e outros que se opunham ao regime de Mubarak. A esfera política online começou a emergir primeiro em formas de blogs e sites pessoais, e depois no Facebook, Youtube e Twitter. Enquanto a Internet ainda não tinha sido censurada, alguns blogueiros foram presos (TUFEKCI e WILSON, 2012). Nas palavras de Pavlik (2011):

Esta história de sinergia entre as mídias sociais e a transparência online na Primavera Árabe continuou na Síria, na Líbia e em outros lugares na região. No Egito, as autoridades tentaram acabar com os distúrbios ao cortar o

\footnotetext{
${ }^{169}$ Em cibercultura a repercussão viral de uma informação ocorre quando uma conteúdo (texto, vídeo, foto, áudio etc.) é intensamente replicada e compartilhada através de plataformas online, principalmente através de redes sociais online como Facebook, Twitter e YouTube.
} 
serviço da Internet. Ironicamente, esta ação poderá ter alimentado ainda mais a revolta, ao tornar os cidadãos mais raivosos (PAVLIK, 2011, p. 15).

O desligamento da Internet feito pelo regime egípcio provocou um efeito contrário ao previsto pela autoridade. Primeiro, porque um grupo pequeno, mas com alto conhecimento em tecnologia da informação, continuou a enviar informações e vídeos para o exterior sobre o que ocorria na Tahrir Square utilizando conexão de satélite e dial-up para Israel e Europa (TUFEKCI; WILSON, 2012; HOWARD; HUSSAIN, 2013). Segundo, o fato de as pessoas não terem mais o acesso à Internet, causou revoltas ou despertou maior interesse ao que estava ocorrendo em seu país, de modo que estimulou as pessoas a saírem às ruas, intensificando os protestos (PAVLIK, 2011). Ainda mais, representava, segundo um dos respondentes de Salem (2015) o quão opressivo o regime poderia ser, sendo uma grande força de enviar as pessoas às ruas. Mubarak desligou os celulares dia 27 de janeiro e dia 28 mais pessoas vieram às ruas (HOWARD; HUSSAIN, 2013).

O corte do fornecimento de serviços foi uma resposta avaliada também por outros governos, pois como Ramadan (2012) explica:

The initial response from all governments, from that of Ben Ali to that Bashar al-Assad was to accuse radical Islamists (a normal charge that was suppose to deceive the West) while simultaneously blocking internet access. In Egypt, the tatic backfired: with support from Google, bloggers were able to foil the government's attempts to silence them. Vodaphone, on the other hand, did not initially support the protesters, sending them messages urging them to go home. Syrian cyber-dissidents were less fortunate than the Egyptian counterparts. They got no help from Google and had to resort to sharing pictures taken by their mobile telephones (p. 47).

A ação desesperada de ditadores de desconectar as pessoas de suas redes de comunicação digital surtiu consequências econômicas. No Egito estima-se pelo menos 90 milhões de dólares de prejuízo, além de prejudicar a reputação do país em sua estabilidade para investimentos (HOWARD; HUSSAIN, 2013).

\section{c) Massificação}

As tecnologias de comunicação e informação também contribuem para a formação da opinião pública nacional e transnacional com efeitos na política interna, alimentada pela intensa troca de informações do cidadão em sinergia com o filtro e difusão da mídia 
tradicional. No contexto da Primavera Árabe, segundo dados de Ramadan (2012), apenas 4\% dos líbios tinham acesso à Internet, 36\% dentre os tunisianos, e no Egito apenas a classe média educada (cerca de $30 \%$ da população) é que detinha acesso à Internet e possivelmente às redes sociais. Nesse sentido, o papel da mídia tradicional ganha relevância e aglutina informações, expondo a população sob uma mesma cobertura midiática, principalmente a Al Jazeera no mundo árabe (SEIB, 2012). No caso da Tunísia, a televisão tinha penetração de cerca de 93\%, um índice de disseminação muito maior do que as mídias sociais (SEIB, 2012). E assim, a rede de televisão era capaz de se apropriar de conteúdo online e dispor para a população em geral, como no caso da repercussão do protesto de Bouazizi:

While Bouazizi was hospitalized with third-degree burns over 90 percent of his body, his mother, other family members, and friends went to the governor's office and threw coins at the fence surrounding it, yelling, "Here is your bribe." Bouazizi's cousin posted the video of the protest on YouTube, and soon Al Jazeera and other channels outside the control of the Tunisian government telecast it. Reports were also posted on Facebook and Twitter (SEIB, 2012, p. 17).

A Síria, que vivia ainda mais restrições da comunicação digital, teve ainda mais necessidade da cobertura da Al Jazeera, que reportava o que ocorria no Egito (SEIB, 2012). Howard e Hussain (2013) mostram que quando a Al Jazeera não cobriu o ativismo digital na Síria, líderes civis fizeram lobby de modo que a empresa produziu um documentário mostrando o conteúdo dos websites sírios, aumentando a partir disso o interesse pelo movimento de oposição na Síria, dentro e fora do país. Outra artimanha para que a Síria pudesse receber cobertura foi feita por protestantes que ao registrarem imagens transmitiam através de programas como mídias sociais Oik e enviavam para amigos sediados fora do país que pudessem fazer upload no YouTube. A partir daí os canais de TV puderam reportar tanto para os sírios, quanto para o exterior, os movimentos que lá ocorriam (SEIB, 2012).

Aliás, os canais de TV por satélite formavam uma nova esfera pública no mundo árabe, pois enquanto as mídias tradicionais serviam aos interesses das elites e eram controladas por regimes autoritários, a Al Jazeera engajava no que é chamado de "reverse agenda-setting', (RAMADAN, 2012; TUFEKCI; WILSON, 2012). Outra importante radiodifusora no mundo árabe foi a Al Arabiya, criada em 2003 por investidores sauditas, com postura mais conservativa, equilibrando o viés alternativo da Al Jazeera (SEIB, 2012). Canais privados também ofereciam cobertura, no caso mais restrita a realidades regionais, 
como são os casos da ON-TV e Dream-TV no Egito, que embora proibidas de reportar as notícias, podiam produzir programas de discussão trazendo entrevistas com participantes chaves na revolução (SEIB, 2012).

Hounshell (2011) explica que organizações de mídia como a $\mathrm{BBC}^{170}$ e a Al Jazeera serviram como filtro para verificação da autenticidade das fontes trazidas nas redes sociais. Para Ramadan (2012) especificamente a Al Jazeera teve um impacto crucial nos levantes da Tunísia e do Egito com cobertura das notícias através de jornalistas presentes no acontecimento, considerando a empresa de comunicação do Qatar mais bem organizada do que a CNN e a BBC. A Al Jazeera se tornou a fonte atualizada de outras organizações como New York Times, Huffington Post, Reuters, Wired (HOWARD; HUSSAIN, 2013).

Reaching more than 150 million households in more than 100 countries worldwide through television, AI Jazeera English's footprint also reaches the Arab digital diaspora, which was an essential ingredient for the digital activists both on the ground in places such as Tahrir Square and their counterparts mobilizing solidarity protests in Europe and North America (HOWARD; HUSSAIN, 2013, p. 99).

Para auxiliar este processo no que se refere à internacionalização, os egipcíos criaram uma corrente de serviços em inglês para atualizar as informações a partir de pessoas do próprio protesto (RAMADAN, 2012). A Al Jazeera estabeleceu uma estratégia bem sucedida durante os protestos: rápido relatório em tempo real e cobertura em profundidade. A recepção de vídeos e imagens era feita online, estimulando os participantes a submeterem o material (HOWARD; HUSSAIN, 2013).

Não é coincidência que justamente no Egito os serviços de transmissão da Al Jazeera foram banidos pelo Ministério das Informações no dia 30 de janeiro de 2011 sob a justificativa de ter cobertura enviesada (RAMADAN, 2012). Era explícito o apoio de alguns jornalistas da emissora aos movimentos contra as ditaduras, como foi o caso do Ayman Mohyeldin ${ }^{171}$. Os organizadores dos protestos transmitiam informações das manifestações, hora e local, para serem veiculados pela Al Jazeera (SEIB, 2012). Vários jornalistas e jornais

\footnotetext{
${ }^{170}$ A British Broadcasting Corporation (BBC) é uma rede britânica de rádio e televisão fundada em $1926 \mathrm{em}$ Londres. É considerada hoje uma das empresas de radiodifusão mais importantes e influentes do mundo, com escritórios e correspondentes espalhados pelos cinco continentes. A BBC não tem fins lucrativos: trata-se de uma empresa pública de comunicação, cujo financiamento vem em boa parte do imposto pago por cidadãos britânicos, além da arrecadação própria de produtos e serviços.

${ }^{171}$ Mohyeldin é um jornalista egípcio que foi repórter da TV Al Jazeera, em sua versão em inglês, atuando na cobertura dos levantes naquele país, incluindo as batalhas campais entre manifestantes e forças de repressão.
} 
do mundo questionaram a parcialidade da Al Jazeera dizendo que faltaria equilíbrio de informação. Na opinião de Ramadan (2012), a Al Jazeera foi um dos principais impulsionadores do despertar árabe e "Whether that of power, counter-power or of an alternative news source, each reflects a specific perception and/or ideology. Of all media that covered the Arab uprisings, al-Jazeera is no exception" (RAMADAN, 2012, p. 51).

O discurso da Al Jazeera na cobertura na Tunísia e no Egito era compartilhado na Casa Branca, que já enquadrava o debate de democratização do mundo árabe. A cobertura foi inclusive reconhecida pelo presidente Barack Obama e pela então Secretária de Estado Hillary Clinton como fonte de informações para acompanharem os acontecimentos correlatos (RAMDAN, 2012). A Al Jazeera ocupava um papel central e crítico transmitindo notícias em inglês 24 horas por dia: "Its two channels broadcast live from the streets, while other programmes covered internet and the social network activities. Time was allocated to individual eyewitness account of protest actions or of politic repression" (RAMADAN, 2012, p. 48).

Figura 14 - Imagem televisiva com cobertura ao vivo da Al Jazeera

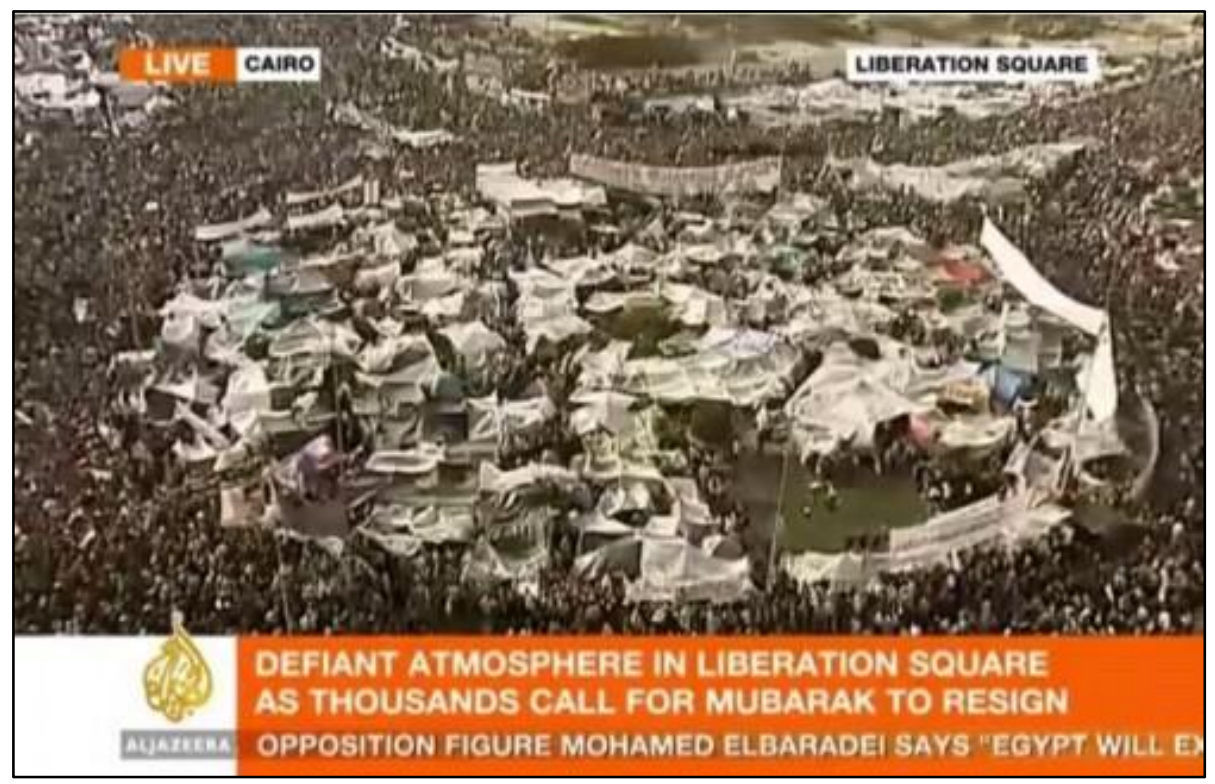

(Fonte: Al Jazeera)

A Al Jazeera em inglês amplificou as narrativas das mídias sociais internacionalmente. Foi um instrumento importante na medida em que, por ser independente, continuava a cobertura apesar do bloqueio das outras agências pelos governos, fornecendo conteúdo local proveniente das vozes dos próprios cidadãos. Além disso, não é apenas uma alternativa às 
fontes de notícias censuradas do governo, mas também às fontes ocidentais (HOWARD; HUSSAIN, 2013).

Para Castells (2012) a atuação da mídia tradicional - em sinergia com as redes digitais - também criou um manto de proteção junto à opinião pública internacional que inibiu, em alguns momentos, a radicalização da repressão estatal: "On the eve of major protests in Tahrir Square, one protestar noted, 'If Al Jazeera turns off its cameras tonight, there will be a massacre in Tahrir Square'" (HOWARD; HUSSAIN, 2013, p. 87). Para não ter acesso a informações externas, foi bastante comum dentre os regimes autoritários durante a Primavera Árabe o bloqueio de cidadãos de ler notícias internacionais, e ativistas de alcançar os jornalistas internacionais (HOWARD; HUSSAIN, 2013).

Castells (2012) explica que esse elo entre mídia tradicional e Internet foi essencial durante as semanas das revoltas, tanto na Tunísia quanto em todo o mundo árabe, onde "Al Jazeera went so far as to develop a communication program to allow mobile phones to connect directly to its satellite without requiring sophisticated equipment" (p. 27). Como salienta Pavlik (2011), as mídias noticiosas tradicionais funcionaram para colocar o fluxo dos acontecimentos trazido pelas mídias sociais num contexto e numa perspectiva mais amplos, fornecendo informações adicionais que não seria conseguida da maneira tradicional de captação de notícias. Mas como bem observam Tufekci e Wilson (2012) os novos sistemas de comunicação política não podem ser facilmente separados das categorias tradicionais de mídia. A Al Jazeera, por exemplo, integrou as mídias sociais online em suas práticas de coleta de fontes e cultivou jornalistas-cidadãos através da região, o que garantiu a cobertura da sucessão de eventos através de vídeos captados basicamente por smartphones (HOUNSHELL, 2011; TUFEKCI; WILSON, 2012). Assim, os canais de TV por satélite (a exemplo da Al Jazeera) em conjunto com as redes sociais online formaram uma nova esfera pública no mundo árabe, através de um dinâmico sistema de comunicação em rede.

No Egito, com a queda de Mubarak, 16 novos canais de TV surgiram, dentre eles a January 25 TV sediada em Cairo:

This channel offers shows such as Hashtag, which collects news from Facebook, Twitter, and YouTube to broadcast to the large audience that has television but not Internet at home. These channels reflect the new spirit of intellectual independence among journalists. One of $25 \mathrm{TV}$ 's reporters said of their programming, "We're broadcasting what Egyptians need to hear, not what the state wants us to say" (SEIB, 2012, p. 43-44). 
O jornal impresso e os rádios também tiveram um papel importante dentre os meios de comunicação. No Egito, por exemplo, a tiragem dos jornais era a maior no mundo árabe, com circulação diária de 4,3 milhões (SEIB, 2012). Mais especificamente o Al-Masry Al-Youm teve importância antes dos levantes, com a cobertura de corrupção do governo, e depois, com a sua versão online e em inglês, além de trazer informação para um nicho não introduzido nos meios eletrônicos de comunicação (SEIB, 2012). No caso dos programas de rádio, o público tinha oportunidade de participar dos debates, inclusive Seib (2012) narra um ativista que após ouvir denúncias de um ouvinte ao vivo, disse: "Listen to that. The revolution is already here" (SEIB, 2012, p. 52).

Por fim, é importante também mencionar a discussão relacionada ao ativismo digital quanto ao possível "modismo" que vem sofrendo. Muitos dos termos como "Twitter Revolution" ou "Facebook Revolution" são trazidos nas coberturas midiáticas ao falar sobre o acontecimento da Primavera Árabe. Em realidade, alguns autores, como é o caso do Hounshell (2011) citam "twitter revolution" ao mostrar como a ferramenta está transformando a forma do mundo ver o que acontece no oriente médio. Gladwell (2010) aproveita para criticar a ideia de "twitter revolution" ao mencionar o caso no Irã afirmando que as pessoas no ocidente não poderiam entender o que ocorria nas ruas do Irã apenas rolando o twitter de conteúdo em inglês sobre a eleição iraniana, já que as pessoas que estavam coordenando os protestos escreveriam em farsi. No caso da Primavera Árabe, o ativismo político organizado já estava iniciado antes e não era apenas um modismo, apenas aproveitou-se das plataformas digitais para anunciar e coordenar os protestos (TUFEKCI; WILSON, 2012).

\subsubsection{Multiplicação do engajamento}

\section{a) Coordenação}

Diferentemente dos dois outros estudos de caso (Al-Qaeda e WikiLeaks), a Primavera Árabe não ocorreu baseada em uma organização apenas (seja ela no formato próximo a uma organização, seja no formato de células terroristas). Trata-se de uma mobilização coletiva popular que, embora tenha um alto grau de espontaneidade, não ocorreu por acaso e teve seus estopins facilitados por lideranças que coordenaram iniciativas importantes através da comunicação digital. $\mathrm{O}$ meio propiciou que lideranças despontassem e ganhassem 
importância no desencandeamento e evolução dos protestos. Mas diferentemente do que ocorria nos modelos tradicionais de protestos pré-digitais, nestes casos, os levantes políticos não estavam centrados na figura tradicional de um líder. Na maior parte do tempo não havia tal figura central revolucionária, seja na forma de um líder de oposição, ou ainda uma figura carismática, ou organização central. Havia pessoas que representavam proeminente nós nas redes digitais, contribuindo para as mobilizações (HOWARD; HUSSAIN, 2013). Trata-se de um poder emanado da ação em rede (cyber power), onde tais engajados eram responsáveis menos por decidir ou influenciar o movimento ideologicamente, mas dar forma ao agir, conectando pessoas criando assim uma ação coletiva não hierarquizada mas de alto impacto.

Como explica Ramadan (2012), blogueiros e ciberdissidentes ${ }^{172}$ foram responsáveis por disseminar informações e criar um estado de consciência coletiva entre as pessoas perante às péssimas condições de submissão ao governo que viviam:

Both new and traditional means of communication, ranging from the internet and the social networks to mobile telephones, were instrumental in bringing people into the streets. With national televisional under the control of the dictatorships, the web made it possible to reach people much more rapidly, and to convey vast amounts of information (RAMADAN, 2012, p. 47).

Um exemplo bastante conhecido deste tipo de engajamento de liderança em rede é o caso do executivo da Google, Wael Ghonim, que criou a página "Somos Todos Khaled Said". "Ghonim fast became the country's most prominent Tweeter, linking a massive Egyptian social network writing in Arabic with networks of interested English-speaking observers overseas" (HOWARD; HUSSAIN, 2013, p. 21). O governo ainda tentou cercear a página quando ela já contava com mais de 300 mil apoiadores (HOWARD; HUSSAIN, 2013). A relevância da sua ação o levou à prisão, detido e encarcerado pelo regime egípcio por ter criado a página no Facebook. Além disso, "the traditional islamists, opposition parties, and union organizations were there, but liberal and civil society voices dominated the digital conversation about events and the public stages in squares around Cairo during the igniting phases" (HOWARD; HUSSAIN, 2013, p. 21).

No caso egípcio e também nos outros países afetados pelos levantes, havia "lideranças" no sentido de "coordenação", mas não preponderava um líder, ou o domínio de

\footnotetext{
${ }^{172}$ Alguns nomes como: "Slim Amamou blogged the revolution (and later took a post in the national unity government and the Arab World's first "Pirate Party"). Sami Ben Gharbia, a Tunisian exile, monitored online censorship attempts and advertised work-arounds. "EI Général," a middle-class Tunisian rapper, streamed digital "soudtracks for the revolution". (HOWARD; HUSSAIN, 2013, p. 20)
} 
partidos políticos, ideologias políticas ou fervor religioso. E, embora a permeabilidade da Internet seja entre 10 a $20 \%$ da população dos países da região, aqueles que estão conectados são pessoas que iniciaram, coordenaram e sustentaram os levantes civis (HOWARD; HUSSAIN, 2013). A liderança era distribuída entre os organizadores dos protestos, cujos centros eram elites públicas como letrados, classe média, jovens, mulheres e tecnocratas (HOWARD; HUSSAIN, 2013).

Segundo Seib (2012), os protestos egípcios, ao contrário do que ocorreu na Tunísia, foram menos espontâneos e surgiram a partir de uma base política crítica pré-existente. Diversas ações de drible dos manifestantes confundindo as tropas de repressão no Egito foram orquestradas online e bem organizadas por grupos previamente articulados há pelo menos três anos:

Mubarak had held power for almost 30 years, and Egypt's riot, police were
adept at choking off demonstrations, using sheer numbers and escalating
force to contain protests. In 2011 , however, buoyed up by events in Tunisia,
antigovernment activists employed sophisticated feints and other deception
to evade security forces. Organizers publicly called for marches on January
25 , the "Day of Rage," at 20 sites, but secretly organized another protest at a
place only they knew about. Police showed up en masse at the 20 announced
sites, but at the twenty-first site-a small plaza in front of a candy shop in
Cairo's Bulaq al-Dakrour slum-no police were on hand. From there,
marchers made their way to Tahrir Square (SEIB, 2012, p. 33).

Organizações e movimentos tradicionais pré-existentes encontraram uma oportunidade para ação e também se engajaram online e atuaram online em prol dos levantes. Um exemplo é a Muslim Brotherhood (Irmandade Muçumana), um dos maiores oponentes do regime de Mubarak. Seu website oficial teve um papel importante durante os levantes, duplicando a produção de conteúdo online, com adaptações na versão em inglês comparada com a árabe (HOWARD; HUSSAIN, 2013). E assim, outros atores também exerceram esse engajamento de coordenação:

But the early months of the Arab Spring were not about traditional political actors such as unions, political parties, or radical fundamentalists. These protests drew out networks of people, many of whom had not been as successful at political organization before: young entrepreneurs, government workers, women's groups, and the urban middle class. (HOWARD; HUSSAIN, 2013, p. 3).

Os grupos que iniciaram os protestos tinham pouca experiência com deliberação pública, eleições e protestos. Porém os ativistas foram politicamente disciplinados, objetivos e 
colaborativos (HOWARD; HUSSAIN, 2013).

Figura 15 - Tela com imagem de vídeo da vlogueira Asmaa Mahfouz

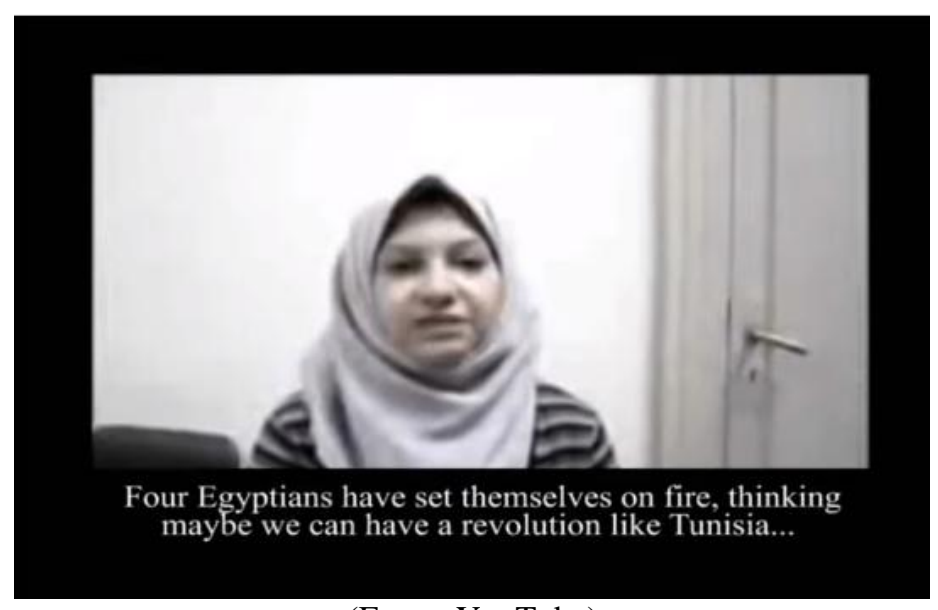

(Fonte: YouTube)

Por fim, um outro exemplo de engajamento online no nível da coordenação ativista que também merece ser destacado é o caso da blogueira Asmaa Mahfouz. Ela foi uma das responsáveis pelo agendamento e difusão dos protestos no Egito. Fazia suas intervenções através de um vídeoblog no YouTube, mencionando a situação crítica do país e conclamando os cidadãos egípcios a fazerem juntos uma revolução como aquela que estava então ocorrendo na Tunísia (MASON, 2012).

\section{b) Adesão}

Como já discutido, a adesão se refere à capacidade do movimento em arregimentar apoio e formar redes de colaboradores que operam coletivamente, a partir da lógica e dos recursos propiciados pela comunicação digital. No caso da Primavera árabe, isso se deu na forma de uma grande mobilização social, que foi capaz de arregimentar o apoio de um grande quantitativo de pessoas em prol de uma causa.

Isso ocorreu tanto do ponto de vista do apoio simbólico, através de manifestação online, quanto no apoio a atividades nas ruas onde a comunicação entre os manifestantes influencia na tomada de decisão e na tática de ação. Duas faces de uma mesma moeda que se retro-alimentava. As comunicações móveis, desde um simples celular até um smartphone 
conectado à Internet, enraizou massivamente a capacidade de coordenar, organizar e romper em velocidade e em números a potencialidade de uma mobilização, possibilitando o que pode ser descrito por Hands (2011) como "mobil(e)isation".

Para Lynch (2011) o espalhar das revoluções contra os regimes mostra a unidade árabe numa unificada narrativa de mudança, numa região que é conhecida por sua fragmentação ideológica. Ao se mostrar na Tunísia que um tirano poderia ser derrubado, tal acontecimento tem o poder emblemático de influenciar os demais a acreditarem que era possível superar o medo e sair nas ruas, mesmo com a ameaça de serem presos, torturados e mortos (LYNCH, 2011). Estes atos de sair às ruas, difundir informações sobre os levantes, incitar as pessoas de seus círculos sociais a reclamarem do regime e contestarem a ordem que estavam obrigados a seguir foram em grande medida impulsionados por redes de contato através do uso de plataformas online.

Pavlik (2011), por sua vez, aponta a influência das tecnologias digitais e móveis na democracia a partir do aumento das discussões e participações públicas na política. Isto leva a acreditar que se terá não apenas cidadãos mais bem informados, mas também mais participativos na arena política. Para Hounshell (2011) o fato de um analista tuitar sobre o que estaria ocorrendo nas revoluções árabes, não o tornaria um revolucionário.

O autor Gladwell (2010) defende que a tecnologia digital (mídias sociais) não está trazendo mudança significativa, e nem positiva, para a democracia. Ele reduz o campo de ação efetivo da comunicação digital para coleta de assinaturas para abaixo-assinados e doações para entidades de caridade. Como explica Pavlik (2011) a respeito do referido autor: "Embora estas mudanças possam valer a pena, na opinião de Gladwell, não são substanciais, nem estão tornando o mundo diferente qualitativamente do que era antes no sentido político ou social" (p. 111). Na concepção de Gladwell (2010) o ativismo que ocorre através de plataformas de mídia social não se parece com o ativismo offline, pois seria marcado por laços fracos, ausentes de disciplina e estratégia, e ainda que haja maior participação, a motivação é menor, de modo a não trazer grandes mudanças políticas e econômicas. Nas palavras dele:

Twitter is a way of following (or being followed by) people you may never have met. Facebook is a tool for efficiently managing your acquaintances, for keeping up with the people you would not otherwise be able to stay in touch with. That's why you can have a thousand "friends" on Facebook, as you never could in real life ( $\mathrm{s} / \mathrm{p})$. 
Ao contrário do que Gladwell (2010) sugere diversos autores, como veremos, defendem que há sim força nestes laços criados na Internet. As redes sociais atuam como importante fonte de informação e novas ideias, de modo que exploram o poder desses tipos de conexões com extrema eficiência. Pavlik (2011), por exemplo, explica:

Com um bilhão de pessoas usando as mídias sociais e uma estimativa de cinco bilhões de telefones celulares em uso no mundo inteiro [dados de 2011 do Banco Mundial] o potencial impacto cumulativo das mídias móveis noticiosas e sociais na democracia é profundo. As provas sugerem que esta tão espalhada tecnologia digital poderia promover não apenas $o$ desenvolvimento econômico, mas também a participação política onde outra infraestrutura fica limitada (p. 111).

Tendo em vista o processo de mobilização utilizado pelo movimento na referida região árabe, que se refere à capacidade de arregimentar simpatizantes, ativistas ou apoiadores através dos usos das mídias sociais, observa-se que não se trata apenas do ato comunicacional em si, mas de mecanismos que utilizam a plataforma digital para a criação de uma mobilização online, a qual por sua vez difere de uma mobilização offline, ainda que possam se sobrepor uma a outra.

Tufekci e Wilson (2012) reconhecem que de fato alguns autores reduzem os limites do ativismo online a desengajados, ou um tipo de engajamento simples, sem nenhum comprometimento. Mas em contextos autoritários, o ativismo digital não é sem custo e muito menos sem potencial político, já que o risco de sofrerem torturas, punições e censuras é preponderantemente maior. Nas palavras dos autores:

The results of this study illustrate how elements of this system contributed to lowering the costs of initiating and coordinating collective action to topple a longstanding authoritarian regime. And perhaps most importantly, they illustrate a monumental shift in the ability of everyday citizens in repressive societies to document and express their desires for social change (TUFEKCI; WILSON, 2012, p. 377).

Paralelamente, o Facebook, o YouTube e o Twitter, além da mídia móvel (celulares), desempenharam papéis vitais que reforçaram esta replicabilidade narrativa, sobretudo formando redes de difusores independentes de narrativas engajadas em prol da causa, principalmente na forma do chamado "jornalismo-cidadão". 
Esse termo compõe parte essencial do novo ecossistema das notícias, pelo fato das informações trazidas em tais plataformas digitais pelos cidadãos comuns serem consideradas fontes para o jornalismo realizado pela mídia tradicional. Ainda que esses cidadãos possam ou não ter histórico em ativismo, surgem num momento crucial para emitir informação crítica para o público (HOUNSHELL, 2011; TUFEKCI e WILSON, 2012). Pavlik (2011) revela que o grande número de jornalistas-cidadãos que colhem e distribuem notícias com seus dispositivos móveis e outras mídias digitais capacitadas pela Internet frequentemente supera, pelo menos em número, a força de trabalho das mídias noticiosas tradicionais. No Egito, por exemplo, estima-se que dezenas, se não centenas de milhares de protestantes estavam agindo como jornalistas-cidadãos durante as manifestações (TUFEKCI e WILSON, 2012).

De fato, a oportunidade de registrar os acontecimentos diretamente pelos participantes foi ampliada também pela facilidade trazida pelas ferramentas disponíveis, como celulares, conexão à Internet, e reconhecimento da grande mídia do material produzido nas ruas: "The use of mobile telephones and the rapid dissemination of photographs and videos had an even broader impact. As millions now use mobile telephones, hundreds of thousands contributed to the coverege of events as they unfolded" (RAMADAN, 2012, p. 47). Um caso emblemático inicial trazido por um jornalista-cidadão é o video egípcio de 25 de janeiro de 2011 cobrindo os milhares de protestantes na Tahrir Square, totalizando na época mais de 600 mil visualizações (HOWARD; HUSSAIN, 2013).

O entendimento da atuação dos jornalistas-cidadãos atravessa outro debate, que é o papel político que tais cidadãos desempenham durante este processo. Alguns os chamam de revolucionários, outros de ativistas, outros simplesmente de mobilizadores sociais que estariam inflamados pelo contexto regional de protestos e levantes. Tal como Ramadan (2012) adverte, deve-se ter cuidado para falar do impacto da Internet nas mobilizações de massa. Isto porque, segundo o autor, uma juventude de estudantes, ativistas políticos e graduados desempregados criam uma rede de conexão online, mas que só se confirmou nos protestos nas ruas na medida em que o sentimento de oposição aos regimes vigentes foi geral, mais do que representava uma uniformidade política ou determinada pelos novos desenhos tecnológicos. Apenas um terço dos egípcios é que tinham acesso a Internet em casa (TUFEKCI; WILSON, 2011), e um terço dentre os 10 milhões de tunisianos usavam a Internet, dentre eles 2 milhões eram usuários do Facebook (SEIB, 2012). A população jovem estar à frente do movimento não pode ser um dado surpresa, na medida em que como Seib (2012) esclarece, aproximadamente um terço da população árabe possui entre 15 e 29 anos, 
com alto índice de desemprego. Outros dados revelam que cerca de $40 \%$ da população da Tunísia e Yemen deseja emigrar (SEIB, 2012).

Segundo Howard e Hussain (2013) defender que o uso da mídia digital conformou o evento e seus resultados não diminui a importância de outros fatores como declínio da produtividade econômica, aumento da concentração de riquezas, alto desemprego e baixa qualidade de vida. Em realidade, estas insatisfações já existiam há anos, mas não foram suficientes para desencadear o processo. Nas palavras dos autores:

Indeed, social discontent is not just a list of grievances. Collective grievances gestate, and people have to come to agreement on what those grievances are. In the last few years, this gestation process occurred online, particularly in Tunisia, Egypt, and Bahrain. Social discontent took on an organizational form and was ultimately translated online into actionable strategies and achievable goals. In the last few months, this translation process has occurred over mobile phones and social-networking applications, even in countries that are usually very good at co-opting or suppressing opposition, such as Syria, Yemen, and Saudi Arabia (HOWARD; HUSSAIN, 2013, p. 25).

A Internet assim teve um papel fundamental em trazer dissidentes individuais e isolados para uma consciência coletiva, sendo então a mídia digital um dos fatores causais consistentes, junto com o fortalecimento dos movimentos de oposição (HOWARD; HUSSAIN, 2013). Portanto, não significa que egípcios e tunisianos decidiram conduzir protestos e se voltaram para as mídias digitais por questão de logística, mas:

Digital media became a proximate cause of political revolution precisely because a significant community of users was already comfortable using digital media before the crisis began. It may seem that digital media use in times of political crisis is new. But for the residents of Tunis, Cairo, and other capitals, it is the everydayness of mobile phones that makes the technology a proximate cause of revolution (HOWARD; HUSSAIN, 2013, p. 27).

Um fator interessante trazido no engajamento de adesão durante a Primavera Árabe trata da maior inserção das mulheres nas discussões online e consequentemente, no engajamento político. Isto se deve, segundo Howard e Hussain (2013), ao maior conhecimento que a Internet trouxe a respeito das discussões do status da mulher e de gênero em outros países, e ao espaço digital de apoio aos debates sobre mulheres e política, distante da repressões dos líderes patriarcais e dos olhares dos jornalistas. 
Na Arábia Saudita, os movimentos tiveram menor impacto, sobretudo devido ao intenso controle físico (há câmeras em cibercafés) e também online (além da censura, há controle de registro dos blogueiros e proprietários de websites através de licenças e cobrança de multas estratosféricas) (SEIB, 2012). Ainda assim, quando houve a prisão de Sharif em junho de 2011, mulher autuada por dirigir, cerca de 30 mil comentários de apoio foram registrados no Twitter (SEIB, 2012).

Por outro lado, o uso de câmeras de celulares durante as manifestações de rua também ajudaram a proteger os engajados da repressão do aparato policial, principalmente gravando e divulgando atos de violência das autoridades. Aquilo que vem sendo chamado de sousveillance (BAKIR, 2010), isto é, a prática da vigilância invertida: quando um ativistas passa a vigiar os atos de violência praticada por forças policiais através das câmeras de aparelhos móveis passando a compartilhar isso em redes sociais online, gerando assim uma pressão da opinião pública sobre o fato e servindo também como um mecanismo de proteção dos manifestantes uma vez que pode causar constrangimento públicos com repercussões políticas aos agressores. O uso constante dos aparelhos móveis para registrar os protestos, englobando as ações dos rebeldes e das tropas na praça Tahrir, foram responsáveis por evitar maiores usos da violência pelo governo, uma vez que o abuso seria registrado e ganharia visibilidade pública (HOWARD; HUSSAIN, 2013). Isto garantia maior margem de manobra e segurança para a organização dos levantes.

\section{c) Colaboração}

Diferentes grupos e organizações simpáticas à causa reivindicada pelos levantes da Primavera Árabe foram também sensibilizados e impelidos a colaborar. Hackers, empresas internacionais, organizações ativistas e até países contribuíram. Como aponta Seib (2012) a própria repressão governamental aos protestos reforçou estas redes de colaboradores que tentaram agir para manter o fluxo de informação online ativo:

With varied degrees of success, Iran, Egypt, Syria, and other countries choked off Internet access within their countries. Efforts to avoid such censorship have spawned a mini-industry that builds ways to evade governments' electronic blockades. Funding for these projects may come from NGOs and from governments that want to keep information flowing. Design of these measures is in the hands of techies who may work for 
intelligence agencies or on their own. The reasons of those who do this work may be idealistic, but particularly in the cases of government-backed innovation, diplomatic and security interests are usually at the heart of the ventures (SEIB, 2012, p. 98-99).

No início dos levantes na Tunísia, comunidades hackers externas ao país, como Anonymous e Telecomix, auxiliaram os ativistas a brecar as operações do governo com o que foi chamado de "Operação Tunísia", utilizaram ataques de denial-of-service e construíram softwares para auxiliá-los acerca do "state firewalls" (HOWARD; HUSSAIN, 2013). O grupo Anonymous forneceu apoio tecnológico para cidadãos na Tunísia, Egito e Líbia (COLEMAN, 2013).

O uso das redes sociais para ativar outros grupos além das fronteiras também foi bastante importante: "Prominent human rights blogger Mahmood al-Yousif tweeted during his arrest, instantly linking up the existing networks of local democratization activists such as @OnlineBahrain with international observers through @BahrainRights" (HOWARD; HUSSAIN, 2013, p. 23). Outro exemplo trazido pelos mesmos autores:

Digital media allowed local citizens access to international broadcast networks, networks that were then used by online civil society organizations to lobby advocacy campaigns regionally by Arab and Western support groups like AccessNow and the Electronic Frontier Foundation in securing information infrastructure and combating regimes' attempts at committing overt violence and censoring coverage of human rights atrocities (HOWARD; HUSSAIN, 2013, p. 119).

Outras formas de apoio aos movimentos são envio de telefones por satélites e chips de telefone para ajudar a evitar a vigilância dos regimes (SEIB, 2012). Mais concretamente, a "Alliance of Youth Movements" desenvolveu um guia voltado ao público externo simpático à causa para colaborar com a conexão dos egípcios:

There were guides to launching a local Facebook protest and sharing images, helping Egyptians dial up through Telecomix, redirecting Egyptian hamradio signals to Twitter, running relays to increase activists' anonymity, or petitioning Vodafone to reopen their mobile networks in Egypt (HOWARD; HUSSAIN, 2013, p. 27).

O Google atuou de maneira significativa, interferindo no desenho da ferramenta, para que esta servisse aos propósitos dos movimentos e facilitasse o acesso ao público que sofre de cerceamento de liberdade de expressão por conta do regime político em que vive. É o caso do lançamento do Speak2Tweet, um aplicativo que conseguia driblar a tentativa de Mubarak de 
bloquear o uso do Twitter ao decodificar mensagens de telefones em mensagens de texto (HOWARD; HUSSAIN, 2013). Outro avanço do Google foi assinar a Global Network Initiative, que previne censuras na Internet de governos autoritários. Quando a Internet foi bloqueada pelo governo no Egito, Mubarak também revogou as licenças de satélite de radiodifusão, em resposta o Google passou a disponibilizar a programação da Al Jazeera via streaming pelo YouTube (HOWARD; HUSSAIN, 2013).

Outras empresas de tecnologia desenvolveram portais para que os usuários pudessem compartilhar conteúdo. Porém, muitas vezes o regulamento da empresa é muito restrito e não compreende as nuances de um jogo político, como é o caso do Facebook, que não permite diferentes níveis de anonimato, importante elemento para ativistas em países ditatoriais (HOWARD; HUSSAIN, 2013).

Até mesmo países engajaram-se nesta rede de colaboração. O Qatar, por exemplo, foi um ator importante de apoio ao movimento na Líbia, como descreve Seib (2012), ainda que não engajasse em reformas dentro do próprio país:

In 2011, Qatar became a principal backer of anti-Qaddafi rebels in Libya, providing financial, humanitarian, and military aid. [...] Qatar also offered to buy and export oil produced in rebel-held Libyan territory, providing a revenue stream for the insurgents. In the longer term, Qatar expected to play a significant role in managing Libya's oil and gas concessions if the rebels prevailed. The Emir was also winning the gratitude of the NATO nations involved in the military campaign against Qaddafi, and was building his credentials as an Arab Spring supporter without engaging in reforms at home (SEIB, 2012, p. 117).

As fortes imagens de repressão e de multidões nas ruas clamando por justiça e melhores condições de vida e reformas políticas (algumas delas com viés democrático) são elementos importantes na formação na diversidade da rede de colaboradores que emergiu durante a Primavera Árabe. A ajuda na manutenção dos fluxos digitais, devido à ameaça de bloqueios dos governos atingidos pelos levantes, foi um dos principais focos dessas redes de colaboração.

\subsubsection{Flexibilização da estrutura}

\section{a) Virtualização}

A organização dos levantes, como vimos, se deu através da comunicação digital, onde 
blogs, microblogs, fan-pages e outras páginas serviram como o locus principal da estruturação do movimento. A Internet privilegiou a sociedade civil árabe sob dois aspectos: o primeiro é de que outras formas de comunicação eram inacessíveis, já que os meios de comunicação tradicionais estavam sob controle do Estado $^{173}$. O segundo trata da facilidade da Internet em permitir troca de conteúdo para além do controle de Estado e facilitar o anonimato (HOWARD; HUSSAIN, 2013).

Paradoxalmente, os países afetados pelo levante não sustentavam altos índices de acesso a Internet, nem mesmo possuíam uma cultura digital amplamente difundida ou enraizada. A penetração deste meio varia substancialmente de país para país no Oriente Médio. Conforme dados trazidos por Seib (2012) contabilizados em meados de 2011 pela Internet World Stats, o cenário era o seguinte: Iraque, Líbia e Yemen possuíam menos de 10\% de usuários de internet; Qatar e Emirados Árabes com cerca de 65\%; Tunísia 43\%, Egito 25\%; Síria $20 \%$ e Líbia 5\%. Em comparação com televisão e celular - mídias mais massificadas na realidade de boa parte da população da região - o acesso a Internet sustentava índices considerados baixo ${ }^{174}$. Mas mesmo com os baixos índices de inclusão digital, o efeito de mobilização se espalhou pelas redes sociais online (no universo daqueles que tinham acesso) e contaminou as redes sociais offline (grupos de amigos, parentes, mesquitas etc.). Dentre as mídias sociais, o Facebook apresentou-se como uma ferramenta recorrente, sobretudo por conta de suas versões em árabe e francês (SEIB, 2012). Naturalmente, o Facebook se tornou um dos principais locus de organização e de informação política (HOWARD; HUSSAIN, 2013), chegando a contabilizar um crescimento de 30\% de usuários na região entre janeiro e abril de 2011. Já o número de usuários do Twitter é mais baixo, porém bastante ativo no período auge das manifestações apresentação as seguintes mais populares hashtags no primeiro trimestre de 2011: "\#egypt (with 1.4 million mentions in the Tweets generated during this period) \#jan25 (1.2 million mentions), \# libya (990,000 mentions), and \#bahrain (640,000 mentions)" (SEIB, 2012, p. 49).

A percepção do meio online como um elemento estruturante dos levantes foi

\footnotetext{
${ }^{173}$ Principalmente aqueles sediados nos países, o que não se aplica a veículos estrangeiros que faziam a cobertura dos eventos.

${ }^{174}$ A título de parâmetro comparativo países em desenvolvimento figuravam em 2010 com um número de usuários geralmente abaixo da linha 50\% de usuários de internet. Por exemplo, o Brasil possuía 40,65\% no mesmo ano; Argentina 45\%; México 31,5\%; África do Sul 24\%; Índia 7,5\%. Já os países desenvolvidos atingiam sifras acima da linha dos $70 \%$, sendo os países nórdicos aqueles com maior penetração: Noruega, 93,39\%; Dinamarca 88,72 \%; Reino Unido 85\%; Canadá 80,3\%; Japão 78,21\%; França 77,28\%; Estados Unidos 71,69\%. Conforme dados copilados pela União Internacional de Telecomunicações (ITU), disponível em < http://www.itu.int/en/ITU-D/Statistics/Pages/stat/default.aspx >. Acesso em: 10 jan. 2016.
} 
percebido pelos governos afetados. Logo lançaram planos de conter esta ferramenta. Segundo os autores Howard e Hussain (2013), a melhor evidência de que a mídia digital foi um importante elemento estruturante na Primavera Árabe é de que os líderes autoritários a trataram como tal. Tanto os governos do Egito quanto da Tunísia tentaram controlar as redes de informação digital que os ativistas faziam uso, porém não foram bem-sucedidos em administrar as informações sensíveis. Já os governos do Bahrain e da Líbia conseguiram efetivamente controlar as mídias digitais (HOWARD; HUSSAIN, 2013).

Além dos governos monitorarem as redes sociais para identificar aqueles envolvidos nos protestos, muitas vezes também roubavam as senhas dos cidadãos de emails e blogs para remover conteúdo, como o que ocorreu com a jornalista e blogueira Sofiene Chourabi (HOWARD; HUSSAIN, 2013). Sob o argumento de causar danos através das redes de telecomunicações ao postar conteúdo online de imagens sem permissão oficial daqueles que foram registrados, tunisianos foram multados e presos (HOWARD; HUSSAIN, 2013).

Ao perceberem que os celulares também estavam amplamente sendo usados, o regime egípcio ordenou que o principal serviço de telefone, Vodafone, enviasse mensagens governamentais a seus clientes, seja passando informações sobre movimentos pró-governo, outras eram em tom de movimentar a opinião pública como: "Youth of Egypt, beware o rumors and listen to the sound of reason," and another called on "Egypt' honest and loyal men to confront the traitors and criminals" (SEIB, 2012, p. 51). Estas repressões ficaram conhecidas como "Repressão 2.0" (SEIB, 2012).

Mais severa foi a atitude de Mubarak de desligar o funcionamento da Internet em 28 de Janeiro de 2011:

State-owned Telecom Egypt, which owns almost all the fiber-optic cables of
the country, made the shutdown easier for the government. Because so many
of Egypt's internal networks rely on systems outside the country -such as the
e-mail servers run by Google, Microsoft, and Yahoo- the country's domestic
Internet was also crippled by the cut off (SEIB, 2012, p. 51-52).

O blackout que durou 5 dias interrompeu operações de negócios no Egito causando grandes danos financeiros, ao mesmo tempo que teve pouco impacto nos levantes, porém foi um lembrete que regimes autoritários podem suprimir a conexão da Internet quando desejarem (SEIB, 2012). Este é um exemplo do impacto que as mídias digitais estavam apresentando ao governo egípcio, sendo possível estabelecer um paralelo do locus digital com a praça pública, mostrando a tomada do controle do Estado em suspender as relações como ocorre no domínio físico. 


\section{b) Descentralização}

O papel da comunicação digital nos levantes árabes foi determinante para refletir e moldar a estrutura da organização política do movimento. Beckett e Ball (2012) explicam que a contribuição não foi apenas instrumental, na medida em que a conectividade não foi liderada por organizações convencionais, conforme trazido no indicador "coordenação", como partidos de oposição ou líderes carismáticos, nem conectado por um evento maior como o que ocorreu no Irã durante as eleições, ou um conflito externo, ou ainda fruto de um golpe militar interno:

They arose incrementally and were then accelerated by a few highly symbolic individual acts combined with multiple collective connections. Some of those actions involved great heroism and suffering, even death. Generally, the initial response to them was networked and diffuse, and directed to nominal goals such as a demonstration. The organizing principle would be a date or a rallying cry honouring an individual, rather than a political slogan: 'We are all Khaled Said.'This relatively amorphous organization was connected around nodal figures that all tended to resist conventional leadership roles. The momentum was begun with plural, marginal actions such as a few silent protesters filmed for a YouTube video on a railway line with their hands on their mouths (BECKETT; BALL, 2012, p. 138).

Por isso o método de luta é apenas um dos impactos trazidos pela tecnologia em rede. $\mathrm{Na}$ ideia do indivíduo conectado trazida por Mason (2012) as pessoas passaram a poder participar de movimentos revolucionários sem interferir em suas próprias rotinas, permitindo produção colaborativa, de tal modo que "[...] networked activism challenges the old methods - parties, trade union, leaders, hierarchies" (p. 141).

Os levantes políticos se desenvolveram de forma descentralizada: não havia uma figura central revolucionária, ou um líder de oposição tradicional, ou ainda uma figura carismática porta-voz para radicalizar o público, porém, havia pessoas que representavam proeminentes nós nas redes digitais, contribuindo para as mobilizações (HOWARD; HUSSAIN, 2013).

Segundo um dos entrevistados de Salem (2015) que participou dos levantes no Egito, a razão pela qual o movimento guiado pelos jovens foi bem sucedido é justamente porque não havia liderança, já que através do Facebook é que se organizavam os movimentos offline. Howard e Hussain (2013) reforçam isto, ao afirmarem que a flexibilidade e diversidade dos movimentos horizontais e difusos fortaleceram os levantes, tornando-os muito difíceis de 
interrompê-los. Além disso, as novas ferramentas formaram uma nova expressão do ativismo na medida em que trazia um novo significado conectando uns aos outros, impactando de maneira diferentes, sobretudo em regimes autoritários preparados para lidar com partidos de oposição ou dissidentes isolados:

This suits the kind of policies that appears to be emerging - not just in developing countries either. There seems to be a similar shift in developed countries towards less rigidly defined political movements. But it is particularly effective in relatively authoritarian regimes that are historically well prepared to crush opposition that manifests itself as a block (opposition party) or individual (dissenter). Sometimes these states find it harder to deal with diffuse networks of protest (BECKETT; BALL, 2012, p. 139).

O nível de descentralização do movimento também variou entre os países. Para Seib (2012) na Tunísia houve maior espontaneidade e descentralização dos protestos. Já no Egito, esse nível de descentralização ocorreu porém de forma menos espontânea pois contou, de forma mais evidente, com a atuação de organizações pré-existentes que, embora nenhuma tenha conseguido centralizar os levantes como um todo, foram elementos importantes em seus nichos de atuação para convocar e apoiar as ações que se seguiram e que culminaram com a queda do governo vigente naquele país.

\section{c) Transnacionalização}

A Primavera Árabe é parte de um processo social, político e econômico mais amplos, caracterizando-se, sobretudo, como um movimento transnacional, na medida em que afetou não apenas regimes nacionais, mas também seus vizinhos (HOUNSHELL, 2011). Por isso, não é possível compreender os protestos apenas através de condições nacionais (LYNCH, 2014). O movimento na Tunísia representou apenas uma inspiração para o rápido contágio na região, bem como seu sucesso trouxe ensinamentos sobre estratégias de organização do movimento através das mídias sociais (HOWARD; HUSSAIN, 2013). Para Lynch (2011) o espalhar das revoluções contra os regimes mostra a unidade árabe numa unificada narrativa de mudança, ainda que numa região que é conhecida por sua fragmentação ideológica. Ao se mostrar na Tunísia que um tirano poderia ser derrubado, tal acontecimento tem o poder emblemático de influenciar os demais a acreditarem que era possível superar o medo e sair nas ruas, mesmo com a ameaça de serem presos, torturados e mortos (LYNCH, 2011). 
No one had expected to see revolutionary moves or spillover effects in other countries of the region. The Tunisian revolution was, in itself, a major event of historic proportions. More likely, however, is the potential demonstration effect based on the logic that holds, " if it can happen in Tunisia, it can happen anywhere" (CHOUCRI, 2012, p. 140)

Esta movimentação interna à região, e de algum modo surpreendente ao resto do mundo, reflete a necessidade de mudança impelida pelos próprios cidadãos: "In a region that has for so long been seen as being both coveted and subjugated by outsiders, the Arab Spring was remarkable for its almost exclusively inward perspective" (SEIB, 2012, p. 166).

Assim que desencadearam os protestos na Tunísia, em efeito cascata outras campanhas se iniciaram em países como Jordânia, Oman, e Yemen. Em países como Líbano, Mauritânia, Arabia Saudita e Sudão, protestos menores e de menor impacto também se seguiram. Em todos os casos, a utilização da comunicação digital na viralização online de cenas dos protestos, da repressão, da persistência política foi elemento estrutural para que o fenômeno ganhasse uma escala além-fronteiras, quebrando assim o eventual pressuposto de alguma organização formal pan-islâmica necessária para tamanha mobilização transnacional.

No Egito, o país de maior permeabilidade da Internet no mundo árabe e uma sociedade politicamente ativa, melhor ajudou a propagar os levantes (HOWARD; HUSSAIN, 2013). Como na Tunísia, o Egito tem um esfera pública online bastante ativa, com partidos políticos ilegais, fundamentalistas radicais, jornalistas investigativos e cidadãos interagindo entre si (HOWARD; HUSSAIN, 2013).

Em análise de tweets em cadeia regional - com confirmação de localização usando geo-data - os autores Howard e Hussain (2013) trazem indicadores relevantes. Primeiramente, mostra a conversação que atravessa a região sobre levantes sociais. Em seguida, demonstra que as pessoas tuitavam sobre os eventos que ocorriam nos países vizinhos trazendo para suas demandas locais o debate sobre liberdade. Os picos sobre um determinado assunto numa dada região, como \#sidibouzid seguia a mesma incidência temporal nas regiões vizinhas, o que demonstra que todos acompanhavam o que ocorria na região, mas trazendo para sua própria realidade a discussão. Observa-se que há uma porosidade dos tweets tanto transnacional, quanto entre os mundos online e offline.

Iniciativas de protestos foram claramente influenciadas pelos vizinhos Egito e Tunísia, como no caso da Algeria: 


\begin{abstract}
Algerians with the same leveis of dissatisfaction over economic prospects found in Tunisia and Egypt broke out in protest in much the same way. Salima Ghezali, a leading Algerian activist, told AI Jazeera in a phone interview that this outbreak of protest was "both very local and very global:' Union-led strikes had been common for decades, but protests of this scale had not oc- curred since 1991. Algerian protesters were not among the most tech-savvy in the region, but before the country's state-run media reported on local protests or Mubarak's resignation, many residents in Algiers had already received the inspirational news by SMS (HOWARD; HUSSAIN, 2013, p. 23).
\end{abstract}

Através das mídias sociais, egípcios acompanharam o sucesso na Tunísia; cidadãos da Líbia e da Síria seguiram a cobertura no Egito; nos casos de Bahrein e Síria, quando houve problemas no monitoramento das ativistas dos ativistas pelo governo, os ativistas ao redor aprenderam a lição. Essa rede além-fronteiras de comunicação online criou uma estrutura de estimulo e reforços que viabilizou a existência de um fenômeno transnacional.

Além desse espalhamento em efeito cascata pela região, as mobilizações passaram a atingir a opinião pública internacional. Tanto pela circulação de imagens fortes sobre os levantes que correram o globo através de mídias sociais seja também pela reprodução de vídeos amadores testemunhais publicados incialmente na Internet e utilizados no noticiário de diversos países. Dentro do próprio movimento, havia o sentimento de pressão transnacional:

What will they do about it? In December 2011, the Egyptian Facebook page "We Are All Khaled Said" offered this message: "Twenty thousand innocent Egyptians were in Mubarak jails being tortured and held without trial for their political views, while the world was friends with Mubarak for 30 years because they thought a dictator can bring them stability. Do you think the world leaders will learn and stop supporting dictators regardless of their interests?" (SEIB, 2012, p. 173).

$\mathrm{Na}$ prática, as redes e plataformas digitais de comunicação foram estruturas incontestáveis na intensificação do processo de transnacionalização do movimento junto a uma esfera pública internacional, inclusive gerando pressões sob outros governos (como potencias ocidentais), forçando-as a agirem ou, pelo menos, tomar partido sobre os levantes e emitir posicionamentos oficiais. 


\subsubsection{Instrumentalização do planejamento}

\section{a) Datificação}

A coleta de dados online estratégicos durante os processos da Primavera árabe ocorreu principalmente visando dois objetivos mais sobressalientes: (a) o desocultamento de informações de denúncia sobre abusos de poder, irregularidades governamentais que serviram como insumos e estímulo estratégico para manter vivo o sentimento de indignação que moveu essas ações coletivas e (b) a coleta, o compartilhamento e cruzamento de dados online com o intuito tático, isto é, cuja função era ajudar na tomada de decisões táticas sobre como driblar repressão policial.

A coleta de dados através do meio digital foi usada para agregar informações sobre as atrocidades e corrupção dos regimes autoritários, além de revelar abusos. Por exemplo, através do uso do Google Earth, a população Shia do Bahrain mapeou e agregou fotos da minoria Sunny no poder mostrando o estilo de vida opulento dos palácios reais em que viviam, enquanto a maioria da população vivia em casas de um único quarto com 17 membros da família (HOWARD; HUSSAIN, 2013, p. 23). Essa datificação seria difícil de se materializar e ganhar escala sem a comunicação digital.

Um outro caso de coleta de informação disponibilizada online e que serviu como base para produzir planejar e concretizar partiu do já mencionado vazamento do WikiLeaks que versava sobre a Tunísia. A partir da base de dados do WikiLeaks, a organização Nawaat criou o projeto TuniLeaks:

Figura 16 - Logotipo do hotsite TuniLeaks publicado em novembro de 2010

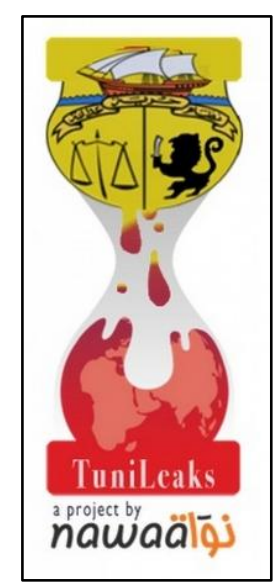

(Fonte: Nawaat) 
York (2013) ressalta que esses dados tiveram efeitos importantes na Tunísia ao serem coletados da plataforma do WikiLeaks, em seguida contextualizados e traduzidos para idioma local. Isso tornou o vazamento acessível aos leitores tunisianos, gerando um efeito bem mais potente ao ganhar uma conotação nacional.

Já no caso do uso tático de informação digital, podemos identificar casos como o uso de mídias sociais para a coleta e difusão de informação estratégica relevante que precedia as ações. Por exemplo, o Twitter foi uma ferramenta útil para compartilhar localizações dos protestos e acompanhar os acontecimentos possibilitando assim o planejamento dos indivíduos que se encaminham para as manifestações de rua: "One activist wrote that Twitter "is easy and flexible to do from your mobile. If we have a lot of action here I might do as many as 20 or 30 Tweets a day" (SEIB, 2012, p. 51). Estima-se que grande parte da troca de informações sobre os levantes deu-se por mensagens de texto, porém devido à própria especificade da ferramenta, a coleta de informações sobre esse uso é menos aberta do que as redes sociais. O Twitter funciona como um bom termômetro para compreender as demais trocas digitais de comunicação. Trazidos também na análise de Howard e Hussain (2013) sobre o uso da ferramenta na Tunísia, os 13.262 tweets de 14 de janeiro a 16 de março com a hashtag \#sidibouzid contabilizaram 18\% de dentro do país, $8 \%$ de países vizinhos e $32 \%$ de fora da região. O conteúdo versava sobre estórias particulares de sofrimento no regime da ditadura, e também links para grupos no Facebook e vídeos no YouTube. Os dados mostram que os picos de tráfico no Twitter coincidem com o pico nos protestos de rua.

Os regimes autoritários acompanhavam estes passos monitorando online e também criando e arquitetando movimentos para contrabalancear os levantes. Os regimes muitas vezes rastreavam essas mídias sociais para identificar o lugar das mobilizações ou ainda bloquear páginas e aplicativos. Na Síria, por exemplo, Facebook e Twitter foram vasculhados à procura de rastros dos protestos. Sírios pró-Assad criaram suas próprias páginas no Facebook, como em agosto de 2011 a página "Bashar al-Asad" contabilizava 197 mil amigos (SEIB, 2012). Como na Tunísia e Egito, as autoridades da Argeria, Bahrain, Arábia Saudita, Síria e Líbia tentaram reprimir as atividades digitais prendendo blogueiros (HOWARD; HUSSAIN, 2013)

Pesquisas de sondagem de opinião durante as manifestações demonstraram que cerca de $50 \%$ dos manifestantes, no caso egípcio, captaram e postaram online vídeos ou imagens dos protestos políticos nas ruas, especialmente através do Facebook (TUFEKCI;WILSON, 2012). 
De todo modo, em linhas gerais a coleta de informação estratégica e seu uso durante os levantes não deve ser considerada um elemento com alto grau de consciência tática, na forma de uma coleta sempre claramente ciente do seu uso em planos estratégicos, no sentido mais formal da palavra. Isso se deve à própria natureza descentralizada que caracterizou os levantes, como vimos. A coleta de informação online e seu uso no planejamento de ações ocorreram, como podemos perceber nos exemplos listados, de forma menos sistemática e mais espontânea, porém, não menos relevante para as estratégias adotadas durante os levantes.

\section{b) Elaboração}

Tufekci e Wilson (2012) trazem uma interessante pesquisa ${ }^{175}$ de campo realizada no Egito, produzida no intuito de explicar através de evidências concretas como a mídia social e a Internet foram usadas pelos protestantes durante os eventos. Segundo os autores, desde o início da Primavera Árabe, com os protestos na Tunísia seguido para o Egito, acadêmicos têm tentado entender como a Internet e a mídia social contribuem para mudança política em regimes autoritários. Demonstram que, até ocorrer o levante na Tunísia, os protestos no Egito existiram previamente mas eram de menor escala e abafados pelo regime controlado por Mubarak, mas já havia pequenos grupos ${ }^{176}$ espalhados que disseminavam ideias dissidentes ao regime.

Claramente, o advento do Facebook no mundo árabe em 2009 amplificou este processo (ao final de 2010 tinha 4 milhões de usuários no Egito), pluralizando o conteúdo político online, de modo que muitas campanhas de jornalistas-cidadãos puderam expor condições de abuso aos direitos humanos, tortura e pobreza (TUFEKCI; WILSON, 2012).

Logo após os massivos protestos na Tunísia ocorreram algumas manifestações dispersas no Egito até que se agendou através das redes de contato (online e offline) para o dia 25 de Janeiro de 2011 um protesto na Tahrir Square, difundindo-se a página no Facebook

\footnotetext{
${ }^{175}$ A pesquisa foi de 4 dias (desde 4 de fevereiro de 2011, menos de duas semanas depois da deposição de Mubarak) e contou com aproximadamente 1000 entrevistas dos participantes das manifestações em Tahrir Square (TUFEKCI; WILSON, 2012).

${ }^{176}$ No Egito, desde 2005, havia pequenos grupos em prol do movimento "Kefaya" (enough em inglês ou, traduzido livremente para "basta") e a sexta coalizão de jovens de abril. E não era limitado à esfera online. As mídias sociais e a TV por satélite eram os únicos espaços públicos onde temas politicamente sensíveis pudessem ser discutidos e dissidentes se expressarem (TUFEKCI; WILSON, 2012).
} 
chamada "We are all Khaled Said" e depois de 18 dias de protestos contínuos, Mubarak anunciou sua resignação em 11 de fevereiro (TUFEKCI; WILSON, 2012). Conforme explicado nos indicadores anteriores, a página fazia referência ao assassinato brutal de Said por policiais egípcios em Alexandria, sobretudo simbolizando a resistência do povo egípcio frente à violência do governo (SEIB, 2012). Em meados de 2011 Seib (2012) registrou 1,5 milhões de "amigos" no perfil "We Are All Khaled Said" e 135 mil na de língua inglesa. A página e outros canais online similares serviram como plataforma para se elaborar e planejar tanto ações de rua como ações online de pressão no ambiente doméstico e também internacional.

Os resultados da pesquisa de Tufekci e Wilson (2012) são bem ilustrativos para demonstrar que a participação nos protestos, seja antes ou a partir do primeiro dia das manifestações na Tahrir Square, está associada a padrões de uso das tecnologias digitais. Isto se dá basicamente por duas razões: mudança na conectividade social de infraestrutura (Internet e mídias sociais) e a difusão de celulares a menores preços aumentou a possibilidade de qualquer indivíduo de captar imagens e vídeos (TUFEKCI; WILSON, 2012). Na prática, os pesquisadores demonstraram que: cerca de $80 \%$ dos manifestantes usaram telefones para se comunicarem sobre o protesto; aproximadamente metade deles tinham Facebook de modo que usaram a plataforma para se comunicarem sobre o protesto, alinhando assim a ação coletiva; $13 \%$ usaram o Twitter também para se comunicarem sobre o protesto; cerca de dois terços dos participantes no primeiro dia dos protestos nunca tinham participado de nenhum tipo de protesto. O Facebook forneceu recursos nos estágios iniciais dos protestos em cada país compartilhando informações sobre onde as ações ocorreriam e quais os passos a serem tomados (HOWARD; HUSSAIN, 2013).

Gladwell (2010), um autor enfático quanto às limitações das ferramentas digitais na intervenção de processos políticos e no ativismo online, reconhece que as novas ferramentas da mídia social reinventaram o ativismo social. Para o autor, com o Facebook e o Twitter tornou-se mais fácil aos desempoderados colaborar, coordenar e dar voz às suas preocupações. Porém, ele inverte a relação entre as causas político-sociais que movem os ativistas com as novas ferramentas por eles utilizadas "Where activists were once defined by their causes, they are now defined by their tools" (GLADWELL, 2010), de modo que, no entendimento dele, são as ferramentas que dão confiança e empoderamento para a mudança político-social, e não o contrário. 
Porém, o estudo de Tufekci e Wilson (2012) mostra que, ao menos no caso do Egito, os argumentos defendidos por Gladwell (2010) são inadequados, na medida em que ele afirma que, apesar de os instrumentos da mídia social tornarem mais fácil para os ativistas se expressarem, é mais difícil para que tal expressão tenha algum impacto efetivo por si só. Contrariamente, para os autores da pesquisa os diferentes laços das redes sociais trouxeram informação, notícias e apoiaram a necessária participação no protesto político: "In the case of protests in Egypt, it appears that social networks, often mediated through the new online platforms in the emergent networked public sphere, played a crucial role" (TUFEKCI e WILSON, 2012, p. 376).

As redes e páginas online serviram como instrumento de elaboração e convocação de protestos, mas não significa que todo chamamento planejado tenha se tornado efetivo. Por exemplo, em março de 2011 ativistas palestinos criaram a página "People Want to End the Division" a fim de reunir pessoas fisicamente em protesto. Na página 41 mil pessoas confirmaram presença, porém apenas cerca de 8 mil apresentaram-se pessoalmente, muito devido às incertezas das complexidades políticas (SEIB, 2012). Na Síria a página criada chamava "The Syrian Revolution 2011" e contava até o verão de 2011 com 250 mil participantes (SEIB, 2012).

Se por um lado o processo de agendamento e elaboração dos protestos contou com a comunicação digital como vetor importante, isso também serviu para governos monitoraram as ações previstas. Sabendo dos esforços de vigilância, os ativistas tinham o cuidado de enviar emails e ou trocar informações estratégicas sensíveis da organização de protestos publicamente no Facebook ou Twitter (HOWARD; HUSSAIN, 2013). As formas de subterfúgio para driblar o monitoramento do governo foram várias. Na Líbia, diante do bloqueio do Facebook pelo governo, os ativistas passaram a usar websites de encontros românticos entre muçulmanos e passaram a usar metáforas linguísticas para agendar ações (HOWARD; HUSSAIN, 2013). Os ativistas sírios usaram o Google Maps para o automonitoramento e verificar se as fontes presentes no Twitter eram confiáveis, uma vez que funcionários do Estado usavam a conta para espalhar informações equivocadas, além de usarem servidores proxy internacionais quando o Facebook foi banido por Assad (HOWARD; HUSSAIN, 2013; SEIB, 2012). Ainda no Egito, o uso do Skype para comunicação estratégica entre os ativistas era amplo, na medida em que as chamadas eram naturalmente criptografadas; porém, o governo de Mubarak utilizou de um software, uma espécie de 
"spyware" implantado como um vírus, para ter acesso às conversas antes de estas serem criptogradas (SEIB, 2012).

A maioria dos blogs era escrita em francês ou árabe, e a discussão sobre revolução na Tunísia permaneceu mesmo após a fuga de Ben Ali do país, já que a autoridade que assumiu era considerada por muitos como continuidade do velho regime (HOWARD; HUSSAIN, 2013).

Um aspecto interessante em relação à linguagem usada é que antes do início dos levantes o inglês e francês eram os idiomas mais usados no apoio à mudança política nos memes e narrativas que se espalhavam pelo meio digital, logo após o árabe se tornou majoritário (HOWARD; HUSSAIN, 2013). Observa-se que as histórias afetivas ganhavam bastante espaço nesse meio.

No Egito, o planejamento do protesto em 25 de janeiro contou com o movimento "April 6" e a página "We are all Khaled Said", a qual criou um evento no qual 50 mil pessoas confirmaram presença. Videos e banners foram difundidos através de emails, blogs e redes sociais, no Twitter a hashtag \#Jan25. No Facebook muitos egípcios vivendo no exterior cogitaram retornar ao Egito por conta da discussão online de revolução e da possibilidade de manifestações reais (SALEM, 2015). Segundo as entrevistas conduzidas por Salem (2015), os participantes dos levantes do Egito argumentaram que o movimento não poderia ter ocorrido sem as novas tecnologias, já que o espaço offline estava fechado pelo governo egípcio e a polícia. Diversas iniciativas offline eram rapidamente interceptadas, e isto não era conseguido da mesma maneira no espaço do Facebook (SALEM, 2015).

Embora não alcançasse todas as pessoas, o conteúdo online era espalhado também offline, seja através de ativistas que distribuíam panfletos nas ruas, seja através de canais da Al Jazeera, seja através de grafite e outras formas de arte pública e música, ou ainda através de boca a boca: "It would thus be more useful to see social media as a tool that facilitated the mobilisation of protesters at the start, and that acted as a "watchdog" of state-controlled media (Cottle 2011, 652)" (SALEM, 2015, p. 184).

\section{b) Instrução}

Logo no início dos levantes na Tunísia e no Egito, os principais organizadores e demais ativistas passaram a circular dicas de como atingir bons resultados com os protestos. 
Os ativistas ao registrarem uso excessivo de força por parte dos policiais, passaram a compartilhar nas redes sociais, ilustrados pelas imagens dos abusos, conselhos úteis para os protestantes:

[...] don't disrupt traffic; display only Egyptian flags, not partisan emblems; bring plenty of water; and so on. Tunisian demonstrators who had gotten a head start on the Arab uprisings offered their own suggestions on Facebook, such as, "Advice to the youth of Egypt: put vinegar or onion under your scarf for tear gas" (SEIB, 2012, p. 51).

Outras instruções online são observadas no diretório de informações boing.boing.net, o qual forneceu informações de como manter o anonimato online; além dos treinamentos de ativistas para saber lidar com as novas ferramentas estarem disponibilizados em websites a partir de guias, sobre por exemplo "How to Set Up a Dial-up Server" (HOWARD; HUSSAIN, 2013).

A revista literária/cultural "Atlantic Monthly" hospedou o "Activist Action Plan" traduzido para o inglês a partir do original em árabe. Segundo a revista ${ }^{177}$, o material foi rapidamente traduzido por um tradutor contatado através do Twitter. Produzido por forças antigoverno no Egito, o manual continha métodos de revolta urbana em massa. Por exemplo, a Figura 17 ilustra o traje e acessórios mais indicados para os protestantes nas ruas que encontravam grande resistência e violência por parte das forças de segurança do Egito:

177 Disponível em: <http://www.theatlantic.com/international/archive/2011/01/egyptian-activists-action-plantranslated/70388/>. Acesso: 10 nov. 2015. 
Figura 17 - Reprodução da versão traduzida do Activists' Action Plan

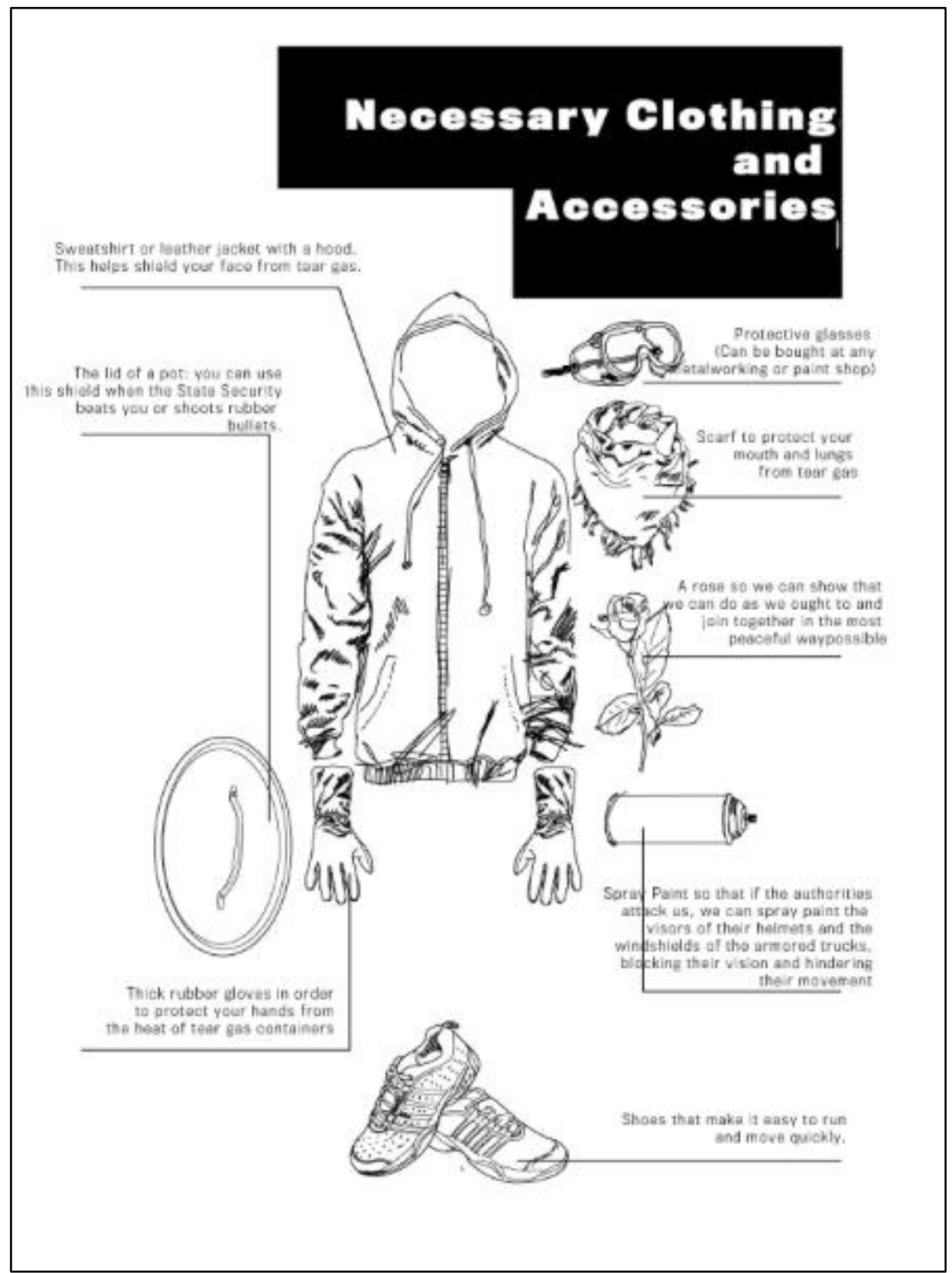

(Fonte: The Atlantic $\left.{ }^{178} / 2011\right)$

O website do grupo de ativistas pela liberdade de expressão "Telecomix" teve grande importância ao compartilhar métodos de como driblar bloqueios de "broadband networks" usando linhas de telefone fixo. O Telecomix ${ }^{179}$, que se trata de um grupo engajado na guerrilha informacional, auxiliou principalmente manifestantes da Líbia, o Egito e a Síria a conseguirem ter suas mensagens visíveis no Twitter, Facebook e outros meios de

178 Disponível em: <http://www.theatlantic.com/international/archive/2011/01/egyptian-activists-action-plantranslated/70388/>. Acesso: 10 nov. 2015.

179 MADLENA, Chavala. Telecomix: Tech support the Arab Spring. 07 jul. 2011. Disponível em: <http://www.theguardian.com/technology/2011/jul/07/telecomix-arab-spring>. Acesso 07 nov. 2015. 
comunicação. Através de ligações para celulares e Skype dos manifestantes para o grupo, o Telecomix disponibilizava as mensagens na rede. Outra forma usada foi indicar plataformas como o TOR para os ativistas não serem identificados na Internet. $O$ grupo ainda auxiliou através de conversas em chats e contatos online a resolver problemas de comunicação durante os protestos no Egito: através de engenhosos meios criou redes de comunicação em terra para os manifestantes, utilizando tecnologia Bluetooth dos celulares, ou conexão entre microfones de rádio, walkie-talkies ou rádio-relógios.

\subsubsection{Diversificação da ação}

\section{a) Cibereventos}

As principais ações da Primavera árabe ocorreram nas ruas. A ocorrência de cibereventos se deu em torno da divulgação de chamados de páginas e convocações para as ruas. A própria natureza da mobilização que ganhou escala popular em países de baixa inclusão digital também explica porque cibereventos (protestos e manifestações especificamente online) estavam tão umbilicalmente conectados ao espaço físico de ação:

\footnotetext{
Shortly thereafter, calls for political change in Egypt flooded Facebook and other social networking websites. As one observer noted, cyber protest is not protest in the streets, but protest in the streets can be reinforced by cyber protest. At a minimum, these processes could, in the case of Egypt, be seen as a release of pent-up frustrations. They could, also been seen as a mechanism for social communication, creating and reinforcing cohesion. Overall, however, the revolution was relatively devoid of large-scale violence (CHOUCRI, 2012, p. 140-142).
}

Na prática, a mídia digital afetou os cursos das ações, explorando as oportunidades de mobilização contra governos e diminuindo os constrangimentos do comprometimento dos ativistas online e alimentando ações offline (HOWARD; HUSSAIN, 2013).

\section{b) Ciberataque}

Na Tunísia ativistas hackers causaram prejuízo econômico ao derrubar a Bolsa de Valores (HOWARD; HUSSAIN, 2013). Os ativistas online (com participação do 
Anonymous, que reivindicava liberdade de expressão e fim da opressão e censura da Internet do governo de Ben Ali) também desabilitaram - através do de um ataque denial-of-service -, ainda que momentaneamente, diversos outros websites tunisianos, incluindo site oficial do governo, dos ministérios da indústria e das relações exteriores, coincidindo com a maior greve desde que Ben Ali havia assumido o poder na Tunísia ${ }^{180}$. Estes ataques ficaram conhecidos como Operação Tunísia.

Na Síria, uma chamada "guerra eletrônica" ${ }^{181}$ foi desencadeada a partir de ações entre ativistas a favor e aqueles contrários ao regime de Assad. Em 2011, grupos ativistas hackearam pelo menos 12 websites governamentais e substituíram o conteúdo por imagens de mapas interativos contendo informações de atrocidades realizadas por forças de segurança contra manifestantes. Anteriormente, um grupo chamado "Syrian Electronic Army" (SEA) a favor do regime já atuava na esfera online identificando manifestantes e atacando suas páginas pessoais, como Facebook, a partir de informações pró-regime e frases como "I love Bashar" e outras de caráter de ameaça. Os ataques do SEA passaram a ser dirigidos também a páginas de celebridades norte-americanas, como Oprah Winfrey e Brad Pitt, além da Newsweek magazine, e até mesmo a página oficial de Harvard University, que foi identificado como um ataque sofisticado, conforme visualiza-se na Figura 18:

Figura 18: Tela do website da Universidade Harvard hackeado

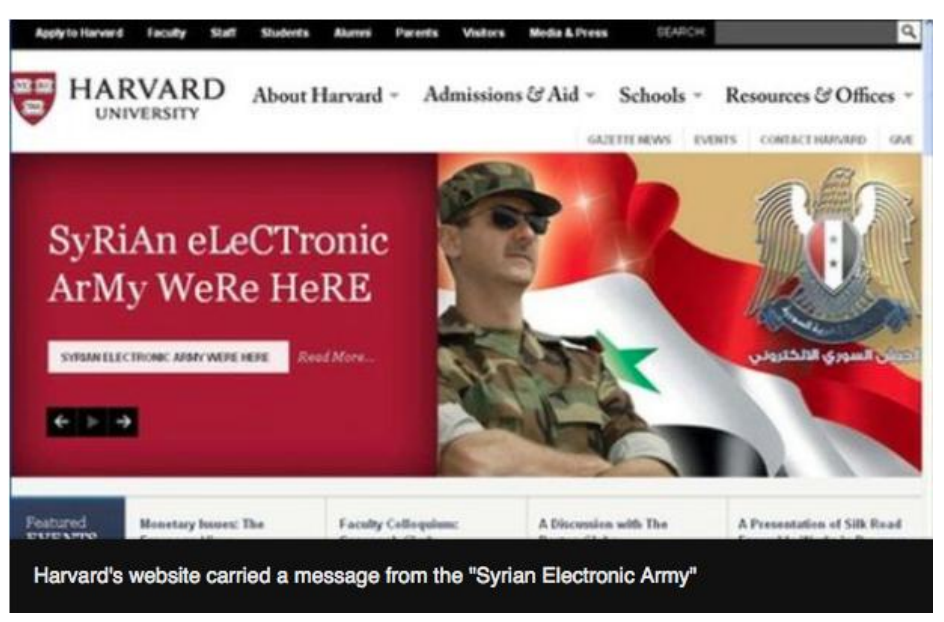

(Fonte: BBC News ${ }^{182} 26$ nov. 2011)

\footnotetext{
${ }^{180}$ Disponível em: <http://www.aljazeera.com/news/africa/2011/01/201113111059792596.html. Acesso em 07 out. 2015.

181 Disponível em: <http://www.huffingtonpost.com/2011/09/27/syrian-electronic-army_n_983750.html>. Acesso em: 14 dez. 2015.

182 HILL, Evan. Hackers hit Tunisian websites. Al Jazeera. 03 jan. 2011. Disponível em: <http://www.bbc.com/news/education-15061377>. Acesso: 07 nov. 2015.
} 
Embora o SEA se proclamasse independente, Assad o reconhecia como um "exército real no mundo virtual" e ativistas contra o regime acreditavam que tinham relação com agentes de inteligência sírios. Mais perigosos no início, os ataques do SEA foram contrabalanceados por grupos de hackers como Anonymous e outros compostos por ativistas sírios, como Free Hackers Union e RevoluSec. O porta-voz de Comitês de coordenação local, Omar Idilbi, reconhece que o SEA coloca suas vítimas em perigo, ameaçando os ativistas antirregime divulgando seus endereços e telefones. Já os hackers contrários aos regimes apenas interceptam páginas governamentais oficiais e substituem o conteúdo para caricaturas de Assad e mensagens como "Don't let Bashar monitor you online".

No caso de ataques na forma de ciberespionagem, não é possível afirmar que houve ações online desta natureza diretamente produzidas como parte do repertório de ação no processo da Primavera árabe. Pelo menos não há registro de ações bem-sucedidas. Porém, houve ações de ciberespionagem indiretas que, embora não tenham sido gestadas no âmbito do processo dos levantes, foi um dos elementos que contribuíram para a criação de um contexto favorável à causa. É o caso dos vazamentos de informações diplomáticas efetuados pelo Wikileaks, que antecederam os levantes. Nesta ocasião foi trazido à tona documentos diplomáticos que revelavam corrupção governamental e submissão da soberania nacional (caso já mencionado indicador sobre difusão da causa).

\subsection{TRÊS CASOS EM PERSPECTIVA ANALÍTICA}

Os três estudos de caso analisados neste capítulo demonstram que os efeitos da comunicação digital no ativismo se posicionam hoje para além das suposições teóricas: tratase de fenômenos reais, com implicações nos diversos processos que compõem o ativismo em geral e o ativismo transnacional em específico. Os dados e fatos descritos comprovam o lastro das categorias de efeitos e também demonstram a sua complexidade e entrelaçamento.

Neste estágio, com um olhar mais analítico e comparativo sobre os casos, pode-se afirmar que os indicadores analisados são úteis para qualificar e compreender melhor o fenômeno, traçando assim linhas transversais sobre questões relevantes e estruturantes que têm emergido no cenário internacional, capazes de reposicionar o ativismo transnacional em novo patamar. Percebe-se que as categorias de efeitos elencadas nesta tese permeiam todos os 
casos, em menor ou maior grau. Os dados apresentados apontam alguns padrões que se repetem e também algumas peculiaridades. Assim, embora nas três seções anteriores elementos analíticos já tenham sido elencados através dos casos, convém fazer uma análise transversal complementar, amarrando essas discussões prévias, identificando as convergências, peculiaridades e questões gerais que possam ser aplicadas a outros casos similares ou que tragam entendimentos para o fenômeno do ativismo transnacional contemporâneo como um todo.

\subsubsection{Estímulo à configuração da causa}

A configuração da causa ativista atravessa elementos contextuais, processuais e históricos e não ocorre de forma unívoca, a partir de um único ingrediente central. Significa dizer que a comunicação digital não é fator determinante, pois sozinha não sustentaria fenômenos tão complexos como mobilizações políticas coletivas.

Isto fica evidente quando retomamos a discussão teórica trazida por Oberschall (1993), conforme debate no capítulo anterior. O autor apontou quatro aspectos relevantes que tendem a influenciar o surgimento (ou ressurgimento) de um movimento ativista, porém notase que nos três estudos de caso, a comunicação digital agiu fortemente em apenas dois itens: Referente às mudanças na capacidade de agir coletivamente, como crescimento de um grupo, aumento na liberdade para se organizar, melhoria nos processos de comunicação e maior coesão entre os membros do grupo; e relativo às mudanças na oportunidade para a ação ser bem sucedida, como fragilidade da oposição, apoio de aliados poderosos, e o sucesso de outros movimentos sociais. Por isso, a comunicação digital deve ser compreendida como um fator estimulante à construção de bandeiras, porém não determinante ou inerente a ela.

O nível deste estímulo ou catalização pode ocorrer de forma distinta, a depender da combinação e reação com outros fatores que orbitam em torno do nascimento de uma causa. Primeiro, porque muitas causas ativistas que hoje existem podem ter suas sementes plantadas antes mesmo da existência das ferramentas digitais e seus usos comunicacionais. Segundo, porque estabelecer causa e efeito na relação entre a tecnologia e o uso social é uma relação determinística que não deve ser tomada como a priori, mas reconhecendo o momentum tecnológico e interpretando historicamente o papel social da ferramenta digital, conforme debatido no início desta pesquisa, mostrando tal abordagem como uma chave analítica 
adequada. Terceiro, os casos analisados demonstram que, mesmo quando a comunicação digital é um elemento ausente no nascimento de uma causa, ela pode atuar na sua reconfiguração ao fornecer instrumentos, catalisando oportunidades, ou ainda evitando a dispersão. Ou seja, a comunicação digital torna a latência mais dinâmica e a visibilidade mais abrangente - conforme as duas concepções colocadas por Alberto Melucci $(1995,1989)$ indo além da dependência dos intermediários, a exemplo da mídia, para difundir-se, mas sem necessariamente descartá-los.

A articulação, sobretudo inicial, apresenta-se bastante central nos casos do WikiLeaks e da Primavera Árabe, inclusive com porosidade entre eles, quando se analisam os impactos dos vazamentos do WikiLeaks, confirmando abusos de poder e corrupção na Tunísia, o que fermentou ainda mais a instabilidade econômica e política que o país enfrentava já antes da viralização das imagens chocantes da autoimolação de Bouazizi. Principalmente nesses dois casos, as discussões em chats online, redes sociais, blogs e outros canais disponibilizados na Internet, ajudaram a construir o momento de latência. No WikiLeaks deu-se a partir de um círculo mais fechado, de ativistas e hackers ao redor do globo, que buscavam elaborar formas a partir das facilidades tecnológicas para aumentar a transparência e diminuir os abusos de poder de governos e grandes corporações. Na Primavera Árabe formou-se um espaço de debate e troca de informações, fazendo convergir as insatisfações populares e interesse de pessoas distantes geograficamente, mas imbuídas por um sentimento de mudança local/regional.

Notadamente, a articulação inicial da Al-Qaeda antecede a inauguração do ciberdomínio, porém, a sua rearticulação global posterior a partir da década de 1990 apoiouse na nova forma de comunicação, sobretudo devido ao caráter clandestino e disperso do grupo. Essa relação com as mídias digitais se tornou mais simbiótica quando seus espaços físicos foram desmantelados pela intervenção dos EUA no Afeganistão, dando ao grupo uma sobrevida digital, reforçando a manutenção da bandeira em sua forma ideológica.

Em todos os três casos, a cultura da convergência, que caracteriza o ciberdomínio, possibilita o cruzamento das rotas de ideias ou visões de mundo similares e servem como um novo elemento para catalisar indivíduos e minorias, antes dispersas pelo globo ou que necessitariam de maiores recursos para interagir e formar uma causa transnacional. $\mathrm{O}$ próprio processo de difusão da causa através da Internet fornece saliência a sentimentos narrativos envolventes e impactantes (vídeos com morte de indivíduos, imagens fortes de violência, narrativas de teor pessoal dando mais lastro a fatos políticos em redes sociais etc.) 
significando, na prática, um novo elemento capaz de estimular o nascimento ou a expansão de uma causa, se o contexto social, político e cultural possibilitarem bases apropriadas para que este estímulo se desenvolva. Historicamente, o jornalismo formal também produziu (e continua produzindo) imagens fortes e narrativas com impactos relevantes capazes de estimular movimentos políticos ${ }^{183}$. Isso não é necessariamente novo. O que há de inovador é (a) a capacidade de multiplicação de imagens que passam a correr o mundo de modo bem mais ágil e imediato; (b) a produção de reações também imediatas da opinião pública que podem ser claramente visíveis através da multiplicação de hashtags e do crescimento do tópico em medidores como trend topics, colocando o tema em clara evidência política de comoção pública; (c) a preponderância histórica das organizações jornalísticas, como gatekeeper, diluiu-se e as imagens passaram a ocorrer de forma bem mais frequente a partir de ângulos diferentes gravadas por indivíduos comuns portando celulares; (d) o próprio ato de compartilhar a foto dá um outro lastro político ao conteúdo, uma vez que o ato de compartilhar significa também, nestes casos, um ato de protesto. Todos esses elementos não estavam previstos na estrutura do jornalismo formal e são uma inovação da comunicação digital e da formação de redes online.

Do ponto de vista da relação entre movimentos ativistas e o público, essa difusão online da causa cria uma relação direta entre o grupo e seu público alvo, passando a operar sem depender dos filtros formais do jornalismo para existir. Isto ocorre mesmo em casos de ativismo com métodos violentos e contestáveis, como é o caso da Al-Qaeda. Apesar da forte repressão, esta organização conseguiu manter a causa viva através de websites vinculados ao grupo, redes de apoiadores online, disponibilização de livros digitais, conversas direta com o público através de chats, dentre outros artifícios para estimular a difusão da bandeira, que envolve proselitismo religioso, contra-contra-terrorismo e propaganda.

A viralização é um exemplo bastante ilustrativo de que não bastaria comunicação digital para haver ativismo, é preciso um gatilho. É claro que a viralização tende a ocorrer quando o fenômeno já está vinculado a uma grande visibilidade (por conta de sua natureza e

\footnotetext{
${ }^{183}$ Um exemplo é a foto De Huynh Cong "Nick" Ut de 1972 que demonstra crianças (incluindo uma garota nua com braços abertos queimados) fugindo de um ataque de napalm pelas forças estadunidenses. A imagem gerou grande comoção nos EUA e em outros países e serviu como combustão para a ampliação das pressões pelo fim da guerra. Um outro exemplo mais recente, foi a foto de uma criança síria morta na praia de Bodrum, na Turquia, após o naufrágio de um barco de refugiados. A foto, da fotógrafa Nilüer Demir, foi divulgada pela Associated Press e estampou as manchetes dos jornais no mundo gerando pressões políticas sobre o problema humanitário dos refugiados da guerra civil na Síria e dos embates contra o Estado Islâmico naquele país e também no Iraque. Neste último caso, o compartilhamento da imagem se tornou viral nas redes sociais e boa parte da sua visibilidade se deu nos canais online.
} 
impacto), e, embora isto seja comum aos três casos aqui estudados, não significa que a viralização funcione como uma condição necessária para que haja difusão da causa. Porém, evidencia a necessidade de elementos para além do contato digital, envolvendo sensibilização coletiva e intensificação nos contatos em rede. No caso da viralização, a difusão se dá pela de circulação de imagens chocantes, seja de indignação, seja de compactuar com a causa. $\mathrm{Na}$ Primavera Árabe houve sensibilização conduzindo à ação de protesto (compartilhado principalmente pelos interessados). Na Al-Qaeda houve repúdio e desqualificação da ação terroristas (compartilhado principalmente por um grande público não-simpatizante com a causa), como a viralização de imagens de Osama bin Laden exortando os jihadistas e valorizando a própria causa. Não é coincidência que, em todos os casos estudados, há em paralelo o registro de uso da linguagem mais globalizada, o inglês, o que demonstra claramente o intuito e a facilidade de atravessar fronteiras.

Antes da Internet, a massificação de uma mensagem ou de uma causa para o grande público (principalmente no âmbito transnacional) dependia da televisão, rádio e jornais. Isso incorria no risco de ficar à mercê do enviesamento dos meios de comunicação, distorcendo ou omitindo parte da mensagem. Ao mesmo tempo, embora a comunicação digital esteja hoje se consolidando como um recurso imprescindível para visibilidade de bandeiras, não há necessariamente uma hierarquia entre novas mídias digitais e velhas mídias. Internet, TV, rádio, impresso formam hoje um complexo sistema interligado. Assim, uma imagem viral de grande impacto político pode ter suas origens na Internet (através da captação por celulares de transeuntes) e romper a fronteira transmídia ganhando em ampliação e massificação em outros meios (como telejornais, jornalismo impresso e até mesmo meios analógicos mais arcaicos). Por outro lado, imagens captadas e publicadas por profissionais de imprensa também se tornam virais no sentido inverso do vetor.

Nota-se que, apesar de os canais online ocuparem um papel cada vez mais importante como meio para difusão da causa e utilizados diretamente pelos grupos, o que se observa é uma relação de porosidade com os meios tradicionais. O WikiLeaks, por exemplo, mesmo com a disponibilização na íntegra de importantes documentos em sua página oficial desde 2007, o início de sua atuação não foi de grande audiência online. A sinergia com os meios tradicionais de comunicação em 2010 representou a guinada no aumento da difusão online, aumentando sua visibilidade. A viralização de seu debate no Twitter e tornar-se trending topic no Google estão bastante vinculados a elementos externos (eventos como prisão de Assange, 
vazamentos dos telegramas de grande impacto na mídia de massa) e comportam-se como catalizadores da viralização online.

\subsubsection{Multiplicação do engajamento}

Os três estudos de caso demonstram que há hoje fortes indícios de ampliação do menu disponível para o engajamento político através do ambiente digital. Na prática, ferramentas como a Internet deram espaço a uma gama mais variada de ativistas e mobilizadores, que além de estarem espalhados pelo globo, podem se comprometer em graus e maneiras diferentes. Trata-se de opções que antes estavam indisponíveis, uma vez que a comunicação online criou novas avenidas antes não existentes. Esse engajamento mais amplo, abarcando diversos estilos e níveis de envolvimento, é potencializado pela comunicação digital em duas frentes principais: através da intensificação da propaganda engajada (na forma de vídeos, depoimentos, chamadas, posts em redes sociais online etc.), que possibilita manter viva a imagem de um movimento, impedindo assim o seu desaparecimento do imaginário público, uma vez que, conforme visto na categoria anterior, os ativistas não dependem mais apenas dos filtros do jornalismo para existir, recrutar e pedir apoio; e através do fortalecimento dos canais de engajamento, seja através de um comportamento legal online (através de doações, participação em fóruns de discussão, chats, colaboração com serviços ou endossos públicos e defesa da causa), seja ilegal (através de ações ilegais online, através da deep web etc.).

Isso corrobora alguns elementos teóricos do engajamento discutido no capítulo 4 de que a identidade coletiva consiste em um processo relacional, por isso está tão umbilicalmente ligada ao engajamento. Como propôs McAdam, Tarrow e Tilly (2001), a criação de identidades políticas envolve mudanças na consciência das pessoas envolvidas, mas também envolve alterações nas conexões entre as pessoas e grupos. A comunicação digital, nos três casos estudados, foi elemento fundamental neste aspecto. Essas conexões entre ativistas foram motivadas tanto por um cálculo racional que envolveu o custo de engajamento melhor facilitado pelo ambiente digital, quanto as vantagens decorrentes do engajamento e os recursos disponíveis para a sua efetividade, conforme já apontava as teorizações de McCarthy e Zald (1977). Um outro elemento importante na dinâmica do engajamento é a dimensão afetiva que também atravessa o ativismo que, conforme colocou Cefaï (2009), a "ação coletiva não está toda no agir, mas também no sofrer e no compartilhar" (p. 30-31). O ato de 
compartilhar sentimentos e narrativas através de websites, blogs, vlogs, petições online, vídeos ou mídias sociais ocorreu claramente em todos os três casos e isso influenciou a forma como o movimento angariou apoio e engajamentos. Além disso, seja através da construção de identidades ou da conexão transitória de interesses comuns, foi possível notar que os processos de comunicação foram recursos fundamentais e operaram como uma espécie de "liga" capaz de viabilizar a continuidade do engajamento, renovando os laços (sejam fortes ou fracos), possibilitando assim a ocorrência de ações conjuntas para além do domínio burocrático ou estatal, reforçando aquilo que Habermas (1981) chama de "mundo da vida".

Essa multiplicação das possibilidades de engajamento em bandeiras ativistas é acompanhada, como vimos nos casos estudados, por um espectro de envolvimento que inclui (a) o engajamento no núcleo mais duro de uma organização; (b) o surgimento de lideranças online responsáveis por coordenar e promover mobilizações; (c) a inserção de indivíduos dispersos que entram em sinergia formando redes de apoio; (d) a formação de redes de colaboradores mobilizando e transferindo, ainda que transitoriamente, diferentes recursos de outras organizações e movimentos simpatizantes. Ao observarmos os três estudos de caso, podemos perceber claramente que essas possibilidades de engajamento - em seus diferentes estilos (BIMBER et al, 2012) e um alto grau de personalização (BENNET, 2012) - foram capazes de gerar impactos relevantes mesmo diante de atores estatais poderosos. Mas isso não quer dizer que movimentos transnacionais ou atores não-estatais estão tomando as rédeas do poder. A Al-Qaeda não atingiu sua meta de erradicar a influência ocidental no mundo islâmico; o WikiLeaks não retirou o poder de todas as potências militares que tiveram dados sigilosos vazados; a Primavera Árabe não mudou a face do Oriente Médio e seu histórico de governos repressivos.

Também foi possível perceber que a potencialidade de comunicação horizontal do ambiente digital não significa que todo ativismo online incorpore tal dinâmica, como apontou Gerbaudo (2012). Embora nem sempre seja do modo tradicional offline, também pudemos localizar hierarquias de engajamento, isto é, há uma assimetria entre aqueles que mobilizam e os que são mobilizados, entre os que lideram o processo e os que seguem, embora a forma de relação entre estas duas partes é mais de inter-dependência do que de subordinação.

Este conjunto de elementos analisados demonstra que o jogo político na arena internacional se transformou em algo mais complexo e menos controlável do ponto de vista dos grandes players como governos nacionais, organizações multilaterais ou corporações globais. Isso ocorre pois a ação coletiva online ganhou em volume, diversidade, 
espontaneidade e também sinergia, dado que o engajamento online não é necessariamente caótico e sem foco: a soma destes envolvimentos em seus diversos níveis de comprometimento produzem algo maior do que a simples soma de partes dispersas. Consequentemente, as possibilidades de engajamento em ações coletivas transnacionais são hoje múltiplas e tendem a afetar o decorrer de determinados embates no nível global, pois inserem mais atores (indivíduos ou organizações colaboradoras) nos processos de disputas.

A formação de identidades prévias em torno de uma causa e capitaneada por organizações não deixou de existir. Na Al-Qaeda a identidade islâmica de viés fundamentalista é um elemento importante no engajamento de ativistas deste movimento, que se veem como uma "irmandade", dispostos a morrer lado a lado em ataques suicidas. No WikiLeaks, a identidade cypherpunk permeou e permeia o engajamento das lideranças da organização desde a sua fundação. E na Primavera Árabe, o sentimento de pertencimento a uma comunidade nacional e pan-islâmica contra a opressão estatal também moveu o engajamento de ativistas que criaram páginas, blogs e outros canais de protesto e reivindicação coletiva. Mas em todos esses casos, aqueles engajados com forte viés identitário não seriam capazes de manter o movimento em expansão e impacto se não fossem as redes de engajamentos mais fluidas, esporádicas e menos formais. Assim, se por um lado a comunicação digital nem sempre foi responsável pela formação da identidade dos movimentos - considerando o sentido sociológico do termo "identidade" -, ela potencializou a coidentificação e o autorrecrutamento. No primeiro caso, trata-se da formação de nuvens de afinidade em torno de determinada bandeira. No segundo caso, consiste na identificação simbólica com a causa, levando indivíduos isolados a se sentirem parte de uma ideia, de um imaginário, ainda que esteja distante das lideranças que a fomentam e não tenham convivido com estas. Em ambos, isso pode atingir uma escala global com alguma facilidade, como os três casos analisados demonstraram. Isso passou a ter um efeito potente no ato de engajamento, comparável à formação de identidades históricas prévias, pois se o ato de engajar a partir da coidentificação ou o autorrecrutamento pode parecer superficial, abstrato ou transitório, quando ocorre em escala e em rede, mobilizando solidariedade dentro e fora das fronteiras, torna-se um importante recurso em prol do ativismo e surge assim uma nova variável no jogo assimétrico de poder característico da arena internacional.

A multiplicação do engajamento através da comunicação online também não torna inócuo ou inoperante o papel das lideranças de um movimento e nem faz com que todo ativismo seja horizontalizado. Embora haja algum nível de espontaneidade nas mobilizações 
através de mídias sociais, isso não ocorre sem que haja agentes capazes de fomentar ou orientar ações coletivas, ainda que não sejam a figura carismática do líder histórico. Em todos os três casos estudados o papel das lideranças existiu e foram parte do quebra-cabeça para que outras pessoas se engajassem na causa, a partir de seus diversos níveis de comprometimento. O fato de haver redes horizontais nestas mobilizações não significou a impossibilidade de coexistência de lideranças personificadas, como é o caso do WikiLeaks. Porém, nestes casos, a liderança não está em uma posição de hierarquia em relação ao movimento como um todo e sim de simbolismo. Ou seja, ainda tomando como exemplo o caso do WikiLeaks: É menos a figura de Julian Assange que faz com que essa organização ganhe redes de apoiadores pelo mundo e mais o simbolismo que este representa: A luta contra grandes players forçando-os a serem transparentes para equilibrar a balança de poder.

\subsubsection{Flexibilização da estrutura}

Como apontou Cefaï (2009), a ação coletiva estrutura-se organizando seus ambientes, produzindo experiências que possibilitam aos seus atores terem uma orientação, uma compreensão acerca daquilo que fazem e, ao mesmo tempo, daquilo que as circunstâncias fazem deles. Nos três casos estudados, foi possível notar que a comunicação digital serviu como uma "base" para que esta estruturação pudesse existir. Reforçando o que o autor propôs, a comunicação digital foi o vetor através do qual se assentaram capitais materiais e humanos, onde redes de ativistas se desenvolveram e foram também capazes de produzir energia simbólica e servir como instâncias de representação coletiva.

Mesmo no caso da Al-Qaeda, nascida da interação face-a-face e caracterizada por ações de violência física, a sua própria sobrevivência se deu ao ocupar de modo mais incisivo o ambiente digital como uma plataforma de manutenção da organização. De outro modo, no caso da Primavera Árabe, ainda que pautada em protestos que ocupavam espaços como praças e ruas, a organização das ações se deu através da comunicação digital. Em nenhum dos três casos foi identificado indícios de relevância de uma sede concreta ou do espaço físico como base organizativa. Mas seria superficial e errôneo concluir que o ativismo se virtualizou totalmente: há, na prática, um fenômeno de virtualização no nível da estrutura, que se tornou menos rígida, mas o mesmo não acontece no nível da ação ou das atividades-fins dos movimentos. Isso ocorre pois ferramentas como a Internet não são apenas uma replicação da 
atividade offline. Trata-se de uma estrutura que cria pontes, possibilita a convivência e organiza narrativas. Isso explica, por exemplo, porque mesmo nos casos caracterizados por mobilizações de públicos com altos índices de exclusão digital (como foi o caso dos países da Primavera Árabe e, de algum modo, o caso da Al-Qaeda), o papel da comunicação digital parece onipresente. Trata-se menos do acesso para agir online e mais do seu papel de estruturar ações coletivas que, ao serem executadas (seja online ou offline) são capazes de se expandir para além do ambiente digital. Uma prova contundente disso é que os governos atingidos buscaram reprimir os casos analisados - bloqueando a comunicação digital -, menos no sentido de reprimir as ações e mais no intuito de quebrar a estrutura de organização desses movimentos, numa tentativa de destruir aquilo que consideravam a fonte do problema. Isso é bastante evidente no caso da Primavera Árabe. Por isso, mesmo retido fisicamente na embaixada do Equador em Londres, o fundador do WikiLeaks continua atuando. Cercá-lo fisicamente não quebrou a estrutura da organização. O mesmo pode ser afirmado para a AlQaeda: destruir a sua base física no Afeganistão ou anunciar a morte de bin Laden não pôs fim às atividades da organização, que adotou a operação nas redes como forma de sobrevivência estrutural. Os indicadores levantados nos três casos corroboram aquilo apontado por Keck e Sikkink (1998): para que esta estrutura exista foi preciso haver processos de comunicação relativamente eficientes, uma vez que as redes são formas de organização caracterizadas por padrões de voluntarismo, reciprocidade e horizontalidade nos processos de comunicação, conforme discutido no capítulo anterior.

Se por um lado o ambiente online é claramente mais fugidio do controle total de governos no uso da força bruta, os três casos demonstraram também que o meio digital não tornou o ativismo transnacional isento de repressão pelo fato de se refugiar na virtualização da sua estrutura. Diversas tentativas de repressão foram aplicadas nos três casos: bloqueio de sites, ciberataques, shutdown da Internet, monitoramento online e subsequente prisões de ativistas. E isso não ocorreu apenas por iniciativa de governos, mas também através de empresas como Facebook e Amazon. Metaforicamente, pelo fato de não ser rígida como um concreto, a flexibilidade da estrutura permite absorver impactos, dirimir danos e continuar inteira se reestruturando por outras vias, driblando assim boa parte dos bloqueios.

Ao se focar o olhar no ativismo transnacional, a importância do papel da comunicação digital na estruturação deste tipo de movimento pode ser explicada através de três frentes paralelas, inter-relacionadas e que se potencializam mutuamente: (a) a descentralização através de redes, células ou núcleos espalhados pelo globo e agindo com alguma consonância 
(seja no nível da organização ou da ação) ocorre mediante uma queda drástica no custo e minimização dos constrangimentos, até então tipicamente exigidos para haver articulação transnacional num mundo analógico, isto é, pré-digital; (b) ao mesmo tempo, isso ocorre não apenas baixando o custo, mas também aumentando o potencial da estrutura em fazer mais com menos, ou seja, essa descentralização de base digital é claramente mais eficiente do que qualquer descentralização de base analógica; (c) se por um lado diminui os custos e potencializa a eficiência, isso gera um efeito inverso do outro lado do processo: O hard power de governos e organismos multilaterais ou internacionais continua existindo e atuando como elemento importante na arena internacional, porém isso perde força no mundo online e os custos para combater ou eliminar movimentos ativistas contemporâneos que operam em uma estrutura digital aumentam consideravelmente (já que se soma aos esforços já empreendidos offline), tornando-se por vezes também menos eficientes. É com base nesta estrutura flexível e de alcance global que se tornou possível aos três casos alcançarem e manterem seu caráter transnacional, desafiando potências militares como os EUA ou governos autocráticos árabes. E esses não são casos isolados, já que é possível afirmar que esta é uma tendência relevante que não necessariamente revolucione os embates na arena internacional, mas gera um relevante empoderamento de atores não-governamentais e outros movimentos.

No que se refere à estruturação enquanto movimentos transnacionais, os três casos reforçam aquilo colocado por Reitan $(2007){ }^{184}$ ao explicar teoricamente que o ativismo começa a se estender internacionalmente a partir da troca de informação em redes e da criação de laços com novos atores para revigorar o movimento. Os três tipos de atribuição atuantes neste sentido, conforme propõe o autor, puderam ser identificadas no uso da comunicação nos casos estudados como elementos capazes de envolver os ativistas além das fronteiras, seja a (a) atribuição de merecimento ${ }^{185}$, (b) atribuição de interconectividade ${ }^{186} \mathrm{e}$ (c) atribuição de similaridade ${ }^{187}$. Estas três diferentes formas de atribuição produziram solidariedade e geraram coesão das redes, conduzindo de diferentes maneiras para a ação coletiva transnacional.

\footnotetext{
${ }^{184}$ Capítulo 4, seção 2 desta tese.

${ }^{185}$ Grupos distantes que realizam um merecido esforço de luta são claramente identificados nas células da AlQaeda, na rede de informantes e apoiadores do WikiLeaks e na solidariedade entre os manifestantes dos países envolvidos durante a Primavera Árabe (por exemplo, no Egito lideranças exaltavam, comemoravam e se espelhavam nos protestos da Tunísia).

${ }^{186}$ Grupos que possuem objetivos distintos demonstraram solidariedade para com os três casos, conforme descrito no indicador "engajamento de colaboração".

${ }^{187}$ Global Islamic Media Front, Muslim Hackers Club e Al-Haramain Foundation no caso da Al-Qaeda; As organizações em prol da transparência que organizaram petições em defesa do WikiLeaks e ativistas islâmicos
} 


\subsubsection{Instrumentalização do planejamento}

A combinação de elementos da comunicação digital, tais como fácil acesso, rápida comunicação, anonimato e ubiquidade trazem para o planejamento das ações do ativismo mais instrumentos para coletar dados, instruir ativistas e elaborar estratégias para a causa. Se, por um lado, já se cria um leque de opções para grupos que não sofrem nenhum tipo de constrangimento ou restrição de governos ou corporações, isto é especialmente potencializador para grupos que são privados de uma livre associação pública, como foi no caso dos levantes da Primavera Árabe, ou até mesmo clandestinos, como a Al-Qaeda. Embora o WikiLeaks resvale no fundamento jurídico de ser uma organização legal, também sofre repressão de outras naturezas, conforme foi observado nas restrições econômicas de empresas online, além do monitoramento constante de países diretamente afetados pelos seus vazamentos, como os EUA.

Aliás, no âmbito das atividades instrutivas, a sujeição de monitoramento e de controle governamental é uma preocupação constante entre os três grupos. Por isso, dentre as orientações disponibilizadas online têm-se os cuidados para driblar a vigilância e evitar a produção de rastros como, por exemplo, a recomendação de uso de instrumentos que evitem a identificação do usuário ao entrar na rede. Por exemplo, o Wikileaks estimula que o vazamento seja realizado a partir de um computador diferente da residência ou do trabalho do informante, pois a depender do teor que este sujeito tem acesso, há um aparato de segurança por parte do Estado ou corporação para vigiar as possibilidades de roubos e compartilhamentos indevidos de dados sigilosos, até mesmo com instalação de câmeras em seus computadores pessoais. A repressão estatal, incluindo riscos de multas, prisão e outras punições ainda mais graves por parte de um regime autoritário, conduziram os ativistas tunisianos e egípcios a recorrer ao anonimato nas redes sociais ou ao uso de artifícios técnicos para driblar o corte de sinais de Internet ou determinadas plataformas essenciais para a organização dos protestos. Especialistas em cyberplanning, os militantes da Al-Qaeda sabiam utilizar espaços como cibercafés e ligações em Skype (onde a ligação é criptografada) para elaborar seus planos de ataques terroristas. Muitas vezes esses aparatos técnicos não eram tão elaborados, com apenas trocas de senhas de e-mails que não se completavam o envio. Essas

que apoiavam os levantes em outros países apontando a repressão estatal, o autoritarismo e injustiça social como um elemento comum entre eles. 
instruções online também surgiam a partir de atividades colaborativas. O compartilhamento de conteúdos resultantes do aprendizado de erros aumentava a garantia de êxito futuro.

Essas ações instrutivas se tornam fundamentais para a construção das estratégias de sobrevivência e também das próprias ações-bases dos movimentos. Por exemplo, o sequestro de informações e o vazamento de dados para o WikiLeaks era incentivado e viabilizado graças à comunicação digital, demonstrando ser improvável de ocorrer na mesma escala e amplitude de outra maneira, já que representaria riscos à preservação da identidade e privacidade do informante. Enquanto a Al-Qaeda disponibilizava manuais de preparação de bombas caseiras e táticas de ataques (com transferência do espaço real de treinamento), a Primavera Árabe circulava manuais de como se comportar nos protestos e se proteger de ações violentas potencialmente perpetradas pelas forças de segurança do regime.

Uma vez que não há grandes barreiras na disponibilização destes manuais e treinamentos online por parte dos grupos ativistas, nota-se que o alcance de suas estratégias atinge um público maior para além dos ativistas mais profundamente engajados na causa. Isto acaba servindo também como uma forma de promover a luta, pois permite algum nível de segurança, incentivando assim a promoção do auto-recrutamento, diminuindo os esforços de angariar indivíduos e, consequentemente fortalecendo o movimento (o que demonstra o retroalimento de um indicador no outro).

A viabilidade de disponibilizar informações está diretamente relacionada com a facilidade de obter informações na rede online. Por isso, outra forma de contribuir para o planejamento é a datificação viabilizada pela ferramenta digital. O grande volume de dados disponíveis online serve tanto para facilitar o planejamento de ações, quanto viabiliza o trato das informações, sejam elas inclusive confidenciais, minimizando os riscos de se conseguir tais dados, embora possa haver rastros virtuais. É um bom exemplo desse tipo de coleta de dados: A compilação de informações para comprovar irregularidades de governos, como os insumos usados para os vazamentos do WikiLeaks. Embora o grande volume represente uma oferta não viável de maneira analógica, pode ser um problema na medida em que a falta de organização de dados não tenha significado imediato. O manejo de softwares e plataformas de processamento de dados, por sua vez, suprem as necessidades nesse processo e conferem mais elaboração na elaboração das ações. Interessante observar que tanto a coleta de dados abertos, arquivos e informações livres, disponibilizadas cada vez mais em países democráticos, quanto o roubo ou manipulação de informações feitas por grupos terroristas ou por ações de 
ciberespionagem, contribuem igualmente como insumos informativos para o planejamento do grupo.

A possibilidade de cocriação de planos de forma descentralizada (sem precisar reunir pessoas em um mesmo espaço físico) e colaborativa também é um elemento importante nesta instrumentalização do planejamento. O processamento de informação para gerar conhecimento passa a ser customizado, isto é, pode ser combinado a partir de diversas colaborações espalhadas pelo mundo, aumentando exponencialmente a qualidade das estratégias que tendem a aumentar a eficiência das ações. Somando-se a isso, a comunicação digital possibilita o desenvolvimento de protocolos próprios, sobretudo em razão do volume de um conteúdo a ser trabalhado, que seria inimaginável de ser tratado e organizado de maneira física com a mesma agilidade e rapidez que lhe é conferido no meio virtual.

\subsubsection{Diversificação da ação}

O repertório e o conjunto de performances pré-configuradas que guiam determinadas ações de um movimento, conforme o propôs Tilly (2006), esteve historicamente circunscrito a marchas populares, protestos pacíficos, campanhas, inclusive também a ações mais violentas, como revoltas armadas e até atentados (estes últimos situados ao extremo do espectro de ações). Com a comunicação digital estas ações continuaram a ser desempenhadas, conforme visto nos indicadores anteriores, mas tendo um novo elemento na equação, com interferência em maior ou menor grau, mas que não podia mais ser ignorado na dinâmica do ativismo. Na prática, o ambiente digital tem trazido novas performances que ainda estão em estágio inicial de configuração. Isto porque é de algum modo recente o processo pelo qual a ferramenta digital passou a fazer parte da realidade das relações sociais, cada vez mais apropriada para as atividades de rotina do indivíduo comum. Naturalmente, o ativismo e sua dinâmica incorporaram as práticas da comunicação digital em seu modus operandi, como acontecia em todas as outras esferas da vida social.

Curiosamente, na era digital, observa-se que a ação em si do ativismo no ciberdomínio pode não ser a principal face dos usos da comunicação digital a depender do grupo analisado. E esta pode ser uma das razões para que muitos autores que se enveredam a analisar o papel da tecnologia digital na sociedade mostrem-se pouco entusiasmados com as novas tecnologias. Eles tendem a descartar o alto impacto da comunicação digital no ativismo e a 
criticar a superestima que o assunto recebe nos meios acadêmicos e noticiosos. Nessa esteira, tem-se a crítica de pouca mudança trazida pelos meios online, bem como a questão do "Twitter revolution" como uma falácia exagerada, ou o "ativismo de sofá" como uma minimização do impacto de uso das ferramentas online, que seriam incapazes de promover uma real mudança política e de reestruturação social. Porém, como visto, a comunicação digital contribui com diversos elementos durante as etapas da dinâmica ativista e ainda que aparentemente não estejam claramente ligadas à ação-fim do grupo (aquela que tem maior visibilidade e impacto na opinião pública) esta própria ação só foi possibilitada muitas vezes em razão do uso prévio do ambiente digital (seja para configurar a causa, estruturar a organização ou instrumentalizar o planejamento) .

Além disso, a ação em si é diversificada a partir de novas opções trazidas com os cibereventos e ciberataques. Portanto, aumenta-se o leque de oportunidades de desempenho de uma causa a partir de ações online. Nem todos os grupos fazem uso dessas modalidades. No caso de cibereventos, o caráter público deste tipo de ação online gera uma tendência maior de possibilidade de repressão a partir do monitoramento digital dessas ações, como ocorreu nos repressivos governos durante a Primavera Árabe. As formas de cibereventos geralmente operam no nível do soft power, pois nem sempre significam real enforcement capaz de obrigar poderosos players a se curvarem diante das reivindicações. Um exemplo disso são as petições online. Na maioria dos países este tipo de ciberevento ainda não é reconhecido pela estrutura legal ou constitucional a ponto de terem o mesmo efeito que uma petição tradicional. $\mathrm{Na}$ prática, servem como termômetro do apoio do público a uma causa e oferecem pressão simbólica de adesão à bandeira.

Assim, o fato de não haver exemplos tão expressivos de cibereventos nos estudos de caso trazidos nesta pesquisa pode indicar tanto o uso preponderante do meio tradicional para o exercício das ações, como também a falta de familiaridade com as manobras de ações desta esfera, que muitas vezes exigem um conhecimento técnico mais apurado (ainda não comum entre um grande coletivo de pessoas), ou ainda a própria falta de legitimidade que ações dessa natureza ainda apresentam frente a impactos políticos almejados. E a depender da própria natureza da mobilização (se é de cunho democrático ou não, por exemplo, se é clandestina ou violenta etc.) pode interferir diretamente no uso do repertório de cibereventos. A Al-Qaeda é um bom exemplo das razões dessa não-apropriação.

Já em relação aos ciberataques, é possível observar na análise dos casos que a ocorrência deste tipo de ação também não foi significativa, embora em cada um deles tenha 
ocorrido em graus e formas diferentes. Isso se explica pois a ação online na forma de ciberataque requer uma expertise (que podemos compreender como um recurso), que nem sempre está disponível para todos os movimentos. A análise demonstrou que as formas de uso das ferramentas de comunicação digital - mundano, especializado, emergente e avançado mais recorrentes foram as duas primeiras tipologias. As duas últimas também tiveram registro, porém de modo mais localizado, principalmente através da colaboração de outros grupos que detinham tal expertise. Isso demonstra que (a) as ações mais complexas que demandam certo know how tecnológico - como ciberataques - ainda não são parte do repertório de ação e do cotidiano de todas as formas de ativismo e (b) que isso não impede que os recursos deste tipo de ação sejam "emprestados" na forma de solidariedade entre movimentos, mesmo que não tenham bandeira em comum. Em termos de hipóteses, é possível pensar que há uma tendência de espraiamento desse know how para diferentes grupos sociais com o tempo e isso pode se transformar em algo mais comum do que é agora. Ao mesmo tempo, também vale lembrar que boa parte dos ciberataques são considerados ilegais e requerem uma decisão política e seus custos e consequências.

Mas, como vimos nos casos, o fato de um grupo não possuir capacidade técnica de realizar ciberataques por si só não quer dizer que este é um recurso restrito à movimentos hackers. Esta necessidade de know how para ataques no ambiente ciber é corroborado nos casos aqui estudados com a participação de terceiros (grupos ou indivíduos que se solidarizam com a causa, ainda que atuem em outro campo ativista). O Anonymous é um grupo chave para ilustrar este ponto. Agiu através de ciberataques, como a retaliação aos bloqueios econômicos que a organização do WikiLeaks sofreu de forma direta, por empresas, e de repressão indireta, por países. Este mesmo grupo agiu em colaboração de outros hackers ativistas da Primavera Árabe para fazer contraponto a repressões que os contrários aos regimes autoritários sofriam online pelos governos e seus grupos de endosso. No caso da AlQaeda, o grupo Muslim Hackers Club também passou a agir instruindo simpatizantes a desenvolver ciberataques em apoio àquela organização.

Outro tipo de ataque online compreendido nesta pesquisa é a ciberespionagem. Entende-se que invadir um sistema online e roubar informações como parte da estratégia de ação é em si, uma ação séria de invasão, que se traduz num impacto de violação na rede. A ciberespionagem já vem sendo usada pelo grupo da Al-Qaeda, principalmente para identificar informações sigilosas e expor alvos, ou auxiliar nos ataques físicos. Se para o referido grupo terrorista este tipo de ataque é de natureza complementar, para o WikiLeaks é peça essencial 
para o desenvolvimento da ação final: Os vazamentos. Para o WikiLeaks, suas ações se comportam numa relação arquidependente da comunicação digital, principalmente porque os vazamentos ocorrem exclusivamente através desse meio em sua webpage, com possível permeação de outras mídias, massificando e difundindo o conteúdo.

Por fim, importante perceber que se por um lado o ambiente digital ainda não é o espaço-mor de desenvolvimento da ação-fim do ativismo transnacional contemporâneo (pelo menos nos três casos analisados), os recursos digitais tornaram os movimentos mais resistentes ao ataque dos grandes players como governos de estados poderosos dotados de grande potência militar. Paralelamente, o aumento das conexões no além-fronteiras e a possibilidade de formação de redes de apoiadores, simpatizantes ou colaboradores, também são elementos novos nas ações de contra-ataque. Em todos os casos, isso se tornou bastante evidente. 


\section{CONCLUSÃO}

Esta pesquisa de doutorado teve como principal objetivo compreender e caracterizar os efeitos fundamentais da comunicação digital no fenômeno do ativismo transnacional. A partir desta questão central, outros objetivos se desdobraram para guiar o horizonte deste trabalho: (a) contribuir para os estudos sobre Relações Internacionais e Comunicação Social, especificamente no tocante ao papel das novas tecnologias de informação e comunicação nesta intersecção; (b) desenvolver uma compreensão atual sobre os modos que o ativismo transnacional contemporâneo tem se apropriado da comunicação digital e que impactos isso tem gerado em sua própria forma de existência e atuação; (c) desenvolver indicadores úteis para o estudo sobre esta relação; (d) Identificar elementos da apropriação da comunicação digital pelo ativismo transnacional que interferem nas relações internacionais. Como se pôde notar, o desenvolvimento da pesquisa requereu o transitar em três grandes áreas de estudo que, historicamente, nem sempre estabeleceram diálogos sistemáticos: Relações Internacionais; Comunicação Social e Tecnologia. Buscou-se assim produzir conexões entre essas áreas, através da cobertura do estado da arte naquilo que dizia respeito ao tema da pesquisa em cada um desses âmbitos.

Para alcançar os intuitos almejados, este estudo buscou clarear conceitos e terminologias que embasam o fenômeno em análise. Em relação ao que se compreende como ativismo transnacional, a pesquisa defendeu que, para se ter um conceito mais preciso e operacionalizável desta expressão deve pressupô-lo como um fenômeno de ação coletiva de ênfase política. Não deve ser atrelado apenas aos movimentos cujas bandeiras e métodos são considerados juridicamente legais, legítimos, do ponto de vista moral, ou ético. Assim, considerou-se que as diversas linhas de grupos políticos (sejam grupos rotulados como terroristas, grupos de direita, movimentos sociais, organizações liberais, grupos de esquerda etc.) devem ser consideradas formas de ativismo político. Esta afirmativa possibilita analisar o fenômeno do ativismo de forma adequada, evitando recortes metodológicos baseados em julgamentos morais como premissas, o que causaria uma perda na análise mais complexa e completa do fenômeno. Ou seja, as formas de ação, táticas e estratégias de grupos ativistas devem ser compreendidas como métodos e não como elementos definidores sobre o que é, ou o que não é, ativismo. Por isso, acredita-se que segmentar os estudos prejudica o diálogo de literatura e de método, provocando lacunas na compreensão de ações coletivas de maneira 
geral. Isso não significa que a questão moral seja irrelevante. Isso pode e deve ser analisado como um importante aspecto do fenômeno. Mas não como seu definidor.

Também frisou-se que o ativismo transnacional não se trata de algo inédito - pois há registro deste fenômeno desde o século XIX. Ao mesmo tempo, deve ser visto como o mesmo processo político contencioso de ação coletiva que chamamos de ativismo em geral, mais especificamente em sua forma transnacional. O que há de inovador são os padrões, a escala e a dinâmica deste fenômeno, que hoje ocorre de modo distinto do que foi no passado. E se o ativismo transnacional não é o mesmo neste começo de século, os usos da comunicação digital são parte da explicação para esta mudança.

Ao se propor analisar qual o papel da comunicação digital no ativismo transnacional foi preciso adentrar na relação entre tecnologia e sociedade, como preceitos de base. Duas visões foram identificadas nesta interseção: de um lado o determinismo tecnológico, que vê o artefato técnico como um ente autônomo, capaz de alterar os rumos e as práticas sociais e o próprio andar da História; do outro, o construtivismo social, que vê os objetos técnicos como um constructo social, um resultado das forças sociais, culturais, políticas e econômicas que agem em seu design e definem seu sentido de uso. Argumentou-se que essas posições possuem fragilidades e acatá-las, sem combinar o que possuem de mais sólido, repercutiria em lacunas. Após delinear os problemas em ambas as perspectivas, sem descartá-las por completo, optou-por uma perspectiva intermediária denominada momentum tecnológico que busca levar em conta o papel social na construção dos artefatos técnicos e, ao mesmo tempo, não negar que a tecnologia também pode ganhar algum grau de autonomia e atuar como vetor que altera as práticas sociais. A partir desta concepção pudemos compreender de modo mais preciso a dinâmica dos usos sociais da tecnologia, o que reverbera diretamente nos usos políticos. Isto significou afirmar que a apropriação e ressignificação dessas ferramentas não é unidirecional e linear: as formas de uso de uma tecnologia podem ser mais moldadas pela própria tecnologia, ou podem moldá-la mais intensamente, a depender do momentum, pois não se trata de uma relação fixa no tempo.

Assim, olhando para os estudos de caso, o design em rede e a lógica fugidia da comunicação digital enquanto constructo social, nota-se como este conjunto de elementos influenciou a forma como ativistas articularam suas causas, suas estruturas de funcionamento e ampliou o leque de seus repertórios de ação. Porém, isso só foi possível porque (a) os 
objetos técnicos ganharam em maturidade e encontraram um momentum propício para esta influência; (b) havia contexto político e social que convergia para esta forma de apropriação.

Com esses conceitos bem delineados, a compreensão do fenômeno da comunicação digital pôde então ser adensado, partindo de suas origens, modo de funcionamento e peculiaridades, demonstrando a relação entra as camadas física, lógica e informacional que compõem o ciberespaço, além de explicar sua natureza descentralizada e distribuída, rompendo com o modelo comunicacional anterior. Explicou-se que a proposta de analisar os efeitos da comunicação digital no ativismo transnacional não deve ser confundida com a análise dos efeitos do objeto tecnológico nas práticas políticas. A comunicação digital não seria o artefato e sim o processo social do ato de se comunicar através da plataforma digital. Naturalmente, isso não nega o papel e impacto dos objetos em si, mas torna a análise mais completa e não determinística, uma vez que trabalha um fenômeno social que vai além dos artefatos, ainda que ocorra em seu bojo.

Assim, a popularização da comunicação digital, principalmente através da Internet, tem gerado impactos relevantes na vida de cidadãos, grupos, organizações e governos, inserindo novos ingredientes no caldeirão das práticas sociais. A partir daí, buscou-se sintetizar quatro principais conjuntos de impactos: (1) a intensificação da conectividade midiática, que envolve colocar os indivíduos em um estado de conexão midiática online permanente; (2) o fomento à agregação de ideias, que consiste na ampliação das oportunidades que os indivíduos possuem hoje à disposição para aglutinar princípios, ideologias, convicções etc.; (3) o aumento perceptivo da realidade, que significa o aumento exponencial dos fluxos de informação para além dos filtros formais em tempo real, fazendo circular globalmente narrativas e informações sobre a realidade que nos cerca; e (4) a ampliação da difusão de poder, que dá aos indivíduos um maior poder para desempenhar atividades através de redes de apoio e colaborativas, reforçando o potencial de ação coletiva. Todos esses impactos, amplamente corroborados pelos chamados Internet Studies produzidos nas últimas duas décadas reverberam, naturalmente, nas práticas políticas, incluindo a forma como a ativismo hoje é configurado tanto em nível nacional quanto transnacional.

Com a discussão de base efetivada, a pesquisa analisou a relação entre Comunicação digital e Relações Internacionais, levando o fenômeno para o campo mais específico das RI. Apontou-se que no Realismo a tecnologia é um artefato passivo e exógeno, uma fonte de poder econômico e militar. Para o liberalismo, o objeto técnico é visto como um fator exógeno que impulsionaria a transnacionalização e a difusão de poder, viabilizando desde 
transações econômicas até destruições globais, redimensionando a configuração de poder e facilitando a emergência de novos atores. Para o construtivismo a tecnologia seria socialmente guiada pelas forças sociais, posicionando-se assim como um constructo social que influencia as estruturas políticas, incluindo aí os assuntos globais. Na nova Escola de Copenhagem, a compreensão de tecnologia dentro do campo de securitização prepondera. Outras vertentes de análise também foram elencadas e demonstrou-se que o volume ainda é escasso de autores das várias escolas teóricas que tratem de forma mais sistemática os fenômenos trazidos pelas Tecnologias de Informação e Comunicação (TICs) a partir de suas lentes. Como um todo, estes estudos demonstram a forma de algumas abordagens de RI endereçarem o ciberdomínio, trazendo assim contribuições para a análise, ao mesmo tempo que levantou-se que há hoje uma dificuldade em tratar da comunicação digital conforme os modelos tradicionais das teorias. Embora o ativismo transnacional possa cruzar diferentes lentes teóricas supracitadas, para fins desta pesquisa este fenômeno não poderia ser devidamente compreendido, no atual contexto da comunicação digital, por nenhuma perspectiva teórica em específico. Por outro lado, as abordagens teóricas, ainda que incompletas per $s i$, podem ser úteis apenas ao serem combinadas (extraindo o que tem de mais sólido e descartando o que há de mais frágil), adotando-se assim a perspectiva de um pluralismo teórico já que nenhuma teoria, in totum, conseguiria dar conta deste complexo fenômeno.

Apesar disso, identificou-se que duas linhas de estudo têm emergido nesta intersecção entre TICs e RI e vem se configurando como campos de análise promissores, com um crescente volume de trabalhos (ainda que incipiente). A primeira delas é a cibersegurança que está fortemente marcada pela tematização do conflito. Nesta linha, as contribuições sobre a caracterização de ciberataques, ciberdefesa e novas formas de embates no ciberdomínio são contribuições relevantes. A segunda linha de estudo, cibergovernança, trabalha a gestão internacional da rede e as relações de poder que se estabelecem nesta arena. Embora nenhuma delas consiga tratar a relação entre ciberdomínio e ativismo transnacional de forma efetiva e sim tangencial, ambas trazem contribuições relevantes que foram incorporadas como background para o desenvolvimento desta pesquisa: no caso da cibersegurança, os estudos sobre ciberataques, suas tipologias e caracterização; no caso de cibergovernança, as análises sobre o gerenciamento que ocorre através de uma cooperação público-privada, ou seja, um esquema híbrido combinando auto-regulação, controle governamental e capacidades de enforcement, além da percepção de que não se trata de um bem comum, porque parte de sua 
estrutura está sob controle de soberania estatal e pode ser influenciada por esta, embora os governos nacionais tenham uma enorme dificuldade em impor-se devido à própria característica do meio.

A discussão teórica deixou evidente que, na verdade, os atores não-tradicionais nas RI (como indivíduos e ativistas) têm aumentado seu poder através do ciberespaço. Na prática, indivíduos conectados uns aos outros através da Internet podem produzir novos formatos de ação coletiva transnacional. Argumentou-se que este é um ponto importante de inflexão para os grupos sociais, uma vez que este novo contexto favorece outros players além dos Estados, e que não estão focados somente no monopólio da força ou buscando apenas resultados no ciberdomínio. Mas isso não significou o fim do poder do Estado como um dos principais players na arena internacional. É preciso reconhecer a permanência do poder econômico e militar para coagir de forma ainda eficiente. Seria ingênuo, portanto, reduzir a importância dos elementos da hard power nos estudos de relações internacionais. Porém, é ainda mais ingênuo desconsiderar a importância da força que os atores não-estatais têm exercido no cenário internacional. Por isso, é preciso reconhecer outros mecanismos de ação que vêm ganhando força política e angariando bons resultados, pois o ciberespaço se tornou um novo domínio de poder onde os Estados continuam atuando de forma expressiva, porém de forma menos enfática e determinante como foi até o século XX. Por isso, argumentou-se que uma das principais alterações provenientes da nova estrutura do ciberespaço não é o surgimento de novos atores não-estatais, pois esses já vinham desempenhando um papel cada vez mais crescente ao longo do século passado, mas sim uma maior difusão do empoderamento entre os atores, de modo que a disponibilidade de novos recursos para o embate trouxe uma maior pluralidade de vozes que se fazem mais evidentes, ouvidas e impactantes na arena internacional, além do aumento da capacidade de articular e atuar frente ao poderio de governos e corporações internacionais, uma vez que o cyberpower insere novas características no jogo. Esta alteração pode ser considerada um ponto crucial no entendimento do papel da comunicação digital nas relações internacionais, já que abre margem para um novo tipo de poder que emerge neste contexto.

A partir da contribuição de diversos analistas, o estudo também demonstrou que, ainda que os atores não-estatais (incluindo grupos ativistas) tenham se sobressaído neste novo domínio, isto não significa que o poder está devidamente equilibrado entre atores estatais e não-estatais pois as assimetrias continuam, porém, com novos componentes que alteram esta relação. Isso afeta diretamente a forma como o ativismo transnacional se desenha neste século 
XXI, uma vez que as ações coletivas que transpassam fronteiras se fortaleceram enquanto fenômeno político devido à potencialização dos próprios fluxos de interação, estrutura em rede, caráter distribuído da comunicação digital e o empoderamento de atores não-estatais diante de um novo domínio de embate.

Em linhas gerais, todas estas abordagens teóricas, principalmente as correntes mais contemporâneas, trouxeram elementos específicos úteis para uma boa compreensão da dinâmica do ativismo hoje. Embora cada uma tenha suas limitações e embates próprios, buscou-se combiná-las naquilo que são complementares organizando suas contribuições em torno dos eixos fundamentais através dos quais a dinâmica do ativismo poderia ser analisada. A partir daí, foram identificados cinco efeitos fundamentais da comunicação digital sobre a dinâmica do ativismo transnacional: (1) estímulo à configuração da causa; (2) multiplicação do engajamento; (3) flexibilização da estruturação; (4) instrumentalização do planejamento; (5) diversificação da execução de ações.

A configuração do ativismo transnacional se dá em torno de uma causa inicial, uma ideia política através da qual será erguido um conjunto de reivindicações. Trata-se do processo de formação das bandeiras, dos objetivos e argumentos que darão a forma conceitual, teórica e ideológica do movimento em questão. A comunicação digital acelera processos de convergência de ideias e serve como um elemento catalisador fomentando a formação de causas, agregando indivíduos mesmo que estejam dispersos espacialmente.

O engajamento consiste no fenômeno do envolvimento político de indivíduos que constituirão a base de recursos humanos necessária para a concretização da ação coletiva. Demonstrou-se que a comunicação digital representou, para indivíduos e grupos, maiores possibilidades para o engajamento político do que havia há duas décadas, antes da Internet. Isso ocorreu principalmente diante do crescimento dos canais de visibilidade, da expansão das oportunidades para o engajamento político, gerando um contexto de múltiplos estilos e graus de envolvimento disponíveis e do aumento do nível de personalização do engajamento político, expandindo-o até o grau das relações interpessoais e subjetivas.

A estruturação de um movimento ativista trata-se do modo o como é organizado, o design sobre o qual o movimento está arquitetado. Na prática, as ferramentas online permitiram conectar de uma maneira inédita movimentos políticos transnacionais levando a concepção de organização em rede a cabo, tornando sua estrutura mais flexível, quebrando assim a tendência de uma organização em formatos rígidos, mas não descartando a coexistência destas. 
Já o planejamento é o processo de elaboração racionalizada dos passos que a ação percorrerá. Através da comunicação digital, os ativistas têm mais ferramentas para reunir informações, avaliar cenários e desenhar táticas e estratégias. O planejamento se tornou mais instrumentalizável, isto é, com maior disponibilidade de ferramentas e insumos a seu dispor a um custo menor, que pode repercutir na qualidade da ação coletiva.

Por fim, a execução da ação é a concretização de iniciativa que busca atingir determinado intuito, seja uma meta ou a própria realização de determinada causa. Tendo em vista que o próprio ciberespaço é uma nova arena de embate, com seus recursos e repercussões próprias e cada vez mais acoplados à vida moderna, através da comunicação digital ativistas têm hoje diferentes modos para realizar seus objetivos lançando mão de ações online que significam um incremento no repertório e performances disponíveis.

As tecnologias digitais de comunicação, na qual a Internet está inserida enquanto fenômeno, têm alcançado um relevante papel na mudança dos processos comunicativos em escala mundial. No nível social esses processos comunicacionais estão afetando a própria estrutura, dinâmica e empoderamento da ação coletiva transnacional. Todos esses efeitos sumarizados representam um conjunto de inovações que não refundam um novo tipo de ativismo, mas coloca este fenômeno em um novo patamar de análise que merece ser analisado de forma mais sistemática.

Para testar, comprovar e ilustrar as análises produzidas, optou-se por uma análise baseada em método qualitativo de fenômenos representativos do problema proposto. Especificamente, considerou-se o método do estudo de caso apropriado uma vez que são capazes de ilustrar e aprofundar o fenômeno a partir do cruzamento de diferentes fontes de informação: pesquisas quantitativas e qualitativas; análises teóricas; estudos sobre os eventos; relatos sobre os fatos. Assim, três estudos de caso foram selecionados por se tratarem de exemplos emblemáticos deste cenário: (a) Al-Qaeda; (b), WikiLeaks; e (c) Primavera Árabe. O primeiro caso se refere a uma rede terrorista, uma organização pan-islâmica fundamentalista, que opera através da estruturação de células descentralizadas, utilizando-se da comunicação online para se organizar, planejar e executar ações. O segundo caso diz respeito a uma organização transnacional, composta por uma rede de ativistas atuantes em diversos países, cuja bandeira é difundir informações sigilosas de governos em prol do que denominam de "transparência total". O terceiro, a Primavera Árabe, trata-se de um fenômeno político ocorrido em países do Oriente Médio e Norte da África, caracterizado por uma onda 
de protestos, repercutindo na derrubada de governos em países como a Tunísia e Egito, mas se formatando na verdade como um complexo movimento transnacional.

Argumentou-se que a escolha desses três objetos ocorreu justamente por se tratarem de formas de ativismo transnacional que carregam suas peculiaridades e são eventos emblemáticos deste início de século, sendo assim considerados representativos para se aplicar uma análise que servisse para ilustrar as categorias de efeitos bem como para identificar as peculiaridades ou questões gerais que emergem dessa problemática.

Para operacionalizar o estudo de forma mais concisa, criou-se um conjunto de indicadores para as respectivas categorias de efeitos, totalizando assim um total de 14 indicadores: articulação, difusão, massificação, coordenação, adesão, colaboração, virtualização, descentralização, transnacionalização, elaboração, datificação, instrução, ciberevento e ciberataque.

Isso nos permitiu esmiuçar e observar melhor a microfísica que compõe as categorias de efeito, analisar onde cada indicador representa um elemento ou uma característica da categoria em questão, de modo que para cada um deles foram pensados elementos práticos que comprovam a sua existência (ou inexistência) e a forma como ocorre.

No caso da Al-Qaeda, o ambiente digital não foi um elemento fundamental para o surgimento da causa, uma vez que suas origens são anteriores ao próprio advento da Internet como meio de comunicação acessível ao público mais amplo. Ao mesmo tempo, se não foi determinante para a articulação da causa, identificou-se que o ciberespaço foi um elemento fundamental na reconfiguração do movimento após o 11 de Setembro. A difusão posterior do movimento ocorreu em grande parte através da Internet, uma vez a própria clandestinidade que caracteriza a organização aliada às facilidades da propaganda online (de baixo custo e de potencial alcance global) foram ingredientes convergentes. No quesito engajamento, demonstrou-se que a comunicação online possibilitou que as lideranças se mantivessem ativas, seja no nível operacional, seja no nível simbólico e propagandístico, divulgando diretrizes e exaltando a luta. Isso também possibilitou a inserção do auto-recrutamento como uma importante característica do modo de engajamento de apoiadores e simpatizantes, multiplicando assim as formas de envolvimento com a organização. No tocante à estrutura, demonstrou-se que a própria forma de organização da Al-Qaeda foi adaptada para um formato em rede, principalmente após as repressões que culminaram com a desarticulação de suas bases físicas. O locus digital se tornou o principal meio de estruturação deste movimento. Quanto ao planejamento, o estudo apontou que a instrumentalização de ações através de 
cyberplanning se tornou um importante recurso na elaboração, coleta de dados e produção de estratégias prévias aos ataques terroristas. Já a utilização do ciberespaço como arena de ação propriamente dita não foi um elemento amplamente utilizado pela organização. No caso de cibereventos, isso se explica devido ao elemento clandestino e violento que caracteriza este tipo de ativismo, o que dificulta mobilizações online públicas. No caso de ações na forma de ciberataques, também não há registro de atividades de fato relevantes e concretas, embora haja informações sobre articulação de indivíduos e grupos islâmicos com expertise hacker, difundindo formas de executar ciberataques em apoio à luta da Al-Qaeda. A hipótese levantada, neste último caso, é que este know how pode ser adquirido com o tempo, embora ainda bastante oneroso e sofisticado, e que ataques cibernéticos na forma de terrorismo podem ser um horizonte cada vez mais comum para este tipo de organização.

No caso do WikiLeaks, a articulação da causa está claramente vinculada ao uso do ambiente digital, uma vez que os seus fundadores, as ações precedentes e o próprio projeto desta organização esteve desde do início inserida em ambientes hackers. Ao mesmo tempo, a organização se tornou amplamente difundida e conhecida em todo o mundo em função da sinergia entre mídias digitais e mídias tradicionais, como o jornalismo formal. No processo de engajamento, demonstrou-se que suas lideranças puderam manter a organização em funcionamento por terem um amplo leque de canais online para agir. Paralelamente, o ciberespaço possibilitou o engajamento online de indivíduos e outras organizações ao redor do mundo, seja através de doações online, colaborações com serviços, expertise ou apoio político. Observa-se, portanto, um leque de formas de envolvimento que seriam dificilmente concretizadas na abrangência que ocorreu sem o ambiente digital para viabilizá-las em termos práticos. A análise também comprovou a flexibilidade de estruturação que a comunicação digital possibilita ao demonstrar-se que o WikiLeaks se construiu em torno de uma dupla forma de organização: (a) centralizada no nível da tomada de decisão e (b) descentralizada no nível da ação, principalmente no que diz respeito à coleta de informação sigilosa por parte dos informantes, que não possuem uma relação de subordinação ao núcleo mais duro das lideranças. No nível do planejamento, o estudo também apontou a intensa instrumentalização dos processos de elaboração, coleta de dados, principalmente através de vazamentos digitais e instruções para redes de apoiadores sobre como vazar dados de forma planejada dirimindo riscos de segurança e repressão. $\mathrm{O}$ ambiente digital também possibilitou a produção de campanhas em prol do grupo na forma de cibereventos. Ao contrário da Al-Qaeda, este tipo de ação foi mais recorrente devido à identificação da causa com bandeiras liberais 
consideradas legítimas, como a transparência e luta contra o autoritarismo de Estado (ainda que os governos acusem a organização de praticar e estimular a ciberespionagem como uma atividade ilegal). Além disso, os ciberataques tiveram um papel importante no grupo, sobretudo a partir da participação da rede de colaboradores, como foi o caso do Anonymous.

Na Primavera Árabe, o estudo de caso também identificou a comunicação digital como um forte componente na articulação da causa, difusão e massificação do movimento. Isso não significou, como foi ressaltado, que os levantes populares ocorreram apenas em função das ferramentas digitais de comunicação e sim a partir da combinação de uma série de fatores contextuais (políticos, sociais, culturais, econômicos) que foram catalisados pelo meio online. Isso possibilitou a formação de uma ampla rede de engajamento, que vai desde o surgimento de lideranças online (que atuaram criando páginas, agendando eventos, convocando protestos etc.), quanto o envolvimento de um grande número de indivíduos que apoiaram o movimento, seja aderindo aos protestos nos espaços físicos, seja apoiando-os através da Internet, englobando assim diferentes estilos de participação. Do ponto de vista da organização do movimento, as redes sociais significaram um importante meio para estruturação descentralizada que caracterizou os levantes. Ainda que o fenômeno contasse com organizações e lideranças na função de articulação do movimento, estas não se comportavam como centros hierárquicos e sim como nós de uma rede descentralizada. O planejamento dos protestos e as táticas também foram densamente instrumentalizados pelos ativistas através do ciberespaço, como demonstrou o estudo. $\mathrm{Na}$ esfera das ações online propriamente dita, as principais ações da Primavera Árabe ocorreram nas ruas, por isso, a ocorrência de cibereventos se deu em torno da divulgação de chamados de páginas e convocações para as ruas. A própria natureza da mobilização que ganhou escala popular em países de baixa inclusão digital também explica porque cibereventos (protestos e manifestações especificamente online) estavam tão umbilicalmente conectados ao espaço. No caso de atividades online na forma de ciberataque, houve registros desta forma de ação na Tunísia, na Síria e também em outros países em apoio ao movimento, demonstrando que a luta das ruas também foi estendida para o ciberespaço.

Os dados e fatos descritos corroboram e dão concretude às categorias de efeitos e também demonstram a sua complexidade e entrelaçamento. Percebe-se que as categorias de efeitos elencadas nesta pesquisa de doutorado permeiam todos os casos, em menor ou maior grau. Os três estudos demonstram que os efeitos da comunicação digital no ativismo transnacional são fenômenos objetivos que podem ser vislumbrados de modo mais 
sistemático através dos indicadores propostos. Ressalta-se, portanto, que o conjunto de efeitos e seus respectivos indicadores não são estáticos e podem ser ampliados ou até mesmo complementados por outras análises futuras. De todo modo, tratam-se de implicações nos diversos processos que compõem o ativismo em geral, e o ativismo transnacional em específico, e que merecem maiores esforços de estudos pois tendem a reverberar no jogo político mais amplo da arena internacional.

Pode-se afirmar que os indicadores analisados são úteis para qualificar e compreender melhor o fenômeno, traçando assim linhas transversais que nos permitiram perceber, através dos casos, questões relevantes e estruturantes que estão emergindo no cenário internacional e que reposicionam o ativismo transnacional em novo patamar. A análise não coloca a comunicação digital como um fenômeno de rompimento a ponto de afirmar que há hoje um outro tipo de ativismo transnacional totalmente diferente do que houve até então. É demasiado cedo para defender tal afirmativa. O que os dados nos permitem afirmar é que há efeitos relevantes em todos os eixos que estruturam o ativismo e isso coloca este fenômeno em um outro patamar no cenário internacional a ponto de, pelo menos, requerer mais atenção e estudos sobre o seu real impacto a longo prazo. 


\section{REFERÊNCIAS}

ALONSO, Angela. As teorias dos movimentos sociais: um balanço do debate. Lua Nova, São Paulo, n. 76, p. 49-86, 2009.

. Repertório, segundo Charles Tilly: história de um conceito. Sociologia \&

Antropologia, Rio de Janeiro, v.2, n.3, p. 21- 41, 2012.

ANDERSON, Chris. A Cauda longa: do mercado de massa para o mercado de nicho. Rio de Janeiro: Elsevier, 2006.

ASAL, Victor. Cannolis, contention and killing: Mobilizing Ideas, abr. 2012, Is a terrorism a form of activism? 2012. Disponível em:

$<$ https://mobilizingideas.wordpress.com/category/essay-dialogues/is-terrorism-a-form-ofactivism/>. Acesso em: 15 mai. 2015.

ASSANGE, Julian. Interview with Julian Assange: 'We Are Drowning in Material'. Entrevista realizada por Michael Sontheimer. Spiegel Online. Em 20 julho, 2015 Disponível em http://www.spiegel.de/international/world/spiegel-interview-with-wikileaks-head-julianassange-a-1044399.html > acesso: out. 2015.

. WikiLeaks Ensures Government Transparency. In: THOMPSON, Thamara.

(Org). Wikileaks (At issue Serie).Nova York: Greenhaven Press, 2013. p. 64-69.

ASSANGE, Julian; ZIZEK, Slavoj. Amy Godman in conversation with Julian Assange and Salvoj Zizek. In: BREVINI, Benedetta; HINTZ, Arne; MCCURDY, Patrick (Org). Beyond Wikileaks: Implications for the future of communications, journalism and society. Nova York: Palgrave Macmillan, 2013, p. 254-272.

ATWAN, Abdel Bari. The Secret History of al Qaeda (Kindle Editon). Londres: Saqi Books, 2012.

BAKIR, V. Sousveillance, Media and Strategic Political Communication: Iraq, USA, UK Nova York e Londres: Continuum, 2010.

BARBER, Victoria. The Evolution of Al Qaeda's Global Network and Al Qaeda Core's Position Within it: A Network Analysis. Perspectives on Terrorism. V. 9, n. 6, jan. 2015.

BARROS, Samuel; REIS, Lucas. Internet e revolução no Egito: O uso de sites de redes sociais durante a convulsão social que derrubou o governo ditatorial egípcio em 2011. In: CONGRESSO LUSO-AFRO-BRASILEIRO DE CIÊNCIAS SOCIAIS (CONLAB), 11 , 2011, Salvador. Anais eletrônicos...Salvador: UFBa, 2011. Disponível em: http://www.xiconlab.eventos.dype.com.br/resources/anais/3/1308356185_ARQUIVO_INTE RNETEREVOLUCAONOEGITO.pdf. Acesso: 5 jun. 2012. 
BECKETT, Charlie; BALL, James. WikiLeaks: News in the networked era. Cambridge: Polity Press, 2012.

BELOW, Katharina C. The Utility of Timeless Thoughts: Hannah Arendt's Conceptions of Power and Violence in the Age of Cyberization. In: KREMER, Jan-Frederik; MÜLLER, Benedikt (Org.). Cyberspace and International Relations: Theory, Prospects and Challenges. Nova York: Springer Heidelberg, 2014.

BENEDIKT, Michael. Cyberspace: some Proposals. In: Benedikt, M. (Org). Cyberspace: first steps. Cambridge: MIT Press, 1991. p. 119-224.

BENKLER, Yochai. WikiLeaks and the Networked Fourth Estate. In: BREVINI, Benedetta; HINTZ, Arne; MCCURDY, Patrick (Org). Beyond Wikileaks: Implications for the future of communications, journalism and society. Nova York: Palgrave Macmillan, 2013. p. 11-34.

BENNET, W. Lance. New Media Power: the Internet and Glboal Activism. In: Nick Couldry; James Curran (Org). Contesting Media Power. Lanham: Rowman and Littlefield, 2003, p. 17-38.

BENNETT, W. Lance. Communicating global activism : strengths and vulnerabilities of networked politics. Information, Communication \& Society, v.6, n.2, p. 143-168, 2003.

The Personalization of Politics: Political Identity, Social Media, and Changing Patterns of Participation. The Annals of the American Academy of Political and Social Science, n. 664, nov. 2012.

BERGER, Jonah. Contágio: porque as coisas pegam. São Paulo: São Paulo: Texto Editores, 2014.

BERNER, Brad K. El mundo según Al Qaeda. Madri: Editorial Popular, 2006.

BIMBER, Bruce. Karl Marx and three faces of technological determinism. In: Working Paper Number 11. Cambridge. Anais eletrônicos... Cambridge: Massachusetts Institute of Technology, 1990. Disponível em http://web.mit.edu/sts/pubs/pdfs/MIT_STS_WorkingPaper_11_Bimber_2.pdf. Acesso: 25 jun. 2013.

BIMBER, Bruce; FLANAGIN, Andrew J.; STOHL, Cynthia. Collective Action in Organizations: Interaction and Engagement in an Era of Technological Change Cambridge: Cambridge University Press. Kindle ed., 2012.

BOBBIO, Norberto. "Relações Internacionais"(verbete). In: Dicionário de Política. Brasília: UnB, 1986.

BOHORQUEZ, Tysha. Soft Power: The Means to Success in World Politics. Los Angeles: UCLA International Institute, 2005. Disponível em: http://www.international.ucla.edu/asia/article/34734 . Acesso: 23 mai. 2013. 
BRACHMAN, Jarret. Watching the watchers: Al Qaeda's bold new strategy is all about using our own words and actions against us. Foreign Policy, Washington, D.C., v.182, online, out., 2010

HWANG transnacional contra o apartheid na Africa do Sul. Brasília: Fundação Alexandre de Gusmão, 2011.

BREVINI, Benedetta; HINTZ, Arne; MCCURDY, Patrick. Introduction. In: BREVINI, Benedetta; HINTZ, Arne; MCCURDY, Patrick (Org). Beyond Wikileaks: Implications for the future of communications, journalism and society. Nova York: Palgrave Macmillan, 2013. p. $1-10$.

BREVINI, Benedetta; MURDOCK, Graham. Following the Money: WikiLeaks and the Political Economy of Disclosure. In: BREVINI, Benedetta; HINTZ, Arne; MCCURDY, Patrick (Org). Beyond Wikileaks: Implications for the future of communications, journalism and society. Nova York: Palgrave Macmillan, 2013. p. 35-55.

BRODOCK, Katharine. Economic and Social Factors: The Digital (Activism) Divide. In: JOYCE, Mary (Org). Digital Activism Decoded: The New Mechanics of Change. Nova York: International Debate Education Association, 2010. p. 71-84.

BROWN, Chris. International Relations Theory Today. In: BROWN, Chris (Org). Understanding International Relations. $2^{\mathrm{a}}$ ed. Londres: Palgrave, 2001.

BRUNO, Fernanda. Monitoramento, classificação e controlenos dispositivos de vigilância digital. In: ANTOUN, Henrique. (Org.). Web 2.0: participação e vigilância na era da comunicação distribuída. Rio de Janeiro: M53auad X, 2008, p. 167-182.

BRUNS, Axel. Gatekeeping, gatewatching, realimentação em tempo real: novos desafios para o Jornalismo. Brazilian Journalism Research, v.7, n.11, p. 119-140, 2011.

BRYM, Robert. What is the relationship between terrorism and social movements?

Mobilizing Ideas, abr. 2012, Is a terrorism a form of activism? 2012.. Disponível em: $<$ https://mobilizingideas.wordpress.com/category/essay-dialogues/is-terrorism-a-form-ofactivism/>. Acesso: 15 mai. 2015.

BURKE, Jason. Al-Qaeda: A verdadeira história do radicalismo islâmico. Rio de Janeiro: Zahar, 2007.

BURNS, John F.; SOMAIYA, Ravi. Hackers Attack Sites Considered WikiLeaks Foes. Nova York Times, Nova York, 8 Dez. 2010. World, online. Disponível em: http://www.nytimes.com/2010/12/09/world/09wiki.html?_r=0 . Acesso: 18 mar. 2015.

CAMARGO, Julia Faria. Mídia e Relações Internacionais: Lições da Invasão do Iraque em 2003. Curitiba: Juruá, 2009.

CARLOS, Euzineia. Das teorias de movimentos sociais à análise de redes sociais. In: CONGRESO DE LA ASOCIACIÓN LATINOAMERICANA DE SOCIOLOGÍA, 27, 2009, Buenos Aires. Anais... Buenos Aires: Asociación Latinoamericana de Sociología, Buenos Aires, 2009. 
CARR, Madeline. A Political History of the Internet: A Theoretical Approach to the Implications for US Power. In: CONFERENCE PAPERS- INTERNATIONAL STUDIES ASSOCIATION. Nova York. Anais...Nova York: ICA, p. 1-39. 2009.

CASTELLS, Manuel. A sociedade em rede. A era da informação: economia, sociedade e cultura. São Paulo: Paz e Terra, 1999 (Vol. 1)

The Internet Galaxy: reflections on the Internet, Business and Society.

Oxford: Oxford University Press, 2003.

Communication Power. Oxford: Oxford University Press, 2009.

Networks of outrage and hope: Social movements in the internet age.

Londres: Polity Press, 2012.

Redes de indignação e esperança: movimentos sociais na era da internet

(Kindle Edition). Rio de Janeiro: Zahar, 2013.

CASTRO, Marcus Faro de. De Westphalia a Seattle: A Teoria das Relações Internacionais em transição. Cadernos do REL, Brasília, n. 20, p. 5-64, jun/jul. 2001.

CEFAÏ, Daniel. Como nos mobilizamos? A contribuição de uma abordagem pragmatista para a sociologia da ação coletiva. Dilemas - Revista de Estudos de Conflitos e Controle Social, Rio de Janeiro, v.2, n.4, p. 11-48. 2009.

CERF, Vinton G. The day the Internet age began. Nature. International Weekly Journal of Science, Nova York, n.461, p. 1202-1203, out. 2009.

CHANDLER, David. Evading the challenge: The limits of global activism. In: OLESEN, Thomas (Org). Power and transnational activism. Nova York: Routledge, 2011. p. 34-50.

CHOUCRI, Nazli. Cyberpolitics in International Relations. Cambridge: Massachusetts Institute of Technology, 2012.

CHOUCRI, Nazli; CLARK, David D. Integrating Cyberspace and International Relations: The Co-Evolution Dilemma. Explorations in Cyber International Relations. In: MIT/HARVARD. ECIR WORKSHOP ON WHO CONTROLS CYBERSPACE? Cambrige... Anais... Cambridge: MIT, 2012.

CHOUCRI, Nazli; GOLDSMITH, Daniel. Lost in cyberspace: Harnessing the Internet, international relations, and global security. Bulletin of the Atomic Scientists, Chicago, v.68, n. 2, p. 70-77. 2012.

CLARK, David. An Insider's Guide to the Internet (Version 2.0 7/25/04). Cambridge: MIT Computer Science and Artificial Intelligence Laboratory, 2004.

COLEMAN, Gabriella. Anonymous and the Politics of Leaking. In: BREVINI, Benedetta; HINTZ, Arne; MCCURDY, Patrick (Org). Beyond Wikileaks: Implications for the future of communications, journalism and society. Nova York: Palgrave Macmillan, 2013. p. 209-228. 
COLEMAN, Stephen. Can the New Media Invigorate Democracy? The Political Quarterly, v. 70, n.1, p. 16-22, jan. 1999.

COLUMBUS, Simon. The New Casualties: Prisons and Persecution. In: JOYCE, Mary (Org). Digital Activism Decoded: The New Mechanics of Change. Nova York: International Debate Education Association, 2010. p. 165-180.

CONGRESSIONAL Digest. Internet History: From ARPANET to Broadband. v. 86, n. 2, p. 35-64, fev. 2007.

COUTINHO, Sara. The Case of al Qaeda. 2012. 65 f. Dissertação de Mestrado (Mestrado em Estudos em História, Relações Internacionais e Cooperação). Faculdade de Letras, Universidade do Porto. Cidade do Porto, 2012.

COUTO, Sérgio Pereira; DOMINGOS, José Antonio. Wikileaks: Segredos, informações e poder. Bauru: Idea Editora, 2011.

MAYER-SCHONBERER, Viktor; CUKIER, Kenneth. Big Data: como extrair volume, variedade, velocidade e valor da avalanche de informaçao cotidiana. Rio de Janeiro: Editora Campus, 2013.

CUKIER, Kenneth Neil; SCHOENBERGER, Viktor Mayer. The Rise of Big Data: How It's Changing the Way We Think About the World. Foreign Affairs. mai./jun. 2013.

CULLUM, Brannon. Devices: The Power of Mobile Phones. In: JOYCE, Mary (Org). Digital Activism Decoded: The New Mechanics of Change. Nova York: International Debate Education Association, 2010. p. 47-70.

CURRAN, Giorel; GIBSON, Morgan. Wikileaks, Anarchism and Technologies of Dissent. Antipode Foundation,v.45, n.2, p. 294-314, 2012.

DEAN, J. Why the Net is not a Public Sphere. Constellations, v.10, n.1, p. 95-112, 2003.

DEIBERT, Ronald J. International plug'n play? Citizen activism, the Internet, and global public policy. International Studies Perspectives, n.1, p. 255-272, 2000.

DELWICHE, Aaron. Agenda-Setting, Opinion Leadership, and the World of Web Logs. First Monday, v.10, n. 12, online, dez. 2005. Disponível em: http://firstmonday.org/htbin/cgiwrap/bin/ojs/index.php/fm/article/viewArticle/1300/1220 . Acesso: 14 jun. 2013.

DEMANT, Peter. O mundo muçulmano. São Paulo: Contexto, 2001.

DEVILLART, Sem; WANIEWSKI, Brian. The Future of Advocacy in a Networked Age In: JOYCE, Mary (Org). Digital Activism Decoded: The New Mechanics of Change. Nova York: International Debate Education Association, 2010. p. 197-208.

DIANI, Mario. Introduction: Social Movements, Contentious Actions, and Social Networks: 'From Metaphor to Substance'? In: DIANI Mario, McADAM, Doug. Social Movements and Networks: Relational Approaches to Collective Action. Oxford: Oxford University Press, 2003, p. 1-20. 
DIJCK, José van. The Culture of Connectivity: A Critical History of Social Media Kindle ed. Oxford: Oxford University Press, 2013.

DIMAGGIO, Paul; HARGITTAI, Eszter; NEUMAN, W Russell; ROBINSON, John P. Social implications of the Internet. Annual Review of Sociology, n.27, p. 307-336. 200.

DIODATO, Emidio. (Org.). Comunicazione e política internazionale: mutamentistrutturali e nuovestrategie. Rubbettino: Soveria Mannellli, 2004.

DOMSCHEIT-BERG, Daniel.Os bastidores do Wikileaks: A História do site mais controverso dos últimos tempos escrita pelo seu ex-porta-voz. Trad. Petê Rissatti. Rio de Janeiro: Elsevier, 2011.

DREZNER, Daniel W. Weighing the Scales: The Internet's Effect On State-Society Relations. Brown Journal of World Affairs. v.16, n.2, abr/jul. 2010.

DUNN, Hopeton S. "Something Old, Something New... ": WikiLeaks and the Collaborating Newspapers - Exploring the Limits of Conjoint Approaches to Political Exposure. In: BREVINI, Benedetta; HINTZ, Arne; MCCURDY, Patrick (Org). Beyond Wikileaks: Implications for the future of communications, journalism and society. Nova York: Palgrave Macmillan, 2013. p. 85-100.

DUNN, Myriam. The Cyberspace Dimension in Armed Conflict: approaching a complex issue with assistance of the morphological method. Information\& Security, n. 7, p. 145158. 2001.

DURKHEIM, Emile. As regras do método sociológico. $3^{\text {a }}$ Ed. Trad. Paulo Neves. São Paulo: Martins Fontes, 2007.

FEARON, James; WENDT, Alexander. Rationalism v. Constructivism: a skeptical view. In: CARLSNAES, Walter; RISSE, Thomas; SIMMONS, Beth A. (Org). Handbook of Internacional Relations. Londres: Sage Publications, 2002, p. 53-72.

FERABOLLI, Sílvia. Entre a revolução e o consenso: os rumos da Primavera Árabe Ciências \& Letras, Porto Alegre, n. 51, p. 101-109, jan./jun. 2012.

FIDLER, David P. Authoritarian Leaders, the Internet, and International Politics. Journal of Diplomacy \& International Relations, v.15 , n.1, p. 7-21, set/fev. 2014

FRIEDMAN, Thomas. O mundo é plano: Uma breve história do século XXI. Trad. Cristiana Serra e S. Duarte. Rio de Janeiro: Objetiva, 2005.

FRITSCH, Stefan. Technology and Global Affairs. International Studies Perspectives, n.12, p. 27-45, 2011.

GALlAGER, Robert G. Principles of Digital Communication. Cambridge: Cambridge University Press, 2008.

GARCÍA-MEXÍA, Pablo. WikiLeaks Is an Abuse of Internet Freedom. In: THOMPSON, Thamara. (Org.). At issue: Wikileaks. Nova York: Greenhaven Press, 2013. p. 50-54. 
GERBAUDO, PAOLO. Tweets and the streets: Social media and contemporary activism. London: Pluto Press, 2012.

GERLACH, Luther P. The Structure of Social Movements: environmental activism and its opponents. In: ARQUILLA, Jonh; RONFELDT, David (Org.). Networks and Netwars: The Future of Terror, Crime, and Militancy. Santa Monica: Rand, 2001, p. 289-310.

GERLACH, Luther P., HINE, Virginia H. People, Power, Change: Movements of Social Transformation. Indianapolis: Bobbs-Merrill, 1970.

GILBOA, Eytan. Global Communication and Foreign Policy. Journal of Communication, dez., p. 731-748, 2002.

GHEIDARY, Lida Khalili. Social Media and Iran's Post-election Crisis. In: PERRY, Jake; SEAN, S. Costigan (Org.). Cyberspaces and Global Affairs. Londres: Asgate Publishing Limited, 2012. p. 215-223.

GLADWELL, Malcolm. Small Change: The Revolution will not be televised. The New Yorker. Out. 2010. Disponível em:

http://www.newyorker.com/reporting/2010/10/04/101004fa_fact_gladwell. Acesso: 28 ago. 2015.

GLAISYER, Tom. Political Factors: Digital Activism in Closed and Open Societies. In: JOYCE, Mary (Org). Digital Activism Decoded: The New Mechanics of Change. Nova York: International Debate Education Association, 2010. p. 85-98.

GOFFMAN, Erving. A representaçao do eu na vida cotidiana. Petrópolis: Vozes, 2006

GOMES, Wilson. Internet e participação política em sociedades democráticas. Revista Famecos, n.27, p. 58-78, 2005.

GONH, Maria da Glória. Teorias dos movimentos sociais: paradigmas clássicos e contemporâneos. São Paulo: Edições Loyola, 2010

GOODALE, James. WikiLeaks's Pro Would Impcril of the Press. In: THOMPSON, Thamara. (Org). At issue: Wikileaks. Nova York: Greenhaven Press, 2013. p. 91-95.

GOODWIN, Jeff. For a Relational Approach to Contentious Strategies, or "It Takes Two to Tango". Mobilizing Ideas, abr. 2012, Is a terrorism a form of activism? 2012. Disponível em: https://mobilizingideas.wordpress.com/category/essay-dialogues/is-terrorism-a-form-ofactivism/>. Acesso em: 15 mai. 2015.

GREATHOUSE, Craig B. Cyber War and Strategic Thought: Do the Classic Theorists Still Matter? In: Kremer, Jan-Frederik; Müller, Benedikt (Org). Cyberspace and International Relations: Theory, Prospects and Challenges. 2014.

GREEN, Joshua. The Myth of Cyberterrorism - There are many ways terrorists can kill you: computers aren't one of them. Washington Montly, online, nov.2002 . Disponível em < http://www.washingtonmonthly.com/features/2001/0211.green.html Acesso: 2 dez 2015. 
GREENGARD, Samuel. The Internet of Things. Cambridge: The MIT Press, 2015.

GRUGEL, Jean. State power and transnational activism. In: PIPER, Nicola; UHLIN, Anders (Org.) Transnational Activism in Asia: Problems of power and democracy. London: Routledge, 2003. p. $26-42$.

GUNARATNA, Rohan. Inside Al Qaeda: Global Network of Terror. Nova York: Columbia University Press, 2002.

GUTIÉRREZ-RUBÍ, Antoni. La política vigilada: la comunicación política en la era de Wikileaks. Barcelona: Editorial UOC, 2011.

HAASS, Richard N. The Age of Nonpolarity: What Will Follow U.S. Dominance. Foreign Affairs, v.87, n.5, p. 44-56, 2008.

HABERMAS, Jürgen. Técnica e Ciência como Ideologia. Lisboa: Edições 70, 1987.

The theory of communicative action. Boston: Beacon Press, 1981.

HALLAMS, Ellen. Digital diplomacy: the internet, the battle for ideas \& US foreign policy. CEU Political Science Journal. v. 5, n. 4, 2013.

HANDS, Joss. @ Is for Activism: Dissent, Resistance and Rebellion in a Digital Culture. London: Pluto Press, 2010.

HARDT, Michael; NEGRI, Antionio. Multidune: war and democracy in the age of empire. Nova York: The Penguin Press, 2004.

HART, Jeffrey A. Information and Communications Technologies and Power. In: PERRY, Jake; SEAN, S. Costigan (Org.). Cyberspaces and Global Affairs. Burlington: Asgate Publishing Limited, 2012. p. 203-214.

HATHAWAY, Melissa E.; KLIMBURG, Alexander. Preliminary Considerations: On National Cyber Security. KLIMBURG, Alexander (Org.). National Cyber Security Framework Manual. Tallinn: NATO CCD COE Publication, 2012. p. 1- 43.

HEGGHAMMER, Thomas. The recruiter's dilemma: Signalling and rebel recruitment tactics. Journal of Peace Research, v.50, n.1, p. 3-16. jan. 2013.

HEIDEGGER, Martin. A questão da técnica. Petrópolis: Vozes, 2001.

HEILBRONER, Robert L. Do Machines Make History? Technology and Culture, n.8, p. 335-345. 1969.

HEPP, Andreas and Krotz, Friedrich. Mediatized Worlds- Understanding Everyday Mediatization. In: HEPP, Andreas; KROTZ, Friedrich (Org). Mediatized Worlds Culture and Society in a Media Age. Nova York: Palgrave, 2014. p. 1-18.

HINTZ, Arne. Dimensions of Modem Freedom of Expression: WikiLeaks, Policy Hacking, and Digital Freedoms. In: BREVINI, Benedetta; HINTZ, Arne; MCCURDY, Patrick (Org). 
Beyond Wikileaks: Implications for the future of communications, journalism and society. Nova York: Palgrave Macmillan, 2013. p. 146-165.

HOUNSHELL, Blake. The revolution will be tweeted: life in the vanguard of the new Twitter proletariat. Foreign Policy, v. 187, online. jan. 2011. Disponível em http://foreignpolicy.com/2011/06/20/the-revolution-will-be-tweeted/ . Acesso 17 set. 2014.

HOWARD; Philip N.; HUSSAIN, Muzammil M. Democracy's fourth wave? Digital media and the Arab spring. Oxford: Oxford University Press, 2013.

HUGHES, Thomas P. Technological Momentum. In: SMITH, Merritt Roe; MARX, Leo. Does technology drive history? The dilemma of technological determinism. Cambridge: MIT, 1994.

HWANG, Tim. Digital Transforms Activism: The Web Ecology Perspective. In: JOYCE, Mary (Org). Digital Activism Decoded: The New Mechanics of Change. Nova York: International Debate Education Association, 2010. p. 119-136.

JACOBSON, Michael. Terrorist Financing and the Internet. Studies In Conflict \& Terrorism, v.33, n.4, p.353-363, mar. 2010.

JASPER, James M. A strategic approach to collective action: looking for agency in socialmovement choices. Mobilization: An International Journal, v.9, n.1, p. 1-16, 2004.

JENKINS, Brian Michael. Al Qaeda in Its Third Decade: Irreversible Decline or Imminent Victory? Santa Monica: RAND Corporation, 2012. . Countering Al Queda: An Appreciation of the Situation and Suggestions for Strategy. Santa Monica: RAND Corporation, 2002.

JENKINS, Henry. Convergence Culture: Where Old and New Media Collide. Nova York: New York University Press, 2008.

Cultura da Convergência. São Paulo: Aleph, 2009.

JHA, N.K. Research Methodology. Chandigarh: Abhisek Publications, 2008.

JOHNSON, Steven. Emergência: a vida integrada de formigas, cérebros, cidades e softwares Tradução: Maria Carmelita Pádua Dias. Rio de Janeiro: Zahar, 2003.

JORDAN, Tim. Activism! Direct Action, Hactivism and the Future of Society. Londres: Reaktion Books, 2002.

Cyberpower: The Culture and Politics of Cyberspace and the Internet.

London: Routledge, 1999.

JOSSELIN, Daphné; WALLACE, William .Non-states actors in world politics: a framework . JOSSELIN, Daphné; WALLACE, William (Org). Non-state actors in world politics. Londres: Palgrave, 2001.p. 1-20.

JOYCE, Mary. Conclusion: Building the Future of Digital Activism. In: JOYCE, Mary (Org). 
Digital Activism Decoded: The New Mechanics of Change. Nova York: International Debate Education Association, 2010b. p. 209-216.

JOYCE, Mary. Introduction: How to Think About Digital Activism. In: JOYCE, Mary (org). Digital Activism Decoded: The New Mechanics of Change. Nova York: International Debate Education Association, 2010a. p. 1-14.

JUNGHERR, Andreas; SCHULTZ, Dan. Applications: Picking the Right One in a Transient World Dan Schultz and In: JOYCE, Mary (Org). Digital Activism Decoded: The New Mechanics of Change. Nova York: International Debate Education Association, 2010. p. 3346.

KARPF, Dave. Measuring the Success of Digital Campaigns. In: JOYCE, Mary (org). Digital Activism Decoded: The New Mechanics of Change. Nova York: International Debate Education Association, 2010. p. 151-164.

KASSAB, Hanna Samir. In Search of Cyber Stability: International Relations, Mutually Assured Destruction and the Age of Cyber Warfare. In: KREMER, Jan-Frederik; MÜLLER, Benedikt (Org). Cyberspace and International Relations: Theory, Prospects and Challenges. Nova York: Springer, 2014. P. 59-76.

KAVADA, Anastasia. Transforms Digital: The Social Movement Perspective. In: JOYCE, Mary (Org). Digital Activism Decoded: The New Mechanics of Change. Nova York: International Debate Education Association, 2010. p. 101-118.

KECK, Margaret E. and SIKKINK, Kathryn. Activists beyond Borders: Advocacy Networks in International Politics. Ithaca and London: Cornell University Press, 1998.

KELLER, Bill. The Media Has an Uncomfortable but Necessary Relationship with WikiLeaks. In: THOMPSON, Thamara (Org). At issue: WikiLeaks. Nova York: Greenhaven press, 2013. p. 28-49.

KELLO, Lucas. The Meaning of the Cyber Revolution. International Security, v. 38 n. 2, p. 7-40. dez-fev. 2013.

KIGGINS, Ryan David. US Leadership in Cyberspace: Transnational Cyber Security and Global Governance. In: KREMER, Jan-Frederik; MÜLLER, Benedikt (Org.). Cyberspace and International Relations: Theory, Prospects and Challenges. 2014. p. 161-180.

KLEINROCK, Leonard. An early history of the Internet. IEEE Communications Magazine. Agosto, 2010, History of communications. p. 26-36. Disponível em:

http://www.lk.cs.ucla.edu/data/files/Kleinrock/An\%20Early\%20History\%20Of\%20The\%20In ternet.pdf . Acesso: 19 out. 2013.

KLUVER, Alan R. The logic of new media in international affairs. New Media \& Society, Londres, v. 4, n. 4, dez. 2002.

KNOEPFEL, Sascha. Clarifying the International Debate on Stuxnet: Arguments for Stuxnet as an Act of War.In: KREMER, Jan-Frederik; MÜLLER, Benedikt (Org). Cyberspace and International Relations: Theory, Prospects and Challenges. Nova York: Springer, 2014. p. $117-124$. 
KOBRIN, Stephen J. Territoriality and the Governance of Cyberspace. Journal ofInternational Business Studies, v. 32, n.4, p. 687-704. 2001.

KOROTAYEV, Andrey V.; ZINKINA, Julia V. Egyptian Revolution: A demographic structuralanalysis. Entelequia, n.13, p.139-169, 2011.

KOTHARI, C.R. Research Methodology: Methods and Techniques. Delhi: New Age International, 2004.

KOWERT, Paul; LEGRO, Jeffery. Norms, identity, and their limits: A theoretical reprise. In: KATZENTEIN, Peter J. (Org.). The culture of national security: norms and identity in world politics. Nova York: Columbia UniversityPress, 1996.

KREMER, Jan-Frederik; MÜLLER, Benedikt. SAM: A Framework to Understand Emerging Challenges to States in an Interconnected World. In: KREMER, Jan-Frederik; MÜLLER, Benedikt (Org.). Cyberspace and International Relations: Theory, Prospects and Challenges. Nova York: Springer Heidelberg, 2014. p. 41-58.

LAI, On-Kwok. Transnational activism and electronic communication: Cyber-rainbow warriors in action. In: PIPER, Nicola; UHLIN, Anders (Org.) Transnational Activism in Asia: Problems of power and democracy. Londres: Routledge, 2003. p. 94-107

LANIER, Jaron. Gadget: Voce Nao e Um Aplicativo! São Paulo: Saraiva, 2010.

LEMOS, André. Aspectos da cibercultura: vida social nas redes telemáticas. In: PRADO, José Luiz Aidar (Org). Críticas das práticas midiáticas: da sociedade de massa às ciberculturas, São Paulo: Hacker Editores , 2002. p. 11-129.

Alegre: Sulina, 2010.

Cibercultura. Tecnologia e vida social na cultura contemporânea. Porto

. A comunicação das Coisas. Teoria Ator-Rede e Cibercultura. São Paulo:

Annablume, 2013.

LEMOS, André; JOSGRILBERG, Fabio (Org). Comunicaçãoe mobilidade: Aspectos socioculturais das tecnologias móveis de comunicação no Brasil. Salvador: Edufba, 2009.

LEROI-GOURHAN. A. Le Geste et la Parole. Technique et Langage. Paris: Albin Michel, 1964.

LEVY, Pierre. As tecnologias da Inteligência: o futuro do pensamento na era da informática. São Paulo: Editora 34, 1995.

LINDSTEDT, Catharina; NAURIN, Daniel. Corruption Transparency is not Enough: Making Transparency Effective in Reducing. International Political Science Review, v.31, p.3, p. 301-322, 2010.

LOVINK, Geert; RIEMENS, Patrice. Twelve Theses on WikiLeaks. In: BREVINI, Benedetta; HINTZ, Arne; MCCURDY, Patrick (Org). Beyond Wikileaks: Implications for 
the future of communications, journalism and society. Nova York: Palgrave Macmillan, 2013. p. 245-253.

LUTZ, James M.; LUTZ, Brenda J. Global terrorism. Abingdon: Routledge, 2004.

LYNCH, Lisa. The Leak Heard Round the World? Cablegate in the Evolving Global Mediascape. In: BREVINI, Benedetta; HINTZ, Arne; MCCURDY, Patrick (Org). Beyond Wikileaks: Implications for the future of communications, journalism and society. Nova York: Palgrave Macmillan, 2013. p. 56-77.

LYNCH, Marc (Org). The Arab uprisings explained: New contentious politics in the Middle East. Nova York: Columbia University Press, 2014. . The big think behind the Arab spring. Foreign Policy. v.190, p. 46, 2011.

MANOVICH, Lev. The language of New Media.Cambridge. MIT Press, 2001.

MARINUCCI, Raquel Boing Marinucci. Relações internacionais e mídia. Univ. Rel. Int., Brasília, v. 6, n. 1, p. 43-52, jan./jun. 2008.

MARTINS, Estevão Chaves de Rezende. Relações Internacionais: economia política e globalização. Brasília: IBRI, 2002.

MARX, Karl; ENGELS, Friedrich. A Ideologia Alemã. São Paulo: Martins Fontes, 1989.

MARX, Karl; Engels, Friedrich. O manifesto Comunista. São Paulo: Saraiva, 2011.

MASON, Paul. Why it's kicking off everywhere: The New Global Revolutions. Nova York: Verso, 2012.

MAXWELL, J.A. Qualitative Research Design: An Interactive Approach. Oaks: Sage, 2005.

MAYER-SCHONBERER, Viktor; CUKIER, Kenneth. Big Data - como extrair volume, variedade, velocidade e valor da avalanche de informaçao cotidiana. Rio de Janeiro: Editora Campus, 2013.

McADAM, Doug, TARROW, Sidney G., and TILLY, Charles. Dynamics of Contention. Cambridge: Cambridge University Press, 2001.

McADAM, Doug; McCARTHY, John D. ;ZALD, Mayer N.(Org.) Comparative perspectives on social movements: political opportunities, mobilizing structures, and cultural framings. Cambridge: Cambridge University Press, 1996.

McCARTHY, John D.; ZALD. Mayer N. Resource Mobilization and Social Movements: A Partial Theory . The American Journal of Sociology, v.82, n.6, p. 1212-1241, 1977.

MCCORMICK, Ty. A look at the Internet's lurid underbelly - your one - stop shop for weapons, drugs, and illegal pornography. Foreign Policy. 9 dez. 2013. Disponível em : http://foreignpolicy.com/2013/12/09/the-darknet-a-short-history/> Acesso em: 20 jun. 2014.

MCCULLAGH, Declan. WikiLeaks Is a Terrorist Organization. In: THOMPSON, Thamara. 
(Org). At issue: Wikileaks. Nova York: Greenhaven press, 2013. p. 70-76.

MCCURDY, Patrick. From the Pentagon Papers to Cablegate: How the Network Society Has Changed Leaking. In: BREVINI, Benedetta; HINTZ, Arne; MCCURDY, Patrick (Org).

Beyond Wikileaks: Implications for the future of communications, journalism and society. Nova York: Palgrave Macmillan, 2013. p. 123-145.

McGRATH, Kevin. Confronting Al-Qaeda: New Strategies to Combat Terrorism. Nova York: Naval Institute Press, 2011.

MCLUHAN, Marshall. Os meios de comunicação como extensões do homem

(Understanding Media). São Paulo: Cultrix, 1996.

MEAD, George Herbert. Mind, Self \& Society .Kindle ed.. Berlim: Heptagon, 2013

MEDEIROS, Leonilde Servolo de. Os movimentos sociais como campo de pesquisa nas ciências humanas.Revista Mundos do Trabalho,v. 4 , n.7, p. 7-31, 2012.

MELO JUNIOR, João Alfredo Costa de Campos. A ação coletiva e seus intérpretes.

Pensamento Plural, n. 01, p. 65 - 87. 2007.

MELUCCI, Alberto. Challenging codes: collective action in the information age. Cambridge: Cambridge University Press, 1996.

. The Process of Collective Action. In: JOHNSTON, Hank; KLANDERMANS,

Bert. (Org.). Social Movements and Culture. Londres: Routledge, 1995, p. 41-63.

p. 49-66.

. Um objetivo para os movimentos sociais? Lua Nova, São Paulo, n.17, 1989,

MESSARI, Nizar; NOGUEIRA, João Pontes. Teoria das Relações Internacionais: correntes e debates. Rio de Janeiro: Elsevier, 2005.

MEY, Stefan. Leak-o-nomy: The Economy of Wikileaks (entrevista com Julian Assange). Medien-Ökonomie-Blog. 4 jan. 2010. Disponível em:

https://p10.secure.hostingprod.com/@ spyblog.org.uk/ssl/wikileak/2010/01/leak-o-nomy-theeconomy-of-wikileaks---julian-assange-interviewed-by-stefan-mey.html. Acesso em: 03 dez. 2015 .

MEYER, David S.; STAGGENBORG, Suzanne. Thinking about Strategy. In: MANEY, Gregory M.; KUTZ-FLAMENBAUM, Rachel V. (Org.). Social Movements, Protest, and Contention: Strategies for Social Change. Minneapolis: University of Minnesota Press, 2012, p. 3-22.

MIARD, Fabien. Call for power? Mobile phones as facilitators of politcal activism. In: Perry, Jake; Sean, S. Costigan (Org.). Cyberspaces and Global Affairs. Burlington: Asgate Publishing Limited. 2012. p. 119-144.

MIGUEL, Luiz Felipe. Os meios de comunicação e a prática política. Lua Nova, São Paulo, n. 55-56, 2002. 
MILAN, Stefania. WikiLeaks, Anonymous, and the Exercise of Individuality: Protesting in the Cloud. In: BREVINI, Benedetta; HINTZ, Arne; MCCURDY, Patrick (Org). Beyond Wikileaks: Implications for the future of communications, journalism and society. Nova York: Palgrave Macmillan, 2013. p. 191-208.

MILLER, Erin; LAFREE, Gary. The Global Terrorism Database: Support for Terrorism as a Fundamental Instrument of Social Movements. Mobilizing Ideas, abr. 2012, Is a terrorism a form of activism? 2012. Disponível em:

$<$ https://mobilizingideas.wordpress.com/category/essay-dialogues/is-terrorism-a-form-ofactivism/>. Acesso em 15 mai. 2015.

MILLER, James. Intensifying Mediatization: Everyware Media. In In: Hepp, Andreas; Krotz, Friedrich (Org). Mediatized Worlds Culture and Society in a Media Age. Nova York: Palgrave, p.107-122. 2014.

MILLIGAN, Susan. WikiLeaks is not Journalism of Any Sort. In: THOMPSON, Thamara (Org). At issue: Wikileaks. Nova York: Greenhaven press, 2013. p. 24-27.

MOHAMEDOU, Mohammad-Mahmoud Ould. Understanding Al Qaeda: Changing War and Global Politics. 2a. Ed. Londres: Pluto Press, 2011.

MOORE, Will H. Movements, Mobilization and the Terror Tactic. Mobilizing Ideas, abr. 2012, Is a terrorism a form of activism? Disponível em:

$<$ https://mobilizingideas.wordpress.com/category/essay-dialogues/is-terrorism-a-form-ofactivism/>. Acesso em: 15 mai. 2015.

MOROZOV, Evgeny. The alternative's alternative. Open Democracy. 29 dez. 2008.

Disponível em: < https://www.opendemocracy.net/article/email/the-alternatives-alternative>. Acesso em: 12 out. 2015.

MUELLER, Milton L. Networks and States. Cambridge: MIT Press, 2010.

MUELLER, Milton; SCHMIDT, Andreas; KUERBIS, Brenden. Internet Security and Networked Governance in International Relations. International Studies Review, v.15, n.1, p.86-104,mar. 2013

MUNSON, Ziad. A Middle Way: Adopting the Sensibility of Social Movement Studies to Understand Terrorism. Mobilizing Ideas, abr. 2012, Is a terrorism a form of activism? 2012. Disponível em: <https://mobilizingideas.wordpress.com/category/essay-dialogues/isterrorism-a-form-of-activism/>. Acesso em: 15 mai. 2015.

MURDOCH, Steven. Destructive Activism: The Double-Edged Sword of Digital Tactics. In: JOYCE, Mary (Org). Digital Activism Decoded: The New Mechanics of Change. Nova York: International Debate Education Association, 2010. p. 137-148.

MURPHY, Laura; MACLEOD-BALL, Michael. Wikileaks should be protected by narrowing the Espionage Act. In: THOMPSON, Thamara. (Org). At issue: Wikileaks. Nova York: Greenhaven Press, 2013. p. 81-90. 
NAURIN, Daniel. Transparency, Publicity, Accountability: The missing links. Swiss Political Science Review, v.12, n.3, p. 90-99, 2006.

NIELSEN, Rasmus Kleis. Digital Politics as Usual. In: JOYCE, Mary (Org). Digital Activism Decoded: The New Mechanics of Change. Nova York: International Debate Education Association, 2010. p. 181-196.

NORRIS, Pipa. Digital Divide: Civic Engagement, Information Poverty, and the Internet Worldwide. Nova York: Cambridge University Press, 2001.

NUNES, Cristina. O conceito de movimento social em debate: Dos anos 60 até à atualidade. Sociologia, Problemas e Práticas, n.75, p. 131-147, 2014.

NYE, Joseph; KEOHANE, Robert. Power and interdependence. 3. ed. Nova York: Longman, 2001.

NYE, Joseph S. Compreender os conflitos internacionais: Uma introdução a Teoria e a História. Lisboa: Gradiva, 2002.

. O paradoxo do poder americano. Por que a única superpotência do mundo não pode prosseguir isolada. São Paulo: Unesp, 2002b.

. The means to success in World Politics. Nova York: Public Affairs, 2004.

Public Diplomacy and Soft Power. The Annals of the American Academy of

Political and Social Science. Public Diplomacy in a Changing World. v.616, p. 94-109, mar. 2008.

Cyber Power. Belfer Center for Science and International Affairs. Cambridge: Harvard Kennedy School, 2010. Disponível em :

http://belfercenter.ksg.harvard.edu/files/cyber-power.pdf . Acesso: 2 jan. 2015.

OBERSCHALL, Anthony. Social movements: ideologies, Interests, and Identities. New Brunswick: Transaction Publishers, 1993.

OBERSCHALL, Anthony. Terrorism: a loss/loss outcome. Mobilizing Ideas, abr. 2012, Is a terrorism a form of activism? 2012. Disponível em:

https://mobilizingideas.wordpress.com/category/essay-dialogues/is-terrorism-a-form-ofactivism. Acesso: 15 mai. 2015.

OECD. Organisation for Economic Co-Operation and Development. Handbook on Constructing Composite Indicators: Methodology and User Guide. Paris: 2008.

OLESEN, Thomas. Introduction: Power and transnational activism framing. In: OLESEN, Thomas (Org). Power and transnational activism. Nova York: Routledge, 2011a. p. 1-20.

Transnational counter-publics and democracy. In: OLESEN, Thomas (Org).

Power and transnational activism. Nova York: Routledge, 2011b. p. 252-268.

OLIVEIRA, Adriana Capuano de. O Potencial Político das Novas Tecnologias de Informação e Comunicação (TICs): Imigrantes Brasileiros criando elos e redes de um 'Estado do 
Emigrante'. In:Congresso Luso-Afro-Brasileiro de Ciências Sociais, 11, 2011. São Paulo. Anais... São Paulo: UFBa, 2011.

OLIVEIRA, Rafael Santos de. A mídia como ator emergente das Relações Internacionais: seu protagonismo no uso do soft power frente aos desafios das mudanças climáticas. 2010. 418 f. Tese de Doutorado (Doutorado em Direito). Centro de Ciências Jurídicas, Universidade Federal de Santa Catarina, Florianópolis, 2010.

OLSON, Marcus. The Logic of Collective Action: Public goods and the theory of groups. Cambridge: Harvard University Press, 1965.

OLSSON, Giovanni. Relações internacionais e seus atores na era da globalização. Curitiba: Juruá: 2011.

OPPERMANN, Daniel. Governança multisetorial e o processo de governança da internet: um estudo de caso sobre crime cibernético e filtragem na internet entre 1990 e 2010. 2002. $264 \mathrm{f}$. Tese de doutorado (Doutorado em Relações Internacionais). Instituto de Relações Internacionais, Universidade de Brasilia, Brasília, 2002.

PAVLIK, John V. A tecnologia digital e o jornalismo: As implicações para a Democracia. Brazilian Journalism Research, v.7, n.2, p. 94-118, 2011.

PETERS, Jonathan. Wikileaks shows the need for a new kind od "watchdog" protection. In: THOMPSON, Thamara. (Org.). At issue: Wikileaks. Nova York: Greenhaven press, 2013. p. 96-100.

PIPER, Nicola; UHLIN, Anders. New perspectivs on transnational actvism. In: PIPER, Nicola; UHLIN, Anders. (Org.). Transnational Activism in Asia: Problems of power and democracy. New York: Routledge, 2004. p. 1-25.

PORTA, Donatella della; TARROW, Sidney. Transnational Processes and Social Activism: An Introduction. In: PORTA, Donatella della; TARROW, Sidney (Org). Transnational protest and global activism. Lanham: The Rowman \& Littlefield Publising, 2005. p.1-17.

PORTA, Donatella Della. Opportunities and framing in the Eastern European revolts of 1989. In: McADAM, Doug; McCarthy, John D.;ZALD, Mayer N.(Org.) Comparative perspectives on social movements: political opportunities, mobilizing structures, and cultural framings. Cambridge: Cambridge University Press, 1996, p. 93-121.

PORTA, Donatella della. Some Reflections on the relationship between terrorism and social movements? Mobilizing Ideas, abr. 2012, Is a terrorism a form of activism? Disponível em: https://mobilizingideas.wordpress.com/category/essay-dialogues/is-terrorisma-form-of-activism/>. Acesso: 15 mai. 2015.

POSTMAN, Neil. The Humanism of Media Ecology. Keynote Address Delivered at the Inaugural Media Ecology Association Convention. Proceedings of the Media Ecology Association, Nova York, n.1, 2000.

QUIAN, Alberto. El impacto mediático y político de WikiLeaks: la historia más apasionante del periodismo moderno. Barcelona: Editorial UOC, 2013. 
RABASA, Angel; CHALK, Peter; CRAGIN, Kim. Beyond Al-Qaeda: The Global Jihadist Movement. Santa Monica: RAND Corporation, 2006.

RADU, Roxana. Power Technology and Powerful Technologies: Global Governmentality and Security in the Cyberspace. In: KREMER, Jan-Frederik; MÜLLER, Benedikt (Org.). Cyberspace and International Relations: Theory, Prospects and Challenges. Nova York: Springer Heidelberg, 2014. p. 3-20.

RAMADAN, Tariq. The arab awakening: Islam and the new Middle East. Nova York: Penguim Group, 2012.

REITAN, Ruth. Global activism. Nova York: Routledge, 2007.

REUS-SMIT, Christian. Constructivism. In: Theories of International Relations.

BURCHILL, Scott et al (Org). Londres: Palgrave, 2001.p. 212-240.

RHEINGOLD, H., A Comunidade Virtual. Lisboa: Editora Gradiva, 1996.

RIVIERA, Francisco.J. URIBE . Agir comunicativo e planejamento social: uma crítica ao enfoque estratégico. Rio de Janeiro: Fiocruz, 1995.

ROBERTS, Alasdair. Wikileaks: The illusion of transparency. International Review of Administrative Sciences, v. 78, n. 1, p. 116-13, mar. 2012.

ROCHA, Antonio Jorge Ramalho da. Epistemologia e níveis de abstração nas teorias das Relações Internacionais. In: ROCHA, Antonio Jorge Ramalho da (Org).Teorias e Agendas. Brasília: IBRI/Funag, 2002.

ROCHA, Elizabete Sanches. Cultura e poder: o papel político do Teatro do Oprimido em Moçambique e sua visibilidade internacional. In: CONGRESSO LUSO-AFRO-

BRASILEIRO DE CIÊNCIAS SOCIAIS, 10, 2009, Braga, Anais.... Braga: Universidade do Minho, 2009.

ROCHE, Alexandre. Tensões da Primavera do mundo árabe-sunita: entre o wahhabismo conservador e o espírito crítico, entre a política do petróleo e a independência econômica. Ciências \& Letras, Porto Alegre, n. 51, p. 47-56, jan./jun. 2012

ROSS, Carne. The end of diplomacy as we know it. The World Post, 30 nov. 2010. Disponível em: http://www.huffingtonpost.com/carne-ross/the-end-of-diplomacy-asw_b_790128.html. Acesso em: 10 jan. 2016

SAGEMAN, Marc. Understanding Terror Networks. Philadelphia: University of Pennsylvania Press, 2004.

SALEH, Ibrahim. WikiLeaks and Arab Spring: The Twists and Turn of Media, Culture, and Power. In: BREVINI, Benedetta; HINTZ, Arne; MCCURDY, Patrick. Beyond Wikileaks: Implications for the future of communications, journalism and society. Nova York: Palgrave Macmillan, 2013. p. 236-244.

SALEM, Sara. Creating Spaces for dissent: The role of social media in the 2011 Egyptian 
Revolution. In: TROTTIER, Daniel; FUCHS, Christian (Org). Social Media, Politics and the State: Protests, revolutions, riots, crime and policing in the age of Facebook, Twitter and Youtube. Nova York: Routledge, 2015. p. 171-188.

SALTER, Lee. Structure and forms of use: A contribution to understanding the 'effects' of the Internet on deliberative democracy. Information, Communication \& Society, v.7, n.2, p. 185-206. 2004.

SCHLOSBERG, Justin. Power Beyond Scrutiny: Media, Justice and Accountability. Londres: Pluto Press, 2013.

SCHOLZ, Trebor. Infrastructure: Its Transformations and Effect on Digital Activism. In: JOYCE, Mary (Org.). Digital Activism Decoded: The New Mechanics of Change. Nova York: International Debate Education Association, 2010. p. 17- 32.

SCHUMANN, Sandy. How the Internet shapes collective actions. Londres: Palgrave Macmillan, 2015.

SEIB, Philip. Real-time diplomacy: Politics and power in the social media era. Nova York: Palgrave Macmillan, 2012.

SERRA, Marcello. Wikileaks: el poder entre bastidores. Estudios sobre el mensaje periodistico. Madri, v. 18, n. 1, p. 211-220. 2012.

SHAHEEN, Salma. Offense-Defense Balance in Cyber Warfare.In: KREMER, Jan-Frederik; MÜLLER, Benedikt (Org). Cyberspace and International Relations: Theory, Prospects and Challenges. Nova York: Springer, 2014. p.77-94.

SHI, Xiaoqing; ZHUGE, Hai. Cyber Physical Socio Ecology. Journal Concurrency and Computation: Practice \& Experience, v.23 n.9, p.972-984, jun. 2010.

SHIRKY, Clay. Lá vem todo mundo O poder de organizar sem organizações .Kindle ed.. Trad. Maria Luiza X. de A. Borges. Rio de Janeiro: Zahar, 2008.

The political power of social media: technology, the public sphere, and political change. Foreign Affairs, v.90, n.1, 2011.

SIFRY, Micah L. Wikileaks and the age of transparency. Berkeley: Counterpoint Press, 2011.

SILVA, Sivaldo Pereira da. Democracia online: pressupostos teóricos e inovações estruturais na comunicação do Estado contemporâneo. In: CONGRESSO DA ASSOCIAÇÃO BRASILEIRA DE PESQUISADORES EM COMUNICAÇÃO E POLÍTICA (COMPOLÍTICA), 3, 2009, São Paulo, Anais... São Paulo: Pontifícia Universidade Católica de São Paulo (PUC-SP), 2009. Disponível em <http://www.compolitica.org/home/wpcontent/uploads/2011/01/sivaldo_pereira.pdf> acesso em: 14 mar. de 2013.

Transparência digital em instituições democráticas: horizontes, limites e barreiras. Texto apresentado no COLÓQUIO TECNOLOGIA E DEMOCRACIA: GOVERNANÇA, ATIVISMO E ACCOUNTABILITY,1, 2013, Belo Horizonte, Anais... Belo Horizonte: Universidade Federal de Minas Gerais (UFMG), 2013. 
SILVEIRA, Sergio Amadeu da. Game-ativismo e a nova esfera pública interconectada. Líbero, v.12, n.24, p. 131-138, 2009.

n.2, p. 6-21, 2011.

O fenômeno Wikileaks e as redes de poder. Contemporânea, Salvador, v. 9 ,

SLAUGHTER, Anne-Marie. America's Edge: Power in the Networked Century. Foreign Affairs, v.88, n.1, p.94-113, 2009.

SMITH, Jackie. Transnational activism, institutions and global democratization. In: PIPER, Nicola; UHLIN, Anders (Org.) Transnational Activism in Asia: Problems of power and democracy. Londres: Routledge, 2003. p. 61-77.

SMITH, Merritt Roe; MARX, Leo. Techlonogical Determinism in American Culture. In: SMITH, Merritt Roe; MARX, Leo (Org.). Does Technology Drive History? The Dilemma of Technological Determinism. Cambridge: MIT Press, 1994, p. 1-37.

SNOW, David A. et al. Frame Alignment Processes, Micromobilization, and Movement Participation. American Sociological Review, v.51, n.4, p. 464-81, 1986.

SORIANO, Manuel R. Torres. El eco del terror: ideología y propaganda en el terrorismo yihadista. Madri: Plaza y Valdés, 2013.

SOUZA, Amaury de. A agenda internacional do Brasil: A política externa brasileira de FHC a Lula. Rio de Janeiro: Elsevier: CEBRI, 2009.

SOUZA, André Matheus; ZACCARON, Beatriz Ávila. A participação do Brasil em missões de manutenção de paz: o caso Haiti. (211-230) In: BRIGAGÃO, Clóvis; PROENÇA JR., Domício (Org.). O Brasil e os Novos Conflitos Internacionais. Rio de Janeiro: Gramma: FundaçãoKonrad Adenauer, 2006.

SPEKTOR, Matias. Wikileaks nas Relações Internacionais. Diplomacia, relações internacionais e jornalismo depois do Wikileaks. Revista de Política Externa. v. 19 n. 4 mar/abr/mai, 2011.

STEEN-THORNHAMMAR, Hannes. VIEWPOINT: Combating. Censorship Should be a Foreign Policy Goal Hannes Steen-Thornhammar. In: PERRY, Jake; Sean, S. Costigan (Org.). Cyberspaces and Global Affairs. Burlington: Asgate Publishing Limited, 2012a. p. 223-233.

: Privacy - There is not enough and it is shrinking fast. p. 309-319. In:

PERRY, Jake; Sean, S. Costigan (Org.). Cyberspaces and Global Affairs. Burlington: Asgate Publishing Limited, 2012b.

STEPHENS, Mark. WikiLeaks Is Not a Threat to National Security. Entrevista com Mark Stephens. Entrevistadora: Emily Badger. In: THOMPSON, Thamara. (Org). At issue: Wikileaks. Nova York: Greenhaven press, 2013. p. 55-63.

STIEGLER, B.. La technique et le temps. Paris: Galilée, 1994. 
STIPP, Horst. Should TV marry PC? American Demographics, v. 20, n.7, p. 16-21, 1998.

STORM, Borten; CRUICKSHANK, Paul; LISTER, Tim. May life inside Al-Qaeda and the CIA. Kindle ed. Nova York: Atlantico Montlhy Press, 2014.

SUlliVAN, Andrew. Tunisia's WikiLeaks Revolution. The Daily Beast. Disponível em $<$ http://andrewsullivan.theatlantic.com/ Acesso em: 21 ago. 2011.

SUSTEIN, Cass. Republic.com. Princeton: Princeton University Press, 2001.

TARROW, Sidney, and MCADAM, Doug. Scale Shift in Transnational Contention. In: PORTA, Donatella della; TARROW, Sidney. Transnational protest and global activism. Lanham: The Rowman \& Littlefield Publising, 2005. p. 121-147.

TARROW, Sidney. O poder em movimento: movimentos sociais e confronto político. Tradução de Ana Maria Sallum. Petrópolis: Vozes, 2009.

Repertórios de ação coletiva e confrontos políticos: entrevista com Sidney Tarrow. Entrevistadores: Angela Alonso e André Botelho. Sociologia \& Antropologia v. 02, n.3, p. 11-19, 2012.

States and opportunities: The political structuring of social movements. In: McADAM, Doug; McCarthy, John D.;ZALD, Mayer N.(Org.) Comparative perspectives on social movements: political opportunities, mobilizing structures, and cultural framings. Cambridge: Cambridge University Press, 1996, p. 41-62.

2006.

The new transnational activism. Londres: Cambridge University Press,

THOMAS, Timothy L. Al Qaeda and the Internet: the danger of "cyberplanning".

Parameters, v.33, n.1, p.112-123, abr/mar, 2003.

THOMPSON, Thamara. (Org). At issue: Wikileaks. Nova York: Greenhaven press, 2013.

THOMPSON, Thamara. Introduction. In: THOMPSON, Thamara. (Org). At issue: Wikileaks. Nova York: Greenhaven press, 2013. p. 7-10.

TILLY, Charles. From Mobilization to Revolution. Nova York: Random House-McGrawHill Publishing, 1978.

Contentious Repertoires in Great Britain, 1758-1834. In: TRAUGOTT, Mark

(Org.) Repertoires and Cycles of Collective Acion. Durham: Duke University Press, 1995, p. 15-43.

. Regimes and Repertoires. Chicago: University of Chicago Press, 2006.

Contentious Performances. Cambridge: Cambridge University Press, 2008.

TILLY, Charles; TARROW, Sidney. Contentious Politics. Bouder e Londres: Paradigm Publishers, 2007. 
TRAQUINA, Nelson. Teorias do Jornalismo: porque as notícias são como são (vol I). Florianópolis: Insular, 2005.

TUFEKCI, Z. and WILSON, C. Social Media and the Decision to Participate in Political Protest: Observations From Tahrir Square. Journal of Communication, v.62, n. 2, p. 363379. 14, abr. 2012.

TUFTE, Thomas. O renascimento da Comunicação para a transformação social: Redefinindo a disciplina e a prática depois da Primavera Árabe. Intercom - Revista Brasileira Ciênc. Comunicação, v.36, n. 2, p. 61-60. 2013.

TURNER, Ralph H. Determinants of Social Movement Strategies. In: Tamotsu Shibutani (Org.). Human Nature and Collective Behavior: papers in honor of Herbert Blumer. New Brunswick: Transaction Books, 1970. p. 145-164.

TYLER, Tom. R. Is the Internet changing social life? It seems the more things change, the more they stay the same. Journal of Social Issues, v.58, n.1, p. 195-205, 2002.

VIANA, Natália. Por dentro do Wikileaks: a democracia passa pela transparência radical. Opera Mundi, 30 nov. 2010. Disponível em http://operamundi.uol.com.br . Acesso: 3 set. 2014.

VON BÜLOW, Marisa. A batalha do livre comércio: A construção de redes transnacionais da sociedade civil nas Américas. Trad. Sonia Midori. São Paulo: Editora UNESP, 2014.

WAKEFIELD, Robert I. Theory of International Public Relations, the Internet, and Activism: A Personal Reflection. Journal of Public Relations Research, n.20, p.138-157, 2008.

WALSH, Eddi. Viewpoint: An alternative perspective on cyber anarchy for policy-makers In: PERRY, Jake; Sean, S. Costigan (Org.). Cyberspaces and Global Affairs. Burlington: Asgate Publishing Limited, 2012. p. 233-235.

WEIMANN, Gabriel. www.terror.net: how modern terrorism uses the internet. Special report: Washington D.C.:United States Institute of Peace, 2004.

Terror on the Internet: The new arena, the new challenges. Whashington: United States Institute of Peace, 2006.

Using the Internet for Terrorist Recruitment and Mobilization. GANOR, Boaz; KNOP, Katharina Von; DUARTE, Carlos (Org.). Hypermedia Seduction for Terrorist Recruiting. Amsterdam: IOS Press, 2007. p. 47-58.

WENDT, Alexander. Anarchy is what makes of it: the social construction of power politics. International Organization, Cambridge, v. 46, n. 2, p. 391-425, abr. 1992.

WENGER, Andreas. The Internet and the Changing Face of International Relations and Security.Information \& Security, v.7, p.5-11. 2001.

WESTCOTT, Nicholas. Digital Diplomacy: The Impact of the Internet on International Relations. Oxford Internet Institute, Research Report, 16, jul. 2008. 
WHEELER, Deborah L. Empowering publics: Information Technology and democratization in the Arab World-Lessons from Internet cafés and beyond. Research Report No. 11 Oxford Internet Institute, Oxford, jul. 2006.

WHITE, David Manning. O gatekeeper: uma análise de case na seleção de notícias. In: TRAQUINA, Nelson (Org.). Jornalismo: questões, teorias e “estórias”. Lisboa: Vega, 1993. p. $142-151$.

WHITE, Robert. Social Movements and "Terrorism": "And if that's what a terrorist is, I want to be a terrorist.” Mobilizing Ideas, abr. 2012, Is a terrorism a form of activism? 2012. Disponível em: <https://mobilizingideas.wordpress.com/category/essay-dialogues/isterrorism-a-form-of-activism/>. Acesso em: 15 mai. 2015.

WIGHT, Colin. Theorising Terrorism: The State, Structure and History. International Relations, v. 23, n.1, p. 99-106. 2009

WIKILEAKS.ORG. WikiLeaks Practices Highly Principled Investigative Journalism. In: THOMPSON, Thamara (Org.). At issue: Wikileaks. Nova York: Greenhaven press, 2013. p. 11-23.

WILHELM, Anthony G. Virtual sounding boards: How deliberative is on-line political discussion? Information, Communication \& Society, v.1, n.3, p.313-338, fev, 1999.

WILLIAMS, Raymond. Television: Technology and Cultural Form. Londres: Fontana, 1974.

WILSON III, Ernest J. Hard Power, Soft Power, Smart Power. The Annals of the American Academy of Political and Social Science, v. 616, n.1, mar. 2008.

WINSECK, Dwayne. Weak Links and WikiLeaks: How Control of Critical Internet Resources and Social Media Companies' Business Models Undermine the Networked Free Press. In: BREVINI, Benedetta; HINTZ, Arne; MCCURDY, Patrick (Org). Beyond Wikileaks: Implications for the future of communications, journalism and society. Nova York: Palgrave Macmillan, 2013. p. 166-177.

WOLF, MAURO. Teorias das Comunicações de Massa. São Paulo: Martins Fontes, 2008. WOLTON, Dominique. E depois da Internet? Para uma teoria crítica dos novos médias. Algés: Difel, 2001.

WOODLY, Deva. New competencies in democratic communication? Blogs, agenda setting and political participation. Public Choice, n. 134, p. 109-123, 2008.

YIN. Robert, K. Estudo de caso: planejamento e métodos. Trad. Cristhian Matheus Herrera. 5. ed. Porto Alegre: Bookman, 2015.

YORK, Jillian C. The lnternet and Transparency Beyond WikiLeaks. In: BREVINI, Benedetta; HINTZ, Arne; MCCURDY, Patrick. Beyond Wikileaks (Org): Implications for the future of communications, journalism and society. Nova York: Palgrave Macmillan, 2013. p. 229-235. 
YOUNG, Joseph. Menu Item or a Specialty? Mobilizing Ideas, abr. 2012, Is a terrorism a form of activism? 2012. Disponível em:

https://mobilizingideas.wordpress.com/category/essay-dialogues/is-terrorism-a-form-ofactivism. Acesso em: 15 mai 2015.

ZAGO, Gabriela da S.; BATISTA, Jandré Corrêa. Ativismo e agendamento nostrending topics do Twitter: o caso Wikileaks. Contemporanea, v.9, n.2, p. 246-259, 2011. 